\title{
O MARQUÊS DE SOUSA HOLSTEIN E A FORMAÇÃO DA GALERIA NACIONAL DE PINTURA DA ACADEMIA DE BELAS ARTES DE LISBOA
}

\author{
Hugo André de Almeida Vale Pereira Xavier
}

Tese de Doutoramento em História da Arte, Especialização em Museologia e Património Artístico 
Tese apresentada para cumprimento dos requisitos necessários à obtenção do grau de Doutor em História da Arte - Especialização em Museologia e Património Artístico, realizada sob a orientação científica da Professora Doutora Raquel Henriques da Silva 
Declaro que esta Tese de Doutoramento é o resultado da minha investigação pessoal e independente. O seu conteúdo é original e todas as fontes consultadas estão devidamente mencionadas no texto, nas notas e na bibliografia.

O Candidato,

(Hugo André de Almeida Vale Pereira Xavier)

Lisboa, ........ de de

Declaro que esta Tese de Doutoramento se encontra em condições de ser apreciada pelo júri a designar.

A Orientadora,

(Prof.a Doutora Raquel Henriques da Silva)

Lisboa, ...... de ....................... de ............... 


\section{AGRADECIMENTOS}

Este trabalho não teria sido possível sem o apoio e a contribuição de todos aqueles que, de uma forma ou outra, me ajudaram e aos quais gostaria de expressar o meu reconhecimento.

À Prof.a Doutora Raquel Henriques da Silva por ter acedido à sua orientação, pelo interesse e acompanhamento, pelo incentivo e confiança e pelas pertinentes sugestões.

À Fundação para a Ciência e Tecnologia pela bolsa concedida que me permitiu iniciar a investigação e mantê-la nos primeiros anos.

Ao Dr. Luís Calado, presidente da Fundação Ricardo do Espírito Santo Silva, e à Dr.a Conceição Amaral, diretora do Museu de Artes Decorativas Portuguesas, meu anterior local de trabalho, por toda a compreensão e facilidades concedidas na conclusão da tese.

Ao Dr. José Alberto Seabra Carvalho, diretor-adjunto do Museu Nacional de Arte Antiga, por todo o incentivo e apoio desde cedo demonstrados.

À Dr. a Celina Bastos e ao Dr. Anísio Franco, do mesmo museu, pela troca de ideias e sugestões assim como pelas válidas sugestões bibliográficas.

Ao Dr. Luís Montalvão, bibliotecário do museu, e à D. Narcisa Ribeiro por toda a disponibilidade nas minhas constantes solicitações.

Aos meus amigos e colegas do curso de doutoramento e do projeto "Fontes para história dos museus de Arte em Portugal", Carla Alferes Pinto, Joana Baião, Leonor Oliveira, Luís Soares, Maria João Vilhena e Sofia Lapa cuja amizade e interesse serviram de motivação e prosseguimento do trabalho.

À minha família pelo apoio sempre dado ao longo da minha formação, especialmente nesta última etapa. 


\title{
O MARQUÊS DE SOUSA HOLSTEIN E A FORMAÇÃO DA GALERIA NACIONAL DE PINTURA DA ACADEMIA DE BELAS ARTES DE LISBOA
}

HUGO ANDRÉ DE ALMEIDA VALE PEREIRA XAVIER

\section{RESUMO}

Neste trabalho definimos e desenvolvemos algumas ideias centrais sobre a Galeria Nacional de Pintura da Academia de Belas Artes de Lisboa, da formação do seu acervo a partir de 1834, com a extinção das ordens religiosas, até à abertura do Museu Nacional de Belas Artes e Arqueologia, em 1884. Em análise estão 50 anos de esforços empreendidos por vários agentes, com destaque para o marquês de Sousa Holstein, vice-inspetor da Academia, em prol da organização, conservação, exposição, estudo, promoção e divulgação do seu acervo, assim como do seu enriquecimento por meio de transferências, aquisições ou doações que estão na origem do mais relevante museu público de arte nacional.

\section{PALAVRAS-CHAVE}

Galeria Nacional de Pintura, Academia de Belas Artes, marquês de Sousa Holstein

\section{THE MARQUIS DE SOUSA HOLSTEIN AND THE CREATION OF THE NATIONAL GALLERY OF PAINTING OF THE ACADEMY OF FINE ARTS OF LISBON HUGO ANDRÉ DE ALMEIDA VALE PEREIRA XAVIER}

\begin{abstract}
In this text we define and develop some key ideas of the National Gallery of Painting - Academy of Fine Arts of Lisbon, since the beginning of its collection in 1834 with the dissolution of the religious orders, until the opening in 1884 of the National Museum of Fine Arts and Archaeology. Under review are 50 years of efforts carried out by several players, mainly the marquis de Sousa Holstein, Deputy Inspector of the Academy, in favour of the organization, conservation, exhibition, study, promotion, dissemination of its collection, in addition to the enrichment through transfers, purchases or donations which were the source of the most important public museum of art of Portugal.
\end{abstract}

\section{KEYWORDS}

National Gallery of Painting, Academy of Fine Arts, marquis de Sousa Holstein 


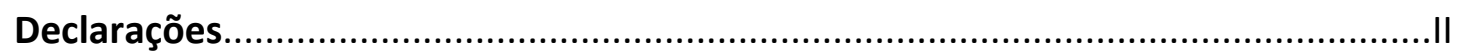

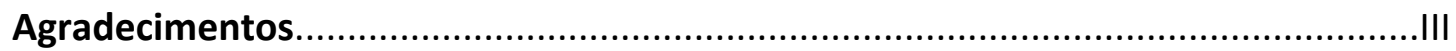

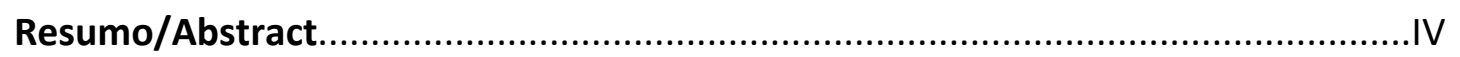

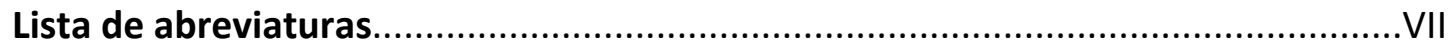

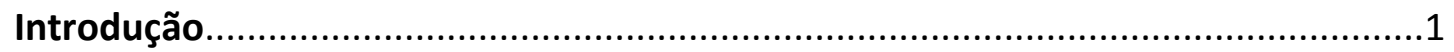

\section{PARTE - ANTECEDENTES DA GALERIA NACIONAL DE PINTURA}

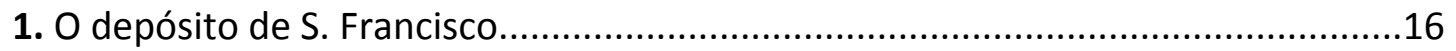

2. A Academia de Belas Artes e o corpo académico....................................................34

2.1. Esforços em prol da organização, divulgação e conservação do acervo...............41

2.2. Projetos para a construção de uma galeria..........................................................59

2.3. Outras incorporações: a coleção da rainha Carlota Joaquina...............................73

II PARTE - O MARQUÊS VICE-INSPETOR

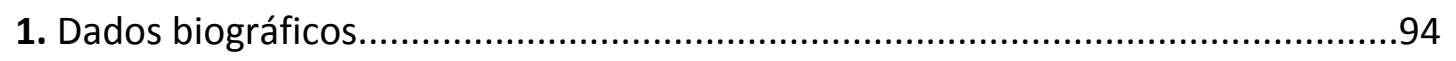

2. Funções e relações no meio artístico: da Academia à Sociedade Promotora

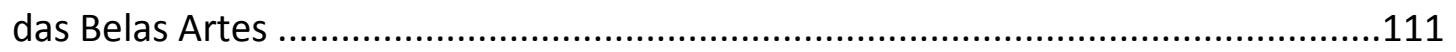

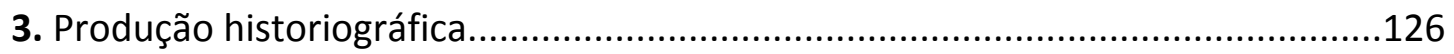

3.1. Domingos Sequeira, o artista de eleição.........................................................134

III PARTE - A FORMAÇÃO DA GALERIA NACIONAL DE PINTURA

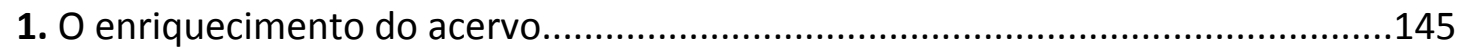

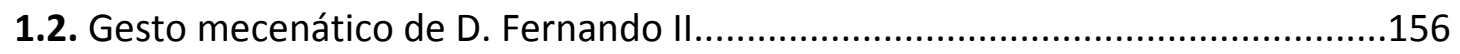

1.3. A coleção Mayne e outras aquisições................................................................183

1.4. Transferências e pedidos de transferência......................................................193

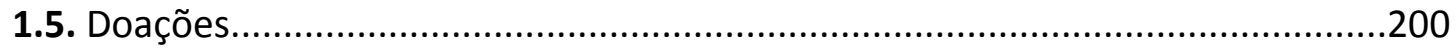




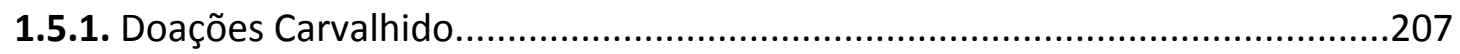

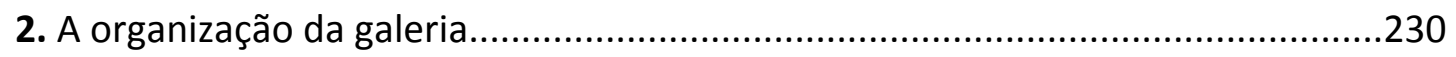

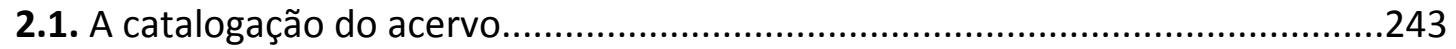

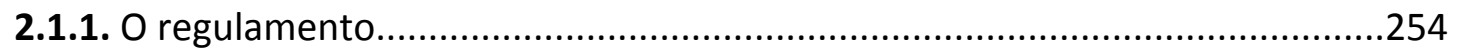

2.2. Abertura ao público e planos de expansão........................................................256

2.3. A fotografia ao serviço da galeria: o caso de Jean Laurent...............................262

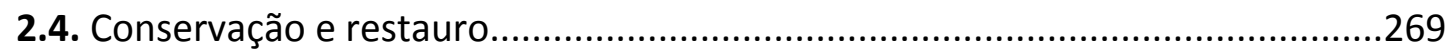

2.4.1. Alfredo Augusto da Costa Camarate, conservador.....................................278

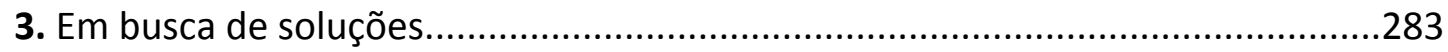

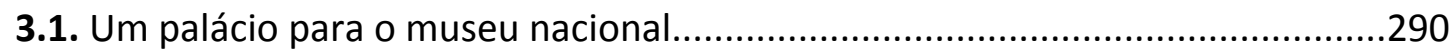

\section{PARTE - AS RESTANTES COLEÇÕES DA ACADEMIA}

1. Diferentes seç̧ões para um museu nacional: o núcleo de arte ornamental........299

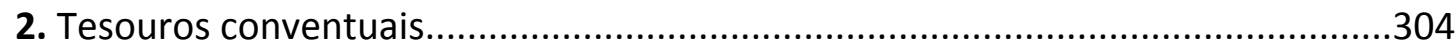

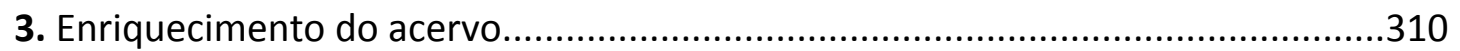

4. Derradeiras aquisições de Sousa Holstein..........................................................322

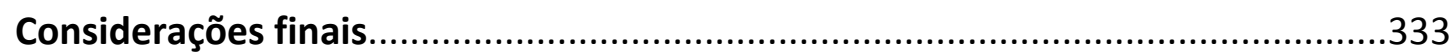

FONTES E BIBLIOGRAFIA

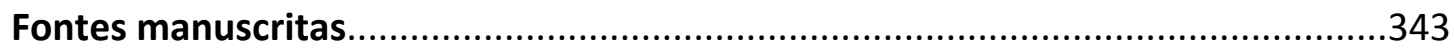

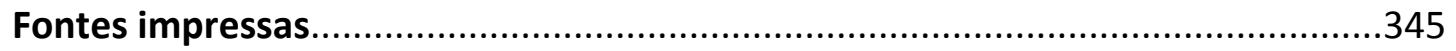

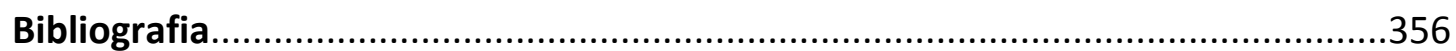




\section{LISTA DE ABREVIATURAS}

ANBA - Academia Nacional de Belas Artes

ANTT - Arquivo Nacional da Torre do Tombo

BNP - Biblioteca Nacional de Portugal

IPCE - Instituto del Patrimonio Cultural de España

MC-MNAC - Museu do Chiado - Museu Nacional de Arte Contemporânea

MNAA - Museu Nacional de Arte Antiga

MNAz - Museu Nacional do Azulejo

MNE -Ministério dos Negócios Estrangeiros

MNMC - Museu Nacional Machado de Castro

NPG - National Portrait Gallery

PNA - Palácio Nacional da Ajuda

PNM - Palácio Nacional de Mafra

PNQ - Palácio Nacional de Queluz 


\section{INTRODUÇÃO}

Os museus de arte estão, no dealbar desta centúria, entre os equipamentos culturais mais importantes para a preservação de patrimónios maiores da humanidade de todas as épocas e lugares. Eles têm vindo a contribuir, desde o século XVIII, para definir e modernizar as tarefas museológicas (adquirir, inventariar, estudar, expor), com a finalidade de contribuir para a formação e fruição de públicos cada vez mais alargados. Fazer a sua história é uma exigência de cada nação e tem inegável importância internacional. A história dos museus relaciona-se com a do colecionismo, as políticas patrimoniais, a criação artística e os modelos expositivos. Em Portugal, o estudo histórico-científico dos museus permanece ainda um território pouco explorado, reduzindo-se, com algumas recentes exceções, a trabalhos de carácter generalista que assentam sobretudo em referências bibliográficas anteriores, e só pontualmente citam documentos originais ${ }^{1}$. Para ultrapassar essa lacuna, num momento em que o interesse pelo tema cresce exponencialmente nas nossas Universidades, torna-se necessário proceder a aprofundados estudos de caso, explorando e articulando as informações contidas em acervos documentais de várias instituições.

Neste contexto, a linha de Museum Studies do Instituto de História da Arte da Faculdade de Ciências Sociais e Humanas - Universidade Nova de Lisboa, desenvolveu entre 2010 e 2013 um programa de investigação, financiado pela Fundação para a Ciência e Tecnologia (FCT), e designado "Fontes para a História dos Museus de Arte em Portugal" (PTDC/EAT-MUS/101463/2008). Contando com a coordenação científica da Prof.a Doutora Raquel Henriques da Silva, teve como objectivo fundamental inventariar, estudar e divulgar fundos documentais que se relacionam com a História dos Museus e das Coleções, nomeadamente, os arquivos do Museu Nacional de Arte Antiga e do Palácio Nacional de Ajuda². Também apoiada pela FCT no âmbito do concurso para Bolsa de Doutoramento

\footnotetext{
${ }^{1}$ Podemos citar, entre outros, o estudo de PIMENTEL, Cristina - O sistema museológico português, 1833-1991: em direção a um novo modelo teórico para o seu estudo, 2005.

${ }^{2}$ Cf. SILVA, Raquel Henriques da; BAIÃO, Joana; OLIVEIRA, Leonor (coord.) - Sources for the History of Art in Portugal (PTDC/EAT-MUS/101463/2008): final report. Coleção Projetha: projects of the Institute of Art History, n.o 1, 2013. Publicação online: http://institutodehistoriadaarte.files.wordpress.com
} 
(SFRH/BD/64602/2009), a tese agora apresentada constituiu parte integrante deste programa, assim como outros doutoramentos já defendidos ou em curso, no sentido de possibilitar a elaboração futura de uma História dos Museus em Portugal.

Em 2009, no âmbito do Mestrado em Museologia e Património, defendemos uma dissertação sobre uma pinacoteca de relevo no contexto artístico-museológico português de Oitocentos, e que permanecia por analisar de forma detalhada: a galeria de pintura criada em 1867 pelo rei D. Luís no Palácio da Ajuda ${ }^{3}$. Apoiado em larga medida nos fundos documentais da Torre do Tombo (Arquivo da Casa Real), este trabalho levou-nos frequentemente ao cotejo com outra iniciativa coeva, porquanto mais ambiciosa, a carecer também de uma investigação aprofundada.

Falamos da Galeria Nacional de Pintura, embrião do Museu Nacional de Belas Artes e Arqueologia, atual Museu Nacional de Arte Antiga (MNAA), cujo historial tem prendido a atenção de escassos autores, a começar por António Manuel Gonçalves que dela se ocupou em 1957, na sua dissertação para o estágio de conservador de museus, palácios e monumentos nacionais ${ }^{4}$. O autor recua à extinção das ordens religiosas e à criação do depósito de S. Francisco, para depois se concentrar na Galeria Nacional de Pintura, num plano que deveria ainda abarcar a Exposição de Arte Ornamental e o Museu Nacional de Belas Artes e Arqueologia. Consultou o arquivo da Academia Nacional de Belas Artes (ANBA), sobretudo os livros de atas em que baseou grosso modo a sua investigação, e que cita de forma recorrente mas sem grande espírito crítico ou interpretativo. Estranhamente, e tendo desenvolvido o curso de conservador no MNAA, não explorou o fundo José de Figueiredo daquele museu que lhe teria fornecido relevantes informações complementares.

A importância dos livros de atas foi também reconhecida por Ayres de Carvalho num estudo que, apesar de centrado na galeria de pintura da Ajuda (sobretudo na

\footnotetext{
${ }^{3}$ XAVIER, Hugo - Galeria de Pintura no Real Paço da Ajuda. Dissertação de Mestrado em Museologia e Património apresentada à FCSH-UNL, 2009. Trabalho publicado em 2013 pela INCM em parceria com o IHA da FCSH-UNL.

${ }^{4}$ GONÇALVES, António Manuel - As origens do "Museu Nacional de Belas Artes". Dissertação para o estágio de conservador dos museus e dos palácios e monumentos nacionais apresentada no Museu Nacional de Arte Antiga, 1957.
} 
apreciação das perdas ocorridas no incêndio que lá deflagrou em 1974), inclui uma breve resenha sobre outras pinacotecas oitocentistas, com destaque para a galeria académica ${ }^{5}$. "Por meio das atas da Academia, podemos seguir a par e passo os entusiasmos e canseiras de todos os que pugnaram pela criação de uma Galeria Nacional de Pintura" ${ }^{6}$, salienta o autor, transcrevendo em anexo algumas informações de relevo até então inéditas.

José-Augusto França também se debruçou brevemente sobre a galeria num dos seus trabalhos de referência ${ }^{7}$, articulando-a com a génese do Museu Portuense e com o ensino nas Academias em ambas as cidades, pondo em relevo o papel do marquês de Sousa Holstein. Explora com particular acuidade o tema do consumo artístico, decompondo-o em factores relativos ao evoluir do gosto, ao ato de colecionar e ao comércio de obras de arte, lançado inúmeras pistas de investigação que se revelam fundamentais para o nosso trabalho.

Especial atenção merece a tese de doutoramento de Maria Helena Lisboa, focalizada no papel desempenhado pelas Academias de Lisboa e do Porto no desenvolvimento do ensino e na divulgação das artes $^{8}$. A Galeria Nacional de Pintura é tratada no contexto dos equipamentos necessários às funções pedagógicas do estabelecimento lisboeta, tendo a autora logrado aceder ao seu arquivo, lamentado todavia o encerramento para consulta da valiosa biblioteca, situação que se mantém até aos dias de hoje.

Neste contexto de investigação académica deverá ser também relevado o contributo de Emília Ferreira, cuja dissertação de mestrado sobre os museus de arte do século XIX em Portugal inclui todo um capítulo dedicado às galerias lisboetas ${ }^{9}$. Não tendo acedido ao fundo documental da ANBA, dá a conhecer um apreciável somatório de fontes primárias que the permitem avançar com uma caracterização mais consistente da Galeria Nacional de Pintura, contextualizada também sob o ponto de vista internacional.

\footnotetext{
${ }^{5}$ CARVALHO, A. Ayres de - A galeria de pintura da Ajuda e as galerias do século XIX, 1982.

${ }^{6}$ Idem, ibidem, p. 8.

${ }^{7}$ FRANÇA, José-Augusto - A arte em Portugal no século XIX, vol. I, 3ạ ed, 1990, pp. 217-237; 416-421.

${ }^{8}$ LISBOA, Maria Helena - As academias e escolas de belas artes e o ensino artístico (1836-1910), 2007.

${ }^{9}$ FERREIRA, Emília - História dos museus públicos de arte no Portugal de Oitocentos. Dissertação de Mestrado em História da Arte Contemporânea apresentada à FCSH-UNL, 2001.
} 
Para enquadrar as origens deste equipamento torna-se fundamental a dissertação de mestrado de Paulo Barata que, apesar centrada na gestão dos fundos bibliográficos dos conventos extintos em 1834, fornece toda uma série de informações relevantes sobre a incorporação dos bens artísticos então também registada ${ }^{10}$. Neste sentido revelam-se também da maior utilidade os trabalhos ultimamente publicados no âmbito de um projeto de investigação financiado pela FCT e coordenado por Clara Moura Soares ${ }^{11}$, cujas conclusões finais não estavam ainda disponíveis por ocasião da entrega da nossa tese.

A Galeria Nacional de Pintura tem sido ainda sumária e repetidamente tratada em pequenos artigos inseridos em publicações editadas até ao presente pelo MNAA, sobretudo roteiros ou catálogos de exposição, que não dispõem da extensão necessária, não só para integrar referências a documentação de arquivo, como também para desenvolver uma sólida contextualização ${ }^{12}$. A grande maioria destes artigos centra-se todavia na história novecentista do estabelecimento, ou seja, num período histórico iniciado em 1911, com a legislação republicana, encontrando-se já fora da baliza cronológica da presente investigação.

Alguns avanços trouxeram estes e outros trabalhos, no entanto, o tema carece ainda de uma investigação aprofundada de maneira a preencher certas lacunas. Com efeito, encontra-se por analisar em detalhe o processo de formação do acervo da galeria, e o seu enriquecimento por meio de aquisições, transferências e doações, assim como reconstituir o papel desempenhado nesse sentido pelo mais prestigiado dos vice-inspetores da Academia, o marquês de Sousa Holstein, figura relevante no contexto artístico-cultural de Oitocentos, que até ao presente não foi objecto de qualquer estudo sobre a sua vida e obra. Os esforços em prol da organização, exposição, divulgação e conservação das pinturas merecem também ser devidamente explorados, tal como a adaptação improvisada de um espaço para as

\footnotetext{
${ }^{10}$ BARATA, Paulo J. S. - Os livros e o Liberalismo: da livraria conventual à biblioteca pública: uma alteração de paradigma, 2003.

${ }^{11}$ Eneias: a coleção de pintura da Biblioteca Nacional de Portugal: do resgate do património artístico conventual na implantação do Liberalismo ao estudo integrado de conservação e divulgação (PTDC/HIS-HEC/113226/2009). Iniciativa conjunta do Artis - IHA/FLUL, da ESTT/IPT e da BNP.

${ }_{12}$ Merece destaque um artigo publicado na versão portuguesa do catálogo da exposição promovida em 1999 pelo Museu Nacional de Arte Antiga em Bona: CARVALHO, José Alberto Seabra e CURVELO, Alexandra - "1834-1981: Breve história da formação de uma colecção". PORFíRIO, José Luís (comiss.) - Museu Nacional de Arte Antiga (cat. expo.), 1999, pp. 44-53.
} 
acolher, frustradas que ficaram as tentativas para construir uma galeria de raiz. processo de catalogação do acervo deve de igual modo ser dado a conhecer, assim como a existência de um conservador interino, sem esquecer a organização do que ficou conhecido por Museu de Arte Ornamental, criado em paralelo à galeria. Estes aspetos revelam bem a escassez de conhecimentos existente, enformando os pontos centrais do estudo que nos propusemos efetuar. Sobre aquele que foi o primeiro museu público de arte de Lisboa, "pouco se sabe, muito pouco até" declara mesmo José Luís Porfírio, no roteiro da coleção de pintura europeia do MNAA ${ }^{13}$.

O fundo documental da ANBA constituiu a principal fonte do nosso estudo, com especial evidência para os livros de atas e de correspondência que, tal como outros documentos pertencentes ao mesmo arquivo, beneficiaram em 2010 de um processo de digitalização levado a cabo pelo Arquivo Nacional da Torre do Tombo (ANTT). Importa assinalar ter esta última entidade assegurado generosamente a sua digitalização, dada a recusa do presidente da Academia em facultar o acesso do investigador ao fundo documental e em assinar um protocolo de colaboração com o projeto "Fontes para a história dos museus de arte em Portugal", comprometendo os objectivos delineados. Tal obrigou-nos a efetuar com a orientadora uma exposição à tutela, tornando assim viável aquela solução que tem vindo a possibilitar outras investigações.

Parte importante da referida documentação foi disponibilizada no site da DirecçãoGeral de Arquivos através da plataforma DIGITARQ, ${ }^{14}$ o que se revelou de grande utilidade para o trabalho em curso, mau grado o facto da informação não ter sido tratada arquivisticamente como poderia ter sido previsto caso a ANBA se associasse ao projeto. Com efeito, a digitalização limitou-se seguir a ordem impressa pela Academia desde o século XIX, com dezenas de milhar de documentos encadernados sem uma ordem cronológica específica, dificultando a pesquisa que se revelou mais

\footnotetext{
${ }^{13}$ PORFÍRIO, José Luís - Pintura europeia: roteiro: Museu Nacional de Arte Antiga, 2005, p. 11.

${ }^{14}$ http://digitarq.dgarq.gov.pt/default.aspx?page=listShow\&searchMode=as\&sort=id\&order=ASC
} 
morosa do que o esperado, para o contribuiu também a lentidão da própria plataforma.

Relevante no contexto da investigação foi também o fundo José de Figueiredo do arquivo do MNAA que encerra um selecionado conjunto de documentos provenientes da Academia, atestando o interesse daquele historiador em se documentar sobre as origens do museu que dirigiu. Tendo beneficiado de tratamento no âmbito do projeto acima referido ${ }^{15}$, a disponibilização online deste fundo ocorreu apenas no decorrer de 2013, quando o nosso trabalho se encontrava já bastante adiantado, pelo que ao contrário do que sucede com o Arquivo da ANBA, optámos por manter nas citações as referências às caixas e pastas de onde as informações foram extraídas. O cruzamento destas informações com as do arquivo académico foram fundamentais para definir os critérios que nortearam a organização da Galeria Nacional de Pintura, bem como para avaliar a ação desenvolvida nesse sentido pelo seu vice-inspetor e pelos respectivos professores.

Não nos foi possível analisar em profundidade o arquivo pessoal do marquês de Sousa Holstein, colocado em hasta pública em Dezembro de 2010 pelo leiloeiro Pedro de Azevedo ${ }^{16}$ como parte integrante da biblioteca de Eugénio da Cunha e Freitas $(1912-2000)^{17}$, tendo sido arrematado por um alfarrabista que o dividiu em lotes procedendo lamentavelmente à sua dispersão ${ }^{18}$. Constituído por centenas de documentos onde a diplomacia e as belas artes tinham o seu principal quinhão, afigurava-se essencial para traçar o perfil biográfico do marquês, tendo-nos sido possível fazer apenas uma consulta apressada do mesmo durante o período de exposição que antecedeu o leilão. Refira-se que tanto a ANBA como o MNAA foram colocados ao corrente da venda, não exercendo nenhuma das instituições o direito

\footnotetext{
${ }^{15}$ NOVO, Andreia; RAMALHEIRA, Ema - "MNAA's historical archives database, 1870-1962. Report of the work undertaken at the Archive of the Museu Nacional de Arte Antiga. Research Fellowship". SILVA, Raquel Henriques da; BAIÃO, Joana; OLIVEIRA, Leonor (coord.) - op. cit., pp. 26-34.

${ }^{16}$ AZEVEDO, Pedro de (org.) - Biblioteca Eugénio da Cunha e Freitas, parte II, 2010, p. 78 (lote 509).

${ }^{17}$ Este estudioso chegou a publicar algumas cartas nele contidas: FREITAS, Eugénio da Cunha e (org.)

- "Cartas de Augusto Filipe Simões para o 1. marquês de Sousa Holstein". Sep. Arqueologia e História, 8a série, vol. X, 1962, pp. 49-59.

${ }^{18}$ Foi arrematado por 2600 euros pelo proprietário d' O manuscrito histórico: livreiros e antiquários Lda., estabelecimento sediado na Calçada do Sacramento, n.o 50, Lisboa. Os contatos estabelecidos desde logo com esta casa revelaram-se infrutíferos.
} 
de opção na compra do arquivo que tão relevante se afigurava para o enriquecimento dos seus fundos documentais.

As consultas em bibliotecas foram naturalmente recorrentes ao longo da investigação, com especial evidência para a Biblioteca Nacional de Portugal (BNP), para a Biblioteca do MNAA e para a Biblioteca de Arte da Fundação Calouste Gulbenkian. Para além da consulta de dissertações, artigos e catálogos, pretendemos sistematizar informações relevantes contidas na imprensa coeva, com demorada indagação nos microfilmes do Diario de Noticias da BNP cujo manancial de informação está bem expresso ao longo de certos capítulos. Entre outras publicações consultadas assinale-se O Occidente, a Revista Universal Lisbonense, a Revista Contemporanea de Portugal e Brazil, o Jornal das Bellas-Artes e o jornal Artes e Letras, onde o marquês de Sousa Holstein chegou a participar ativamente como autor.

Refira-se que tanto nos títulos dos periódicos como nos das restantes publicações, entendemos manter a grafia original, atualizando-a todavia nas citações de maneira a tornar a leitura mais fluida. Seguimos a Norma Portuguesa 405 na inclusão das notas de rodapé, assim como nas referências bibliográficas.

No decorrer do processo de investigação, optámos por organizar o nosso trabalho aliando uma leitura cronológica à reflexão de temas centrais necessários para o conhecimento do objecto em estudo. Como tal, desenvolvemos a tese de acordo com a estrutura seguidamente elencada, num total de 340 páginas de texto corrido, cumprindo assim os limites impostos pelas normas regulamentares da FCSH-UNL (máx. 350 páginas, incluindo referências bibliográficas e excluindo anexos ${ }^{19}$ ). número indicado não contempla os espaços ocupados pelas imagens que entendemos integrar ao longo do texto, de maneira a tornar a leitura das mesmas mais imediata, prescindindo-se portanto do anexo.

\footnotetext{
19 Ponto 3o do artigo 220 das Normas regulamentares relativas aos Ciclos de Estudos de Doutoramento FCSH-UNL. Despacho n.ㅇ 16/2013
} 


\section{PARTE - ANTECEDENTES DA GALERIA NACIONAL DE PINTURA}

\section{O depósito de S. Francisco}

Na sequência da extinção dos conventos masculinos, o Estado ficou com um enorme volume de bens para conservar, levando à criação no convento de S. Francisco de Lisboa de um depósito, onde se arrecadaram diversas pinturas das casas religiosas da região da Estremadura. Este processo é objecto de análise, nomeadamente, o papel desempenhado por António Nunes de Carvalho, encarregado do depósito, e pela comissão administrativa que o substituiu nessas funções.

\section{A Academia de Belas Artes e o corpo académico}

Nascida em 1836 por decreto de Passos Manuel, e igualmente instalada no convento de S. Francisco, a Academia de Belas Artes de Lisboa é aqui colocada em evidência, dando-se a conhecer o seu processo de formação, as chefias e os docentes escolhidos.

\subsection{Esforços de organização, divulgação e conservação do acervo}

A nova instituição de ensino artístico cedo reclamou a posse das pinturas conservadas no depósito, conseguindo, por ação de Silva Oeirense, proceder à escolha e transferência das obras consideradas mais relevantes. Importa explorar também os esforços desenvolvidos por outros académicos, com destaque para António Manuel da Fonseca, em prol da organização do espólio e da sua divulgação através da gravura, assim como os cuidados tidos para com a sua conservação.

\subsection{Projetos para a construção de uma galeria}

As deficientes condições do edifício do antigo convento de S. Francisco, levaram durante décadas os académicos a acalentar ser possível proceder à sua reformulação. Como daremos a conhecer, o professor João Pires da Fonte elaborou alguns projetos onde previa a construção de uma galeria de pintura, sem qualquer consequência prática, contentando-se a instituição com alguns reparos efectuados nas salas de aula. 


\subsection{Outras incorporações: a coleção da rainha Carlota Joaquina.}

Esgotado o abundante caudal dos primeiros conventos extintos, pouco mais se passou em termos de incorporações no acervo da Academia. A iniciativa do governo ao adquirir em 1848 parte selecionada da coleção de pintura da rainha Carlota Joaquina permaneceu um caso praticamente isolado que importa analisar em detalhe, constituindo a grande exceção para o incremento do acervo no período anterior à vigência de Sousa Holstein.

\section{PARTE - O MARQUÊS VICE-INSPETOR}

\section{Dados biográficos}

Centramo-nos aqui no percurso pessoal e profissional de Sousa Holstein, com especial atenção ao atribulado historial familiar e aos exemplos do avô e do pai a quem as belas artes interessaram. É igualmente evidenciada a frequência do curso de Direito em Coimbra, às funções diplomáticas exercidas em Itália, os cargos políticos, e o casamento com D. Maria Eugénia de Melo Breyner. A morte prematura do marquês e a dispersão do seu espólio artístico e bibliográfico será também dada a conhecer.

\section{Funções e relações no meio artístico: da Academia à Sociedade Promotora das}

\section{Belas Artes}

Em 1862, Sousa Holstein é nomeado vice-inspetor da Academia de Belas Artes, lutando pela modernização daquele estabelecimento de ensino artístico, em prol do qual desenvolveu um conjunto de contactos internacionais que importa destacar. Merece de igual modo a nossa atenção o papel desempenhado à frente da Sociedade Promotora das Belas Artes cujo historial procuramos traçar.

\section{Produção historiográfica}

Possuidor de uma boa biblioteca, Sousa Holstein, deixou-nos uma fragmentária mas assinalável obra ensaística, sobretudo no domínio da pintura portuguesa, que será objecto da nossa atenção. Em destaque estarão as demolidoras críticas de Joaquim de Vasconcelos ao trabalho desenvolvido nesse sentido pelo marquês. 


\subsection{Domingos Sequeira, o artista de eleição}

Possuidor de um relevante conjunto de trabalhos de Domingos Sequeira, Sousa Holstein a ele se dedicou com empenho, procurando divulgar e valorizar a obra daquele que cedo reconheceu como o mais representativo artista da transição do século XVIII para o XIX no nosso país. Foi o seu primeiro biógrafo, através de uma série de artigos publicados na revista Artes e Letras, acerca dos quais nos iremos deter.

\section{PARTE - A FORMAÇÃO DA GALERIA NACIONAL DE PINTURA}

\section{O enriquecimento do acervo}

Em 1864, Sousa Holstein nomeou uma comissão encarregada de examinar as coleções de pintura que se encontravam disponíveis para venda em Lisboa, no intuito de incrementar o acervo. Constituída pelos professores de pintura da Academia, a comissão apresentou um relatório cuja análise se revela da maior importância para o conhecimento do colecionismo da época, nomeadamente no que diz respeito a figuras como Husson da Câmara, Sousa Lobo ou Sousa Cambiaço.

\subsection{Gesto mecenático de D. Fernando II}

Atendendo às dificuldades da Academia, D. Fernando II passou a ceder da dotação que lhe era atribuída pelo Estado uma parte destinada à compra de pinturas. Damos a conhecer o papel do vice-inspetor e da "comissão de pintura" na gestão das verbas com vista à aquisição das coleções atrás mencionadas, acrescidas do acervo reunido pelo conde de Farrobo. A dinâmica aquisitiva estender-se-á igualmente a conjunto de personalidades olvidadas - Bustelli, Anastácio Rosa, O’Sullivan, entre outras - e em que nos iremos deter.

\subsection{A coleção Mayne e outras aquisições}

Se o enriquecimento do acervo da Academia se deveu ao gesto mecenático de $D$. Fernando II, convém assinalar a ocorrência de outras incorporações fora desse âmbito, começando por uma trintena de quadros pertencentes ao chamado Museu 
Maynense a que iremos consagrar a nossa atenção. São ainda examinadas algumas propostas de aquisição não realizadas por incapacidade financeira, com a honrosa exceção do tríptico de Jan Provoost.

\subsection{Transferências e pedidos de transferência}

A transferência de espécies pictóricas na posse de instituições públicas e religiosas foi uma realidade que contribuiu pontualmente para o enriquecimento da coleção académica. Maior expressão tiveram os pedidos de transferência de pinturas que se encontravam na posse de dioceses ou casas religiosas extintas, nem sempre atendidos, como sucedeu com o caso do convento da Madre de Deus de Lisboa.

\subsection{Doações}

Apoiado do exemplo da National Gallery de Londres, Sousa Holstein depositava grandes esperanças nesta modalidade de enriquecimento da coleção mas, como veremos, poucos foram os doadores a tomar tal iniciativa. Registou-se todavia alguma adesão por parte de estrangeiros que procederam à remessa de algumas obras no intuito de virem a ser agraciados com distinções honoríficas, numa curiosa forma de promoção social que é aqui dada a conhecer.

\subsubsection{Doações Carvalhido}

Especial destaque entre os doadores merece o conde de Carvalhido, negociante portuense enriquecido no Brasil e residente em Paris onde desenvolveu hábitos colecionistas. No intuito de vir possuir uma sala na galeria com o seu nome, procedeu a partir de 1865 à remessa de diversas pinturas para Lisboa, atingindo o volume de obras doadas tal dimensão que justifica por si só o tratamento individualizado que the consagramos.

\section{A organização da galeria}

Coube à "comissão de pintura" a tarefa de proceder à organização da galeria que se improvisou nas antigas salas de aula de pintura histórica e de paisagem, reformuladas com o auxílio pecuniário de D. Fernando II. É reconstituído o trabalho 
desenvolvido nesse sentido por Miguel Ângelo Lupi e Cristino da Silva, cumprindo os objectivos definidos nesse sentido pelo vice-inspetor.

\subsection{A catalogação do acervo}

A necessidade de um catálogo da coleção de pintura foi desde cedo reivindicada pelos responsáveis da Academia, com diversas tentativas frustradas nesse sentido. Sousa Holstein procurou materializar esse projeto, numa nova sucessão de avanços e recuos, com diferentes contributos aqui analisados. O projeto será concretizado, de uma forma menos ambiciosa do que inicialmente previsto, em 1868, com a inauguração da Galeria Nacional de Pintura.

\subsubsection{O regulamento}

Publicado no catálogo, o regulamento da galeria é constituído por 24 artigos que importa dar a conhecer por estipularem regras e orientações aos visitantes ou utilizadores do equipamento que se disponibilizou.

\subsection{Abertura ao público e planos de expansão}

A abertura ao público da galeria constituiu um factor de afirmação da Academia e de Sousa Holstein que viu concretizado um projeto há muito acalentado. A atenção do marquês centrou-se depois no aumento do espaço ocupado por aquele equipamento, pugnando energicamente junto dos poderes públicos pela sua concretização.

\subsection{A fotografia ao serviço da galeria: o caso de Jean Laurent}

A atenção dada aos processos fotográficos como forma de documentar e divulgar a pinacoteca foi uma realidade, sendo assinalados os casos de Pereira Guimarães e Augusto César Pardal \& Filho. Especial destaque merece o exemplo do francês Jean Laurent que ao chegar a Lisboa, em 1869, será bem acolhido pelo vice-inspetor, desenvolvendo na galeria uma vasta campanha fotográfica.

\subsection{Conservação e restauro}


Desde cedo o vice-inspetor revelou preocupação pela conservação e restauro do acervo. Em análise estará o papel desenvolvido por Silva Oeirense e pelos artistas agregados nesse sentido, assim como por uma comissão presidida por Tomás da Anunciação que propiciará a contratação de alguns restauradores externos.

\subsubsection{Alfredo Augusto da Costa Camarate, conservador}

Por iniciativa do vice-inspetor ocorrerá a nomeação de um funcionário público em comissão na Academia, Alfredo Augusto da Costa Camarate, para o cargo de conservador interino da galeria, figura em que nos iremos deter, dando conta de algumas tarefas desenvolvidas pelo próprio.

\section{Em busca de soluções}

As inadequadas condições da galeria levaram a que fosse nomeada uma comissão encarregada de examinar o espaço e propor soluções, com algumas consequências imediatas de cariz preventivo. Em 1875, outra comissão propôs aos puderes públicos uma reforma do ensino artístico e a organização de um museu nacional, tendo Sousa Holstein elaborado um relatório que será aqui analisado.

\subsection{Um palácio para o museu nacional}

Na sequência dos trabalhos da comissão de 1875 , foi discutida a instalação do museu nacional que se perspetivava, importando elencar as diferentes hipóteses debatidas a esse respeito. Vários palácios foram considerados, optando-se pelo do marquês de Abrantes cujo arrendamento se recomendou ao governo. Esta solução não teve todavia seguimento e, como daremos a conhecer, o marquês viu-se obrigado a efetuar outra proposta que quase ganhou forma.

\section{PARTE - AS RESTANTES COLEÇÕES DA ACADEMIA}

\section{Diferentes secções para um museu nacional: o núcleo de arte ornamental}

O museu nacional ideado por Sousa Holstein deveria incluir diferentes secções, entre as quais uma de arte ornamental que desde cedo vinha sendo organizada, enformando um pequeno núcleo museológico paralelo à galeria. Influenciada pelo 
exemplo londrino do South Kensington Museum, esta iniciativa é aqui objecto da nossa atenção.

\section{Tesouros conventuais}

A transferência para a Academia das alfaias litúrgicas dos conventos extintos conservadas na Casa da Moeda está na base do núcleo fundador do Museu de Arte Ornamental. Como daremos a conhecer, essas alfaias irão atrair a atenção de alguns fotógrafos como Jean Laurent ou Pardal \& filho, no intuito de comercializaram as respectivas provas.

\section{Enriquecimento do acervo}

Colocamos aqui em evidência os esforços do marquês de Sousa Holstein no incremento do acervo, através de campanhas de recolha de objetos nos conventos femininos entretanto extintos, de transferências e trocas com corporações religiosas e organismos públicos. Não são esquecidas as ofertas de alguns particulares, assim como as aquisições efectuadas junto de negociantes da especialidade.

\section{Derradeiras aquisições}

Na sequência da morte de Sousa Holstein e perante a existência de dívidas relativas aos objetos ultimamente adquiridos, será nomeada uma comissão com o fim de examinar a legalidade dos contratos de aquisição. Presidida por Delfim Guedes, a comissão elaborou um relatório por nós analisado, pondo em evidência várias faltas, da omissão de dados a certas contradições, sempre em desfavor do marquês cuja atuação importava criticar para salvaguardar os interesses do Estado.

Durante o período de redação da tese, fomos dando conta dos resultados da investigação através de comunicações e de artigos submetidos a revistas da especialidade. A revista Mvseu publicou um artigo intitulado "O Museu de Arte Ornamental da Academia de Belas Artes de Lisboa" que resulta grosso modo de uma 
síntese dos pontos que enformam a IV parte da tese $\mathrm{e}^{20}$. Um dos aspetos abordados nesta parte, a aquisição pela Academia do grande painel de azulejos representando uma vista de Lisboa antes do terramoto de 1755, foi desenvolvido numa comunicação proferida no âmbito do I encontro sobre património azulejar - Lisboa: o azulejo e a cidade ${ }^{21}$ organizado pelo Instituto de História da Arte da FCSH-UNL em colaboração com a Câmara Municipal de Lisboa. Um artigo baseado naquela comunicação, alargado também à entrada de outros painéis de azulejos nas coleções académicas, será publicado no n.o 11 da Revista de História da Arte (IHA$\mathrm{FCSH} / \mathrm{UNL})^{22}$.

As doações do conde de Carvalhido à Galeria Nacional de Pintura a que nos dedicámos em profundidade no ponto 1.5.1, foram apresentadas no colóquio Coleções de arte em Portugal e Brasil nos séculos XIX e XX: perfis e trânsitos ${ }^{23}$, organizado pelo ARTIS - Instituto de História da Arte da Faculdade de Letras de Universidade de Lisboa, em parceria com o Programa de Pós-Graduação em Artes Visuais da Escola de Belas Artes da Universidade Federal do Rio de Janeiro, iniciativa que contou com a publicação de $\operatorname{atas}^{24}$. O papel do marquês de Sousa Holstein na formação da Galeria Nacional de Pintura foi por sua vez objecto de uma comunicação no colóquio $O$ património artístico das ordens religiosas: entre o Liberalismo e a atualidade $^{25}$, resultante do projeto Eneias já referido ${ }^{26}$.

\footnotetext{
${ }^{20}$ XAVIER, Hugo - "O museu de arte ornamental da Academia de Belas Artes de Lisboa". Mvseu, IV série, n.o 19, 2011-2012, pp. 67-94.

${ }^{21}$ Teatro Aberto, 25 de Novembro de 2011

${ }^{22}$ XAVIER, Hugo - "Incorporações de azulejos pela Academia de Belas Artes na segunda metade do século XIX: a aquisição da Vista de Lisboa”. Revista de História da Arte, n.o 11, 2014/2015 [no prelo]

${ }^{23}$ Fundação Calouste Gulbenkian, 18 de Junho de 2014

${ }^{24}$ Idem - "As doações do conde de Carvalhido à Academia de Belas Artes de Lisboa". NETO, Maria João; MALTA, Marize (eds.) - Coleções de arte em Portugal e Brasil nos séculos XIX e XX: perfis e trânsitos, 2014, pp. 399-424.

${ }^{25}$ Biblioteca Nacional de Portugal, 21 de Fevereiro de 2014

${ }^{26}$ Idem - "O marquês de Sousa Holstein e a formação da Galeria Nacional de Pintura da Academia de Belas Artes de Lisboa". SOARES, Clara Moura (coord.) - O património artístico das ordens religiosas: entre o Liberalismo e a atualidade, 2014/2105 [no prelo].
} 


\section{PARTE - ANTECEDENTES DA GALERIA NACIONAL DE PINTURA}

“É de justiça dizer-se que, atendendo a todas as preocupações e embaraços daquele tempo, se tratou ainda assim de semelhante arrecadação de um modo mais satisfatório do que seria talvez de esperar".

marquês de Sousa Holstein, 1868

\section{O depósito de S. Francisco}

Em 1834, assim que foi conseguida uma relativa pacificação do país, com a assinatura da Convenção de Évora Monte, impuseram-se decisões radicais que pudessem imprimir à vitória liberal o selo de garantia e de irreversibilidade. 0 sucesso militar sobre os absolutistas tinha sido obtido a muito custo, e D. Miguel (1802-1866) contava ainda com uma ampla base de apoio social, ideológica e económica; por outro lado, o Tesouro estava depauperado, tornando-se indispensável encontrar um meio que viesse em socorro da dívida pública e do défice orçamental. A solução gizada por Joaquim António de Aguiar (1792-1884) procurou garantir, em simultâneo, a resolução da situação financeira e a consolidação do regime liberal, erradicando um dos principais esteios do absolutismo ${ }^{1}$.

Com efeito, alguns dias após a Convenção de Évora Monte, teve lugar aquela que tem sido considerada uma das mais audaciosas medidas tomadas após 1820, constituindo no dizer de Luís Espinha da Silveira um "poderoso golpe vibrado na estrutura social do antigo regime ${ }^{\prime 2}$. Falamos do decreto de 28 de Maio, promulgado a 30 do mesmo mês que, de uma assentada, extinguiu todas as ordens regulares masculinas (conventos, mosteiros, colégios, hospícios, etc.) e nacionalizou os seus bens, permitindo ao governo atingir os dois fins estratégicos acima enunciados. Não foram então abrangidas as corporações femininas, cujas casas persistirão até à

\footnotetext{
${ }^{1}$ SILVA, António Martins da - "O fenómeno desamortizador e a sua inserção histórica". MATTOSO, José (dir.) - História de Portugal, vol. V, 1993, pp. 339-340.

${ }^{2}$ SILVEIRA, Luís Espinha da - "A venda dos bens nacionais (1834-43): uma primeira abordagem". Análise Social, vol. XVI (61-62), 1980, p. 90.
} 
morte das últimas freiras, solução de compromisso que um ano antes havia levado já à proibição dos noviciados ${ }^{3}$.

Convém salientar que este tipo de reações contra o clero regular inserem-se num movimento iniciado no século XVIII que visava a redução da sua influência e poderio económico, como ficou expresso com a expulsão dos Jesuítas empreendida pelo marquês de Pombal. Foi precisamente na segunda metade desse século que, sob a influência do lluminismo, se começam a fazer sentir algumas críticas contra a relaxação de costumes de muitos dos seus membros, dando a entrever claros sintomas da decadência das ordens. Esta atitude crítica seria herdada pelo nosso Liberalismo que, atendendo aos exemplos externos, sobretudo francês e espanhol, caminhou a passos largos para a sua abolição, tendo todavia chegado a considerar um processo de reforma, inserido numa reorganização geral de todo o aparelho eclesiástico ${ }^{4}$.

Mal foram extintas as corporações religiosas, diversas portarias começaram a tratar da arrecadação e/ou da venda dos seus bens, começando pelos chamados "bens móveis comuns" (objetos domésticos, alfaias agrícolas...) e "semoventes" (géneros comestíveis, aves, gados e outros da mesma natureza), desde logo colocados em hasta pública ${ }^{5}$. Outra categoria de bens móveis que convém distinguir dos anteriores, é a dos objetos preciosos em ouro e prata, por vezes enriquecidos com pedraria, na sua maioria utensílios de culto. Alguns foram distribuídos pelas igrejas mais necessitadas conforme estipulava o decreto de 30 de Maio, outros extraviaramse antes ou durante o processo de recolha ${ }^{6}$, e o restante deu entrada na Casa da Moeda de Lisboa que amoedou e vendeu parte significativa, com perdas históricoartísticas relevantes ${ }^{7}$, tendo conservado apesar de tudo um núcleo que mais tarde será transferido para a Academia de Belas Artes de Lisboa ${ }^{8}$.

\footnotetext{
${ }^{3}$ Decreto de 5 de Agosto 1833. Idem, ibidem, p. 88

${ }^{4}$ SILVA, António Martins da - Nacionalizações e privatizações em Portugal: a desamortização oitocentista, 1997, p. 25

${ }^{5}$ Portarias de 4 e 20 de Junho de 1834 respectivamente. SILVEIRA, Luís Espinha da - op. cit., p. 94.

${ }^{6}$ A esses roubos se refere posteriormente um decreto que nos diz existirem "escondidas e sobnegadas consideráveis quantias de dinheiro, joias ou alfaias pertencentes aos extintos conventos, algumas das quais estariam enterradas. Idem, ibidem, pp. 94-95.

7 CARVALHO, José Alberto Seabra - "Dos conventos aos museus: histórias que o forno apagou". Inventário do Museu Nacional de Arte Antiga: coleção de ourivesaria: do Românico ao Manuelino, vol. I, 1995, pp. 20-21.

${ }^{8}$ A este respeito cf. o ponto 2 da IV parte deste trabalho.
} 
Especial interesse oferece-nos outra categoria de bens móveis então considerada, constituída pelas bibliotecas, objetos científicos e obras de arte dos religiosos que o Estado quis conservar, procurando travar os descaminhos entretanto registados com a debandada dos frades. Nesse sentido importa evidenciar o gesto de D. Pedro IV (1798-1834) na qualidade de regente do reino ao manifestar em Julho de 1834 ser necessário "suster a venda de quadros e pinturas", procurando de igual modo “impedir a sua deterioração (...) e as trocas e malversações que porventura podem ocorrer". Com uma consciência patrimonial digna de ser assinalada, determinava ainda que se procedesse "à sua classificação e colocação em um só edifício, onde possa fiscalizar-se a sua arrecadação e conveniente conservação, até que definitivamente se estabeleça a galeria ou galerias que devem formar-se com aquelas mencionadas pinturas, muitas das quais são preciosíssimas" ${ }^{\prime 9}$.

A preocupação para com a preservação destes e outros bens, assim como para com a sua futura utilização para fins públicos, era partilhada pelo governo chefiado por D. Pedro de Sousa Holstein (1781-1850), ainda marquês de Palmela, e a 16 de Outubro de 1834, falecido D. Pedro IV, uma portaria assinada pelo bispo-conde D. Francisco de S. Luís (1766-1845), ministro do Reino, criava um "depósito das livrarias, cartórios, pinturas e de mais preciosidades literárias e científicas dos extintos conventos de Lisboa, e província da Estremadura, para aí serem devidamente guardadas, classificadas e inventariadas". Para dirigir esses trabalhos seria na mesma ocasião nomeado um fiel adepto do novo regime, António Nunes de Carvalho (17861867), que estava igualmente autorizado a "requisitar de todas e quaisquer autoridades a entrega das referidas livrarias e mais objetos mencionados, podendo propor os indivíduos que julgar necessários para o coadjuvarem nesta comissão"10. Doutorado em Jurisprudência pela Universidade de Coimbra (1822), Nunes de Carvalho havia desempenhado anteriormente as funções de professor de Latim em Viseu, de Humanidades em Évora, a convite de Frei Manuel do Cenáculo, e de Lógica

\footnotetext{
${ }^{9}$ Apud SOARES, Clara Moura; RODRIGUES, Rute Massano - "A criação de um Museu Nacional de Belas Artes no Convento de S. Francisco: um desígnio de D. Pedro IV". Artis, n.o 1, 2. a série, 2013, pp. 170 171 (Ministério do Reino, ofício de 20 de Outubro de 1834, aludindo à portaria de 15 de Julho daquele ano). A respeito da dimensão cultural e artística de D. Pedro IV cf. SOARES, Clara Moura - "D. Pedro I do Brasil, IV de Portugal: o 'gosto do bello' e o incremento das Belas-Artes: traços de um perfil quase desconhecido do rei-soldado". NETO, Maria João; MALTA, Marize (eds.) - Coleções de arte em Portugal e Brasil nos séculos XIX e XX: perfis e trânsitos, 2014, pp. 381-398.

${ }^{10}$ Boletim da Academia Nacional de Belas-Artes: documentos, III, 1938, pp. 4-5, doc. VII.
} 
no Real Colégio das Artes em Coimbra. O seu apoio ao partido liberal levou-o, em 1823, a ser incluído na lista de proscrição dos lentes associados àqueles ideais e, cinco anos mais tarde, após a subida ao trono de D. Miguel, foi obrigado a exilar-se, dedicando-se ao exame dos manuscritos portugueses nas bibliotecas de Londres e Paris. Publicou então alguns trabalhos e foi escolhido para professor de Literatura Portuguesa da futura rainha D. Maria II (1819-1853), até à sua partida para Lisboa em $1833^{11}$.

Os contactos com os exilados políticos e com a própria soberana levaram-no a conhecer de perto os novos agentes do poder, entrando na disputa pelos empregos públicos que tem lugar com o novo regime. Em Setembro de 1834, escreve uma carta dirigida a um ministro de Estado, na qual faz alusão aos cargos para os quais se achava apto, tais como o de reitor do Colégio dos Nobres ou bibliotecário-mor, mostrando-se igualmente disponível para assumir as funções de encarregado do que viria a ser o depósito dos conventos extintos, argumentando com "o conhecimento especial que tenho dessas matérias, e o estudo e experiência das principais bibliotecas de Inglaterra e de França"12. Entre os cargos mencionados era o único que se encontrava vago, afigurando-se assim natural a sua nomeação.

A portaria de 16 de Outubro que esteve na base da criação do referido depósito, determinava como local o antigo convento de S. Francisco (fig. 1), "que pela sua situação central e sólida construção, é o edifício mais próprio para esse fim" ${ }^{13}$. Dias antes, outra portaria havia encarregue António Nunes de Carvalho de examinar "a capacidade e cómodos do extinto convento de S. Francisco da cidade, por assim convir ao bem público" ${ }^{14}$, o que revela ter sido aquela escolha sancionada pelo próprio, abandonando-se em definitivo outras hipóteses inicialmente consideradas pelo governo, nomeadamente, os conjuntos monásticos de S. Francisco de Xabregas e de Nossa Senhora do Monte do Carmo ${ }^{15}$.

\footnotetext{
${ }^{11}$ Seguimos aqui as informações fornecidas por BARATA, Paulo J. S. - Os livros e o Liberalismo: da livraria conventual à biblioteca pública: uma alteração de paradigma, 2003, p. 33.

${ }^{12}$ Apud. Idem, ibidem, p. 33.

${ }^{13}$ Boletim da Academia Nacional de Belas-Artes: documentos, III, 1938, p. 5, doc. VII.

${ }^{14}$ Idem, p. 4, doc. VI.

${ }^{15}$ SOARES, Clara Moura; RODRIGUES, Rute Massano - "A salvaguarda do património históricoartístico na regência de D. Pedro IV: a consciência patrimonial no contexto das guerras liberais". Atas do Simpósio Património em Construção: contextos para a sua preservação, 2011, p. 353.
} 


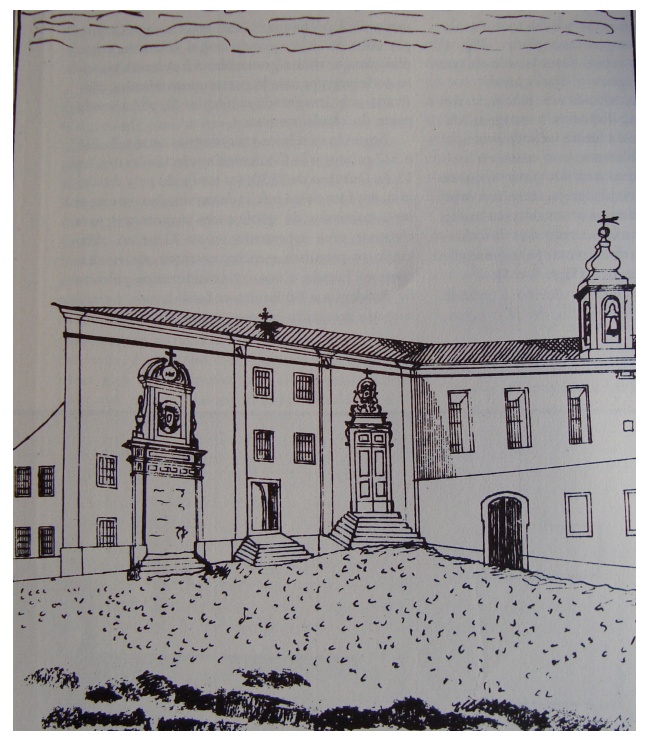

Fig. 1 - Convento de São Francisco de Lisboa, gravura publicada in Monumentos sacros de Lisboa em 1833

O vetusto edifício franciscano fora fundado em 1217 por um frade vindo de Assis, implantando-se numa colina sobranceira ao Tejo, o chamado Monte Fragoso, local então ermo e despovoado. Cresceu exponencialmente à custa de patrocínios régios e aristocráticos, ao ponto de ficar conhecido por "cidade de S. Francisco", tal a grandiosidade da sua fábrica e o poder da sua influência na vida religiosa, social e cultural de Lisboa. Alvo de dois incêndios em 1707 e 1741 respectivamente, obrigando a obras de reconstrução onde se consumiram grossos cabedais, seria muito prejudicado pelo terramoto de 1755 e com o fogo que se lhe seguiu. Começou então a lenta reedificação da igreja, com traço majestoso de Francisco António Cangalhas, "arquiteto geral da cidade e águas livres", seguido pelo seu discípulo e sucessor, Honorato José Correia, obra que se encontrava longe de estar concluída quando foram extintas as ordens religiosas ${ }^{16}$. As dependências do convento com as suas extensas galerias estavam em parte reformadas, tendo sido precisamente 0 local escolhido para a instalação do referido depósito.

Logo a partir de Novembro de 1834, começaram a dar entrada no edifício diversas pinturas recolhidas em diferentes casas religiosas da região de Lisboa, elaborando-se

\footnotetext{
${ }^{16}$ A este respeito cf. CALADO, Margarida - O convento de São Francisco da Cidade. Coleção $B$ 'A Biblioteca d'Artes, n. 1, 2000; RAMALHO, Maria de Magalhães - "O sítio e o convento de S. Francisco da Cidade: da fundação ao Terramoto de 1875" e MONTEIRO, Joana Sousa - "Os Espaços do conventos de S. Francisco: da progressiva desagregação ao Museu do Chiado". SILVA, Raquel Henriques da (coord.) - Obraçom: Museu do Chiado: histórias vistas e contadas (cat. expo.), 1995, pp. 19-34.
} 
relações das existências, por convento, indicando-se por vezes os locais concretos de onde foram retiradas (refeitórios, dormitórios, livrarias, etc.) ${ }^{17}$. Muito sumárias, identificam quase sempre os temas ou personagens representados, aludindo ao suporte em que foram pintadas, à existência ou não de molduras e, quando muito, ao estado de conservação. Bastante mais rara é a identificação ou atribuição de autorias ou escolas (registam-se algumas referências a "Vasco", o Grão Vasco, e também a Josefa de Óbidos, para além de uma ou outra alusão fantasista a grandes mestres da pintura europeia como Rafael ou Rubens). Parte importante destas relações foram efectuadas pelo pequeno corpo de funcionários do depósito, constituído essencialmente por excedentes oriundos de organismos públicos extintos pelo Liberalismo, egressos recrutados, e capitães de fragata reformados em regime de voluntariado. A sua atividade ficou marcada por uma constante mobilidade e até algum absentismo, revelando pouca motivação para levarem a cabo a tarefa de organização do acervo que se ia recebendo ${ }^{18}$.

Criado num âmbito geográfico delimitado à província da Estremadura, depressa o depósito obteve o alargamento da sua ação. A 26 de Dezembro de 34, uma portaria do Ministério do Reino ordenava "fazer extensiva à província do Alentejo as disposições constantes da portaria de 16 de Outubro próximo passado", autorizando António Nunes de Carvalho a solicitar às autoridades daquela região os bens artísticos e livrescos ${ }^{19}$. Para a guarda e segurança do espólio que se ia acumulando em S. Francisco, reconhecia a portaria de 17 de Janeiro de 1835 uma representação entretanto efectuada pelo mesmo encarregado, mostrando a conveniência de passar a residir no edifício com alguns funcionários: "Hei por bem conceder-lhe faculdade para que possa habitar dentro do mencionado convento, enquanto durar a comissão de que está incumbido, e igualmente quatro empregados do dito depósito, aos quais designará as casas desocupadas que forem suficientes para sua habitação, e mais próprias para melhorar a guarda do depósito e pronto expediente do serviço"20.

\footnotetext{
${ }^{17}$ Relações publicadas no Boletim da Academia Nacional de Belas-Artes: documentos, III, 1938 e IV, 1939.

${ }^{18}$ BARATA, Paulo J. S. - op. cit., p. 83.

${ }^{19}$ Portaria de 26 de Dezembro de 1834. Boletim da Academia Nacional de Belas-Artes: documentos, III, 1938, p. 15, doc. XVI.

${ }^{20}$ Portaria de 17 de Janeiro de 1835. Boletim da Academia Nacional de Belas-Artes: documentos, III, 1938, p. 64, doc. XLVXX.
} 
Três semanas mais tarde, empenhado na organização do acervo pictórico e na sua futura disponibilização, o bispo-conde nomeava uma comissão para escolher e classificar os "mais de mil quadros de pintura, e entre eles um grande número dos mais excelentes e primorosos que se têm recolhido nas casas religiosas extintas nesta capital, e suas vizinhanças, e que devem a seu tempo servir à fundação de um Museu Nacional de Belas Artes"21. Importa abrir aqui um parêntesis e referir que em 1833 havia sido fundado na cidade do Porto o primeiro museu público de arte do país, iniciativa de D. Pedro IV a partir de uma sugestão do lente de desenho da Academia Real de Marinha e Comércio, João Baptista Ribeiro (1790-1868). Seria aquele artista incumbido de organizar o estabelecimento, recorrendo aos bens artísticos daquela Academia, das casas sequestradas aos opositores do Liberalismo, e dos conventos extintos, tendo sido precisamente escolhido como local o convento de Santo António da Cidade ${ }^{22}$. De acordo com o regulamento redigido pelo diligente Baptista Ribeiro, o museu serviria sobretudo aos artistas e alunos de Belas Artes mas "as obras magistrais que porventura ali estejam, espelharão até nas últimas classes do povo o gosto do belo e o sentimento das artes" ${ }^{23}$, espelhando assim os ideais liberais empenhados na generalização da educação como condição de progresso ${ }^{24}$. Os museus públicos constituíam portanto uma componente julgada indispensável da nova ordem, não podendo a capital ficar privada de um equipamento já existente na segunda cidade do reino. Diversas contrariedades obstaram todavia à concretização daquele projeto, e Lisboa muito terá de aguardar até ver nascer o seu museu de arte.

É neste contexto que deverá ser enquadrada a portaria do bispo-conde e o consequente indigitamento da comissão, composta por "artistas e pessoas inteligentes, as quais concorrendo ao referido depósito em um ou dois dias de cada semana, assentem de comum acordo na escolha, plano de classificação e colocação

\footnotetext{
${ }^{21}$ Portaria de 11 de Fevereiro de 1835. Idem, p. 62, doc. XLVIII.

${ }^{22}$ Para uma análise aprofundada à criação do Museu Portuense cf. ALMEIDA, António Manuel Passos - Museu Municipal do Porto: das origens à sua extinção (1836-1940), 2008. Cf. também FERREIRA, Emília - História dos museus públicos de arte no Portugal de Oitocentos: 1833-1884, 2001, pp. 54-98. ${ }^{23}$ RIBEIRO, João Baptista - Exposição historica da creação do Museo Portuense: com documentos officiaes para servir à historia das bellas artes em Portugal e à do cêrco do Porto, 1836, p. 15, doc. 7.

${ }^{24}$ SILVA, Raquel Henriques da - "Os museus: história e prospectiva". PERNES, Fernando (coord.) Panorama da cultura portuguesa no século XX, 2002, p. 68.
} 
que Ihe parecer mais útil ao fim do futuro estabelecimento do Museu Nacional”25. Presidiu aos trabalhos António Nunes de Carvalho, tendo sido convidados o cónego Luís Duarte Vilela da Silva (1761-1842/3), erudito investigador e editor de Cyrillo Volkmar Machado, e os seguintes artistas: Joaquim Rafael (1783-1864), José da Cunha Taborda (1766-1834), José António do Vale (1765-1840), Maurício José Sendim (1786-1870) e António Manuel da Fonseca (1796-1890), "dos quais todos espera Sua Majestade que desempenharão este tão agradável como útil trabalho, com o zelo que os caracteriza, e de que todos têm dado abonadas provas" concluía a mesma portaria ${ }^{26}$.

Provável resultado daquela iniciativa, foram os trabalhos de restauro que meses mais tarde se iniciaram em alguns dos painéis, com destaque para os mais antigos que se associavam na generalidade ao então mítico Vasco Fernandes, deteriorados não só por ação do tempo mas também pelo pouco criterioso apeamento e transporte dos mesmos até ao depósito. O estado dos quadros não passou seguramente desapercebido aos membros da comissão, o que levou António Nunes de Carvalho a oficiar em Setembro de 1835 ao novo ministro do Reino, Rodrigo da Fonseca Magalhães (1787-1858), manifestando "grande receio que as preciosas pinturas de Grão Vasco feitas em madeira (...) sofram com a humidade (...), se as tábuas soltas em que se acham não forem a tempo bem unidas e ligadas solidamente em caixilhos próprios" ${ }^{27}$. Dando seguimento ao pedido do encarregado que sugeria para a tarefa um funcionário da repartição das Obras Públicas, o ministro ordenava pouco depois "que fiquem trabalhando nos reparos necessários nas pinturas de Grão Vasco e debaixo das ordens do dito doutor, o pintor empregado na mesma repartição, André Monteiro da Cruz, e os dois oficiais marceneiros por ele escolhidos"28. Miguelista de coração, Monteiro da Cruz (17701851) havia pintado até à data alguns tectos dos palácios de Queluz e da Ajuda, e mais tarde chegará a exercer as funções de professor de pintura de paisagem e

\footnotetext{
${ }^{25}$ Portaria de 11 de Fevereiro de 1835. Boletim da Academia Nacional de Belas-Artes: documentos, III, 1938, p. 62, doc. XLVIII.

${ }^{26}$ Portaria de 11 de Fevereiro de 1835. Idem, p. 62, doc. XLVIII.

${ }^{27}$ Apud SOARES, Clara Moura; RODRIGUES; Rute Massano; CRUZ, António João e REGO, Carla "Conservação e destruição de pinturas dos conventos em Portugal durante o século XIX". ECR: estudos de conservação e restauro, n. 4, 2012, p. 243 (ANTT/MR/Mç 2126, cx 2).

${ }^{28}$ Portaria de 11 de Setembro de 1835. Idem, p. 63, L.
} 
produtos naturais da Academia de Belas Artes de Lisboa ${ }^{29}$. Como Nunes de Carvalho justificará no seu oficio, a escolha deste artista resultava de ser "pessoa capaz de se encarregar daquele trabalho e de, por outro lado, provavelmente não menos importante, se oferecer para o referido serviço que é compatível com o da dita repartição, sem exigir gratificação alguma" ${ }^{30}$.

Recuemos um pouco para assinalar que o anterior governo procurou tomar providências em relação aos espólios que se encontravam disseminados pelo país, pensando criar bibliotecas e museus nas capitais dos distritos, como revela a portaria assinada em Março de 35 pelo então ministro do Reino, Agostinho José Freire (17801836), sucessor do bispo-conde. António Nunes de Carvalho seria uma vez mais incumbido de "reunir e guardar em depósitos seguros e centrais, e fazer classificar e inventariar todas as livrarias e mais objetos mencionados das corporações extintas nas províncias do Douro, Minho, Trás-os-Montes, Beira Alta, Beira Baixa e Algarve, pelo mesmo modo por que havia sido encarregado, de igual comissão quanto às províncias da Estremadura e Alentejo". À semelhança do que havia sucedido naqueles casos, ficava o mesmo responsável autorizado "para requisitar das autoridades competentes tudo o que for a bem desta diligência, e para propor à aprovação do governo as pessoas de inteira probidade e inteligência que julgar necessárias para o auxiliarem em semelhante trabalho" ${ }^{31}$. Registe-se que os distritos do Porto e Coimbra constituíam casos autónomos e especiais, tendo disposto de comissões próprias para proceder às incorporações ${ }^{32}$.

As entradas massivas de livros e pinturas dos conventos da região de Lisboa pouco tempo deram ao encarregado para se ocupar desses e outros assuntos, informando naquele mesmo mês ao ministro do Reino que "no depósito geral ainda se não tem podido tratar até ao presente senão de recolher as livrarias, cartórios, pinturas dos extintos conventos de Lisboa e seu termo, e destes mesmos ainda faltam alguns" ${ }^{33}$.

\footnotetext{
${ }^{29}$ Sobre este artista cf. MACEDO, Diogo de - Académicos e românticos: a fundação. Coleção Museum, 1a série, n.o 7, 1950, pp. 5-7.

${ }^{30}$ Apud SOARES, Clara Moura; RODRIGUES; Rute Massano; CRUZ, António João e REGO, Carla - op. cit., p. 243 (ANTT/IOP liv. 50:130 v).

${ }^{31}$ Portaria de 24 de Março de 1835. Boletim da Academia Nacional de Belas-Artes: documentos, III, 1938, pp. 30-31, doc. XXIX.

${ }^{32}$ SOARES, Clara Moura; RODRIGUES, Rute Massano - op. cit., p. 353.

${ }^{33}$ Oficio datado de 17 de Março de 1835. Apud BARATA, Paulo J. S. - op. cit., p. 37 (ANTT, Ministério do Reino, 4a repartição, mç. 2126).
} 
De acordo com uma relação posteriormente efectuada, sabemos ter Nunes de Carvalho arrecadado um total de 43.693 livros e cerca de 2600 pinturas, provenientes de 62 conventos e casas religiosas da Estremadura ${ }^{34}$.

Ao grande volume de trabalho e à evidente falta de meios, acresceram algumas contrariedades relacionadas com o próprio convento de S. Francisco que, dada a sua amplitude e situação central, começou a ser cobiçado para nele se instalarem alguns organismos da administração pública nascidos com o Liberalismo. Foi o caso do Governo Civil de Lisboa que passou a ocupar um sector específico do complexo, o chamado Hospício da Terra Santa, construído para residência dos religiosos que se dedicavam a fazer peditórios de terra em terra, com o fim de angariar fundos para o convento franciscano de Jerusalém ${ }^{35}$. Em Agosto de 35, Rodrigo de Fonseca Magalhães dava a conhecer a decisão a Nunes de Carvalho, informando ser necessário "desembaraçar aquela parte do edifício [...] dos quadros e pinturas pertencentes aos extintos conventos e que naquele local se conservam em depósito". Ordenava por isso que aquele se entendesse "com a pessoa que Sua Majestade se dignar nomear governador civil, afim de serem removidos daquele local os referidos quadros e painéis, e reunidos aos outros cuja guarda e conservação está encarregado o sobredito doutor"36.

A decisão do governo foi naturalmente mal recebida pelo encarregado do depósito que, em Novembro de 35, em carta dirigida ao novo presidente do Ministério, Sá da Bandeira (1795-1876), tecia uma teoria conspirativa envolvendo, entre outros, o anterior ministro do Reino, Rodrigo da Fonseca Magalhães, e o governador civil de Lisboa, Joaquim Larcher: "Para esse fim se ideou o estabelecimento da secretaria do Governo Civil na parte do edifício que fora o Hospício da Terra Santa, por ser o lugar mais próprio para dali se invadir o depósito, cuja invasão se paliaria com o plausível motivo de que bastava que o governador civil tivesse a direção dele, visto morar no mesmo edifício" ${ }^{37}$. Em Janeiro de 36, em carta ao bispo-conde, a exercer as funções de presidente da Câmara dos Pares após ter passado pelo governo, volta a aludir às

\footnotetext{
${ }^{34}$ Idem, ibidem

${ }^{35}$ CALADO; Margarida - op. cit., p. 11

${ }^{36}$ Portaria de 13 Agosto 1835. Boletim da Academia Nacional de Belas-Artes: documentos, III, 1938, pp. 62-63, doc. XLIX.

${ }^{37}$ Carta datada de 15 de Novembro de 1835. Apud BARATA, Paulo J. S. - op. cit., p. 66 (BN, COD. 6963, f. Iv.-2).
} 
"infernais tramas que duram há seis meses debaixo do comando do governador Larcher", mostrando também a necessidade de se legislar no sentido de reservar o edifício de S. Francisco a instituições de cariz cultural, na tentativa de impedir a sua ocupação por uma companhia da Infantaria e outra de Cavalaria da Guarda Nacional, igualmente autorizadas por portaria ${ }^{38}$.

Como bem notou Paulo Barata, importa sobremaneira destacar a visão estratégica de Nunes de Carvalho para o convento de S. Francisco, por ele entendido como um complexo cultural de dimensão nacional e até europeia, defendendo na carta ao bispo-conde que o mesmo fosse "destinado unicamente para nele se estabelecer uma biblioteca pública digna da capital da nação, um museu de produtos naturais, de raridades das artes e de antiguidades, uma galeria de pinturas que nada terá de invejar às melhores da Europa, e a Academia das Belas Artes" ${ }^{39}$.

Naquele ano de 36 seria efetivamente criada a Academia de Belas Artes a que iremos consagrar a nossa atenção no ponto seguinte, vindo também a ocorrer uma mudança na administração do depósito dado o afastamento de Nunes de Carvalho, entretanto nomeado para o cargo de guarda-mor da Torre do Tombo ${ }^{40}$. Para tal terão contribuído os conflitos mantidos com as instituições com quem partilhava o espaço de S. Francisco, como sucedeu com o caso do Governo Civil, e a ausência de uma gestão controlada do numeroso espólio. Não terá sido igualmente alheio neste processo o peso institucional da própria Real Biblioteca Pública da Corte ${ }^{41}$ que transferiu em Maio e Junho do mesmo ano as suas instalações no Terreiro do Paço para o antigo convento franciscano, incorporando mais tarde (1841) o numeroso acervo bibliográfico nele contido.

No seguimento destas alterações, seria nomeada a 30 de Dezembro uma comissão administrativa presidida pelo conde da Taipa (1794-1866) e composta por vários vogais, como o visconde de Balsemão (1802-1862), bibliotecário-mor, Luís Duarte

\footnotetext{
${ }^{38}$ Carta datada de 31 de Janeiro de 1836. Idem, ibidem, p. 66 (BN, MSS. 243, n. 32).

${ }^{39}$ Idem, ibidem, p. 66 (BN MSS. 243, n. 32).

${ }^{40}$ A nomeação para guarda-mor da Torre do Tombo ocorreu em Setembro de 1836. Foi igualmente designado responsável da comissão para a instalação da Biblioteca das Cortes e membro da comissão encarregada de estudar o estabelecimento das bibliotecas das secretarias de estado, desconhecendose se chegou a exercer estas duas últimas funções. Idem, ibidem, p. 44.

${ }^{41}$ Criada a 29 de Fevereiro de 1796 por alvará de D. Maria I e aberta ao público a 13 de Maio de 1797, ocupando parte do segundo pavimento de um edifício do lado ocidental do Terreiro do Paço, onde se encontrava a Livraria da Real Mesa Censória. CALADO, Margarida - op. cit., pp. 29-30.
} 
Vilela da Silva, André Monteiro da Cruz e até Nunes de Carvalho que nunca chegou a comparecer às reuniões, incomodado por ver escrutinado e posto em causa o seu trabalho ${ }^{42}$. Competia a esta comissão gerir o depósito, "procedendo quanto antes a formalizar o catálogo dos livros e manuscritos, das estátuas, e de outros objetos de raridade existentes no Convento de S. Francisco desta cidade" ${ }^{43}$.

Em Janeiro de 1837, na sequência de uma portaria que instava à "entrega imediata" dos objetos à comissão administrativa, Nunes de Carvalho responderá com algum azedume ao ministro do Reino, justificando que "até a esta hora, nem a referida comissão nem pessoa ou ofício algum da parte dela se me apresentou neste depósito; logo que se apresentem pode V. Ex. ${ }^{\text {a }}$ estar certo que as ordens de Sua Majestade hão de ser por mim pronta e pontualmente cumpridas, como sempre têm sido até agora". Procurando defender-se quando à necessidade de fornecer inventários conforme alude a mesma portaria, declara: "De muita parte dos objetos reunidos neste depósito há relações parciais feitas no ato de recepção deles, e estas apresentarei eu à comissão para por elas verificar a existência e identidade dos mesmos objetos. Dos que foram recolhidos em montão não há relações, nem inventários, nem nunca houve tempo nem meios para se fazerem; há porém relações exatas de tudo o que tem saído do depósito até hoje, e as ordens originais da secretária de Estado que ordenou essas saídas, assim como os competentes recibos ${ }^{44}$. A esse respeito, destaque-se um conjunto de pinturas remetidas em Dezembro de 1836 para o Museu Portuense, aparentemente escolhidas pelo próprio Nunes de Carvalho que terá procurado fazer uma seleção abrangente de artistas nacionais, assinando a respectiva relação onde efetua alguns comentários qualitativos e dá conta das proveniências. Elenca um total de sete obras associadas a Grão Vasco, António Machado Sapeiro, André Gonçalves, Joaquim Manuel da Rocha, Pedro Alexandrino, Domingos Sequeira e Cyrillo Volkmar Machado ${ }^{45}$.

\footnotetext{
${ }^{42}$ Note-se que a comissão sofre, após a saída da sua portaria constitutiva, significativas alterações com a nomeação de novos vogais e a exoneração de outros. Idem, ibidem, pp. 44-45.

${ }^{43}$ Portaria de 30 de Dezembro 1836. Boletim da Academia Nacional de Belas-Artes: documentos, III, 1938, p. 85, doc. LXXIII.

${ }^{44}$ Ofício de 10 de Janeiro de 1837. Idem, p. 88, doc. LXXVII.

45 "Relação das pinturas remetidas para o Museu do Porto em 7 de Dezembro de 1836". Idem, p. 82, doc. LXXI.
} 
Reunidos em Janeiro de 1837, os membros da comissão hesitam em tomar posse do depósito dada a inexistência de um inventário completo, evidenciando-se a opinião do visconde de Balsemão que "informado do estado de confusão em que se acham os objetos do depósito, concluiu ser o seu inventário obra para largo prazo, e portanto forçoso prescindir dele" ${ }^{46}$. A desorganização é aliás reconhecida pelo próprio Nunes de Carvalho, em carta dirigida no mesmo ano à comissão, ao referir que "os objetos existentes no depósito são de muitas sortes, e se acham pela maior parte amontoados, em grande confusão e desordem, por causa das frequentes mudanças que por ordem superior delas se tem feito" ${ }^{47}$, como vimos anteriormente ter sucedido com as pinturas conservadas no Hospício da Terra Santa.

O deficiente estado de organização do depósito era portanto uma realidade reconhecida pelos novos administradores, e explicitamente assumida pelo encarregado demissionário. Reflexo disso é a própria documentação ou ausência dela, uma vez não existir qualquer rasto de escrita organizada como salienta Paulo Barata. Acrescenta que Nunes de Carvalho, aquando a sua saída, e numa "autêntica política de 'terra queimada', leva consigo muita documentação relativa à função pública que desempenhara, a qual só em parte tardiamente devolve" ${ }^{48}$. Em oposição, a vigência da comissão administrativa caracteriza-se por documentar sistematicamente a sua atividade, com livros de atas das reuniões da comissão, copiadores de correspondência recebida e expedida, registo de ponto dos funcionários, mapas mensais com o registo de entradas e saídas de obras, entre outros instrumentos de gestão ${ }^{49}$.

As atas das sessões da comissão dão-nos a conhecer o dinamismo da mesma, com destaque uma vez mais para o visconde de Balsemão que, procurando conferir-lhe melhor operacionalidade, propôs logo em Janeiro de 37 dividi-la em duas secções essenciais: a artística, de que ficariam incumbidos os já citados Vilela da Silva e André Monteiro da Cruz, e a bibliográfica, por sua vez desdobrada em várias subsecções de que se encarregariam os restantes vogais (ciências físico-médicas, matemáticas, belas letras, ciências civis e políticas e a subsecção eclesiástica). Ficou

\footnotetext{
${ }^{46}$ Ata de 7 de Janeiro de 1837. Idem, p. 88, doc. LXXVII.

${ }^{47}$ Apud BARATA Paulo J. S. - op. cit., p. 44 (BN, MSS. 225, n.o 32).

${ }^{48}$ Idem, ibidem, p. 39

${ }^{49}$ Idem, ibidem, p. 44
} 
igualmente decidida a atribuição dos novos funcionários que haviam sido entretanto requisitados ao governo para trabalhar no depósito, e que ainda não se tinham apresentado ao serviço, reservando-se dois para a secção artística e seis para a bibliográfica ${ }^{50}$. À semelhança do sucedido durante a direção de Nunes de Carvalho, serão estes funcionários recrutados do corpo de excedentes dos organismos públicos extintos, tais como a Junta do Comércio ou o Conselho de Guerra, não detendo portanto especiais qualificações ${ }^{51}$.

À secção artística caberá, em particular, a articulação com a Academia de Belas Artes no processo de inventariação e transferência das pinturas dos antigos conventos, dando seguimento à portaria de 30 de Dezembro de 1836 que ordenava a entregar "por inventário à mesma Academia os quadros existentes naquele depósito, afim de que ela os possa classificar, e designar os que devam servir para o estudo dos académicos e artistas ${ }^{\prime 2}$. Este aspecto irá ser tratado em profundidade mais adiante, importando aqui salientar a colaboração mantida entre os responsáveis designados pela Academia e os membros da secção artística, com destaque nesta última para Vilela da Silva que, apesar da sua idade avançada e débil estado de saúde, prestou relevante serviço. Em 1838, em resposta a um ofício do Ministério do Reino acerca da atividade desempenhada até à datada pelo cónego aposentado da Sé, a comissão Administrativa revela bem o apreço em que o tinha: "não sabe ela que conte a nação muitos sábios que o pudessem aqui substituir" ${ }^{53}$. Ainda de acordo com a comissão, a Vilela da Silva se deve, não apenas a identificação de artistas e escolas das pinturas conservadas no depósito, mas também de outras existentes em diversos conventos. Competindo à comissão administrativa a gestão do edifício de S. Francisco, seria em 1837 encarregada por portaria do Ministério do Reino "de proceder à distribuição do mesmo convento, tanto pela Academia das Belas Artes de Lisboa, que deve ser contemplada com um local suficiente e espaçoso, como pela Biblioteca Nacional, Administração Geral e Contadoria da Fazenda do Distrito, de acordo com o

\footnotetext{
${ }^{50}$ Ata de 13 de Janeiro de 1837. Boletim da Academia Nacional de Belas-Artes: documentos, III, 1938, pp. 89-90, doc. LXXIV.

${ }^{51}$ A este respeito cf. portaria de 14 de Janeiro de 1837. Idem, p. 90, doc. LXXX.

${ }^{52}$ Portaria de 30 de Dezembro de 1836. Idem, p. 93, doc. LXXXIV.

${ }^{53}$ Ofício de 14 de Maio de 1838. Apud BARATA, Paulo J. S. - op. cit., p. 79 (BN/AH-10, p. 113).
} 
respectivo administrador geral" ${ }^{54}$. Procurava-se assim tornar o complexo mais funcional, evitando as constantes tensões entre as entidades que o ocupavam, algumas com maior peso e poder na hierarquia administrativa. Após a respectiva aprovação da tutela ${ }^{55}$, o espaço ficou dividido da seguinte forma: o primeiro piso para a Academia de Belas Artes, o segundo para a Biblioteca Pública e o terceiro para o depósito, sendo o terraço e a cisterna comuns aos três organismos. Ficou ainda decidido que após a extinção do depósito, seria o seu espaço dividido pelos dois primeiros. A Administração Geral e Contadoria da Fazenda do Distrito (Governo Civil) manter-se-ia circunscrita ao Hospício da Terra Santa que ocupava.

Mau grado a amplitude e a excelência da localização do antigo convento de S. Francisco, certo é que este debatia-se com os problemas inerentes à manutenção de uma massa não concebida de raiz para acolher as instituições que a ocupavam. Era bem conhecido o deficiente estado de conservação das obras do depósito, sobretudo devido à humidade que se agravava pelas infiltrações das águas pluviais, sem esquecer as infestações causadas pela traça, com sérios prejuízos para o espólio pictórico e bibliográfico ${ }^{56}$. Registe-se todavia que parte importante daqueles espécimes entraram em S. Francisco em estado precário, resultado da incúria de muitas comunidades religiosas e das condições desfavoráveis a que estivarem sujeitas durante séculos nos respectivos conventos ${ }^{57}$.

A comissão administrativa procurou fazer face a estes problemas, acautelando o espólio e organizando o melhor que podia as instalações, entretanto libertas das mais de 500 pinturas selecionadas pela Academia de Belas Artes. Fora da seleção ficaram para cima de um milhar, o que levou o Ministério do Reino, em 1838, a aprovar uma proposta da comissão, "propondo que se distribuam pelas igrejas e casas de Câmaras Municipais que os quiserem aceitar, muitos quadros de pouco valor que existem naquele depósito" ${ }^{\prime 58}$. Às solicitações das paróquias e irmandades somaram-se portanto as de alguns municípios, no intuito de ver enriquecida a

\footnotetext{
${ }^{54}$ Portaria de 22 de Maio de 1837. Boletim da Academia Nacional de Belas-Artes: documentos, III, 1938, p. 99, doc. LXXXIX.

${ }^{55}$ Portaria de 9 de Agosto de 1837. Idem, p. 105, doc. CII.

${ }^{56}$ SOARES, Clara Moura; RODRIGUES; Rute Massano; CRUZ, António João e REGO, Carla - op. cit., pp. 234-238.

${ }^{57}$ Idem, ibidem, pp. 238-240.

${ }^{58}$ Portaria de 9 de Janeiro de 1838. Boletim da Academia Nacional de Belas-Artes: documentos, III, 1938, p. 109, doc. CVII.
} 
decoração dos respectivos Paços do Concelho, como sucedeu com a Câmara do Barreiro que, em 1839, requisitou um total de 22 pinturas, acrescidas de uma imagem destinada à igreja do cemitério público da então vila ${ }^{59}$. Extensíveis a outros estabelecimentos, estas remessas não foram todavia suficientes para fazer escoar o acervo que era ainda avultado por ocasião da extinção do depósito, em 1841.

Com efeito, a 12 de Novembro de 1841, alegando a necessidade de "conciliar em todos os ramos da administração pública a conveniência do serviço com as regras da mais estrita economia", Joaquim António de Aguiar ordenava a fusão do depósito com a Biblioteca Pública, incorporando esta não só as dezenas de milhar de volumes e demais documentos das antigas livrarias conventuais, mas também as pinturas que vinham sendo cedidas. Com a fusão ficava "exonerada a comissão Administrativa do mesmo depósito e dispensados do serviço todos os empregados" ${ }^{60}$, o que não é de estranhar dado aquela entidade ter sido encarada desde a sua criação como transitória. Alguns dos membros da comissão pertenciam aliás aos quadros da biblioteca que procurou dar continuidade aos trabalhos desenvolvidos, afigurandose portanto natural a incorporação do espólio.

Se os livros do extinto depósito mereceram a atenção da biblioteca, o mesmo não sucedeu com as pinturas, cada vez menos objecto de requisições, tendo sido votadas a algum abandono. Disso dá conta José Feliciano de Castilho (1810-1879) que após ter assumido em 1843 as funções de bibliotecário-mor, escreverá ter achado aqueles quadros "em desordem num corredor que a Academia das Belas Artes emprestara, com janelas sempre abertas, expostos a todas as inclemências, calcados aos pés pelas pessoas que tinham de entrar no dito corredor e, enfim, na sua maior parte, já completamente estragados e inúteis". Procurando fazer face à dramática situação de um espólio que se encontrava sob a sua responsabilidade, concebeu uma engenhosa solução e assim mandou instalar "ao centro dos longos corredores de S. Francisco, no andar superior, uma série de roldanas e cordas, por meio das quais, e de uma particular disposição, pude, com insignificante dispêndio, formar uma extensa galeria onde os painéis ficaram conservados no mesmo estado em que hoje se acham, e poderão um por um ser examinados, sem necessidade de deslocação, o

\footnotetext{
${ }^{59}$ Boletim da Academia Nacional de Belas-Artes: documentos, IV, 1939, p. 21, doc. XIX.

${ }^{60}$ Idem, pp. 31-32, doc. XXXV.
} 
que até hoje não se dava, pois para procurar um era necessário revolver todos, aumentando, com esses contínuos movimentos, a deterioração a que pus por fim termo". Assim escrevia Castilho em 44, um ano após ter dado entrada na Biblioteca Pública, expressando com assinalável espírito patrimonialista que apesar de muitos quadros se encontrarem inutilizados, "não consinto em que um se destrua, e vou guardando até esses inúteis panos" ${ }^{\prime 61}$.

Entendimento diferente teve o bibliotecário seguinte, José Barbosa Castelo Branco (1804-1857) que, em 1853, autorizado pelo governador civil, solicitou ao intendente das Obras Públicas que pusesse à sua disposição dois carros para que "no Campo Pequeno se procedesse à queima do avultado número de quadros sacros recolhidos no depósito geral das livrarias dos extintos conventos, que pelo seu estado de total ruína, não podem ter a devida aplicação" ${ }^{62}$. Este gesto não deverá ser interpretado como resultado da indiferença daquele bibliotecário para com os quadros do extinto depósito que, como esclarece numa notícia publicada pouco depois, procurou organizar "em locais separados, dividindo-os em sacros e históricos" ${ }^{63}$. A maioria das pinturas de temática religiosa (cerca de 800 ) foram então colocadas à disposição do Cardeal Patriarca, com a exceção das que se encontravam muito degradadas, "não eram já mais que farrapos", dizia, num total de 55 arrobas (cerca de 800 kg) reduzidas a cinzas no Campo Pequeno ${ }^{64}$. Conservou a biblioteca diversos retratos de figuras históricas que estarão na base da mencionada notícia, para além de um núcleo de pinturas de temática religiosa acerca das quais esperava Castelo Branco tirar partido.

Em 1857, num oficio dirigido ao Ministério do Reino, o bibliotecário contabilizava em 519 as espécies de pintura subsistentes, expressando a vontade de conservar algumas "para ornamento da sala de leitura ainda em projeto", nomeadamente, "os 14 que vieram do Mosteiro de S. Bruno de Laveiras, por serem os únicos que por seu merecimento artístico correspondiam à grandeza a que ainda espero seja elevado

\footnotetext{
${ }^{61}$ CASTILHO, José Feliciano de - Relatorio acerca da Bibliotheca Nacional de Lisboa e mais estabelecimentos anexos (...), 1844, pp. 92-95. Apud PEREIRA, Gabriel - Biblioteca Nacional de Lisboa: noticia dos retratos em tela, 1900, pp. 2-3.

${ }^{62}$ Oficio datado de 3 de Outubro de 1853. Boletim da Academia Nacional de Belas-Artes: documentos, IV, 1939, p. 48-49, doc. LIX.

${ }^{63}$ CASTELO BRANCO, José Barbosa - Estudos biographicos ou noticia das pessoas retratadas nos quadros historicos pertencentes à Bibliotheca Nacional de Lisboa, 1854, p. X.

${ }^{64}$ Idem, ibidem, p. XI.
} 
este estabelecimento" ${ }^{65}$. Com os restantes, incluindo estranhamente alguns dos retratos a que dedicara a notícia, propunha fazer a troca por livros, uma vez que o governo não se prestava "a fazer uma sala destinada a galeria, porque principalmente era necessário atender à extensão de lugar para estantes de livros" ${ }^{66}$. Menciona explicitamente uma proposta do marquês de Valada que estava interessado em 13 pinturas, trocando-as por livros, negócio encarado como vantajoso pelos membros do conselho da biblioteca que solicitavam a venda em leilão dos restantes quadros, "aplicando o produto exclusivamente para a compra de livros; mas guardando-se para o estabelecimento, além dos do mosteiro de Laveiras, todos os que representassem escritores portugueses, não duplicados" ${ }^{\prime 67}$.

Por portaria de 8 de Junho de 1861, o governo ordenará que os incómodos restos pictóricos em posse da Biblioteca Pública fossem remetidos à academia para ali se proceder a uma seleção, reservando-se para a biblioteca os espécimes considerados com interesse histórico e artístico, e avaliando-se os restantes para se proceder à sua venda em hasta pública ${ }^{68}$. Atualmente, a Biblioteca Nacional de Portugal conserva ainda disseminados por corredores, gabinete e salas de leitura cerca de sete dezenas de pinturas, na sua maioria retratos executados entre os séculos XVI e $\mathrm{XIX} \mathrm{X}^{69}$, últimos testemunhos de todo aquele espólio pictórico, objecto recente de um projeto de investigação financiado pela $\mathrm{FCT}^{70}$.

Num breve balanço, o aparelho montado para a administração do depósito, alicerçou a sua atuação "numa coerência de valores e princípios que revelam a determinação do governo liberal em assegurar uma criteriosa gestão dos bens dos extintos conventos" como concluem Clara Moura Soares e Rute Massano Rodrigues.

\footnotetext{
${ }^{65}$ Entre essas pinturas encontravam-se as que Domingos Sequeira executou para aquele cenóbio e que mais tarde serão transferidas para a Academia de Belas Artes.

${ }^{66} \mathrm{Em} \mathrm{1837,} \mathrm{o} \mathrm{então} \mathrm{bibliotecário-mor,} \mathrm{visconde} \mathrm{de} \mathrm{Balsemão,} \mathrm{referia} \mathrm{já} \mathrm{o} \mathrm{desejo} \mathrm{de} \mathrm{possuir} \mathrm{"uma}$ proporcionada galeria de pinturas" associada a biblioteca, solicitando ao presente da Comissão Administrativa a cedência de "uma coleção de quadros de homens e varões ilustres, em cujo numero poderá compreender-se uma série dos reis de Portugal". Boletim da Academia Nacional de BelasArtes: documentos, III, 1938, p. 108, doc. CIV.

${ }^{67}$ Ofício de 8 de Junho de 1857. Idem, IV, 1939, pp. 49-50, doc. LX.

${ }^{68}$ RIBEIRO, José Silvestre - Historia dos estabelecimentos scientificos, litterarios e artisticos de Portugal nos successivos reinados da monarchia, T. X, 1882, p. 15.

${ }^{69}$ SOARES, Clara Moura; RODRIGUES; Rute Massano; CRUZ, António João e REGO, Carla - op. cit., p. 233

${ }^{70}$ Eneias - A coleção de pintura da Biblioteca Nacional de Portugal: do resgate do património artístico conventual na implantação do Liberalismo ao estudo integrado de conservação e divulgação (PTDC/HIS-HEC/113226/2009).
} 
Para além de engrossar o seu património, procurou o Estado "promover o conhecimento, a salvaguarda e a divulgação de inúmeros objetos que até então permaneciam inacessíveis a uma escassa minoria" numa atitude que revela "uma nova consciência patrimonial" herdeira das ideologias e práticas da França pósrevolucionária $^{71}$. Como também foi já notado, há todavia a registar em todo este processo uma contradição entre o cuidado estatal com o espólio dos conventos que esteve na origem do depósito, e a incúria que levou à destruição de parte significativa desse espólio pelas deficientes condições em que o mesmo foi arrecadado $^{72}$. Fica assim patente a incapacidade do depósito (e posteriormente até da Biblioteca Pública) em gerir tanto material, merecendo apesar de tudo destaque os esforços desenvolvidos pela comissão administrativa. Embora muito se tivesse perdido e alienado, muito também, e porventura o fundamental, foi preservado, a avaliar pelo núcleo que transitou para a Academia.

\section{A Academia de Belas Artes e o corpo académico}

Várias foram as tentativas frustradas de criação de uma Academia de Belas Artes em Portugal, quer por parte de entidades privadas quer depois, já em Oitocentos, por parte do próprio regime liberal ${ }^{73}$. Em 1823, Francisco Trigoso de Aragão Morato (1777-1838), lente da Universidade de Coimbra, havia proposto a criação de um "centro de belas artes", receando que "daí a poucos tempos acontecesse que quando fosse necessário pintar alguma coisa, não tivessem quem a fizesse" ${ }^{\prime 74}$. Três anos mais tarde, já ministro do governo do marquês de Saldanha, faria sair um decreto de centralização do ensino artístico, reunindo as antigas aulas que funcionavam junto da Corte. O miguelismo deitou tudo por terra e será necessário esperar até 1833, já com D. Pedro IV vitorioso de Lisboa, para retomar aqueles intentos, tendo Aragão Morato integrado uma comissão secretariada por Almeida

\footnotetext{
${ }^{71}$ SOARES, Clara Moura; RODRIGUES, Rute Massano - op. cit., p. 355.

72 SOARES, Clara Moura; RODRIGUES; Rute Massano; CRUZ, António João e REGO, Carla - op. cit., p. 245.

${ }^{73}$ A este respeito cf. FERREIRA, Emília - op. cit., pp. 1-54

${ }^{74}$ Diario das Cortes da Nação Portugueza, 1822-23, T. I, p. 515. Apud FRANÇA, José-Augusto - A arte em Portugal no século XIX, vol. I, 3a ed., 1990, p. 218.
} 
Garrett (1799-1854) que deveria estudar e propor um projeto de reforma de todo o ensino público.

Em Outubro de 1834, Joaquim Rafael (1783-1864), Primeiro Pintor de Câmara e Corte desde o tempo de $\mathrm{D}$. João $\mathrm{VI}$, irá propor aos poderes públicos a criação de um Ateneu ou Academia de maneira a proporcionar "aos estudantes um centro artístico em que tenham lições, e os professores num só golpe de vista possam contemplar originais instrutivos que precisarem para sua maior ilustração, assim como (...) os amadores de arte ${ }^{\prime 75}$. Foi todavia com o ministro Agostinho José Freire que, através do decreto de 18 de Fevereiro de 1835, se nomeou uma comissão para preparar os estatutos de uma Academia de Belas Artes, dando seguimento a um documento enviado no mês anterior pelo diretor das Aulas de Desenho, Gravura e Escultura, o general Ferreira de Sousa. Seria este último nomeado presidente da comissão que teve como secretário-relator Francisco de Assis Rodrigues (1801-1877), professor assistente da Aula e Laboratório de Escultura e, como vogais, os mestres de outras aulas que funcionavam junto da Corte, assim como artistas ligados à empreitada do Palácio da Ajuda ou à Repartição de Obras Públicas ${ }^{76}$.

Esta comissão, com base no documento entregue em Janeiro daquele ano por Ferreira de Sousa, redigiu um plano de estatutos académicos que submeteu ao governo. O ministro mudara entretanto e o projeto, apesar dos protestos generalizados dos artistas e outras personalidades ${ }^{77}$, permaneceu engavetado até

\footnotetext{
${ }^{75}$ Proposta apresentada a 26/10/1834. Apud SOARES, Clara Moura - op. cit, p 392 (ANTT, MR - Mç. 2122).

${ }^{76}$ Encontravam-se no primeiro caso José António do Vale e Francisco Vasques Martins, professor e substituto da aula de desenho de figura respectivamente; João Maria Feijó, professor da aula de arquitetura civil; e Benjamim Comte, professor da aula de gravura de paisagem e arquitetura. Compreendiam o segundo Joaquim Rafael e José da Cunha Taborda, pintores de história; André Monteiro da Cruz, pintor de paisagem, flores e ornato; José da Costa Sequeira e João Pires da Fonte, arquitetos civis, sendo o primeiro empregado nas Obras Públicas; e João Vicente Priaz, gravador de história e empregado no Jardim Botânico e Real Museu da Ajuda. Segundo o mesmo decreto, a comissão poderia ainda solicitar o parecer de outros artistas, tendo sido convidados gratuitamente a participar António Manuel da Fonseca, pintor de história; Luís Pereira Resende e Joaquim Primavera, retratistas em miniatura; Maurício José Sendim, desenhador de história; o escultor João José de Aguiar; o gravador Domingos José da Silva; e os arquitetos Joaquim Possidónio da Silva e Francisco António de Sousa. Cf. LISBOA, Maria Helena - As academias e escolas de belas artes e o ensino artístico (1836-1910), 2007, pp. 338-339.

${ }^{77}$ Veja-se o caso do arquiteto Possidónio da Silva ao afirmar que "sem negar as boas intenções dos redatores destes estatutos, Ihes não conhece cabedal para esta obra sair perfeita de suas mãos, pois que todos eles vivem em um país onde não há artes e nenhum visitou as Academias estrangeiras". Apud SOARES, Clara Moura - op. cit, p 393 (ANTT, MR - Mç. 2122, Cx. 2).
} 
que Freire, de novo no governo, o fez ressuscitar em Julho de 36 , enviando-o para informação à Academia das Ciências que, por sua vez, nomeou uma comissão de estudo. Menos de dois meses depois teve lugar a Revolução de Setembro e Passos Manuel (1801-1862) (fig. 2), há cinco dias no poder, fez voltar o documento ao Ministério, criando a 25 de Outubro a Academia de Belas Artes de Lisboa e, pouco depois, a 22 de Novembro, a do Porto.

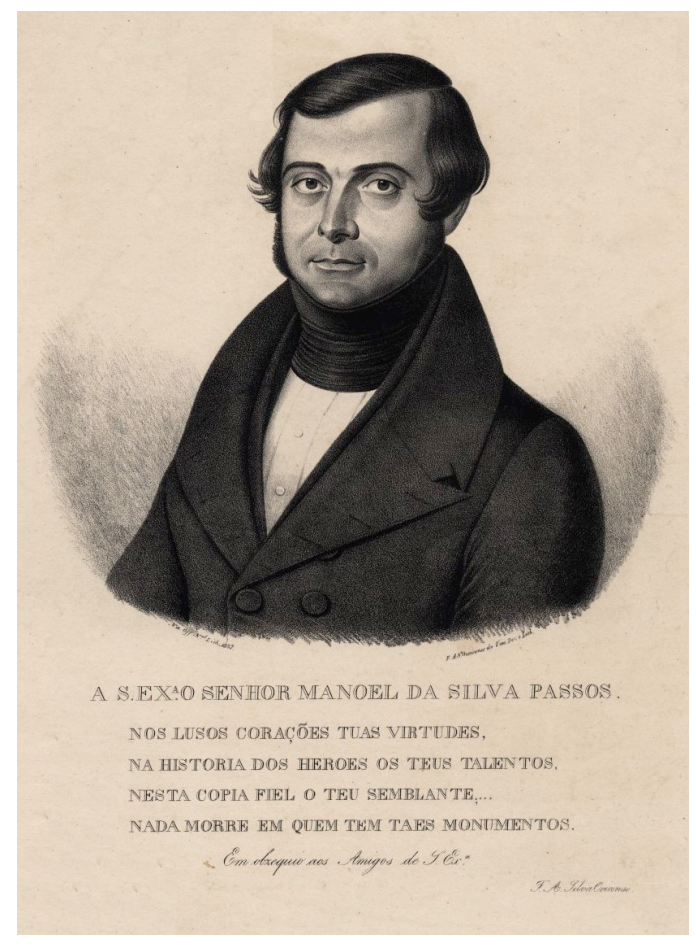

Fig. 2 - Passos Manuel, litografia de Silva Oeirense, 1837. BNP, E-6-A

No pequeno relatório que acompanhou os decretos e os respectivos estatutos submetidos à rainha, Passos sensibiliza-a para a necessidade de abertura da instituição, traçando um breve historial dos fracassos registados nesse sentido. Aproveitava para evocar os casos dramáticos de alguns artistas que haviam ultimamente perecido "entre os horrores da mais cruel indigência", cabendo portanto a D. Maria II a honra de acabar com tão inglória situação ${ }^{78}$. Para tal, contaria a rainha com o apoio do seu segundo marido, figura dedicada às artes que o ministro entendeu vincular também à instituição, conforme ficou expresso no artigo 3o do respectivo decreto: "A Academia das Belas Artes fica debaixo da minha

\footnotetext{
${ }^{78}$ Cf. "Relatório". Academia Real de Bellas-Artes de Lisboa: organização primitiva e organização actual: academicos, 1904, p. 6.
} 
imediata proteção e da de meu muito amado e prezado esposo, o príncipe D. Fernando de Saxe-Coburgo-Gotha"79.

Procurando evitar eventuais objecções relacionadas com a contenção orçamental vivida na época, Passos Manuel refere ainda no relatório não ser agravada a despesa do Estado, já que a verba anual prevista para a Academia (22.788\$000 réis), não excedia o somatório dos gastos efectuados com a formação dos arquitetos, escultores e pintores da obra da Ajuda (até 1833, no montante de $16.000 \$ 000$ réis / ano), acrescidos dos relativos às aulas de desenho de figura, arquitetura civil, e gravura, assim como as Casas do Risco e de Escultura (na Repartição das Obras Públicas), suprimidas pelo artigo 4. o decreto. Esperava-se atingir com esta centralização do ensino artístico o seguinte propósito iluminista enunciado no preâmbulo: "promover a civilização geral dos portugueses, difundindo por todas as classes o gosto do belo, e proporcionando os meios de melhoramento aos Ofícios e Artes, pela elegância das formas dos seus artefactos, a fim de que se goze quanto antes das incalculáveis vantagens que as nações mais cultas da Europa estão colhendo deste ramo de Instrução Pública" ${ }^{80}$.

Como esclarece Helena Lisboa, mais do que o fomento das artes ou a expansão da sua prática, "é no âmbito do desejo de preparação de quadros destinados a promover a industrialização e a modernização geral do país, que se pode entender a ideia defendida nos considerandos da lei". De acordo com a mesma autora, essa preocupação (expressa já pelas comissões que antecederam a sua promulgação), era a de que "as belas artes poderiam e deveriam contribuir também para o progresso, garantindo à indústria, ou melhor, aos seus produtos, a qualidade e beleza que anteriormente tinha sido possível obter com os processos artesanais" ${ }^{81}$. A fundação da Academia de Belas Artes enquadra-se aliás numa política geral que incluiu a criação de outros estabelecimentos vocacionados para vários graus de ensino técnico e profissional, como a Escola Politécnica de Lisboa e o Conservatório de Artes e Ofícios.

\footnotetext{
${ }^{79}$ Cf. "Decreto". Idem, p. 8.

${ }^{80}$ Idem, p. 7.

${ }^{81}$ LISBOA, Maria Helena - op. cit., p. 34.
} 
Os estatutos académicos apresentados à rainha, afiguram-se em larga medida subsidiários do projeto submetido pela comissão de 35 , estabelecendo em conformidade com o que acabou de ser referido, ter o novo estabelecimento como objectivo "unir em um só corpo de escola todas as Belas Artes, com o fim de facilitar os seus progressos, de vulgarizar a sua pratica e de a aplicar às Artes Fabris" (art. 2.ㅇ, cap. I). Para tal, a escola deveria ensinar desenho, pintura, arquitetura, escultura e gravura, num estudo que seria de "instrução teórica elementar", a partir da natureza e do antigo, insistindo-se na sua "aplicação às artes fabris" (art. 4ㅇ, cap. I) ${ }^{82}$.

Compunham-se as chefias do novo estabelecimento, por ordem hierarquia, de um inspetor-geral (o próprio ministro do Reino), representado por um vice-inspetor por ele nomeado, seguido de um diretor-geral. Este último cargo foi entregue a um respeitado lente jubilado de Medicina, o Dr. Francisco de Sousa Loureiro (17721844), a quem incumbia velar pelo bom andamento da vida académica, fazer respeitar internamente os estatutos, e as ordens vindas dos órgãos governamentais (foi mais tarde ocupado por Francisco de Assis Rodrigues, Joaquim Pedro de Sousa e, interinamente, Tomás da Anunciação, escolhidos sempre entre os professores mais antigos). Ao vice-inspetor competia grosso-modo a administração executiva do estabelecimento ${ }^{83}$, em representação do ministro, tendo sido o conde de Farrobo (1801-1869) convidado para ocupar esse cargo, atendendo aos esforços desenvolvidos para a consolidação do regime liberal e ao interesse que expressava pelas belas artes. Procurava-se talvez com aquela nomeação a ajuda de um mecenas, mas o conde pouca atenção dispensou à Academia onde não foi muito assíduo, renunciando um ano e meio depois na sequência de alegados desentendimentos com alguns elementos (deu lugar ao conde de Melo, seguido do general Ferreira de Sousa que ocupou longamente o cargo até à chegada do marquês de Sousa Holstein).

\footnotetext{
${ }^{82}$ Cf. "Estatutos". Academia Real de Bellas-Artes de Lisboa: organização primitiva e organização actual: academicos, 1904, pp. 9-10.

${ }^{83}$ De acordo com os estatutos, eram atribuições do vice-inspetor: "1. o Fazer as vezes do inspetor geral; 2. Assistir às conferências, com voto, e ser ouvido nos objetos do governo económico da Academia; 3. - Resolver casos que lhe forem propostos pelo diretor geral, quando a sua gravidade não exigir que sejam decididos em conferência, ou que subam ao conhecimento do Governo para sua decisão; 4. Receber o juramento dos empregados que o devem prestar; 5 o Rubricar os livros e folhas da contabilidade". Idem, p. 11.
} 
Para um ensino novo, contou Passos Manuel com o velho corpo docente que enformara a comissão de 1835, alvo de poucas mas significativas alterações. Os professores vieram pois em larga medida da obra paralisada da Ajuda e do ensino das aulas anteriores, com a exceção de um protegido do conde de Farrobo, António Manuel da Fonseca, formado em Roma e porta-voz de uma nova romanização, a quem foi atribuída a pintura de história, na ausência de José da Cunha Taborda, entretanto falecido. Máximo Paulino dos Reis (1778-1865) foi convidado para substituto (assistente) mas recusou por achar que lhe era devido o posto de titular, e só vinte anos mais tarde Francisco Metrass (1825-1861) seria nomeado para tal cargo (após a precoce morte deste último, foi ocupado interinamente por Marciano Henriques da Silva, com José Maria Franco como substituto). Mau grado a sua antiga devoção miguelista, Joaquim Rafael seria incumbido do desenho de história (dando a vez a Miguel Ângelo Lupi, em 1864), tendo como substituto Caetano Aires de Andrade (1787-1852) que fora pintor na Ajuda. André Monteiro da Cruz que também trabalhou na Ajuda e que vimos ter sido encarregado de efetuar restauros no depósito de S. Francisco, chegando depois a integrar a respectiva comissão administrativa, será, como já se referiu, nomeado professor de paisagem e de natureza morta (o seu substituto, José Francisco Ferreira de Freitas sucedeu-lhe mais tarde, deixando o lugar a Tomás da Anunciação que irá depois a assumir a titularidade do cargo, tendo como assistente João Cristino da Silva).

No domínio da arquitetura, encontramos dois homens formados na Ajuda, João Pires da Fonte (1790-1873) e José da Costa Sequeira (1800-1872), mas não Possidónio da Silva (1806-1896), jovem arquiteto de formação parisiense, no que estará relacionado com questões de ordem administrativa, no sentido de tirar partido dos indivíduos que eram já funcionários do Estado, à semelhança aliás da maioria dos casos aqui citados $^{84}$. Para professor de escultura, estando velho e doente João José de Aguiar (1769-1841), seria escolhido Francisco de Assis Rodrigues, secretáriorelator da comissão de 35, e desde há muito assistente da aula de escultura, então sem titular. Constantino José dos Reis ficou com o lugar de substituto mas por pouco tempo pois seria transferido para a Academia do Porto, na qualidade de professor

\footnotetext{
${ }^{84}$ LISBOA, Maria Helena - op. cit., p. 206.
} 
proprietário (daria lugar a Francisco de Paula Araújo Cerqueira, a quem Vítor Bastos sucedeu em 60). Na cadeira de gravura de história ficou um discípulo de Bartolozzi (1725-1815), Domingos José da Silva (1785-1863), tendo como substituto João Vicente Priaz (?-1845) (sucedeu-lhe em 52 Joaquim Pedro de Sousa), enquanto a gravura de paisagem seria entregue a Benjamim Comte (1762-1851), colaborador do conhecido gravador italiano. Não teve esta última cadeira direito a substituto, tal como a de cunhos e medalhas que coube a José António do Vale, antigo professor da aula de desenho de Figura e membro da comissão de 35.

Aos oito professores proprietários e seis substitutos, acrescia ainda um numeroso conjunto de "artistas agregados" (14 na pintura, 16 na arquitetura, 11 na escultura e cinco na gravura), categoria não mencionada nos estatutos mas que surge de forma algo imprevista na tabela dos vencimentos e nos quadros do decreto de 25 de Outubro de 36. Na sua maioria desconhecidos ou de pequeno valor, estes artistas não tinham uma função específica mas sabemos terem dado vago apoio às aulas, executando algumas tarefas declinadas pelos professores, nomeadamente e no caso da pintura, a realização de alguns restauros e cópias das espécies provenientes do depósito. Com a criação destes cargos que, em ordenados variados, absorviam quase $60 \%$ do orçamento geral da instituição, Passos Manuel procurava assistir aos artistas desamparados, desígnio já indicado no relatório dirigido à rainha.

Estabelecidas nas disposições de 36 , ficaram ainda a realização de exposições trienais das obras dos alunos, professores e mesmo de artistas estranhos à instituição, a concessão de prémios, bolsas para os melhores estudantes, e pensões para completar os estudos no estrangeiro. No seguimento dos tradicionais esquemas académicos, foram igualmente criadas situações honoríficas com a nomeação de académicos honorários, "escolhidos de entre as pessoas mais insignes por sua literatura, crédito público e amor às belas artes" (art. 27.ํ, cap. II), e académicos de mérito que apenas teriam de se propor, apresentando e oferecendo uma obra especialmente concebida para o efeito ${ }^{85}$. Eram estes em número ilimitado, ao contrário dos primeiros que os estatutos restringiram a 12 personalidades (seis em

\footnotetext{
85 Cf. "Estatutos". Academia Real de Bellas-Artes de Lisboa: organização primitiva e organização actual: academicos, 1904, pp. 11-13.
} 
Lisboa e seis no Porto), para logo em 1837 se aumentar para 50, com o predomínio de políticos (Passos Manuel naturalmente e com justiça à cabeça).

No processo de formação da Academia, incluindo na indicação de nomes para os artistas agregados, foi o ministro aconselhado por Francisco António da Silva Oeirense (1797-1868) que conquistou desde logo a apetecível situação de "pensionista viajante" com 800000 réis anuais (mais 300000 réis que os professores), vindo depois a administrar a Oficina Nacional Litográfica, passada para a dependência da Academia. Foi ainda nomeado académico de mérito e até mesmo diretor honorário, após a morte de Domingos Sequeira (1768-1837) para quem fora criado expressamente o cargo, por decreto de 9 de Fevereiro de $1837^{86}$. Figura "sagaz e oportunista" no dizer de Varela Aldemira ${ }^{87}$, virá a desempenhar um papel enérgico nos primeiros passos da instituição, sobretudo na transferência das pinturas dos conventos extintos conservadas no depósito, processo que nos merece em seguida especial atenção. Efémera foi a sua ação pois caído Passos Manuel em 38, e após algumas quezílias com alunos e colegas em Lisboa, viria a transferir-se para o Porto onde assumiu o cargo de professor de gravura de história da Academia daquela cidade, regressando apenas na década de 1860 como oportunamente veremos.

\subsection{Esforços em prol da organização, divulgação e conservação do acervo}

Para além das prerrogativas acima mencionadas, Silva Oeirense veio a ser autorizado por portaria a assistir com voto à chamada conferência académica que, até à reforma de 1881, foi o órgão máximo de gestão do estabelecimento, integrando

\footnotetext{
${ }^{86}$ A nomeação de Domingos Sequeira ocorreu na sequência de uma proposta de António Manuel da Fonseca: "A Academia foi unanime na resolução tomada sobre a proposta do Sr. António Manuel da Fonseca para se pedir a Sua Majestade, se digne conferir o titulo de Director Honorário da Academia das Belas Artes de Lisboa ao insigne pintor português Domingos António de Sequeira, residente em Roma, em atenção ao mui distinto mérito e excelência deste célebre artista, sendo aquele título lembrado pelo Sr. Ayres de Andrade, no momento de se hesitar sobre o lugar distinto que competia ao referido artista". Conferência ordinária de 19 de Janeiro de 1836. Arquivo da ANBA, disponível em http://digitarq.dgarq.gov.pt/ A-001-00001_m0087.TIF.

${ }^{87}$ ALDEMIRA, Luís Varela - Um ano trágico em Lisboa em 1836: a propósito do centenário da Academia de Belas Artes: impressões, comentários, documentos, 1936, p. 215.
} 
todos os docentes, sob a presidência do diretor-geral ou do vice-inspetor. Pela leitura das atas redigidas pelo secretário, cargo exercido durante muito tempo pelo professor José da Costa Sequeira, constatamos ter tido Oeirense um papel especialmente ativo na tentativa de resolução dos problemas com que se debatia a jovem instituição, mostrando-se eficaz nos privilegiados contactos mantidos com o Ministério do Reino. Começou-se por dar prioridade à realização de algumas obras de adaptação do espaço conventual, assim como à organização das aulas que funcionaram até concluídos aqueles trabalhos no edifício do Tesouro Velho (antigas Aulas de Desenho Histórico e de Arquitetura) e no convento dos Caetanos (antiga Aula e Laboratório de Escultura). Tal só terá lugar em Abril de 1837, mas logo em Dezembro do ano anterior, ainda mal iniciadas as obras, Oeirense sugeria que se pedisse ao "Doutor António Nunes de Carvalho uma relação dos quadros que existem no edifício do extinto convento de S. Francisco, indicando aqueles que ainda se acham dispersos por vários pontos do reino, por ser muito importante que este conhecimento não morra com o sobredito doutor" ${ }^{88}$.

O bem informado académico estava seguramente ao corrente do iminente afastamento do encarregado do depósito e da nomeação da comissão administrativa, daí a preocupação em garantir algumas informações sobre as pinturas que desejava fazer incorporar no novo estabelecimento. Com efeito, dias mais tarde, voltava a propor "que todos os quadros depositados no dito edifício, sejam submetidos à inspeção, direção e escolha da Academia, para esta não só proceder aos seus reparos, como à sua classificação que só ela deve fazer convenientemente, no que pode muito bem empregar os seus agregados, que igualmente podem copiar os melhores para serem litografados, ou gravados, revertendo os lucros para a Academia" ${ }^{89}$. Foi então enviada uma representação ao Ministério do Reino que com assinalável rapidez (logo no dia seguinte, levando a crer encontrar-se o assunto já encaminhado), expediu uma portaria decalcada de certa forma nas reivindicações expressas por Oeirense. Começa por ordenar que a recémnomeada comissão administrativa do depósito entregasse "por inventário à mesma

\footnotetext{
${ }^{88}$ Conferência ordinária de 12 de Dezembro de 1836. Arquivo da ANBA, disponível em http://digitarq.dgarq.gov.pt/PT-ANBA-ANBA-A-001-00001_m0051.TIF e_m0052.TIF.

${ }_{89}$ Conferência ordinária de 29 de Dezembro de 1836. Idem, disponível em http://digitarq.dgarq.gov.pt/PT-ANBA-ANBA-A-001-00001_m0070.TIF
} 
Academia os quadros existentes naquele depósito, afim de que ela os possa classificar, e designar os que devam servir para o estudo dos académicos e artistas". Determinava em seguida que a Academia, "depois de ter classificado os quadros que hão de pertencer-lhe, e dos que devem ser mandados para os museus nas cabeças dos distritos, envie a este Ministério o catálogo de todos estes quadros para ser publicado pela imprensa". O mesmo estabelecimento estava autorizado a "ocupar os artistas agregados no restauro dos quadros", devendo igualmente mandar “litografar e gravar uma coleção seleta e respeitável dos nossos pintores clássicos" 90 . Por último, recomendava-se que a comissão administrativa apresentasse à Academia uma listagem das pinturas conservadas noutros distritos, tarefa inviabilizada pela ausência de registos desse tipo no depósito.

$\mathrm{Na}$ sequência desta portaria, e como já tivemos oportunidade de aludir anteriormente, seriam Silva Oeirense e António Manuel da Fonseca nomeados por parte da Academia para se encarregarem daquela incumbência, em articulação com a chamada "secção artística" da comissão administrativa, constituída de igual modo por dois membros, o cónego Vilela da Silva e o pintor André Monteiro da Cruz. Em Maio de 37, decorridos poucos meses do início da seleção das pinturas e, em virtude de uma proposta submetida pelo professor Joaquim Rafael que pretendia ver pendurados na sala de aula de desenho histórico os trabalhos dos antigos alunos, os restantes membros da conferência decidiram "que isso não poderia ter lugar por se destinarem as paredes daquela aula para nelas se colocarem os quadros da Academia"$^{91}$. Na falta de um espaço adequado para servir de galeria, teriam os académicos de recorrer às salas de aula do estabelecimento, para aí se iniciando a transferência de parte importante das pinturas, com destaque para as tábuas dos nossos primitivos a que os responsáveis pela seleção deram prioridade.

Em finais daquele ano, terminada aparentemente a instalação dos quadros, o recémnomeado diretor honorário propunha "que se expusesse a Academia ao público em um dia da semana, e aos Domingos se franqueasse aos Srs. deputados, para o que devia quanto antes fazer-se o anúncio nos jornais". A urgência de Oeirense em

\footnotetext{
${ }^{90}$ Portaria de 30 de Dezembro de 1836. Boletim da Academia Nacional de Belas-Artes: documentos, IIII, 1938, p. 93, doc. LXXXIV.

${ }^{91}$ Conferência ordinária de 19 de Maio de 1837. Arquivo da ANBA, disponível em http://digitarq.dgarq.gov.pt/PT-ANBA-ANBA-A-001-00001_m0177.TIF
} 
mostrar publicamente (e politicamente) o resultado da tarefa, seria todavia frustrada por António Manuel da Fonseca, ao lembrar na mesma sessão que antes disso ter lugar, "se organizasse um relatório dos trabalhos que se tinham feito, e um inventário geral e circunstanciado dos quadros para se imprimir e vender à porta da Academia àquelas pessoas que a desejassem examinar em todo o conhecimento de causa" ${ }^{\prime 2}$.

Desconhecemos a existência de qualquer relatório alusivo aos trabalhos efectuados mas sabemos ter sido realizado um inventário, "de que existem dois autógrafos, um de entrega e outro de recepção, aquele devendo achar-se colocado na secretaria da mencionada Academia, e este que se acha depositado no arquivo do depósito, rubricado em todas as folhas pelo diretor-geral da dita e por ele encerrado com a sua assinatura e a do fiel da mesma Academia". Assim declara a própria comissão administrativa ao dar conta da finalização dos trabalhos, em Agosto de 38, deixando entrever não ter sido aquele documento efectuado com o intuito de ser publicado, mas como um elemento decorrente do todo o processo. A comissão destaca ainda o "ativo zelo e laboriosa fadiga" demonstrados por Oeirense no desempenho da tarefa, "com o que prestou um relevante serviço à Academia concorrendo para que ela, quanto antes, possuísse em seu recinto os materiais da sua galeria, cuja classificação e catálogo à mesma é incumbido pela portaria de 30 de Dezembro de $1836^{\prime \prime 3}$.

O "inventário geral" de 38 dá-nos a conhecer a distribuição das 540 obras selecionadas, devidamente numeradas e identificadas em relação aos temas representados, suporte em que foram pintadas, escolas ou autorias, e respetivas dimensões. Começa pela "Aula de Pintura de Paisagem" (91), seguida da "Aula de Pintura Histórica" (129), "Gabinete contíguo à Aula de Pintura Histórica" (42), "Grande Sala destinada para a Aula dos Ofícios Fabris" (63), "Gabinete imediato à Aula de Desenho Histórico chamado a Casa dos Gessos" (24) e "Aula de Desenho

92 Conferência ordinária de 1 de Dezembro de 1837. Arquivo da ANBA, disponível em http://digitarq.dgarq.gov.pt/ PT-ANBA-ANBA-A-001-00001_m0294.TIF

${ }_{93}$ Ofício de 7 de Agosto de 1838. Boletim da Academia Nacional de Belas-Artes: documentos, IIII, 1938, pp. 111-112, doc. CXII. 
Histórico" (21), permanecendo por colocar um número assinalável de obras $(170)^{94}$. Este documento terá sido provavelmente precedido por uma "relação dos quadros" com o qual deve ser cotejado, e onde se verifica igual distribuição numérica em relação às Aulas de Pintura de Paisagem e de Pintura de História, singularizando-se todavia pelo conjunto elencado no gabinete do Diretor Honorário, nada mais nada menos que 320 pinturas $^{95}$. Seguramente subdividido por outros espaços subjacentes ao dito gabinete, em reservas improvisadas, tal contingente é bem revelador do interesse de Oeirense pela coleção da Academia em cuja formação se empenhou. Como havia sido sugerido por aquele artista e confirmado pelo Ministério do Reino no decreto de Dezembro de 36, deveria o estabelecimento divulgar o acervo à sua guarda através de uma coleção de gravuras das obras consideradas mais representativas, a ser desejavelmente editada em paralelo com o catálogo que se pretendia também organizar. Dessa tarefa se encarregaram o professor titular de gravura, Domingos José da Silva, e o seu substituto, José António Priaz, tendo sido a metodologia a adoptar depois reavaliada pela conferência. Com efeito, em Julho de 38, António Manuel da Fonseca, ao notar "a grande demora de tempo que levariam as gravuras das cópias dos quadros clássicos de nossos pintores que a Academia se propôs publicar, pediu que se observasse a prática seguida por todos os artistas que se têm dado a esta qualidade de obras, de se gravarem somente em perfis ou, quando muito, a mezza macchia, apresentando para corroborar a sua opinião algumas cópias de quadros célebres feitas conforme este método". Fonseca seria apoiado por quase todos os académicos, com a exceção do próprio Domingos José da Silva, ao contrapor que "assim mal poderiam dar a conhecer os gravadores a sua perícia, e que as estampas não teriam tanta extração, pois só as comprariam os entendedores". Mau grado o reparo, decidiu a conferência avançar com aquele método, "acelerando-se de modo que para 25 de Outubro próximo, no dia de abertura solene da Academia, se apresentasse já alguma estampa, podendo com

\footnotetext{
${ }^{94}$ Apud SOARES, Clara Moura - "Na origem da Galeria Nacional de Pintura da Academia de Belas Artes de Lisboa: 540 quadros selecionados do Depósito das Livrarias dos Conventos Extintos". Artis, n.o 2, 2014, pp. 200-201 (ANTT/MR, Mç. 2122, cx. 2).

${ }^{95} \mathrm{~A}$ referência neste rol ao gabinete do diretor honorário (Silva Oeirense), permite-nos supor ter sido realizado em data anterior a 1838 . Uma nota existente na capilha indica ter sido este documento encontrado nos documentos de Luciano Freire que o terá coligido no arquivo da Academia. Arquivo do MNAA, fundo José de Figueiredo, cx. 1. pasta 1, doc. 1.
} 
mais pausa os Srs. professores dar-se ao acabamento completo das outras para comprovarem a sua perícia" ${ }^{96}$.

No segundo aniversário da sua fundação, a 25 de Outubro de 1838, realizou efetivamente a Academia uma sessão solene de abertura que contou com a presença de D. Fernando II. O longo "relatório dos trabalhos" lido pelo professor José da Costa Sequeira, na qualidade de secretário, começa por aludir aos esforços desenvolvidos pelo jovem estabelecimento, considerando ter aquele enfrentado "com o maior empenho as imensas dificuldades que pareciam opor-se à sua completa organização". Assinala como positivo o facto de ter sido instalado no edifício de S. Francisco, junto ao depósito dos conventos extintos onde se conservava parte significativa do espólio pictórico nacional: "Esta oportuna ocorrência não podia deixar de ser considerada pelos artistas da Academia como do mais feliz agouro para a prosperidade das artes, e como o mais seguro fundamento de uma Galeria Nacional que pudesse servir de escola clássica aos jovens artistas" ${ }^{97}$. Rende por isso homenagem às facilidades concedidas pela comissão administrativa do depósito que "não só coadjuvou a Academia na aquisição daqueles magníficos quadros, mas tem contribuído muito para a organização da sua biblioteca, para a qual tem fornecido já perto de 2000 volumes" $^{98}$. Dignos de louvor são também os esforços de alguns académicos em prol da conservação e da divulgação do acervo, como o agregado Norberto José Ribeiro (1774-1844) $)^{99}$, por ter restaurado "vinte quadros originais, cujo estado de ruína parecia irremediável", sem esquecer os professores de gravura história que "já concluíram as cópias de dois dos melhores

\footnotetext{
96 Conferência ordinária de 26 de Julho de 1838. Arquivo da ANBA, disponível em http://digitarq.dgarq.gov.pt/PT-ANBA-ANBA-A-001-00002_m0118.TIF

97 "Sessão real e pública de abertura da Academia de Belas Artes de Lisboa, no dia 25 de Outubro do ano de 1838, segundo aniversário da sua fundação". Arquivo da ANBA, disponível em http://digitarq.dgarq.gov.pt/PT-ANBA-ANBA-A-001-00002_m0176.TIF

${ }_{98}$ Idem, disponível em http://digitarq.dgarq.gov.pt/ PT-ANBA-ANBA-A-001-00002_m0178.TIF

${ }^{99}$ Alice Alves considera-o "o pintor que mais se destacou no restauro de pintura na primeira década de vigência da Academia". ALVES, Alice - "Os restauradores da coleção de pintura da Academia de Belas Artes de Lisboa proveniente dos conventos extintos". SOARES, Clara Moura (coord.) - $O$ Património Artístico das Ordens Religiosas: entre o Liberalismo e a atualidade, 2014/2015 [no prelo]. Há ainda notícias de intervenções de restauro executadas por outros dois agregados, Joaquim Primavera (1793-18??) e Luís José Resende (1760-1847). SOARES, Clara Moura; RODRIGUES; Rute Massano; CRUZ, António João e REGO, Carla - op. cit., p. 243.
} 
quadros do nosso insigne Grão Vasco, os quais têm começado a gravar, afim de serem assim propagadas"100.

Terminada a leitura do discurso, seguiu D. Fernando em visita com os professores pelos diferentes espaços da Academia, com destaque para as salas onde se encontravam colocadas as pinturas, tendo ficado agradado com o que observou. No dia seguinte, recebeu o estabelecimento uma honrosa portaria informando que o monarca "observara o asseio, boa ordem e judiciosa colocação do gabinete de pinturas". A visita e as conversas mantidas com o corpo académico transmitira-lhe ainda a "esperança de que a Academia nascente em Portugal podia, pelo aturado zelo e eficazes esforços dos seus respectivos lentes, emparelhar no futuro com os estabelecimentos análogos dos países mais cultos da Europa" ${ }^{101}$. As lisonjeiras esperanças do monarca contrastam todavia com as apreciações efectuadas anos mais tarde pelo conde Athanasius Raczynski (1788-1874), esclarecido diplomata prussiano que, em 1843, em visita ao estabelecimento, comentará de forma lapidar: “Je ne découvre pas encore dans cette Académie d'éléments de progrès" ${ }^{102}$. Como já tivemos oportunidade de referir, o corpo académico vinha até à data - e continuará por muito tempo - a concentrar-se em três tarefas essenciais, com tímidos ou nulos resultados: a conservação do acervo, pugnado pela melhoria das instalações e pelo incremento dos restauros; a sua divulgação, dando continuidade ao projeto da coleção de gravuras; e a sua documentação com o objectivo de ver editado um catálogo. Logo em Dezembro de 38, o diretor-geral alertava ser "necessário que os Srs. professores tratassem de organizar um catálogo circunstanciado no qual mencionassem com particularidade as belezas e propriedades de cada quadro", de maneira a "satisfazerem-se as pessoas conhecedoras das belas artes que visitassem o estabelecimento, pois assim se pratica em toda a parte onde existem estas produções de belas artes" ${ }^{103}$. A ideia foi abraçada pelo recém-nomeado vice-inspetor, Luís Francisco da Silva Breyner (1801-

\footnotetext{
100 Arquivo da ANBA, disponível em http://digitarq.dgarq.gov.pt/ PT-ANBA-ANBA-A-00100002_m0180.TIF

${ }^{101}$ Apud RIBEIRO, José Silvestre - op. cit., T. VI, 1876, p. 97.

${ }^{102}$ RACZYNSKI, A. - Les arts en Portugal: lettres adressées a la Société Artistique et Scientifique de Berlin et accompagnées de documents, 1846, p. 97.

103 Conferência ordinária de 5 de Dezembro de 1838. Arquivo da ANBA, disponível em http://digitarq.dgarq.gov.pt/ PT-ANBA-ANBA-A-001-00002_m0210.TIF
} 
1865), conde de Melo, antigo estudante de pintura na Academia de S. Lucas em Roma, que a participou ao Ministério do Reino. Semanas mais tarde, aquele ministério comunicava por portaria que "o catálogo dos quadros conservados na Academia de Belas Artes de Lisboa e dos que possam vir a pertencer-lhe de futuro, seja acompanhado de um juízo crítico sobre o merecimento de cada um deles", nomeando para tal uma comissão de maneira a "proceder à confecção daqueles trabalhos pelo método que for mais útil e conveniente" ${ }^{104}$. Seria composta pelo conde de Melo, pelo professor António Manuel da Fonseca, e pelo académico honorário António Dâmaso de Castro e Sousa (1804-1876), mais conhecido por abade de Castro, tido como entendido naquelas matérias ${ }^{105}$. Em desacordo com certas opções que a instituição vinha tomando, Fonseca acabou por não acompanhar aquele processo, usufruindo de uma prolongada estadia em Roma. Um projeto por si apresentado no mês anterior para "se reconhecer o valor infalível de todos os quadros que formarão a Galeria Nacional de Pintura", onde propunha mandar à avaliação de um júri da Academia romana de São Lucas as obras consideradas mais significativas, certamente agravou a divergência ${ }^{106}$.

Para além da ausência do professor Fonseca, os trabalhos contaram com um conde de Melo pouco disponível dadas as funções entretanto assumidas à frente do município de Lisboa, arrastando-se durante cerca de um ano e meio até Junho de 40, altura em que o abade de Castro se dirigiu por escrito à conferência, "dando conta da conclusão do exame e análise dos quadros existentes na Academia". O secretário apresentou na mesma ocasião a relação efectuada, "decidindo-se que fosse remetida ao governo, depois de copiada a limpo" onde permaneceu arquivada, sem qualquer consequência prática ${ }^{107}$.

À semelhança do inventário anterior, o designado "catálogo analítico" organizou-se de acordo com os temas, suportes, escolas ou autorias, sem incluir todavia as dimensões das obras. Possuía, no entanto, indicações quanto ao seu "merecimento" (de "muito distinto" a "mais do que medíocre"), "lugares de onde vieram"

\footnotetext{
${ }^{104}$ Portaria datada de 19 de Dezembro de 1838. Boletim da Academia Nacional de Belas-Artes: documentos, IV, 1939, p. 20, doc. XVII.

${ }^{105}$ Sobre o abade de Castro cf. o ponto 1.2 da III parte deste trabalho.

${ }^{106}$ Apud SOARES, Clara Moura - op. cit, p. 201 (ANTT/MR, Mç. 2122, cx. 1).

107 Conferência ordinária de 4 de Junho de 1840. Arquivo da ANBA, disponível em http://digitarq.dgarq.gov.pt/PT-ANBA-ANBA-A-001-00003_m0160.TIF
} 
(proveniências) e "observações", ponto onde se incluíram apreciações estéticas adicionais, retificações iconográficas face ao inventário de 38 e referências ao estado de conservação ${ }^{108}$. Regista-se naturalmente o predomínio da pintura portuguesa, com destaque para os nossos primitivos que se associavam a "Vasco" ou à "Escola de Vasco", espelhando a recente tendência de redescoberta pela produção do mítico mestre viseense que encarnava "todo um glorioso quanto mal conhecido passado artístico da nação portuguesa"109. Acresciam algumas atribuições sonantes a mestres estrangeiros como Miguel Ângelo, Júlio Romano e Rafael, correspondendo a este último a Virgem da Anunciação que hoje se atribui a Cornelis van Cleve ${ }^{110}$.

Se a edição de um catálogo não avançava, o mesmo parecia suceder com a anunciada coleção de gravuras, tema lembrado em Agosto de 1841 por António Manuel da Fonseca, ao notar que "deviam começar-se a gravar os desenhos das cópias dos quadros de Grão Vasco para se dar impulso à publicação da galeria"111. 0 compromisso dos académicos responsáveis no andamento daquele trabalho não terá convencido Fonseca que, adivinhando a manutenção do impasse, se associou meses mais tarde a dois alunos, Manuel Maria Bordalo Pinheiro (1815-1880) e José Maria Baptista Coelho (1812-1891), a quem havia ocorrido propor semelhante projeto à Revista Universal. Na edição de 4 de Novembro, era efetivamente noticiada a publicação futura de uma "galeria artística" sob a direção do professor Fonseca, recorrendo aos "preciosos quadros de autor que na nossa Academia de Belas Artes se conservam". As estampas seriam desenhadas pelo referido professor e gravadas pelos dois alunos, devendo ser acompanhadas por "juízos críticos sobre elas e capítulos narrativos acerca dos sujeitos que representam, escritos pelos senhores Srs. Alexandre Herculano, António Feliciano de Castilho, João Baptista de Almeida Garrett, José Mendes da Silva Leal, etc.", todos colaboradores da revista ${ }^{112}$. A notícia foi recebida com desconforto por vários académicos que redigiram uma representação ao vice-inspetor, considerando lesado o estabelecimento e

\footnotetext{
${ }^{108}$ Apud SOARES, Clara Moura - op. cit, p. 201 (ANTT/MR, Mç. 2122, cx. 2).

${ }^{109}$ CARVALHO, José Alberto Seabra; BARREIRA, Marta - "Museus e exposições: ideias, formas e discursos de representação e celebração da arte portuguesa (do Liberalismo ao Estado Novo)". RODRIGUES, Dalila (coord.) - Arte Portuguesa da pré-História ao Século XX, vol. 20, 2009. p. 95.

${ }^{110}$ MNAA, inv. 107 Pint.

111 Conferência ordinária de 13 de Agosto de 1841. Arquivo da ANBA, disponível em http://digitarq.dgarq.gov.pt/ PT-ANBA-ANBA-A-001-00003_m0282.TIF

${ }^{112}$ Revista Universal, n. 6, 4 Novembro 1841, p. 70.
} 
solicitando explicações ${ }^{113}$. Este último argumentou não ver "naquela pretensão fim algum oposto aos interesses da Academia", nomeadamente em relação ao projeto que aquela acalentava desenvolver, "em muito maior ponto e noutra qualidade de gravura". A permissão havia sido aliás requerida "sob condição de que os desenhos devam ser no formato de jornal de quarto, e que não serão publicados sem exame e aprovação da conferência". Entendendo a divulgação do acervo como prioritária, acrescentava que "a concessão não se podia de maneira alguma negar, pois que semelhantes objetos nacionais devem ser quanto possível generalizados e estudados" ${ }^{\prime 14}$. Mau grado a abertura do vice-inspetor, nada seria publicado pela Revista Universal. Manuel Maria Bordalo Pinheiro continuou todavia a desenvolver esforços nesse sentido e, em 1843, solicitava o prolongamento da autorização concedida para a cópia das pinturas ${ }^{115}$, no provável intuito de adaptar o projeto ao Jornal das Bellas-Artes então fundado, o que veio efetivamente a suceder.

Dirigido por Almeida Garrett, aquele jornal tinha como subdiretor o mestre Fonseca, presidente e vice-presidente de uma "reunião de literatos de artistas" conforme enunciado. Entre a vasta lista de colaboradores contavam-se alguns dos nomes já apontados para a Revista Universal como António Feliciano de Castilho (1800-1875) e José da Silva Mendes Leal (1820-1886), acrescidos de Luís Augusto Rebelo da Silva (1822-1871), todos responsáveis pelos textos que acompanharam as reproduções em litografia das pinturas da Academia, em seis números entre 1843-46. Começouse por uma Adoração dos Reis Magos ${ }^{116}$ ou Epifania (fig. 3) gravada por Pedro Augusto Guglielmi (act. 1837-1852), entrevendo outras colaborações para além de Bordalo Pinheiro. No texto que Ihe dedicou, Rebelo da Silva segue a atribuição a Vasco Fernandes há muito dada pelos académicos, considerando, na sequência de indagações levadas a cabo por Fonseca, estar "corroborada a opinião geral de ter o autor, necessariamente, estudado debaixo da direção de Perugino"117 ${ }^{117}$ Também

\footnotetext{
${ }^{113}$ Assinaram a representação: Joaquim Rafael, José Francisco Ferreira de Freitas, André Monteiro da Cruz, João Pires da Fonte, Francisco de Assis Rodrigues, Domingos José da Silva, Caetano Ayres de Andrade, Benjamim Comte e Francisco de Paula Araújo Cerqueira.

${ }^{114}$ Conferência ordinária de 10 de Novembro de 1841. Arquivo da ANBA, disponível em http://digitarq.dgarq.gov.pt/ PT-ANBA-ANBA-A-001-00003_m0308.TIF

115 Conferência ordinária de 13 de Fevereiro de 1843. Idem, disponível em http://digitarq.dgarq.gov.pt/ PT-ANBA-ANBA-A-001-00003_m0375.TIF

${ }^{116}$ Gregório Lopes e Jorge Leal, Adoração dos Reis Magos, c. 1520-25. MNAA, inv. 5 Pint.

${ }^{117}$ SILVA, L. A. Rebelo da - “A Epifania". Jornal das Bellas-Artes, vol. I, n. 1, 1843, p. 7.
} 
atribuída a Grão Vasco era a tábua representando o príncipe D. João (futuro D. João III) e S. João Baptista ${ }^{118}$, (fig. 4) pormenorizadamente descrita por Mendes Leal que não deixa de chamar a atenção para o seu mau estado de conservação, lamentando ainda desconhecer-se a sua proveniência, numa crítica ao processo de extinção dos conventos que diz ter sido descuidado ${ }^{119}$. Em nota destaca ainda a singularidade da gravura onde predomina o contorno das figuras, "não é senão um ensaio deste género de trabalhos, quase novo entre nós, executado por alunos distintos da nossa Academia, e dignos discípulos do seu ilustre professor o Sr. Fonseca"120. Tal era, como tivemos anteriormente oportunidade de aludir, o resultado do método mais sintético proposto por aquele professor que procurava assim agilizar aquele processo, na sequência do que vinha sendo praticado noutros países.
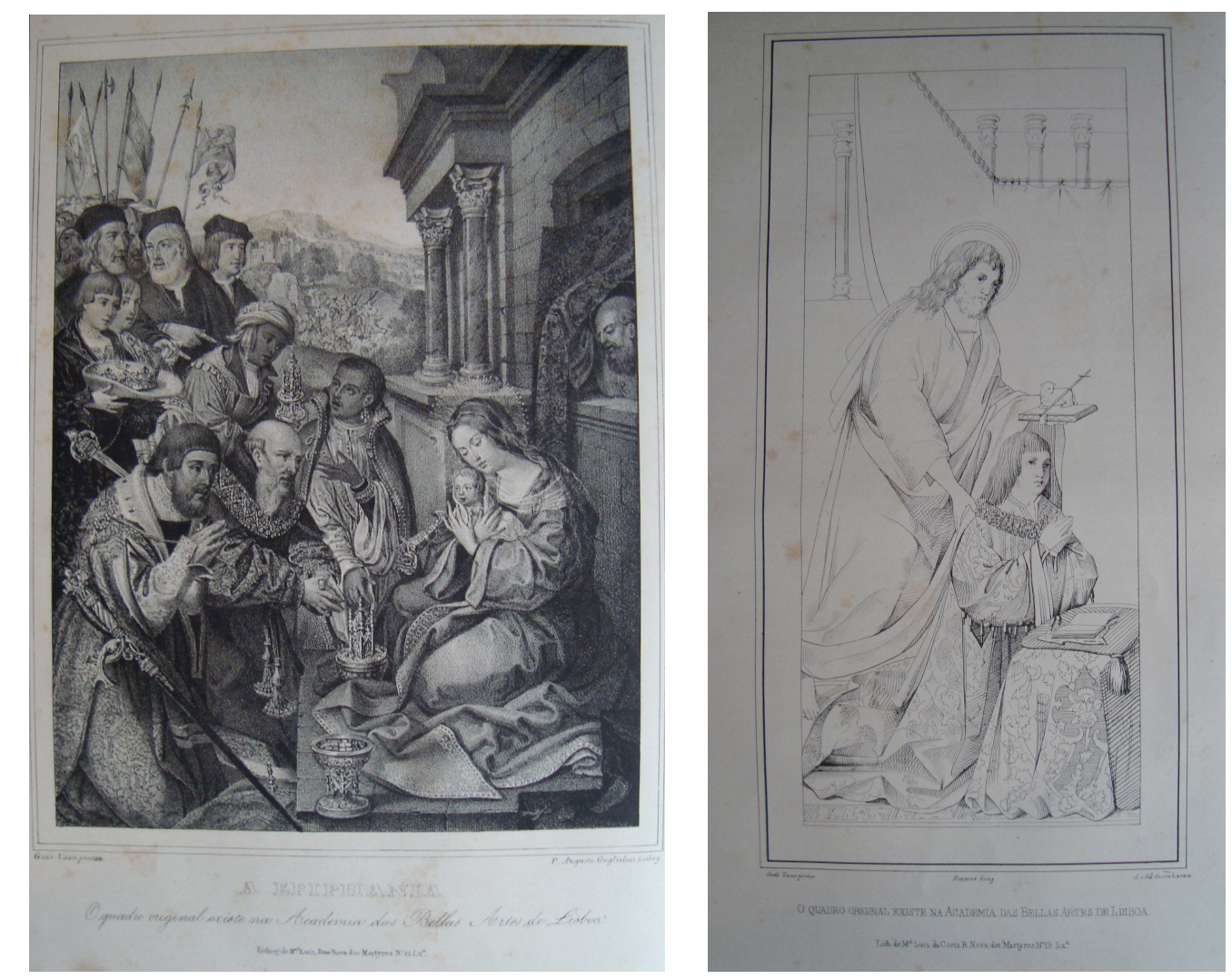

Fig. 3 - Adoração dos Reis Magos, litografia de P. Augusto Guglielmi publicada no Jornal das BellasArtes, 1843

Fig. 4 - Príncipe D. João e S. João Baptista, litografia publicada no Jornal das Bellas-Artes, 1843

\footnotetext{
${ }^{118}$ Mestre desconhecido, O príncipe D. João e S. João Baptista, c. 1515-18. MNAA, inv. 27 Pint.

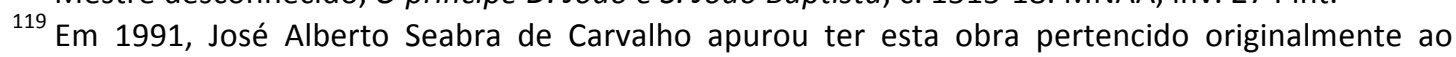
Mosteiro Real de Nossa Senhora da Serra (Almeirim). CARVALHO, José Alberto Seabra de - Estudo sobre as proveniências do Museu Nacional de Arte Antiga (inédito), 1991, p. 39.

${ }^{120}$ LEAL, J. M. da Silva - "São João Baptista". Jornal das Bellas-Artes, vol. I, n.o 1, 1843, p. 14.
} 
Pondo de parte os primitivos, a terceira escolha do jornal recaiu no S. Bruno em oração de Domingos Sequeira (fig. 5) ${ }^{121}$, litografado por Charles Legrand (act. 18391847), e acompanhado por um texto de Castilho que se alonga na história do santo e das virtudes da vida monacal ${ }^{122}$. No mesmo número, Silva Leal apresentou uma biografia possível do artista, dando conta de diversas obras na posse de particulares, diminuto que era o núcleo conservado na Academia (apenas quatro com destaque para a referida pintura) ${ }^{123}$.
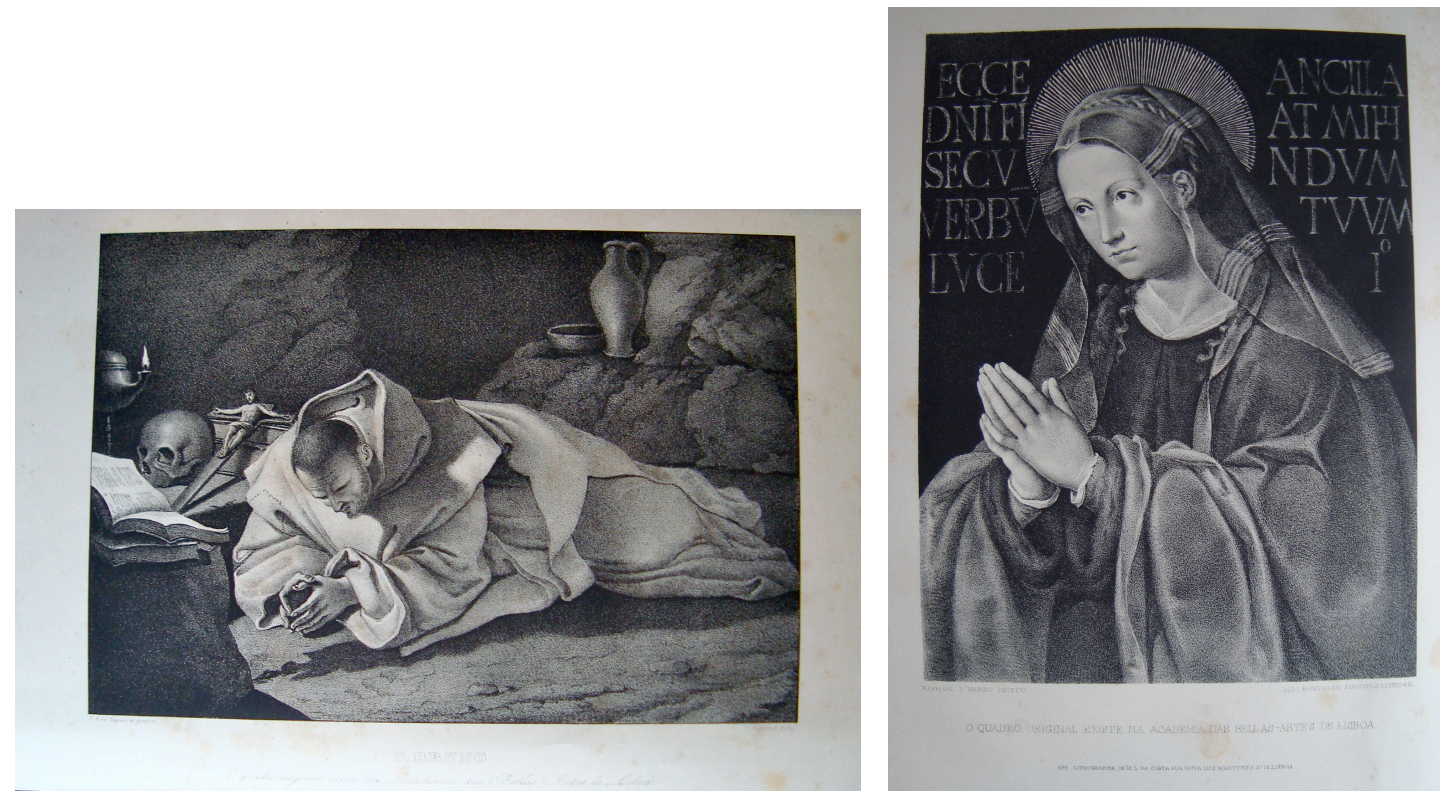

Fig. 5 - S. Bruno em oração, litografia de C. Legrand publicada no Jornal das Bellas-Artes, 1844 Fig. 6 - Virgem da Anunciação, litografia de M. M. Bordalo Pinheiro publicada no Jornal das BellasArtes, 1845

Seguiu-se depois uma Virgem da Anunciação, "cuja cópia se publica a claro-escuro, litografada pelo Sr. Bordalo Pinheiro com aquele esmero a que ele se não poupa nos seus desenhos" (fig. 6), escrevia Silva Leal a quem foi confiado o artigo. Regozijava-se o mesmo autor pela "luminosa ideia que deu existência a este jornal" ao serem dadas a conhecer as mais notáveis pinturas conservadas na Academia, "como há muito era de necessidade e justiça que o tivessem sido"124. Era precisamente o caso da obra em apreço, há muito associada a Rafael ${ }^{125}$, atribuição sustentada pelo

\footnotetext{
${ }^{121}$ Domingos Sequeira, S. Bruno em oração, 1799-1800. MNAA, inv. 118 Pint.

${ }^{122}$ CASTIILHO, A. F. - "S. Bruno". Jornal das Bellas-Artes, vol. I, n.o 2, 1844, pp. 19-27.

${ }^{123}$ LEAL, J. M. da Silva - "Biografia: Domingos António de Sequeira”. Ibidem, pp. 28-32.

${ }^{124}$ Idem - "Ancilla Domini: quadro de Rafael". Jornal das Bellas-Artes, vol. I, n. o 3, 1845, p. 39.

${ }^{125}$ Cornelis van Cleve (atrib.), Virgem da Anunciação, 1541-55. MNAA, inv. 107 Pint.
} 
professor Fonseca que se encarregara do seu restauro. Ao contrário do que sucedida com a generalidade do acervo académico, era conhecida a proveniência da pintura, oferta do Papa Inocêncio XI a D. Catarina de Bragança que a legou ao irmão, D. Pedro II, passando depois para o filho deste, D. João V. Terá sido doada pelo Magnânimo ao bispo do Algarve e, por último, ao convento de Brancanes de Setúbal, entrando na posse do Estado com a extinção daquele cenóbio.

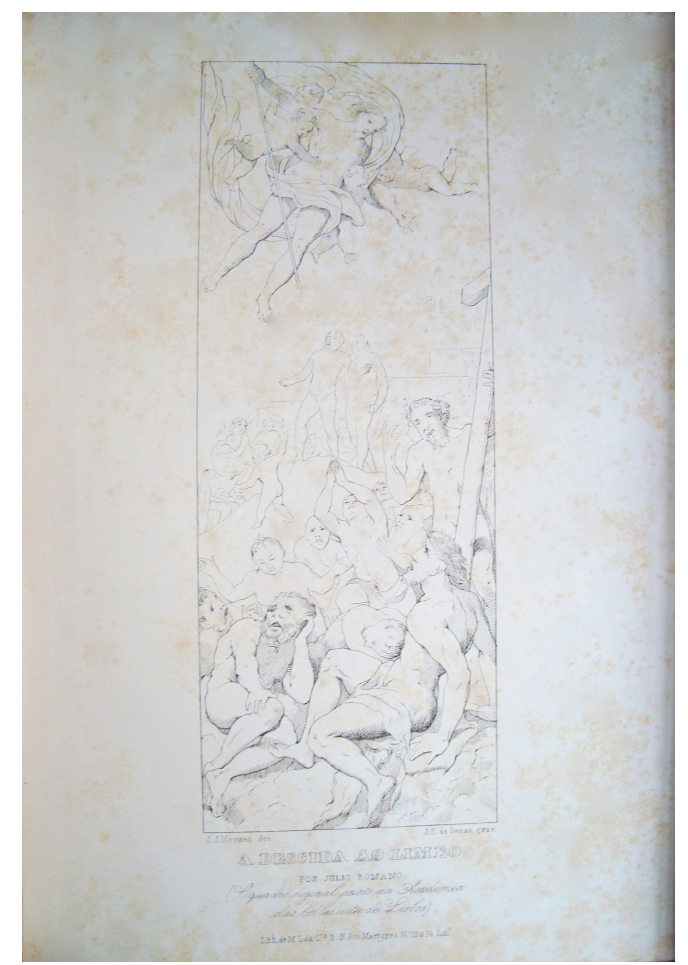

Fig. 7 - Descida de Cristo ao Limbo, litografia de J. P. De Sousa publicada no Jornal das Bellas-Artes, 1845

Ao pretenso Rafael seguiu-se um suposto Júlio Romano representando a Descida de Cristo ao Limbo, painel lateral esquerdo de um grande tríptico ${ }^{126}$ cuja cópia Silva Leal informa ter sido "tirada pelo Sr. Novais, e gravada na pedra pelo Sr. Sousa, ambos alunos da Academia" (fig. 7). Esclarecia ainda ser "o segundo trabalho deste género que apresenta o nosso jornal" ao basear-se essencialmente no contorno das figuras, no seguimento da gravura alusiva ao painel do príncipe D. João e S. João Baptista ${ }^{127}$. Com ele se finou o projeto que revelou ser de fôlego limitado, com apenas cinco gravuras publicadas. Pouco, com certeza, mas o suficiente para dar razão às

\footnotetext{
${ }^{126}$ Pieter Coecke van Aelst, Tríptico da Descida da Cruz, 1540-1550. MNAA, inv. 112 Pint.

${ }^{127}$ LEAL, J. M. da Silva - "A Descida ao Limbo por Júlio Romano". Jornal das Bellas-Artes, n.o 6, 1846, p. 89 .
} 
considerações do artigo de abertura, segundo as quais "o culto das belas artes [...] nunca fora verdadeiramente popular: aquele gosto geral, aquela inteligência comum que nacionalizavam as artes entre um povo não se difundira nunca bastante" ${ }^{128}$. Mau grado aquela incitava, a Academia não deixara de acalentar a ideia de ver editada a sua "galeria artística". Confiada aos artistas agregados à aula de gravura devido aos afazeres dos respectivos professores, aquela coleção de estampas seria, em 1844 , objecto de um ponto de situação por proposta submetida à conferência pelo professor substituto de arquitetura José da Costa Sequeira. Apresentadas as chapas, verificou-se que decorridos quase dois anos, "apenas se achava gravada pelo artista Francisco Tomás de Almeida a cópia do quadro de Grão Vasco que representa a Anunciação de Nossa Senhora, estando em grandíssimo atrasamento a que representa os Desponsórios da Virgem, incumbida ao artista António Maria de Oliveira Monteiro"129. Em resultado daquele exame, "determinou a mesa que se dessem louvores ao primeiro dos mencionados artistas, e que o Sr. professor Domingos José da Silva admoestasse os seus artistas e repreendesse o agregado Monteiro pela pouca diligência com que se tem havido na execução dos trabalhos que estão a seu cargo"130. As admoestações do professor pouco efeito terão tido na falta de empenho generalizada dos artistas agregados que não chegaram nunca a apresentar resultados expressivos. O projeto ficou assim irremediavelmente comprometido, deixando aos poucos de ser mencionado nas atas da conferência académica.

Na mesma sessão, o professor António Manuel da Fonseca que vinha fazendo constantes reparos sobre o mau estado de conservação dos quadros ${ }^{131}$, instou que

\footnotetext{
${ }^{128}$ Apud FRANÇA, José-Augusto - op. cit., p. 406.

${ }^{129}$ Correspondem seguramente aos dois painéis (MNAA, inv. 8 e 9 Pint) do chamado "Retábulo do Paraíso" que se atribui hoje à oficina de Gregório Lopes (c. 1520).

130 Conferência ordinária de 12 de Abril de 1844. Arquivo da ANBA, disponível em http://digitarq.dgarq.gov.pt/PT-ANBA-ANBA-A-001-00004_m0028.TIF

131 “O Sr. professor Fonseca falou acerca da precisão de se mandarem reparar os melhores quadros da Academia que se vão deteriorando consideravelmente". Conferência ordinária de 13 de Agosto de 1841. Arquivo da ANBA, disponível em http://digitarq.dgarq.gov.pt/ PT-ANBA-ANBA-A-00100003_m0281.TIF. “O Sr. professor António Manuel da Fonseca recordou a necessidade de se proceder quanto antes ao conserto de alguns dos melhores quadros da Academia que se estão arruinando de dia para dia". Conferência ordinária de 12 de Novembro de 1841. Idem, disponível em http://digitarq.dgarq.gov.pt/ PT-ANBA-ANBA-A-001-00003_m0356.TIF. Sobre a atuação de António Manuel da Fonseca neste domínio cf. ALVES, Alice - "O restauro de pintura na Academia de Belas-
} 
se "nomeasse uma comissão de três professores para os examinarem e proporem os meios de obviar a sua ruína"132, tendo sido ele próprio escolhido com Joaquim Rafael e André Monteiro da Cruz. Menos de dois meses depois, dada a aparente inércia dos colegas, tornava a lembrar "a necessidade de se acudir de pronto aos reparos dos quadros da Academia, assegurando que fazia estas instâncias para arredar de si toda e qualquer responsabilidade". Decidiu então a conferência acrescentar mais dois membros à comissão, os agregados Caetano Ayres de Andrade e José Francisco Ferreira de Freitas, e fixar as terças e sextas-feiras para as respectivas reuniões. Foram ainda discutidas as dificuldades que obstavam ao exame dos quadros e sobretudo a falta de um local adequado para os colocar após reparados, propondo alguns académicos "a casa que se destinava para a aula de arquitetura, que pela sua extensão e claridade pode remediar até certo ponto" ${ }^{133}$.

Por ocasião de uma visita efectuada um ano antes, o já citado Raczynski, diplomata prussiano de origem polaca cujos estudos artísticos eram já reconhecidos, motivo pelo qual foi desde logo nomeado académico honorário ${ }^{134}$, recomendava nas suas Lettres alguma prudência em relação aos restauros das pinturas do acervo. Com efeito, sugeria que "Si j' avais à donner mon avis, ce serait de réunir tous les tableaux d'un certain mérite, au nombre d'une vingtaine, dans une chambre de l'Académie, mais de ne pas permettre que l'on les retouchât avant que les arts eussent pris un nouvel essor"135.

Indiferente a qualquer sugestão nesse sentido, a comissão apresentará em Julho de 1844 o seu parecer, concluindo deverem quanto antes empregar-se os artistas agregados à aula de pintura de história nos respectivos restauros, suspendendo-se temporariamente os retoques que aqueles vinham há muito a efetuar nos tectos e pinturas murais do Palácio da Ajuda, a pedido do governo ${ }^{136}$. De acordo com um

Artes de Lisboa: a contribuição de António Manuel da Fonseca”. Arte e Teoria, n.o 16-17, 2014 [no prelo].

${ }^{132}$ Conferência ordinária de 12 de Abril de 1844. Arquivo da ANBA, disponível em http://digitarq.dgarq.gov.pt/PT-ANBA-ANBA-A-001-00004_m0029.TIF

133 Conferência extraordinária de 26 de Junhōo de 1844 . Idem, disponível em http://digitarq.dgarq.gov.pt/PT-ANBA-ANBA-A-001-00004_m0052.TIF

${ }^{134}$ A este respeito cf. conferência ordinária de 2 de Agosto de 1842. Idem, disponível em http://digitarq.dgarq.gov.pt/PT-ANBA-ANBA-A-001-00003_m0339.TIF

${ }^{135}$ RACZYNSKI, A. - op. cit., p. 266.

${ }^{136}$ Conferência extraordinária de 3 de Julho de 1844. Arquivo da ANBA, disponível em http://digitarq.dgarq.gov.pt/PT-ANBA-ANBA-A-001-00004_m0053.TIF 
levantamento dos intervenientes nos processos de restauro daquele estabelecimento $^{137}$, será então indicado o nome do agregado Gregório Luís Maria Rato, coadjuvado por Joaquim Gregório da Silva, e pouco depois Joaquim Gregório da Silva, estes últimos alunos de Norberto José Ribeiro, entretanto falecido. Ter-seão ocupado não tanto das pinturas do antigo depósito mas de uns painéis vindos de Tomar que a pedido daquele município, e por ordem do governo, haviam sido conduzidos à Academia com o objectivo de serem restaurados ${ }^{138}$, trabalho dirigido pelo mestre Fonseca, pela mesma altura chamado a colaborar nas obras de pintura decorativa do Palácio das Necessidades ${ }^{139}$.

Fonseca sucedeu a Oeirense na dinâmica que se pretendeu promover em torno da organização da galeria, dinâmica essa entretanto prejudicada pelas perturbações políticas de 1846-48, com prejuízos no regular funcionamento do estabelecimento, obrigado a ceder algumas das suas dependências para servirem de quartel do 2.을 Batalhão Nacional do Comércio. Será necessário aguardar até 1855 para a conferência voltar a discutir o tema da conservação das pinturas, uma vez mais por iniciativa do professor Fonseca ao observar "que os quadros existentes na sua aula caminhavam à sua total ruína e completa destruição por causa da grande humidade que constantemente existe na casa da referida aula". Sugeriu então aplicar-Ihes verniz de conservação e tapá-los com cortinas, ideia rejeitada por Joaquim Pedro de Sousa que se pronunciou contra as cortinas "as quais, disse, seriam um caricato para a Academia", propondo antes que "se afastassem os quadros das paredes e se fizesse o uso de fogões" para os proteger da humidade ${ }^{140}$.

Em Março do ano seguinte, numa invulgar conjugação de esforços, seria convocada uma sessão extraordinária a pedido dos professores António Manuel da Fonseca, Francisco Augusto Metrass e Joaquim Pedro de Sousa, "afim de se tratar definitivamente da conservação e da colocação dos quadros existentes na

\footnotetext{
${ }^{137}$ ALVES, Alice - "Os restauradores da coleção de pintura da Academia de Belas Artes de Lisboa proveniente dos conventos extintos". SOARES, Clara Moura (coord.) - O Património Artístico das Ordens Religiosas: entre o Liberalismo e a atualidade, 2014/2015 [no prelo].

${ }^{138}$ A este assunto voltaremos no ponto 1.4 da III parte deste trabalho.

${ }^{139}$ Estes trabalhos tiveram a supervisão do arquiteto da Casa Real, Possidónio da Silva, e a direção artística de Cinatti. A este respeito cf. TEIXEIRA, José - D. Fernando II: rei-artista: artista-rei (cat. expo.), 1986, p. 147 e CORTE-REAL, Manuel - O Palácio das Necessidades, 2001, pp. 80-84.

140 Conferência ordinária 29 de Novembro de 1855. Arquivo da ANBA, disponível em http://digitarq.dgarq.gov.pt/PT-ANBA-ANBA-A-001-00007_m0318.TIF
} 
Academia", visto existir ainda um largo número armazenado. Metrass que havia sido recentemente nomeado para o lugar de substituto de pintura de história, começou por pedir a palavra para demonstrar "a necessidade de se cuidar seriamente da conservação dos quadros; que não obstante não haver ainda uma galeria própria para a sua colocação, julgava urgentíssimo tirar quanto antes o grande número deles que ainda hoje se acham amontoados em arrecadação, e colocarem-se pelas paredes das diferentes aulas e mais casas da Academia enquanto não se construir essa galeria tão necessária para a boa conservação de tais objetos de arte"141.

Como daremos a conhecer no ponto seguinte, acalentavam os académicos um espaço expositivo a construir nas dependências do estabelecimento, propondo Metrass ser necessária uma comissão para tratar da colocação provisória das pinturas e assegurar a sua conservação. Seriam designados Fonseca, Metrass, Joaquim Rafael e José Francisco Ferreira de Freitas, acrescidos pouco depois de Tomás da Anunciação (1818-1879), nomeado substituto de pintura de paisagem ${ }^{142}$. Na mesma sessão, o diretor-geral não quis deixar de observar e fazer registar em ata que a Academia "nunca se descuidara da boa conservação dos quadros, que a falta de uma galeria própria para tal fim era o motivo porque muitos deles ainda hoje se acham em arrecadação, que já tinham estado colocados mas em consequência de um ter aparecido danificado, a conferência determinou que se retirassem enquanto não houvesse galeria".

Deve ainda ser mencionada a intervenção de Joaquim Rafael ao expor que apesar de aprovar a necessidade de melhorar a conservação dos quadros, "formalmente se oporia à colocação deles na sua aula, alegando que aquelas paredes só devem ser destinadas aos trabalhos premiados dos seus discípulos". Como já referimos anteriormente, Rafael sempre insistira nesse sentido mas a conferência deitou por terra aquela pretensão, "devendo-se sobretudo atender e tomar-se em consideração o cuidado e esmero que merecem os quadros que compõem a nossa

141 Conferência extraordinária de 15 de Março de 1856. Idem, disponível em http://digitarq.dgarq.gov.pt/ PT-ANBA-ANBA-A-001-00007_m0349.TIF

${ }^{142}$ Conferência ordinária de 30 de Março de 1857. Idem, disponível em http://digitarq.dgarq.gov.pt/ PT-ANBA-ANBA-A-001-00008_m0017.TIF 
galeria nacional e de que a Academia é responsável"143. Assim argumentou Fonseca como o apoio da generalidade dos colegas, determinando o diretor-geral que a comissão assim procedesse.

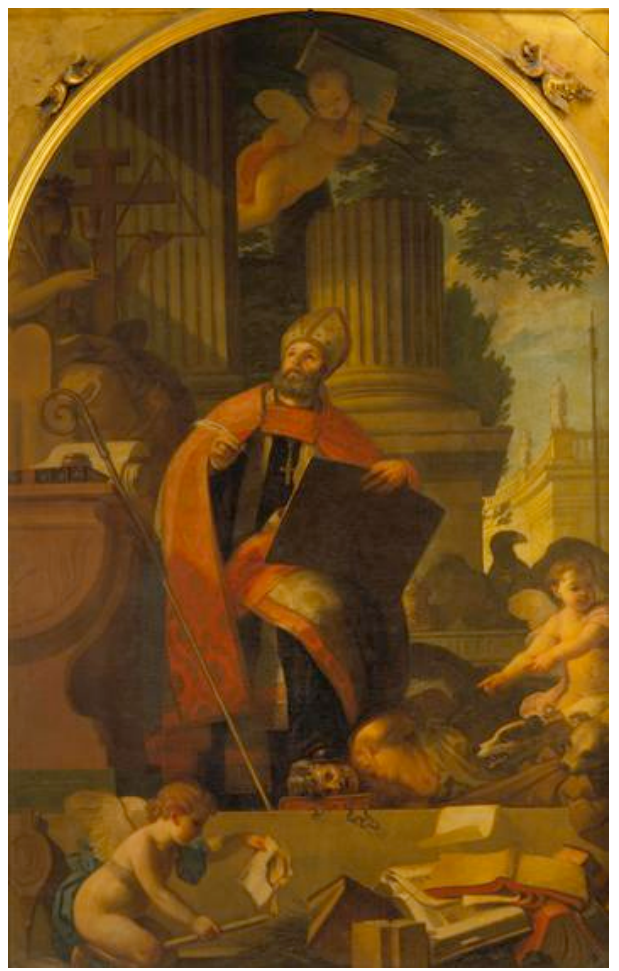

Fig. 8 - Vieira Lusitano, Santo Agostinho, 1736. MNAA, inv. 119 Pint

Entre as pinturas então colocadas na aula de desenho, sobressaía o monumental Santo Agostinho de Vieira Lusitano (fig. 8), pouco depois objecto de uma intervenção cuja metodologia foi debatida, considerando Fonseca ser de "fácil restauro pelas suas formas simples, grandiosas e nenhum empaste de tinta". De acordo com o mesmo professor, os quadros existentes na Academia "deviam e podiam ser restaurados pelo mesmo modo que se tem praticado nas galerias estrangeiras, e pela maneira que o têm tratado vários autores em seus escritos". Foi aprovada por maioria aquela proposta com a exceção de Metrass ao expressar "que não se restaurassem os quadros mas sim que se conservassem"144. Seria aquele trabalho entregue a três artistas agregados, Franco, Oliveira e Caetano, podendo cada um

${ }^{143}$ Idem, disponível em http://digitarq.dgarq.gov.pt/ PT-ANBA-ANBA-A-001-00007_m0350.TIF e m0351.TIF

${ }^{144}$ Conferência extraordinária de 16 de Maio de 1859. Idem, disponível em http://digitarq.dgarq.gov.pt/PT-ANBA-ANBA-A-001-00008_m0127.TIF 
deles "tomar livremente à sua conta para restaurar uma das figuras da parte inferior do dito quadro" sob a inspeção dos professores de pintura da comissão acima referida ${ }^{145}$.

No intuito de conferir maior operacionalidade à dita comissão, foi entretanto nomeado para seu presidente António Manuel da Fonseca, determinando-se a realização de uma reunião semanal entre os seus membros, a ter lugar todas as quartas-feiras. Ficou ainda decidido que as suas atribuições passavam não só por promover e inspecionar os trabalhos de conservação e restauro das pinturas do acervo, e a sua colocação provisória nas salas de aula, mas também selecionar as obras destinadas a integrar as exposições trienais ${ }^{146}$. No constante vai e vem de comissões que tão caro era aos académicos, a esta irão suceder-se outras mais, acrescidas de novas competências e atualizadas nos seus membros, vindo a exercer um papel ativo durante a vigência de Sousa Holstein enquanto vice-inspetor como veremos na III parte.

\subsection{Projetos para a construção de uma galeria}

As pequenas e apressadas obras que se realizaram no extinto Convento de São Francisco para a instalação da Academia de Belas Artes, não permitiram adaptar de forma satisfatória o edifício às suas novas funções escolares e de divulgação artística. A estrutura conventual continuou a fragmentar o espaço, sendo escassas as divisões amplas, bem iluminadas e ventiladas, que permitissem alojar condignamente as aulas e o acervo pictórico selecionado no depósito. A zona poente que dava para a antiga Rua Nova dos Mártires (atual Serpa Pinto), seria objecto da intervenção mais aprofundada, tendo sido escolhida para as aulas de pintura e desenho, então dotadas de iluminação zenital, com estruturas envidraças rasgadas nos tetos. Pior instalada ficou a aula de escultura, empurrada para as dependências que comunicavam com os restos do claustro, assim como a aula de gravura e a oficina de litografia, alojadas na zona nascente, virada para a antiga Rua de S. Francisco, em

145 Conferência extraordinária de 19 de Maio de 1859. Idem, disponível em http://digitarq.dgarq.gov.pt/ PT-ANBA-ANBA-A-001-00008_m0130.TIF

${ }^{146}$ Conferência ordinária de 30 de Maio de 1859. Idem, disponível em http://digitarq.dgarq.gov.pt/ PT-ANBA-ANBA-A-001-00008_m0134.TIF 
construções degradadas que mais tarde serão demolidas, dando origem ao largo hoje existente ${ }^{147}$.

Com decorrer dos anos, e mau grado outras obras entretanto efectuadas, os problemas foram-se avolumando, o que levou frequentemente os académicos a chamar a atenção dos poderes públicos para as deficientes condições do edifício, sobretudo no que dizia respeito à humidade, tornada na principal causa da degradação das pinturas e de outros espécimes que integravam o espólio artístico do estabelecimento. Essas deficiências não deixaram de ter eco na opinião pública, como se verifica num artigo publicado na revista $O$ Panorama, em que o escritor Ribeiro de Sá (1822-1865) ${ }^{148}$, ao comentar a exposição trienal de 1843, alerta para a necessidade da Academia dispor de instalações mais adequadas, ao nível da importância das obras que estavam à sua guarda:

“É muito para sentir ver a inconveniência que o extinto convento de S. Francisco apresenta para servir de Academia das Belas Artes: todos os reparos que se the tem feito, todos os esforços do digno corpo académico, têm sido quase inúteis para remediar os imensos inconvenientes que este edifício tem para o fim que o destinaram. É mister que todos se convençam da necessidade de transferir a Academia para um edifício onde os quadros se não danifiquem continuamente pela humidade das salas em que estão colocados, em que haja luz suficiente e que se possa apropriar do modo que mais convier aos diferentes quadros, e finalmente que tenha proporções para se formarem as galerias indispensáveis, e que tanta falta fazem" ${ }^{149}$.

Acrescentava o articulista ter o nosso país uma riqueza nacional nos quadros que possuía, "mas nem muitos portugueses a conhecem, pela falta de galerias onde se exponham em separado os quadros antigos e os que formam a exposição". Referiase às salas de aulas de pintura onde as obras contemporâneas do certame trienal

\footnotetext{
${ }^{147}$ A este respeito cf. SILVA, Luís Cristino da - A sede da Academia Nacional de Belas Artes no vetusto edifício do antigo convento de S. Francisco da cidade: estudos e subsídios, 1973, pp. 14-17.

${ }^{148}$ Sebastião Ribeiro de Sá, filho do barão de Palma, foi membro do Conservatório Nacional, escritor e colaborador de vários jornais, entre os quais $O$ Panorama, e revistas como a Revista Universal.

${ }^{149}$ SÁ, S. J. Ribeiro de - "Academia de Bellas-Artes de Lisboa: exposição de 1843". O Panorama, vol. III, 3으 da 2a série, n.o 107, 13 de Janeiro de 1844, p. 13.
} 
tinham de conviver com os quadros provenientes dos conventos extintos. Aproveita para destacar alguns, centrando-se nos primitivos, "recordação mais sublime que temos do esmero e perfeição dos nossos antigos, e que modernamente têm sido assunto de uma grave questão", numa referência ao interesse então demonstrado por Vasco Fernandes. Aqueles trabalhos, diz, "mereciam bem que houvesse um local onde pudessem ser vistos do modo que merecem", lançando um repto para que, sem demora, "se tratasse de remediar tão grande dano" ${ }^{150}$.

A conjuntura económica não era todavia favorável para se pensar na transferência para outro edifício como propunha Ribeiro de Sá e, muito menos, para uma construção de raiz, por muito parcimoniosa que fosse. A exposição chegou aliás a incluir dois projetos para uma Academia de Belas Artes analisados em profundidade pelo nosso articulista, mas tratavam-se de monumentais exercícios escolares, um de "estilo grego" elaborado pelo aluno João Pedro Monteiro, premiado com a medalha de ouro, e outro "romano" da autoria de Valentim José Correia. Eram pois propostas utópicas, eivadas de modelos estrangeiros, tal como as que Manuel Joaquim de Sousa havia apresentado em 38 , ao ser nomeado académico de mérito, a mais elaborada das quais num arrebatador neoclassicismo com algum pendor fantástico ${ }^{151}$.

Às apreciações de Ribeiro de Sá, importa acrescentar as da filha do poeta inglês William Wordsworth, Dora Wordsword (1804-1847), que durante uma estadia em Lisboa, em 1845, assiná-la no seu diário as deficientes condições de instalação dos quadros na Academia, merecendo destaque a expressão "lumber room" popularizada pelos escritores britânicos no século XIX, e alusiva às arrecadações existentes nas grandes residências da época:

"All the pictures in this museum, native and foreign, were equally badly off for light and arrangement. They were disposed in lumber room fashion. Some were hung up, some were resting on the floor, and some had their faces turned to the wall, and these were not the worst pictures. Senhor Assis, the sculptor of several statues in

\footnotetext{
${ }^{150}$ Idem, ibidem, p. 14.

151 Cf. SILVA, Luís Cristino da - op. cit, p. 30.
} 
the Ajuda Palace, was the director of this part of the establishment; and he may, perhaps, by this time, have contrived to put this gallery in order" ${ }^{\prime 152}$.

As esperanças da visitante inglesa na organização do acervo muito tardaram a ser cumpridas, o que está naturalmente relacionado com a contenção de despesas imposta pelos sucessivos governos. Refira-se que por decreto de 28 de Novembro de 1842, Costa Cabral reduziu drasticamente os quadros da Academia, "em atenção à urgente necessidade que havia de diminuir as despesas do Estado" ${ }^{153}$, determinando que as vagas para os artistas agregados, à medida que se verificassem, não fossem preenchidas. Estes artistas em número de 46, diminuíram para 29, em 1843.

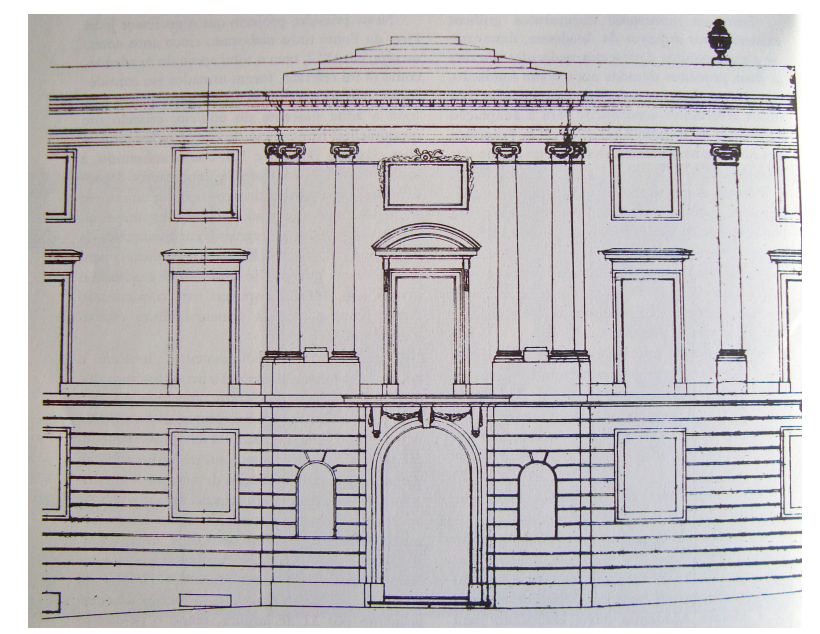

Fig. 9 - João Pires da Fonte, proposta para a fachada do edifício da Biblioteca Pública e Academia de Belas Artes de Lisboa, 1840. Arquivo da ANBA

Mau grado as dificuldades do Tesouro Público, os académicos acalentaram durante muito tempo ser possível (e até preferível) proceder à reformulação do edifício existente que, apesar dos problemas enunciados, possuía inegáveis vantagens pela sua amplitude e situação central. Porventura mais económica, esta solução ocupou longamente o professor João Pires da Fonte, discípulo do arquiteto F. A. Rosa da Ajuda, que logo em 40, na primeira exposição trienal, apresentou um projeto para a fachada principal que importava nobilitar, atribuindo-Ihe alguma monumentalidade inerente às funções do edifício (fig. 9). Para tal, pensou em duas opções, uma mais

\footnotetext{
${ }^{152}$ WORDSWORTH, Dora - Journal of a few month's residence in Portugal and glimpses of the south of Spain, vol. II, 1847, pp. 244-245.

${ }^{153}$ Apud RIBEIRO, José Silvestre - op. cit., T. VI, 1876, p. 101.
} 
simples (à esquerda) e outra mais ornamentada (à direita), revelando-se no seu traço muito arreigado aos alçados do pátio interior daquele palácio real: piso térreo em silharia, e andar nobre com pilastras jónicas e vãos com lintel de ressalto, à exceção do central, com frontão semicircular.

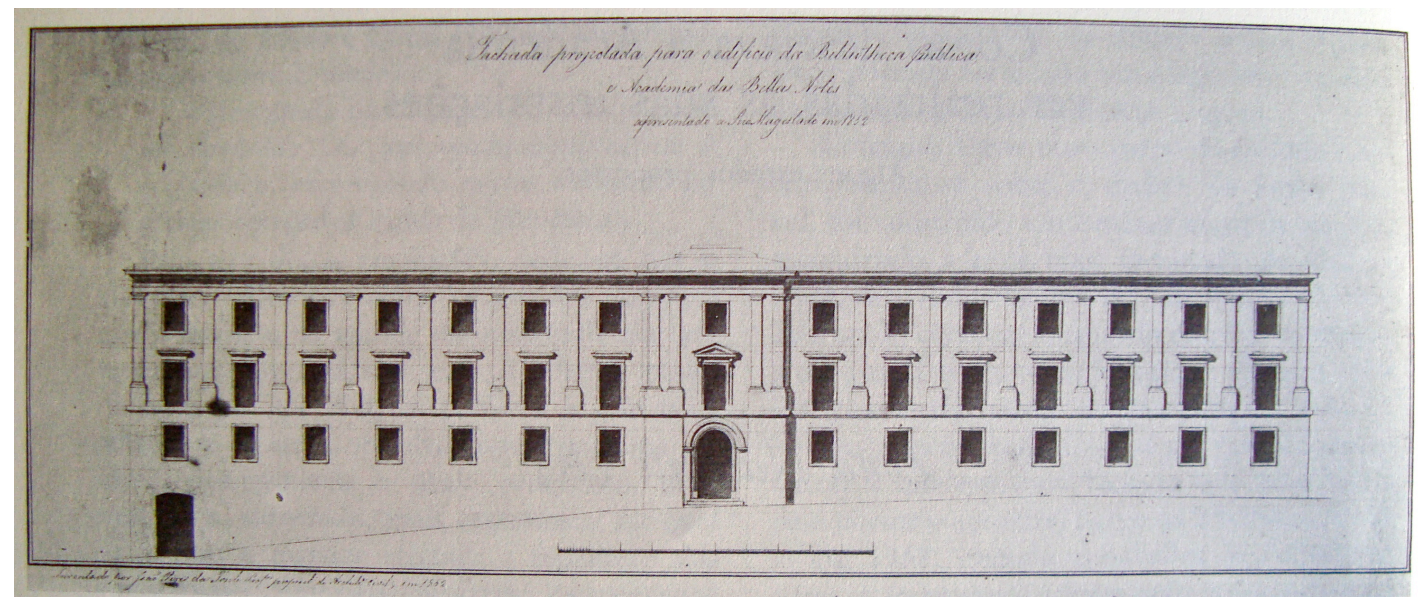

Fig. 10 - João Pires da Fonte, Fachada projetada para o edifício da Biblioteca Pública e Academia das Belas Artes apresentado a Sua Majestade em 1852. Arquivo da ANBA

Decorridos 12 anos, em 1852, Pires da Fonte retomou o mesmo projeto, simplificando a ordem das pilastras que de jónicas passaram a dóricas, e eliminando a silharia (fig. 10). Tal estará relacionado com a portaria de 15 de Maio daquele ano que, de acordo com a sessão onde foi dada a conhecer, encarregava o inspetor geral das Obras Públicas e dois arquitetos daquela repartição para, "de acordo com o bibliotecário-mor da Biblioteca Pública e com o vice-inspetor da Academia das Belas Artes, cada um na parte relativa no estabelecimento a seu cargo, delinearem o projeto das obras que forem consideradas precisas tanto na Biblioteca como na Academia". Alertava a mesma portaria ser necessário indagar se o edifício permitia ficarem nele bem instalados os dois estabelecimentos, "sem ter de recorrer-se de novo ao projeto de mudança da biblioteca para outro local” ${ }^{\prime 154}$. Pelas mesmas razões da Academia, verificamos ter a biblioteca ensaiado a mudança de local, sem sucesso, vendo-se agora perante a hipotética reformulação das suas instalações, numa conjugação de esforços com a instituição vizinha que esperava ver desta forma concretizada a sua galeria de pintura. Possuindo o nosso estabelecimento de ensino

\footnotetext{
154 Conferência ordinária de 29 de Maio de 1852. Arquivo da ANBA, disponível em http://digitarq.dgarq.gov.pt/PT-ANBA-ANBA-A-001-00007_m0104.TIF
} 
artístico uma cadeira de arquitetura, achou por bem avançar rapidamente com os trabalhos em detrimento das Obras Públicas a quem havia sido confiado o risco, surgindo assim o projeto em apreço que seria no mesmo ano apresentado à rainha de acordo com a indicação da legenda.

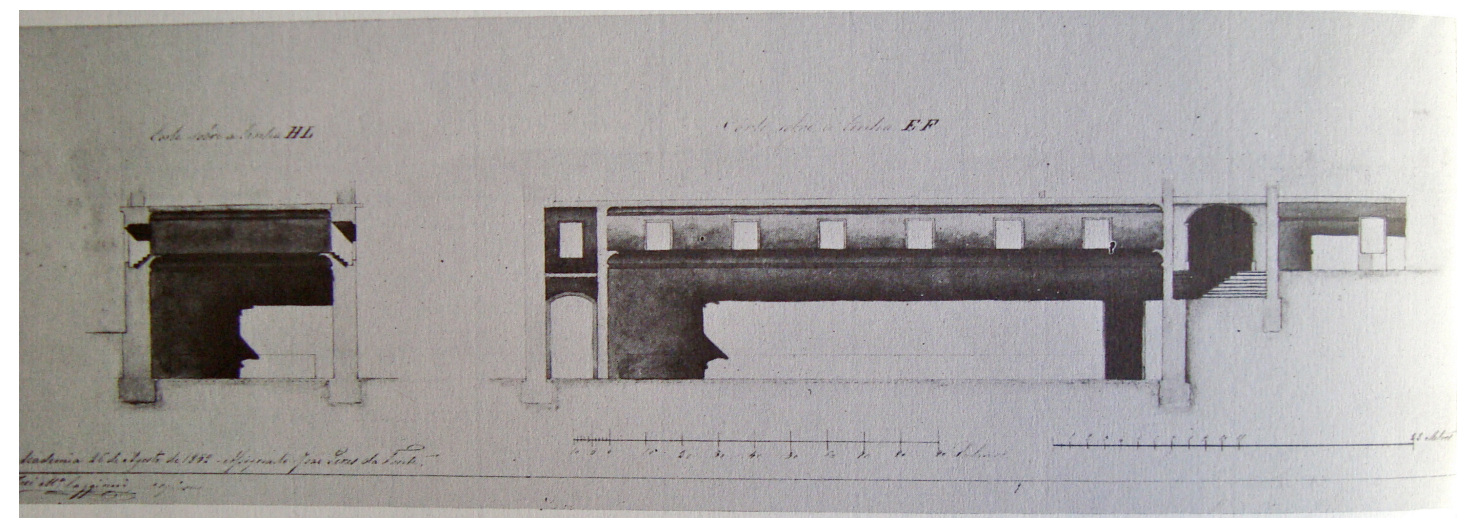

Fig. 11 - João Pires da Fonte, secção transversal e longitudinal da galeria de pintura, 1852. Arquivo da ANBA

Como previra na proposta elaborada em 40, Pires da Fonte tirou partido do espaço livre existente a sul do edifício, na zona do antigo claustro, o que Ihe permitiu projetar uma nova ala simétrica ao corpo do extinto convento, tomando como eixo a entrada principal, comum a ambos os organismos. Nos dois pisos inferiores desta ala propunha construir a tão desejada pinacoteca da Academia, em ligação com as cotas ocupadas pelo estabelecimento, e nos dois superiores, uma ampla sala de leitura de que carecia a Biblioteca Pública. A galeria apresentava 33 metros de comprimento por 11 de largura, desenvolvendo-se com um pé-direito duplo, correspondendo à cave e ao rés-do-chão do edifício (fig. 11), criando-se assim um vasto espaço rectangular dotado de luz bilateral para expor o acervo pictórico, podendo ainda servir à realização das exposições trienais e às sessões solenes de distribuição dos prémios. Para acesso à galeria e à sala de leitura, seria aproveitada a antiga escadaria conventual que pelas suas boas proporções poderia contribuir para a dignificação do ambiente.

A pertinência deste projeto que servia em partes iguais as duas instituições culturais alojadas no edifício, não foi suficiente para convencer o governo que adiou qualquer resolução a tomar nesse sentido. Em Janeiro de 1856, perante a manutenção daquele impasse, convocou a Academia uma sessão extraordinária com o objectivo 
de discutir "o estado ruinoso em que existe a frontaria do edifício em que se acha estabelecida, e bem assim as diferentes providencias que em diversas datas tem reclamado do Governo de Sua Majestade". Após várias reflexões, resolveram os académicos que o estabelecimento "devia dirigir novamente uma memória ao governo, e que uma em duplicado fosse apresentada a S. Majestade o Senhor D. Pedro V"155.

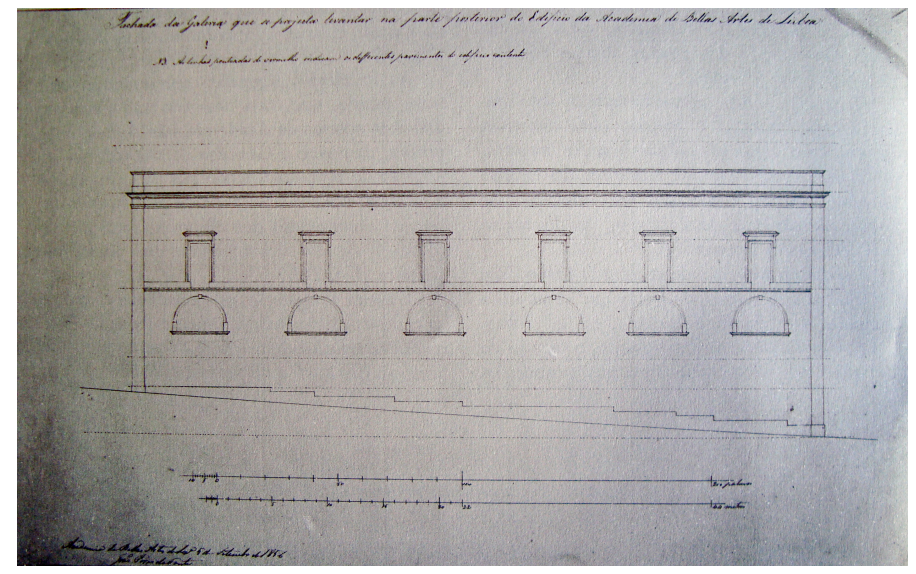

Fig. 12 - João Pires da Fonte, Fachada da galeria que se projeta levantar na parte posterior do edifício da Academia das Belas Artes de Lisboa, 1856. Arquivo da ANBA

A participação ao jovem monarca que sucedeu a D. Maria II, entretanto falecida, teve resultados imediatos, e logo no mês seguinte seria dada a conhecer a portaria real, instando a Academia a propor, com "a mais estrita economia", os projetos necessários "à feitura de uma galeria para a conservação dos quadros, e bem assim à construção de um laboratório de escultura para estudo e exercício dos alunos". Decorridos quase quatro anos da apresentação do projeto anterior, e já sem a parceria com a Biblioteca Pública que se manteve à margem desta representação, entenderam os académicos ampliar as reivindicações, daí a referência ao laboratório de escultura, entre outros equipamentos como veremos. O risco elaborado para a fachada principal do edifício mantinha-se, informando-se ter o Ministério do Reino ordenado às Obras Públicas "para que se proceda quanto antes à feitura da mesma"156. Os novos equipamentos reivindicados obrigaram todavia a que fosse

155 Conferência extraordinária de 6 de Janeiro de 1856 . Idem, disponível em http://digitarq.dgarq.gov.pt/PT-ANBA-ANBA-A-001-00007_m329.TIF

${ }^{156}$ Conferência extraordinária de 14 de Fevereiro de 1856. Idem, disponível em http://digitarq.dgarq.gov.pt/PT-ANBA-ANBA-A-001-00007_m329.TIF e_330.TIF 
nomeada uma comissão para deles se ocupar, composta por João Pires da Fonte, António Manuel da Fonseca, Francisco Augusto Metrass e Joaquim Pedro de Sousa. Das deliberações da comissão nasceu outro projeto igualmente traçado por Pires da Fonte que recorreu ao espaço livre existente a poente, na zona posterior do edifício, confinando com a antiga Rua Nova dos Mártires, atual Serpa Pinto (fig. 12). Para este espaço planeou uma ampla construção de dois andares onde previu a concentração da maioria das aulas de pintura e escultura, além de uma grandiosa e bem iluminada galeria de pintura. A grande sala a construir na nova ala da fachada principal abandonaria assim aquela função, ficando eventualmente reservada às exposições trienais e às sessões públicas. A sua localização, entre a cave e o rés-do-chão do edifício, zona propícia a humidades, poderá ter pesado na adopção desta nova solução.

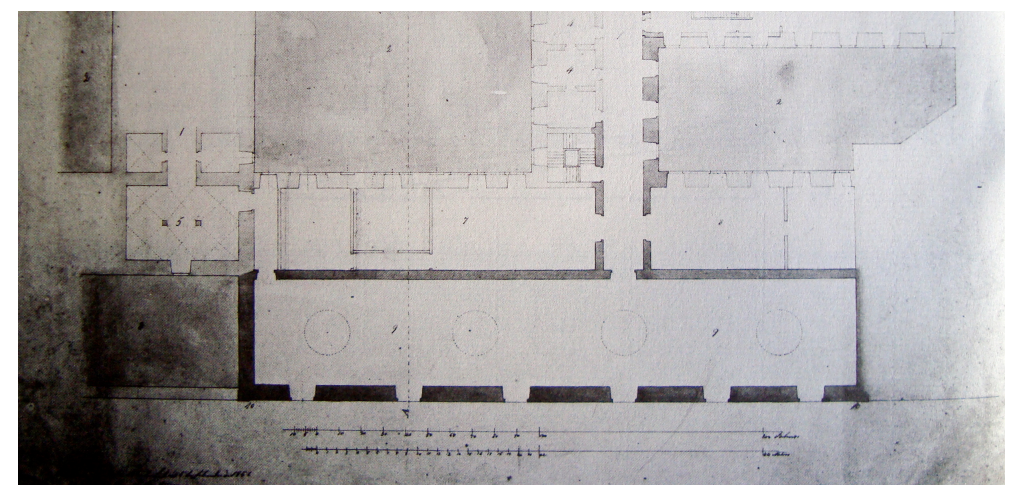

Fig. 13 - João Pires da Fonte, planta do 1ㅇ piso do corpo a construir com o grande espaço retangular destinado a galeria de pintura, 1856. Arquivo da ANBA

No piso térreo do corpo projetado a poente, iluminado por grandes lunetas, localizar-se-iam o laboratório de escultura, tendo em anexo os respectivos serviços auxiliares constituídos por uma oficina de formador, arrecadação de formas e modelos de gesso, depósito de ferramentas e utensílios de escultura, além de uma sala em anfiteatro destinada ao desenho de modelo-vivo. O primeiro andar seria reservado à galeria de pintura, dotada de excepcionais dimensões, cerca de 60 metros de comprimento por 11 de largura, praticamente o dobro do que havia sido previsto no projeto anterior (fig. 13). Ao contrário deste último, disporia de iluminação zenital, mais adequada, acrescida de luz lateral vinda dos seis vãos rasgados em toda a extensão da fachada sobre a antiga Rua Nova dos Mártires. 
Previa ainda uma comunicação direta com a biblioteca académica através de um pequeno corredor.

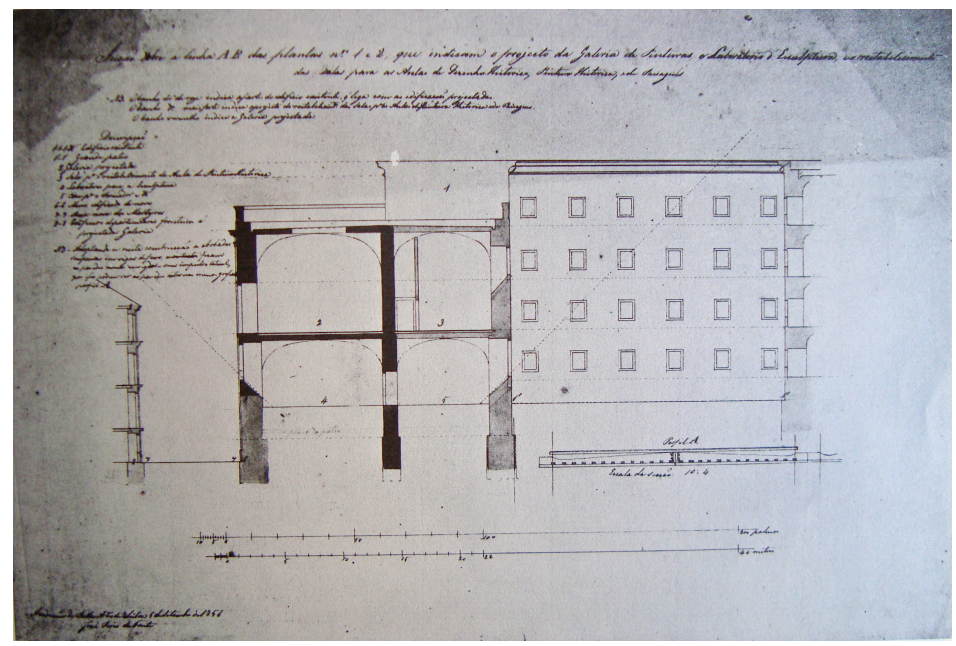

Fig. 14 - João Pires da Fonte, secção transversal do corpo projetado, 1856. Arquivo da ANBA

Desenvolvendo-se em paralelo à galeria, e confinando com os pátios interiores do extinto convento, ficariam localizadas as aulas de pintura de história e de paisagem, e um pouco mais à frente, a aula de desenho. Propunha-se portanto de forma algo ambiciosa a reinstalação de parte importante dos serviços do estabelecimento, o que só poderia ser satisfatoriamente conseguido com a construção de um novo corpo, marcado por um elevado pé-direito, sobretudo no andar correspondente à pinacoteca, como nos dá a ver a secção transversal (fig. 14). Apesar do seu enorme volume, e como já foi notado, apresentava a fachada "proporções de grande leveza, graças à simplicidade e pureza do traçado clássico adoptado na sua composição"157. Em Agosto de 1856, seriam os planos apresentados à conferência, contando estranhamente com a oposição de um dos professores escolhidos para os trabalhos preparatórios, António Manuel da Fonseca, ao referir ter-se a comissão "afastado das ordens do governo", uma vez que se havia "excedido na confecção de projetos gigantescos cujas despesas não comportavam a pobreza do tesouro público", e que sendo aprovados pela Academia, "era o meio de se não fazerem a galeria e laboratório". Pires da Fonte procurou sustentar a viabilidade do seu projeto "que era

\footnotetext{
${ }^{157}$ SILVA, Luís Cristino da - op. cit., p. 25. Na impossibilidade de acedermos fisicamente ao arquivo da ANBA, recorremos apenas aos projetos publicados no estudo deste autor, acrescidos das referências fornecidas por José-Augusto França.
} 
também o da comissão que o aprovou" como fez lavrar em ata, esclarecendo que para a instituição "ficar menos mal estabelecida, convinha orçá-lo em 37.000\$000 reis, mas que não convindo ao Governo fazer esta despesa, que a Academia se sujeitaria tão somente a possuir a galeria e o laboratório, no que se gastariam $17.000 \$ 000$ reis". Acreditamos que a diferença de 20 contos de réis seria respeitante ao plano de reformulação da fachada principal do edifício e da nova ala a ser construída na zona do antigo claustro, propondo Pires da Fonte que o estabelecimento poderia delas prescindir. Após alguma discussão sobre o assunto, "foram os projetos aprovados pelo conselho, à exceção do Sr. António Manuel da Fonseca que os rejeitou" ${ }^{\prime 158}$.

Alguma razão assistia ao professor Fonseca pois o governo não deu sequer seguimento à solução mais económica, escudando-se na política de contenção que mal disfarçava o desinteresse devotado às belas artes. A situação era todavia insustentável, e as críticas subiam de tom na imprensa que naquele mesmo ano de 56, considerava o edifício mais apropriado a uma "cadeia pública" ou mesmo a um "carneiro sepulcral" 159 . Entre 57 e 58 a fachada principal de S. Francisco será então intervencionada pelas Obras Públicas que se limitaram a uma mera reconstrução das zonas arruinadas, rasgando os pequenos vãos conventuais em janelas mais amplas, e abrindo uma porta no eixo dos antigos corredores, enquanto a zona sul equivalente à ala projetada e ao arruinado claustro, seria ocultada com um muro de suporte (fig. 15). Marcada por uma confrangedora severidade, esta intervenção contou naturalmente com a oposição dos académicos que, ao tomarem conhecimento do projeto das Obras Públicas, "muito diferente daquele que a Academia havia elaborado para o frontispício do edifício", resolveram dirigir uma representação ao Ministério do Reino, "mostrando que a frente do edifício pode ser decorada por um modo conveniente, empregando nestes trabalhos os artistas agregados à aula de escultura" $^{\prime 160}$.

\footnotetext{
${ }^{158}$ Conferência extraordinária de 5 de Agosto de 1856. Arquivo da ANBA, disponível em http://digitarq.dgarq.gov.pt/PT-ANBA-ANBA-A-001-00007_m371.TIF e_330.TIF e_372.TOF

${ }^{159}$ A Federação, 22 de Novembro de 1856

${ }^{160}$ Conferência ordinária de 28 de Junho de 1857. Idem, disponível em http://digitarq.dgarq.gov.pt/ PT-ANBA-ANBA-A-001-00008_m0029.TIF
} 


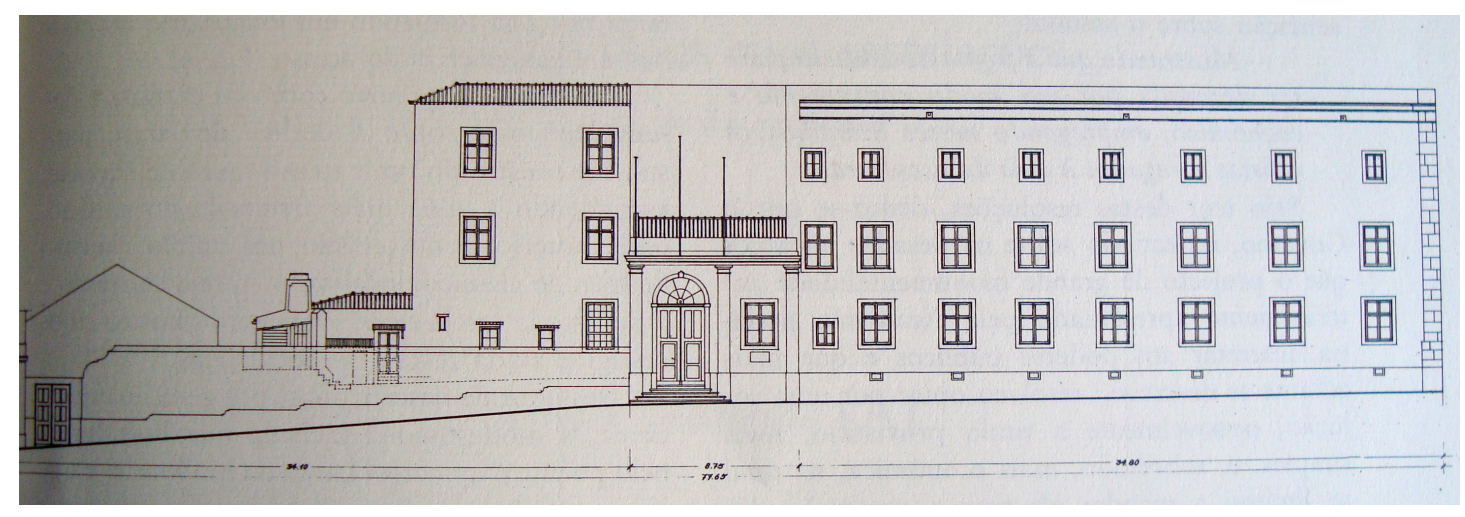

Fig. 15 - Fachada do antigo convento de S. Francisco após as obras de 1857-58. Levantamento publicado in A sede da Academia de Belas-Artes no vetusto convento do edifício de S. Francisco da cidade, 1973.

O apelo pela dignificação da fachada de nada valeu, assim como não foi tomada qualquer iniciativa quanto à instalação da pinacoteca, vendo-se a instituição obrigada a recorrer, como anteriormente, aos constantes pedidos de reparos das salas de aula que albergavam o acervo. Situadas a poente do edifício, estas salas haviam sido dotadas logo em 1837 de estruturas envidraçadas rasgadas nos tectos que com o passar dos anos foram dando problemas, tornando-se numa das principais causas da humidade apontada pelos professores. Em Julho 58, resolveu a conferência "que se repetissem os ofícios ao Ministério das Obras Públicas, fazendoIhe ver a necessidade que há dos reparos requeridos há anos pela Academia, mormente de se construírem novas clarabóias nas aulas de pintura que se acham inteiramente arruinadas, do que resulta introduzir nas ditas aulas grande quantidade de água nas estações invernosas, com grande prejuízo dos quadros existentes nas mesmas aulas" ${ }^{161}$.

As Obras Públicas que tanto se compraziam com a sua política de "pequenas reparações" deram pouco depois luz verde à solicitação, e em Janeiro de 59 reuniram-se os académicos para discutir o assunto, decidindo a construção em cada uma da aulas de pintura de "uma clarabóia ao centro que tivesse de comprimento 18 a 20 palmos aproximadamente", recomendando especiais cuidados com os materiais escolhidos e a respectiva montagem, no sentido de se poderem "adaptar

\footnotetext{
${ }^{161}$ Conferência ordinária de 29 de Julho de 1858. Idem, disponível em http://digitarq.dgarq.gov.pt/ PT-ANBA-ANBA-A-001-00008_m0075.TIF
} 
os vidros com a precisa segurança, sem que deixem penetrar as águas pluviais" ${ }^{162}$. Resolveu-se ainda elevar a altura das paredes em quatro palmos, rasgar um amplo arco de comunicação entre as salas, e suprimir as portas de serventia destas com os corredores e gabinetes dos professores. Procuravam-se com estas medidas improvisar uma galeria, e assim se explica a resolução tomada pela conferência em Agosto, para que "se fizesse um gradeamento ou resguardo de ferro em volta da sala que serve para as duas aulas de pintura, cujo gradeamento mede mais de 200 palmos" 163 .

Aparentemente indiferente aos pequenos esforços desenvolvidos, a imprensa continuava a fazer notar a necessidade de uma galeria, destacando-se em 59 a intervenção crítica de José Maria de Andrade Ferreira no Diario de Lisboa, inserida no contexto da reforma da Academia que então se projetava. Referindo-se à ausência de uma pinacoteca, dá injustamente a entender que "não se pensa em a organizar, como se houvesse de vencer impossíveis", lamentando o "fatal divórcio entre os governos que ultimamente se têm sucedido e as coisas da arte"164. Esta e outras acusações levaram o bibliotecário e artista agregado à Aula de Gravura João José dos Santos a proceder à defesa da Academia, numa série de artigos publicados no jornal A Federação, esclarecendo que "o governo mandou e se vão concluindo duas salas para a galeria, não sendo exato o que o Sr. Andrade Ferreira diz" ${ }^{165}$. Refira-se ainda ter o jornalista sugerido como local para a pinacoteca "a velha igreja do Carmo, pela sua poesia tradicional que a reveste e mérito arquitectónico que a recomenda" ${ }^{166}$. A desadequação da proposta será criticada com ironia pelo académico: "Uma igreja de três naves é excelente para uma galeria, pelo cruzamento de sombras e luz que a arcaria necessariamente deve produzir no seu recinto" ${ }^{\prime 167}$.

162 Conferência extraordinária de 17 Janeiro de 1859 . Idem, disponível em http://digitarq.dgarq.gov.pt/PT-ANBA-ANBA-A-001-00008_m0105.TIF

163 Conferência extraordinária de 19 Agosto de 1859. Idem, disponível em http://digitarq.dgarq.gov.pt/ PT-ANBA-ANBA-A-001-00008_m0152.TIF

${ }^{164}$ Os artigos foram reunidos num opúsculo: FERREIRA, José Maria Andrade - $A$ reforma da Academia das Bellas Artes de Lisboa, 1860, p. 64.

${ }^{165}$ Foram também reunidos no seguinte folheto: SANTOS, João José dos - Exame critico do opusculo reforma d'Academia de Bellas Artes de Lisboa pelo Sr. José Maria de Andrade Ferreira, 1860, p. 73.

${ }^{166}$ FERREIRA, José Maria de Andrade - op. cit., p. 64.

${ }^{167}$ SANTOS, João José dos - op. cit, 1860, pp. 73. 
As obras nas aulas de pintura arrastar-se-iam por algum tempo, resolvendo a conferência em Março de 1860 comunicar ao governo não poder distribuir publicamente os prémios relativos ao concurso, "visto o estado em que se acham as salas da Academia, pelos concertos que há mais de ano e meio estão em andamento, não permitem à mesma Academia celebrar a sessão pública" ${ }^{168}$. Dois meses mais tarde estava concluída a intervenção, e o professor António Manuel da Fonseca apressou-se a propor "que visto estarem prontas as duas salas de Pintura e bem secas as paredes das mesmas, se tratasse de colocar nelas os quadros", então amontoados em reserva. Retomando uma ideia recusada anteriormente como tivemos oportunidade de verificar, sugeriu que, após serem envernizados, "fossem resguardados com cortinas de paninho escuro para os preservar do alcalino que os destrói, no que a conferência conveio"169. Reformadas, as salas de aula de pintura voltaram no essencial ao que haviam sido desde o início - um arremedo de galeria cujo acesso público era muito limitado devido às funções lectivas a elas adstritas, adivinhando-se a falta de critério expositivo agravado pela ausência de um catálogo. As modestas intervenções nas aulas de pintura e na fachada de S. Francisco não desencorajaram todavia os académicos de continuar a sonhar com um espaço específico para o acerco pictórico e com a dignificação do exterior do edifício. Outras propostas irão suceder-se às anteriores, como as de Feliciano de Sousa Correia que, segundo José-Augusto França, "apresentou dois projetos, cingidos aos do mestre Pires da Fonte, mas mais atualizados no desenho, que mostravam janelas de verga semicircular com chave, num esquema que se desenvolveria nos anos 50, e grupos escultóricos sobre a cornija"170.

Em 62, para espanto da Academia, o Ministério das Obras Públicas abriria um concurso que levou a conferência a discutir e aprovar um ambicioso programa destinado à completa reformulação do edifício, Biblioteca Pública incluída, dando a entender não terem sido considerados definitivos os reparos anteriormente efectuados. Resolveu-se que para a fachada "combinar-se-á a elegância e

\footnotetext{
168 Conferência ordinária de 12 Março de 1860. Arquivo da ANBA, disponível em http://digitarq.dgarq.gov.pt/PT-ANBA-ANBA-A-001-00008_m0196.TIF

169 Conferência ordinária de 30 de Maio de 1860. Arquivo da ANBA, disponível em http://digitarq.dgarq.gov.pt/PT-ANBA-ANBA-A-001-00008_m0209.TIF

${ }^{170}$ FRANÇA, José-Augusto - op. cit., p. 318.
} 
simplicidade com a bem entendia economia e a devida conveniência relativa aos mesmos estabelecimentos", não sendo ventilado qual o tipo de ornamentação adequado, engavetados que estavam os projetos de Pires da Fonte e Sousa Correia. No que dizia respeito aos materiais construtivos, abria duas possibilidades, uma mais tradicional (alvenaria e tijolo) e outra mais inovadora (alvenaria e ferro), alertando deverem ser tomadas medidas contra incêndios. Finalmente, enumera as principais dependências necessárias, prevendo-se, para além das salas de aula e de espaços específicos para as intervenções de restauro, uma "galeria o mais espaçosa possível para os quadros"171. Dado o sucessivo historial de fracassos, não será de estranhar não ter tido este plano seguimento.

Deve ser ainda mencionado um derradeiro projeto para a fachada apresentado em 70, já sob a vigência do marquês de Sousa Holstein como vice-inspetor, pela mão do filho do mestre Fonseca, António Tomás (1822-1894), influenciado pelas tendências do Segundo Império francês, com a sua sucessão de pilastras, relevos e estatuária, combinados de forma pouco hábil ${ }^{172}$. Este arquiteto que virá a ser diretor-geral do estabelecimento, admitirá pouco depois a transformação deste figurino classicizante por outro "que servisse de monumento aos navegadores portugueses", substituindo a estátua de Minerva cuja colocação previa ao centro pela do Infante D. Henrique. Nesse caso, acrescentava, "talvez conviesse delinear a frente no estilo arquitectónico conhecido em Portugal pelo estilo manuelino", sintoma ingénuo mas curioso de penetração do neomanuelino que só mais tarde se desenvolveráa ${ }^{173}$.

Que os académicos não se tenham conformado com a desadequação do edifico que ocupavam é fácil compreender, mas o não reconhecimento dessa falha pelos poderes públicos é, como já refletiu Helena Lisboa, assunto mais complexo, prendendo-se com a falta de uma política de fundo para a intervenção construtiva na capital por parte do Ministério das Obras Públicas: “Uma mal entendida economia serviu quase sempre de desculpa para a adopção de soluções de recurso a pequenas e constantes obras que, ao sabor do rotativismo político, acabaram por

${ }^{171}$ Conferência ordinária de 28 de Abril de 1862. Arquivo da ANBA, disponível em http://digitarq.dgarq.gov.pt/ PT-ANBA-ANBA-A-001-00008_m0340.TIF

172 Cf. FRANÇA José-Augusto - op. cit., p. 226.

${ }^{173}$ Apud. Idem, ibidem, pp. 318-319. 
custar ao Estado muito mais do que grandes obras de fundo e de carácter definitivo" ${ }^{174}$.

\subsection{Outras incorporações: a coleção da rainha Carlota Joaquina}

Os problemas inerentes à gestão do espólio pictórico detido pela Academia de Belas Artes, sobretudo no que diz respeito às tentativas frustradas de edição de um catálogo e de uma coleção de gravuras, aos morosos trabalhos de restauro, e à difícil conquista de um espaço para servir de galeria, pouca margem deram aos académicos para definirem estratégias para o seu incremento. Ainda assim, algumas transferências de obras que jaziam esquecidas em estabelecimentos públicos e em certos conventos foram sendo efectuadas, podendo mencionar-se algumas telas de Pedro Alexandrino, vindas em 1840 da Alfândega de Lisboa ${ }^{175}$. No ano seguinte, sabemos terem sido tomadas "providências acerca da remoção para a Academia de Belas Artes de dois quadros do século XVI, existentes na capela sepulcral de D. João I da Batalha, representando a morte de Nossa Senhora e S. Tomás"176.

Esta tendência estendeu-se aliás a outros domínios, com destaque para a notável coleção de desenhos conservada na Imprensa Nacional, requisitada ao governo pela Academia em 1845. Reunida por Jerónimo de Barros Ferreira (1750-1803), um pouco conhecido pintor com obra em igrejas e casas particulares, seria adquirida após a sua morte pelo Estado com destino a um centro especializado de impressão de livros ilustrados, a chamada Oficina do Arco do Cego, vindo depois a transitar para a Imprensa Nacional. Constituída por várias centenas de trabalhos, sobretudo de autores italianos (Correggio, círculo de Veronese, Luca Cambiaso), mas também alguns portugueses (sobressaindo um raro núcleo da artistas dos séculos XVI e XVII como Fernão Gomes, Amaro do Valle, António Campelo ou Francisco Venegas), esta coleção prendeu desde logo a atenção dos académicos que se apressaram a

\footnotetext{
${ }^{174}$ LISBOA, Maria Helena - op. cit., p. 269, nota 12.

175 "Registo das ofertas, legados, depósitos e incorporações de objetos de arte de que a Academia de Belas Artes de Lisboa foi depositária (...)". Arquivo do MNAA, fundo José de Figueiredo, cx. 4, pasta 2, doc. 2.

${ }^{176}$ Arquivo do MNAA, Doações, depósitos e incorporações (1838 a 1912), livro n.o 86. Segundo apurou José Alberto Seabra Carvalho, correspondem as pinturas em questão ao Trânsito da Virgem (MNAA, inv. 63 Pint) que se atribui a Cristóvão de Figueiredo e ao São Tomás de Aquino (MNAA, inv. 68 Pint) de autor não identificado.
} 
formular o pedido, invocando a utilidade de tais espécimes na formação dos futuros $\operatorname{artistas}^{177}$. Favorável à ideia, o Ministério do Reino comunicará pouco depois ter "expedido ordens à Imprensa Nacional para entregar a coleção de desenhos que a Academia reclamara" ${ }^{178}$. Solicitado no âmbito do exercício de uma função pedagógica e, como tal, guardado na biblioteca académica, aquele acervo só mais tarde será alvo de preocupações museológicas/expositivas, constituindo o núcleo fundador de um gabinete de desenho ideado por Sousa Holstein ${ }^{179}$.

A política de contenção orçamental imposta pelos sucessivos governos e as carências generalizadas do estabelecimento, não foram todavia impeditivas da realização de algumas aquisições, sobretudo no domínio do desenho cujos valores se revelavam substancialmente mais baixos em relação à pintura, merecendo destaque um conjunto de 21 livros de esquissos de Vieira Portuense, pertencentes ao período da sua formação artística. Propostos para aquisição em 1850, considerou a conferência que "sendo uma obra tão sublime, a Academia dando por ela 48.000 reis por uma só vez conforme o exige o dono, não deve deixar de a comprar antes que possa haver da parte do vendedor qualquer arrependimento" ${ }^{180}$. Casos como este foram muito pontuais dado o permanente aperto financeiro do estabelecimento, levando à recusa de outras propostas. Não será portanto de estranhar que em 1861, ao ser discutida a aquisição de dois desenhos de Domingos Sequeira, acrescidos de uma gravura de Bartolozzi, "a conferência resolveu que se não comprassem por não haver meios na Academia para isso" ${ }^{181}$.

As magras possibilidades orçamentais explicam naturalmente a pouca frequência das aquisições, com especial evidência para a pintura, podendo mencionar-se o caso do professor Joaquim Rafael que, em 1853, propôs vender a sua "coleção de quadros clássicos da escola flamenga pintados a óleo que representam flores, aves e mais objetos pelo preço de $120 \$ 000$ reis". Conforme ficou registado, eram oito as

\footnotetext{
${ }^{177}$ GOMES, Alexandra Reis - "A coleção de desenho do Museu das Janelas Verdes". Desenho: $a$ coleção do Museu Nacional de Arte Antiga (cat. expo.), 1994, pp. 16-17.

178 Conferência académica de 30 de Outubro de 1845. Arquivo da ANBA, disponível em http://digitarq.dgarq.gov.pt/PT-ANBA-ANBA-A-001-00004_m0117.TIF

${ }^{179}$ A este respeito cf. o ponto 4 da III parte deste trabalho.

180 Conferência ordinária de 23 de Março de 1850. Arquivo da ANBA, disponível em http://digitarq.dgarq.gov.pt/ PT-ANBA-ANBA-A-001-00004_m0332.TIF

${ }^{181}$ Conferência ordinária de 31 de Agosto de 1861. Arquivo da ANBA, disponível em http://digitarq.dgarq.gov.pt/ PT-ANBA-ANBA-A-001-00008_m0287.TIF
} 
pinturas e haviam sido inicialmente avaliadas por outros professores do estabelecimento em 300 mil reis, o que representava um considerável abatimento. O diretor-geral observou então que "sendo os aludidos quadros bons originais, a aula de pintura de paisagem e produtos naturais muito lucraria com tão boa aquisição, e tendo os mais professores a mesma opinião, a conferência reconheceu que os quadros fossem comprados pela quantia proposta pelo vendedor", em prestações mensais ${ }^{182}$. Reflexo do consumo artístico possível do professor de desenho histórico, aquela pequena coleção assumia-se portanto aos olhos dos académicos como uma mais valia para o ensino ministrado na referida aula, não sendo feita significativamente qualquer referência ao interesse que poderia ter para a projetada galeria de pintura. Não dispomos de elementos que confirmem a concretização do negócio mas sabemos que, decorridos dez anos, em 1863, já com Sousa Holstein, os herdeiros do professor venderam à Academia dois quadros, seguidos no ano seguinte de mais de meia centena de desenhos de diversos autores $^{183}$.

Maior pertinência teria outra coleção cuja compra foi em 1862 sugerida ao governo, com destino à Academia. O diretor-geral convocou expressamente a conferência para informar ter recebido um oficio do Ministério do Reino, acompanhado de um requerimento de Susana Constança Savage de Bastos, "que propõe como herdeira e testamenteira do cônsul geral dos Países Baixos, a venda de uma coleção de quadros a óleo e de gravuras de autores de boa nota, por the constar que os referidos quadros faltam nesta Academia de Belas Artes" ${ }^{184}$. De acordo com uma relação anexa, sabemos ter integrado um total de 14 pinturas, com destaque para um esboço representando Andrómeda e Perseu cuja autoria era dada a Rubens, entre algumas cenas de género associadas a Teniers e van Ostade. Resulta a relação de um exame efectuado às obras pelos académicos que recomendaram ao governo a utilidade da compra, avaliando o conjunto em 642 mil reis (só o pretenso Rubens era estimado em 300 mil). A falta de verba disponível terá servido de argumento para

\footnotetext{
${ }^{182}$ Conferência ordinária de 29 de Julho de 1853. Idem, disponível em http://digitarq.dgarq.gov.pt/ PT-ANBA-ANBA-A-001-00007_m0174.TIF e_m0175.TIF

${ }^{183}$ Arquivo do MNAA, Aquisições 1850-1900, n.ㅇ 87.

${ }^{184}$ Conferência extraordinária de 17 de Maio de 1862. Arquivo da ANBA, disponível em http://digitarq.dgarq.gov.pt/PT-ANBA-ANBA-A-001-00008_m0344.TIF
} 
interditar o negócio, frustrando-se então uma das escassas tentativas desenvolvidas em prol do enriquecimento do acervo. Atrevemo-nos todavia a avançar com a sugestiva hipótese de parte desta coleção ter entrado na posse de José Luís Pereira Crespo, vindo mais tarde a ser adquirida pela Academia com o patrocínio de D. Fernando II. A este assunto nos iremos deter mais adiante ${ }^{185}$.

Um caso ocorrido anos antes merece todavia especial destaque, constituindo a grande exceção ocorrida no período anterior à vigência de Sousa Holstein: a compra pelo Estado de parte da coleção pertencente à rainha D. Carlota Joaquina de Bourbon (1775-1830) (fig. 16), colocada em hasta pública após a sua morte. Tratouse, na realidade, de uma das incorporações mais significativas realizadas pela Academia, não só pelo número de obras selecionadas, algumas das quais de assinalável qualidade apesar da maioria das atribuições se ter revelado falaciosa, como pelo investimento público que representou num país nada propenso a este tipo de gestos.

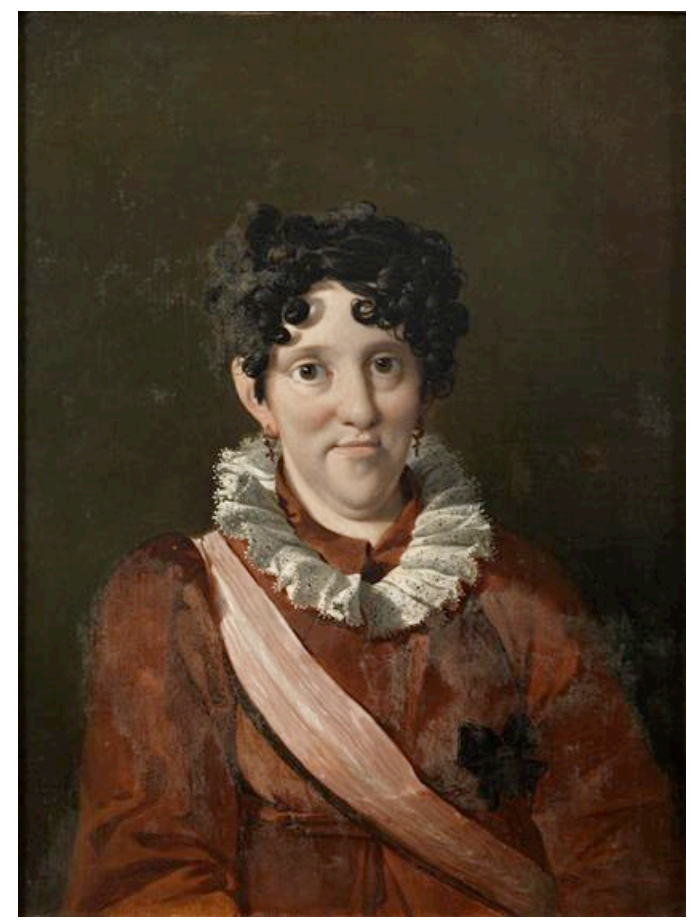

Fig. 16 - Nicolas-Antoine Taunay (atrib.), D. Carlota Joaquina, c. 1816. PNQ, inv. 255A/6

${ }^{185}$ Cf. o ponto 1. da III parte 
Aquela que foi considerada a "águia política" do absolutismo português ${ }^{186}$ nasceu no Palácio de Aranjuez, em 1775, no seio de uma família detentora de um dos mais relevantes acervos pictóricos jamais reunidos, iniciado no século XVI com os Áustrias. O interesse do pai, Carlos IV (1748-1819), pela pintura foi desde cedo uma realidade, como comprovam os gestos mecenáticos e as aquisições iniciadas enquanto príncipe das Astúrias ${ }^{187}$. O seu reinado (1788-1808), veio a ser um período da maior relevância sob o ponto de vista artístico graças a Goya, pintor da corte e figura próxima do monarca de quem deixou diversos retratos.

Com apenas dez anos de idade, D. Carlota Joaquina casou com um príncipe português, D. João, declarado príncipe herdeiro em 1788, por morte do irmão primogénito, e regente a partir de 1792 dada a incapacidade mental da mãe, D. Maria I. Durante esse período sabemos ter-se dedicado amadoristicamente à pintura, aderindo a uma prática que vinha sendo seguida na nossa corte pelas irmãs da rainha, sobretudo por D. Maria Francisca Benedita (1746-1829), a quem se deve o único dos retábulos da Basílica da Estrela que não saiu da oficina de Batoni. Nas coleções do Palácio Nacional da Ajuda, conserva-se um retrato de figura popular com a seguinte inscrição “D. Carlota princesa do Brasil pintou ano de 1798"188, mas sabe-se terem existido pelo menos outros dois, perdidos no incêndio que deflagrou na antiga galeria de pintura daquele palácio em $1974^{189}$. Este tipo de trabalhos foram sendo sempre acompanhados por pintores próximos da corte, destacando-se a partir de 1803 Domingos Sequeira que, após ter sido nomeado "Primeiro Pintor de Câmara e Corte", seria apontado para mestre de Pintura e Desenho de D. Carlota

\footnotetext{
${ }^{186}$ Retomamos aqui a expressão de José da Cunha Saraiva, pioneiro nos estudos sobre esta coleção. SARAIVA, José da Cunha - "Os quadros do Ramalhão que foram para a Academia de Belas Artes". Sep. Feira da Ladra, 1937, p. 6.

${ }^{187}$ A este respeito cf. JORDÁN DE URRÍES, Javier; SANCHO, José Luis (comiss.) - Carlos IV: mecenas y coleccionista (cat. expo), 2009.

${ }^{188}$ PNA, inv. 2930

${ }^{189}$ Correspondiam ao inv. 41455 e 41456 do PNA, sendo descritas como "Duas pinturas de D. Carlota Joaquina quando era princesa do Brasil, do ano de 1796, uma representando uma mulher do norte de Espanha, como montera em forma de capacete pontiagudo, e outra pintada sobre chapa de cobre com a figura de S. Francisco". CARVALHO, Ayres de - A galeria de pintura da Ajuda e as galerias do século XIX, 1982, p. 24.
} 
Joaquina, da princesa da Beira, sua filha, e das irmãs da rainha (D. Maria Francisca Benedita e D. Maria Ana) ${ }^{190}$.

Paralelamente a estas iniciativas, D. Carlota Joaquina terá demonstrado interesse por coligir pinturas, tal como o marido, futuro D. João VI, não sendo a esse respeito estranho o facto de se terem rodeado de pessoas com interesses no meio artístico, como D. Rodrigo de Sousa Coutinho (1755-1812) ou António de Araújo de Azevedo (1754-1817) (futuros condes de Linhares e da Barca respectivamente), dois cultos estadistas que se destacaram por assinar importantes diplomas no domínio das Belas Artes e por dar proteção aos artistas ${ }^{191}$. Em carta dirigida a D. Rodrigo de Sousa Coutinho, enviada de Londres, em 1798, o pintor Vieira Portuense (1765-1805) dános conta de uma importante transação efectuada com o príncipe de Ligne "que tendo em Viena a sua coleção de pinturas, por via do Exmo. Sr. D. Lourenço de Lima cedeu a S. M. F[idelíssima] a dita galeria por 30 mil cruzados, recebendo por espaço de 10 anos a soma de 5000 cruzados" $^{192}$.

Portuense parece servir-se daquela informação como pretexto pois, na realidade, pretendia que o príncipe regente adquirisse a sua a sua própria coleção, composta por "vários quadros antigos e clássicos" que haviam sido deixados em Itália, quando os acontecimentos políticos de então o forçaram a abandonar aquele país. Como tal, sugere um negócio semelhante: "se a corte quisesse fazer tal aquisição eu não teria dificuldade recebendo a metade da soma na entrega da mesma coleção, e passado um ano ou dois receber o resto". Na opinião do pintor, esta proposta revelava-se bastante vantajosa para o complemento da coleção acabada de adquirir pelo regente, uma coleção que dizia ser "rica dos flamengos" e, por isso, "necessária de ser guarnecida dos grandes mestres italianos" como seriam justamente os de Vieira, a acreditar nas referências que faz a Guido Reni, Albani, Tiarini e Schedoni ${ }^{193}$.

Os dados de que dispomos não nos permitem confirmar a realização deste negócio onde perpassa a intenção de enriquecer o acervo régio que tinha crescido

\footnotetext{
${ }^{190}$ CARVALHO, José Alberto Seabra - “Uma cronologia”. PORFírIO, José Luís (comiss.) - Sequeira: um português na mudança dos tempos: 1768-1837 (cat. expo.), 1997, p. 111.

${ }^{191}$ SANTOS, Paula - "A coleção de pintura de D. Carlota Joaquina de Bourbon, oriunda do Ramalhão, em Sintra: o seu resultado na formação do Museu Nacional de Arte Antiga". Vária escrita, n.o 2, 1995, p. 293.

${ }^{192}$ BLANCO, Francisco Cordeiro - "Uma carta inédita de Vieira Portuense". Boletim do Museu Nacional de Arte Antiga, vol. I, n.o 3, 1948, pp. 149-151.

${ }^{193}$ Idem, ibidem.
} 
exponencialmente com a coleção do príncipe de Ligne. Sabemos, no entanto, que decorridos alguns anos, uma ordem de António Araújo de Azevedo dirigida a João de Barros Leitão Carvalhosa (1757-1818), futuro visconde de Santarém, datada de 1805, mandava que se recebessem "na quinta denominada de Baixo [Belém], três caixas com pinturas antigas, vindas de Nápoles para se venderem, afim de S.S. A.A. R.R. [Suas Altezas Reais] as poderem ver, e comprar se forem do seu real agrado"194. Naquele ano de 1805 teve precisamente lugar a conjura arquitectada contra o regente e apoiada por Carlota Joaquina com quem vinha desenvolvendo crescentes manifestações de conflito, levando ao afastamento do casal que fixou residência em diferentes palácios (Queluz e Mafra). Dois anos mais tarde, sob a ameaça das tropas napoleónicas, D. João transferiu-se com a família real para o Brasil, para onde seguiram diversas pinturas das coleções reais, conservando-se atualmente um núcleo no Museu Nacional de Belas Artes do Rio de Janeiro ${ }^{195}$. A subida ao trono do desavindo casal ocorreu precisamente no Rio de Janeiro, período durante o qual Carlota Joaquina deu azo à sua ambição política, no sentido de se tornar regente de Espanha, caída nas mãos de Napoleão, e das suas colónias na América Latina.

Logo após o regresso a Portugal, em 1821, enquanto o monarca cedia às imposições do Congresso vintista, não o fez a rainha que se recusou prestar juramento à Constituição, sendo desterrada da corte e isolada no Palácio do Ramalhão, nos arredores de Sintra. Com origens que remontam ao século XV mas reconstruído no século XVIII, este edifício onde chegou a habitar Beckford durante a sua permanência no nosso país, passou a partir do início do Oitocentos a servir de residência privativa de D. Carlota Joaquina, tendo sido então reformado com algumas intervenções ao gosto neoclássico. Nele veio a reunir parte importante dos seus bens pessoais, com destaque para a pintura como se pode constatar num inventário realizado em 1807, meses antes da partida da família real para o Brasil, onde se descrimina a existência no piso nobre de uma "Casa da Pintura" que

\footnotetext{
${ }^{194}$ Documento datado de 25 de Setembro de 1805. Boletim da Academia Nacional de Belas-Artes: documentos, II, 1939, pp. 84-85.

${ }^{195}$ Integram o fundo "Coleção Real de D. João VI" onde, entre outras obras, se encontra um retrato seiscentista de um antepassado do príncipe de Ligne (informação resultante de um contacto estabelecido com Zuzana Paternostro, curadora da secção de pintura estrangeira daquele museu). A este respeito cf. também MARQUES, Luiz - "A contribuição de D. João VI para a formação do acervo de pintura italiana nas coleções públicas do Brasil". NETO, Maria João; MALTA, Marize (eds.) Coleções de arte em Portugal e Brasil nos séculos XIX e XX: perfis e trânsitos, 2014, pp. 249-264.
} 
concentrava contingente apreciável de 180 obras: "71 quadros de moldura doirada"; "97 ditos com moldura de pau-santo" e "12 ditos com frutas d'América em vulto". Compunham o ambiente decorativo "12 cortinas e 8 bambinelas de paninho arrendado com guarnição azul e branco", estas últimas correspondendo provavelmente ao número de vãos daquele espaço que, como não será de estranhar, revelava-se parco em mobiliário, assinalando-se a presença de um lustre de oito lumes com ornatos de alabastro, três mesas, uma das quais em mármore negro, com ornamentos também de alabastro, dois espelhos "de vestir", 12 cadeiras douradas com assentos estofados, e duas colunas que suportavam um par de peças em porcelana da China ${ }^{196}$.

Resultado de aquisições e, eventualmente, ofertas ou heranças dos seus familiares espanhóis - como Carlos III de quem consta ter sido a neta preferida ${ }^{197}$ - aquele acervo seria caro à então princesa que evitou a sua dispersão por outras salas do Ramalhão, reunindo-o num só espaço de consideráveis dimensões, possível memória dos palácios da sua infância e dos hábitos colecionistas dos Bourbon. Durante a primeira invasão francesa, alguns dos quadros foram transportados para Queluz por indicação de Mr. Geoffre, cunhado de Laura Junot, escapando aparentemente aos saques registados noutros palácios ${ }^{198}$. Mau grado a agitação política registada nas décadas de 1820-30, resultante em larga medida das conspirações urdidas pela rainha que tudo fez para colocar no trono o seu filho dileto, D. Miguel, o acervo conservado no Ramalhão foi aumentado, conhecendo um derradeiro e relevante acréscimo com a herança do pai da soberana, Carlos IV. Exilado por Napoleão em França após ter abdicado em favor do filho, Fernando VII (1784-1833), virá na sequência da Guerra Peninsular a estabelecer-se em Roma

\footnotetext{
196 “Inventário de toda a mobília que existe no Real Paço do Ramalhão da Princesa N. Sr.a feito em Julho de 1807". ANTT, Casa das Rainhas, liv. 234. Agradeço a indicação deste documento a Celina Bastos que desenvolveu em paralelo uma investigação sobre a coleção de pintura da rainha Carlota Joaquina para uma mostra do MNAA, e com quem tive oportunidade de trocar impressões. A este respeito cf. BASTOS, Celina - "Percurso de uma pintura". CAETANO, Joaquim Oliveira (comiss.) - Luca Giordano: Êxtase de São Francisco (cat. expo.), 2014, pp. 6-32. Sobre o ambiente decorativo do palácio cf. idem, "Os interiores régios de D. Maria I a D. Maria II". SOUSA, Gonçalo de Vasconcelos e (dir.) - Matrizes da investigação em artes decorativas, V, 2013, pp. 115-145.

${ }^{197}$ Pertencente a um conjunto conservado no Museu do Prado, a notável credência realizada no Laboratório de Pedras Duras e Musaico do Buen Retiro, conservada no PNA (inv. 1890), tem sido associada a uma oferta de Carlos III.

${ }^{198}$ A respeito dos saques cf. XAVIER, Hugo - "Os tempos monárquicos: dos faustos joaninos ao ateliê de D. Carlos". Pintura e mobiliário do Palácio da Belém, 2005, pp. 29-31.
} 
(1812) onde deu continuidade aos seus hábitos colecionistas, encorajado e orientado pelos seus pintores de câmara, Juan Antonio de Ribera (1779-1860) e, sobretudo, José de Madrazo (1781-1859) que procurou conferir qualidade e coerência às aquisições. Num curto espaço de tempo até à sua morte, ocorrida em 1819, reuniu um notável conjunto de 688 quadros, divididos entre o Palácio Barberini e a villa Sant'Alessio, antigo convento jerónimo, onde pensou construir uma grandiosa galeria de pintura ${ }^{199}$. A coleção será então inventariada e enviada para Madrid para efeitos de partilhas entre os numerosos herdeiros, como Fernando VII que, muito incentivado pela sua segunda mulher e sobrinha, Maria Isabel de Bragança, filha de Carlota Joaquina, havia acedido à criação do que ficou conhecido por Museu do Prado, inaugurado naquele mesmo ano de 1819, com um núcleo substancial de espécimes provenientes dos palácios reais.

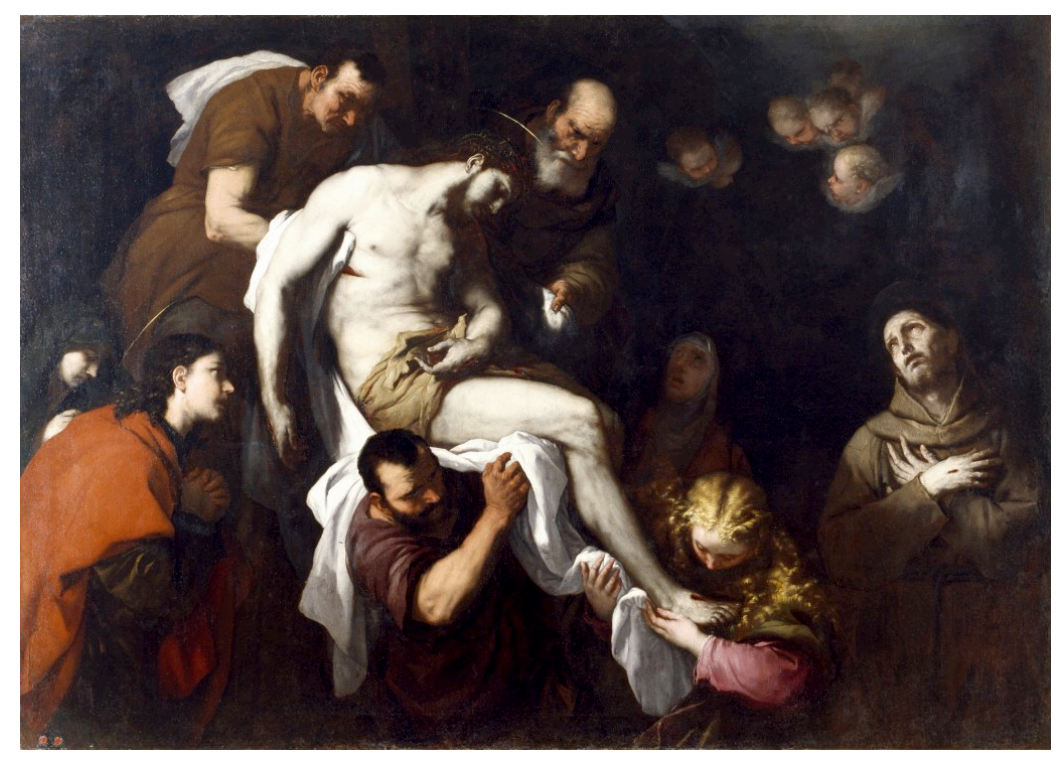

Fig. 17 - Luca Giordano, Êxtase de S. Francisco, c. 1665. MNAA, inv. 179 Pint

O monarca terá demonstrado pouco interesse pelo espólio pictórico paterno em detrimento de outros objetos no domínio das artes decorativas (móveis, porcelanas, relógios...), igualmente incluídos na herança, vindo a selecionar apenas três pinturas, instado seguramente por Madrazo, diretor do museu. O desinteresse de Fernando VII pela pintura em detrimento dos objetos terá causado alguma frustração ao

\footnotetext{
${ }^{199}$ SANCHO, José Luis - "Coleccionista hasta la muerte: casas y obras artísticas de Carlos IV en Francia y Roma 1808-1819". Reales Sitios, n.o 175, 2008, pp. 10-12.
} 
artista e explicará o singular episódio da Descida da Cruz ou Êxtase de S. Francisco de Luca Giordano (fig. 17). "Obra maestra del autor" de acordo com o inventário de 1819 elaborado por Madrazo e Juan António Ribera, "clasificación raríssima en tal documento a propósito de tal pintor y en el contexto neoclássico" como clarifica José Luis Sancho, aquela pintura foi alvo de especial atenção pelo pintor de Câmara e diretor da galeria real que, provavelmente, interviera já na sua aquisição por Carlos $\mathrm{IV}^{200}$. Procurando integrá-la no museu que dirigia, obteve a sua transferência do Palácio Real de Madrid a pretexto de ser restaurada e enquanto decorrida o processo de partilhas, o que era no mínimo irregular ${ }^{201}$.
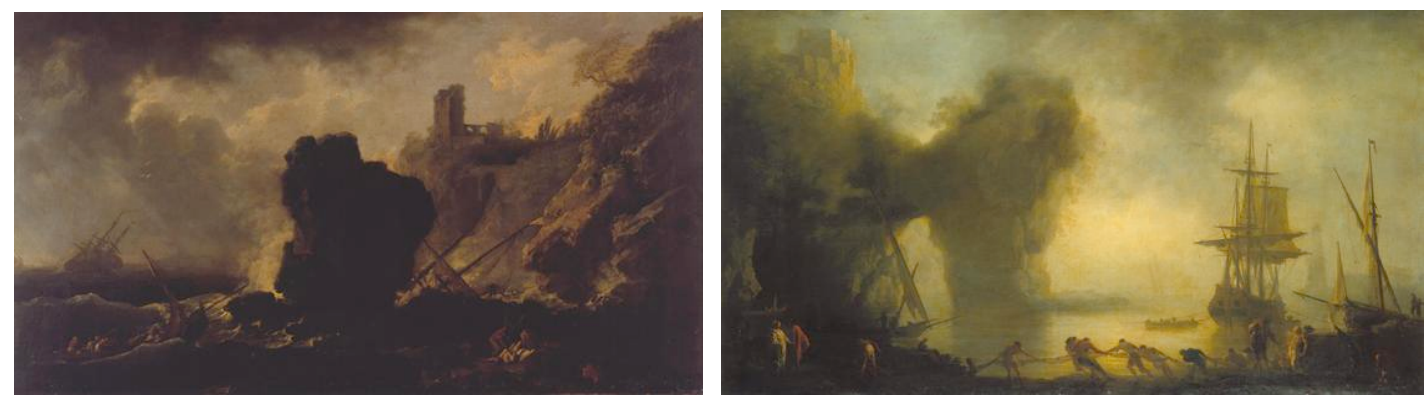

Figs. 18 e 19 - Claude-Joseph Vernet, Naufrágio; Porto de mar, séc. XVIII (meados). MNAA, inv. 467 e 468 Pint

Atribuída à rainha de Portugal, permaneceu Madrazo silencioso, "como si pensase que con un poco de suerte los lusos no echarian cuenta, o no se atreverían a reclamar" ${ }^{202}$. Enganava-se o pintor pois, entre o quinhão destinado a Carlota Joaquina, onde se incluíam duas marinhas de Claude-Joseph Vernet (fig. 18 e 19), artista francês muito do agrado de Carlos $\mathrm{IV}^{203}$, a falta da pintura seria notada e exigida a sua entrega. Sabe-se que em 1828 os quadros estavam ainda em Madrid, tendo sido Carlota Joaquina aconselhada a proceder à venda dos mesmos, no intuito

\footnotetext{
200 Idem, ibidem, p. 14.

${ }^{201}$ A este respeito cf. também CUESTA, Miguel Hermoso - "A propósito de un lienzo de Lucas Jordán en el Museu Nacional de Arte Antiga de Lisboa". Anales de Historia da Arte, n.o 20, 2010, pp. 197-207. 202 SANCHO, José Luis - op. cit., p. 14.

${ }^{203}$ MNAA, inv. 167 e 468 Pint. A este respeito cf. GARCÍA-FRIAS, Carmen - "Nuevas aportaciones al estudio de la collección pictórica de Carlos IV en el exilio". Actas de las Jornadas de Arte y Iconografía sobre Carlos IV y el arte de su reinado: Seminario de Arte e Iconografía "Marqués de Lozoya", 2011, p. 227 e 245.
} 
de impedir outros "desvios". Tal não veio a suceder e acabariam por dar entrada em Portugal, em data ainda por averiguar ${ }^{204}$.

Falecida a rainha em 1830, a coleção permaneceu no Ramalhão, não só em virtude da agitação decorrente da guerra civil (1828-1834) como do próprio processo da herança que se revelou complexo. Como apurou Celina Bastos, esta última ficou durante anos indivisa, sucessivamente administrada pelo duque de Bragança, pela sua viúva e, a partir de 1838, por D. Maria II, como testamenteira e cabeça de casal. A avaliação dos bens teve lugar em 1835, detectando-se um enorme passivo onde avultavam os empréstimos contraídos ao conde de Farrobo e a Castro Guimarães, para além de dívidas a diversos fornecedores ${ }^{205}$. Iniciou-se o inventário pela descrição e avaliação dos quadros, tendo o conselho de família aprovado os nomes do pintor António Manuel da Fonseca e do restaurador italiano Luigi Tirinanzi cuja atividade se assinalava então em Lisboa ${ }^{206}$. Seria acordada a venda pública do espólio, pelo que foi necessário proceder à sua transferência para o palácio da Bemposta, em Lisboa, o que sucedeu apenas no final de 1843, após a entrega dos inventários ao solicitador da Casa Real. Durante a conferência dos objetos naquele palácio, Fonseca e Tirinanzi serão novamente chamados para atestar que os quadros destinados à venda pública se tratavam dos mesmos avaliados no Ramalhão, procedendo à colocação em cada um dos seus selos em lacre. Tendo notado algumas imprecisões nas transcrições do inventário, os artistas efetuaram uma nova relação que reorganizava a realizada anteriormente, sem qualquer consequência prática. Com efeito, e para descontentamento dos dois artistas, seria em 1844 impressa a versão da listagem elaborada nove anos antes, com o seguinte título: "Relação dos quadros pertencentes à herança da imperatriz rainha a senhora D. Carlota Joaquina de Bourbon, hoje existentes no Real Palácio da Bemposta, onde hão-de ser vendidos em hasta pública perante o juiz do respectivo inventário, na conformidade da deliberação tomada pelo Conselho de Família, confirmado por aquele juiz, e que

\footnotetext{
${ }^{204}$ Celina Bastos coloca a hipótese de terem sido trazidos para Portugal pelo infante D. Carlos Maria Isidro de Bourbon que tivera parte importante na reclamação da herança da irmã e que residiu no Ramalhão entre 1832 e 1833. BASTOS, Celina - op. cit, p. 28, nota 12.

${ }^{205}$ Idem, ibidem, p. 14.

${ }^{206}$ Sobre a atividade de Luigi Tirinanzi enquanto restaurador cf. ARAÚJO, Agostinho - "O restauro de painéis e a actividade de alguns pintores italianos em Portugal (c. 1710-1860)". Nel mezzo del cammin: atas da Jornada de Estudos Italianos em honra de Giuseppe Mea, 2009, pp. 33-38.
} 
foram descritos e avaliados pelos senhores António Manuel da Fonseca, lente de pintura histórica da Academia das Belas Artes, e Luís Tirinanzi, pintor restaurador de quadros" $^{207}$.

Como já foi anteriormente referido, Fonseca exercia então funções docentes na Academia, organismo que não demorou em manifestar interesse pelo acervo. $\mathrm{Na}$ realidade, em Janeiro de 1844, o diretor-geral ao falar "nos quadros que estavam inventariados e avaliados no Palácio da Bemposta para se venderem em hasta pública, disse que muito convinha à Academia dirigir uma representação ao governo pedindo que se comprassem por conta do Estado os que fossem originais clássicos para se utilizarem na Academia, evitando-se que vão para fora do reino, acrescentando que ira falar pessoalmente a Suas Majestades a respeito deste objecto" $^{208}$. No respectivo ofício ao ministro, assinalava-se a pertinência da compra, "por não ser possível que haja algum nacional cujos lances não cubram os de muitos agentes comerciais de vários países, expressamente encarregados de fazerem tão óptimas aquisições" ${ }^{209}$.

A eventual saída para o estrangeiro das pinturas que integravam o acervo e a necessidade de assegurar a aquisição das mesmas por parte do Estado tornar-se-á desde logo tema na imprensa, com destaque para Ribeiro de Sá que encabeçou essa corrente de opinião. Como vimos anteriormente, este articulista havia defendido n' O Panorama a necessidade da Academia dispor de instalações mais adequadas, ao nível da importância das obras que estavam à sua guarda, vindo agora a lançar no mesmo periódico "um brado a favor da glória nacional e das belas-artes", dirigido precisamente aos quadros reunidos pela falecida rainha. Considerava exageradamente serem aqueles "os últimos restos dos muitos primores de arte que enriqueciam Portugal", alertando estarem "em perigo de por vil preço irem aumentar os museus estrangeiros". Lamentava por isso que "a troco de quatro ou cinco contos de reis, verão os portugueses cortar as águas do Tejo o navio que levar

\footnotetext{
${ }^{207}$ Documento bastante raro a que José da Cunha Saraiva, informando ter sido impresso em 1844 numa tipografia do Largo do Pelourinho. SARAIVA, José da Cunha - op. cit., p. 7. Como adiante veremos, o seu conteúdo veio a ser publicado na íntegra na Revista Universal Lisbonense.

${ }^{208}$ Conferência ordinária de 15 de Janeiro de 1844. Arquivo da ANBA, disponível em http://digitarq.dgarq.gov.pt/ PT-ANBA-ANBA-A-001-00004_m0008.TIF

${ }^{209}$ Ofício de 18 de Janeiro de 1844. Idem, disponível em http://digitarq.dgarq.gov.pt/ PT-ANBA-ANBAB-003-00002_m000268.TIF
} 
para Inglaterra os quadros de grandes mestres que poderiam servir para junto com o pouco que nos tem restado, principiar-mos a organização de uma galeria nacional, tão necessária e que sem sacrifício poderia ser levada a cabo"210.

O olhar crítico de Raczynski não se deixou impressionar com os "grandes mestres" aludidos por Ribeiro de Sá cujo artigo analisa nas suas Lettres, recusando lisonjeiras atribuições a Domenichino, Guercino ou Salvador Rosa. Refere aliás ter contemplado as pinturas na companhia do professor Fonseca que procedera com Tirinanzi às respectivas classificações, relativizando o interesse do conjunto ao concluir que "parmi les tableaux de cette collection il ya a de bons; mais qu'à propôs de ces objets il ne saurait être question ni de chefs-d'oeuvre ni de gloire et de richesse nationale" ${ }^{211}$.

Aguardado para 1844, o leilão da pinacoteca acabaria por não ocorrer, aparentemente devido ao complexo processo da herança. As dificuldades políticas depois registadas terão talvez ditado o seu adiamento, sendo necessário aguardar até 1847 para se voltar a falar na venda, destacando-se de novo Ribeiro de Sá, desta vez na Revista Universal Lisbonense. Refere o articulista que o "brado" lançado anos antes n' O Panorama se estendera a outros dois jornais, a Nação e a Carta, inspirando-se no exemplo deste último para publicar uma seleção dos quadros considerados mais representativos, retirada da listagem impressa em 1844 e que já então ganhara foros de raridade: "desapareceu como se fora algum exemplar clássico antigo e raro". Considera genericamente baixos os valores conferidos às pinturas, levantando a questão das atribuições que Raczynski garantira não serem fiáveis: "Ou os quadros são dos autores a que se atribuem ou não. Se o são, como podem tais avaliações subsistir? Se o não são, as quantias talvez estejam exageradas. Essa é que é a questão". Em qualquer dos casos, importava "que os quadros não saiam para fora do país como já tem acontecido a muitos que possuímos, e que se comece a cuidar de um museu nacional” ${ }^{212}$, ideia já defendida no artigo d' $O$ Panorama, e que voltará a desenvolver em breve. Registe-se todavia que desde

\footnotetext{
${ }^{210}$ SÁ, S. J. Ribeiro de - "Um brado a favor da glória nacional e das belas-artes". O panorama, vol. III, 3ㅇ da 2a série, n.ㅇ 109, 27 de Janeiro de 1844, p. 28.

211 RACZYNSKI, A. - op. cit., p. 283.

${ }^{212}$ SÁ, S. J. Ribeiro de - "Bellas-artes: almoeda no Palácio da Bemposta”. Revista Universal Lisbonense, vol. VII, série I, n.ㅇ 2, 16 de Dezembro de 1847, p. 20.
} 
Dezembro de 1847 decorriam já na Bemposta leilões relativos aos móveis, pratas, porcelanas e demais objetos decorativos provenientes do Ramalhão, igualmente incluídos nas partilhas ${ }^{213}$.

Decorridos quatro meses, em Abril de 1848, o Diario do Governo anunciava a pública exposição das pinturas cuja venda se iniciaria a 23 do mês seguinte ${ }^{214}$, desconhecendo-se qualquer tomada de posição quanto a uma possível compra. Talvez por isso, logo a 27 de Abril, Ribeiro de Sá regressaria ao tema na Revista Universal Lisbonense, defendendo uma vez mais a utilidade da aquisição para se fundar na capital do reino um museu: “A necessidade de um Museu Nacional não é contestada, nem a conveniência que haveria de comprar o governo os quadros que estão na Bemposta para que juntamente com outros que o Estado possui, servissem de núcleo ao museu". A opinião pública partilharia as mesmas ideias, ao acreditar nos comentários de quem visitava a exposição: "por todas as salas se ouviam evidentes provas de quanto se desejava que os quadros ficassem no país"215.

O valor global atribuído às pinturas, cerca de 10 contos de reis, não parecia a Ribeiro de Sá excessivo num "país que tem dissipado centos de contos, e que ainda há pouco despendeu 300 com um teatro que lhe podia ter custado 100" [referia-se ao Teatro D. Maria II] ou "que dá anualmente 24 contos de reis a um empresário para que haja teatro lírico". Propunha por isso reduzir-se a metade uma das temporadas do São Carlos, e a rápida nomeação de uma comissão - "mas das que trabalham" para tratar da compra e organizar um museu, sugerindo como local a igreja do Carmo (cremos ter sido o primeiro a defender essa ideia que terá seguidores como tivemos anteriormente oportunidade de aludir).

Termina com a transcrição integral de um documento cuja raridade vimos ter sido já então assinalada: a relação publicada em 1844, "recordação da venda mais importante de objetos de belas artes que entre nós se tem feito", repartida por dois

\footnotetext{
${ }^{213}$ Estas vendas prolongaram-se pelos meses seguintes como nos dá a conhecer um ofício datado de 30 de Março de 1848, onde se informa que "estando a terminar a almoeda dos objetos inventariados por óbito de S. M. imperial e real D. Carlota Joaquina de Bourbon, restando só os quadros, e como hajam ainda vários móveis no Real Palácio do Ramalhão, que precisam serem remetidos para esta cidade afim de se avaliarem com antecipação (...)". IAN/TT, ACR, cx. 7327, m. I.

${ }^{214}$ Anúncio redigido em francês para mais ampla divulgação. Cf. SANTOS, Paula Mesquita - op. cit.. pp. 287-288.

${ }^{215}$ SÁ, S. J. Ribeiro de - "Os quadros da Bemposta e a possibilidade de organizar em Lisboa um Muzeu Nacional". Revista Universal Lisbonense, vol. VII, série II, n. 21, 27 de Abril de 1848, p. 241.
} 
números do jornal dada a sua extensão ${ }^{216}$. Compreendia a relação 201 lotes, na sua grande maioria espécies de pintura (cerca de 132, entre telas, tábuas e cobres), incluindo ainda um considerável número de estampas e algumas peças de escultura em mármore. Dominava a pintura religiosa onde se assinalam figuras de santos caros ao catolicismo espanhol, seguida das paisagens, das cenas de género e dos retratos, estes com a representação de alguns Bourbons, característica que se verificava sobretudo nas estampas. Mais rara era a componente mitológica e alegórica tão conotada com o neoclassicismo, detetada numa ou noutra tela.

As atribuições, já o referimos, necessitavam de ser encaradas com alguma prudência, sobretudo em relação aos afamados mestres italianos e espanhóis que Fonseca e Tirinanzi pretenderam ver representados, mau grado terem desde logo identificado um avultado número de cópias. Sobressaíam apesar de tudo algumas obras de qualidade assinalável e que nenhum museu recusaria ter no seu acervo, como o já mencionado Êxtase de S. Francisco de Luca Giordano que se associava erradamente a Guercino, um "excellent tableau" no parecer de Raczynski. Era, no fundo, uma "pinacoteca muito variável onde de tudo havia, desde o bom, razoável e mau" como concluiu, na esteira do crítico polaco, Paula Santos, que chama igualmente à atenção para a diversidade de formatos, de enormes telas, a composições de pequeno e médio formato, por vezes distribuídos em pendants, de grande efeito decorativo 217 .

O silêncio que os governos vinham demonstrando desde 1844 perante a crescente pressão pela compra estava naturalmente relacionado com as permanentes dificuldades do Tesouro Público, sendo ainda de admitir uma hipotética resistência de alguns liberais pelo facto dos bens em apreço estarem conotados com uma das figuras de proa do partido absolutista. $\mathrm{O}$ executivo chefiado pelo então marquês de Saldanha acabaria todavia por anuir à aquisição, não no todo como vinha defendendo Ribeiro de Sá, mas em parte, tendo a Academia de Belas Artes procedido à seleção dos espécimes considerados mais representativos. Coube a tarefa aos professores António Manuel da Fonseca, Silva Oeirense e Joaquim Rafael, acrescidos do académico Luís Pereira Meneses (1820-1878), nomeados por portaria

\footnotetext{
${ }^{216}$ n.o 21 , pp. 242-246 e n.ㅇ 22, pp. 254-258.

${ }^{217}$ SANTOS, Paula Mesquita - op. cit, pp. 296-297.
} 
de D. Maria II de 2 de Maio de 1848 para examinarem os quadros postos em leilão "e que possam servir pela sua preciosidade de estudo aos discípulos de Pintura e Escultura da Academia de Belas Artes", devendo "ser colocados na Galeria Nacional ali já principiada a estabelecer" ${ }^{218}$. O relatório apresentado pelos membros da comissão não só confirmava a existência de muitas cópias, cuja compra não tinha utilidade pública, como as baixas avaliações, o que não deixa de ser curioso pois entre os seus membros figurava precisamente o mestre Fonseca que com Tirinanzi fora anos antes responsável pelas mesmas ${ }^{219}$. Do conjunto efetuaram uma seleção 43 lotes cuja aquisição se recomendava, escolha esta pouco depois elevada a 48 lotes.

O leilão teve início a 23 de Maio, conforme agendado, tendo o governo autorizado apenas a compra de 25 lotes por um valor não superior a mais de $20 \%$ das avaliações. Ao contrário do que se previa, os grandes mestres anunciados e os baixos valores das avaliações não conseguiram atrair o público comprador, quer nacional, quer estrangeiro, com a destacada ausência dos agentes comerciais de outros países. A fraca adesão do público foi assim uma constante, "com uma praça quase deserta ou sem compradores, o que obrigou a baixar os preços e, mais tarde, a aceitar o valor oferecido em praça" constatou Celina Bastos ${ }^{220}$.

Domingos José de Serpa e Azevedo, oficial do Ministério dos Negócios do Reino, agiu como representante do governo, adquirindo a maioria das obras com um único lance na licitação (100 reis), e chegando no fim da venda a arrematar quatro lotes por valores bastante inferiores aos das avaliações ${ }^{221}$. Parte importante das obras adquiridas detinham as avaliações mais expressivas da relação editada em 1844, como as duas marinhas atribuídas a Vernet (576\$000 reis), o Êxtase de S. Francisco devido a Luca Giordano (500\$000 reis) e a pequena Sagrada Família atribuída a Ludovico Mazzolino, então associada a Rafael (500\$000 reis) ${ }^{222}$. Destaque-se ainda o par de bodegóns de Pereda (fig. 20 e 21) (160\$000 reis), e um retrato que se pensava

\footnotetext{
${ }^{218}$ ANTT, ACR, cX. 7100, capilha XX/2/81 (12).

${ }^{219}$ RIBEIRO, José Silvestre - op. cit., vol. VI, 1876, p. 107.

${ }^{220}$ BASTOS, Celina - op. cit., p. 23.

${ }^{221}$ Veja-se o caso de uma tela de Cades que, avaliada em $120 \$ 000$ reis, seria arrematada por $34 \$ 000$ reis. A relação dos lotes adquiridos com os respectivos valores de arrematação foi publicada por SARAIVA, José da Cunha - op. cit., pp. 13-15.

${ }^{222}$ MNAA, inv. 460 Pint
} 
representar uma imperatriz alemã por Bronzino, sabendo-se hoje ter sido pintado por Ligozzi e retratar talvez Maria de Médicis (120\$000 reis) ${ }^{223}$. Habitualmente integradas na exposição permanente do Museu Nacional de Arte Antiga, estas obras permanecem como as mais qualificadas da aquisição que se revestiu de um dado importante a ser assinalado: a oportunidade de enriquecer o acervo académico com mestres estrangeiros, então representados de forma bastante deficitária.
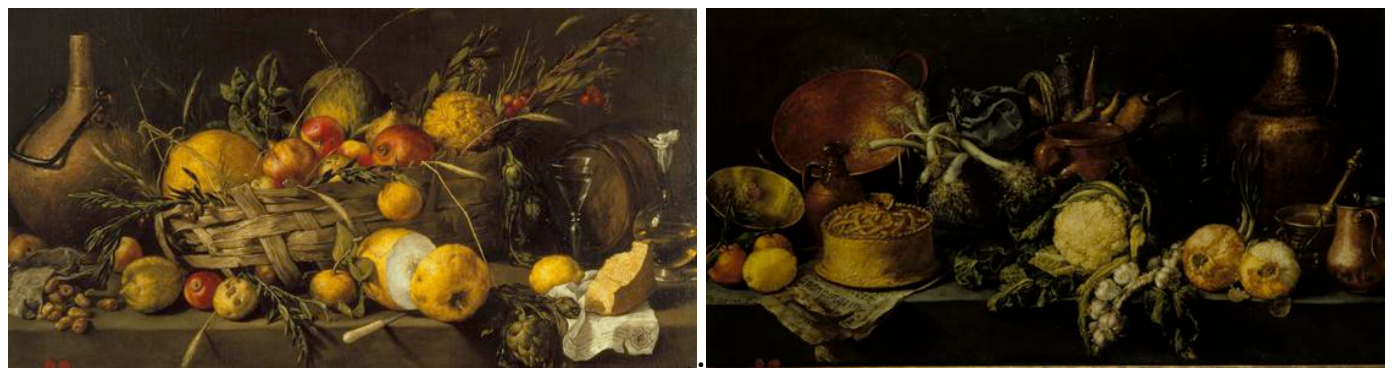

Figs. 20 e 21 - Antonio de Pereda, Natureza morta com frutos; Natureza-morta com vegetais, 165051. MNAA, inv. 469 e 470 Pint

No total foram adquiridas 25 pinturas, acrescidas de uma escultura e um baixorelevo em mármore. As obras estiveram vários anos no Palácio da Bemposta até serem levantadas pela Academia, devido à morosidade do integral pagamento por parte do Estado. Note-se também que até à data, o nosso estabelecimento de ensino artístico mal conseguira instalar e organizar o espólio oriundo dos conventos extintos, não se registando portanto qualquer efeito imediato da compra na formação do desejado museu ou galeria como acalentava Ribeiro de Sá. $\mathrm{Na}$ realidade, só em 1859, significativamente o ano em que tiveram início as obras de adaptação a galeria das duas salas de aula de pintura de história e de paisagem, frustradas que estavam as tentativas de erigir uma dependência especifica com esse fim, seria o espólio reclamado. O vedor da Casa Real ordenou então ao almoxarife daquele palácio que pusesse à disposição da Academia as respetivas obras, devendo a entrega ser feita "à pessoa que se apresentar devidamente autorizada pelo diretor da referida Academia, Francisco de Assis Rodrigues, e que vier munida de um recibo

\footnotetext{
${ }^{223}$ MNAA, inv. 453 Pint
} 
em duplicado, assinado pelo mesmo diretor, em que se mencione o número dos quadros e se faça a sua descrição" ${ }^{224}$.

A 9 de Abril de 1859 apresentaram-se no palácio os professores de pintura António Manuel da Fonseca e Tomás José da Anunciação, acrescidos do fiel da Academia, Cristóvão Leandro de Melo, fazendo-se acompanhar de uma credencial assinada pelo diretor-geral e de um certificado passado pelo escrivão da sexta vara, António Augusto de Freitas Jácome, com a relação dos lotes adquiridos e respectivos valores de arrematação, num total de $4.655 \$ 600$ reis $^{225}$. Dois dias depois, acusava Assis Rodrigues ao vedor a recepção dos " 25 quadros e dois relevos em mármore de Itália que se achavam arrecadados no dito real palácio, pertencentes ao espólio da falecida rainha a senhora D. Carlota Joaquina de Bourbon, e que forram arrematados por ordem do governo de Sua Majestade, para uso da Academia das Belas Artes de Lisboa" ${ }^{226}$.

Recepcionadas as pinturas, não tardou a ser notado o deficiente estado de conservação em que se encontravam, tendo a conferência entendido proceder a um exame, findo o qual seria lavrada uma ata "para que em todo tempo constasse qual o estado em que os ditos quadros foram recebidos, podendo entretanto continuarem a ser limpos do pó e envernizados com o bom verniz de goma almécega pelo artista António Caetano da Silva e dirigido pelo Sr. professor proprietário da aula de pintura histórica"227. A 30 de Abril seria então efectuado o levantamento, assinalando-se patologias em quase todas as pinturas, sobretudo lacunas na camada cromática, sem esquecer os prejuízos causados por restauros anteriores ${ }^{228}$. Parte importante daquelas intervenções haviam sido realizadas por um obscuro artista espanhol, D. Félix Torres, "restaurador que estragou os quadros do palácio" segundo

\footnotetext{
${ }^{224}$ Apud. Idem, ibidem., p. 9

${ }^{225}$ José da Cunha Saraiva alude a outro documento em que o valor total sofre uma ligeira variação (4.957\$600). Idem ibidem, p. 16.

${ }^{226}$ Apud. Idem, ibidem, p. 15. Outro documento citado pelo mesmo autor refere ter sido a aquisição efetuada por intervenção de um tal de Domingos José de Serpa e Azevedo, a quem o governo porventura encarregou tomar parte no leilão. Idem, ibidem, p. 12.

227 Conferência ordinária de 28 de Abril de 1859. Arquivo da ANBA, disponível em http://digitarq.dgarq.gov.pt/ PT-ANBA-ANBA-A-001-00008_m0118.TIF

228 Conferência extraordinária de 30 de Abril de 1859. Idem, disponível em http://digitarq.dgarq.gov.pt/ PT-ANBA-ANBA-A-001-00008_m0120.TIF a_m0124.TIF
} 
a relação editada em 1844 , onde estavam presentes três paisagens da sua autoria das quais se valorizavam apenas as molduras ${ }^{229}$.

Dois anos após a transferência daquele acervo, em Março de 1861, solicitaria o governo a realização de um mapa com a descriminação das obras de arte conservadas na Academia, "declarando-se igualmente o estado da sua conservação, melhoramentos e aquisições que se tornam necessárias, e bem assim que aquisições se têm feito" ${ }^{230}$. Na mesma sessão, lembrou Cristino da Silva (1829-1877) a necessidade de se prestar homenagem a Francisco Metrass que havia falecido ultimamente na ilha da Madeira, propondo solicitar ao pai do artista um retrato do mesmo para ser copiado e colocado numa das salas do estabelecimento. 0 reconhecimento para com o falecido professor estendeu-se ainda naquele ano à compra de um dos seus quadros, $O$ alabardeiro ${ }^{231}$, por subscrição aberta entre os académicos $^{232}$, naquela que foi uma das raríssimas aquisições de pintura coeva.

$\mathrm{Na}$ sequência das diretivas do governo, seria nomeada uma comissão composta pelos professores António Manuel da Fonseca, Tomás da Anunciação e Cristino da Silva "para avaliar os melhores quadros da Academia e propor os meios da sua melhor conservação"233. A ideia de se proceder à avaliação do espólio académico não havia sido expressamente solicitada pelo governo, mas assumia-se como prioritária pela comissão que dias mais tarde ver-se-á ampliada com os professores Domingos José da Silva e Vítor Bastos $(1830-1894)^{234}$. Decorridos seis meses, elaboraram os seus membros uma lista com a avaliação de cerca de 100 obras, correspondendo aquele número às consideradas mais notáveis.

Começam pelas pinturas adquiridas no leilão da rainha Carlota Joaquina, verificandose um aumento exponencial atendendo aos baixos valores de arrematação

\footnotetext{
${ }^{229}$ Lote 106 - "Três ditos [quadros] do restaurador que estragou os quadros do palácio, o espanhol D. Félix Torres, de paisagem, valor só das molduras - $2 \$ 400$ ". Revista Universal Lisbonense, n.ㅇ 22, p. 254.

230 Conferência ordinária de 26 de Março de 1861. Arquivo da ANBA, disponível em http://digitarq.dgarq.gov.pt/PT-ANBA-ANBA-A-001-00008_m0252.TIF

${ }^{231}$ MC-MNAC, inv. 107

${ }^{232}$ A este respeito cf. "Lista dos subscritores para a aquisição do quadro $O$ alabardeiro por Francisco Augusto Metrass". Arquivo do MNAA, fundo José de Figueiredo, cx. 1, pasta 13, doc. 15.

${ }^{233}$ Conferência ordinária de 29 de Maio de 1861. Arquivo da ANBA, disponível em http://digitarq.dgarq.gov.pt/PT-ANBA-ANBA-A-001-00008_m0260.TIF

${ }_{234}$ Conferência extraordinária de 1 de Junho de 1861 . Idem, disponível em http://digitarq.dgarq.gov.pt/PT-ANBA-ANBA-A-001-00008_m0262.TIF
} 
registados anos antes. Por exemplo, o Êxtase de S. Francisco de Luca Giordano que havia custado $500 \$ 100$ reis, apenas mais 100 reis que a respectiva avaliação (um único lance na licitação), importava agora a $9.000 \$ 000$ reis, enquanto a pequena Sagrada Família de Mazzolino (500\$100 reis) ascendia a 6.000\$000 reis.

Um dos quadros mais celebrados do fundo de origem conventual, a Virgem então atribuída a Rafael e a que já tivemos anteriormente oportunidade de nos referir, avaliava-se em $10.000 \$ 000$ reis, quantia também adotada para algumas tábuas dos nossos primitivos, tidas como sendo de Vasco Fernandes. O valor mais expressivo registado - $20.000 \$ 000$ reis - era relativo a um São Jerónimo que os académicos acreditavam estar associado a Miguel Ângelo como atrás também aludimos. As pinturas excluídas desta avaliação individualizada e que representam cerca de dois terços do acervo foram globalmente estimadas em $30.000 \$ 000$ reis, ascendendo o valor total no seu conjunto a $208.300 \$ 400$ reis.

Terminam os membros da comissão a listagem com uma nota solicitando ao governo a quantia de $4.000 \$ 000$ reis para a ser aplicada em prol da conservação das pinturas. Declaram mesmo, "para descargo da sua responsabilidade, que se não forem atendidas as suas justas reclamações, os ditos quadros em poucos anos ficarão inteiramente destruídos, perdendo-se um tesouro que as nações mais cultas saberiam apreciar se o possuíssem" ${ }^{235}$. Procuravam com estas palavras chamar a atenção do ministério para a relevância daquele espólio pictórico e para a necessidade de o conservar de forma adequada, o que só seria possível com a concessão da referida verba. O governo não só não a concedeu como ficou surpreendido com o valor total indicado, solicitando explicações.

Com efeito, meses depois receberia o diretor-geral um ofício governamental, ordenando a referida comissão a justificar "as razões artísticas em que se funda para arbitrar o valor dos quadros existentes na mesma Academia" ${ }^{236}$. Será então convocada uma sessão extraordinária para discutir o assunto, verificando-se alguma crispação entre os académicos por ter sido posto em causa o seu trabalho. Fizeram

\footnotetext{
235 "Avaliação por estimativa dos quadros existentes na Academia das Belas Artes de Lisboa feita pela comissão eleita na conferência da mesma Academia de 29 de Maio de 1861". Arquivo do MNAA, fundo José de Figueiredo, cx. 1, pasta 12, doc. 3.

${ }^{236}$ Conferência extraordinária de 13 de Fevereiro de 1862. Arquivo da ANBA, disponível em http://digitarq.dgarq.gov.pt/ PT-ANBA-ANBA-A-001-00008_m0314.TIF
} 
então registar em ata que a comissão, "sendo composta de professores competentes para este fim, tendo até alguns deles viajado e visitado as galerias mais célebres de Itália, não podia deixar de apreciar o sabido merecimento e valor dos quadros que possui, determinando o preço de alguns deles que, parecendo excessivo, verdadeiramente o não é", dando como exemplo a referida pintura de S. Jerónimo "que pelo seu singular merecimento e por ser da escola e talvez da mão de Miguel Ângelo" havia sido avaliada em $20.000 \$ 000$ reis $^{237}$.

Consideravam que para atestar a legitimidade das avaliações, "bastaria recorrer aos valores que as nações cultas têm dado aos quadros de reconhecido merecimento dos mais célebres pintores", remetendo para a venda da coleção de pintura do marechal Soult, realizada em 1852, onde o governo francês havia dado mais de 600 000 francos pela célebre Imaculada Conceição de Murillo ${ }^{238}$, "o que não acontece com alguns dos nossos quadros de Grão Vasco, porque se não encontram nas galerias estrangeiras". Acreditavam por isso que "se estes lá se oferecessem seriam muito apreciados e obteriam um valor muito superior ao que a comissão os avaliou" 239 .

Tão optimistas como irrealistas, os juízos da comissão mostram a falta de preparação dos membros que a constituíam, a quem o evocado conhecimento de galerias estrangeiras e as notícias de mediáticos leilões não se revelavam suficientes para uma tarefa deste tipo. Importa acima de tudo sublinhar a estratégia de apelar ao governo para a riqueza pública que constituía o espólio pictórico à guarda da Academia, esperando-se desta forma obter os necessários apoios há muito aguardados. Os argumentos caíram naturalmente em saco roto e o ministério continuará, como no passado, a ser indiferente à maioria das propostas submetidas pelo estabelecimento. Tal situação começou todavia a ser debelada com a chegada de uma enérgica personalidade que contará com o mecenato régio para fazer face a parte das dificuldades, o marquês de Sousa Holstein, futuro vice-inspetor, a quem iremos em seguida consagrar a nossa atenção.

\footnotetext{
237 Conferência extraordinária de 26 de Fevereiro de 1862. Idem, disponível em http://digitarq.dgarq.gov.pt/ PT-ANBA-ANBA-A-001-00008_m0320.TIF

${ }^{238}$ Adquirida em 1852 pelo Estado francês para o Louvre, transitou, em 1941, para o Prado ao abrigo de uma permuta celebrada pelos dois países. Museu do Prado, inv. P02804.

${ }^{239}$ Conferência extraordinária de 26 de Fevereiro de 1862. Arquivo da ANBA, disponível em http://digitarq.dgarq.gov.pt/PT-ANBA-ANBA-A-001-00008_m0321.TIF
} 


\section{PARTE - O MARQUÊS VICE-INSPETOR}

“O marquês de Sousa procurou despertar a indiferença pública, e procurou fundar o que tanto falta entre nós, a literatura artística. Os seus trabalhos para conseguir a criação de um museu nacional e formação da galeria académica são altamente dignos de louvor. A Vida de Domingos António de Sequeira escrita por ele é uma obra excelente, que dá honra ao seu talento de escritor, e que constituiu um alto serviço prestado pelo marquês à arte portuguesa".

Pinheiro Chagas, 1878

\section{Dados biográficos}

D. Francisco de Borja Pedro Maria António de Sousa Holstein, 13 filho do primeiro duque de Palmela, D. Pedro, nasceu em Paris a 20 de Abril de 1838, num exílio temporário motivado pela Revolução de Setembro que levou a família a abandonar Lisboa. Com os duques e a numerosa prole, seguiu ainda para a capital francesa outra criança, filha do falecido conde da Póvoa que Palmela projetara casar com o filho mais velho quando aquela completasse 12 anos, idade determinada pela lei. A morte do único irmão da menina e herdeiro da riquíssima Casa Póvoa, ocorrida naquele mesmo ano, irá despoletar uma atribulada contenda pela herança entre as duas famílias que marcará os primeiros anos de vida de D. Francisco.

Após a vitória liberal na guerra civil (1832-34) em que D. Pedro tanto se empenhou, a sua Casa ressentia-se dos anos em que esteve confiscada, e o seu rendimento mal se adequava à importância político-social do dono. Procurando mitigar esse problema, negociou o casamento do filho mais velho, D. Domingos, marquês do Faial, com D. Maria Luísa, filha do conde da Póvoa, Henrique Teixeira de Sampaio, cuja fortuna à data da sua morte ascendia a 8400 contos de reis, valor que ultrapassava então a soma da despesa e da receita do Orçamento do Estado. Com a inesperada morte do irmão em 1838, tornou-se a menina herdeira daquele vasto património, acontecimento que não pôde deixar de ser recebido com contentamento pelo duque, como deixará expresso nas suas memórias: "A notícia 
era para a fortuna da minha família de imprevista magnitude, porquanto considerando o caso financeiramente, ficava pelo menos quadruplicada a riqueza da minha nora, e excedendo todas as outras fortunas de Portugal” ${ }^{1}$.

Inicialmente favoráveis ao enlace, a mãe e os tios paternos de D. Maria Luísa, começaram a opor-se à sua concretização, iniciando-se uma rocambolesca série de acontecimentos que levará a duquesa a instâncias do marido a viajar incógnita com a menina, configurando uma espécie de rapto da rica herdeira. Em Paris ficou o duque com a maioria dos filhos, incluindo o mais novo, num ambiente marcado pela ausência materna como dão conta algumas cartas dirigidas por D. Pedro à mulher: “O Francisco saiu agora do meu quarto, não podes crer como ele está galante e o dó que faz quando ouve falar no teu nome! Põe-se a olhar para todos os lados como se tivesse lembrança de alguém que Ihe falta e na verdade parece impossível na sua idade" $^{2}$. Palmela conseguirá ultrapassar com engenho todos os entraves e o casamento será finalmente ratificado em 1842. Nas suas memórias, não hesita em comparar a questão aos esforços desenvolvidos em prol do trono de D. Maria II: "Assim terminou uma contenda tão importante para meu filho, para a minha família, que posto não envolvesse em si questões políticas nem de interesse público, me obrigou a tantos trabalhos de corpo e agitação de espírito, como em outro tempo a luta para a restauração da rainha, ostentando golpes de fortuna e peripécias semelhantes daquelas pelas quais eu já tinha passado"3.

Os primeiros quatro anos de vida de D. Francisco tiveram portanto como pano de fundo essa agitada disputa que está na base da prosperidade da sua família, tornada numa das mais opulentas e influentes do país. Um conjunto de retratos conservados hoje entre os descendentes dos duques espelham exemplarmente aquela nova fase, a começar por uma representação daquele que virá a ser agraciado com o título de 1. marquês de Sousa Holstein, montado num cavalo de baloiço em alegre brincadeira (fig. 22), obra executada por António Manuel da Fonseca e apresentada na exposição trienal da Academia em 1843, junto ao célebre Eneias daquele pintor. $\mathrm{O}$ ambiente requintado da sala, com a sua étagère ao gosto romântico, o fato de

\footnotetext{
${ }^{1}$ BONIFÁCIO, Maria de Fátima (trans., pref. e ed.) - Memórias do duque de Palmela, 2011, p. 327.

${ }^{2}$ Carta datada de 20 de Janeiro de 1839. Apud URBANO, Pedro - A Casa Palmela, 2008, p. 30. (ANTT, ACP, cx. 121, fol. 159; cx. 171, fol. 150).

${ }^{3}$ BONIFÁCIO, Maria de Fátima (trans., pref. e ed.) - op. cit, p. 339.
} 
veludo do pequeno cavaleiro e os seus brinquedos importados são bem reveladores de um quotidiano tranquilo e de grande desafogo económico. Tal é igualmente visível num pequeno retrato colectivo das crianças da família Palmela (fig. 23), obra datada de 1846 e atribuída a Adolphe-David Fink (n. 1802) que então se destacava nas exposições do Salon de Paris com os seus retratos pintados a aguarela e pastel. D. Francisco surge-nos à direita da composição, de pé, amparando a mão no ombro do seu irmão, marquês de Monfalim, montado num cavalo de pau semelhante ao da pintura anterior. Entre as restantes crianças, ostentando uma boneca, figura a futura 3. a duquesa de Palmela, fruto do casamento do filho mais velho do duque com a herdeira do conde da Póvoa.
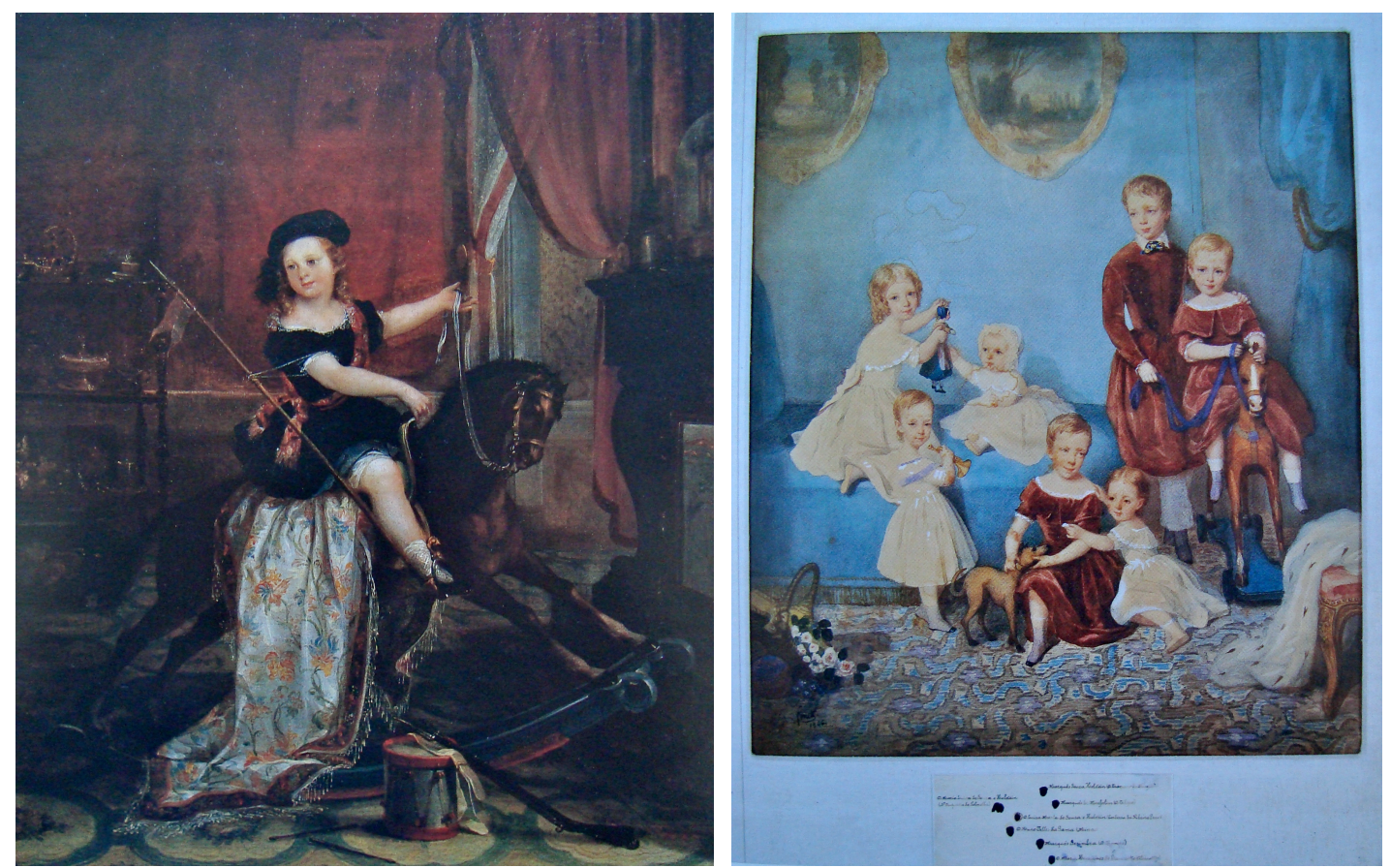

Fig. 22 - António Manuel da Fonseca, D. Francisco de Sousa Holstein, c. 1842-1843. Coleção particular Fig. 23 - Adolphe-David Fink (?), Retrato colectivo das crianças da família Palmela, 1846. Coleção particular

Àquelas duas pinturas sucede um grandioso retrato executado em 1847 por Ferdinand Krumholz (fig. 24), artista formado em Viena de Áustria e que exerceu durante três anos atividade em Lisboa onde pintou algumas figuras proeminentes da sociedade portuguesa, incluído a rainha D. Maria II e o seu segundo marido, D. Fernando de Saxe-Coburgo-Gotha. O cenário é uma sala adamascada do palácio do Calhariz de Lisboa, numa viva e delicada composição presidida pelo 1. duque de 
Palmela, apoiado num piano, em atitude enternecida rodeado pelos seus descendentes. A seu lado, sentada, a 1.o duquesa, junto do 1. marquês de Monfalim. À esquerda, o 2.o duque de Palmela, sua mulher e a condessa das Alcaçovas, sentada ao piano. No primeiro plano, colocando flores no cabelo, a 3. duquesa que virá a ser celebrada como escultura e fundadora das Cozinhas Económicas, ladeada pelo marquês de Sesimbra, seu tio, e a condessa da Ribeira Grande. Completa a sofisticada cena de harmonia familiar o marquês de Sousa Holstein, de pé, junto a um cão negro.

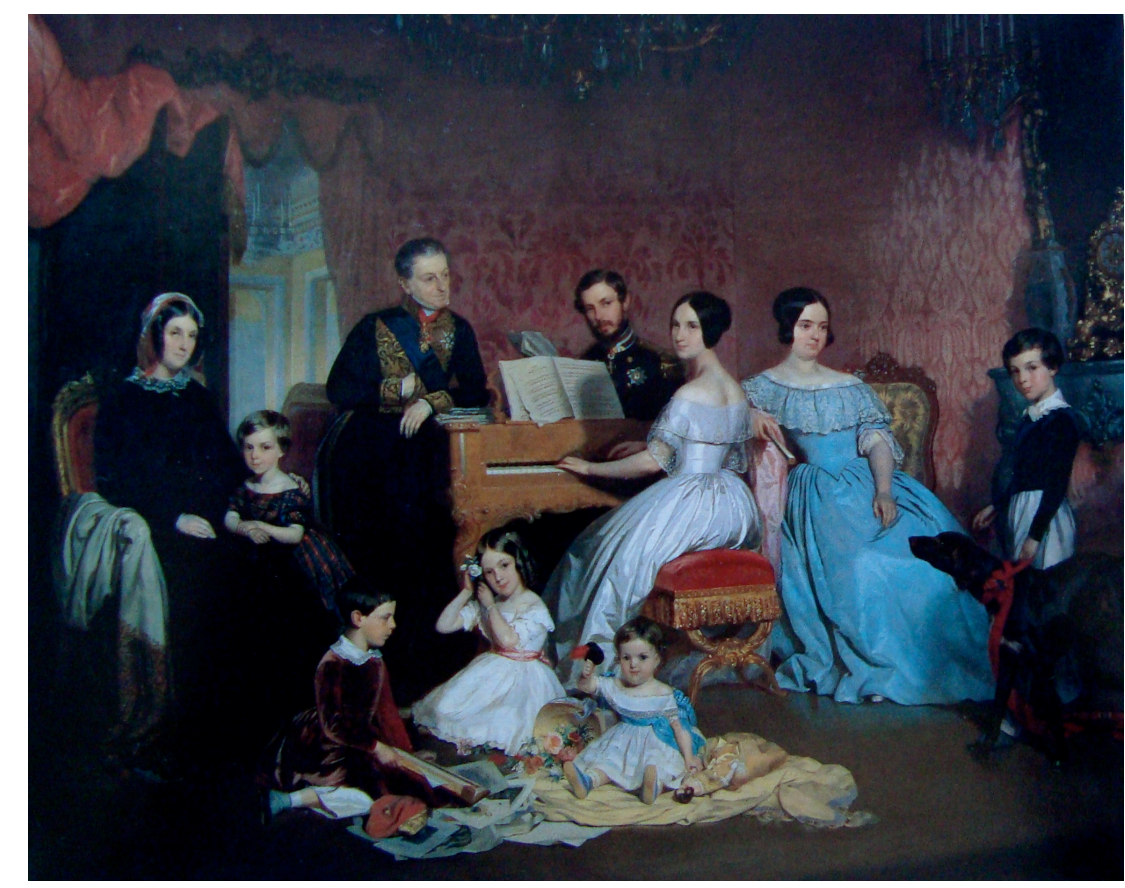

Fig. 24 - Ferdinand Krumholz, Retrato do duque de Palmela e família, 1847. Coleção particular

Cinco anos após ter posado para aquele retrato, aos 14 anos de idade, D. Francisco deu entrada na Faculdade de Direito da Universidade de Coimbra, tendo estado matriculado nas cadeiras de Princípios de Física e Química e Introdução à História Natural dos Três Reinos, curso do Liceu, e nalgumas do Curso Administrativo da Faculdade de Filosofia ${ }^{4}$. Os estudos académicos superiores foram o destino

\footnotetext{
${ }^{4}$ No ano lectivo de 1854-55, frequentou o 3.o ano do curso de Direito da Faculdade e a cadeira de Princípios de Física e Química, e Introdução à História Natural dos três Reinos do Liceu, sendo morador na rua da Esperança, n. 2, Coimbra. Cf. Relação e indice alphabetico dos estudantes matriculados na Universidade de Coimbra e no Lyceu no anno lectivo de 1854 para 1855 com suas filiações, naturalidades e moradas e com a designação das diversas cadeiras e disciplinas, e dos lentes e professores respectivos, 1854, pp. 13 e 41.
} 
escolhido para os três filhos mais novos do 1. duque de Palmela (D. Francisco, D. Tomás e D. Filipe), percurso semelhante ao do seu meio-irmão, D. Filipe de Sousa Holstein, que foi bacharel em lei pela Universidade de Coimbra, onde esteve matriculado entre $1816-1821^{5}$. À semelhança do que sucedia com a aristocracia inglesa de meados do século XIX, a frequência da Universidade não tinha como único objectivo a aquisição de conhecimentos, pautando-se também pelo alargamento de relações interpessoais que viessem a revelar-se proveitosas, quer a nível social, quer a nível político. A essa opção não terá sido naturalmente estranha a preocupação em conseguir um cargo adequado aos filhos segundos que não iriam viver dos rendimentos do património familiar.

D. Francisco foi aparentemente um aluno aplicado como revelam os cadernos de várias cadeiras (Direito Penal, Comercial, Civil e Romano) e outros documentos originários do seu arquivo pessoal que tivemos oportunidade de consultar por ocasião da venda da biblioteca Eugénio da Cunha e Freitas, promovida em 2010 . Parece ter demonstrado especial interesse pelo sistema penitenciário português de que elaborou diversos apontamentos, incluindo um relatório sobre assistência nos estabelecimentos prisionais. Frequentava o 4. ano do curso quando foi agraciado com o título de marquês de Sousa Holstein, concedido por D. Fernando II, regente na menoridade de D. Pedro V, por decreto de 3 de Setembro de 1855. Essa concessão deveu-se seguramente ao facto de ser filho de duque e, como tal, ter direito às honras de marquês, podendo usar para tal as armas da família (Sousa dos Senhores de Arronches; timbre: de Sousa dos Senhores de Arronches; coroa de marquês). O mesmo viria a suceder aos seus irmãos mais novos, mais tarde agraciados com os títulos de marqueses de Sesimbra e Monfalim respectivamente ${ }^{7}$.

Em 1858 doutorou-se pela Faculdade de Direito com a tese: Se o sistema das circunstâncias atenuantes ou agravantes é conveniente ou é prejudicial à ordem pública. Foi então publicada uma síntese em latim dos argumentos que aquela continha $^{8}$, assim como a "oração" ou discurso de apresentação do candidato,

\footnotetext{
${ }^{5}$ URBANO, Pedro - op. cit., p. 33.

${ }^{6}$ AZEVEDO, Pedro de (org.) - op. cit., p. 78 (lote 509).

${ }^{7}$ URBANO, Pedro - op. cit., p. 45.

8 Theses ex universo jure selectae [...] pro doctorali obtienda in Conimbricensi Academia: propugnandas marchio de Sousa Holstein, 1858.
} 
proferido pelo lente António dos Santos Pereira Jardim. Marcadamente laudatório e enfático, começa por assinalar a solenidade da ocasião, pondo em evidência os ilustres costados do jovem marquês: "Um mancebo que, por seu alto nascimento e títulos, ocupa um elevado cargo junto do trono, é aquele que hoje, com satisfação e aplauso de todos, vem receber o maior dos graus que a nossa Universidade confere $^{\prime 9}$. Recordava descender de uma das personalidades mais ilustres do Liberalismo, "porque o Sr. marquês de Sousa Holstein é a haste mais vigorosa dessa árvore secular de todos conhecida - duque de Palmela", falecido oito anos antes e então elevado a herói pátrio.

Tal como o pai, encontrava-se desde cedo destinado à carreira diplomática, no entanto, segundo somos levados a crer, "não quis segui-la somente com a instrução e conhecimentos que o seu nascimento the proporcionavam". No intuito de se preparar convenientemente, terá entendido que "sem aprofundar a excelente ciência do Direito, não poderia desempenhar os lugares que seu pai lhe legara nos grandes congressos da Europa e aí tomar parte na resolução dos difíceis problemas sociais ${ }^{\prime 10}$. Centrado naquele objectivo, parece ter adquirido os hábitos de um mero estudante: "simples pelo seu viver de fácil trato e sem ostentação, mas eminente pela sua dedicação e aproveitamento", refere Pereira Jardim que acreditava poder vir o antigo aluno a "prestar à pátria relevantes serviços" ${ }^{11}$.

O patrono do candidato foi nada mais nada menos que o rei D. Pedro $V$, representado pelo duque da Terceira, o que concorreu para o cariz solene da cerimónia. Apesar de considerada um sucesso junto da família, constava não ter sido em Coimbra um triunfo total. Disso nos dá conta a condessa de Rio Maior em carta ao filho José, igualmente estudante de Direito, criticando com dureza as lisonjas do discurso de apresentação:

"Quanto às teses do Francisco Palmela, o que se diz na família é que foram brilhantíssimas, que foi um verdadeiro triunfo, vejo pela tua carta que não é tanto assim, e acho que essas adulações são nojentas. Assim como acho mal feito bater

\footnotetext{
9 JARDIM, António dos Santos Pereira - Oração recitada na Universidade de Coimbra no doutoramento do marquez de Sousa Holstein, 1858, p. 11.

${ }^{10}$ Idem, ibidem, p. 13.

${ }^{11}$ Idem, ibidem, p. 14
} 
nos fidalgos só porque o são, também acho que é uma injustiça pô-los acima de tudo só porque nasceram numa classe elevada. A verdadeira elevação na Universidade é a do merecimento. Estou longe de supor o Francisco tolo, mas primeiro que chegue a dever ser o primeiro conselheiro de El-Rei ainda lhe devem passar muitos anos por cima" ${ }^{12}$.

O primeiro membro da família doutorado por Coimbra constituiu seguramente motivo de júbilo para os Palmela, originando rumores de voos mais altos, o que explicará a referência a primeiro conselheiro de D. Pedro V. As pertinentes críticas da carta acima citada não escondem uma reação a esses rumores por parte de uma aristocrata que colocara os seus filhos na mesma Universidade (incluindo o primogénito), almejando igual sucesso político num meio algo concorrencial. $\mathrm{O}$ caminho do marquês encontrava-se todavia apontado e passava, como se referiu, pela diplomacia, seguindo os passos do pai e do avô. Logo em 1857, um ano antes de se doutorar, havia sido convidado para adido de embaixada em Viena e São Petersburgo, não tendo tomado posse, o que só sucedeu a 6 de Novembro do ano seguinte ao ser nomeado primeiro-adido da embaixada de Roma.

Aquela nomeação revestiu-se de um significado especial dadas as vetustas ligações da família a Itália que importa aqui evidenciar. Remontavam estas a D. Luís de Sousa (1637-1690) que foi bispo de Lamego, arcebispo de Braga e embaixador extraordinário em Roma, assumindo-se como uma das personalidades mais prolixas da vida política, cultural e diplomática portuguesa do tempo de D. Afonso VI e de D. Pedro $\|^{13}$. Orador insigne, hábil político e diplomata, íntimo dos grandes na Cúria papal, amigo de poetas e artistas, a ele se deveu importante recolha de peças italianas para ornar a quinta do Calhariz em Sesimbra, imprimindo-lhe certo requinte cosmopolita ${ }^{14}$. Com efeito, D. Luís de Sousa revelou durante os cerca de seis anos da sua permanência na cidade pontifica (1676-1682), especial interesse pela produção

\footnotetext{
${ }^{12}$ Carta datada de 30 de Junho de 1858. MÓNICA, Maria Filomena (org.) - Isabel, condessa de Rio Maior: correspondência para seus filhos 1852-1865, 2004, p. 225.

${ }^{13}$ Sobre esta figura cf. SOROMENHO, Miguel - "D. Luís de Sousa (1637-1690): o gosto de um mecenas". MATOS, Maria Antónia Pinto de; CAMPILHO, Maria de Sousa Holstein (coord.) - Uma família de coleccionadores: poder e cultura: antiga colecção Palmela (cat. expo.), 2001, pp. 15-41

${ }^{14}$ SERRÃO, Vítor - "As colecções artísticas Sousa e Holstein/Palmela: notas sobre um recheio coleccionístico de excepção". Ibidem, pp. 76-89.
} 
artística italiana, no que é um caso digno de destaque no panorama nacional do barroco de Seiscentos ${ }^{15}$.

Foi contudo com a bisavó de D. Francisco, D. Maria Leopoldina de Holstein Beck (1717-1789), que a ligação àquele país se tornou mais evidente ao herdar e integrar no património familiar o título e as ricas propriedades do conde de Sanfré, no Piemonte, onde se fixou anos após as perseguições pombalinas à alta aristocracia que levaram à prisão do marido e dos filhos mais velhos. Nascido em Turim, o 1.ㅇ duque de Palmela, D. Pedro, passaria precisamente os primeiros cinco anos da sua vida no castelo de Sanfré com a avó, acompanhando depois o pai, D. Alexandre de Sousa Holstein (1751-1803), nas suas funções diplomáticas junto das cortes de Copenhaga e Berlim. Regressariam em 1790 a Itália, instalando-se em Roma onde D. Alexandre, homem de instrução e gosto, desempenhou papel ativo na reorganização da Academia Portuguesa, aconselhando o Intendente Pina Manique e sugerindo a escolha do seu amigo Giovanni Gherardo de Rossi $(1754-1827)^{16}$ para a dirigir.

Aquela fase revelou-se determinante na estruturação do gosto de D. Pedro, gosto que, como veremos, terá no filho Francisco um digno herdeiro e cultor. Com efeito, a estadia na Cidade Eterna viu nascer-Ihe o interesse pela arte como recordará mais tarde nas suas memórias: "comecei desde então a conceber a paixão que tenho tido pelas belas artes, que tanto floresciam em Itália, e cujo entusiasmo é tão contagioso. A música, a pintura, a escultura, sobretudo os monumentos antigos de Roma, excitavam em mim sensações que não se têm apagado da minha memória, e cuja influência nunca mais desvaneceu" ${ }^{17}$. Poucos anos se demoraram na cidade pontifícia, tendo o futuro duque de Palmela viajado por outros países europeus,

\footnotetext{
${ }^{15}$ VALE, Teresa Leonor M. - "Colecionadores ou adquirentes de obras de arte? Os embaixadores portugueses na Roma barroca e seus contactos com a produção artística: o caso de D. Luís de Sousa (1676-1682)". Artis, n. 2, 2a série, 2014, pp. 22-31.

${ }^{16}$ Figura polifacetada, advogado, banqueiro, poeta mas acima de tudo estudioso das belas artes, Giovanni Gherardo de Rossi colaborou em diversas academias italianas e no Instituto de França. Dotou a Academia Portuguesa com uma grande coleção de material didático, estampas e gessos, vindos em parte do espólio de Mengs, e instituiu nela o estudo do nu. Encerrada a Academia com a entrada dos franceses em Roma, em 1798, foi Rossi quem salvou aquele material que mais tarde (1802) viria para Lisboa, para uso da Casa Pia, passando finalmente para a Academia de Belas Artes. Sobre a ação desta figura cf. NETO, Maria João - "Construção e desconstrução de coleções: o mercado de arte em Roma no período napoleónico aos olhos dos diplomatas portugueses". NETO, Maria João; MALTA, Marize (eds.) - Coleções de arte em Portugal e Brasil nos séculos XIX e XX: perfis e trânsitos, 2014, pp. 51-69

${ }^{17}$ BONIFÁCIO, Maria de Fátima (trans., pref. e ed.) - op. cit., p. 72
} 
encontrando-se com o pai em Lisboa onde ingressou na carreira militar. Em 1802, após um hiato de dez anos, D. Alexandre regressou a Roma como embaixador e o filho acompanhou-o na qualidade de conselheiro de embaixada, seguindo assim as pisadas paternas. O regresso muito agradou ao aprendiz de diplomata que teve assim oportunidade de incrementar o entusiasmo pela Antiguidade Clássica partilhado com o pai: "O interesse que excitavam no meu ânimo os passeios que com meu pai, e com os mais célebres antiquários de Roma dávamos quase diariamente, visitando as famosas ruínas daquela capital do mundo, aumentava com a leitura, que nesse tempo começava a fazer, da história antiga e romana” ${ }^{18}$. Entre os companheiros dessas peregrinações contavam-se o já citado Rossi e o abade Fea $(1753-1834)^{19}$, mas D. Pedro teve oportunidade de se relacionar com outras personalidades, a começar pela célebre Madame de Staël cujo salão frequentou e onde conheceu Humboldt, Schegel, Sismondi, entre outros.

D. Alexandre morreu subitamente em Roma, aos 53 anos de idade, e foi sepultado na igreja de Santo António dos Portugueses onde D. Pedro mandou colocar um baixo-relevo à sua memória executado pela oficina de Canova, encomendando ao mesmo escultor uma cópia que se conserva no monumental jazigo de família que mandou erigir no cemitério dos Prazeres ${ }^{20}$. Nas suas memórias, o duque confidencia que aquelas duas obras "não foram pagas a preço de dinheiro; em compensação delas cedi ao sobredito Canova uma estátua grega de um sileno de tamanho natural, e de mármore, que entre outras antiguidades preciosas havia sido achada por meu pai numa escavação que mandara praticar nas vizinhanças de Roma"21 0 interesse pela arqueologia e pela Antiguidade Clássica que ambos comungavam está na base da formação de uma notável coleção de "vasos etruscos" que D. Pedro conseguiu conservar e porventura até aumentar mau grado as dificuldades decorrentes das

\footnotetext{
${ }^{18}$ Idem, ibidem, p. 89.

${ }^{19}$ Tradutor de Winckelmann, Carlo Fea supervisionou durante o pontificado de Pio VII as obras que os franceses executaram na Academia Romana. Bibliotecário do Príncipe Chigi e membro da Academia Romana, foi autor de uma vasta bibliografia de onde se destaca Miscellanea filologica-critica ed antiquaria (Roma, 1790).

${ }^{20}$ Uma moldagem em gesso deste relevo será oferecido em 1850 pelo duque à Academia de Belas Artes de Lisboa. Cf. conferência ordinária de 31 de Agosto de 1850. Arquivo da ANBA, disponível em http://digitarq.dgarq.gov.pt/ PT-ANBA-ANBA-A-001-00004_m0369.TIF

${ }^{21}$ BONIFÁCIO, Maria de Fátima (trans., pref. e ed.) - op. cit., p. 91.
} 
lutas políticas ${ }^{22}$. Aos vasos juntou algumas esculturas em mármore e um apreciável conjunto de pinturas onde entre atribuições sonantes avultavam as quatro célebres telas de Domingos Sequeira alusivas à vida de Cristo, obras adquiridas aos herdeiros do artista no ano de $1845^{23}$. O acervo seiscentista do ilustre prelado D. Luís de Sousa foi assim sendo extraordinariamente enriquecido, o que fez da Casa Palmela uma das primeiras do reino em termos de património artístico ${ }^{24}$, justificando-se em meados do século XIX a edição de um catálogo reunindo as obras de arte mais significativas conservadas no palácio do Calhariz em Lisboa ${ }^{25}$.

D. Francisco cresceu portanto num ambiente rodeado de testemunhos artísticos, revelando desde cedo uma sensibilidade que, à semelhança do sucedido com o pai e o avô, a permanência em Itália irá estimular. Dominando bem a língua daquela que era para a família uma segunda pátria, o marquês seria bem acolhido em Roma onde o nome Sousa Holstein havia deixado boas impressões, tendo passado depois a Florença. As notícias deste período são bastante escassas ${ }^{26}$ mas sabemos ter aproveitado para desenvolver a sua propensão pelos estudos artísticos, coligindo elementos e adquirindo desenhos de Domingos Sequeira, com destaque para os cartões das quatro telas sobre a vida de Cristo que haviam sido anteriormente compradas por seu pai. Relacionou-se também com artistas e colecionadores, alguns do quais do meio diplomático, estabelecendo contactos que se revelaram benéficos

\footnotetext{
${ }^{22}$ Sobre a coleção de vasos cf. PEREIRA, Maria Helena da Rocha - "Notícia sobre vasos gregos existentes em Portugal". Sep. Humanitas, v. 8, nova série, 1959, pp. 11-26.

${ }^{23}$ As obras em questão foram pintadas em Castel Gandolfo entre 1827 e 1832 . O rei Carlos Alberto da Sardenha terá chegado a oferecer por elas 4 mil Luíses, mas o negócio não foi fechado. Após a morte do artista, ficaram na posse da sua filha, Mariana Benedita, e seu genro, J. P. Migueis de Carvalho e Brito, ministro de Portugal em Roma, a quem o duque de Palmela as adquiriu, consta que por 40 mil francos. FRANÇA, José-Augusto (org.) - Homenagem a Sequeira, 1968, p. 3.

${ }^{24}$ Sobre a atividade colecionista do primeiro duque cf. SERRÃO, Vítor - op. cit., pp. 80-89.

${ }^{25}$ Aí se descrevem algumas mesas de "mosaico e mármore" de provável origem florentina, 62 "vasos etruscos achados em Itália, Sicília e Grécia", 15 "estátuas esculpidas modernas", sete "estátuas e outras esculturas antigas" e 63 pinturas de autores italianos, flamengos e portugueses. Catalogo dos quadros e mais objetos de belas-artes que se acham no palácio dos duques de Palmela ao Calhariz, s.d. Sobre a coleção de pintura cf. "Catálogo dos quadros antigos e modernos que formam parte da galeria do Exmo. duque de Palmela". Revista Universal Lisbonense, n. 12, 1851, pp. 142-143, e n.o 13, 1851, pp. 153-154 e 166. Cf. ainda PEREIRA, Gabriel - A colecção de pinturas do Sr. duque de Palmela no pallacio do Rato, 1903.

${ }^{26}$ Os fundos documentais das Legações de Portugal em Roma e Florença que tivemos oportunidade de consultar no Arquivo Histórico-Diplomático do MNE, não oferecem a este respeito grande soma de pormenores.
} 
para o enriquecimento das coleções nacionais como veremos na III parte deste trabalho.

Durante a sua estadia em Itália mostrou também interesse pelos estabelecimentos de ensino, tendo enviado em 1859 ao conselho da Universidade de Coimbra um relatório onde fazia uma avaliação muito positiva daquela instituição, comparada com outras congéneres que tivera oportunidade de visitar num périplo por diferentes províncias ${ }^{27}$. Anunciou então o envio de uma coleção de minerais do Vesúvio que obtivera em Nápoles, várias obras sobre Medicina da Academia MédicoCirúrgica de Roma e legislação académica de algumas universidades. Aproveitamos a referência à mineralogia para acrescentar ter essa ciência interessado ao marquês na qualidade de investidor, destacando-se como acionista de várias companhias e sociedades de mineração portuguesa, como atesta um conjunto de documentos colocados em 2011 em leilão ${ }^{28}$.

Algo inesperadamente, a experiência do marquês no meio diplomático em que se depositavam tantas esperanças demorou menos de um ano, regressando a Portugal em Agosto de 1859. Ingressará na política como deputado às Cortes na legislatura de 1860-61, não constando do Diário daquela Câmara qualquer intervenção sua. Deve datar desse período uma fotografia "carte de visite" tirada no primeiro estúdio de A. Fillon, situado na rua das Chagas, bem próximo do palácio do Calhariz, onde nos surge em pose digna da sua condição (fig. 25). Regressará mais tarde à atividade política na qualidade de par do reino hereditário, tomando posse e assento na sessão de 16 de Novembro de 1865, tendo sido introduzido na sala pelo marquês de Valada e pelo marquês de Sá da Bandeira ${ }^{29}$.

Naquela câmara integrou várias comissões, entre as quais a de Negócios Eclesiásticos (1865, 1868, 1870 e 1876), Petições (1865 e 1870), Obras Públicas

\footnotetext{
${ }^{27}$ PEREIRA, Esteves; RODRIGUES, Guilherme - Portugal: diccionario historico, chorografico, heraldico, biographico, bibliographico, numismatico e artistico. vol. VI, 1912, p. 1081.

${ }^{28}$ Cabral Moncada Leilões (org.) - Antiguidades e obras de arte, pintura, pratas e jóias, n.․ 128, Maio 2011, p. 13 (lote 9). Compreendia um conjunto de 71 documentos contidos numa pasta em marroquim vermelho forrada a seda pertencente ao 1. marquês de Sousa Holstein. Incluíam-se cartas e títulos de subscrição referentes à "Companhia de Mineração da Azambujeira", "Sociedade Pesquizadora das Minas de Odemira", "Companhia de Mineração de Estanho de Trás-os-Montes" e "Companhia de Mineração Trastagana", entre outros documentos diversos datados de 1865 a 1878.

${ }^{29}$ MARTINHO, Maria José - "HOLSTEIN, D. Francisco de". MÓNICA, Maria Filomena (dir.) - Dicionário biográfico parlamentar 1834-1910, vol. 2, 2005, p. 430.
} 
(1865, 1870, 1871 e 1873), Negócios Externos (1871 e 1873) e Agricultura (1871 e 1876). Fez a sua primeira intervenção a 28 de Maio de 1866, quando se discutia o parecer sobre o projeto de lei para restabelecer o lugar de ministro dos Negócios Estrangeiros, tal como existia antes de 1852, cargo que chegou a ser exercido algumas vezes por seu pai. Entendia que a pequena despesa com a criação do lugar de ministro seria mais do que recompensada pelos benefícios que o país teria com a nomeação de um ministro especialmente encarregado da política externa, demonstrando, ao mesmo tempo, quanto era absurda a sua supressão por razões de economia. No final declarou a confiança nas capacidades de Casal Ribeiro que era, ao mesmo tempo, ministro das Obras Públicas e dos Negócios Estrangeiros, para manter a política que permitira a Portugal continuar "no constante desenvolvimento das suas liberdades e da sua civilização" ${ }^{30}$.
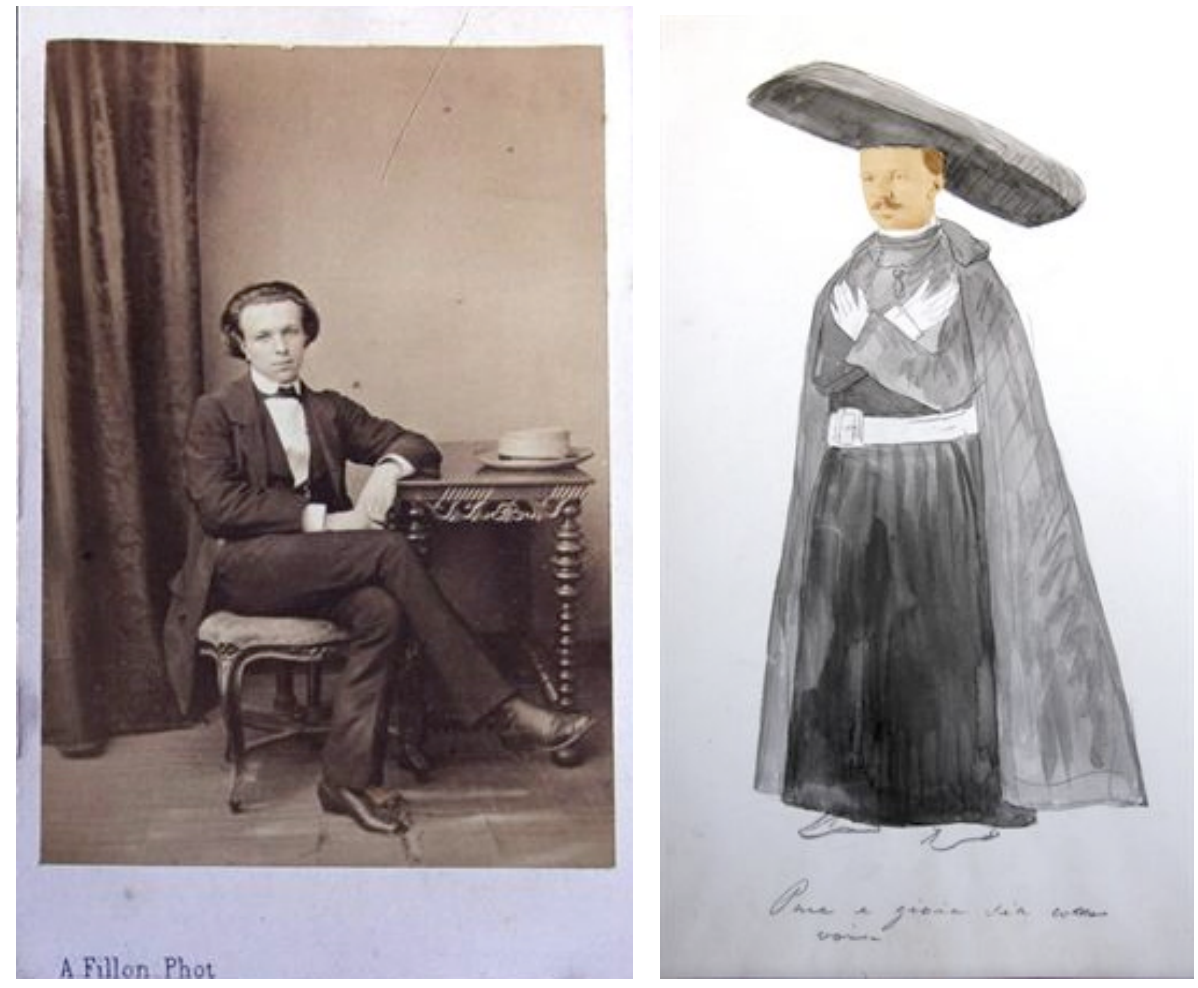

Fig. 25 - D. Francisco de Sousa Holstein, fotografia de A. Fillon, c. 1859. PNA, inv. 60133

Fig. 26 - D. Luís de Bragança, representação caricatural do marquês de Sousa Holstein como conde de Almaviva, c. 1870. PNA, inv. 55454/48

${ }^{30}$ Idem, ibidem, pp. 430-431. 
Paralelamente, desempenhou alguns cargos associados à Casal Real, tais como o de gentil-homem da Câmara do rei D. Luís, moço-fidalgo e oficial-mor, estabelecendo alguma proximidade com o monarca que, dedicado de forma amadora à caricatura, o representou num dos seus álbuns como uma personagem da ópera $O$ barbeiro de Sevilha de Rossini (fig. 26). D. Luís utilizou um recorte fotográfico do rosto do marquês, aguarelando a negra indumentária utilizada no II ato daquela ópera pelo conde de Almaviva quando, disfarçado de professor de música, entra em casa de Don Bartolo para falar a sós com a sua amada, Rosina. A inscrição "pace e gioia sia con voi" aposta na zona inferior alude ao conhecido dueto que tem então lugar entre Almaviva e Bartolo. Desconhecemos as razões do espirituoso monarca em optar por tal caricatura para Sousa Holstein que, à primeira vista, parece ter apenas em comum com a personagem a condição de aristocrata. $\mathrm{O}$ gesto de $\mathrm{D}$. Luís constitui um sinal de humorística distinção para com o marquês, figura que prezava e a quem não deixou de reconhecer o papel desempenhado em prol das belas artes, atribuindo-lhe em 1869 a ordem de S. Tiago, "digna de quem tanto se esforça por ajuntar aos herdados brasões os mais imorredouros títulos que dão a inteligência e o estudo" escreverá então o Diario de Noticias $^{31}$. Viria ainda a ser agraciado com a ordem de Nossa Senhora da Conceição de Vila Viçosa, para além de diversas condecorações estrangeiras $^{32}$, em parte reflexo dos contactos internacionais que mantinha, tendo sido convidado para académico ou sócio de prestigiadas associações $^{33}$.

As funções exercidas por Sousa Holstein no Palácio da Ajuda serão extensíveis à mulher, D. Maria Eugénia Braamcamp Sobral de Melo Breyner (1837-1879), filha dos segundos condes de Sobral e dama honorária da rainha D. Maria Pia, com quem casou aos 24 anos de idade, a 20 de Agosto de 1862. A D. Maria Eugénia será transmitido parte do desvinculado património dos Sobrais, com destaque para o palácio situado ao Calhariz, lado a lado com o dos Palmela, edifício construído

\footnotetext{
${ }^{31}$ Diario de Noticias, 6 de Fevereiro de 1869.

${ }^{32}$ Orden del Mérito Militar e Real Orden de Carlos Tercero (Espanha), Ordine dei Santi Maurizio e Lazzaro (Itália), Ordem de S. Gregório Magno (Roma), Ordre de François-Joseph (França), War Wasa Orden (Suécia) e Ordem Imperial e Real de S. Estanislau (Rússia). Os diplomas destas condecorações integraram o leilão da Biblioteca Eugénio da Cunha e Freiras. Cf. AZEVEDO, Pedro de (org.) - op. cit., p. 78 (lote 509).

${ }^{33}$ Société Parisienne d'Archéologie et d'Histoire, Sociedade Antropológica Española, Real Academia de las Tres Nobles Artes de S. Fernando, entre outras. Cf. Idem, ibidem.
} 
durante o governo de Pombal pelo abastado Joaquim Inácio da Cruz e onde, entre esplendorosas festas, cantou Luísa Todi. Desconhecemos se chegou a ser habitado pelo casal que fixou residência mais espartana no n.o 48 da antiga calçada dos Caetanos, hipotecando o palácio a uma instituição bancária e alugando-o depois para servir de hotel ${ }^{34}$. Os já referidos investimentos do marquês como acionista de companhias de mineração, assim como a destacada participação detida numa empresa dedicada ao fabrico de garrafas em vidro ${ }^{35}$, parecem não ter sido suficientes para fazer face à delicada situação financeira familiar, o que obrigou ainda à alienação de algum património artístico. Foi o caso de um suposto Salvador Rosa representando S. Romualdo no deserto, acerca do qual Raczynski havia tecido os maiores encómios em 1845 ao visitar o palácio Sobral, e que Sousa Holstein venderá ao conde de Daupias para a notável galeria criada na sua casa ao Calvário ${ }^{36}$. Marcado pelo nascimento de três filhos, Pedro, Luís e Adelaide ${ }^{37}$, o casamento terá decorrido com normalidade até 1876, ano em que Sousa Holstein começou a manifestar sinais da "tísica" ou tuberculose pulmonar que o vitimou. Por provável indicação médica, procurou outros ares e repouso em Carnide numa propriedade pertencente à família da mulher, a Quinta das Romeiras, onde expirou na manhã de 30 de Setembro de 1878, "ao fim de uma prolongada doença que tanto afligia os seus amigos" ${ }^{38}$. Com o óbito do marquês tem início um drama familiar que se ampliou um ano mais tarde, a 7 de Outubro de 1879, com a morte da mulher, provavelmente em idênticas circunstâncias, deixando órfãos os três filhos menores. Estes serão divididos e criados entre a família paterna e materna, como recordará mais tarde uma prima: "tendo morrido o nosso tio, marquês de Sousa Holstein e, um ano depois, a sua mulher, os tios Monfalins decidiram logo substituir estes pobres pais, e foi assim que o Pedro e o Luís, então com treze e onze anos, entraram no

\footnotetext{
${ }^{34}$ Diz-nos a esse respeito Júlio de Castilho: "Em 1879 ali funcionava desde anos, e continuou algum tempo, o afamado Hotel Mata. Lembro-me de aí ter jantado duas ou três vezes; a grande sala da mesa era a 4. , a antiga sala da música de 1783! Achava-se o palácio onerado de pesadas hipotecas na Companhia de Crédito Predial pelo Marquês de Sousa, malogrado e talentoso homem!". CASTILHO, Júlio - Lisboa antiga: o Bairro Alto, vol. III, 3a ed., 1956, p. 101.

${ }^{35}$ URBANO, Pedro - op. cit., p. 30.

${ }^{36}$ CASTILHO, Júlio de - op. cit., p. 98

${ }^{37}$ Pedro de Sousa Holstein (1865-?), solteiro e sem geração; Luís de Sousa Holstein (1868-1935), 2o marquês de Sousa Holstein; Adelaide de Sousa Holstein (1869-1948), solteira e sem geração.

${ }^{38}$ Diario de Noticias, 1 de Outubro de 1878
} 
numero dos filhos adoptivos dos nossos tios. A Adelaide, única irmã deles, ficou na família da mãe, como mais uma filha dos seus tios, condes de Moçâmedes"39.

Na sequência da morte de $D$. Maria Eugénia, foi organizado um leilão judicial do recheio da casa da calçada dos Caetanos, tendo sido dado especial destaque à biblioteca do marido que reunia aproximadamente seis mil volumes, e que contou com a cuidada edição de um catálogo ${ }^{40}$. Abarcando diversos temas dentro dos interesses do marquês, do Direito à Literatura passando pela Filosofia, tinha um ponto forte nos domínios da História e sobretudo da História e da Crítica da Arte, com uma alargada e atualizada seleção de autores onde avultavam Théophile Gautier, Charles Robinson, Viollet-le-Duc, Charles Blanc ou Ralph Nicholson Wornum, por vezes citados na produção historiográfica deixada por Sousa Holstein. Agendado apressadamente para Outubro de 79 e depois adiado para Dezembro, o leilão foi acompanhado de perto pelo Diario de Noticias que informou ter começado "sob excelentes auspícios", com larga percentagem de obras licitadas. "Venderam-se cerca de 120 lotes; a concorrência era grande e bastantes deles atingiram preços consideráveis", relatará o jornal no primeiro dia da venda, identificando entre os arrematantes o marquês de Ficalho e o jovem António Augusto de Carvalho Monteiro, tornado em breve num distinto bibliófilo, que venceu a licitação dos raros volumes que enformam as Décadas da Ásia de João de Barros ${ }^{41}$.

Ocupou alguns dias o leilão da biblioteca, passando-se depois ao mobiliário e demais peças que ornamentavam a residência. "O Sr. José Palha foi um dos que arrematou maior número de lotes" escrevia o jornal que temos vindo a citar, informando existir ainda "grande numero de objetos de cerâmica para vender, entre eles jarros e talhas da mais fina porcelana", para além de "dois contadores antigos e apreciados dos amadores" $^{42}$. Na edição seguinte, assinalava-se entre o público comprador a presença de Ramalho Ortigão. "Escusado é dizer que ele teve bom gosto nos objetos

\footnotetext{
${ }^{39}$ SESIMBRA, Mariana - Madre Monfalim: memórias de sua irmã Marianna Cezimbra, 1946, p. 98.

${ }^{40}$ Catalogo da livraria do finado marquez de Souza Holstein, sub-inspector da Real Academia das Bellas-Artes, etc. que se há-se vender judicialmente, em hasta pública na Calçada dos Caetanos, n.으 48, no mez de Outubro de 1879.

${ }^{41}$ Diario de Noticias, 5 de Dezembro de 1879.

${ }^{42}$ Idem, 27 de Dezembro de 1879.
} 
que escolheu" comentava o articulista, anunciando o início da venda das pinturas e desenhos reunidos pelo marquês ${ }^{43}$.

Compreendia aquela um total de 59 telas, logo à cabeça com Domingos Sequeira e Vieira Portuense, passando por Madrazo, o único estrangeiro citado, e por vários nomes do agrupamento romântico com que Sousa Holstein manteve relações: Anunciação, Marciano de Silva, Pedroso, Tomasini ou Ferreira Chaves. Bastante mais numerosos eram os desenhos de alguns desses românticos mas sobretudo de Sequeira que, de acordo com o jornal, "obtiveram muito bom preço", destacando-se ainda um conjunto de aguarelas de artistas franceses ${ }^{44}$. Entre os licitantes surge 0 colecionador Teixeira de Aragão, conservador do gabinete numismático do Palácio da Ajuda e, algo ironicamente, o sucessor de Sousa Holstein na Academia de Belas Artes, Delfim Guedes que, como teremos oportunidade dar a conhecer na IV parte, se encontrava pela mesma altura a coordenar um relatório muito crítico sobre a política de aquisições desenvolvida pelo falecido vice-inspetor para a instituição.

A nomeação do marquês para aquele cargo ocorrera por ocasião do seu casamento, em 1862, entrosando-se assim com o meio artístico que tanto o vinha seduzindo. 0 lente coimbrão Augusto Filipe Simões (1835-1884), recordará no obituário que the dedicou ter exercido aquelas funções sem qualquer tipo de remuneração, "empregando os maiores esforços para elevar o ensino tanto quanto era possível com a deficiente e acanhada organização daquela escola, e com os escassos recursos que o Estado Ihe proporcionava". Homem cultivado, "falava e escrevia expeditamente as línguas francesa, italiana e inglesa", tendo viajado por aqueles países, sobretudo por Itália onde assegura ter adquirido a paixão pelas belas artes. Dizia ainda ser-Ihe reconhecível nas palavras e gestos "inequívocos sinais de uma fina educação aristocrática e literária" que faziam dele um agradável conversador, muito embora o seu "espírito vivo e irrequieto" não o detivesse muito tempo num mesmo assunto ${ }^{45}$.

No obituário publicado n'O Occidente, valorizado com uma gravura do último retrato conhecido do marquês (fig. 27), Pinheiro Chagas (1842-1895) assinala de igual modo

\footnotetext{
${ }^{43}$ Idem, 28 de Dezembro de 1879.

${ }^{44}$ Idem, 30 de Dezembro de 1879. A este respeito cf. também a ed. de 25 de Dezembro.

${ }^{45}$ SIMÕES, Augusto Filipe - "Marquês de Sousa Holstein". Escriptos diversos de Augusto Filippe Simões, 1888, pp. 205-206.
} 
o dinamismo que o caracterizava: "Foram talvez as influições misteriosas dos ares que respirou em criança que the deram essa atividade febril que manifestou até aos últimos dias da sua vida e que tanto o distanciavam dos nossos hábitos indolentes de meridionais" ${ }^{46}$. Destaca ter colocado ao servido da arte portuguesa todas as suas faculdades, embora esses esforços nem sempre se tenham revelado frutuosos, o que atribui em larga medida à falta generalizada de cultura artística do país. "Os seus trabalhos para conseguir a criação de um museu nacional e formação da galeria académica são altamente dignos de louvor" salienta o erudito escritor que coloca igualmente em evidência a produção historiográfica do marquês.

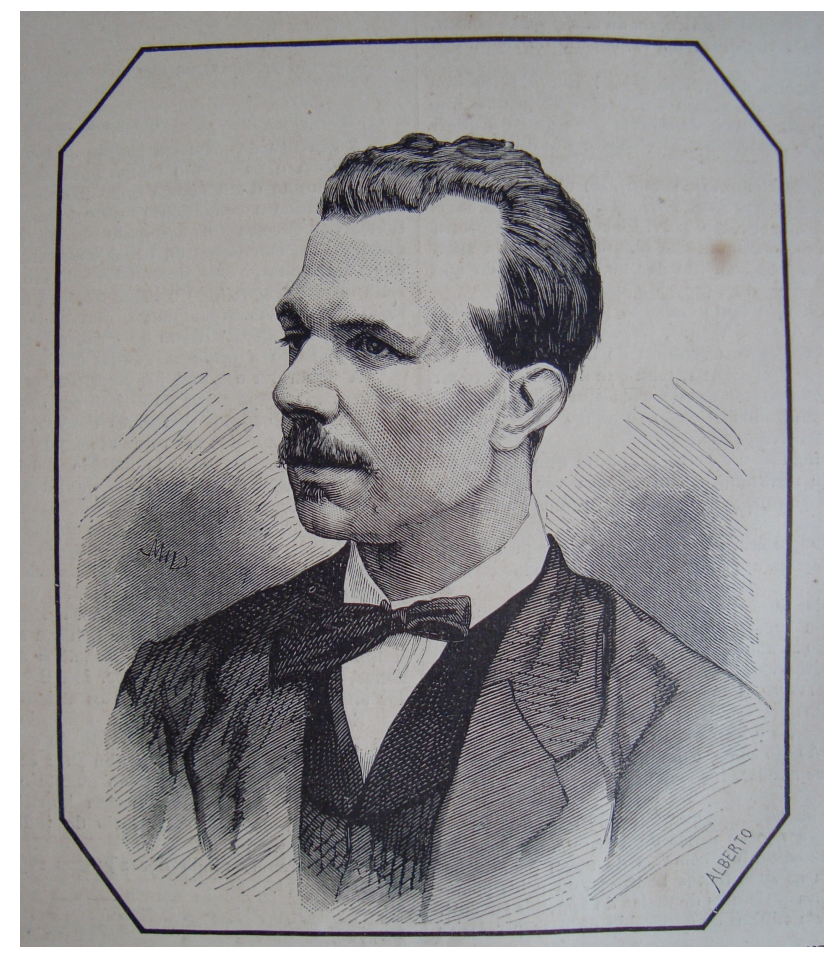

Fig. 27 - D. Francisco de Sousa Holstein, gravura publicada n'O Occidente, 1878

Refere que os serviços prestados, por mais relevantes, são em Portugal "facilmente esquecidos e as fraquezas do carácter avultam de um modo exorbitante", numa alusão às criticas de alguns elementos do meio artístico quanto ao falecido viceinspetor. O ímpeto por aquele demonstrado em enriquecer e patentear ao público as coleções da Academia, assim como as várias tentativas de reforma do ensino ministrado na instituição, originaram divergências com artistas e professores, nem

\footnotetext{
${ }^{46}$ CHAGAS, Pinheiro - "Marquês de Sousa Holstein". O Occidente, I ano, vol. I, n.o 20, 15 de Outubro de 1878, p. 156.
} 
sempre bem geridas por ambas as partes, e que perpassam nos livros de atas como veremos. Muito em consequência disso, morreu Sousa Holstein com uma imagem desgastada que os seus opositores não cessaram em diminuir ao ponto de quase ficar apagada. Conclui por isso Pinheiro Chagas o seu texto com a seguinte advertência: "quando os que lidam no mesmo campo não têm uns pelos outros a indulgência fraternal que evita muitos atritos, não se admirem de que o público encolha os ombros, e passe adiante desdenhando essa pobre arte que nestas lutas é afinal de contas a entidade em cujo nome se combate, mas em que menos se cuida" ${ }^{\prime 4}$.

\section{Funções e relações no meio artístico: da Academia à Sociedade Promotora das}

Belas Artes

Será enquanto deputado às Cortes que ocorre a aproximação de Sousa Holstein à Academia, ao ser nomeado em Outubro de 1861 académico honorário por proposta do visconde de Meneses ${ }^{48}$. Para tal nomeação contribuíram decerto o interesse pelas belas artes que vinha expressando e a coleção de desenhos de Domingos Sequeira reunida, objecto de um elogioso artigo por parte do jornalista, crítico e dramaturgo Ernesto Biester (1829-1880), publicado naquele mesmo ano na Revista contemporanea de Portugal e Brazil. Após deter-se na genialidade do artista através de alguns espécimes que Ihe foram dados a ver, Biester evidenciava o "atrativo da ilustrada conversação do Sr. marquês de Sousa Holstein", conhecido por reunir "às ideias teóricas o conhecimento prático das belas artes". Terminava o artigo com um recado dirigido ao governo, na pessoa do ministro do Reino: "Aí tem um homem

\footnotetext{
${ }^{47}$ Idem, ibidem, p. 157.

48 "Terminada a conferência geral, o Exmo. académico de mérito visconde de Meneses mandou para a mesa uma proposta por S. Ex.a, assinada pelo Sr. conde de Melo e João Cristino da Silva, para ser nomeado académico honorário desta Academia o marquês de Sousa Holstein, e sendo unanimemente aprovada esta proposta terminou esta conferência". Conferência geral e extraordinária de 5 de Outubro de 1861. Arquivo da ANBA, disponível em http://digitarq.dgarq.gov.pt/ PT-ANBA-ANBA-A-001-00008_m0291. A 21 de Dezembro, acusava-se a recepção de uma "carta do Exmo. marquês de Sousa Holstein, agradecendo à mesma Academia, o havê-lo proposto para académico honorário". Conferência ordinária de 21 de Dezembro de 1861. Idem, disponível em http://digitarq.dgarq.gov.pt/ PT-ANBA-ANBA-A-001-00008_m0303.
} 
competente para dirigir a Academia. Hoje insinuamos-lhe a ideia, para outra vez a justificarmos" ${ }^{49}$.

Não necessitou o jornalista de justificar a opinião expressa, pois logo em Junho de 1862 seria o marquês nomeado para o cargo de vice-inspetor da instituição, deixado vago pelo velho general Ferreira de Sousa que o ocupara durante cerca de 20 anos. A eleição do marquês para presidente da Sociedade Promotora das Belas Artes, ocorrida alguns meses antes e de que adiante falaremos, não passou naturalmente desapercebida ao governo, tendo estado na base da nomeação. Como já tivemos anteriormente oportunidade de referir, competia ao vice-inspetor representar o inspetor-geral (o próprio ministro do Reino) na administração executiva do estabelecimento, enquanto o diretor-geral (escolhido entre os professores mais antigos), deveria essencialmente velar pelo bom andamento da vida académica. Cabia portanto a Sousa Holstein (e, na sua ausência, ao diretor-geral) presidir ao órgão máximo de gestão da Academia, a conferência académica, podendo analisar ou elaborar propostas para a estruturação do ensino ministrado e contribuir para a definição dos métodos pedagógicos. Se, no primeiro caso, as propostas ou projetos tinham de ser obrigatoriamente sujeitas à aprovação do poder central, no segundo, eram os docentes e o vice-inspetor livres de os pôr em prática, desde que aprovados por maioria ${ }^{50}$.

A um de Julho de 62 , Sousa Holstein abriu a sua primeira conferência e, num gesto de atenção para com os professores, convidou-os a "requisitarem os livros de que carecessem na sua especialidade para instrução própria e das suas respectivas aulas, afim de se obterem do governo de Sua Majestade". Ficou na mesma ata registado que aqueles, "tendo manifestado grande satisfação pela acertada escolha que Sua Majestade houve por bem fazer da pessoa do Exmo. marquês de Sousa Holstein para vice-inspetor da mesma Academia", passaram a fazer sentir outras necessidades, como a de "bons modelos para o estudo do nu que reunissem às boas formas a conveniente idade e mais circunstâncias para que bem possam servir ao estudo nas

\footnotetext{
${ }^{49}$ BIESTER, Ernesto - “Crónica Literária”. Revista Contemporanea de Portugal e Brazil, vol. III, (n.o 6), 1861, p. 330.

${ }^{50}$ LISBOA, Maria Helena - op. cit., pp. 252.
} 
aulas académicas" ${ }^{51}$, tendo sido decidido recorrer para o efeito a anúncios publicados nos jornais.

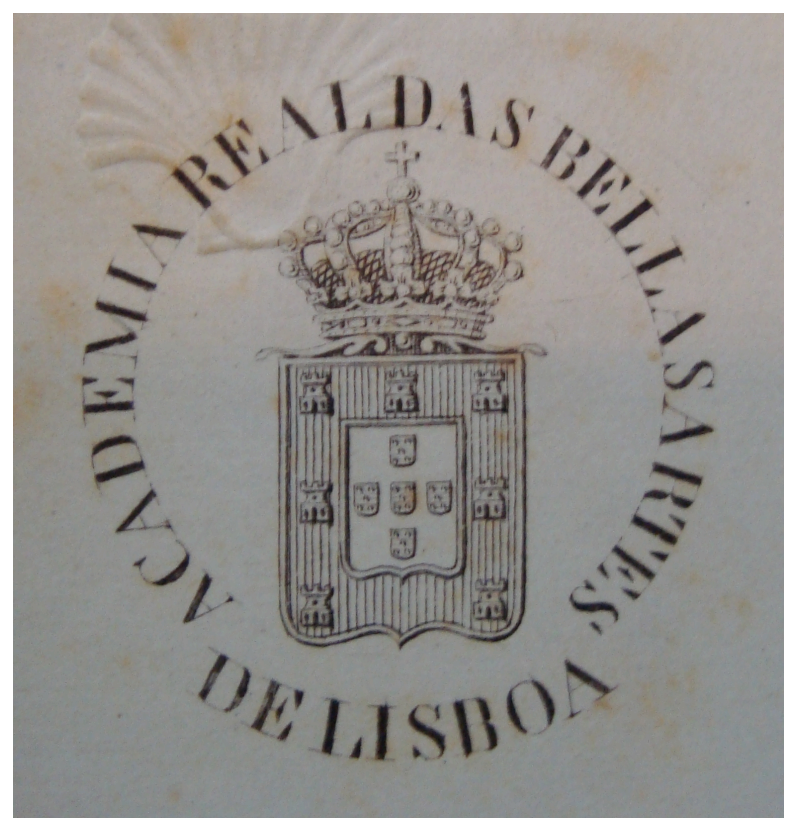

Fig. 28 - Papel timbrado da Academia Real das Belas Artes de Lisboa (pormenor). Arquivo do MNAA

A estas e outras carências Sousa Holstein procurará dar resposta, lutando não só pela atualização daquele estabelecimento de ensino artístico, mas também pelo enriquecimento e pública exposição do seu acervo. Em Maio de 1863, num relatório dirigido ao ministro do Reino, fazia o ponto de situação da Academia que conseguira entretanto elevar à categoria de "real" (fig. 28) ${ }^{52}$, evidenciando a falta de interesse que os puderes públicos haviam tido para com a instituição. Com efeito, o orçamento fora sendo sempre diminuindo e afigurava-se insuficiente para fazer face aos encargos impostos pelos estatutos. As parcas verbas dispensadas às belas artes não produziam pois grandes melhoramentos, e o marquês questionava a existência de duas Academias, "ambas fracas, ambas incompletas", num país cujo rendimento estava aquém dos planos estabelecidos ${ }^{53}$. Cioso de reformas, ventilava a hipótese de

\footnotetext{
${ }^{51}$ Conferência extraordinária de 1 de Julho de 1862. Arquivo da ANBA, disponível em http://digitarq.dgarq.gov.pt/PT-ANBA-ANBA-A-001-00008_m0360 e_m0361.

52 "O Exmo. vice-inspetor leu uma representação dirigida a Sua Majestade, para que esta Academia possa usar do título de Real Academia de Belas Artes de Lisboa - e sendo aprovada e assinada pelo conselho desta Academia, o mesmo Exmo. vice-inspetor se encarregou de solicitar junto do governo de Sua Majestade esta mercê". Conferência extraordinária de 5 de Agosto de 1862. Idem, disponível em http://digitarq.dgarq.gov.pt/ PT-ANBA-ANBA-A-001-00008_m0366.TIF

${ }^{53}$ Apud ALDEMIRA, Luís Varela - op. cit., p. 246.
} 
se exigir aos alunos o curso completo dos liceus, procurando assim elevar a Academia ao grau de ensino superior, ao mesmo tempo que solicitava a abertura das cadeiras de anatomia, história geral, história da arte, geometria e arqueologia que alguns professores de resto já ensinavam por iniciativa própria. Não deixa de aludir à necessidade de organização de uma galeria de pintura, e de apontar as deficiências do edifício de S. Francisco, tema que já se tornava recorrente.

Nove meses após a realização daquele trabalho, em Fevereiro de 1864, outro relatório será redigido pelo vice-inspetor, ativo nos contactos com o governo ${ }^{54}$. Trata-se de documento programático de especial relevância a que iremos recorrer diversas vezes nos próximos capítulos, e onde dá a conhecer as alterações introduzidas na Academia desde a sua tomada de posse, apontando de igual modo as linhas futuras a seguir. Aborda pontos relacionados com as alterações de pessoal, reformulação e criação de cadeiras, aquisição de material didático, incorporação de obras de arte, inventariação, restauro e catalogação das coleções que planeava patentear ao público, propondo-se não à remodelação do edifício como se vinha insistindo, mas à mudança de instalações.

Pouco antes, o vice-inspetor obtivera aliás luz verde do governo para mandar elaborar a planta e executar o respectivo orçamento para um edifício a construir de raiz, informando ter encontrado, juntamente com os professores de arquitetura, um "terreno que confina com o convento das freiras Francesinhas e propriedades do Quelhas, etc., o qual parece muito conveniente para o pretendido fim" ${ }^{55}$. O projeto, se esboçado, não saiu do papel, sendo as atas subsequentes e outros documentos internos completamente omissos a esse respeito. Assim, e como já foi notado, "nem mesmo Sousa Holstein que foi o vice-inspetor mais atuante da Academia e aquele que a dirigiu no seu período talvez mais prestigiado, logrou conseguir a realização das desejadas obras de remodelação e, muito menos, a construção de um edifício" ${ }^{56}$. As verbas que esforçadamente conseguiu captar, permitiram todavia a realização de

\footnotetext{
54 "Relatório acerca do estado da Academia Real das Belas Artes". Documento manuscrito assinado por Sousa Holstein e datado de 26 de Fevereiro de 1864. Arquivo do MNAA, fundo José de Figueiredo, cx. 1 , pasta 1 , doc. 1 .

${ }^{55}$ Conferência extraordinária de 19 de Janeiro de 1864. Arquivo da ANBA, disponível em http://digitarq.dgarq.gov.pt/ PT-ANBA-ANBA-F-002-00001_m0126.TIF

${ }^{56}$ LISBOA, Maria Helena - op. cit., p. 271.
} 
pequenas obras de adaptação do convento às funções escolares e de divulgação artística como adiante daremos conta.

Uma das preocupações desde cedo revelada pelo marquês, foi estabelecer e reforçar contactos com figuras relevantes da cena artística internacional. Logo em 64 seria nomeado académico de mérito Viollet-le-Duc com quem se irá corresponder, convidando-o a colaborar numa reforma do ensino de arquitetura e, simultaneamente, a autorizar a tradução dos seus Entretiens sur l'architecture ${ }^{57}$. As reformulações entretanto produzidas não deverão contudo ser atribuídas a uma influência direta das propostas que gizou em 63 para a École Imperiale des Beaux Arts. "A maioria dos académicos e professores, talvez com exceção feita a Sousa Holstein, não deu mostras de as conhecer no seu conjunto, facto que os impediria de ter uma noção de todo o seu alcance", justifica Maria Helena Lisboa ${ }^{58}$. Outro conhecido arquiteto francês, Charles Garnier, trocará correspondência com o viceinspetor, procedendo em 68 ao envio de um conjunto de fotografias da Ópera de Paris por intervenção de um seu discípulo, o português Luís Caetano Pedro d'Ávila que colaborara no projeto ${ }^{59}$. Garnier tinha sido por aquele informado do interesse de Sousa Holstein em formar uma coleção de material sobre arquitetura, disponibilizando-se a remeter outros espécimes para grande agrado do vice-inspetor que fará expressar em ata o seu reconhecimento ${ }^{60}$.

Durante todo este período verifica-se uma grande preocupação em dotar a Academia das obras e materiais necessários à sua função pedagógica. Em 1863 conseguiu-se, por exemplo, um conjunto de 14 estudos e cópias de quadros do pintor suíço Calame executados por Alfredo de Andrade, artista português radicado em Itália que com ele estudara ${ }^{61}$. Ainda que em Génova onde se fixou a partir de 1860, tenha ficado mais conhecido pelas atividades ligadas à arquitetura de restauro arqueológico, foi pela sua atividade de pintor que veio a ser nomeado académico de

\footnotetext{
${ }^{57}$ FRANÇA, José-Augusto - op. cit., p. 416.

${ }^{58}$ LISBOA, Maria Helena - op. cit., p. 215.

${ }^{59}$ Carta datada de 28 de Julho de 1868. Arquivo da ANBA, disponível em http://digitarq.dgarq.gov.pt/ PT-ANBA-ANBA-B-001-00003_m1324.TIF

${ }^{60}$ Conferência ordinária de 8 de Outubro de 1868. Idem, disponível em http://digitarq.dgarq.gov.pt/ PT-ANBA-ANBA-F-002-00001_m0522.TIF

${ }^{61}$ Conferência geral de 16 de Março de 1863. Idem, disponível em http://digitarq.dgarq.gov.pt/ PTANBA-ANBA-F-002-00001_m0031.TIF
} 
mérito $^{62}$, prestando à Academia de Lisboa um importante apoio que os seus contactos internacionais facultavam ${ }^{63}$. O seu nome é algumas vezes citado nas atas, em parte resultado da correspondência mantida com o vice-inspetor, envolvendo-se em estudos para a atualização do ensino artístico ministrado naquele estabelecimento.

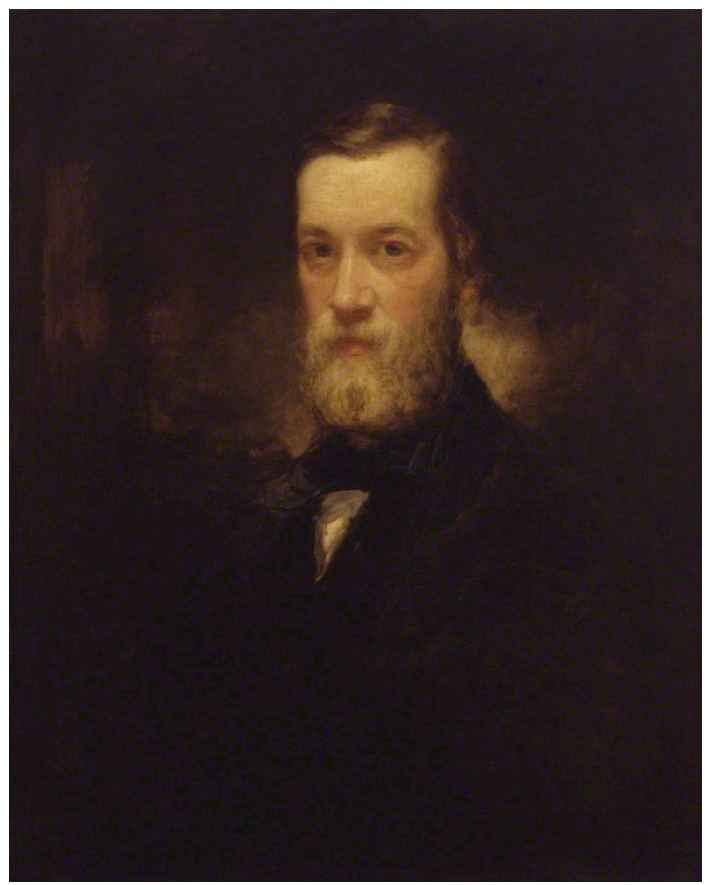

Fig. 29 - John James Napier, Sir John Charles Robinson, c. 1880. NPG, 2543

Entre os contactos internacionais deve ser destacado o nome de John Charles Robinson (1824-1913) (fig. 29), reputado consultor e superintendente das coleções de arte do South Kensington Museum, atual Victoria \& Albert, que ajudou a constituir através de aquisições efectuadas um pouco por toda a Europa, incluindo Portugal. Em Outubro de 1865 encontrava-se em Lisboa na companhia de um amigo, membro do parlamento britânico, como revela um ofício da Legação de Inglaterra dirigido ao vice-inspetor, solicitando "o especial favor de mandar facilitar a entrada àqueles dois cavalheiros nesse estabelecimento a fim de eles poderem examinar à

62 Conferência geral de 21 de Dezembro de 1863. Arquivo da ANBA, disponível em http://digitarq.dgarq.gov.pt/ PT-ANBA-ANBA-F-002-00001_m0119.TIF

${ }^{63}$ A este respeito cf. COSTA, Lucília Verdelho - Alfredo de Andrade 1839-1915: da pintura à invenção do património, 1997. 
sua vontade as pinturas e quadros que aí se acham, o que eles desejam fazer"64. A visita à Academia prender-se-á pois com interesse de Robinson pelo estudo das primícias da pintura nacional, nomeadamente pelo caso de Grão Vasco que conheceria pelos escritos de Raczynski ${ }^{65}$, vindo a ter como consequência a publicação de um artigo sobre a escola portuguesa em que mais à frente nos iremos deter.

A localização daquele ofício deita de certa forma por terra as hipóteses já formuladas de Robinson ter sido chamado a Portugal por D. Fernando II, assim como por Sousa Holstein que, à data, não conhecia. A estadia em Lisboa enquadra-se no contexto das prospecções artísticas que o inglês vinha empreendendo na Península Ibérica, tendo entrado naquele ano de 65 pela Galiza, para tratar do projeto da moldagem em gesso e reprodução fotográfica para o seu museu do "Pórtico da Glória" da catedral de Santiago de Compostela. Daí passou ao norte do nosso país que teve oportunidade de explorar, viajando por terra a partir da cidade do Porto até à capital. O vice-inspetor dispensou-Ihe o melhor acolhimento, tirando partido da presença do especialista para o consultar e pedir pareceres, incluindo sobre duas pinturas italianas adquiridas naquele ano com a verba cedida pelo rei D. Fernando ${ }^{66}$. A respeito de Sousa Holstein, Charles Robinson registou então num dos seus relatórios ser "a young nobleman of the highest rank to whom appears to be entrusted the administration of all maters connected with the Fine Arts", entrevendo facilidades no acesso aos objetos das coleções nacionais para estudo e reprodução ${ }^{67}$.

Na sequência da visita, a conferência aprovava "por aclamação" uma proposta assinada por todos os presentes propondo-o para académico honorário ${ }^{68}$, nomeação

64 Oficio datado de 17 de Outubro de 1865. Arquivo da ANBA, disponível em http://digitarq.dgarq.gov.pt/ PT-ANBA-ANBA-B-001-00003_m1138.TIF a_m1140.TIF

${ }^{65}$ Sobre o interesse do historiador por Grão Vasco cf. RODRIGUES, Paulo Simões - "O conde Athanasius Raczynski e a historiografia da arte em Portugal". SILVA, Raquel Henriques da (coord.) Revista de História da Arte, n.o 8, 2011, pp. 264-277.

${ }^{66}$ A este respeito cf. testemunho de SILVA, Marciano Henriques - A Lanterna: Folha Política, n. 0 30, Outubro de 1869.

${ }^{67}$ Apud FONTANELLA, Lee - Charles Thurston Thompson e o proxecto fotográfico ibérico, 1996, s. p.

${ }^{68}$ Conferência geral extraordinária de 3 de Novembro de 1865. Arquivo da ANBA, disponível em http://digitarq.dgarq.gov.pt/ PT-ANBA-ANBA-F-002-00001_m0294.TIF 
confirmada pelo governo em Janeiro do ano seguinte ${ }^{69}$. Em 1871, nova prova de reconhecimento ser-Ihe-á dispensada com a atribuição do grau de oficial da ordem de S. Tiago pelo rei D. Luís, sob proposta de Sousa Holstein. No oficio dirigido ao governo, aquele último salienta "a publicação importante sobre a antiga escola portuguesa de pintura, na qual esclareceu vários pontos obscuros da intricada questão acerca de Grão Vasco", assim como a oferta de todas as obras que publicara à biblioteca académica, sem esquecer "um grande número de fotografias e de modelos de valor" provenientes do South Kensigton Museum e enviados logo em 1866. Destacava ainda o facto do inglês se ter disponibilizado "para classificar a valiosa coleção de desenhos que possui esta Academia"70 ${ }^{70}$, ferta que entusiasmou o vice-inspetor pois Robinson era também versado naquele domínio, tendo catalogado um ano antes os desenhos de Miguel Ângelo e Rafael pertencentes ao Ashmolean Museum de Oxford" . Ainda que Sousa Holstein refira no ofício ter aceite "gostoso esse oferecimento", desconhecemos se tal classificação veio a ter efetivamente lugar.

Os contactos internacionais foram portanto propiciando o enriquecimento do material didático da instituição para contentamento dos alunos, professores e do vice-inspetor que procurou dar atenção aos denominados "gessos", símbolos por excelência de uma academia de arte $^{72}$. Logo em 1863, anunciava ter conseguido obter autorização do provedor da Casa Pia para se tirarem moldes dos ornamentos do Mosteiro do Jerónimos, "e que em virtude disso passaria brevemente a ir ali em companhia do Sr. Vítor Bastos, afim de fazer a escolha dos melhores fragmentos que se devem extrair" ${ }^{73}$. Dois meses depois, informava ter mandado formar e vazar cópias de folhas de árvores para servirem de ferramenta aos estudantes da aula de ornamento e produtos naturais, cópias essas que colocou à disposição dos

\footnotetext{
${ }^{69}$ Conferência ordinária de 10 de Janeiro de 1866. Idem, disponível em http://digitarq.dgarq.gov.pt/ PT-ANBA-ANBA-F-002-00001_m0318.TIF

70 Cópia manuscrita do ofício datado de 5 de Maio de 1871. Idem, disponível em http://digitarq.dgarq.gov.pt/ PT-ANBA-ANBA-B-007-00001_m0040.TIF

${ }^{71}$ NETO, Maria João Baptista - "Colecionadores e connaisseurs de obras de arte: Francis Cook (18171901) e John Charles Robinson (1824-1913) em Portugal”. Artis, n. 6, 2007, p. 411.

${ }^{72}$ A este respeito cf. MENDONÇA, Ricardo - A recepção da escultura clássica na Academia de Belas Artes de Lisboa. Tese de doutoramento a ser defendida na FBAUL.

73 Conferência ordinária de 3 de Março de 1863. Arquivo da ANBA, disponível em http://digitarq.dgarq.gov.pt/ PT-ANBA-ANBA-F-002-00001_m0024-2.TIF
} 
académicos para serem apreciadas. Perante as reações pouco positivas de Cristino da Silva e Vítor Bastos, Sousa Holstein argumentará em prol da utilidade dos modelos em questão, escrevendo o secretário da Academia em ata ter-se aquele inspirado "em autorizadas opiniões de alguns artistas de crédito, cujas obras tem lido, e nas práticas mais seguidas nas aulas das academias que visitou em alguns países cultos ${ }^{\prime 74}$. Se atendermos às opiniões expressas pelo vice-inspetor quando, em 1875, integrou a comissão que estudou a reforma do ensino artístico e a organização dos museus, essa opção por modelos simples retirados da Natureza, poderia, como já foi notado ${ }^{75}$, ter em vista um desenho verdadeiramente ornamental, susceptível de ser adaptado a objetos industriais, e não tanto um desenho cópia ou reprodução da Natureza, entendido dentro do âmbito das belas artes.

Sousa Holstein conhecia bem a realidade do ensino industrial inglês, reformado após a exposição de Londres de 1851, e que fora a fonte de inspiração de todas as intervenções do mesmo género que se realizaram em vários países europeus. Esse conhecimento viria precisamente a ser confirmado em 75 ao presidir aos trabalhos da comissão encarregada de elaborar o mencionado projeto de reforma, sem qualquer consequência prática, tal como sucedeu com outras comissões nomeadas anteriormente para o efeito ${ }^{76}$. Como texto norteador da discussão, o presidente havia elaborado umas extensas Observações onde alude ao processo de reforma inglesa do South Kensington, quer no âmbito da sua intervenção nas escolas, como no da criação do museu de apoio ao seu ensino. Não só compreende os seus pressupostos e os seus resultados positivos, como constata a sua expansão pela Europa, lamentando que só Portugal não tivesse dela recebido qualquer influência: “Em toda a Alemanha, na Rússia, nas monarquias escandinavas, e até na própria Suíça é unânime o movimento a favor das escolas populares de arte. Nós que tanto as temos descurado, não podemos evocar em favor da nossa indiferença o argumento de que não nos são precisas, pois é certo que há no nossa país inúmeras

\footnotetext{
74 Conferência ordinária de 29 de Maio de 1863. Arquivo da ANBA, disponível em http://digitarq.dgarq.gov.pt/ PT-ANBA-ANBA-F-002-00001_m0056.TIF

${ }^{75}$ LISBOA, Maria Helena - op. cit, p. 283.

${ }^{76}$ A este respeito cf. Idem, ibidem, pp. 363-377. Iremos aludir melhor a esta questão na III parte.
} 
profissões que muito poderiam desenvolver-se e trazer indiretamente aumento de riqueza pública"77.

Estas e outras sugestões procuravam de certa forma fazer face à apressada reforma imposta anteriormente à Academia pelo governo radical do bispo de Viseu, por decreto de 31 de Dezembro de 1868. Nascida num quadro de contenção de despesas públicas, condicionadas pela profunda crise económica que o país atravessava, aquela medida reduziu para seis o número de professores, suprimindo os substitutos, entre outros cortes e reduções. O vice-inspetor, que meses antes lograra ver inaugurada a Galeria Nacional de Pintura, protestou veementemente e manifestou mesmo vontade de se demitir, conforme foi noticiado pela imprensa: "Com grande sentimento receberam os artistas ontem a notícia de que o Sr. marquês de Sousa ia pedir a sua demissão do encargo de vice-inspetor da Academia Real das Belas Artes. Atribui-se esta sua resolução à reforma do mesmo estabelecimento, decretada pelo governo, de modo inteiramente diverso do plano que tinha apresentado"78. A promessa do ministro em nomear nova comissão para uma completa reforma da instrução pública, tê-lo-á feito recuar desse intento que o jornal acima citado dava noutra notícia como consumado, lamentando profundamente a decisão ${ }^{79}$. De maneira a mostrar confiança no trabalho desenvolvido até então pelo marquês, e em simultâneo encorajá-lo a prosseguir na sua cruzada em prol das belas artes, o rei D. Luís agraciou-o pouco depois com a já referida comenda de S. Tiago ${ }^{80}$.

À semelhança de outras instituições congéneres europeias, competia à Academia a organização de exposições onde deveriam ser patenteados ao público os trabalhos

\footnotetext{
77 [HOLSTEIN, marquês de Sousa] - Observações sobre o actual estado do ensino das artes em Portugal: a organização dos museus e o serviço dos monumentos historicos e da archeologia: offerecidas á commissão nomeada por decreto de 10 de Novembro de 1875 por um vogal da mesma commissão, 1875, pp. 13-14.

${ }^{78}$ Diario de Noticias, 8 de Janeiro de 1869.

79 "A dedicação com que o nobre marquês se ocupa das coisas da arte é por certo caso novo entre nós, e por isso não poderíamos de deixar de sentir profundamente que S. Ex. a abandonasse o cargo de vice-inspetor da Academia que foi nomeado há seis anos e meio". Idem, 16 de Janeiro de 1869.

${ }^{80}$ Idem, 6 de Fevereiro de 1869.
} 
executados internamente pelos professores, artistas agregados e pelos alunos premiados nos concursos de pintura, escultura, arquitetura e desenho. Foi, no entanto, pequeno o número de mostras que tiveram lugar, atendendo à periodicidade estabelecida pela lei, de três em três anos. Até 1862, a Academia organizou cinco das oito exposições "trienais" que deveria ter realizado, muito por culpa das movimentações políticas e consequentes dificuldades de tesouraria. $\mathrm{O}$ vice-inspetor então nomeado interrompê-las-ia pouco depois, gerando algum descontentamento entre os professores. Questionado a esse respeito por Tomás da Anunciação, em 1868, o diretor-geral "expendeu as razões que têm atuado para não se dar cumprimento a este artigo dos Estatutos, sendo a principal as obras que há anos sucessivos tem havido no interior do edifício, já dividindo a sala da exposição em quartos, já reformando inteiramente as salas de pintura histórica e de paisagem, tornando-as próprias e com as condições necessárias para servirem de galeria nacional de quadros" ${ }^{81}$. Desvalorizando aquela iniciativa académica, Sousa Holstein justificará nas Observações publicadas em 75 que "havendo em cada ano a exposição da Sociedade Promotora das Belas Artes, pareceu desnecessário apresentar duas exposições anuais em que forçosamente se haviam de repetir obras" $^{\prime 82}$.

A ideia da constituição de uma sociedade de belas artes havia nascido em 1853, tendo chegado os seus estatutos a ser redigidos por Manuel Maria Bordalo Pinheiro, antigo aluno da Academia. A ideia caiu no esquecimento mas sete anos mais tarde seria ressuscitada por um grupo de artistas, coadjuvada por vários amadores de arte que, reunidos em assembleia sob a presidência do abade de Castro, aprovaram os estatutos da associação e lhe conferiram a designação liberal de "promotora" 83 . Tendo como principal objectivo "excitar a emulação entre os artistas portugueses, propagar o conhecimento, e facilitar a venda das suas obras por meio de exposições

81 Conferência geral de 22 Agosto de 1868. Arquivo da ANBA, disponível em http://digitarq.dgarq.gov.pt/ PT-ANBA-ANBA-F-002-00001_m0517.TIF

${ }^{82}$ [HOLSTEIN, marquês de Sousa] - Observações sobre o actual estado do ensino das artes em Portugal: a organização dos museus e o serviço dos monumentos historicos e da archeologia: offerecidas á commissão nomeada por decreto de 10 de Novembro de 1875 por um vogal da mesma commissão, 1875, p. 26

${ }^{83}$ QUEIRÓS, Amílcar de Barros - Da Sociedade Promotora de Belas Artes e do Grémio Artístico à Sociedade Nacional de Belas Artes: exposição documental 1860-1951, 1951, pp. 3 e 4. 
públicas anuais" ${ }^{84}$, esta organização elegeu em Dezembro de 1861 para seu presidente o marquês de Sousa Holstein que meses mais tarde acumulou essa função com a de vice-inspetor da Academia. O conde de Ficalho integrava o conselho diretivo da sociedade na companhia do visconde de Meneses, nomeados ambos para vice-presidentes. Professores como Francisco de Assis Rodrigues, José da Costa Sequeira ou Tomás da Anunciação, jovens críticos como Rangel de Lima e amadores como Herman de Moser compunham o corpo de vogais ${ }^{85}$.

Paralelamente à edição dos catálogos das exposições, procurou o seu presidente publicar pormenorizados relatórios anuais ou bianuais que fornecem valiosas informações para o conhecimento não só da associação mas da vida artística nacional deste período. Tendo tido lugar em 1862, a primeira exposição decorreu num clima de franco optimismo, dada a afluência dos visitantes e o número de associados contabilizados que ascendia a 242, registando-se no relatório ser "difícil esperar tanto, impossível exigir mais. Podemos afoitamente dizer que este ano inaugurou brilhantemente a série das nossas exposições" ${ }^{\prime 86}$. Em 64 congratulava-se Sousa Holstein e o seu secretário, Joaquim Pedro de Sousa, em dar conta da "manifesta prosperidade com que se vai desenvolvendo a nossa associação", acreditando estarem as belas artes a despertar da prolongada obscuridade em que se viam mergulhadas: "amadurecem os talentos já conhecidos, revelam-se outros; o público concorre às nossas exposições, festeja-as a impressa e, o que mais importante é, analisa-as com interesse e simpatia" ${ }^{87}$. O número de sócios cifrava-se então em 454, 112 dos quais recrutados entre a colónia portuguesa residente no Brasil que representará um papel primordial na economia da Promotora, colmatando as restritas possibilidades do mercado nacional.

Cada sócio tinha o direito de participar na chamada "extração dos prémios", espécie de lotaria de obras de arte, "entrando o seu nome na urna tantas vezes quantas

\footnotetext{
${ }^{84}$ Cf. estatutos. Sociedade Promotora das Bellas-Artes em Portugal: primeira exposição, 1862, p. 3.

${ }^{85}$ QUEIRÓS, Amílcar de Barros - op. cit, p. 4.

${ }^{86}$ PRIETO, Joaquim - "Sociedade Promotora das Bellas Artes em Portugal: relatório do ano social de 1861-1862, apresentado pelo conselho administrativo". Revista Contemporanea de Portugal e Brazil, vol. IV, (n. 6), 1862-1863, p. 319. Os relatórios seguintes foram publicados de forma autónoma pela sociedade.

${ }^{87}$ HOLSTEIN, marquês de Sousa; SOUSA, Joaquim Pedro (co-auto.) - Relatório e contas da Sociedade Promotora das Bellas Artes em Portugal no anno de 1863-1864, 1864, p. 3
} 
forem as ações que houver pago", no dizer dos estatutos ${ }^{88}$. Os maiores acionistas encontravam-se entre a família real - D. Luís, D. Maria Pia (protetora da instituição a partir de $1863^{89}$ ) e D. Fernando II com dez ações cada - número igualado apenas por um sócio residente no Rio de Janeiro, António Emílio Machado Reis, presidente da Sociedade Madrépora ${ }^{90}$, instituição filantrópica que detinha outras dez. Para dar alguns exemplos, seguia-se com sete o infante D. Augusto, irmão de D. Luís, a duquesa de Palmela com cinco, o marquês de Sousa Holstein com três e o conde de Farrobo com duas. A esmagadora maioria dos sócios detinha uma só ação.

Em 67 o número de associados ascendia a 512, o que se devia em larga medida aos luso-brasileiros que representavam um total 191. Com satisfação anunciava-se o "notável progresso" na afluência registada nos meses da exposição, 14.703 visitantes, "prova bem clara de que não há no nosso público indiferença para as artes $^{\prime \prime 1}$. Na realidade, o certame tornara-se mundano, o nosso salon, com cada vez mais senhoras a acorrerem na companhia dos maridos como revelam os dados estatísticos presentes no relatório. À falta de instalações próprias, realizava-se em salas cedidas pela Academia, "porque ainda ali não estavam colocados os quadros da galeria nacional", solução provisória que não poderia voltar repetir-se no ano seguinte ${ }^{92}$.

Logo em 65, Sousa Holstein, na qualidade de presidente da sociedade, solicitava à conferência que se "pedisse ao governo concessão para se construir no grande pátio contíguo às aulas de desenho e de escultura um barracão onde se pudessem fazer as exposições públicas da mesma associação" ${ }^{93}$. A falta de verbas estatais frustrou esse projeto, o que não impediu Luciano Cordeiro de chamar em 68 baraque ao salon que

\footnotetext{
${ }^{88}$ Cf. estatutos. Sociedade Promotora das Bellas Artes em Portugal: primeira exposição, 1862, p. 3.

${ }^{89}$ RIBEIRO, José Silvestre - op. cit, T. XV, 1876, p. 225.

${ }^{90}$ De acordo com o Art. 1.o dos estatutos aprovados no Rio de Janeiro, por decreto de 27 de Maio de 1863, “A Sociedade Madrépora é uma associação puramente filantrópica composta de portugueses para auxiliar todas as instituições e empresas que tenderem a desenvolver o progresso e a civilização em Portugal, procurando criar por si o máximo gosto e amor pelas Letras e pelas Artes em geral". Cf. Estatutos da Sociedade Madrépora. Disponível em:

http://www.camara.gov.br/Internet/InfDoc/conteudo/colecoes/Legislacao/leis1863/Leis1863-27.pdf

${ }^{91}$ HOLSTEIN, marquês de Sousa; SOUSA, Joaquim Pedro (co-auto.) - Relatório e contas da Sociedade Promotora das Bellas Artes em Portugal no anno de 1865-1866, 1867, p. 7.

${ }^{92}$ Idem, ibidem, p. 11.

${ }^{93}$ Conferência extraordinária de 3 de Novembro de 1865. Arquivo da ANBA, disponível em http://digitarq.dgarq.gov.pt/ PT-ANBA-ANBA-F-002-00001_m0294.TIF
} 
continuou a improvisar-se em espaços cedidos pela Academia ${ }^{94}$. Dois anos antes, chegou a sociedade a solicitar oficialmente ao município a doação "do terreno que mede entre o chafariz de S. Pedro de Alcântara e o parapeito do passeio que olha para o norte para nele poder levantar um edifício elegante, destinando-o à exposição das belas artes" ${ }^{\prime 95}$. Procurando convencer a edilidade, e num momento da história municipal em que a cidade se repensa, argumentava-se que o edifício em questão, "contribuirá para o embelezamento do passeio de S. Pedro de Alcântara e atrairá ali maior concorrência", não se especificando qual o arquiteto em mente para se ocupar do projeto ${ }^{96}$. A desejada obra não teve concretização e anos mais tarde, uma portaria do governo incumbia a Academia a dispensar anualmente uma sala para a realização das exposições da sociedade, deitando por terra o sonho de aquela poder vir a ter edifício próprio ${ }^{97}$.

No relatório de 68 expressava-se a vontade de ampliar as atividades da associação que não deveriam circunscrever-se às exposições: "A criação de cursos gratuitos, a fundação de um jornal, a distribuição de prémios e recompensas, a publicação de obras de história ou de critica artística, seriam utilíssimos meios de alargar a ação da sociedade, de a tornar mais útil”, declaravam o presidente e o secretário ${ }^{98}$. Nesse sentido, anunciava ter-se custeado a edição nacional do estudo de Charles Robinson sobre Grão Vasco e a antiga escola portuguesa de pintura, fazendo votos de outras

\footnotetext{
94 "O salon não existe cá. Temos a baraque. E ainda bem que a temos, que nem eu sei como nesta época de economias, não se lembrou o ministério do reino de economizar o armazém onde vegeta a Academia de Belas Artes, mandando pendurar os quadros nos postos dos telégrafos". CORDEIRO, Luciano - Segundo livro de critica: arte e litteratura portuguesa d'hoje (livros, quadros e palcos), 1871, p. 5 (texto publicado originalmente $\mathrm{n}^{\prime}$ A Revolução de Setembro). Ao aspecto "abarracado" da exposição aludem também, em 1872, As Farpas: "Num velho muro da rua de S. Francisco, esbeiçado, negro, rendido, alagartado pelas rachaduras e pelas podridões, há uma porta atamancada com ripas de pinho e coroada por uma tabuleta de barraca de feira ou de estalagem de ópera bufa. Por aqui se entra. Estamos na exposição das belas artes em Portugal". MÓNICA, Maria Filomena (coord.) - As Farpas: Eça de Queiroz, Ramalho Ortigão: As Farpas originais de Eça de Queiroz, 2004, p. 446.

${ }^{95}$ Apud FERREIRA, Emília - op. cit., p. 174. (Archivo Municipal, 1866, n.o 362, p. 292).

${ }^{96}$ Idem, ibidem, p. 175.

${ }^{97}$ Portaria de 4 de Abril de 1870. Por essa ocasião, comentará Sousa Holstein: "Se na academia houvesse uma sala especialmente consagrada para exposições, não careceríamos talvez de nos ocuparmos desta questão; mas como infelizmente no nosso primeiro estabelecimento artístico semelhante sala ainda não existe, é forçoso em ocasião de exposição aproveitar alguma das aulas, e por isso destinar para a exposição tempo de férias". HOLSTEIN, marquês de Sousa; SOUSA, Joaquim Pedro de (co-auto.) - Relatório e contas da Sociedade Promotora das Bellas Artes em Portugal no anno de 1869-1870, 1871, p. 11.

${ }^{98}$ Idem - Relatório e contas da Sociedade Promotora das Bellas Artes em Portugal no anno de 18661867,1868, p. 3.
} 
publicações futuras. Afigurava-se para tal necessário incrementar as receitas, apelando-se ao aumento do número de associados que ultrapassavam já largamente as cinco centenas. No relatório seguinte registava-se um recorde absoluto na afluência de visitantes à exposição, 17.375 pessoas nos 39 dias em que esteve aberta, 6.298 das quais do sexo feminino, revelando estar assim em definitivo implantada na vida social dos lisboetas. De maneira a reconhecer e encorajar o esforço dos sócios, era anunciada a distribuição de um álbum com gravuras de alguns artistas nacionais, acrescidos do rei D. Luís que vinha presidindo sempre à inauguração dos certames e que se quis fazer associar à iniciativa na qualidade de artista amador ${ }^{99}$.

O clima de optimismo até então vigente começou entretanto a ser prejudicado por vários factores, levando ao adiamento da exposição e da respectiva assembleia que publicará um novo relatório em 73. "Neste largo espaço de tempo, senhores, forçoso é confessá-lo, poucos progressos temos podido realizar", declarava Sousa Holstein, comprometendo-se perante os sócios a desenvolver todos os esforços em prol da "tão civilizadora missão" que acarinhava ${ }^{100}$. Os esforços do presidente não puderem evitar as dificuldades que se prendiam em larga medida com atrasos e faltas nas remessas dos fundos do Brasil, a braços com uma crise financeira, comprometendo o "rigoroso cumprimento do nosso programa social" confessará no relatório seguinte ${ }^{101}$.

Lisonjeira ao início, a crítica da imprensa, florescida em paralelo com o desenvolvimento das exposições, tornar-se-á progressivamente hostil, traduzindo a emergência de um novo gosto. Logo em 1868, Luciano Cordeiro deu o mote num longo e polémico texto sobre o nosso salon, a baraque como já referimos ter-lhe chamado, denunciando o que considerava ser a mesquinhez dos esquemas românticos dominantes ${ }^{102}$. Em 1872, $\mathrm{n}^{\prime}$ As Farpas, elegia-se como único foco de interesse a pintura de costumes, "o resto da exposição - ou pela ideia ou pela arte -

\footnotetext{
${ }^{99}$ Idem - Relatório e contas da Sociedade Promotora das Bellas Artes em Portugal no anno de 18671868, 1869, pp. 9-11.

${ }^{100}$ Idem - Relatório e contas da Sociedade Promotora das Bellas Artes em Portugal no anno de 18721873,1873, p. 3.

${ }^{101}$ Idem - Relatório e contas da Sociedade Promotora das Bellas Artes em Portugal no anno de 18731874,1875 , p. 3.

102 CORDEIRO, Luciano - op. cit., pp. 2-112 (texto publicado originalmente $\mathrm{n}^{\prime}$ A Revolução de Setembro).
} 
afogava-se monotamente numa grande mediocridade dispersa" de onde não escapavam Anunciação ou Cristino ${ }^{103}$. Dois anos mais tarde, António Enes, na revista Artes e Letras que era apoiada pela própria associação, fazia um balanço das suas atividades, escrevendo que enquanto a educação oficial dos artistas se mantivesse atrasada, "a Promotora, por mais que amiudasse as exposições e avolumasse as recompensas de merecimento, havia de continuar a ver os seus esforços tristemente despremiados" ${ }^{104}$.

A sociedade afundara-se efetivamente num certo convencionalismo e isso teve reflexos nas entradas que começaram aos poucos a decrescer atestando a falta de vitalidade da sua fórmula, para além da própria falta de consumo do público e as complicações com as remessas dos sócios do Brasil. Obra dos românticos que a mantiveram com dedicação durante um quarto de século, "não é certamente por acaso que a sua quebra se acelera após 79, à morte de Sousa Holstein e de Anunciação" refere José-Augusto França ${ }^{105}$. No relatório editado naquele ano, o vicepresidente, visconde de Pernes, alude aos "obstáculos e contrariedades" com que a sociedade vinha ultimamente lutando, assinalando como o mais doloroso a morte do marquês, "obreiro infatigável que desde a sua fundação, e durante 17 anos sucessivos, tanto cooperou para o seu engrandecimento" ${ }^{106}$. Outra geração com interesses estéticos fora dos limites do romantismo estará na base da criação do Grupo do Leão, em 81, precipitando o fim da Promotora que terá o derradeiro abalo em 90 com o Grémio Artístico com quem acabará por se fundir, estando na origem da Sociedade Nacional de Belas Artes.

\section{Produção historiográfica}

Abruptamente truncada pela sua morte prematura em 1878, aos 40 anos de idade, a produção escrita de Sousa Holstein conta ainda assim com alguns trabalhos nos domínios da história e da história da arte com válidos contributos que compete aqui

\footnotetext{
103 MÓNICA, Maria Filomena (coord.) - op. cit., p. 452.

${ }^{104}$ ENES, António - Artes e Letras, III, 1874, p. 29.

${ }^{105}$ FRANÇA, José-Augusto - op. cit., p. 433.

${ }^{106}$ PERNES, visconde de; PRIETO, Joaquim (co-auto.) - Relatório e contas da Sociedade Promotora das Bellas Artes em Portugal no anno de 1875-1876, 1879, p. 4.
} 
destacar. Os últimos anos de vida do marquês foram bastante profícuos a esse respeito, podendo começar-se por mencionar a colaboração mantida com a Academia das Ciências de Lisboa de que era sócio honorário. Com efeito, seria em 1877 convidado por aquela instituição para participar num ciclo de conferências centrado na temática dos Descobrimentos, inaugurando-o com uma comunicação intitulada A Escola de Sagres e as tradições do infante D. Henrique ${ }^{107}$.

Publicada separadamente pela Academia que pretendia reunir todas as intervenções num só volume, o que não chegou a suceder, a longa e bem documentada conferência revela a importância atribuída pelo autor aos factores científicos na génese dos Descobrimentos, de acordo com a mentalidade positiva e racionalista da época. Sousa Holstein tinha lido amplamente os documentos existentes e levantou sérias objecções à existência de uma verdadeira escola náutica, inclinando-se para a ideia de um "centro de ação" ou "princípio inspirador", donde dimanariam a tradição e a experiência necessárias para os Descobrimentos ${ }^{108}$. A teoria causou polémica e estaria na origem de uma cisão na historiografia contra a maioria dos autores que, como Oliveira Martins, acreditavam ser impossível realizar aquela empresa sem um sistema organizado de ensino ${ }^{109}$. O debate prolongar-se-á pelo século XX que acentuará o cariz lendário da denominada escola, não obstante ter-se aquela imposto no imaginário como símbolo de uma época e de um povo.

Na qualidade de sócio da Academia das Ciências, Sousa Holstein havia pouco antes proposto a publicação de uma cópia manuscrita dos Diálogos sobre Pintura de Francisco da Holanda que se conservava na biblioteca académica. Tal cópia tinha sido executada por um antigo sócio da instituição, Monsenhor Ferreira Gordo, que estando em Madrid em 1790 ali transcreveu o original do manuscrito de Holanda conservado em biblioteca particular e cujo paradeiro depois se perdeu. Ciente da importância do documento, consta ter a Academia tentado várias vezes a sua

\footnotetext{
${ }^{107}$ O manuscrito original da conferência, assim como algumas cartas e cartões de felicitações acerca da mesma, integraram o espólio particular do marquês que foi leiloado em 2010. AZEVEDO, Pedro de (org.) - op. cit., p. 78 (lote 509).

${ }^{108}$ HOLSTEIN, marquês de Sousa - A Escola de Sagres e as tradições do infante D. Henrique, 1877, p. 54.

${ }^{109}$ A este respeito cf. JOÃO, Maria Isabel - "Sagres, lugar mítico da memória". Des(a)fiando discursos: homenagem a Maria Emília Ricardo Marques, 2005, p. 414 e Idem - "História e ficção: o infante D. Henrique em Oliveira Martins". Sep. da Revista da Universidade de Coimbra, vol. XXXVIII, 1999, p. 280.
} 
impressão até que em Fevereiro de 1876 se ofereceu o marquês para comentar a edição. A ideia era fazer uma publicação integral do texto só parcialmente conhecido, e com imprecisões, pela mão de alguns estrangeiros como Raczynski, o primeiro a chamar a atenção internacional para a obra de Holanda ${ }^{110}$.

António Nogueira Gonçalves apurou como decorreu o processo, marcando entretanto pela entrada em cena do jovem Joaquim de Vasconcelos que, apesar de estar em Berlim, ofereceu a sua colaboração, dado ter alegadamente coligido elementos com o mesmo intuito. Ao que tudo indica Sousa Holstein teria aceite, no entanto, a Academia não concordou, talvez pelo facto do preponente não pertencer à associação, "o que levou Joaquim de Vasconcelos a lembrar que poderia colaborar extraoficialmente, como esclarecem certas minutas de cartas datadas de $1876^{\prime 111}$. Dois anos depois falecia o marquês, sem nada conseguir editar. Vasconcelos reclama então o interesse pela obra daquele que permanece como um dos maiores vultos do Renascimento em Portugal, publicando logo em 1879 dois outros tratados, $D a$ fábrica que falece à cidade de Lisboa e Da ciência do desenho, ambos em edição critica comentada, seguidos a partir de 1890 do Da Pintura Antiga, em folhetim, e só em 1918 em edição completa com os célebres Diálogos ${ }^{112}$.

Nogueira Gonçalves informa que a cópia do manuscrito de Monsenhor Ferreira Gordo utilizada por Joaquim de Vasconcelos havia sido na sua origem destinada a Sousa Holstein, tendo tido oportunidade de a examinar detalhadamente em espólio particular $^{113}$. Acrescenta que no leilão da biblioteca do marquês, o decano dos historiadores de arte em Portugal "teria adquirido certas publicações e reproduções de grande formato, a que frequentemente se referia como base nas suas citações" ${ }^{114}$. Sandra Leandro vai mais longe e dá-o como redator do catálogo do

\footnotetext{
${ }^{110}$ DESWARTE-ROSA, Sylvie - "Athanase Raczynski au Portugal, 1842-1848: luz e sombra”. Artis, n.ㅇ 9/10, 2010-2011, p. 42. RODRIGUES, Paulo Simões - op. cit, p. 267.

${ }^{111}$ GONÇALVES, António Nogueira - Joaquim de Vasconcelos e o opúsculo "São Pedro de Rates", 1976, p. 5.

${ }^{112}$ VASCONCELOS, Joaquim de (ed.) - Da fábrica que falece à cidade de Lisboa. Da ciência do desenho. "Archeologia artística", tomo VI, 1879; Idem, Da pintura antiga. "A vida moderna", 1890-92; Idem, Da pintura antiga, 1918.

${ }^{113}$ Nogueira Gonçalves fez emendas ortográficas aos Diálogos sobre pintura para a publicação de uma edição regular.

${ }^{114}$ GONÇALVES, António Nogueira - op. cit, p. 5.
} 
leilão, ficando assim "a conhecer de perto as preciosidades que aquela biblioteca continha" ${ }^{115}$

Apesar de ter tentado encetar colaboração com o marquês (que aparentemente não Iha negou), e de ter tirado proveito da sua biblioteca e espólio documental, Vasconcelos desenvolveu especial antipatia pela figura do antigo vice-inspetor da Academia, não perdendo nunca oportunidade de atacar o seu trabalho, ao ponto de ser apontado como o seu "permanente crítico"116. No capítulo seguinte teremos oportunidade aludir às apreciações negativas ao Catalogo provisorio da Galeria Nacional de Pintura coordenado por Sousa Holstein (1868), assim como às já mencionadas Observações (1875) e ao consequente relatório produzido, importando aqui evidenciar as duras críticas em relação à antiga escola portuguesa de pintura, nomeadamente à tradução e ao prefácio efectuado pelo marquês ao opúsculo de Charles Robinson.

Como atrás mencionámos, em 1865 o especialista inglês viajou até Lisboa vindo a mostrar interesse pelas primícias da nossa pintura, nomeadamente, pela questão de Vasco Fernandes. Da viagem resultou um artigo publicado primeiro no The Fine Arts Quarterly Review ${ }^{117}$, e logo depois em separata própria ${ }^{118}$, onde narra as impressões de uma deslocação a Viseu e Coimbra para observar as pinturas atribuídas ao lendário pintor. Em nota declara ter escrito aquele relato "for the information of his Majesty the King Dom Fernando of Portugal" a quem terá sido apresentado por Sousa Holstein durante a sua estadia em Portugal ${ }^{119}$.

Desde os escritos de Raczynski que o estado da questão sobre Vasco Fernandes, o Grão Vasco, se encontrava num impasse dadas as contradições registadas entre a obra que Ihe era atribuída e um suposto assento de baptismo datado de 1552 . Privilegiando o testemunho da análise visual, de acordo com a tradição inglesa do

\footnotetext{
${ }^{115}$ LEANDRO, Sandra - Joaquim de Vasconcelos (1849-1936): historiador, crítico de arte e museólogo. Dissertação de Doutoramento em História da Arte Contemporânea apresentada à FCSH-UNL, vol. I, 2008, p. 101.

${ }^{116}$ FRANÇA, José-Augusto - op. cit., p. 423

${ }^{117}$ ROBINSON, John Charles - "The early Portuguese school of painting: with notes on the pictures at Viseu and Coimbra traditionally ascribed to Gran Vasco". The Fine Arts Quarterly Review, n.o 2, Oct. 1866, pp. 375-400.

${ }^{118}$ Idem - The early Portuguese school of painting: with notes on the pictures at Viseu and Coimbra traditionally ascribed to Gran Vasco. Sep. The Fine Arts Quarterly Review, 1866. O exemplar conservado na BNP apresenta uma dedicatória manuscrita do autor a D. Fernando II.

${ }^{119}$ Idem, ibidem, p. 11.
} 
empirismo lokeano como notou Maria João Neto, as apreciações de Robinson "traduziram-se num texto renovador e estruturante dentro de uma historiografia da arte portuguesa, que então começava a sua fase de gestação" ${ }^{120}$. Apoiada em diversa pintura coeva observada um pouco por toda a Europa, a análise científica do inglês permitiu-Ihe chegar a conclusões que o desenvolvimento dos estudos sobre Grão Vasco vieram confirmar ${ }^{121}$.

A Sociedade Promotora de Belas Artes patrocinou a publicação do artigo de acordo com uma proposta de Sousa Holstein que se ofereceu para fazer a sua tradução e para assinar o respectivo prefácio ${ }^{122}$. Tal ocorreu em 1868 , na sequência da abertura da Galeria Nacional de Pintura onde se destacava toda uma sala consagrada à produção daquele período, numa forte aposta em realçar os valores da nossa pintura, procurando consolidar a existência de uma escola nacional. Por proposta do vice-inspetor, serão pela mesma altura distribuídos gratuitamente exemplares do artigo aos melhores alunos da Academia, de acordo com uma listagem elaborada pelos professores, propagando-se assim o conhecimento do tema através do único trabalho científico em português existente até à data ${ }^{123}$. Editado naquele mesmo ano, o Catalogo provisorio da Galeria Nacional de Pintura que oportunamente iremos analisar, sintetizou de igual modo na sua introdução os principais contributos do trabalho de Robinson ${ }^{124}$.

No prefácio à tradução, Sousa Holstein refere ter como principal objectivo “apresentar ao público português o nome ilustre e respeitável de Mr. Robinson, e resumir em muito poucas palavras o estado da questão para melhor inteligência da

\footnotetext{
${ }^{120}$ NETO, Maria João Baptista - "Coleccionadores e connaisseurs de obras de arte: Francis Cook (1817-1901) e John Charles Robinson (1824-1913) em Portugal". Artis, n.o 6, 2007, p. 410.

${ }^{121}$ De acordo com Dalila Rodrigues, Robinson sugeriu uma adequada cronologia para as obras que observou, tendo reconhecido a influência nórdica patente em algumas. RODRIGUES, Dalila - "Vasco Fernandes ou a contemporaneidade do diverso". Vasco Fernandes e a pintura europeia do Renascimento (cat. expo.), 1992, pp. 39 e 71 (nota 18). Maria João Baptista Neto, acrescenta ter o inglês notado a presença do "grandioso do estilo italiano" na composição, nas proporções do desenho e no claro-escuro de outras obras, e ter validado a autenticidade da assinatura do mestre num tríptico pertencente ao pintor António José Pereira. NETO, Maria João Baptista - op. cit., p. 410.

${ }^{122}$ ROBINSON, John Charles; HOLSTEIN, marquês de Sousa (pref.) - $A$ antiga escola portugueza de pintura: com notas acerca dos quadros existentes em Vizeu e Coimbra e attribuidos por tradição a Grão Vasco, 1868, pp. 11-23.

${ }^{123}$ Conferência extraordinária de 15 de Maio de 1868. Arquivo da ANBA, disponível em http://digitarq.dgarq.gov.pt/ PT-ANBA-ANBA-F-002-00001_m0492.TIF

${ }^{124}$ HOLSTEIN, marquês de (co-auto.) - Catalogo provisorio da Galeria Nacional de Pintura existente na Academia Real das Belas Artes de Lisboa, 1868, pp. 12-17.
} 
memória que se segue" ${ }^{125}$. Na realidade, alonga-se num balanço historiográfico sobre o pintor de Viseu (Cirilo, Taborda, Barbosa Machado, Juromenha...), detendose naturalmente em Raczynski cujos escritos "são e serão ainda por muito tempo o manual da arte portuguesa", mas que "não podem contudo ser seguidos sem um certo exame crítico que destruirá sem dúvida alguma das suas conclusões" ${ }^{\prime 26}$. É o caso já aludido do nascimento do artista corresponder a 1552 como supôs o diplomata prussiano, teoria liminarmente recusada por Robinson que, perante as obras analisadas, refere não poderem ter sido executadas após essa data mas sim 30 anos antes, por volta de 1520 .

Esta e outras opiniões do expert britânico, ainda que firmadas em bases aparentemente sólidas, deveriam na opinião do marquês ser acompanhadas por uma discussão séria e profunda dado haver determinados pontos a ser rectificados e/ou a carecer de maior desenvolvimento. "É para desejar que a publicação deste trabalho provoque novos estudos e novas indagações que deem em resultado a descoberta de novos argumentos" refere, lançando um repto aos investigadores nacionais: "Dois estrangeiros deram-nos o exemplo de investigações conscienciosas e científicas; não é muito que lhes sigamos o passo, já que fomos nós quem abrimos o caminho"127.

Decorridos 13 anos Joaquim de Vasconcelos debruçar-se-á sobre a questão, num trabalho depois reeditado, e onde mais do que avançar com novos dados, procura acima de tudo fazer a crítica do texto de Robinson, da tradução de Sousa Holstein e do seu prefácio. A sua intenção foi, como revela, "preparar o terreno e restabelecer a verdade dos factos, reduzindo as descobertas do Sr. Robinson ao seu justo valor", nomeadamente o seu ensaio que considera "um fragmento muito incompleto de uma questão complexa e com erros importantes" ${ }^{128}$. A isso soma-se a tradução que reputa de "miserável", identificando-Ihe "incoerências, contradições e até verdadeiros disparates". Refere a esse respeito que o marquês "não só traduziu mal, e em muitas partes com sinais evidentes de não ter entendido o original inglês, mas

\footnotetext{
${ }^{125}$ ROBINSON, John Charles; HOLSTEIN, marquês de Sousa (pref.) - op. cit., p. 13.

${ }^{126}$ Idem, ibidem, p. 12.

${ }^{127}$ Idem, ibidem, p. 19.

${ }^{128}$ VASCONCELOS, Joaquim de - A pintura portuguesa nos séculos XV e XVI, 2.a ed., 1929, p. VI (o texto foi publicado pela primeira vez no Porto em 1881).
} 
cortou, mutilou e parafraseou onde lhe aprouve!". No intuito de o demonstrar, deuse ao trabalho de transcrever 64 passagens para as confrontar com o inglês, concluindo ter sido o original "completamente transvestido", no que diz ser prova da “leviandade do tradutor"129.

As impiedosas críticas de Vasconcelos não podem fazer esquecer as dificuldades inerentes a um trabalho que nunca poderia ser literal. Sousa Holstein era um amador nesse domínio mas as falhas que efetivamente cometeu não serão tão infames como faz crer o acusador, tendo a tradução sido seguida por outros investigadores. Refira-se não ser aquela a única experiência do marquês como tradutor que anos mais tarde verteu do francês a História da civilização na Europa de François Guizot, mostrando-se no prólogo bastante consciencioso acerca das problemáticas deste tipo de trabalhos ${ }^{130}$.

Joaquim de Vasconcelos nada de positivo assinala e, tal como a tradução, considera ter o prefácio "estampado o carácter da insuficiência e falta de escrúpulo científico do seu autor"131. Aproveita para o dissecar, rebatendo algumas das afirmações nele contidas, como a da existência de uma escola portuguesa de pintura que o marquês considerava estar demonstrada. "O que constitui uma escola é a originalidade da concepção, junta à novidade dos processos técnicos" ${ }^{132}$ observa o historiador, apelidando de "gratuita" outra afirmação relativa às relações artísticas entre Portugal e a Flandres, por si entretanto estudadas. As referências aos estudos sobre pintores flamengos e alemães são prova de "extraordinária ignorância", estando na base "das fantasias do marquês que são ainda as do público que o considerava um especialista" ${ }^{133}$. Saliente-se que ao tempo de Sousa Holstein, o conhecimento sobre as escolas setentrionais de pintura era escasso, não tendo ainda sido dados grandes

\footnotetext{
${ }^{129}$ Idem, ibidem, p. 3.

130 “Duas palavras só acerca do meu trabalho. Usam dizer os italianos traduttore, tradittori. E com efeito assim é quase sempre. Nem eu me lisonjeio de haver fugido ao perigo. A linguagem de Guizot é severa, concisa e difícil de verter. Procurei quando pude transferir para o nosso idioma o estilo do autor, e sem seguir servilmente a sua linguagem, dar em português a ideia exata das impressões que o leitor francês deverá sentir ao lê-lo (...)". GUIZOT, François - História da civilização na Europa, 2. a ed., 1907, p. 16 (prólogo do tradutor).

${ }^{131}$ Idem, ibidem, p. 2.

${ }^{132}$ Idem, ibidem, p. 8.

${ }^{133}$ Idem, ibidem, p. 13.
} 
avanços nesse domínio. Na realidade, a primeira grande exposição sobre primitivos flamengos ocorreria em Bruges, em $1902^{134}$.

O mesmo tom crítico estende-se a um artigo intitulado Grão Vasco e a história da arte em Portugal, publicado pelo vice-inspetor quatro anos após a tradução do trabalho de Robinson na revista Artes e Letras, onde desenvolve algumas das considerações tecidas apressadamente no prefácio. Volta o marquês a pôr em evidência a necessidade e as consequentes dificuldades inerentes às investigações sobre a primitiva pintura nacional, obrigando a "largas e trabalhosas indagações nos arquivos, fastidiosas comparações de quadros, discussões técnicas e históricas que levariam muito tempo, exigindo de quem as empreenda conhecimentos muito profundos e completos". "Esse trabalho não é para mim" reconhece, acusando faltar-lhe tempo e forças, não se adequando por outro lado à índole da publicação. “O meu fim é mais modesto. Desejo apenas dizer em poucas palavras os resultados não a que eu cheguei, mas a que chegaram os poucos que se dedicaram a este espinhoso estudo"135.

Escreverá a esse respeito Vasconcelos que Sousa Holstein "não soube senão repetir em 1872, inconscientemente, o que traduziu mal em $1868^{\prime 136}$. Incomplacente, volta a evidenciar as "mesmas afirmações gratuitas, a mesma audácia, perante um público indefeso, a mesma falta de conhecimento da história da arte"137, comparando de forma muito redutora as conclusões explanadas às ideias de Varnhagen e Garrett em 1842 e 1854.

Joaquim de Vasconcelos ultrapassa com este chorrilho de críticas os limites académicos aceitáveis, denotando a intenção de menorizar o falecido vice-inspetor e o seu trabalho, o que não constituiu caso isolado. António Nogueira Gonçalves fala mesmo de uma "atitude sistemática" que o levava a guardar "rancores até ao fim, tanto àqueles que se Ihe haviam oposto, como simplesmente [aos que] escreviam sob outra orientação"138, e dá como exemplo o caso de Augusto Filipe Simões, lente

\footnotetext{
${ }^{134}$ CAETANO, Joaquim Oliveira; CARVALHO, José Alberto Seabra - "Uma revisão à luz de novos documentos". Jan Provoost: o tríptico de Nossa Senhora da Misericórdia (cat. expo.), 2012, p. 57.

${ }^{135}$ HOLSTEIN, Marquês de Sousa - "Grão Vasco e a história da arte em Portugal". Artes e Letras, n.o 1, 1872 , pp. 1 e 2.

${ }^{136}$ VASCONCELOS, Joaquim de - op. cit, p. 17.

${ }^{137}$ Idem, ibidem, p. 21.

${ }^{138}$ GONÇALVES, António Nogueira - op. cit. p. 6.
} 
da Universidade de Coimbra que veremos colaborar com a Academia em 1875, a quem Vasconcelos nunca perdoou uma crítica publicada no Instituto, "a pedido do criticado que a solicitara severa e sem contemplação". As duras repostas de Vasconcelos terão alegadamente contribuído para a forte crise depressiva que esteve na origem do prematuro fim do professor. Referia-se ainda a recepção à obra de Albrecht Haupt, A arquitetura da Renascença em Portugal, que atacou repetidamente de forma depreciativa, tal como a compra pelo Estado do S. Jerónimo de Dürer, em $1880^{139}$. Homem de incontestável qualidade como historiador da arte, o primeiro entendido como tal no nosso país, foi de igual modo um polemista difícil como classifica Sandra Leandro, observando que "o modo agressivo de comunicar a sua opinião, a forma incisiva, direta, pouco prudente também, acabaria por prejudicá-lo ao longo da sua vida” ${ }^{140}$.

\subsection{Domingos Sequeira, o artista de eleição}

A antiga escola portuguesa de pintura e o caso específico de Vasco Fernandes não foram o único alvo do interesse de Sousa Holstein que se debruçou por períodos e artistas posteriores, nomeadamente, por Domingos Sequeira de quem reuniu relevante acervo. Logo em Outubro de 1861, na sequência de ter sido nomeado académico honorário, proporá à Academia a cedência de alguns dos espécimes que possuía para figurarem na exposição trienal a ser organizada, conforme ficou expresso em ata: "para que the seja concedido um lugar nas salas da exposição, onde possa expor as pinturas e desenhos do nosso insigne pintor Domingos António de Sequeira, de que ele fizera aquisição em Roma"141. A ideia parece ter sido bem acolhida pelos académicos mas seria frustrada pela morte de $D$. Pedro $V$, o que obrigou ao adiamento da exposição e da concessão dos respectivos prémios.

Domingos Sequeira era ainda mal conhecido do público nacional, pelo que o marquês não desistiu do seu intento e, sete anos mais tarde, na qualidade já de vice-

\footnotetext{
${ }^{139}$ Sobre o processo de compra cf. MACHADO, Alda de Guimarães Guedes Pinto - $O$ conde de Almedina e a arte em Portugal no século XIX, 1954, p.p. 13-21.

${ }^{140}$ LEANDRO, Sandra - op. cit., pp. 224-225.

141 Conferência ordinária de 31 de Outubro de 1861. Arquivo da ANBA, disponível em http://digitarq.dgarq.gov.pt/ PT-ANBA-ANBA-A-001-00008_m0295.TIF
} 
inspetor da Academia, voltará a propor outra exposição, tirando partido de uma sala contigua à Galeria Nacional de Pintura que se encontrava em construção: "Fez ver então que nutrindo vivos desejos de tornar bem patente e conhecido o grande mérito do nosso insigne pintor histórico Domingos António de Sequeira que tanto ilustrou a Pátria com suas magníficas obras, desejos estes que os dignos membros da Sociedade Promotora das Belas Artes compartilham, esperava que de comum acordo com a Academia, concorrêssemos todos para que a abertura da nova sala fosse feita com a exposição de todas as obras daquele artista que se pudessem obter e coligir, adornando-se com o seu retrato e os instrumentos de arte de que se servia, etc". De acordo com a mesma ata, ficamos a saber ter sido a declaração do marquês "unanimemente acolhida e aprovada por todos os membros da conferência", tendo sugerido o professor Vítor Bastos batizar a sala com o nome do pintor, o que também foi sancionado ${ }^{142}$.

A unânime aprovação dos professores não foi então suficiente para fazer vingar a mostra que se pretendia retrospectiva e, em 1874, ao discutir-se a compra pela Academia do importante conjunto de desenhos do artista pertencentes às herdeiras do falecido professor José da Costa Sequeira, seu sobrinho, o marquês voltou a relançar a ideia. A conferência académica deveria tomar a iniciativa da exposição, "nomeando-se uma comissão da qual [Sousa Holstein] desejava fazer parte e seria composta do secretário e de um dos membros do conselho, aceitando-se a coadjuvação de todos os professores ou quaisquer pessoas que para este fim se prestem a fornecer algumas obras que porventura a conferência não tivesse conhecimento" $^{143}$. Uma vez mais os bons propósitos do vice-inspetor não tiveram seguimento, e só decorrido mais de meio século seria o artista objecto de uma primeira grande exposição no Museu Nacional de Arte Antiga, pela mão de João Couto $^{144}$.

Apesar de ver goradas as tentativas de expor publicamente Sequeira, Sousa Holstein conseguiu divulgar por outros meios a obra do pintor. Nesse sentido, convém

\footnotetext{
${ }^{142}$ Conferência extraordinária de 16 Maio 1868. Idem, disponível em http://digitarq.dgarq.gov.pt/ PTANBA-ANBA-F-002-00001 m0493.TIF

${ }^{143}$ Conferência ordinária de 16 de Maio de 1874. Arquivo da ANBA, disponível em http://digitarq.dgarq.gov.pt/ PT-ANBA-ANBA-F-002-00002_m0397.TIF e_m0398.TIF

${ }^{144}$ Por ocasião da mostra seria publicado o estudo de COSTA, Luís Xavier da - Domingos António Sequeira: notícia biográfica, Lisboa, 1939.
} 
começar por destacar a colaboração mantida com a Revista contemporanea de Portugal e Brazil, onde em 1862 se estreou com um artigo laudatório dedicado à princesa Maria Pia de Sabóia, discorrendo sobre a ainda curta existência da futura rainha de Portugal e a história da família real italiana ${ }^{145}$. A experiência do marquês no meio diplomático daquele país estará na origem do convite do co-fundador e diretor da publicação, Ernesto Biester, que no ano anterior havia relatado com espanto a visita efectuada à coleção de trabalhos de Domingos Sequeira reunida pelo jovem aristocrata.

Na Crónica literária publicada na revista, Biester deu efetivamente destaque ao interesse colecionista de Sousa Holstein que "sabendo sermos dos poucos que nesta terra sentíamos afeição pelas belas artes, nos convidou para irmos admirar ao seu gabinete diferentes e variados trabalhos do grande pintor". Ao entrar, a surpresa superou todas as expectativas alimentadas. "Tudo o que nos rodeava eram obras do fecundíssimo artista. Era de pasmar (único verbo adequado) e pasmamos" refere o escritor, destacando os "quatro cartões dos quadros que possui a casa do Sr. duque de Palmela, a lápis branco e preto, nas mesmas dimensões dos referidos quadros mas todos acabados, apresentando todavia algumas variantes". Emoldurados e suspensos numa parede, aqueles cartões excediam "tudo quanto se possa imaginar" no entender de Biester que chama também à atenção para 13 esboços a óleo, igualmente colocados nas paredes, "denunciando a notável elegância e riqueza de composição que havia no pincel de Sequeira". Salienta por último a presença de uma grande pasta com cerca de 200 desenhos, merecendo-lhe várias exclamações enfáticas $^{146}$.

No final da visita, e como ficou registado na crónica, Sousa Holstein ofereceu à publicação uma gravura a água-forte representado um episódio da Divina Comédia de Dante Alighieri, Ugolino e os filhos na prisão, trabalho executado por Sequeira nos últimos anos de vida (fig. 30). Biester comunicou desde logo a intenção de proceder à sua estampagem e distribuição pelos assinantes da revista, o que ocorreu em Novembro de 1862, cabendo a Sousa Holstein a elaboração de um artigo

\footnotetext{
${ }^{145}$ HOLSTEIN, marquês de Sousa - "Sua alteza real a senhora D. Maria Pia, princeza d'Italia". Revista Contemporanea de Portugal e Brazil, vol. IV, (n.o 2), 1862-1863, pp. 61-64.

${ }^{146}$ BIESTER, Ernesto - “Crónica Literária”. Ibidem, vol. III, (n.o 6), 1861, p. 330.
} 
explicativo, publicado no mesmo número. Começa por esclarecer que tendo "encontrado em Roma, em 1859, a chapa desta gravura e juntamente grande número de desenhos e esboços de Sequeira que jaziam esquecidos nos armários do Monte de Piedade, deu-se pressa em assegurar a Portugal a posse daqueles magníficos trabalhos", entre os quais estavam os célebres cartões acima referidos ${ }^{147}$. Ficamos assim a saber ter adquirido de uma assentada e seguramente a preços módicos grande quantidade de trabalhos do artista, há muito empenhados à referida instituição bancária pelos seus descendentes diretos, permanecendo ao que tudo indica olvidados do interesse dos amadores romanos. Com esse resgate revelou o marquês extraordinário golpe de vista, para além de uma sensibilidade especial em acautelar parte significativa do espólio de um artista que cedo reconheceu como o mais representativo da transição do século XVIII para o XIX no nosso país.

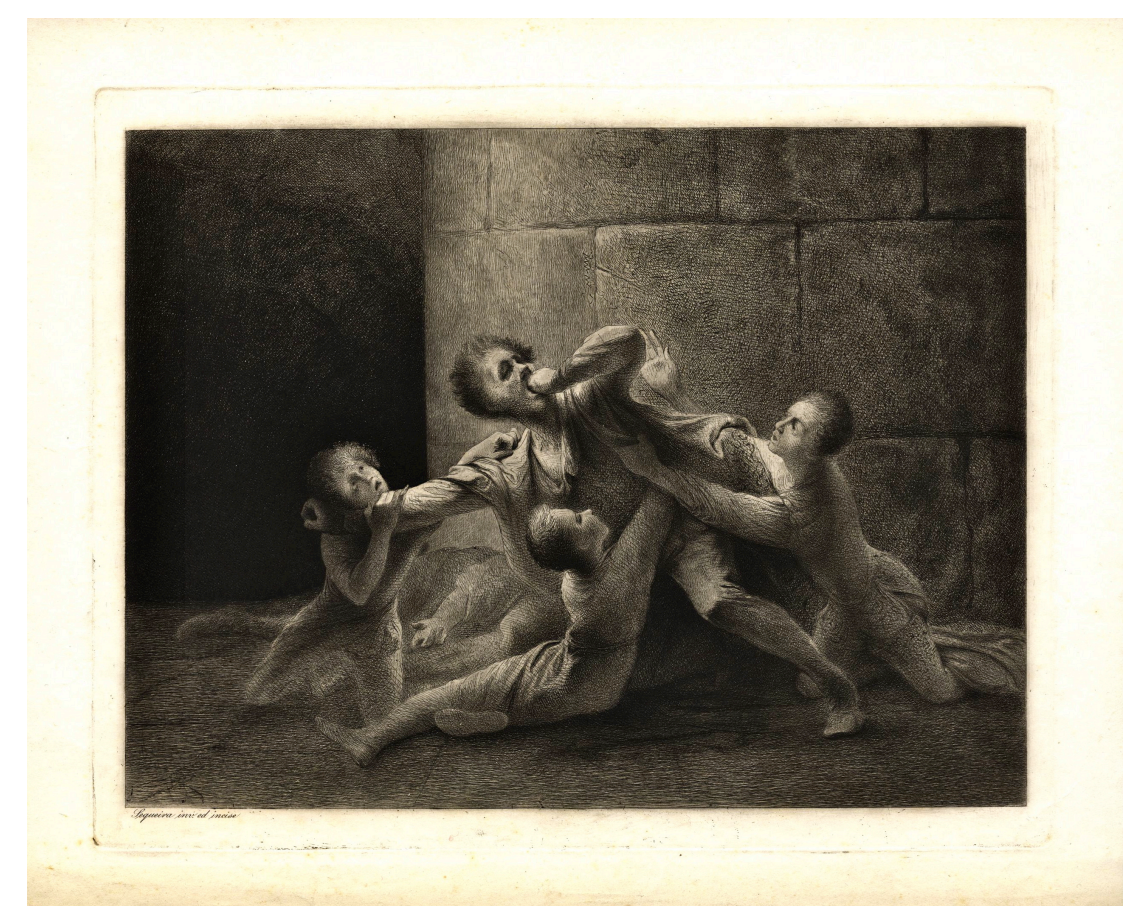

Fig. 30 - Domingos Sequeira, Ugolino e os filhos na prisão, 1862. BNP, E-1446-A

A chapa da gravura em questão não terá chegado a ser mandada estampar por Sequeira, devendo-se portando a Sousa Holstein a sua difusão ${ }^{148}$. "Pareceu que

\footnotetext{
${ }^{147}$ HOLSTEIN, marquês de Sousa - "O conde Ugolino (gravura de D. A. Sequeira)". Ibidem, vol. IV, (n.o 8), 1862-1863, p. 403.

${ }^{148} \mathrm{Em}$ nota do artigo esclarece: "Esta gravura nunca esteve ao comércio. Não consta que Sequeira a mandasse estampar. Além dos exemplares que se estamparam agora para a revista tiraram-se cem
} 
vulgarizar tão excelente produção era prestar culto à memória de um dos maiores artistas do século XIX, cujas obras notáveis são infelizmente pouco conhecidas em Portugal", justifica no artigo o colecionador que depositava grandes esperanças na divulgação por aquele meio: "popularizar o nome de Sequeira, tornar acessível a todos, pelo auxílio da gravura, o conhecimento das suas obras seria um verdadeiro serviço prestado às belas artes" ${ }^{\prime 149}$.

Importa referir que se a gravura poderia ajudar a democratizar o acesso à obra do artista, o mesmo acontecia com a fotografia cujos inovadores processos não passaram desapercebidos ao marquês. Com efeito, a ata da conferência académica de Agosto de 1865 informava ter aquele mandado "fotografar os quatro magníficos cartões que possui com os desenhos originais dos últimos e melhores quadros do nosso insigne pintor D. A. Sequeira, representando o Juízo Final, o Descimento da Cruz, a Ascensão e a Adoração dos Magos, dos quais mandara extrair poucos exemplares, e que desejando perpetuar na Academia a memória de um artista tão célebre, Ihe oferece os clichés das ditas fotografias que se podem reproduzir e vender com vantajoso proveito da mesma Academia"150. Recorde-se que à data a galeria de pintura era ainda um projeto por concretizar, e a quase totalidade da produção do artista permanecia em mãos privadas, vedada portanto ao olhar da generalidade dos artistas e amadores.

Três anos mais tarde teria lugar nova campanha fotográfica, desta vez pela mão do italiano Francesco Rocchini que, de acordo com o Diario de Noticias, "esteve em casa do Sr. marquês de Sousa, reproduzindo com a sua máquina um dos quatro admiráveis desenhos que S. Ex. a possui executados pelo nosso imortal artista Domingos António de Sequeira". Informava ter sido aquela fotografia mandada fazer "para auxiliar o Sr. Novais na execução da cópia litográfica que vai fazer para ser dada este ano pela Sociedade Promotora das Belas Artes aos seus membros que não forem contemplados com a sorte na lotaria dos quadros". O desenho escolhido havia sido o da Epifania ou Ascensão e o mesmo jornal acrescentava com invulgar espírito

antes da letra, seis dos quais são em papel da China, e um em papel de cor. Há mais seis tirados antes da firma que se mandou abrir no canto superior esquerdo". Idem, ibidem, p. 407.

${ }^{149}$ Idem, ibidem, p. 405.

150 Conferência ordinária de 5 de Agosto de 1865. Arquivo da ANBA, disponível em http://digitarq.dgarq.gov.pt/ PT-ANBA-ANBA-F-002-00001_m0276.TIF 
crítico não deverem os sócios "ter grande desgosto este ano por não obterem prémio no sorteio dos quadros, porque muito valerá uma boa cópia de tão notável composição do que muitos dos originais que todos os anos se veem nas exposições para servirem de prémios na extração da lotaria"151.

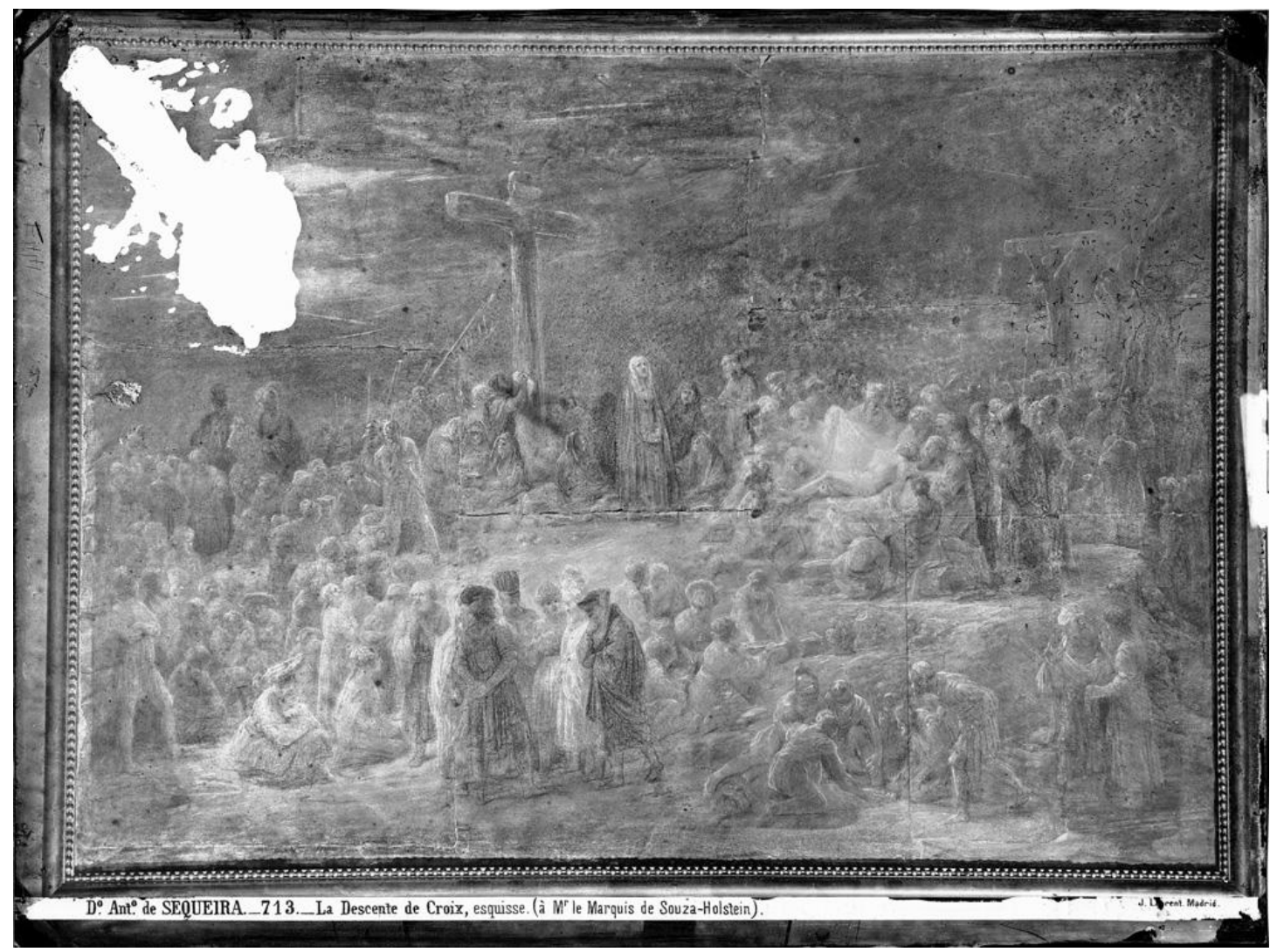

Fig. 31 - Domingos Sequeira, Descida da Cruz, digitalização a partir de negativo de Jean Laurent, 1869. IPCE, VN-06950

Sousa Holstein continuou a disponibilizar os tesouros da sua coleção de desenho para serem reproduzidos e divulgados como sucedeu ainda com Jean Laurent, célebre fotógrafo francês estabelecido em Madrid que, em 1869, viajou até Portugal. Da campanha então realizada na Academia nos iremos ocupar na III parte, importando aqui evidenciar o facto de ter aproveitado para fotografar os cartões de Sequeira, a convite do vice-inspetor que não quis talvez deixar perder a oportunidade de difundir a nível internacional a obra do artista português (fig. 31). Redigido em francês e comercializado um pouco por toda a Europa e nas Américas, o

${ }^{151}$ Diario de Noticas, 11 de Fevereiro de 1868. 
catálogo de Laurent elenca os quatro desenhos da coleção do marquês (A 712 a 715) cujas provas poderiam ser adquiridas por encomenda ${ }^{152}$.

A divulgação das obras deveria idealmente ser acompanhada por um estudo detalhado sobre a vida de Sequeira, como Sousa Holstein faz notar no artigo da Revista Contemporanea: "Verdade é que o nosso grande artista carece ainda de uma biografia circunstanciada e exata, contendo a relação dos seus principais quadros e observações sobre o seu estilo, a influência que teve sobre os seus contemporâneos, etc". Refere ter "o maior desejo de coordenar alguns apontamentos que sirvam de materiais para aquela obra", não deixando no entanto de assinalar "a dificuldade em obter notícias exatas acerca da vida do nosso artista, principalmente durante o tempo que passou fora de Portugal". Enunciado aquele entrave, lança o seguinte repto aos leitores: "Muito agradecido ficará [o autor] a todos aqueles que lhe quiserem ministrar alguns esclarecimentos", esperando "levar a cabo este trabalho que tão útil se afigura"153.

Em 1874, decorridos doze anos da formulação daquele intento, Sousa Holstein lançar-se-á na publicação de um esboço biográfico do artista, repartido por vários números da revista Artes e Letras. Logo no primeiro artigo, esclarece ter sido seu objectivo "dizer com verdade e consciência o que sei acerca do ilustre pintor português, aproveitando estudos antigos e algumas informações e notícias que pude colher". Os "estudos artigos" cingiam-se a uma meia dúzia de títulos por si elencados em nota de rodapé, de apressadas notas biográficas como as efectuadas por Cirilo Wolkmar Machado ou Silva Leal, às impressões de Raczynski que, não conhecendo as ultimas composições do artista, começou por desvalorizar a sua obra para depois se confessar rendido.

Maior proveito terão as "informações que obsequiosamente me puderam dar as pessoas de sua família que ainda existem e vários amigos que o conheceram", o que denota um paciente trabalho de recolha e investigação que se estendeu ainda a vários arquivos nacionais. Há ainda a acrescentar as pesquisas levadas a cabo pelo

\footnotetext{
${ }^{152}$ Para o efeito, recorremos ao catálogo incluído na obra do genro de Jean Laurent, ROSWAG, A. Nouveau guide du touriste en Espagne et Portugal: itinéraire artistique, 1879, p. 187. Da coleção do marquês foi ainda fotografada uma peça arqueológica: "Verre globulaire, de l'epoque romaine, vu sur trois côtés différents; il à été trouvé dans une mine près d'Odemira, jadis exploité par les Romains" (B 235).

${ }^{153}$ HOLSTEIN, marquês de Sousa - op. cit. p. 406.
} 
próprio na Cidade Eterna: "durante a minha permanência em Roma tive ocasião de ler e de copiar alguns papéis que muito me auxiliaram neste trabalho", confessado todavia ter-lhe faltado a oportunidade de indagar por documentos em mãos dos netos de Sequeira ${ }^{154}$.

A recolha de relatos e as transcrições efectuadas pelo marquês revelaram-se da maior importância para perpetuar informações que de outra forma não teriam chegado até aos nossos dias. Tome-se o exemplo das cartas escritas pelo artista a uma família endinheirada com quem se relacionou durante a sua estadia em Roma, os Cometti, para quem chegou a pintar um tecto de uma casa de campo que possuíam. A leitura das missivas, depois desaparecidas, deram a conhecer um alegado desgosto amoroso com uma filha ou sobrinha daquela família que the terá recusado a mão, e que poderá ter contribuído para o retiro na Cartuxa de Laveiras, em Caxias. A experiência monástica do pintor será recordada ao autor pelo "Sr. Meira", um amigo com quem conviveu entre $1820-23$, e que relatou ter aquele seguido sempre todos os rigores da ordem de S. Bruno, considerando-se noviço e não hóspede.

Apoiado em documentos e testemunhos como estes, Sousa Holstein constrói uma narrativa sólida, seguindo um percurso cronológico iniciado com a infância de Sequeira e a sua aprendizagem na Aula Pública de Desenho. Descreve e analisa várias obras de relevo conservadas em coleções privadas, tirando assim partido dos seus privilegiados contactos no meio artístico-social de Lisboa que anos antes haviam possibilitado a aquisição para a Galeria Nacional de Pintura de um notabilíssimo conjunto de trabalhos do artista, como daremos conta na III parte deste trabalho. Refere-se várias vezes a espécimes daquele que era seguramente o mais numeroso acervo de obra gráfica de Sequeira, detido pelo seu sobrinho, o professor de arquitetura José da Costa Sequeira que procederá ao seu depósito na Academia. Composto por 387 desenhos, entre os quais os célebres retratos dos deputados às cortes constituintes, virá a ser adquirido pela Academia a instâncias do marquês após a morte do professor como já se referiu. Na sessão de 16 de Maio de 1874, seria efetivamente discutida e aprovada aquela aquisição às suas herdeiras,

\footnotetext{
${ }^{154}$ HOLSTEIN, marquês de Sousa - "Domingos António de Sequeira". Artes e Letras, n.o 5, 3. a série, 1874, p. 76.
} 
Mariana e Vitória da Costa Sequeira, calculando-se em 750\$000 reis o valor total dos desenhos (só os retratos dos deputados encontravam-se avaliados em $450 \$ 000$ reis), a ser pago em prestações ${ }^{155}$.

Iniciada em 1874, a publicação dos artigos na Artes e Letras foi interrompida no ano seguinte com o abrupto cessar da revista, motivo pelo qual Sousa Holstein não conseguiu finalizar aquele trabalho que ficou suspenso no VII capítulo (12ㅇartigo), dedicado ao envolvimento do artista na concepção da baixela em prata oferecida ao duque de Wellington ${ }^{156}$. Terá sido na sequência daquele revés que começou a acalentar a edição de uma obra de igual pendor biográfico, dando continuidade às suas pesquisas que conciliará com outros trabalhos em mãos, como a tradução da História da Civilização na Europa de Guizot $^{157}$ ou a colaboração num dicionário dirigido por Pinheiro Chagas ${ }^{158}$. Especial destaque merece o avisado levantamento sobre o estado do ensino e das coleções públicas de arte no nosso país, as já referidas Observações, documento publicado no final de 1875 e que adiante será analisado $^{159}$. Dirigia-se aquele trabalho a uma comissão governamental nomeada para estudar a reforma do ensino artístico e a organização dos museus, originando uma sucessão de reuniões onde o marquês participou na qualidade de presidente e que tiveram como resultado a publicação de um relatório em $1876^{160}$.

Como já tivemos oportunidade de aludir, no ano seguinte dará continuidade à sua atividade enquanto investigador com a preparação da conferência sobre a Escola de Sagres e o infante D. Henrique, proferida na Academia das Ciências de Lisboa, a quem havia proposto a publicação dos Diálogos sobre Pintura de Francisco da Holanda. Durante esse período manifestava já sinais da doença que o iria vitimar e,

155 Conferência ordinária de 16 de Maio de 1874. Arquivo da ANBA, disponível em http://digitarq.dgarq.gov.pt/PT-ANBA-ANBA-F-002-00002_m0396.TIF e_m0397.TIF

${ }^{156}$ HOLSTEIN, marquês de Sousa - "Domingos António de Sequeira". Artes e Letras, n.o 4, 4. série, 1875, pp. 70-72.

${ }^{157}$ GUIZOT, François - op. cit.

${ }^{158}$ CHAGAS, Pinheiro - Diccionario popular, historico, geographico, mytologico, biographico, artistico, bibliographico e litterario, vol. I a VIII, 1876-1890.

${ }^{159}$ [HOLSTEIN, marquês de Sousa] - Observações sobre o actual estado do ensino das artes em Portugal: a organização dos museus e o serviço dos monumentos historicos e da arqueologia offerecidas á commissão nomeada por decreto de 10 de Novembro de 1875 por um vogal da mesma commissão, 1875.

${ }^{160}$ Relatorio dirigido ao illustrissimo e excellentissimo senhor ministro e secretário de Estado dos Negocios do Reino pela comissão nomeada por decreto de 10 de Novembro de 1875 para propor a reforma do ensino artistico, a organização do serviço de museus, monumentos historicos $e$ archeologia, I e II parte, 1876. 
consciente talvez do seu fim próximo, procurou salvaguardar os tesouros da sua coleção, procedendo não a uma doação (o mau estado das finanças pessoais, com dívidas acumuladas, não o permitia), mas a uma proposta de compra dirigida à Academia de Belas Artes. Em Junho de 1878, seria efetivamente apresentada por Joaquim Pedro de Sousa uma "proposta para que os professores desta Academia representem ao governo sobre a vantagem de adquirir quatro cartões desenhados pelo ilustre pintor Domingos António de Sequeira que o Exmo. marquês viceinspetor pretende vender"161. Foi unanimemente aprovada e os cartões deram pouco depois entrada nas coleções nacionais, pela importante quantia de 6 contos de reis $^{162}$.

Os restantes desenhos e demais esboços a óleo do artista foram dispersos no leilão que sucedeu à morte de Sousa Holstein, tendo sido a maioria adquirida por um colecionador e aguarelista amador do norte do país, Manuel Braga S. Romão que, ao abrigo de um acordo previamente estabelecido, cedeu parte importante dos trabalhos ao cunhado, o conselheiro José Maurício Rebelo Valente. Grande apreciador da obra de Sequeira, este último ofereceu em 1901 dois desses espécimes ao então "Museu do Instituto de Coimbra" (fig. 32 e 33), tendo reunido uma notável coleção que legou ao filho, Vasco Valente, organizador do Museu Nacional de Soares dos Reis de que foi diretor ${ }^{163}$.

A morte prematura do marquês de Sousa Holstein deitou por terra o projeto da obra biográfica sobre Domingos Sequeira na qual vinha trabalhando e que, de acordo com algumas fontes, terá deixado quase pronta para impressão, tendo conseguido o patrocínio do governo para a publicar em edição luxuosa ${ }^{164}$. Das suas investigações restam portanto apenas os artigos da revista Artes e Letras, a fonte primária de onde

\footnotetext{
161 Conferência ordinária de 27 de Junho de 1878. Arquivo da ANBA, disponível em http://digitarq.dgarq.gov.pt/ PT-ANBA-ANBA-F-002-00002_m0538.TIF

${ }^{162}$ A 1 de Agosto de 1878 foi "autorizada a aquisição de 4 cartões de Domingos António Sequeira, $A$ Ascensão, A Adoração dos Magos, O Calvário e o Juízo Final que pertenciam ao marquês de Sousa Holstein pela quantia de 6:000\$000 reis". Arquivo do MNAA, Aquisições 1850-1900, livro n.o 87.

${ }^{163}$ COSTA, Luís Xavier da - A morte de Camões: quadro do pintor Domingos António de Sequeira, 1922, p. 20 e pp. 148-149 ("apenso C"). Em 1936 a coleção Rebelo Valente foi leiloada pela Leiria \& Nascimento, tendo sido editado um catálogo prefaciado por Luís Xavier da Costa. Cf. Catálogo dos desenhos originais do pintor Domingos António de Sequeira que constituíam a importante e valiosa coleção Rebelo Valente, 1936.

${ }^{164}$ PEREIRA, Esteves; RODRIGUES, Guilherme - op. cit., vol. VI, 1912, p. 1081. A essa questão refere-se também COSTA, Luís Xavier da - op. cit., p. 150 (“apenso D”).
} 
partiram todos os que posteriormente se debruçaram sobre o artista português. Apesar de incompleto, aquele trabalho sobressai pelo seu pioneirismo e, mais do que tudo, pela paciente e apaixonada recolha de informações, constituindo no dizer de José-Augusto França o resultado de um "amadorismo esclarecido bem raro entre nós e ao qual deve fazer-se justiça"165.
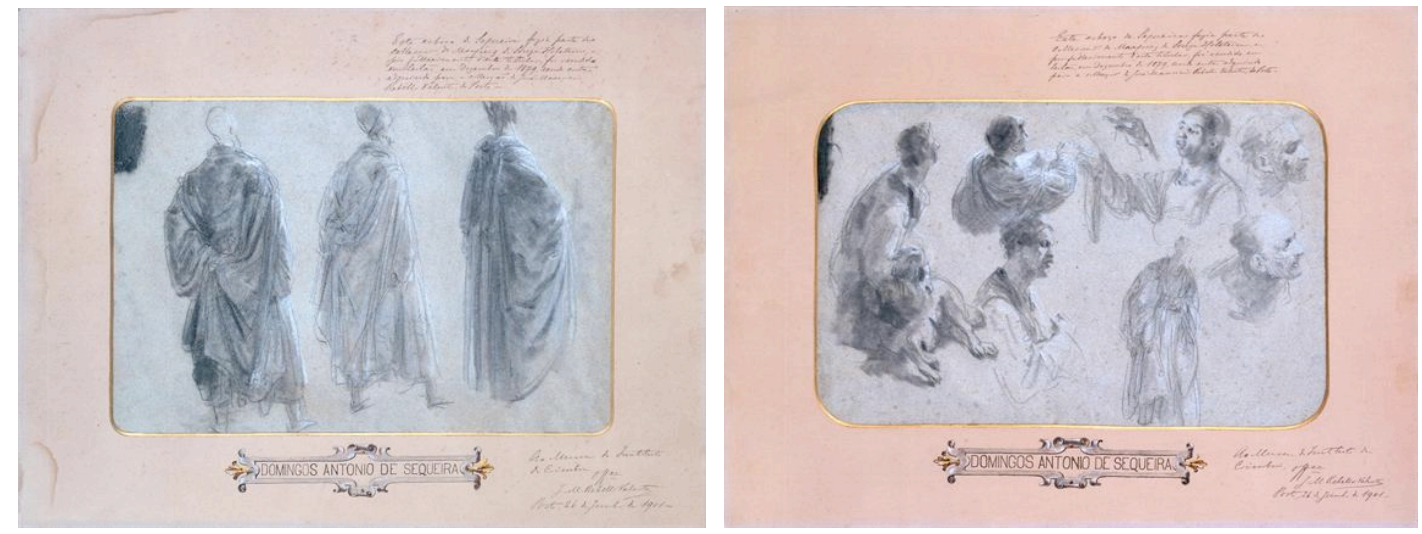

Fig. 32 e 33 - Domingos Sequeira, Três figuras com manto; Esboço de várias figuras, c. 1820. MNMC, inv. 10285 e 10286

${ }^{165}$ FRANÇA, José-Augusto - op. cit., p. 396. 


\section{PARTE - A FORMAÇÃO DA GALERIA NACIONAL DE PINTURA}

"O nosso país tem sido por enquanto quase o único em que a fundação dos museus e galerias não tem encontrado as gerais simpatias. Talvez proceda este facto da opinião muito vulgar, de que para a formação de semelhantes coleções são indispensáveis grossos cabedais de que o nosso país não pode dispor. Para muitos a arte é uma superfluidade da qual não deve cuidar-se enquanto o nosso país lutar com o deficit."

marquês de Sousa Holstein, 1868

\section{O enriquecimento do acervo}

Esgotado o abundante caudal dos primeiros conventos extintos, pouco mais se passou em termos de incorporações no acervo da Academia. A iniciativa do governo ao adquirir em 1848 parte selecionada da coleção de pintura da rainha Carlota Joaquina permaneceu um caso praticamente isolado que tardou em ser repetido. Em 1863, num depoimento concedido a José Silvestre Ribeiro, o professor José da Costa Sequeira corroborava esse facto ao referir que "nenhum quadro antigo e de escola clássica se tem adicionado à coleção, por falta dos necessários meios para se comprarem, e apesar dos fortes desejos do vice-inspetor e do corpo académico"1 ${ }^{1}$.

Sousa Holstein empenhou-se seriamente em reverter esse estado de coisas, questionando num relatório dirigido em 1864 ao ministro e secretário de Estado dos Negócios do Reino: "O que não seria hoje a galeria nacional de pinturas se desde a fundação da Academia se houvesse destinado uma pequena verba para a compra de quadros?" ${ }^{2}$. Recordava que nas décadas anteriores, por quantias razoáveis, poderiam ter sido adquiridas diversas obras, mercê das dificuldades de algumas famílias aristocráticas que se viram obrigadas a vender os seus bens artísticos ${ }^{3}$. "Hoje mais

\footnotetext{
${ }^{1}$ Apud RIBEIRO, José Silvestre - op. cit., T. X, p. 27.

2 "Relatório acerca do estado da Academia Real das Bellas Artes". Documento assinado por Sousa Holstein e datado de 26 de Fevereiro de 1864. Arquivo do MNAA, fundo José de Figueiredo, cx. 1, pasta 1 , doc. 1.

${ }^{3}$ A mesma ideia será repetida na "advertência" ao Catalogo provisorio: "Naquele período de tempo perderam-se muitas ocasiões que não mais voltarão, para segurar à nação, a posse de obras de arte de indisputável merecimento. A extinção ou decadência de muitas famílias antigas levava constantemente
} 
difícil é comprar nas mesmas condições, contudo muitos quadros de valor existem entre nós" advertia o marquês que fazia anexar ao relatório um parecer académico e uma longa listagem de pinturas cuja aquisição propunha ao governo.

Com efeito, a 25 de Janeiro de 1864, Sousa Holstein havia nomeado uma comissão encarregada de "examinar as coleções de quadros que se acham para venda em Lisboa, pertencentes a diversos indivíduos", a que incumbiria indicar as obras "de mais merecimento artístico ou histórico, cuja compra devesse propor-se competentemente ao governo para enriquecimento da galeria de pinturas da Academia Real das Belas Artes $^{\prime 4}$. Constituída pelos professores de pintura da instituição - Tomás da Anunciação, Marciano Henriques da Silva, João Cristino da Silva e Miguel Ângelo Lupi a comissão apresentou a 20 de Fevereiro do mesmo ano um parecer ou relatório que será lido por Lupi em sessão académica ${ }^{5}$.

No total, eram indicados sete indivíduos que se encontravam interessados em vender as pinturas em seu poder: visconde da Baía; Jorge Husson da Câmara; Francisco António de Sousa Cambiaço, António Eleutério Dias de Sousa; João de Sousa Lobo, José Luís Pereira Crespo e José Maria. Tratavam-se na generalidade de coleções numericamente modestas e de formação recente, resultado de aquisições em certos casos e de heranças noutros, correspondendo o último nome (sem indicação de apelido) a um negociante, proprietário de um bazar na calçada marquês de Abrantes a quem a comissão pretendia comprar apenas duas obras.

Francisco António de Sousa Cambiaço (fal. 1872), fiel adepto do absolutismo ao qual consagrara toda a sua atividade política, vivendo retirado em Belém desde a

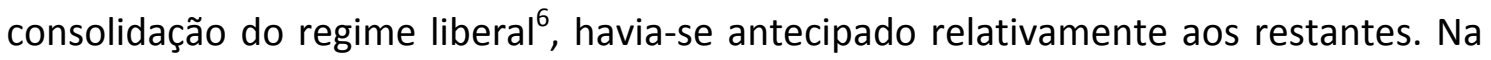
realidade, já em 1862 propusera ao governo a venda dos 22 quadros que possuía, depositados desde então na Academia que em sessão extraordinária de 10 de Abril

\footnotetext{
ao mercado um grande numero de obras que fora fácil e pouco dispendioso adquirir". HOLSTEIN, marquês de Sousa (co-auto.) - Catalogo provisorio da Galeria Nacional de Pintura existente na Academia Real das Belas Artes de Lisboa, 1868, p. 9.

${ }^{4}$ Relatório da comissão nomeada "para examinar as coleções de quadros que se acham para venda em Lisboa", 26 de Fevereiro de 1864. Arquivo do MNAA, fundo José de Figueiredo, cx. 1, pasta 1, doc. 11.

5 Conferência ordinária de 3 de Março de 1864. Arquivo da ANBA, disponível em http://digitarq.dgarq.gov.pt/ PT-ANBA-ANBA-F-002-00001_m0155.

${ }^{6}$ PEREIRA, Esteves; RODRIGUES, Guilherme - op. cit., vol. VI, 1912, p. 1070.
} 
daquele ano considerava ser de "muita utilidade" a sua aquisição". Especificava dois anos mais tarde a comissão que "conquanto alguns deles sejam de menos mérito, se deve comprar toda a coleção, pois que na mesma figuram outros quadros que muito conviriam ao ensino académico" ${ }^{8}$. De acordo com uma relação anexada ao relatório, verificamos serem, na sua grande maioria, composições de cariz religioso, com duas cenas mitológicas a marcar a exceção.

Sousa Cambiaço parece ter exercido influência junto de outros proprietários para a venda de pinturas, como terá sido o caso de António Eleutério Dias de Sousa, residente em Tomar, que enviará à Academia três quadros para serem examinados. No entender dos professores, "dois dos referidos quadros são, na verdade, de pouco valor mas aquele que representa Santa Cecília com um anjo de cada lado é muito distinto", sabendo-se corresponder hoje a uma obra do italiano Antiveduto Grammatica (fig. $34)^{9}$. À morte do seu proprietário, Sousa Cambiaço atuará como procurador da sua presumível herdeira no negócio com a Academia.

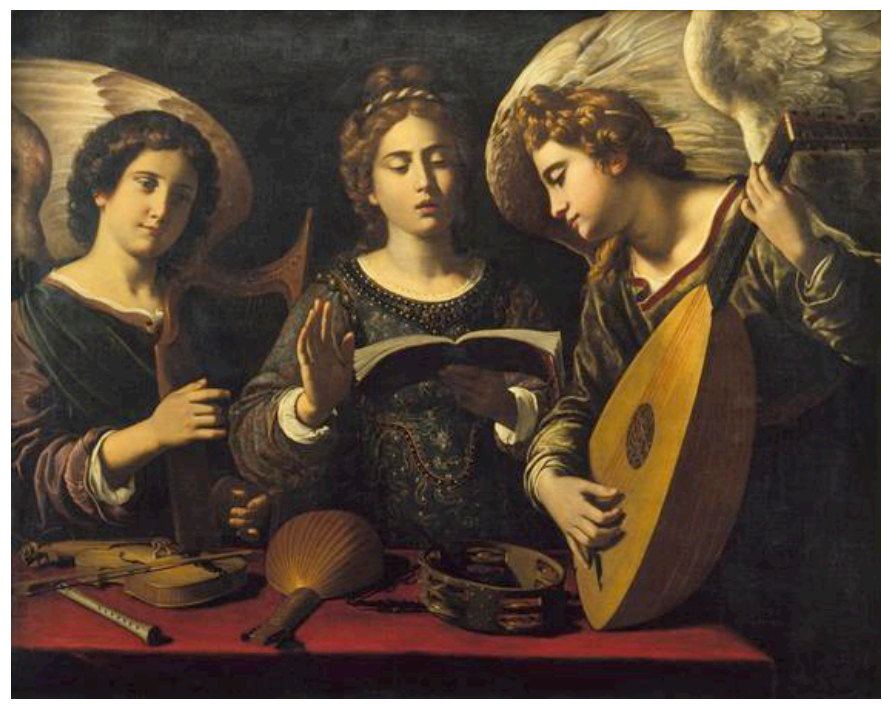

Fig. 34 - Antiveduto Grammatica, Santa Cecília e dois anjos músicos, c. 1595-1625. MNAA, inv. 532 Pint

Absolutista convicto era também o visconde da Baía (1808-1889) que serviu no exército de D. Miguel durante a guerra civil, tendo sido nomeado seu ajudante de

\footnotetext{
7 Conferência extraordinária de 10 de Abril de 1862. Arquivo da ANBA, disponível em http://digitarq.dgarq.gov.pt/ PT-ANBA-ANBA-A-001-00008_m0332.

${ }^{8}$ Relatório da comissão nomeada "para examinar as coleções de quadros que se acham para venda em Lisboa", 26 de Fevereiro de 1864. Arquivo do MNAA, fundo José de Figueiredo, cx. 1, pasta 1, doc. 11.

${ }^{9}$ Figura na 1.a ed. do Catalogo provisorio: 103 Carracci (escola dos), Santa Cecília e dois anjos.
} 
ordens e chegado ao posto de tenente ${ }^{10}$. Com a convenção de Évora Monte deixou o serviço militar, retirando-se por completo da vida pública e dedicando-se à organização de uma modesta pinacoteca na sua casa de S. Sebastião da Pedreira onde dominavam as pinturas de paisagem. Resultado de heranças familiares e do que 0 mercado nacional ia então proporcionando, ostentava autorias mais ou menos credíveis a Salvador Rosa, Rosa da Tivoli, Pillement e Morgado de Setúbal, de acordo com o rol anexado ${ }^{11}$. Ficou registado no relatório de 64 que "da grande coleção do Sr. visconde da Baía foram escolhidos pela comissão 23 quadros por serem os mais notáveis, posto que alguns deles estejam deteriorados, parecendo-Ihe regulares os respectivos preços" ${ }^{\prime 2}$.

Maior interesse possuíam as obras reunidas pelo conselheiro Jorge Husson da Câmara (fal. 1877), reputado diplomata a quem a passagem por Itália (Roma) onde em 1828 já era adido, e dez anos mais tarde encarregado de negócios da nossa legação no Vaticano $^{13}$, imprimiu gosto por colecionar ${ }^{14}$. Mantinha relações próximas com a nossa Academia de quem era académico honorário, intervindo em 59 na oferta de uma estampa alusiva à Descida da Cruz de Domingos Sequeira, gravada por um seu discípulo, o conde Antonio Biordi ${ }^{15}$. Anos mais tarde, durante uma estadia em Lisboa, seria contactado para dar parecer sobre um conjunto de quadros de suposto interesse menor que os professores de pintura haviam selecionado para vender em leilão, seleção essa que não reunia consenso académico. Foi então lavrado em ata que a escolha de Husson da Câmara se devia aos "conhecimentos e prática que tem do verdadeiro valor das pinturas" ${ }^{16}$, sendo tido portanto como um connaisseur.

\footnotetext{
${ }^{10}$ PEREIRA, Esteves; RODRIGUES, Guilherme - op. cit., vol. II, 1906, p. 21.

${ }^{11} \mathrm{Na}$ 1.a ed. do Catalogo provisorio identifica-se uma só obra: 82 Salvador Rosa (atrib.), Uma paisagem.

12 Relatório da comissão nomeada "para examinar as coleções de quadros que se acham para venda em Lisboa", 26 de Fevereiro de 1864. Arquivo do MNAA, fundo José de Figueiredo, cx. 1, pasta 1, doc. 11.

${ }^{13}$ Exerceu as funções de encarregado de negócios da nossa legação no Vaticano em 1838 e 1841-1858. Foi ainda encarregado de negócios interino junto da nossa legação em Nápoles entre 1853 e 1854. Instituto Diplomático, Ministério dos Negócios Estrangeiros: http://idi.mne.pt/pt/relacoesdiplomaticas/42-relacoes-diplomaticas/titulares/643-santa-se.html

${ }^{14}$ Sobre este colecionador cf. NETO, Maria João - "Construção e desconstrução de coleções: o mercado de arte em Roma no período napoleónico aos olhos dos diplomatas portugueses". NETO, Maria João; MALTA, Marize (eds.) - Coleções de arte em Portugal e Brasil nos séculos XIX e XX: perfis e trânsitos, 2014, pp. 51-69

${ }^{15}$ Conferência extraordinária de 19 de Agosto de 1859. Arquivo da ANBA, disponível em http://digitarq.dgarq.gov.pt/ PT-ANBA-ANBA-A-001-00008_m150.TIF

${ }^{16}$ Conferência extraordinária de 11 de Março de 1864. Idem, disponível em http://digitarq.dgarq.gov.pt/ PT-ANBA-ANBA-F-002-00001_m159.
} 
Na realidade, já em 1861, Ernesto Biester, ao relatar uma visita à residência lisboeta do colecionador (rua Vicente Borga) na companhia de Tomás da Anunciação e Cristino da Silva, fazia notar de forma muito elogiosa a sua erudição naquele domínio: "Versado na história da arte, como raros, falando dela, tornava a sua palestra uma lição do melhor livro. Todos os cultores Ihe são familiares, todos os pincéis the são conhecidos; a todos sabe a escola, a todos descobre pela tinta". Referia ainda que o nosso encarregado de negócios em Roma teve durante muitos anos oportunidade de estudar por bons modelos, sendo "em sua casa que se reuniam os primeiros artistas, onde de certo os atraiam a valia dos conhecimentos e a justeza da opinião que em tais assuntos manifestava o Sr. Jorge Husson"17. Mais informa ter sido a coleção do nosso diplomata formada não só em Itália, mas também em Espanha e Portugal, compreendendo 17 obras elencadas na crónica publicada, com a identificação dos temas ou figuras representadas, atribuições de autorias e, por vezes, indicação de proveniências.

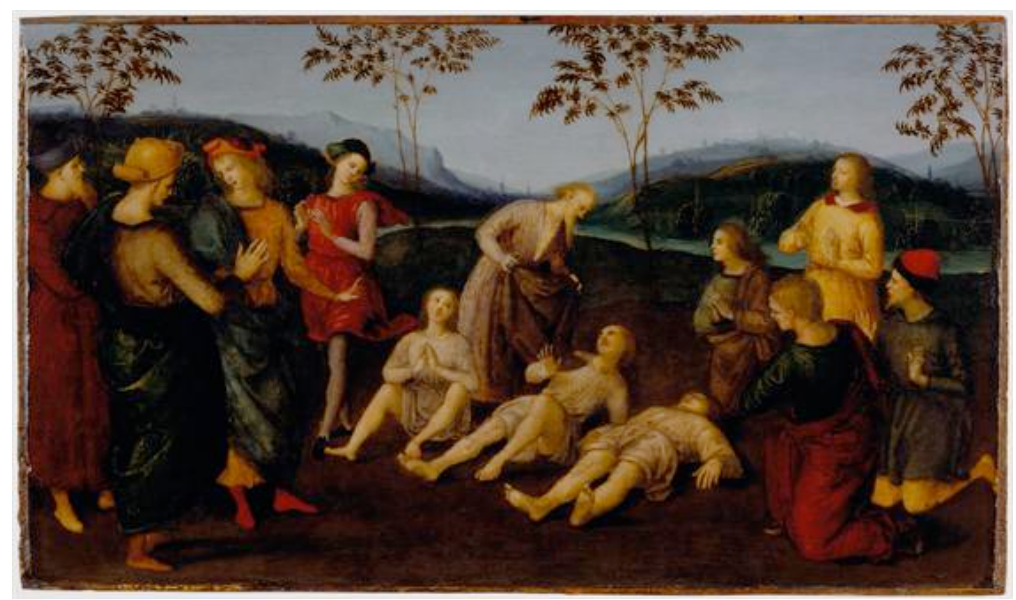

Fig. 35 - Rafael Sanzio de Urbino, Santo Eusébio de Cremona ressuscitando três mortos, 1502-1503. MNAA, inv. 568 Pint

O relatório da comissão nomeada três anos mais tarde por Sousa Holstein a quem a coleção muito interessava, ao ponto de cedo desenvolver esforços para a sua aquisição ${ }^{18}$, acrescentava ter sido aquele acervo expressamente avaliado em Roma,

\footnotetext{
${ }^{17}$ BIESTER, Ernesto - “Crónica”. Revista Contemporanea de Portugal e Brazil, vol. II, (n.o 10), 1860, pp. 484-485.

${ }^{18}$ A este respeito diz-nos José da Costa Sequeira em 1863: “Uma das coleções mais recomendáveis, cuja venda se propunha, e que o vice-inspetor desejou muito efetuar, era a que possui o conselheiro Jorge Husson da Câmara, composta de obras originais dos primeiros clássicos, entre as quais se nota uma do insigne Rafael de Urbino (autenticada): até agora porém tudo se ficou em bons desejos e infrutuosas
} 
sendo composto na sua maioria por trabalhos "de elevado merecimento e de autores muitos distintos", citando-se desde logo os nomes de Rafael, Poussin, Rembrandt, Sebastiano del Piombo e Garofalo. A listagem anexada ao relatório segue no essencial a enumeração de Biester e confirma a preferência dada à pintura italiana, com alusões não menos sonantes a Rosso Fiorentino, Brueghel, Bronzino, Guido Reni, Elsheimer, Rigaud, Fernando Gallego, Ferdinand Bol, Giorgio Vasari e até mesmo a Miguel Ângelo. Sonantes mas duvidosas como a passagem dos anos viria a revelar, merecendo todavia destaque o pequeno painel de predela executado por um jovem Rafael Sanzio para o retábulo da capela Gavari em San Domenico de Citttà di Castello (fig. 35).

De acordo com a crónica acima citada, algumas obras haviam pertencido a afamadas pinacotecas aristocráticas, tais como a dos princípes Chigi e Pallavicini, concorrentes dos Colonna e dos Doria Pamphilj no meio artístico romano, podendo também ser mencionada a colecção Albani e a do cardeal Bernis (1715-1794), homem do ancien regime que exerceu funções diplomáticas em Veneza e depois em Roma onde chegou a acolher Jean-Honoré Fragonard ${ }^{19}$. Adquiridas em Portugal foram uma Nossa Senhora da Conceição em glória atribuída ao salamantino Fernando Gallego, proveniente da coleção do marquês do Louriçal, e uma Deposição de Cristo que constava ter sido oferecida por monsenhor Conti, núncio da corte pontifícia, a D. João V que por sua vez a doara ao mosteiro de Odivelas. Associada a Sebastiano del Piombo, essa obra fora alienada no início do século XIX para angariar fundos destinados às obras do edifício, tendo sido adquirida pela família do nosso diplomata que revelava já pendor para as artes. As invasões francesas tiveram em larga medida reflexo nestas aquisições, não só no caso português, mas também, e sobretudo, no italiano. Após alterarem dramaticamente a ordem naquele centro cultural e artístico europeu, muitas coleções de arte se dispersaram, dando origem a outras. No período em que o nosso diplomata se fixou em Roma, em lenta retoma económica, o mercado animava-se com muitas obras disponibilizadas por necessidade financeira dos seus proprietários, o que explicará algumas das proveniências mencionadas ${ }^{20}$.

diligências do vice-inspetor; e teremos talvez o sentimento de ver em breve sair de Portugal esta primorosa coleção". Apud RIBEIRO, José Silvestre - op. cit., T. X, p. 27.

${ }^{19}$ Francois-Joachim de Pierre Bernis, cardeal e estadista que interferiu na supressão da Companhia de Jesus em 1773 e se opôs com firmeza à constituição civil do clero imposta pela Revolução Francesa.

${ }^{20}$ Sobre o mercado de arte no período napoleónico cf. NETO, Maria João - op. cit, pp. 51-69. 
Motivo de orgulho para Husson da Câmara era a apreciação que das suas pinturas fizera um destacado artista com quem privara, Jean-Auguste Dominique Ingres (17801867), diretor da Academia Francesa em Roma entre 1834 e 1841, facto mencionado na crónica de Biester e citado também no relatório: "Foi presente à comissão um extracto de uma carta que Mr. Ingres, quando diretor da Academia de Belas Artes de França em Roma, dirigiu a Mr. Sande, encarregado então de negócios naquele corte, na qual fala muito favoravelmente a respeito dos referidos quadros, mostrando desejos de que eles enriquecessem algum dos museus daquele país" ${ }^{21}$. Se as proveniências acima mencionadas conferiam pedigree às pinturas, o juízo do celebrado pintor francês validava de certa forma as atribuições, tornando a aquisição mais apetecível.

O diplomata disponibilizara igualmente para venda um alto relevo representando a Virgem com o Menino, enquadrado por imagens de dois santos ${ }^{22}$, acerca do qual foi solicitado um parecer e avaliação independente a Francisco de Assis Rodrigues, diretor geral da Academia, e a Vítor Bastos, professor de escultura, que se anexou ao relatório. Com base em informações fornecidas pelo colecionador, escreviam ser obra "do insigne Luca della Robbia, feita para a igreja dos monges olivetanos em Roma de onde foi deslocada na época da ocupação dos estados pontifícios pelos franceses e passou ao poder de João Gerardo Rossi ${ }^{23}$, famoso amador e conhecer das belas artes" $^{\prime 24}$. Advertiam ser esta a única obra de Luca della Robia identificada em Roma, acrescentando ter sido naquela cidade avaliada pelo presidente da Academia de S. Lucas, Giovanni Silvagni (1790-1853). Ilustrativa do grande interesse por peças das oficinas dos della Robbia que então se registava um pouco por toda a Europa, esta

\footnotetext{
${ }^{21}$ Relatório da comissão nomeada "para examinar as coleções de quadros que se acham para venda em Lisboa", 26 de Fevereiro de 1864. Arquivo do MNAA, fundo José de Figueiredo, cx. 1, pasta 1, doc. 11.

${ }^{22}$ Transcrevemos a descrição completa desta peça: "Um alto relevo de porcelana circundado de um festão de frutos e flores, representando Nossa Senhora coroada por dois anjos com o Meninos Jesus nos braços; e duas estátuas de santos, de um terço do tamanho natural, separadas, mas que servem para agrupar e compor o dito alto relevo". Cf. cópia manuscrita do documento original. Idem, cx. 1, pasta 11, doc. 1.

${ }^{23}$ Sobre Giovanni Gherardo de Rossi (1754-1827), poeta e cultor das belas artes que chegou a director da Academia Portuguesa das Belas Artes em Roma, nos referimos já no ponto 1 da II parte deste trabalho.

${ }^{24}$ Informavam ainda que ao "remover do muro o referido relevo quebraram uma perna do Menino Jesus a qual o mesmo Rossi fez restaurar ao célebre Canova". Arquivo do MNAA, fundo José de Figueiredo, cx. 1, pasta 11, doc. 1.
} 
proposta de aquisição não chegou todavia a efetivar-se, desconhecendo-se o paradeiro do relevo.

Prova do interesse que nutria pela história da arte e do cuidado em manter-se bem informado, Husson da Câmara reunira ainda uma notável biblioteca cuja venda propôs igualmente à Academia. No parecer então efectuado, o bibliotecário João José dos Santos comparava-a à celebrada livraria artística do conde Cicognara (1767-1834) adquirida em 1824 pelo papa Leão XII para enriquecer a biblioteca do Vaticano, não sendo todavia tão numerosa como esta última (cerca de 2000 volumes contra 5000). Referia ainda que para a reunir, empregou o colecionador "vinte e oito anos com bastante diligência e dispêndio, conseguindo juntar todas as obras que o escritor Lanzi cita no seu catálogo, e que Ihe forneceram todos os elementos para compor a sua história da pintura italiana" ${ }^{26}$. Empenhado na venda à Academia da sua biblioteca, "verdadeiro monumento de Belas Artes" nas palavras de João José dos Santos, o diplomata mostrava-se disposto em reduzir substancialmente o valor por que estava avaliada.

Provável reflexo dos contactos desenvolvidos por Sousa Holstein durante a sua passagem por Itália, outra figura do meio diplomático surge indicada no relatório de 64. Trata-se de João de Sousa Lobo, secretário da nossa legação naquele país, a quem a dinâmica aquisitiva do mercado de arte pós-napoleónico propiciou também a compra e venda de pinturas. Tais vendas estenderam-se ao rei $D$. Luís que pelos mesmos anos se entusiasmava com a formação de uma pinacoteca no Palácio da Ajuda, vindo a adquirir-lhe pelo menos dois quadros, entre os quais um suposto Guercino $^{27}$.

O trabalho de Sousa Lobo na legação de Portugal em Florença era bastante apreciado pelo nosso ministro que em carta ao marquês de Sá da Bandeira, chefe do governo, referia ter aquele dado "exuberantes provas da sua aptidão e zelo pelo serviço do Estado, o que junto a vinte e seis anos de carreira diplomática tornam este empregado

\footnotetext{
${ }^{25}$ Leopoldo Cicognara, político e historiador da arte italiano, amigo de Schlegel, Winkelmann e Canova de quem foi o primeiro biógrafo. Falido pelo custo das suas publicações, vendeu a biblioteca que reuniu ao Sumo Pontífice. Aquele fundo bibliográfico foi recentemente objecto de um projeto de investigação ítalo-americano. Cf. "The Cicognara Project" http://www.cicognara.com

${ }^{26}$ Cf. parecer de João José dos Santos datado de 8 de Fevereiro de 1864. Arquivo do MNAA, fundo José de Figueiredo, cx. 1, pasta 1, doc. 10.

${ }^{27}$ XAVIER, Hugo - Galeria de Pintura no Real Paço da Ajuda, 2013, pp. 101-102.
} 
muito digno de ser promovido a chefe de missão, o que de resto lhe compete por direito" ${ }^{28}$. A recomendação não ficou esquecida e o competente funcionário chegará a ministro de Portugal em Washington ${ }^{29}$, vindo a interessar-se por questões relacionadas com a imigração para as Américas ${ }^{30}$.

A comissão referia serem 14 os quadros disponibilizados por Sousa Lobo, "os quais são em geral de escola italiana, distinguindo-se pelo seu mérito os n.ㅗs 1 a 4" da relação anexada ao relatório ${ }^{31}$. Com a exceção de uma Batalha de Dário, frente pintada de um cassone (arca) do século XVI ${ }^{32}$, de um Sileno ébrio que se atribuiu a Luca Giordano ${ }^{33}$, e de uma ou outra paisagem, eram as referidas pinturas de temática religiosa, encontrando-se associadas às escolas florentina e bolonhesa, sem contar com um esboço a óleo sobre cartão para a Ascensão de Domingos Sequeira, adquirido provavelmente em Roma ${ }^{34}$. "Nesta coleção se compreende também uma aguarela representando diversos costumes de Roma, e um alto-relevo em madeira, figurando Nossa Senhora com o Menino Jesus", acrescentavam os professores, propondo a aquisição de todas as obras.

Falta ainda fazer referência a José Luís Pereira Crespo, proprietário de oito pequenos quadros, a maioria dos quais tidos por flamengos e holandeses do século XVII, tendência em voga entre os colecionadores da época. Como já tivemos oportunidade de aludir anteriormente ${ }^{35}$, pensamos que parte destas pinturas poderão ter integrado a coleção do cônsul dos Países Baixos, proposta para venda à Academia pela sua herdeira em 1862, aquisição impossibilitada por falta de verba. A listagem alusiva a esse acervo enumera, entre outros, um esboço de Rubens representando Andrómeda

\footnotetext{
${ }^{28}$ Oficio dirigido pelo visconde de Borges de Castro ao marquês de Sá da Bandeira a 2 Janeiro de 1869. Arquivo Histórico-Diplomático do MNE, Legação de Portugal em Florença, cx. 55, n.o 1.

${ }^{29}$ Foi enviado extraordinário e ministro plenipotenciário junto da nossa legação em Washington entre 1872 e 1874. Instituto Diplomático, Ministério dos Negócios Estrangeiros, Estados Unidos Titulares, http://idi.mne.pt/pt/relacoesdiplomaticas/42-relacoes-diplomaticas/titulares/582-estados-unidos-daamerica.html

${ }^{30}$ Cf. ofício de João de Sousa Lobo a Andrade Corvo, 10 de Maio de 1874. Negocios externos: documentos apresentados ás Cortes na sessão legislativa de 1875 pelo ministro e secretário d'Estado dos Negocios Estrangeiros: emigração Portuguesa, 1875, p. 74

${ }^{31}$ Relatório da comissão nomeada "para examinar as coleções de quadros que se acham para venda em Lisboa", 26 de Fevereiro de 1864. Arquivo do MNAA, fundo José de Figueiredo, cx. 1, pasta 1, doc. 11.

32 MNAA, inv. 522 Pint.

${ }^{33}$ MNAA, inv. 512 Pint. Cf. CAETANO, Joaquim Oliveira (comiss.) - Luca Giordano: Êxtase de São Francisco (cat. expo.), p. 87.

${ }^{34}$ MNAA, inv. 521 Pint.

${ }^{35}$ Cf. ponto 2.3 da I parte deste trabalho
} 
e Perseu, uma composição representando um ceifeiro, e uma festa campestre associada a van Ostade, obras igualmente mencionadas na relação de Pereira Crespo. A ausência de descrições detalhadas e das dimensões dos quadros não nos permitem confirmar isso, mas a coincidência e por demais sugestiva para a formulação desta hipótese.
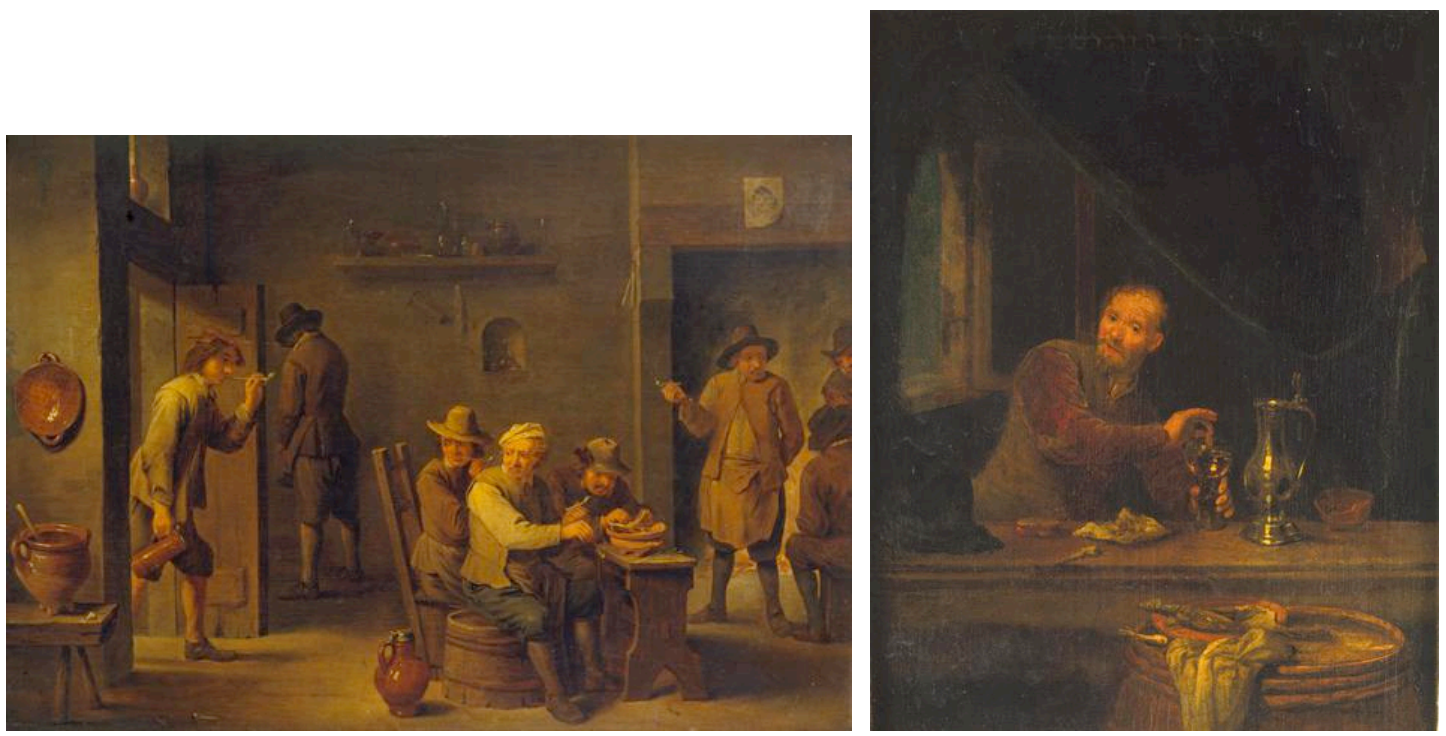

Fig. 36 - David Teniers, o Moço - Fumadores, c. 1640-1680. MNAA, inv. 524 Pint Fig. 37 - Gerrit Dou, Cena de interior, c. 1635-1665. MNAA, inv. 530 Pint

De acordo com o que ficou escrito no relatório, "a comissão, conhecendo serem alguns deles pouco distintos, escolhera os três primeiros em que figura um esboço de Rubens, que se vende por $1.000 \$ 000$ reis; mas como o preço de toda a coleção é de $1.200 \$ 000$ reis, parece-lhe mais conveniente que se comprem todos" ${ }^{36}$. Na realidade, pouco distinto era o esboço associado a Rubens, vindo a revelar-se de maior interesse as restantes obras, onde se incluíam David Teniers (fig. 36) e Gerrit Dou (fig. 37). Não foram localizadas referências precisas sobre Pereira Crespo, no entanto, seguindo a linha diplomática que tem sido mencionada, ele poderá corresponder ao cônsul da Venezuela em Portugal, nomeado em $1856^{37}$. Não será também de excluir a hipótese de se tratar de um benemérito afortunado oriundo da Marinha Grande, a quem legou

\footnotetext{
${ }^{36}$ Relatório da comissão nomeada "para examinar as coleções de quadros que se acham para venda em Lisboa”, 26 de Fevereiro de 1864. Arquivo do MNAA, fundo José de Figueiredo, cx. 1, pasta 1, doc. 11.

37 "O primeiro intercâmbio de cônsules ocorreu em 1856 com as designações de José Luís Pereira Crespo, no consulado da Venezuela em Lisboa, e de Eugenio Thirion, cônsul do reino, em Ciudad Bolívar". XAVIER, António de Abreu - "A comunidade portuguesa na Venezuela: uma cronologia da sua presença contemporânea”. PADILHA, Beatriz; XAVIER, Maria (org.) - Revista Migrações, n.o 5, p. 172.
} 
ao falecer, em 1908, uma quantia assinalável para a construção e manutenção de uma creche à qual foi dado o seu nome ${ }^{38}$.

Sintetizando, as propostas dos sete indivíduos perfaziam a quantia de $49.197 \$ 200$ reis, compreendendo um total de 90 quadros. Advertia a comissão que esse valor ficaria "reduzido a $30.000 \$ 000$ reis, pouco mais ou menos, em virtude do grande abatimento que o Exmo. Cons. Husson tenciona fazer de $19.000 \$ 000$ reis na avaliação dos seus quadros, livraria e alto-relevo" ${ }^{39}$. Ainda assim, a avaliação da sua pinacoteca representava mais de metade do valor total, sobrepondo-se de forma esmagadora aos restantes conjuntos que, longe de grandes preocupações colecionistas, pareciam ter sido na maioria dos casos entendidos pelos seus proprietários como um complemento dos recheios das suas casas. Mais que Sousa Lobo a quem a passagem por Itália trouxe hábitos continuados de compra, Husson da Câmara surge como uma figura à parte, colecionador informado como atestava a sua biblioteca, e com contactos de relevo no meio artístico italiano do seu tempo.

Voltando ao relatório, entendia a comissão que a Academia, "adquirindo os mencionados 90 quadros, livraria e alto-relevo, poderá melhor preencher o fim da sua instituição". Informava ainda que tendo-se abstido "de confirmar a autenticidade de todos os autores indicados nas relações sob os números 1 e 2 [Visconde da Baía e Jorge Husson da Câmara], as quais foram ministradas pelos possuidores das obras a que se referem, deixando ao mesmo tempo de determinar nas restantes relações os autores ou escolas a que pertencem os quadros descritos, julga ter procedido com prudência e cautela". Alguma prudência e cautela mas também fragilidade e insegurança dos professores de pintura que não se encontravam muito confortáveis nessa tarefa, entrando em contradição: se se abstiveram de certificar ou indagar a plausibilidade das atribuições fornecidas por alguns proprietários, que crédito mereciam as avaliações efectuadas? Procurando salvaguardar-se, acrescentam que "nada [é] mais difícil do que classificar quadros antigos, e a prova está em que os mais peritos nessa especialidade muitas vezes vacilam em semelhantes classificações".

\footnotetext{
38 "Creche Pereira Crespo", atual sede da Junta de Freguesia da Marinha Grande.

${ }^{39}$ Relatório da comissão nomeada "para examinar as coleções de quadros que se acham para venda em Lisboa", 26 de Fevereiro de 1864. Arquivo do MNAA, fundo José de Figueiredo, cx. 1, pasta 1, doc. 11. As restantes citações reportam-se a esta referência.
} 
Ao concluir o relatório, a comissão fazia lembrar ao vice-inspetor "a necessidade de se ornarem com boas molduras muitos dos quadros distintos que existem nas salas da Academia, os quais além de falta de luz e de outras condições necessárias têm como ornamento umas simples réguas de madeira pintada". Antes de avançarem com eventuais aquisições, importava pois alterar esse estado de coisas, "para honra da nação", sugerindo a comissão que se solicitasse ao governo uma verba de $8.000 \$ 000$ reis. O ministro e secretário de Estado dos Negócios do Reino a quem foi dado a ler o relatório parece ter-se remetido ao silêncio, não sendo conhecida qualquer deliberação a respeito das propostas de aquisição ou do subsídio para molduras e arranjos nas salas da Academia. Tudo isso e muito mais irá ser todavia concretizado graças a um gesto mecenático sem precedentes na história da instituição, naquele que foi um dos momentos altos da vigência de Sousa Holstein. Veremos o seu resultado no ponto seguinte.

\subsection{Gesto mecenático de D. Fernando II}

A 24 de Dezembro de 1864, Sousa Holstein reunia-se em sessão extraordinária com o restante corpo académico para proceder à leitura de um decreto datado de 16 do corrente, pelo qual D. Fernando II (fig. 38) cedia da dotação que Ihe era atribuída anualmente pelo Estado, no valor de 100 contos de reis, ${ }^{40}$ uma parte assinalável para a compra de obras de arte. Publicado no Diario de Lisboa de 21 de Dezembro, o documento constava do seguinte:

"Tendo atenção às urgências do Estado, declaro que da dotação que me compete, em virtude do contrato matrimonial celebrado em Coburgo a um de Dezembro de 1835, faço cessão como donativo espontâneo, da quantia de 30 contos de reis para ser deduzida na dita dotação no ano económico de 1865-1866, nas prestações mensais

\footnotetext{
${ }^{40}$ A respeito das dotações atribuídas aos elementos da família real, veja-se a seguinte notícia: "A dotação de sua majestade el-rei o Sr. D. Luís é de 365 contos de réis por ano; a de sua majestade a rainha é de 60 contos; a do príncipe real é de 20 contos; a do Sr. infante D. Afonso é de 10 contos; a de El-rei D. Fernando é de 100 contos; a do Sr. infante D. Augusto é de 16 contos; a de sua majestade imperial a duquesa de Bragança é de 40 contos; a de sua alteza a Sr.a infanta D. Isabel Maria de 40 contos. Destas duas últimas deduzem-se para as despesas do estado 40 contos. El-rei D. Luís e o Sr. D. Fernando também tem feito generosíssimas cedências e fazem considerável número de donativos com diversíssimas aplicações filantrópicas". Diario de Noticias, 26 de Maio de 1868 (sublinhado nosso).
} 
como se tem praticado nos anos antecedentes; e outrossim sou servido declarar ser minha vontade, que desta soma sejam aplicados 20 contos de reis para a compra de objetos de arte para a Academia de Belas Artes de Lisboa e que a restante quantia de 10 contos de reis reverta a favor do Tesouro Público, sendo compreendia na receita geral do Estado" ${ }^{41}$.

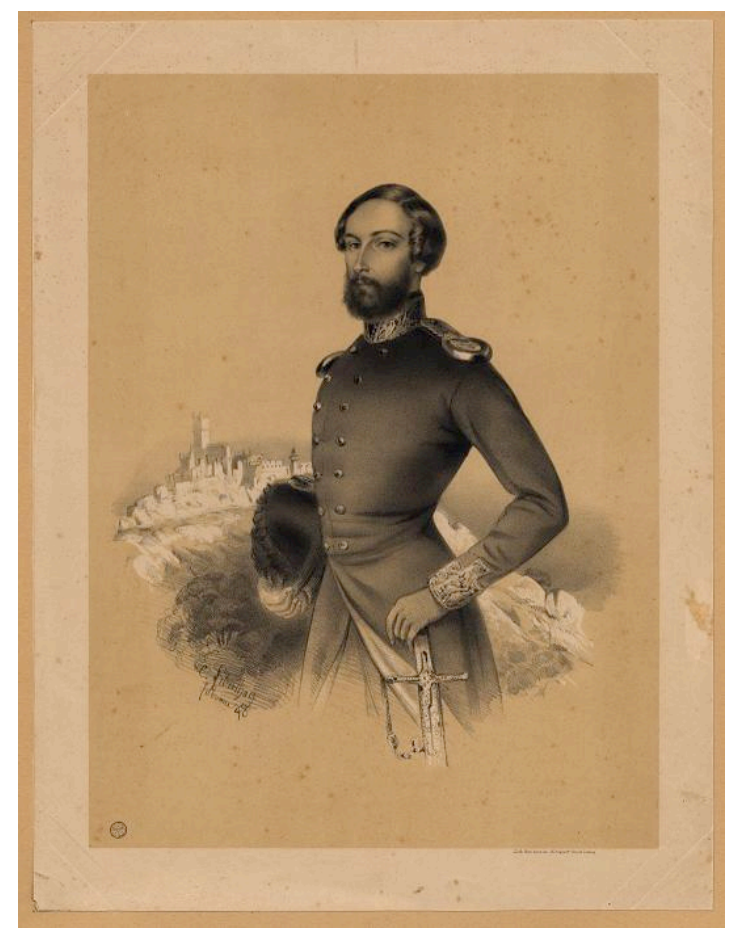

Fig. 38 - D. Fernando II, litografia de C. Leberthais, 1848. BNP, 929.7

Atendendo às dificuldades do país, há muito que D. Fernando II reforçava a receita geral do Estado com a sua dotação, no entanto, tratava-se da primeira vez que a maior fatia revertia a favor da Academia de Belas Artes de Lisboa, com a determinação expressa de favorecer o enriquecimento das suas coleções. Subjacente a essa decisão poderá ter estado uma intervenção do vice-inspetor junto do monarca que porventura terá tomado conhecimento do relatório elaborado pela comissão. Certo é que, meses após este ter sido apresentado, e perante a falta de resposta do Ministério, D. Fernando assinava o decreto real, num gesto mecenático estranho à instituição e ao país.

\footnotetext{
${ }^{41}$ Conferência extraordinária de 24 de Dezembro de 1864. Arquivo da ANBA, disponível em http://digitarq.dgarq.gov.pt/ PT-ANBA-ANBA-F-002-00001_m0201 e PT-ANBA-ANBA-F-00200001_m0202
} 
O interesse generalizado que nutria pelas artes plásticas cativou desde cedo o meio académico. Em 1840, na sessão solene de abertura da primeira exposição pública da Academia a que assistiu na companhia de D. Maria II, ambos "protetores" do estabelecimento conforme o decreto de $36^{42}$, seria alvo de uma referência elogiosa na alocução do professor José da Costa Sequeira, mostrando não terem passado despercebidas as palavras de encorajamento dadas a professores e a discípulos por ocasião de visitas anteriores ${ }^{43}$. Este tipo de mostras conhecerão no monarca um visitante especialmente atento, o mesmo sucedendo anos depois com as exposições da Sociedade Promotora de Belas Artes, de que foi sócio fundador. Tornar-se-á um comprador fiel, vindo a reunir a maior e mais destacada coleção dos artistas nacionais do seu tempo, muitos dos quais representados com obras de primeira importância ${ }^{44}$. Mas não só de palavras de encorajamento e de aquisições se resumiu a ação mecenática do rei-consorte que concedeu ainda bolsas de estudo, assinou cartas de recomendação e acionou canais diplomáticos para facilitar o acolhimento de artistas no estrangeiro. "No silêncio resgata S. M. El-Rei o Senhor D. Fernando o esquecimento imperdoável dos nossos governos", escrevia em 1860 Ernesto Biester ao referir-se ao apoio que o monarca dispensava às artes ${ }^{45}$.

A cedência de uma parcela da sua dotação à Academia revestia-se de um aspecto importante que deve ser realçado: permitir a aquisição de obras atribuídas em larga medida a mestres estrangeiros da pintura antiga em que o acervo da instituição era deficitário. Procurava assim o régio mecenas engrandecer a galeria nacional que há muito se reclamava para Lisboa e, simultaneamente, fornecer qualificadas ferramentas

\footnotetext{
${ }^{42}$ A este respeito cf. o ponto 2 da I parte deste trabalho.

${ }^{43}$ "E deixariam porventura as animadoras frases do augusto esposo de Vossa Majestade, liberalizadas a professores, e a discípulos, de produzir aqueles eficazes resultados, que só podem nascer do mais nobre e valioso estimulo!? Qual seria o coração digno de um artista, em o qual elas não fizessem a mais tocante e duradoura impressão?". SEQUEIRA, José da Costa - Relatório que o professor substituto de arquitetura, servindo de secretario da Academia das Bellas Artes de Lisboa, leu perante a augusta pessoa de Sua Majestade, a rainha, e d'el-rei seu augusto esposo [...] - Descripção das obras apresentadas na primeira exposição triennal da Academia das Bellas Artes de Lisboa, 1840, p. 8.

${ }^{44}$ Vejam-se os casos de António Manuel da Fonseca com o Eneias salvando o pai Anquises do incêncio de Tróia (PNM, inv. 1772), Cristino da Silva com os Cinco artistas em Sintra (MC-MNAC, inv. 23), Metrass com o Só Deus! (MC-MNAC, inv. 500) ou Columbano Bordalo Pinheiro com Soirée chez lui (MC-MNAC, inv. 498). O catálogo do leilão de pintura promovido após a morte do monarca totaliza 478 lotes, $60 \%$ dos quais correspondendo a obras de artistas nacionais contemporâneos. Cf. Catalogo dos quadros existentes no real palacio das Necessidades pertencentes á herança de Sua Magestade el-rei o senhor D. Fernando e que hão de ser vendidos em leilão, 1892.

${ }^{45}$ BIESTER, Ernesto - “Crónica”. Revista Contemporanea de Portugal e Brazil, vol. II, (n.o 8), 1860, p. 390.
} 
para o ensino, de acordo com a tradicional prática académica que impunha a cópia continuada de modelos.

Grande entusiasmo causou entre os académicos o gesto de D. Fernando, propondo logo o vice-inspetor em Dezembro de 64 a nomeação de uma comissão que em nome da Academia "fosse agradecer ao mesmo augusto senhor este novo ato de proteção e munificência em prol das belas artes em Portugal". Foi porém unanimemente votado que, em vez de uma comissão, "fossem convidados todos os professores e académicos de mérito e honorários para irem cumprir esse dever de gratidão e reconhecimento" ${ }^{46}$. Na sessão realizada a 28 de Janeiro de 1865, continuaram a ser discutidas outras formas de homenagear o monarca, sugerindo Joaquim António Marques que se pintasse e expusesse na sala das sessões o retrato de D. Fernando e também o de seu filho, D. Luís, "por serem devidas a esta altas personagens os maiores tributos de respeito e gratidão da Academia pela relevante proteção e favores recebidos". O professor interino de pintura histórica, Marciano Henriques da Silva, que então administrava lições a D. Luís no Palácio da Ajuda, e que será pouco depois encarregado de proceder à organização de uma pinacoteca no mesmo palácio, apressou-se a aprovar a proposta, lamentando enfaticamente "que não se tivesse pago já esta dívida sagrada" ${ }^{47}$.

Uma vez que a verba cedida por D. Fernando começou a ser disponibilizada em prestações a partir de Agosto, seria convocado no mês anterior o corpo académico para se discutir a sua aplicação. De acordo com a ata então lavrada, informava o viceinspetor que o objectivo principal daquela reunião "era o exame e aprovação das propostas de venda das diferentes coleções de quadros que a Academia pretende adquirir para a Galeria Nacional, comprando-os por conta da soma que El-Rei o Senhor D. Fernando generosamente ofereceu do seu real bolsinho" ${ }^{\prime 48}$. Como tal, questionava os académicos sobre o "modo como se deve efetuar esta compra e, entre as propostas que já foram examinadas e aprovadas pela comissão de pintura, quais são as que devem comprar-se primeiro e como se poderão fazer os respectivos pagamentos, etc".

\footnotetext{
${ }^{46}$ Conferência extraordinária de 24 de Dezembro de 1864. Arquivo da ANBA, disponível em http://digitarq.dgarq.gov.pt/ PT-ANBA-ANBA-F-002-00001_m0201.

${ }^{47}$ Conferência ordinária de 28 de Janeiro de 1865. Idem, disponível em http://digitarq.dgarq.gov.pt/ PTANBA-ANBA-F-002-00001_m0231.

${ }^{48}$ Conferência extraordinária de 10 de Julho de 1865. Idem, disponível em http://digitarq.dgarq.gov.pt/ PT-ANBA-ANBA-F-002-00001_m0262. As restantes citações reportam-se a esta referência
} 
Após terem sido elencadas as sete propostas analisadas no relatório de 64 e lidas as respectivas observações, pediu a palavra o presidente da comissão, Tomás da Anunciação, referindo que "tendo ultimamente considerado este objecto com a seriedade e atenção que ele merece, não duvidava declarar que sobre alguns pareceres já dados tinha mudado de opinião, pois que oferecendo-se depois à venda algumas obras de pintura melhores do que as que se tinham proposto [...] não hesitava em declarar que a comissão desejava considerar de novo este objecto para emitir uma opinião segura e verdadeiramente imparcial” ${ }^{49}$.

Em causa estariam duas propostas, a primeira das quais respeitante a Francisco António Silva Oeirense que, após vários anos ao serviço da Academia Portuense de Belas Artes, se encontrava de novo em Lisboa, mantendo o cargo de diretor honorário, na sequência de Domingos Sequeira. Deste artista reuniu um conjunto assinalável de nove trabalhos, na sua maioria pequenos esboços a óleo destacando-se um primeiro modelo para a Alegoria à Constituiçãa $0^{50}$ que se propôs vender juntamente com uma "cabeça de homem" pela diminuta importância de $22 \$ 500$ reis. Quando às restantes obras, onde se incluíam uma Batalha de D. Afonso $V$ e um Desembarque de Afonso de Albuquerque $e^{51}$, subiu já a parada, solicitando o valor total de $2.000 \$ 000$ reis $^{52}$. Raczynski cita Oeirense como um artista que "possede aussi de bonnes choses", referindo-se às coleções de arte que visitara no Porto, quando aquele se encontrava a reger a cadeira de gravura histórica da Academia daquela cidade. Entre outras obras, possuía algumas composições religiosas anónimas, retratos e cenas mitológicas que serão também vendidas à Academia após a sua morte, em $1868^{53}$.

A segunda proposta foi efectuada por João Anastácio Rosa (1812-1884), ator dramático do teatro português que se destacou como intérprete nas peças $O$ Estudante de São Ciro e A Profecia ou a Queda de Jerusalém, drama bíblico no qual alcançou enorme sucesso, valendo-lhe uma bolsa de estudo em França, atribuída pelo governo em 1853. Retirado dos palcos a partir de 1866, dedicou-se às artes plásticas

\footnotetext{
${ }^{49}$ Conferência extraordinária de 10 de Julho de 1865. Idem, disponível em http://digitarq.dgarq.gov.pt/ PT-ANBA-ANBA-F-002-00001_m0265.

${ }^{50}$ MNAA, inv. 502 Pint.

${ }^{51}$ MNAA, inv. 505 e 499 Pint.

52 Documento assinado e datado de 3 de Julho de 1865, com parecer da comissão de pintura. Arquivo do MNAA, fundo José de Figueiredo, cx. 1, pasta 4, doc. 4.

${ }^{53}$ Não foi incluído nesse conjunto o Juramento de Viriato de Vieira Portuense que, vendido depois a Amorim Braga, se conserva hoje no Museu de Artes Decorativas Portuguesas - FRESS, inv. 1357.
} 
por que se havia entusiasmado na juventude, enquanto discípulo da Aula Régia de Desenho. Alcançou alguma notoriedade como caricaturista e fez experiências na área da escultura, sendo da sua autoria o busto de Garrett conservado no átrio do Teatro Nacional D. Maria II. Uma das pinturas mais relevantes propostas para venda à Academia encontrava-se na posse deste ator, "um quadro-esboço do insigne pintor Domingos António de Sequeira representando a queda do Despotismo e a apoteose da Liberdade". Tendo pertencido anteriormente a Félix da Costa Pinto em cujo leilão fora adquirido, encontrava-se avaliado em $600 \$ 000$ reis, "valor que a dita Academia já lhe concedeu" ${ }^{\prime 54}$. Tratava-se pois do derradeiro esboço para a Alegoria à Constituição (fig. 39), trabalho revelador da maturidade atingida pelo artista e dos seus entusiasmos vintistas, muito próximo já das opções compositivas finais (a tela definitiva, não se sabe se terminada, ter-se-á perdido num incêndio).

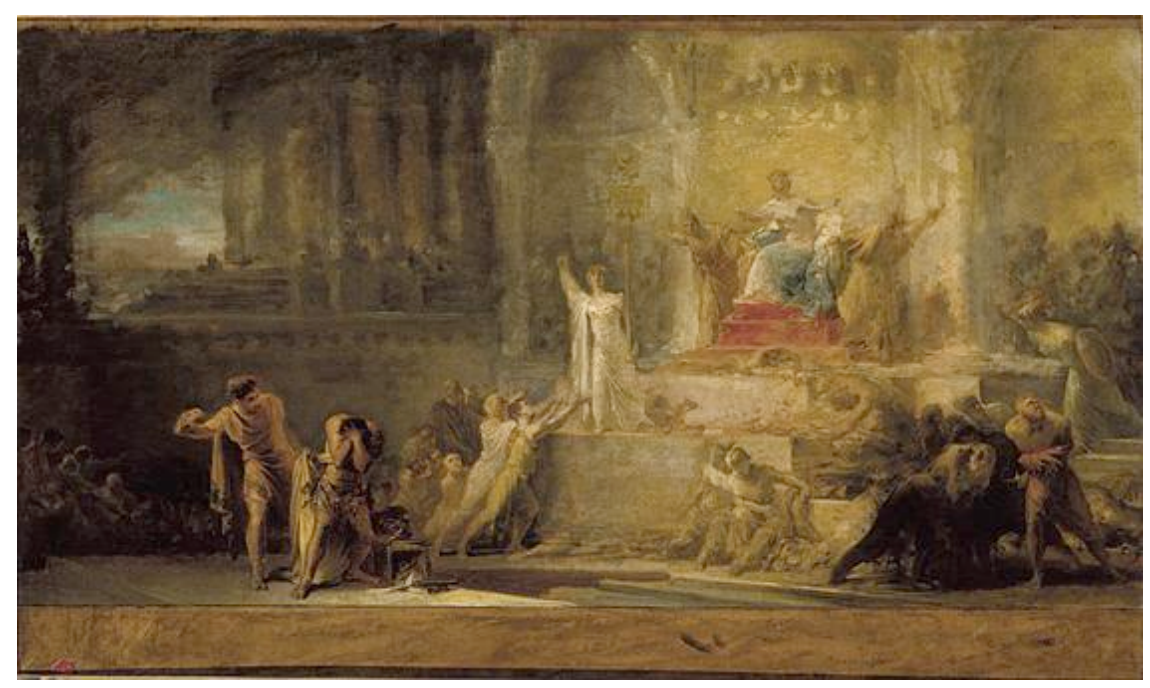

Fig. 39 - Domingos Sequeira, Alegoria à Constituição, 1821. MNAA, inv. 497 Pint

Dirigidas ao vice-inspetor, ambas as propostas haviam sido por ele remetidas à comissão de pintura que as aprovou, decisão corroborada com o voto unânime da conferência académica. Sousa Holstein congratulava-se seguramente com aquelas aquisições, e com o facto de ver reunidos em simultâneo sob o tecto da Academia, vindos de diferentes proprietários, dois dos esboços subsistentes para a Alegoria à Constituição. Atendendo ao interesse que nutria pelo artista, não será despropositado

\footnotetext{
${ }^{54}$ Documento original assinado e datado de 7 de Julho de 1865, com parecer da comissão de pintura. Arquivo do MNAA, fundo José de Figueiredo, cx. 1, pasta 4, doc. 2.
} 
pensar ter exercido alguma influência junto de Oeirense e Rosa para a venda daquelas obras.

Alguns dos colecionadores que se haviam disponibilizado há mais tempo a vender as suas pinturas, procedendo ao depósito das mesmas na Academia, impacientavam-se com a morosidade desta em entrar em acordos definitivos. Era o caso de Sousa Cambiaço que Julho de 1865 escrevia dois ofícios ao vice-inspetor, um em seu nome e outro na qualidade de procurador de Maria Cândida Dias da Silva, presumível herdeira de António Eleutério Dias de Sousa, solicitando a conclusão dos respectivos processos. Sousa Holstein remeteu os ofícios para a comissão de pintura que aprovou o segundo, não chegando a consenso relativamente ao de Cambiaço pelo facto de alguns professores terem alterado a opinião expressa no relatório elaborado no ano anterior, assunto discutido longamente em sessão académica.

$O$ rosto da contestação foi o professor substituto de pintura de paisagem, João Cristino da Silva que depreciava não só a coleção Cambiaço mas também a de Sousa Lobo, considerando que apesar de terem sido inicialmente aprovadas para integrarem o acervo da Academia, "não estava esta na obrigação rigorosa de as comprar, visto aparecerem outras melhores e terem variado as circunstâncias que então militavam" ${ }^{25}$ [leia-se, a concessão de uma verba para aquisições]. Tal declaração motivou fortes reações de protesto por parte do diretor-geral, Francisco de Assis Rodrigues, e de outros professores que "fizeram ver a injustiça e inconveniência de semelhantes ideias, dizendo que a rejeição dos quadros há tanto tempo aprovados, importava um manifesto engano e grande prejuízo a seus donos que, fiados nas resoluções da Academia, deixaram de os vender por igual ou maior preço daquele em que estavam avaliados".

Prolongando-se a discussão, propôs o vice-inspetor que se dispusessem todos os quadros em questão na aula de pintura para ali serem novamente examinados pela comissão e pelos restantes académicos, no intuito de se chegar a um "acordo prudente e razoável". Findo o exame, declararam Anunciação, Lupi e Marciano da Silva que mantinham o seu primeiro parecer a respeito daquelas propostas, o mesmo não

\footnotetext{
55 Conferência extraordinária de 10 de Julho de 1865. Arquivo da ANBA, disponível em http://digitarq.dgarq.gov.pt/ PT-ANBA-ANBA-F-002-00001_m0266. As restantes citações reportam-se a esta referência.
} 
sucedendo com Cristino que exigiu a integração de uma declaração de voto na ata, o que Ihe foi concedido. Justificava o artista ter reconsiderado o seu primeiro parecer com o novo exame, efectuado com luz apropriada, "o que não se deu na primeira ocasião, pois não me teria enganado tão facilmente ${ }^{\prime 56}$. Considerava que a maioria dos quadros "são medíocres e os mais distintos estão, em grande número, cheios de restauros, razão de sobra suficiente para serem depreciados no seu valor artístico".

Antes de dar por encerrada a sessão, e uma vez que a quantia cedida por D. Fernando se mostrava insuficiente para todas as coleções que a Academia entendia comprar, comunicava Sousa Holstein a intenção de "apresentar a Sua Majestade uma relação das propostas que fossem definitivamente aprovadas, para ver se El-Rei se dignava ampliar o seu oferecimento no seguinte ano económico". Advertia em todo o caso que os quadros antes de serem comprados "deviam ser submetidos ao exame de Sua Majestade que tinha todo o direito de os aprovar e escolher".

A 18 de Agosto, recebida a primeira tranche de $5.000 \$ 000$ reis relativos aos meses de Julho, Agosto e Setembro, Sousa Holstein convocava uma sessão extraordinária para comunicar não ter sido possível fechar a compra da coleção Husson da Câmara, considerada prioritária entre as demais, pelo facto do seu proprietário se encontrar ausente do país. Como tal, sugeria que se avançasse com a aquisição das restantes coleções já aprovadas, "visto que S. M. o Sr. D. Fernando prometera fazer outro donativo para o futuro $a{ }^{\prime \prime 5}{ }^{57}$, revelando assim ter o monarca anuído à solicitação atrás mencionada. O diretor-geral, Francisco de Assis Rodrigues, aproveitou para comunicar o facto de Sousa Cambiaço estar na disposição de fazer um abatimento no valor da sua coleção de maneira a apressar a conclusão do negócio. Corroborando de certa forma a opinião expressa anteriormente por Cristino da Silva, Tomás da Anunciação considerou tal abatimento muito oportuno, "visto que alguns daqueles quadros não poderiam ser colocados nas salas por terem pouco mérito".

Animada com a perspectiva de um novo donativo real, encetará a Academia outros processos de negociação, merecendo destaque duas obras vindas de Itália, objecto de notícia na imprensa em Setembro de 1865:

\footnotetext{
${ }^{56}$ Declaração assinada por Cristino da Silva e datada de 12 de Julho de 1865. Idem, disponível em http://digitarq.dgarq.gov.pt/ PT-ANBA-ANBA-F-002-00001_m0267 e _m0268.

57 Conferência extraordinária de 18 de Agosto de 1865 . Idem, disponível em http://digitarq.dgarq.gov.pt/PT-ANBA-ANBA-F-002-00001_m0279.
} 
"Acham-se expostos na Academia das Belas Artes dois quadros de muito valor, que foram trazidos pelo nosso cônsul em Civitavecchia. Um deles representa uma formosa mulher com um triângulo na mão. É de Bernardino Luini, o mais eminente pintor da escola de Leonardo da Vinci. Está avaliado em três contos de réis. O outro é o retrato de um mancebo. Parece ser feito por André del Sarto, pois tem as iniciais A. V. São ambos admiráveis de colorido e desenho, e estão perfeitamente conservados. 0 segundo avalia-se em oito contos de reis" ${ }^{\prime 58}$.

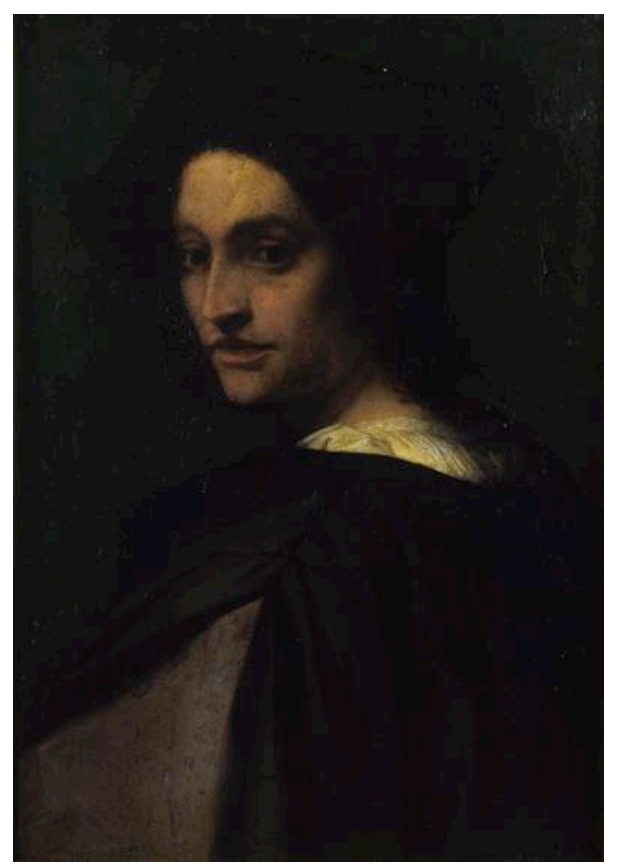

Fig. 40 - Andrea del Sarto (atrib.), Retrato de homem ou auto-retrato, c. 1513-1516 MNAA, inv. 542 Pint

O nosso cônsul em Civitavecchia era o italiano Giovanni Andrea Bustelli que no ano anterior oferecera à Academia um conjunto apreciável de desenhos antigos, numa manobra que tinha como principal objectivo ver o seu gesto reconhecido pelo governo português e conseguir que o seu filho e genro fossem agraciados com grau de cavaleiros da Ordem de Cristo. O facto de Filippo Bustelli ter reprovado na escola militar que frequentava ${ }^{59}$, e as suspeitas de burla do pai num negócio particular,

\footnotetext{
${ }^{58}$ Diario de Noticias, 9 de Setembro de 1865

${ }^{59}$ Num oficio dirigido ao ministro do Reino, o nosso embaixador em Itália refere: "Quanto a Filippo Bustelli, filho do cônsul de Portugal em Civitavecchia, devo dizer a V. Ex.a que há pouco saiu ele da escola miliar de cavalaria de Pinerolo onde cursou os estudos durante três anos, saindo reprovado e não
} 
levando à perda do cargo de cônsul em $1866^{60}$, terão constituído fortes entraves à concessão das desejadas mercês. Numa carta dirigida um ano mais tarde a Sousa Holstein ${ }^{61}$, o ex-cônsul reafirmava a sua inocência e lamentava com amargura a ausência de resposta do nosso governo que acabará eventualmente por reconhecer o gesto tido em 64, como sugere uma nova dádiva efectuada em 73. À semelhança de duas outras coleções congéneres doadas por intervenção do vice-inspetor (Carlo Becchis e Emílio Pampana), os desenhos de Bustelli encontram-se entre os mais relevantes incorporados pela Academia, com espécimes de Poussin, Tiepolo ou Guardi, entre outros mestres ${ }^{62}$.

Paralelamente aos desenhos, possuía Bustelli um conjunto de pinturas que se disponibilizou não a doar mas a vender. Estas prenderam desde logo a atenção do marquês que em 1864 custeou a deslocação de um funcionário do consulado de Portugal em Milão, seu intermediário, à residência florentina do ainda cônsul no sentido de mandar aferir a qualidade daquelas obras. Numa missiva enviada ao viceinspetor, escrevia que de acordo com as instruções recebidas se dirigira a Florença "para fazer ajuizar por pessoas competentes de mérito artístico os quadros que possui o Sr. G. A. Bustelli na sua casa sita nos subúrbios daquela cidade" ${ }^{63}$. Quando ao resultado do exame, o funcionário referira sentir "imensamente que o juízo pouco favorável dos peritos e o preço que o proprietário dos quadros pede por eles não seja talvez de acordo com os desejos em vista de V. Ex.므. Apesar dessa observação, e na sequência de terem sido expostos na Academia como vimos na notícia acima citada, Sousa Holstein entrará em acordo para a aquisição de dois quadros, porventura os únicos sancionados na peritagem: um suposto Andrea del Sarto (fig. 40) e um pretenso Luini $^{64}$, pelo valor global de $5.000 \$ 000$ reis, menos de metade do inicialmente pedido

podendo por tal motivo ser promovido a oficial". Oficio datado de 10 de Outubro de 1865. Arquivo Histórico-Diplomático do MNE, Legação de Portugal em Florença, cx. 54, doc. 51.

${ }^{60}$ A este respeito cf. os respectivos ofícios. Arquivo Histórico-Diplomático do MNE, Legação de Portugal em Florença, cx. 54, doc. 77 e 92.

61 Carta datada de Florença, 23 de Agosto de 1867. Arquivo da ANBA, disponível em http://digitarq.dgarq.gov.pt/ PT-ANBA-ANBA-B-001-00003_m1252.

${ }^{62}$ A este respeito cf. GOMES, Alexandra Reis - op. cit., pp. 18-19.

63 Carta datada de Milão, 2 de Junho de 1865. Arquivo da ANBA, disponível em http://digitarq.dgarq.gov.pt/ PT-ANBA-ANBA-B-001-00003_m1028 a _m1031. A citação seguinte reporta-se a esta referência.

64 Posteriormente atribuído a Francesco Melzi. MNAA, inv. 541 Pint. 
(11.000\$000 reis), a serem pagos em quatro prestações mensais, conforme acordo celebrado em Setembro de $65^{65}$.

A compra destas obras revestiu-se de um aspecto novo que deve ser assinalado: o não ter sido consultada a comissão de pintura para dar o seu parecer oficial, seguramente pela insegurança, falta de consenso e consequentes atritos gerados sempre que os seus membros se reuniam para deliberar. O vice-inspetor passaria a partir de então a chamar a si a decisão sobre as obras a adquirir, socorrendo-se dos pareceres informais de um ou outro professor ou de "peritos" estrangeiros como sucedeu com a coleção Bustelli, cabendo naturalmente a palavra final a D. Fernando II. O régio mecenas foi acompanhando com vivo interesse as propostas que lhe iam sendo submetidas, vindo também a tomar de forma autónoma decisões a esse respeito.

Com efeito, na sessão de 10 de Janeiro de 1866, Sousa Holstein comunicava que "por uma nova graça à Academia por El-Rei o Senhor D. Fernando, se dignara o mesmo senhor oferecer onze quadros que se compraram ao conde de Farrobo pela quantia de dezassete contos e duzentos mil reis" ${ }^{\prime 66}$. De acordo com o mesmo relato, o corpo académico "ouviu com geral satisfação esta notícia, decidindo unanimemente que se agradecesse a Sua Majestade e se fizesse dela honrosa menção na ata". Na sessão seguinte, fez-se de novo notar o espírito contestatário de Cristino da Silva ao pôr em causa a redação da ata anterior, acusando terem sido omitidas algumas palavras do vice-inspetor, "porque S. Ex. a tinha então declarado que apesar dos quadros serem de menor valor do que o de dezassete contos e duzentos mil reis, Sua Majestade se resolvera comprá-los por esse preço", insistindo para que disso se fizesse menção expressa na ata ${ }^{67}$.

Tanto o diretor-geral que presidia à conferência na ausência de Sousa Holstein, como os restantes membros se opuseram a tal explicação que consideravam despropositada, "fazendo ver que para ela ter lugar era preciso que aquela compra e avaliação tivesse sido presente à Academia". Sentindo-se ultrapassado na qualidade membro da

\footnotetext{
${ }^{65}$ Documento original assinado e datado de Setembro de 1865. Arquivo do MNAA, fundo José de Figueiredo, cx. 1, pasta 2, doc. 4/18

${ }^{66}$ Conferência ordinária de 10 de Janeiro de 1866. Arquivo da ANBA, disponível em http://digitarq.dgarq.gov.pt/ PT-ANBA-ANBA-F-002-00001_m0319 e_m0320.

67 Conferência ordinária de 3 de Fevereiro de 1866. Arquivo da ANBA, disponível em http://digitarq.dgarq.gov.pt/ PT-ANBA-ANBA-F-002-00001_m0323 e _m0324. As restantes citações reportam-se a esta referência.
} 
comissão de pintura, à qual não foi pedida qualquer opinião, Cristino não se deu por convencido com os argumentos dos colegas e protestará veementemente, envolvendo-se numa acesa discussão com o professor José da Costa Sequeira que exercia as funções de secretário. Foi então que "usando de palavras muito descomedias, se atreveu a insultá-lo, asseverando que era falsário". Escandalizado com a imoderação verbal, Sequeira abandonou a sala e o diretor-geral viu-se obrigado a dar por encerrada a sessão.

Polémicas académicas à parte, convirá enquadrar melhor esta aquisição que surge na sequência da derrocada financeira de Joaquim Pedro Quintela, em 1865, ao perder o processo do monopólio dos tabacos que the havia sido movido há muito por outro capitalista, Manuel Joaquim Pimenta, obrigando-o ao pagamento de uma pesadíssima indemnização ${ }^{68}$. Perseguido pelos credores, viu-se na contingência de se desfazer de parte dos seus bens, entre os quais algumas das melhores pinturas conservadas nos palácios da rua do Alecrim e das Laranjeiras, pelas quais D. Fernando entendeu dar mais de 17 contos de reis, provável gesto de apoio solidário para com um homem que compreendia talvez melhor que ninguém, atendendo ao interesse comum pela música e artes plásticas.

Figura retumbante da sociedade romântica portuguesa, o conde de Farrobo nutria verdadeira paixão pelo teatro lírico, estando o seu nome vinculado à história do São Carlos, de que foi empresário, e à construção de um teatro de seiscentos lugares na sua quinta das Laranjeiras, consumindo grossos cabedais na contratação de músicos, cantores e maestros de nomeada. Foi também, como já tivemos oportunidade de referir, vice-inspetor da Academia das Belas Artes, o primeiro a ocupar o cargo por nomeação de Passos Manuel, e chegou a custear a formação romana de António Manuel da Fonseca, a quem se devem as grandes composições com figuras mitológicas que se estendem por paredes e tectos do palácio da rua do Alecrim.

O contrato de venda celebrado com a Academia a 2 de Janeiro de $1866^{69}$ incluía duas telas daquele artista, uma Transfiguração de Cristo, cópia de Rafael, e uma Comunhão de São Jerónimo, segundo Domenichino ${ }^{70}$, ambas executadas durante os seus estudos

\footnotetext{
${ }^{68}$ Cf. NORONHA, Eduardo de - Estroinas e estroinices: ruina e morte do conde de Farrobo, 1922.

${ }^{69}$ Cópia manuscrita conservada no arquivo do MNAA, fundo José de Figueiredo, cx. 1, pasta 4, doc. 7.

${ }^{70}$ MNAA, inv. 555 e 556 Pint.
} 
em Roma e adquiridas provavelmente pelo conde em 1835, naquela que terá sido a primeira exposição pública realizada em Lisboa, no desafectado convento do Espírito Santo, ao Chiado. Entre os autores estrangeiros, uma grande composição floral de van Dael, especialidade do pintor, e duas Virgens com o Menino associadas a Perugino e Holbein, esta última mais tarde atribuída a Eduardo, o Português (fig. 41). O grande destaque ia então para um suposto retrato de Vasco de Gama (fig. 42), obra anteriormente restaurada por um italiano residente em Lisboa, Lugi Tirinanzi, que chegou a publicar no Diario do Governo de 1845 uma "descrição artística" do mesmo ${ }^{71}$, dando como certa a identificação do retratado, e atribuindo a sua execução a Cristóvão de Utrecht, discípulo de Moro $^{72}$. Apesar de não ser hoje consensual, a identificação acabou por se tornar quase indelével por força das sucessivas referências em comemorações e efemérides ao longo de Oitocentos, pelo que se veio a impor como fonte iconográfica do navegador.
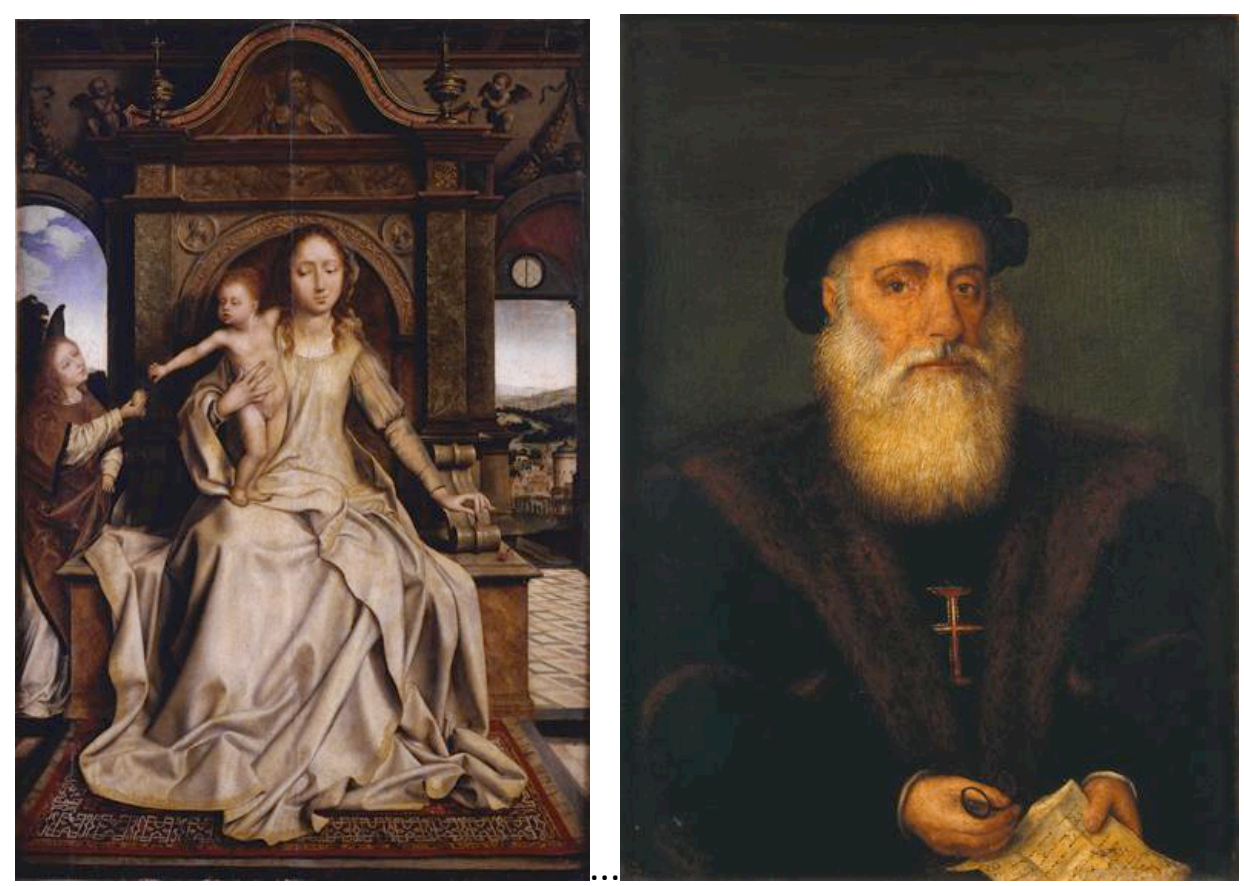

Fig. 41 - Eduardo, o Português (atrib.) ou autor luso-flamengo não identificado, Virgem com o Menino $e$ Anjo, c. 1520. MNAA, inv. 546 Pint

Fig. 42 - Autor não identificado, Suposto retrato de Vasco da Gama, séc. XVI. MNAA, inv. 550 Pint

\footnotetext{
71 "Descrição artística do retrato do insigne Vasco da Gama, oferecido ao público por Luís Tirinanzi". Diário do Governo, 22 de Junho de 1845. Tirinanzi solicitou ao conde a autorização para mandar litografar o retrato, o que foi feito em colaboração com Maurício José Sendim. Sobre a atividade Tirinanzi enquanto restaurador cf. ARAÚJO, Agostinho - op. cit., pp. 33-38.

${ }^{72}$ Figura na 1.a edição do Catalogo provisorio com o n.o 146 como sendo já obra de "Cornelio de Leão" (Corneille de Lyon), pintor francês do séc. XVI.
} 
Sousa Holstein terá ficado à margem deste negócio, gizado entre o conde e o monarca, o que justifica talvez a ausência naquele agrupamento de algumas obras de Domingos Sequeira existentes na coleção, como as duas telas pintadas em 1812 para o barão de Quintela (pai), representando respectivamente o Génio da Nação Portuguesa e Lisboa protegendo os seus habitantes ${ }^{73}$.

Durante o ano de 1866, serão celebrados pela Academia contratos com uma periodicidade quase mensal, onde à semelhança do que sucedera ultimamente, não foi chamada a comissão de pintura para dar o seu parecer oficial. Mais dirigidas, essas aquisições abrangerão diversos proprietários, circunscrevendo-se muitas vezes a uma só obra por contrato. Foi o caso de um Festim de Herodes associado a Rubens, obra avaliada na importante quantia de $3.500 \$ 000$ reis e pertencente a um amigo de $D$. Fernando II, António Maria Fidié que fechou negócio com a Academia a 24 de Janeiro daquele $a{ }^{74}$. Fidié ocupava em 1825 o posto de 2. tenente e ajudante de ordens do governo de Porto Santo, sendo anos mais tarde promovido por D. Miguel a capitão do regimento de artilharia de Faro conforme anúncio publicado na Gazeta de Lisboa ${ }^{75}$. Terá abandonado a carreira militar com o advento do Liberalismo, surgindo com pose de grande burguês em 1848, numa luxuosa litografia de Santa Bárbara com fac-símile de assinatura ${ }^{76}$. Dedicar-se-ia já então à aquisição de pinturas, reunindo uma coleção cuja amplitude permanece por avaliar, sabendo-se ter incluído uma Lamentação sobre Cristo Morto do Retábulo das sete dores da Virgem que a oficina de Quentin de Metsys executou no início do séc. XVI para o convento de Madre de Deus ${ }^{77}$, um tondo renascentista em faiança associado à produção dos Della Robbia, e quatro tábuas com representações de santos atribuídos aos Mestres de Ferreirim ${ }^{78}$, obras hoje conservadas no Museu D. João VI da Universidade Federal do Rio de Janeiro.

\footnotetext{
${ }^{73}$ Passaram mais tarde à coleção do conde de Ameal, vindo a ser adquiridas no seu leilão (1921) pelo Município de Lisboa. Conservam-se hoje no Museu da Cidade, inv. 268 e 269 Pint. O conhecido retrato de Farrobo executado pelo mesmo autor, em 1813, seria comprado pelo MNAA a um seu descendente, em 1937, inv. 1826 Pint.

${ }^{74}$ Contrato manuscrito original assinado por Fidié e datado de 24 de Janeiro de 1866. Arquivo do MNAA, fundo José de Figueiredo, cx. 1, pasta 3, doc. 1/D. A obra figura na 1a ed. do Catalogo provisorio (1868) com o n.o 131 como sendo já de "estilo de Rubens". MNAA, inv. 543 Pint.

${ }^{75}$ Gazeta de Lisboa, n.․7, 30 de Março de 1833

${ }^{76}$ Cf. Biblioteca Nacional Digital http://purl.pt/4553

77 LEITE, J. R. Teixeira - “Um quadro de Metsijs no Brasil”. Colóquio, n.o 8, 1960, p. 25.

78 SERRÃO, Vítor - "Quatro ignorados painéis dos Mestres de Ferreirim no Museu D. João VI da Universidade Federal do Rio de Janeiro". Estudo da Pintura Portuguesa: oficina de Gregório Lopes: actas/seminário internacional, 1999, pp. 123-127.
} 
A 10 de Março é adquirido por $112 \$ 500$ reis um miniatural retrato a óleo que o proprietário, António Dâmaso de Castro e Sousa (1804-1876), assegurava disparatadamente representar o "Doutor João das Regras, insigne jurisconsulto e famoso na história pelos fins do século décimo quarto" ${ }^{\prime 79}$. Efetuará ainda outras vendas que se estenderam ao domínio da escultura, nomeadamente, um conjunto de dez bustos em cera atribuídos a Gaetano Zumbo, "nas suas obras superior a Jean Varin" conforme declaração assinada em 1870 , já fora das dádivas de D. Fernando ${ }^{80}$. Sócio honorário da Academia com quem vimos ter colaborado na catalogação de pinturas, o abade de Castro como era vulgarmente conhecido, dedicou-se à investigação histórica tendo publicado diversos opúsculos de temática vária que deixam transparecer uma erudição algo caricatural, representativa de uma mentalidade ainda monástica, transplantada para o Liberalismo ${ }^{81}$. Seria retratado por Rebelo da Silva em 1852 na Mocidade de $D$. João $V$, dele deixando igualmente uma impressão caricata a marquesa de Rio Maior nas suas memórias ${ }^{82}$.

Num recibo passado em Maio, José Augusto Palha declarava ter recebido do marquês de Sousa Holstein $39 \$ 600$ reis, "importância de um quadro de paisagem comprado na venda da Exma. Sr. D. Maria Carlota de Bragança, para o que S. Ex. a me autorizou" ${ }^{83}$. Relativa à coleção de uma das grandes famílias do reino, a dos duques de Lafões, a venda em questão corresponderá à que se realizou naquele ano no palácio do Grilo, próximo do Beato, compreendo mais de 100 lotes de acordo com o catálogo então editado $^{84}$. José Augusto Palha surge-nos aqui como um mero intermediário, função

\footnotetext{
${ }^{79}$ Recibo assinado e datado de 10 de Março de 1866. Arquivo do MNAA, fundo José de Figueiredo, cx. 1, pasta 2, doc. 4/9.

${ }^{80}$ Declaração assinada e datada de 12 de Maio de 1870. Idem, cx. 1, pasta 5, doc. 7.

${ }^{81}$ Poderemos destacar textos sobre Mosteiro de Santa Maria de Belém (1837), a Bíblia dos Jerónimos (1839), o Castelo dos Mouros de Sintra (1843), Francisco da Holanda (1844), entre outros.

82 "Este abade de Castro era um tipo muito conhecido de Lisboa (...). Não era padre, mas dava-se ares de bispo. Usava um grande anel de ametista, que as educandas de S. Pedro de Alcântara beijavam com respeito. Acreditava-se que era conhecedor em coisas de história, e histórias antigas; de vez em quando publicava obras de uma dúzia de folhas; e mesmo assim, se se aprofundavam, ai dele. Dava raia. Era bastante alto, e usava uma casaca excessivamente comprida; escanhoava-se muito, e trazia sempre um bonezinho preto, de padre". COLAÇO, Branca de Gonta - Memórias da marquesa de Rio Maior, 2. ed., 2005, p. 179.

${ }^{83}$ Documento assinado e datado de 16 de Março de 1866. Arquivo do MNAA, fundo José de Figueiredo, cx. 1, pasta 2, doc. 4; 11. A pintura corresponde ao n.o 167 da 1.a ed. do Catalogo provisorio: "Lyvio Mevio / Paisagem com figuras". É indicada a proveniência: "comprado no leilão da galeria Lafões em 1866".

${ }^{84}$ Leilão de quadros a óleo antigos pertencentes à galleria do Illm.o e Exm.o Sr. duque de Lafões, existentes no seu palacio ao Grillo (próximo do Beato) em Lisboa. Por intervenção do agente Casimiro
} 
que sabemos ter exercido em 1867, ao trazer consigo de Paris, com destino à galeria da Ajuda, duas pinturas de Yvon e Palizzi que haviam figurado na exposição internacional promovida naquele $a^{85}{ }^{85}$. Filho de um influente desembargador do Paço, José Pereira Palha de Faria Guião, fidalgo com larga atividade agrícola no Alentejo e Ribatejo, cursou direito em Coimbra onde se encontrava matriculado em $1842^{86}$. Pouco mais conseguimos apurar sobre esta figura, provável colecionador com alguma experiência no mercado de arte que em Maio de 66 venderia à Academia cinco pinturas, associadas respectivamente a Salvator Rosa, Rigaud, Pieter van Laer, Philippe de Champaigne e, merecendo destaque estre os demais, uma cena bíblica de Godfried Schalcken ${ }^{87}$, num total de $1.600 \$ 000$ reis $^{88}$.

Nesse mesmo mês seria fechado outro acordo, desta vez com um alemão da Boémia, Wensceslau Cifka (1811-1883), conselheiro artístico e colaborador devotado de D. Fernando, cuja atividade se estendeu à fotografia, de que foi um dos pioneiros em Portugal, ao desenho, à litografia e sobretudo à cerâmica, influenciando o monarca que também experimentou essa arte. Reuniu uma numerosa coleção de gravuras que Ihe serviam de inspiração nas suas criações cerâmicas, para além de uma notável colectânea de 171 desenhos de mestres nacionais e estrangeiros, integrados no chamado "Álbum Cifka", adquirido pelo Estado aos herdeiros do artista, em 1892. À Academia venderia três pinturas, uma Crucifixão atribuída a Mengs, um Cristo perante Pilatos tido como executado por Martin de Vos, e um retrato de Vieira Lusitano, pela importância de $1.100 \$ 000$ reis $^{89}$.

Um recibo datado de 12 de Junho atesta uma compra de $300 \$ 000$ reis, "importância de um quadro, a qual fica lançada a crédito do Exmo. Sr. J. L. O’Sullivan" ${ }^{\prime 90}$. Influente colunista norte-americano, co-fundador e editor da Democratic Review, John Louis O’Sullivan (1813-1895) fora nomeado em 1854 para exercer funções diplomáticas em

Cândido da Cunha no dia 23 de Abril de 1865, e dias seguintes às 11 horas da manhã. Esta venda viria a realizar-se um ano após a data indicada no catálogo.

${ }^{85}$ XAVIER, Hugo - op. cit., p. 119.

${ }^{86}$ Relação e indice alfabetico dos estudantes matriculados na Universidade de Coimbra no anno lectivo de 1842 para 1843 com suas naturalidades e filiações e moradas, 1842, p. 13.

${ }^{87}$ Godfried Schalckein, $A$ pitonisa de Endor, MNAA, inv. 538 Pint

${ }^{88}$ Documento original assinado e datado de 24 de Maio de 1866. Arquivo do MNAA, fundo José de Figueiredo, cx. 1 , pasta 3 , doc. $1 / \mathrm{H}$.

${ }^{89}$ Documento assinado e datado de 15 de Maio de 1866. Arquivo do MNAA, fundo José de Figueiredo, cx. 1, pasta 3, doc. $1 / \mathrm{F}$.

${ }^{90}$ Documento assinado e datado de 12 de Junho de 1866. Idem, cx. 1, pasta 2, doc. 4/33. 
Portugal, após ter sido julgado por participar ativamente na angariação de fundos para a independência de Cuba, comprometendo a neutralidade do seu país ${ }^{91}$. Ocupou o cargo de ministro até 1858, mas continuaria a viver entre nós por mais alguns anos, revelando extraordinário golpe de vista na aquisição de várias pinturas, como uma inacabada Coroação da Virgem de Sequeira (fig. 43), obra a que se refere o recibo acima citado.

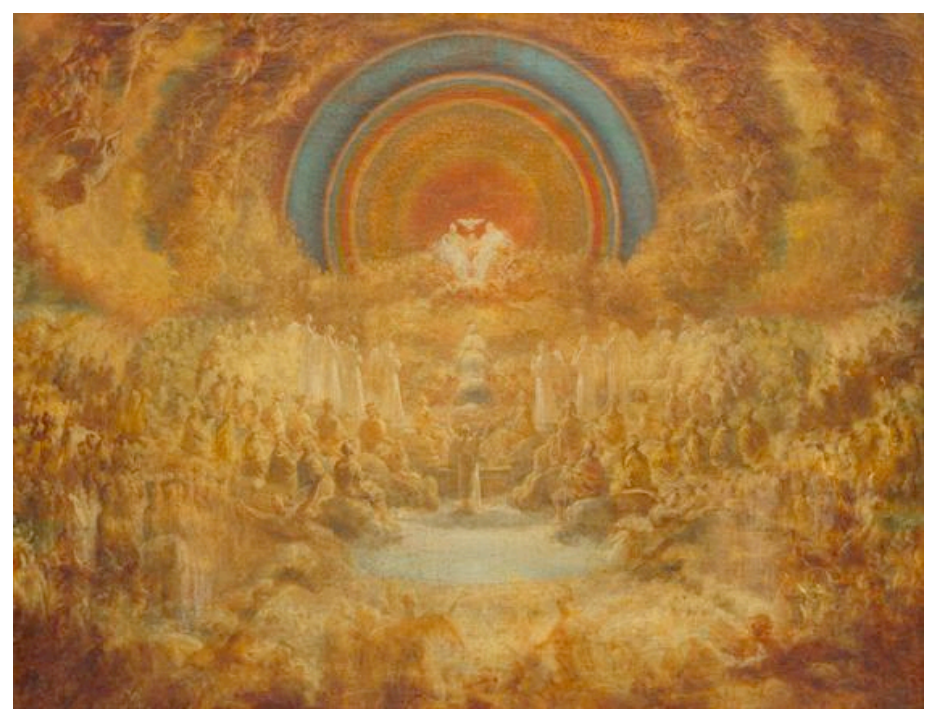

Fig. 43 - Domingos Sequeira, Coroação da Virgem, c. 1830. MNAA, inv. 544 Pint

O seu resgate pela Academia deixa transparecer a provável interferência de Sousa Holstein que revelava especial pendor pelo artista e cujos contactos no meio diplomático haviam já proporcionado diversas aquisições. Talvez por intervenção do vice-inspetor, viria o diplomata americano a fazer-se sócio da Sociedade Promotora das Belas Artes, tendo sido contemplado na primeira exposição com um prémio do sorteio de obras de arte que Ihe valeu um quadro de Cristino da Silva ${ }^{92}$. Celebrizado pela expressão "Manifest Destiny" cunhada em 1845 para promover a anexação das regiões do Texas e Oregon, O'Sullivan chegou ainda a adquirir em Lisboa uma pequena cena mitológica de um seguidor de Rubens que levou para os Estados Unidos onde se fixou na década de 1870, obra conservada atualmente no Museu de Belas Artes de Boston 93 .

\footnotetext{
${ }^{91}$ Sobre esta figura cf. SAMPSON, Robert - John L. O'Sullivan and his times, 2003.

92 PRIETO, Joaquim - op. cit., p. 321.

${ }^{93}$ Follower of Peter Paul Rubens, Drunken Bacchus with Faun and Satyr, Museum of Fine Arts, Boston, inv. 79.164.
} 
A 10 de Julho adquiriam-se por $150 \$ 000$ reis dois quadros, "um dos quais composição de Bernardo Castelli (sic) representando a mulher adúltera, acusada pelos fariseus; o outro de autor incerto, que representa uma pequena expedição desembarcando em uma paragem desconhecida"94. Assinava essa declaração António José Viale (18061889), erudito latinista e helenista de origem italiana que se distinguiu pelas suas traduções do latim e do grego clássico para português e do português para latim ${ }^{95}$. No mesmo mês seriam efectuadas outras aquisições a dois proprietários cujos nomes não deixaram aparentemente rasto. Por um lado, João José Dantas que fez cobrar $150 \$ 000$ reis por um esboceto de Viera Portuense figurando a Assunção de Nossa Senhora, e por uma notável "cabeça flamenga" que revelou ser obra de Antonio Moro (fig. 44) . $^{96}$. Por outro, Dâmaso Pires Vila Nova com um Interior de igreja de Pieter Neefs avaliado em $600 \$ 000$ reis $^{97}$, obra referenciada pela imprensa ao considerar ser "uma das melhores aquisições que a Academia Real das Belas Artes fez ultimamente" ${ }^{\prime 98}$.

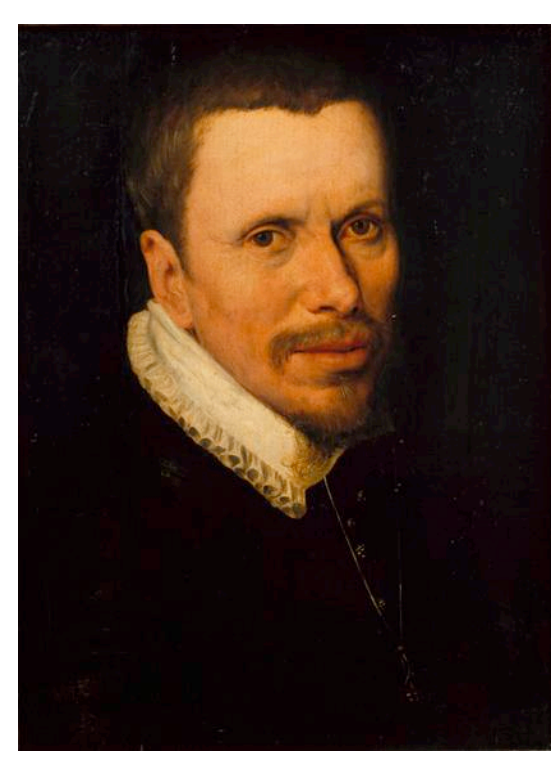

Fig. 44 - Antonio Moro, Retrato de homem, c. 1555-1565. MNAA, inv. 565 Pint

\footnotetext{
${ }^{94}$ Documento assinado e datado de 10 de Julho de 1866. Arquivo do MNAA, fundo José de Figueiredo, cx. 1, pasta 2, doc. 4/31. No Catalogo provisorio figura apenas a segunda pintura com o n. 0 114, "Desembarque de uma força militar", atribuído a Jacques Callot. A primeira corresponde ao Cristo e a mulher adúltera de Valerio Castello, MNAA, inv. 563 Pint.

${ }^{95}$ Entre outras obras produziu uma versão de Os Lusíadas em latim e o Bosquejo histórico-poético, uma história de Portugal em verso hexâmetro.

${ }^{96}$ Declaração assinada e datada de 11 de Julho de 1866. Arquivo do MNAA, fundo José de Figueiredo, cx. 1 , pasta 2, doc. 4/32.

${ }^{97}$ Recibo assinado e datado 19 de Julho de 1866. Idem, cx. 1, pasta 2, doc. 3/36. A obra em questão corresponde ao n.o 145 da 1. a ed. do Catalogo provisorio: “NEEFS (Peter) / Flamengo 1570-1651 / 145. Interior de uma catedral / A. 0,72 L. 0,85 (cobre) / D. F. Idem". MNAA, inv. 567 Pint.

${ }^{98}$ Diario de Noticias, 30 de Novembro de 1866
} 
A 15 de Novembro fechou-se finalmente negócio com Jorge Husson da Câmara que entendeu reduzir o valor por que havia sido avaliada a sua coleção de 27 para 20 contos de reis, "prova do muito que desejo contribuir para o aumento das nossas galerias nacionais e para a prosperidade das Belas Artes", como declarou no contrato $^{99}$. Simultaneamente, num gesto de grande generosidade, fazia "plena, inteira e perpétua doação à Academia da minha livraria no valor de seis contos de reis, expressando a vontade que aquela fosse "conservada na ordem em que se acha, com uma declaração que ateste a sua proveniência" (fig. 45).

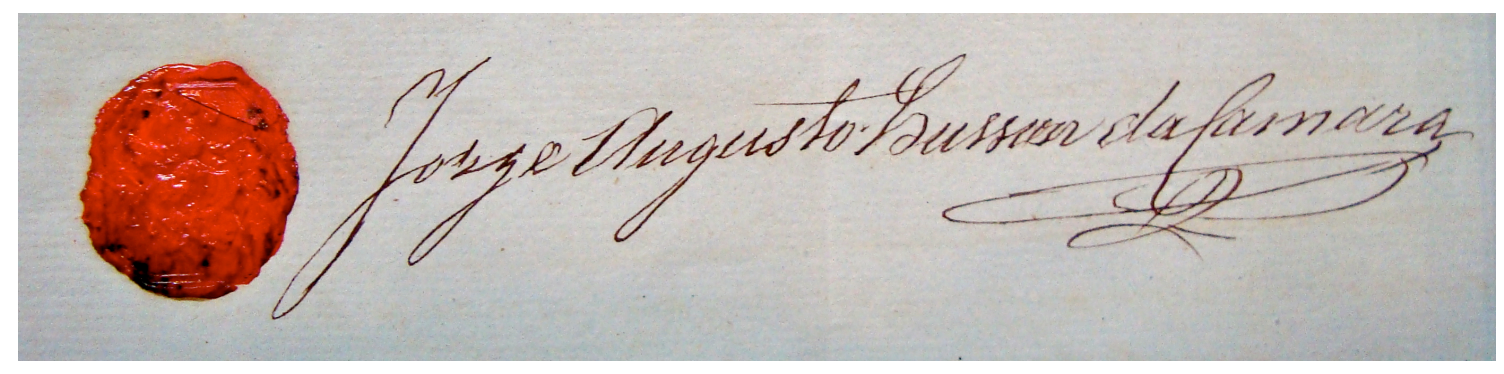

Fig. 45 - Assinatura e selo em lacre de Jorge Husson da Câmara, 1866. Arquivo do MNAA

O balanço das aquisições realizadas durante o ano de 1866 teve lugar na sessão académica de 5 de Dezembro. De acordo com a ata, o vice-inspetor, "fazendo a breve exposição das diligências e trabalhos que tinha empregado para organizar e enriquecer a galeria nacional, e dando conta das importantes aquisições de quadros comprados mediante os valiosos auxílios pecuniários concedidos à Academia por S. M. El-Rei o Sr. D. Fernando, participou que já se achavam colocadas na respectiva sala as magníficas pinturas que formavam a coleção do Exmo. comendador Jorge Husson da Câmara", dando a conhecer o "notável abatimento" efectuado ${ }^{100}$. Participou ainda à conferência a oferta da respectiva biblioteca, propondo que se "consignasse na ata um voto de agradecimento ao mencionado comendador, fazendo-se-lhe constar por escrito os agradecimentos do corpo académico". Saudado pelo Diario de Noticias como "a prova mais evidente do seu verdadeiro amor pátrio"101, o gesto de Husson da Câmara,

\footnotetext{
${ }^{99}$ Documento assinado e datado de 15 de Novembro de 1866. Arquivo do MNAA, fundo José de Figueiredo, cx. 1, pasta 3, doc. 1. A citação seguinte reporta-se ao mesmo documento.

100 Conferência ordinária de 5 de Dezembro de 1866. Arquivo da ANBA, disponível em http://digitarq.dgarq.gov.pt/ PT-ANBA-ANBA-F-002-00001_m0381 a_m0382.

${ }^{101}$ Diario de Noticias, 8 de Dezembro de 1866
} 
associado à sua longa carreira diplomática, terá seguramente contribuído para o título de visconde de São Justo com que foi agraciado por D. Luís, por decreto de 6 de Setembro de 1877. Pouco pôde usufruir da distinção pois viria a falecer um mês e meio depois, na estância balnear de San Benedetto del Tronto, deixando viúva Sofia Lanoir Parisieu.

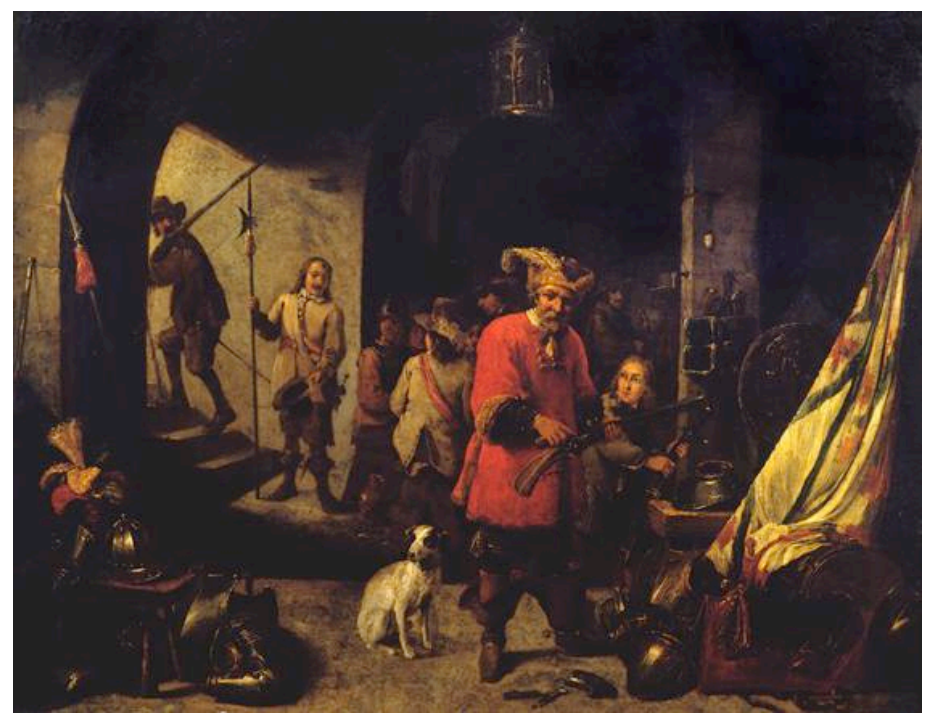

Fig. 46 - David Teniers, o Moço, Depósito de armas, 1667. MNAA, inv. 585 Pint

Voltando à ata, comunicava ainda o vice-inspetor que "com permissão do Senhor D. Fernando havia efectuado a compra de um novo quadro". Tratava-se do Depósito de armas de David Teniers, o Moço, (fig. 46) derradeira aquisição daquele ano pelo vantajoso preço de $112 \$ 500$ reis, conforme declaração assinada a 4 de Dezembro ${ }^{102}$ por Domingos Garcia Peres (1811-1902), influente médico tornado político que havia estudado em Espanha, onde estabeleceu contactos com algumas figuras eminentes tais como o duque de Rivas, Mariano José de Larra ou dramaturgo Antonio García Gutiérrez, seu colega no Colégio Universitário de Granada. No negócio com a Academia atuou como representante de um outro espanhol, Don Santiago Vasco y Sarria (1810-1871), aristocrata granadino a quem pertencia a pintura. Domingos Garcia Peres foi ainda um entusiasta da arqueologia ${ }^{103}$, destacando-se na qualidade de sócio

\footnotetext{
102 Documento assinado e datado de 4 de Dezembro de 1866. Arquivo do MNAA, fundo José de Figueiredo, cx. 1, pasta 2, doc. 4/6.

103 Tal interesse favoreceu a aproximação à Academia a quem ofereceu, em 1865, "duas obras literárias sobre arquitetura e arqueologia escritas por Mr. Eduard Laforge". Conferência ordinária de 30 de maio
} 
fundador da Sociedade Arqueológica Lusitana, presidida vitaliciamente pelo 1. duque de Palmela, pai de Sousa Holstein ${ }^{104}$.

O ritmo das aquisições abrandou significativamente em 1867, com parte importante da verba a ser aplicada no pagamento de prestações, em restauros e em obras nas salas reservadas à galeria de que adiante falaremos. A 22 de Março regista-se uma nova compra, $143 \$ 800$ reis "em metal sonante pela venda de um quadro pintado a óleo representado frutos, mariscos e objetos de prata" ${ }^{105}$. O recibo em questão encontra-se assinado por Casimiro Cândido da Cunha, avaliador e agente leiloeiro responsável pela venda Lafões atrás referenciada ${ }^{106}$ e por diversos leilões generalistas anunciados com alguma regularidade na imprensa da época ${ }^{107}$. Elegantemente situado na então rua do Chiado, atual rua Garrett, o estabelecimento que possuía lograva ser visitado por D. Fernando II, seu cliente ${ }^{108}$. Para a galeria do rei D. Luís forneceu no mesmo ano de 67, entre outras pinturas, um pretenso Rubens cuja factura indica ter sido adquirido em Lisboa por sua intervenção ${ }^{109}$. Tal sugere ter agido como intermediário ou licitante, provavelmente na segunda venda Lafões, um "leilão judicial" para efeito de partilhas entre os herdeiros de D. Maria Carlota de Bragança, entretanto falecida. Não foi editado catálogo mas apenas uma relação que podia ser consultada no Tribunal da Boa Hora, segundo informação do Diario de Noticias que alude à existência de obras Van Dyck, Rubens ou Tintoretto, entre outros presumidos mestres $^{110}$. A natureza-morta adquirida naquele ano pela Academia provém

de 1865. Arquivo da ANBA, disponível em http://digitarq.dgarq.gov.pt/ PT-ANBA-ANBA-F-00200001_m254.TIF

${ }^{104}$ Parte importante do espólio arqueológico reunido por esta sociedade virá a reverter a favor da Academia. A este respeito cf. ponto IV.

105 Documento assinado e datado de 22 de Março de 1867. Arquivo do MNAA, fundo José de Figueiredo, cx. 1 , pasta 2 , doc. $7 / 52$

${ }^{106}$ Leilão de quadros a óleo antigos pertencentes à galleria do IIIm.o e Exm.o Sr. duque de Lafões, existentes no seu palacio ao Grillo (proximo do Beato) em Lisboa. por intervenção do agente Casimiro Cândido da Cunha no dia 23 de Abril de 1865, e dias seguintes ás 11 horas da manhã. Esta venda viria a realizar-se um ano após a data indicada no catálogo e não terá tido grande sucesso o que explica a ocorrência de um segundo leilão em 1867.

${ }^{107}$ Cf. o anúncio: "Leilão de loiças, sedas e móveis da Índia, antigos e modernos". Diario de Noticias, 25 de Janeiro de 1867.

108 “El-rei o sr. D. Fernando saiu ontem de tarde com sua esposa a Sr.a condessa d'Edla [...] el-rei e sua esposa dirigiram-se para o Chiado, entrando no escritório do agente de leilões o Sr. Casimiro C. da Cunha". Idem, 7 de Abril de 1870.

${ }^{109}$ XAVIER, Hugo - op. cit., pp. 81-82.

110 “LEILÃO DE QUADROS A OLEO (ANTIGOS) pelo Juízo de Direito dos órfãos da 1. a vara, escrivão Coimbra. - No dia 20 do corrente mês de Março e seguintes, às 11 horas da manhã, na Praça Luís de Camões, 36, 3. andar, se há de proceder á venda em leilão judicial dos quadros a óleo da antiga galeria 
precisamente dessa venda como atesta a indicação patente no Catalogo provisorio "comprado em 1867 à galeria da casa Lafões" - encontrando-se classificada como obra de Jan Davidsz de Heem ${ }^{111}$.

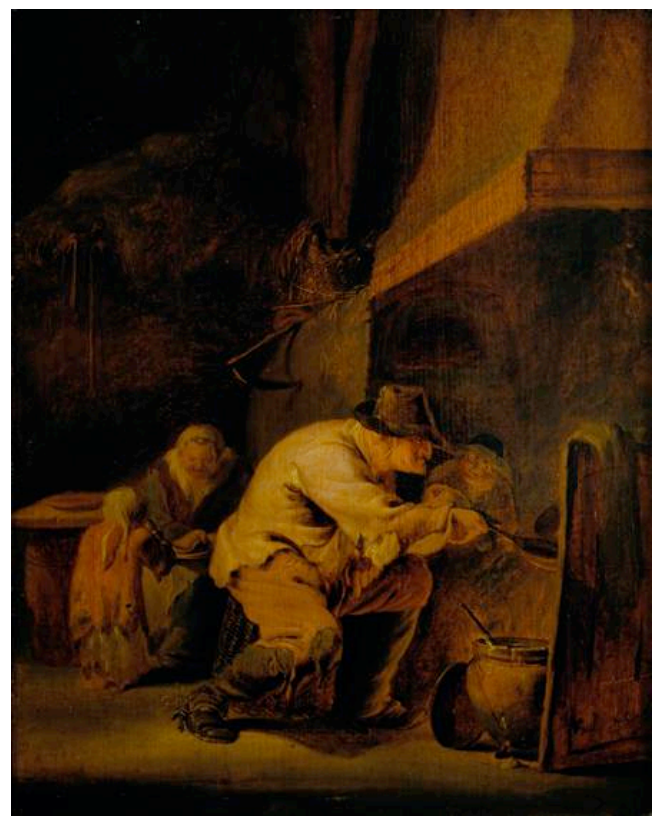

Fig. 47 - Jan Steen, Homem cozinhando, c. 1650-1675. MNAA, inv. 696 Pint

A partir de então registou-se uma quebra quase definitiva na dinâmica aquisitiva da Academia que concentrou todos os esforços e recursos na organização e abertura da tão aguardada galeria nacional, finalmente ocorrida a 29 de Março de 1868. A 15 de Fevereiro do ano seguinte teve lugar a derradeira aquisição, $60 \$ 000$ reis "por um quadro pintado a óleo sobre madeira com a dimensão de 33 de altura por 27 de largura, representando uma cena doméstica à lareira"112, declarava o proprietário e antigo aluno da instituição, o pintor José Rodrigues (1828-1887). Atribuída hoje a Jan Steen, a obra em questão (fig. 47) é um bom exemplo do interesse pelos costumes populares e castiços dos pintores holandeses de seiscentos, valores retomados com um empenho algo etnográfico e de vaga preocupação social pelos artistas românticos

da casa de Lafões, e cuja venda ora se procede em virtude do inventário da falecida Exma. Sr.a D. Maria Carlota de Bragança; compondo-se a dita galeria de muitos quadros, sendo alguns dos seguintes autores; Van Dyck, Rubens, Bassano, Tintoretto, Mignard, Carracci, Lucas Giordano, Domenichino, André del Sarto, Giacomo Brandi, Carlos Lorraine, e de muitos outros autores das escolas italiana, holandesa e espanhola. O catálogo dos ditos quadros pode ver-se no inventário, no cartório do escrivão Coimbra, no tribunal da Boa Hora". Diario de Noticias, 9 de Março de 1867

${ }^{111}$ Corresponde ao n.o 315 da 1. a ed. do Catalogo provisorio. MNAA, inv. 627 Pint.

${ }^{112}$ Recibo assinado e datado de 15 de Fevereiro de 1869. Arquivo do MNAA, fundo José de Figueiredo, cx. 1 , pasta 3 , doc $6 / 121$. 
como José Rodrigues, celebrado autor de $O$ cego rabequista $(1855)^{113}$. Homem de origens modestas, foi acima de tudo um prolifero e qualificado retratista, especialidade a que se dedicou mais por obrigação do que por vocação e onde alcançou grande notoriedade.

O ano de 1869 será marcado por uma acesa polémica despoletada pelo sensacionalista Diario Popular que na sua edição de 18 de Outubro lançava várias acusações à ação do vice-inspetor, ao referir que na compra das pinturas "raras vezes é consultada a comissão de pintura para dar o seu parecer oficial", e pondo em causa a transparência de certos negócios, como o dos pretensos Andrea del Sarto e Luini comprados em 1865 ao cônsul Bustelli: "basta dizer que por dois quadros n.ํs 144 e 155, avaliados oficiosamente por peritos em 200 mil libras, se deram 5 contos de réis!" ${ }^{\prime 14}$. Sousa Holstein reagirá de imediato em carta enviada ao mesmo jornal, dizendo-se "atrozmente caluniado" e indagando sobre quem tomava a responsabilidade das acusações $^{115}$. Previsível, a resposta recaiu sobre Cristino da Silva que já vimos ter manifestado o seu espírito contestatário nas sessões académicas a respeito de certas aquisições, espírito esse que ganhava agora outros contornos, com o artista a distribuir publicamente uns panfletos onde desafiava o marquês a defender-se das acusações feitas na imprensa. O jornal $A$ Lanterna radicalizou a questão, ao dar cobertura a Cristino num artigo publicado sob o título de "Um crime de camarilha", juntamente com uma carta de Marciano da Silva que, desentendido com Sousa Holstein a respeito do concurso para professor de pintura histórica, cargo que pretendia acumular com o de diretor da Galeria de Pintura da Ajuda, intervinha a favor do ex-colega, deitando mais achas para a fogueira. Escrevia Marciano que durante a visita efectuada à Academia, em 1866, Charles Robinson, superintendente das coleções do South Kensington Museum, havia considerado "muito duvidosos" os dois quadros adquiridos a Bustelli, avaliando-os tão somente em 100 mil libras $^{116}$.

A polémica terminaria abruptamente com um novo e melodramático escândalo desencadeado pelo artista que, no seu gabinete da Academia, agrediu fisicamente um

\footnotetext{
${ }^{113}$ RAMOS, Afonso - “José Rodrigues e 'O cego rabequista'”. SILVA, Raquel Henriques da (coord.) Revista de História da Arte, n.ㅇ 8, 2011, pp. 276-285.

${ }^{114}$ Diario Popular, 18 de Outubro de 1869

115 Idem, 19 de Outubro de 1869

${ }^{116}$ A Lanterna: Folha Politica, n. 30, Outubro de 1869
} 
contínuo a quem acusou de roubo, gerando grande alvoroço. Estudantes, entre os quais José Malhoa, professores como Vítor Bastos, Lupi e outros, acorreram ao local e conseguiram afastar Cristino que se barricou num compartimento contíguo, exigindo a presença do diretor-geral. Francisco de Assis Rodrigues apareceu com dois polícias que o conduziram a Rilhafoles onde foi internado com "manias e delírios agudos", segundo diagnóstico do diretor daquela instituição hospitalar ${ }^{117}$. Esse derradeiro escândalo coincidiu com a defesa de Sousa Holstein que publicou no jornal onde haviam sido feitas as acusações uma carta de D. Fernando II, reafirmando a confiança na sua pessoa e aprovando a compra dos referidos quadros.

Em Fevereiro de 1870, o vice-inspetor apresentou ao monarca o balanço das aquisições num relatório ${ }^{118}$ acompanhado por vários documentos, entre recibos, facturas e um mapa detalhado das despesas ${ }^{119}$. Começa por referir que o valor total disponibilizado foi de 65 contos de reis, "divididos por quatro anos económicos - os de 1865 a 1866 até 1868 a 1869, sendo vinte contos em cada um dos três primeiros e cinco no último"120. A referida quantia foi aplicada, na sua esmagadora maioria, nos quadros para a galeria nacional, reservando-se, na falta de subsídio estatal, uma pequena parcela para a compra de "alguns livros para a biblioteca da Academia, vários objetos de valor arqueológico ou artístico para o Museu de Arte Ornamental, alguns arranjos indispensáveis nas salas da galeria, num gabinete de recepção e à compra de molduras". Só na aquisição de pinturas foram despendidos $62.524 \$ 072$ reis, seguindose as despesas com molduras ( $872 \$ 269$ reis), com as obras na galeria ( $809 \$ 550$ reis), com a compra de livros para a biblioteca ( $429 \$ 280$ reis) e, finalmente, com alguns objetos destinados ao futuro Museu de Arte Ornamental de que adiante falaremos (61\$800 reis). Contabilizadas foram ainda algumas “despesas miúdas" relativas ao

\footnotetext{
${ }^{117}$ Cf. Diario de Noticias, 18 de Novembro de 1869 e acta da conferência extraordinária de 17 de Novembro de 1869. Arquivo da ANBA, disponível em http://digitarq.dgarq.gov.pt/ PT-ANBA-ANBA-F002-00002_m0090 a_m0100

${ }^{118}$ Documento assinado por Sousa Holstein e datado de 14 de Fevereiro de 1870. Arquivo do MNAA, fundo José de Figueiredo, cx. 1, pasta 4, doc. 16.

119 "Desenvolvimento da receita e despesa da verba generosamente doada por Sua Mag. El-Rei o Senhor Dom Fernando à Academia Real das Belas Artes de Lisboa". Documento datado de 14 de Fevereiro de 1870. Idem, cx. 1, pasta 4, doc. 17.

${ }^{120}$ Relatório dirigido por Sousa Holstein a D. Fernando II. Arquivo do MNAA, fundo José de Figueiredo, cx. 1, pasta 4, doc. 16. As seguintes citações reportam-se a este documento.
} 
transporte dos quadros ${ }^{121}$, e a gratificação de $100 \$ 00$ reis dada ao fiel tesoureiro da Academia, Cristóvão Leandro de Melo, pelo trabalho extraordinário de gestão e escrituração das verbas ${ }^{122}$.

A Academia comprou um total de 114 quadros, "entrando neste número alguns muito distintos e sendo todos mais ou menos notáveis, à exceção de poucos que fomos obrigados a adquirir em uma coleção cujo dono não queria vender separadamente os que haviam sido escolhidos", numa alusão a Sousa Cambiaço. Cumprindo as instruções dadas por D. Fernando, "foram todos esses quadros levados à sua augusta presença antes da sua definitiva aquisição, para que Vossa Majestade houvesse por bem determinar se deviam ou não ser comprados e o preço que por cada um se devia dar". Informava ainda o vice-inspetor que os respectivos quadros "foram colocados numa sala especial da galeria à qual em sinal de profundo reconhecimento, a Academia determinou que se lhe pusesse o nome de - Sala D. Fernando - resolvendo outrossim que estes constituíssem sempre uma coleção especial à qual não pudessem ser adicionados nenhuns outros para desta forma perpetuar a memória de tão valioso donativo". Terminava acreditando ter cumprido "tanto quanto em minhas forças podia, as intenções de Vossa Majestade" e solicitando a "régia aprovação das contas que tenho a honra de lhe enviar juntas". A resposta chegou em finais de Abril pela mão de Joaquim Roiz Chaves que devolveu o relatório e demais documentos anexados, declarando ter sido a conta "vista e aprovada por Sua Majestade e conferida por mim na qualidade de seu secretário particular" ${ }^{\prime 23}$.

Da análise de todo este processo se conclui ter sido adquirido o que havia disponível no mercado nacional, fértil em obras de autenticidade duvidosa que o olhar pouco experimentado dos professores da Academia tomou quase sempre por genuínas. Estas cingem-se na sua maioria a autores europeus de nomeada, do Renascimento italiano ao Barroco flamengo, de presença obrigatória nas grandes galerias coevas, e quase sempre de pequeno formato, o que se adequava aliás à exiguidade do espaço disponível. Progressivamente relegadas nas primeiras décadas do século XX para as

\footnotetext{
${ }^{121}$ Documento assinado por Cristóvão Leandro de Melo e datado de 15 de Fevereiro de 1869. Idem, cx. 1, pasta 3, doc. 123.

${ }^{122}$ Idem, cx. 1, pasta 3, doc. 124.

${ }^{123}$ Documento assinado por Joaquim Roiz Chaves e datado de 25 de Abril de 1870. Idem, cx. 1, pasta 5, doc. 6.
} 
reservas do Museu Nacional de Arte Antiga, permanecem desde então envoltas num certo esquecimento, aguardando estudos atualizados que permitam esclarecer eventuais zonas de dúvida. Cabe ainda assim assinalar a compra de alguns valores seguros, como o Rafael de Husson da Câmara, sem esquecer o apreciável conjunto de pintura flamenga e holandesa do século XVII (David Teniers, Jan Steen, Gerrit Dou, Godfried Schalcken ou Pieter Neefs só para dar alguns exemplos).

Entre os autores nacionais, domina o nome de Domingos Sequeira com um total estimado de 13 telas provenientes das coleções de Silva Oeirense, Sousa Lobo, O’Sullivan e Anastácio Rosa a quem foi comprado o derradeiro estudo para a Alegoria à Constituição. O interesse que Sousa Holstein dispensava ao artista explica tal cifra, e está na origem da aquisição das largas centenas de desenhos que se encontravam na posse do professor de arquitetura José da Costa Sequeira, ocorrida poucos anos mais tarde e a que já nos referimos. Há ainda a acrescentar a Alegoria à fundação da Casa Pia adquirida também por intervenção de D. Fernando mas já fora das dádivas, em $1873^{124}$. Encontrava-se em 1863 na posse de um neto do intendente Pina Manique, Diogo Manique (1809-1864) que recusara uma avaliação de $2.000 \$ 000$ reis então efectuada pelos professores da Academia ${ }^{125}$. Decorridos dez anos, entrou o viceinspetor em acordo com os herdeiros de Diogo Manique para a venda da enorme tela pela importância de $3.000 \$ 000$ reis, concedidos pelo monarca por provável solicitação marquês, após fracassada a tentativa de sensibilizar o governo para a compra ${ }^{126}$.

A crítica contemporânea já fez reparos à "falta de perspectiva global de gestão das avultadas verbas" concedidas por D. Fernando, considerando ter sido possível "com mais planeamento e juízos ponderados fazer outra política de aquisições, sensibilizando grandes colecionadores ou tentando comprar no mercado internacional” ${ }^{127}$. Convém notar que ao contrário de outras instituições coevas como a National Gallery ou o South Kensigton Museum de Londres, não possuía a nossa Academia pessoal suficientemente idóneo para efetuar prospecções a esse nível no

\footnotetext{
${ }^{124}$ ALMEDINA, conde de (co-auto) - Museu Nacional de Bellas Artes e Arqueologia: catalogo provisorio: seç̧ão de pintura, 1883, Sala B, n.o 881, p. 17.

${ }^{125}$ Cf. correspondência trocada em Março e Abril de 1863 entre Diogo Manique e Sousa Holstein. Arquivo da ANBA, disponível em http://digitarq.dgarq.gov.pt/ PT-ANBA-ANBA-B-001-00003_m1704 a m1708.

${ }^{126}$ Cf. ofício datado de 9 de Julho de 1872. Idem, disponível em http://digitarq.dgarq.gov.pt/ PT-ANBAANBA-B-007-00001_m0069.TIF.

${ }^{127}$ TEIXEIRA, José - op. cit., p. 279.
} 
estrangeiro, nem sequer meios para financiar tais deslocações, ainda que tal pudesse ter sido previsto nas verbas de D. Fernando. Ao ser chamado pelo rei D. Luís para organizar a galeria de pintura do Palácio da Ajuda, Marciano da Silva que foi membro da comissão de pintura, exercerá precisamente essas funções, viajando por França e Itália em busca pinturas para a coleção real, chegando a aceder à reputada coleção Lechi de Brescia onde fará aquisições. O resultado não foi melhor, com uma suposta Madonna de Leonardo da Vinci que revelou ter saído da mão de Cesare da Sesto, para não falar de meras cópias de Bellini, Ticiano ou Veronese ${ }^{128}$.

Recorde-se que a política de aquisições gizada por Sousa Holstein teve ainda assim alcance internacional, podendo citar-se os casos das coleções dos portugueses Husson da Câmara e Sousa Lobo, formadas em Itália e constituídas maioritariamente por autores italianos. Refira-se também o cônsul Bustelli que o vice-inspetor poderá ter conhecido em Florença, e a quem se ficou a dever a doação de um notável conjunto de desenhos, para além da venda de duas telas. Nesse negócio, serviu-se o marquês dos seus contactos diplomáticos para colmatar a falta de especialistas a quem pedir pareceres, solicitando a um funcionário da legação de Portugal em Milão que se deslocasse até à residência do colecionador com peritos locais para avaliar a qualidade das pinturas.

Finalmente, e quanto às "avultadas verbas", convirá referir que os 65 contos de reis concedidos por D. Fernando, importância elevada à escala nacional, tende a relativizarse se a compararmos ao que os grandes museus e colecionadores particulares europeus despendiam. Só A família de Dário perante Alexandre de Veronese custou em 1865 o equivalente a 63 contos de reis ao governo inglês para National Gallery ${ }^{129}$ de acordo com o Diario de Noticias que costumava dar eco desse tipo de transações ${ }^{130}$. Noutra edição, a mesma fonte mostrava-se atónita com o valor atingido por uma pintura contemporânea, lembrando as mediáticas reações aos recordes alcançados hoje em dia nas principais leiloeiras internacionais. Tratava-se de um quadro de Paul Delaroche representando Maria Antonieta, "ultimamente comprado em Londres por um abastado cervejeiro que deu a enorme soma de 32 mil libras ou 144 contos de réis!

\footnotetext{
${ }^{128}$ XAVIER, Hugo - op. cit., pp. 98-100.

${ }^{129}$ Paolo Veronese, The family of Darius before Alexandre, 1565-67. NG 294

${ }^{130}$ Diario de Noticias, 9 de Julho de 1865
} 
Assim afiança um jornal inglês. Aliás nunca o acreditaríamos" ${ }^{131}$. Ainda sobre a National Gallery, em franca expansão do seu acervo, temos notícia de outras aquisições, por valores mais baixos mas ainda assim dignos de destaque como sucedeu em 1866 com um quadro vindo "diretamente da galeria do conde Alvide Mocenigo de Veneza e comprado por 3400 libras esterlinas ou $15.300 \$ 000$ reis $^{\prime 132}$. Tratava-se de uma Virgem com o Menino ladeados por vários santos e pelo doge Giovanni Mocenigo, antepassado do proprietário ${ }^{133}$. "O que é bom custa caro" concluía o nosso jornal.

\subsection{A coleção Mayne e outras aquisições}

Se o enriquecimento do acervo da Academia de Belas Artes se deveu essencialmente ao gesto mecenático de D. Fernando II, convém assinalar a ocorrência de outras incorporações fora desse âmbito, começando desde logo por algumas dezenas de quadros pertencentes ao chamado Museu Maynense, instalado na Academia das Ciências. A designação de "Maynense" deriva do nome do franciscano José Mayne (1723-1792) da Congregação da Terceira Ordem da Penitência, o qual desempenhou funções de "ministro geral" dessa ordem a partir de 1780. Mayne que teve papel destacado na vida social do seu tempo como confessor do rei D. Pedro III (1717-1786), marido de D. Maria I (1734-1716), era homem com posses que the provinham de heranças familiares e dos serviços que prestava. Seriamente interessado em certos aspectos da cultura humanística e científica, decidiu aplicar os seus rendimentos no incremento da livraria do convento de Jesus onde habitava, assim como na aquisição de instrumentos de física, espécimes de história natural, curiosidades várias, medalhas, desenhos e pinturas com que organizou um museu.

O interesse de Mayne pela pintura foi desde cedo uma realidade, estando documentadas algumas encomendas específicas por si realizadas, como os onze quadros animalistas realizados por Bernardino da Costa Lemos para o museu do convento de Jesus ${ }^{134}$. Ao visitar o edifício em 1784, Francisco Pérez Bayer, diretor da

\footnotetext{
${ }^{131}$ Idem, 2 de Junho de 1865

132 Idem, 11 de Janeiro de 1866

${ }^{133}$ Obra atribuída anteriormente a Carpaccio: Venetian Workshop, The Virgin and Child with Saints Christopher and John the Baptist and Doge Giovanni Mocenigo, c. 1478-85. NG 750

${ }^{134}$ BRIGOLA, João Carlos Pires - Colecções, gabinetes e museus em Portugal no século XVIII, 2003, p. 416.
} 
Biblioteca Nacional de Madrid, registará que em relação a pinturas "tiene algumas que me parecieron buenas", não se mostrando muito entusiasmado em relação aos restantes núcleos, ainda em fase inicial de formação ${ }^{135}$. Na realidade, e apesar do juízo aparentemente favorável de Bayer, os quadros reunidos pelo "ministro geral" não evidenciavam sinais de especial tacto ou gosto, perdendo quando equiparados aos coleccionados por D. Frei Manuel do Cenáculo (1724-1814), seu contemporâneo.

Para além do museu, propôs-se Mayne criar uma aula no convento dedicada ao ensino da história natural e da botânica, uma iniciativa inserida "na escala de valores aceites e praticados, entre nós, pelo lluminismo Católico e informada pelos princípios científicos da voga naturalista" ${ }^{136}$. Para assegurar o funcionamento da sua aula e a boa conservação do acervo já abundante do museu, decidiu que se nomeasse a recémcriada Academia Real das Ciências de Lisboa (1779), entendendo que era nessa instituição, da qual era sócio, que se congregavam as pessoas capazes de procederem à execução do seu projeto. Mayne faleceria em 1792 e, supostamente nesse mesmo ano, a Academia das Ciências deu início no convento de Jesus à que ficaria conhecida por "Aula Maynense", prosseguindo-a sem interrupções nos período que se the seguiu. A instalação da Academia das Ciências em edifício próprio foi morosa. Mudando-se com frequência desde a sua fundação, só em 1834 com a extinção das ordens religiosas conseguiu conquistar um local definitivo o qual, sem grandes surpresas, foi precisamente o convento de Jesus a que já estava ligada por tradição. Viu-se então na posse de um rico espólio, mau grado as perdas sofridas nos anos de ocupação francesa: o do Museu Maynense que Ihe fora legado, o do próprio convento de Jesus (livraria e arte sacra), e o que conseguira organizar graças aos esforços dos seus fundadores, como o segundo duque de Lafões (1719-1806) ou o abade Correia da Serra (1750-1823), aí se incluindo um numeroso conjunto de material didático de física experimental, para além de diversos apetrechos necessários ao funcionamento de um laboratório químico ${ }^{137}$.

Foi somente após instalada no edifício do antigo convento, ultrapassada a instabilidade social sofrida com as lutas políticas internas, que se tornou possível à

\footnotetext{
${ }^{135}$ Apud. Idem, ibidem, p. 415.

136 Idem, ibidem, p. 420.

${ }^{137}$ CARVALHO, Rómulo de - Museu Maynense da Academia das Ciências de Lisboa, 1993, pp. 3-8.
} 
Academia das Ciências pensar na organização do seu espólio. No que diz respeito à coleção de pintura, foi inicialmente pensada a sua instalação num local adequado, recorrendo-se através do Ministério do Reino ao parecer dos professores da Academia de Belas Artes. Com efeito, uma portaria daquele ministério datada de 2 de Maio de 1844 solicitava a "nomeação de dois Srs. professores para irem à Academia das Ciências designar o local em que deve fazer-se uma galeria de pinturas"138. A solução não terá sido logo encontrada e permanecerá em suspenso até 1846, ano em que o Ministério do Reino enviará nova portaria, instando o vice-inspetor a designar "os mesmos Srs. professores que já foram à Academia das Ciências ou outros que estejam desimpedidos, para no dia 26 do mesmo mês, pelas duas horas da tarde, comparecerem naquele estabelecimento para o exame de um local para uma galeria de pinturas"139.

Ter-se-á optado então pelo segundo andar do edifico conventual, espaço hoje ocupado pelo Museu Geológico e Mineiro. Aí terá permanecido a pinacoteca durante mais de uma década até se proceder à sua venda em hasta pública, decisão motivada talvez pela necessidade de instalar naquele espaço a chamada "Comissão Geológica", e a que não terá sido estranho o desejo de um vantajoso encaixe financeiro. Reconhecendo pouca utilidade nas pinturas que tinha à sua guarda, a Academia das Ciências optava assim pela sua alienação, chegando a acalentar a mesma ideia em relação às "curiosidades" reunidas por José Mayne, como nos dá a conhecer uma pormenorizada avaliação efectuada em 1864 por Casimiro Cândido da Cunha e J. L. do Vale ${ }^{140}$. Particularmente notável, esse espólio era constituído por mais de 400 espécimes, nele sobressaindo cocos, corais ou conchas lavradas, para além de objetos em tartaruga, cristal de rocha ou âmbar, alguns com montagens em metais preciosos, incluindo uma pedra bezoar ornamentada com filigrana de ouro, fazendo recordar as Câmaras de Maravilhas do Renascimento.

138 Conferência ordinária de 27 de Fevereiro de 1846. Arquivo da ANBA, disponível em http://digitarq.dgarq.gov.pt/ PT-ANBA-ANBA-A-001-00005_m0029.

${ }^{139}$ Conferência ordinária de 30 de Março de 1846. Idem, disponível em http://digitarq.dgarq.gov.pt/ PTANBA-ANBA-A-001-00005_m0033.

140 "Casimiro C. da Cunha e J. L. do Vale, avaliadores, certificamos que por determinação do Conselho Administrativo da Academia Real das Ciências de Lisboa, avaliamos os seguintes objetos pertencentes ao Museu do P. Mayne". No final do inventário, declaram os avaliadores que "o valor que demos aos objetos é o positivo e não o estimativo, e com o intento de serem vendidos em leilão". Documento datado de 14 de Julho de 1864. ANTT, ACR, cx. 7332, maço 2, doc. s. n. 
O catálogo do leilão da galeria de pintura compreende um total de 429 lotes, a maioria dos quais de temática religiosa e com predomínio das representações de S. Francisco, ilustrativas da ordem professada pelo colecionador ${ }^{141}$. Regista-se igualmente a presença de várias composições com conchas e búzios, reforçando o interesse de Mayne pela história natural, assim como de algumas paisagens e retratos, entre os quais um de D. Rosa, anã dileta de D. Maria I e figura central de um grupo de negros e anões que marcavam de forma exótica a sua corte ${ }^{142}$. Indicava o catálogo que a coleção se havia de "arrematar em hasta pública perante o conselho administrativo da Academia Real das Ciências de Lisboa no dia 27 do mês de Novembro às 11 horas da manhã". Tal estava previsto para 1864 mas viria efetivamente a ocorrer no início de Março de 65 como informa o Diario de Noticias: "Na Academia das Ciências houve ultimamente leilão de quadros. Separaram-se vinte e tantos quadros para esta academia oferecer à das Belas Artes. Também aquele instituto científico não pôs em leilão e reservou para as suas salas, alguns retratos de escritores eminentes, e que foram membros da mesma Academia. O distinto pintor António Caetano está encarregado de restaurar alguns desses quadros" ${ }^{143}$.

Ao contrário do que refere a notícia, a Academia das Ciências procurou vender e não oferecer à sua congénere artística as pinturas em questão, sugerindo ao Ministério do Reino que efetuasse a compra. A ata da sessão académica de 1 Junho de 1866, regista a recepção de um ofício do dito ministério, "acompanhado de cópia de uma relação de 47 quadros existentes na Academia Real das Ciências de Lisboa que pertenciam ao Instituto Maynense e que a mesma Academia propôs ao governo que sejam comprados para a Academia Real das Belas Artes por se Ihes reconhecer mérito artístico e histórico". Vinha o ofício acompanhado "do ato de avaliação dos peritos na quantia total de $898 \$ 250$ (reis)", ordenando "ao Exmo. vice-inspetor que consultando a conferência, informe o que se oferecer a semelhante respeito"144.

\footnotetext{
${ }^{141}$ Catalogo da galeria do P.e Mayne que se ha de arrematar em hasta publica perante o Conselho Administrativo da Academia Real das Sciencias de Lisboa no dia 27 e seguintes do mez de Novembro às 11 horas da manhã, [1864].

${ }^{142}$ XAVIER, Hugo - "Os tempos monárquicos: dos faustos joaninos ao ateliê de D. Carlos". Pintura e mobiliário do Palácio de Belém, 2005, pp. 23-27.

${ }^{143}$ Diario de Noticias, 9 de Março de 1865

144 Conferência ordinária de 1 de Junho de 1866. Arquivo da ANBA, disponível em http://digitarq.dgarq.gov.pt/ PT-ANBA-ANBA-F-002-00001_m0352.
} 
A conferência estaria já ao corrente do assunto pois entre os "peritos" responsáveis pela avaliação encontra-se o nome de João Cristino da Silva ${ }^{145}$. Da seleção efectuada, predominam as pinturas de paisagem, dez das quais associadas a Pillement, para além de naturezas mortas e incêndios de Joaquim Manuel da Rocha, bem exemplificativos do consumo artístico nacional dos finais do século XVIII. Compreensivelmente poucas foram as composições religiosas escolhidas, merecendo destaque uma Virgem com o Menino já então associada a Luís de Morales (fig. 48), talvez a mais qualificada das pinturas reunidas por Mayne.

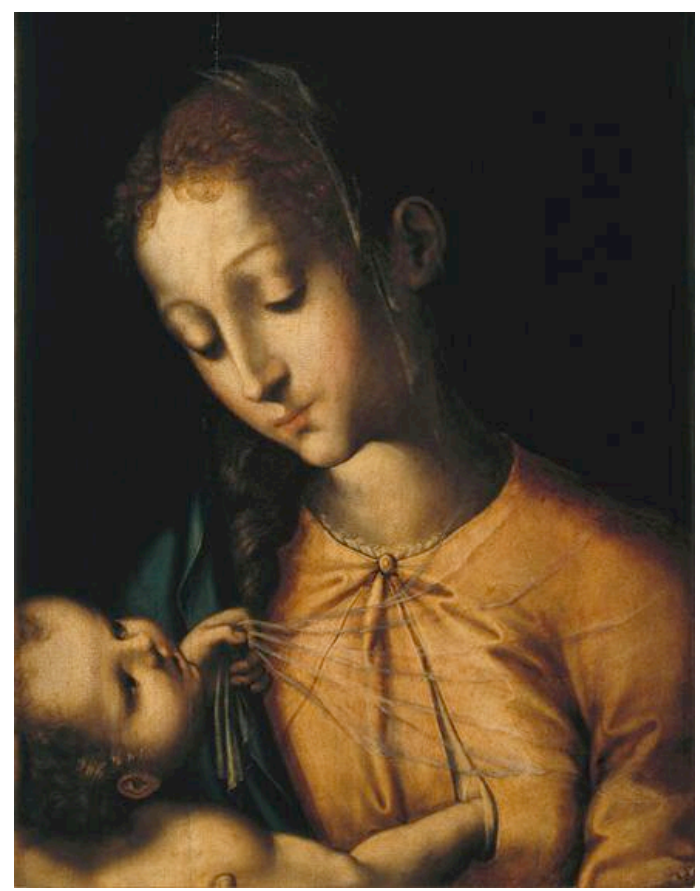

Fig. 48 - Luis de Morales, Virgem com o Menino, c. 1560-1570 MNAA, inv. 633 Pint

Na sessão de 18 de Março de 1867, Sousa Holstein informava que se "achavam já na Academia os quadros que vieram da Academia das Ciências", acrescentando que se “pagariam oportunamente" ${ }^{146}$. As contas do tesoureiro não registam todavia aquela despesa que deverá ter sido suportada pelo Ministério do Reino como estava aliás

\footnotetext{
${ }^{145}$ Assinaram a avaliação o conde de Ficalho, João Cristino da Silva e José Faustino Botelho. Cópia manuscrita do documento datado de 22 de Maio de 1866. Arquivo do MNAA, fundo José de Figueiredo, cx. 1 , pasta 12 , doc. 5 .

146 Conferência ordinária de 18 de Março de 1867. Arquivo da ANBA, disponível em http://digitarq.dgarq.gov.pt/ PT-ANBA-ANBA-F-002-00001_m0401.
} 
previsto, figurando as pinturas na primeira edição do Catalogo provisorio (1868) com a indicação de terem sido compradas no mencionado leilão ${ }^{147}$.

Da leitura sequencial dos livros de atas, facilmente se depreende ter a Academia algumas vezes tentado obter do governo a aquisição de obras que surgiam no mercado ou que the iam sendo propostas. Na sessão de 30 de Outubro de 1866, Tomás da Anunciação participava ao corpo académico encontrar-se à venda "a coleção de quadros pertencentes ao Sr. Ferreira de Almeida ${ }^{148}$, na qual havia alguns que considerava muito dignos de figurarem na galeria da Academia, e que entre eles havia dois muito notáveis do nosso distinto Vieira Lusitano". Ficou igualmente registado que o vice-inspetor, "sempre solícito e desejoso de ver a nossa galeria enriquecida de bons quadros, sobretudo bem representados nela os artistas portugueses, convidou os Srs. professores de pintura a irem na sua companhia examinar os ditos quadros para depois ver se haverá meio de se poderem adquirir"149. Na sessão seguinte, informava Sousa Holstein que "apesar dos fortes desejos que teve de fazer a compra da coleção de quadros do cavalheiro Ferreira de Almeida, a qual concorreria muito para enriquecer a galeria nacional, não tinha podido obter do governo os indispensáveis meios para esse fim" ${ }^{\prime 150}$. À recusa do governo, juntava-se a impossibilidade de se poder dispor da verba de D. Fernando, cativada à data para outras aquisições, no que resultou na perda daquela oportunidade.

As compras ocorridas serão em regra modestas como os dois quadros comprados em 1863 aos herdeiros do professor Joaquim Rafael, obras associadas ao espanhol Juan Simón Navarro $(1619-1666)^{151}$, acrescidas um ano depois de mais de cinquenta desenhos de autores nacionais e estrangeiros ${ }^{152}$. Devem igualmente ser mencionadas as oito pinturas compradas à família de Silva Oeirense, em 1868, conjunto

\footnotetext{
147 “A. S. - Quadros comprados no leilão da Academia das Siências de Lisboa”. HOLSTEIN, marquês de Sousa (co-auto.) - Catalogo provisorio da Galeria Nacional de Pintura existente na Academia Real das Bellas Artes de Lisboa, 1868, p. 3.

${ }^{148}$ Provavelmente Manuel Augusto Ferreira de Almeida, agraciado em 1867 por D. Luís com o grau de comendador da Ordem de Cristo. Não confundir com Luís Augusto Ferreira de Almeida, conde de Carvalhido, de que adiante nos iremos deter.

149 Conferência ordinária de 30 de Outubro de 1866. Arquivo da ANBA, disponível em http://digitarq.dgarq.gov.pt/ PT-ANBA-ANBA-F-002-00001_m0379.

${ }^{150}$ Conferência ordinária de 5 de Dezembro de 1866. Idem, disponível em http://digitarq.dgarq.gov.pt/ PT-ANBA-ANBA-F-002-00001_m0382.TIF

${ }^{151}$ HOLSTEIN, marquês de Sousa (co-auto.), Catalogo provisorio da Galeria Nacional de Pintura existente na Academia Real das Bellas Artes de Lisboa, 2a ed., 1872, p. 40 (cat. 91 e 62).

${ }^{152}$ Arquivo do MNAA, Aquisições 1850-1900, n.ㅇ 87.
} 
maioritariamente anónimo e de temática religiosa, com a exceção de uma Alegoria para um tecto atribuída a Cirilo Wolkmar Machado ${ }^{153}$.

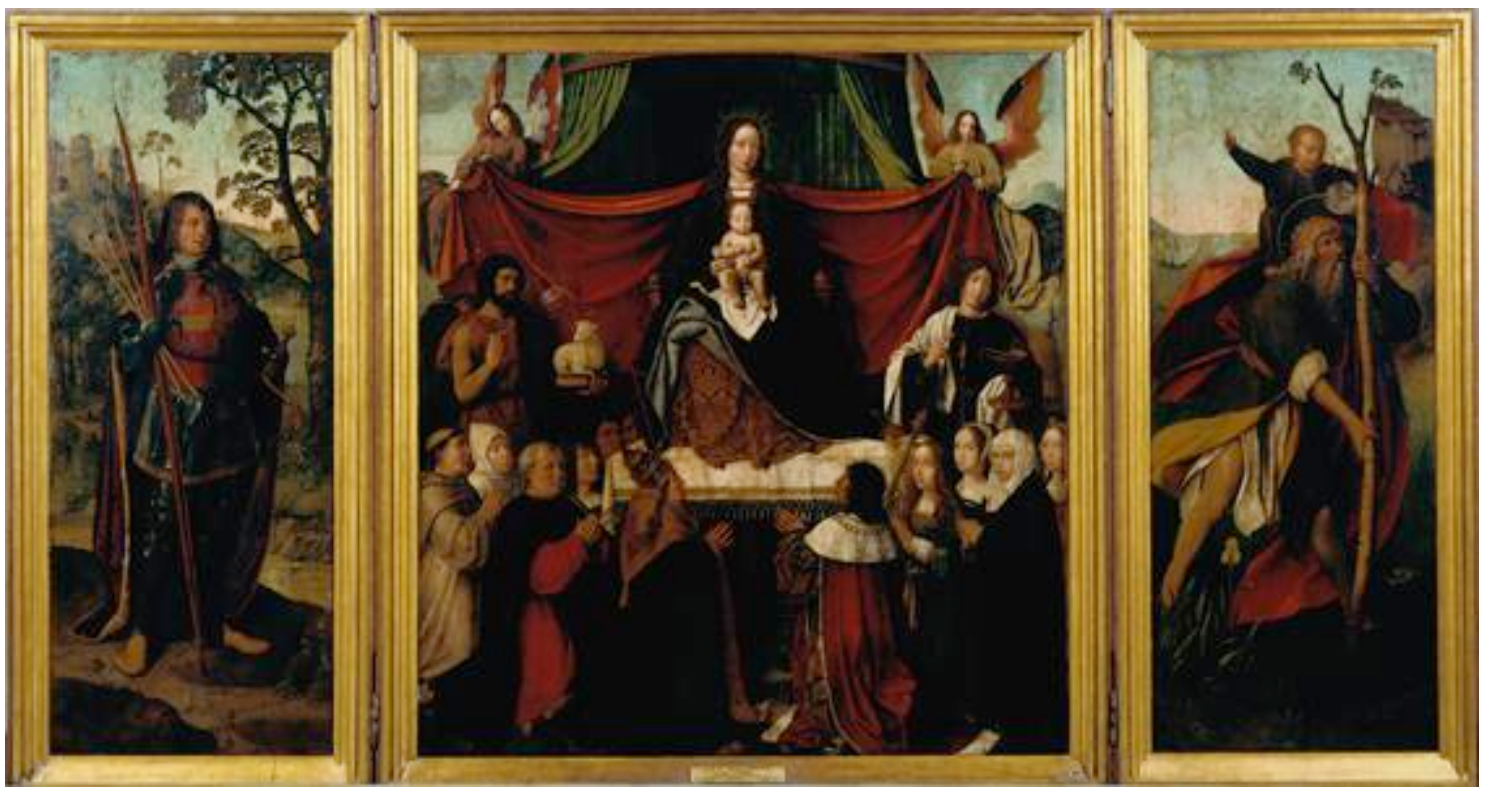

Fig. 49 - Jan Provoost, Tríptico de Nossa Senhora da Misericórdia, c. 1512-1515. MNAA, inv. 697 Pint

Caso raro e de especial relevo será anos mais tarde a aquisição de um tríptico representando a Virgem da Misericórdia, ladeada nos volantes por São Sebastião e São Cristóvão, obra do flamengo Jan Provoost (fig. 49) cujo processo de incorporação foi recentemente investigado ${ }^{154}$. Tendo pertencido não à Misericórdia do Funchal como suposto mas à desaparecida capela de São João de Latrão daquela ilha, conforme nota do recibo do depósito da peça na Academia, datada de Abril de 1875, custou ao Ministério do Reino $1.350 \$ 000$ reis, tratando-se da pintura mais dispendiosa adquirida pelo Estado durante o mandato de Sousa Holstein ${ }^{155}$. Num ofício redigido meses após o depósito, o vice-inspetor convidava Tomás da Anunciação e Miguel Ângelo Lupi “a

\footnotetext{
${ }^{153}$ HOLSTEIN, marquês de Sousa (co-auto.) - op. cit., pp. 72-74 (cat. 332, 334, 335, 336, 337, 338, 339, 342).

${ }^{154}$ BASTOS, Celina; CLARA, Isabel Santa; CAETANO, Joaquim Oliveira e RODRIGUES, Rita - "A incorporação do tríptico de Provoost no Museu Nacional de Arte Antiga e a sua origem". CAETANO. Joaquim: CARVALHO, José Alberto Seabra de (coord.) - Jan Provoost: o tríptico de Nossa Senhora da Misericórdia (cat. expo.), 2012, pp. 31-55.

${ }^{155}$ Recibo do depósito datado de 12 de Abril de 1875. Arquivo da ANBA, disponível em http://digitarq.dgarq.gov.pt/ PT-ANBA-ANBA-E-002-00001_m0005.TIF
} 
examinarem esta obra de arte dando por escrito o seu parecer sobre a conveniência da aquisição e sobre o preço pedido"156.

Favorável à compra mas seguramente lacónico como tantos outros elaborados pelos professores de pintura $^{157}$, o parecer original (de que não se localizou cópia) terá sido enviado ao Ministério do Reino, junto com o pedido formal de aquisição do marquês que se revela interessante pelas considerações tecidas. Após descrever a obra e se referir ao seu estado de conservação, debruça-se sobre a relevância da mesma procurando integrá-la no contexto da pintura primitiva que tanto interesse lhe suscitava: "Considero esta obra superior a quantos quadros chamados góticos nós já possuímos. Ignoro se foi executada por artista português. Pertence indubitavelmente à série de pinturas de escola flamenga à qual se liga a nossa antiga escola de pintura. Para determinar exatamente a sua origem é indispensável estudo mais detido e que não cabe nos limites deste ofício". Apelava por isso ao ministro, considerando não se dever perder a ocasião de "adquirir um quadro que virá aumentar o nosso já tão rico museu de quadros góticos" ${ }^{158}$. A resposta ministerial será comunicada ao corpo académico em finais de Agosto de 1876, numa sessão cuja ata se refere a "uma ordem de pagamento para a compra do quadro em forma de tríptico que o Exmo. Sr. Par do Reino, Agostinho de Ornelas, vendeu a esta Academia"159.

Agostinho de Ornelas e Vasconcelos Esmeraldo Rolim de Moura e Teive (1836-1901), 14으 senhor do Morgado do Caniço, nasceu na ilha da Madeira, vindo a cursar Direito em Coimbra nos mesmos anos em que Sousa Holstein frequentou a Universidade. Tal como o seu colega, seguiu a carreira diplomática e chegará a enviado extraordinário e ministro plenipotenciário em São Petersburgo, vindo depois a abraçar a política como deputado da nação às cortes, par do reino, e conselheiro de Sua Majestade Fidelíssima. Sócio correspondente da Academia das Ciências, interessou-se pela

156 Cópia do ofício original datado de 1 de Agosto 1876. Arquivo da ANBA, disponível em http://digitarq.dgarq.gov.pt/ PT-ANBA-ANBA-B-007-00002_m0355.TIF

${ }^{157}$ A este respeito cf. os pareceres elaborados em relação às propostas de compra de Silva Oeirense, Maria Cândida Dias da Silva e João Anastácio Rosa. Arquivo do MNAA, fundo José de Figueiredo, cx. 1, pasta 4, docs. 2, 3 e 4.

${ }^{158}$ Cópia do ofício original datado de 9 de Agosto de 1876. Arquivo da ANBA, disponível em http://digitarq.dgarq.gov.pt/ PT-ANBA-ANBA-B-007-00001_m0187.TIF e_m0188.TIF

${ }^{159}$ Conferência ordinária de 29 de Agosto de 1876. Idem, disponível em http://digitarq.dgarq.gov.pt/ PTANBA-ANBA-F-002-00002_m0482. 
investigação história sobre a ilha, ${ }^{160}$ o que explicará o facto do tríptico se encontrar na sua posse, alienado provavelmente na sequência das vendas promovidas pelo último morgado de São João de Latrão, a partir de $1870^{161}$.

Apesar da maioria das propostas de aquisição dirigidas a Sousa Holstein não terem sido efectivadas por incapacidade financeira da Academia e da tutela, casos houve que merecem ser aqui evidenciados, por revelarem aspectos peculiares do mercado daquela época. Entre as cartas arquivadas nos livros de correspondência daquela instituição, sobressaem as de António Jacinto Prenda, pintor menor e negociante expedito de Estremoz que em 1869 propôs vender diversas pinturas antigas angariadas na região. Numa longa missiva fará a apreciação das principais obras, avançando com atribuições ou integrando-as em escolas, "porque estrangeiros e nacionais têm visto os meus quadros e me dizem de que escola são pois eu não pesco nada a tal respeito"162. Decerto curioso com as pinturas em questão, Sousa Holstein acede ao envio das mesmas para grande contentamento de Prenda que noutra carta, entre elogios ao vice-inspetor, propõe-se no seu português peculiar "encher a Academia de quadros que só eu dou com eles porque entro por toda a parte mas de uma maneira bem simples, pintando Cristos e oratórios com muitos encarnados". Revelava assim a sua forma de atuar, distinta dos restantes negociantes a quem os proprietários fechavam muitas vezes a porta, "porque esses que vêm comprar coisas antigas não os querem em casa e cuidam que vêm por espias" ${ }^{163}$.

Outra ocorrência singular, já oportunamente analisada ${ }^{164}$, deve ser aqui também enquadrada: a permuta proposta à Academia por Sir Francis Cook (1817-1901), destacado negociante no ramo da produção e comércio de têxteis que em 1856 se fez proprietário da Quinta de Monserrate em Sintra, utilizada como estância de veraneio nas frequentes vindas ao nosso país. Detentor de uma das maiores fortunas da Inglaterra vitoriana, virá a reunir uma coleção de especial qualidade e dimensão, tendo

\footnotetext{
${ }^{160}$ Das suas pesquisas resultou a publicação de uma Memória sobre a residência de Cristóvão Colombo na ilha da Madeira, 1892.

161 BASTOS, Celina; CLARA, Isabel Santa; CAETANO, Joaquim Oliveira e RODRIGUES, Rita - op. cit., p. 43.

${ }^{162}$ Carta s. d. Arquivo da ANBA, disponível em http://digitarq.dgarq.gov.pt/ PT-ANBA-ANBA-B-00100003_m1518.

163 Carta datada de 7 de Dezembro de 1869. Arquivo da ANBA, disponível em http://digitarq.dgarq.gov.pt/ PT-ANBA-ANBA-B-001-00003_m1531.

${ }^{164}$ NETO, Maria João Baptista - "Colecionadores e Connaisseurs de obras de arte: Francis Cook (18171901) e John Charles Robinson (1824-1913) em Portugal”. Artis, n.o 6, 2007, pp. 403-442.
} 
a pintura como principal vector ${ }^{165}$. Para tal contribuíram os contactos mantidos com o superintendente do South Kensignton Museum, Charles Robinson, a quem Cook adquiriu parte importante da coleção que possuía. Robinson que sabemos ter-se interessado e escrito sobre Grão Vasco, viria precisamente a vender a Cook, entretanto feito visconde de Monserrate por D. Luís (1870), um tríptico com a assinatura do mestre adquirido em Viseu ao pintor António José Pereira.

No seguimento dessa aquisição, o colecionador escreveu a Sousa Holstein expressando o desejo de efetuar uma permuta, assunto que levou à convocação de duas sessões extraordinárias no mês de Julho de 1875. Tal consistia "na troca do quadro que a Academia possui como sendo de Rafael, pelo que acaba de adquirir o mesmo visconde, assinado por Vasco Fernandes e outros que da sua galeria poderiam ser escolhidos como obras notáveis de outros mestres cujo valor equivalesse ao que a Academia dá ao seu de Rafael". Cook cobiçava portanto o pequeno quadro do mestre italiano comprado anos antes a Husson da Câmara, jogando com o trunfo do Grão Vasco e com o facto de poder colmatar lacunas existentes na pinacoteca nacional. Muito discutida, a proposta pareceu tentadora aos olhos de alguns académicos, "porquanto poderia dar-se o caso de se poderem obter alguns quadros de tal ordem que não só serviriam a aumentar o número de bons quadros ainda muito limitado na nossa galeria, como a representarem bem a escola florentina, flamenga, a espanhola ou a veneziana, tornando-se assim a galeria mais útil também aos que estudam". Para além disso, possuindo o estabelecimento um consistente núcleo de primitivos, considerava-se "muito importante a aquisição do único até hoje conhecido que seja assinado por Vasco Fernandes" ${ }^{166}$.

O Ministério do Reino não autorizou a Academia a negociar a troca do Rafael com o visconde de Monserrate que seis anos mais tarde, na sequência da Exposição de Arte Ornamental organizada em Londres, voltou a propor, sem sucesso, a permuta do tríptico por algumas das alfaias litúrgicas dos conventos extintos enviadas à mostra.

\footnotetext{
${ }^{165}$ Compreendia mais de 500 quadros, parte dos quais de assinalável importância como a Velha cozinhando ovos de Velázquez (National Gallery of Scotland), o Cristo na coluna de Antonelo da Messina (Museu do Louvre) ou o Retrato de senhora de François Clouet (National Gallery of Art). Idem, ibidem, p. 412.

${ }^{166}$ Conferência extraordinária de 13 de Julho de 1875. Arquivo da ANBA, disponível em http://digitarq.dgarq.gov.pt/ PT-ANBA-ANBA-F-002-00002_m0432.
} 
Em 1945, iniciada a dispersão da coleção Cook, viria a pintura a dar entrada no Museu Nacional de Arte Antiga por doação dos descendentes do colecionador.

\subsection{Transferências e pedidos de transferência}

Os pedidos de transferência de espécies pictóricas na posse de instituições públicas e religiosas foram comuns durante a vigência de Sousa Holstein que procurou concentrar na Academia obras relevantes disseminadas pelo país. Tencionava assim, sem dispêndio de verbas, incrementar a pinacoteca da instituição, sobretudo em relação à antiga escola portuguesa, processo nem sempre exequível dadas as frequentes resistências das entidades detentoras das pinturas.

Logo em 1863, Cristino da Silva fazia ver à conferência "que na praça de Tomar existe uma igreja que contém belos quadros que muito conviria requisitar para o enriquecimento da nossa galeria" (em vias de organização). Referia-se aquele professor à Igreja de São João Baptista e ao relevante conjunto de painéis hoje associados a Gregório Lopes que, segundo informa, "já aqui estiveram por muito tempo, e ultimamente para ali foram reconduzidos". A presença daquelas obras na Academia é assinalada nas atas em finais da década de 1840, tendo sido enviadas para Lisboa por ordem do governo e a pedido do Município de Tomar com o objectivo de serem restauradas, trabalho dirigido por António Manuel da Fonseca, dado por concluído em 1855, procedendo-se apenas em 60 à sua devolução. Três anos mais tarde aprovavam os académicos "o expediente de se mandarem reverter os grandes quadros da igreja de Tomar", concordando todos, com a única exceção do diretorgeral, Francisco de Assis Rodrigues, "que em parte alguma eles podiam ter uma colocação e emprego mais conducente do que na galeria nacional” ${ }^{167}$.

Cioso do seu património artístico, aquele Município não só não aceitou a solicitação como, quatro anos depois, elaborou um extenso requerimento, "pedindo ao governo que sejam restituídos à igreja dos freires daquela vila os quadros e esculturas que pela extinção dos conventos dali saíram e se acham hoje na Academia". Assim se refere a ata da conferência onde o assunto foi exposto pelo vice-inspetor que, a pouco tempo

\footnotetext{
${ }^{167}$ Conferência extraordinária de 3 de Março de 1863. Idem, disponível em http://digitarq.dgarq.gov.pt/ PT-ANBA-ANBA-F-002-00001_m0025.TIF
} 
da abertura da galeria nacional, recusou atender ao pedido, propondo que "para se satisfazer de algum modo ao que a Câmara pedia, se podiam mandar copiar os referidos quadros" ${ }^{\prime 168}$. Nada se fez então mas o Município voltou à carga em 1873, obrigando à convocação de uma sessão extraordinária onde o diretor-geral, na ausência do vice-inspetor, comunicou a necessidade de se proceder por ordem do governo "a uma escolha entre os quadros que pertenceram ao extinto Convento de Cristo de Tomar, afim de serem restituídos os que não se julgaram dignos de figurar na galeria e de algum modo satisfazer-se ao pedido que faz a Câmara Municipal da mesma cidade". Pedindo a palavra, Miguel Ângelo Lupi expressou a opinião de que "haveria inconveniência em restituir dois que se acham colocados na galeria e um no depósito que é grande e que pela sua importância artística são dignos de estarem expostos"169. $^{169}$. Refia-se o professor a duas pinturas que sabemos hoje terem sido executadas por Gregório Lopes para os altares da charola do Convento de Cristo, identificáveis no respectivo Catálogo provisório ${ }^{170}$, e a um dos monumentais painéis atribuídos em tempos a Jorge Afonso que ornamentavam as paredes daquele espaço. A Academia conservará efetivamente aquelas obras e as restantes regressarão a Tomar onde podem ser contempladas.

Outras transferências foram intentadas pelo nosso estabelecimento de ensino artístico, de maneira a enriquecer o seu espólio pictórico. Em Março de 1863, Sousa Holstein participava aos professores que por portaria do Ministério da Fazenda, "se ordenara ao delegado do Tesouro do distrito de Coimbra que ponha à disposição desta Academia, e entregue à pessoa devidamente autorizada por ela, os dois quadros que se acham nos claustros da Igreja de Santa Cruz da dita cidade". A forma de entrega e transporte dos mesmos foram tema de debate entre os académicos, "resolvendo-se por último que se adoptasse o expediente lembrado pelo Exmo. vice-inspetor, de mandar autorizar pessoa da sua confiança, afim de se encarregar da recepção e da

\footnotetext{
${ }^{168}$ Conferência ordinária de 23 de Dezembro de 1867. Idem, disponível em http://digitarq.dgarq.gov.pt/ PT-ANBA-ANBA-F-002-00001_m0448.TIF

169 Conferência extraordinária de 17 de Janeiro de 1873. Idem, disponível em http://digitarq.dgarq.gov.pt/ PT-ANBA-ANBA-F-002-00002_m0320.TIF

${ }^{170}$ Correspondem ao n.o 197 Martírio de S. Sebastião e ao n.o 268 Nossa Senhora e o Menino e vários anjos tocando e cantando. Cf. HOLSTEIN, marquês de Sousa (co-auto) - Catalogo provisorio da Galeria Nacional de Pintura existente na Academia Real das Bellas Artes de Lisboa, 1868, pp. 54 e 61. Ambas as obras conservam-se no MNAA, inv. 30 e 80 Pint.
} 
condução dos sobreditos quadros para Lisboa"171. Desconhecemos a presença de pinturas identificáveis com aquela proveniência nos antigos fundos da Academia, não se podendo portanto atestar a concretização da transferência. Cremos todavia que o pedido poderá ter sido impulsionado por um carta publicada meses antes por Cristino da Silva no Jornal do Commercio ${ }^{172}$, na sequência de uma visita a Santa Cruz de Coimbra onde, entre outras pinturas, fala do Pentecostes de Vasco Fernandes, assinalando o facto até então inédito daquela tábua se encontrar assinada pelo mestre, motivo pelo qual defende a sua remoção para Lisboa.

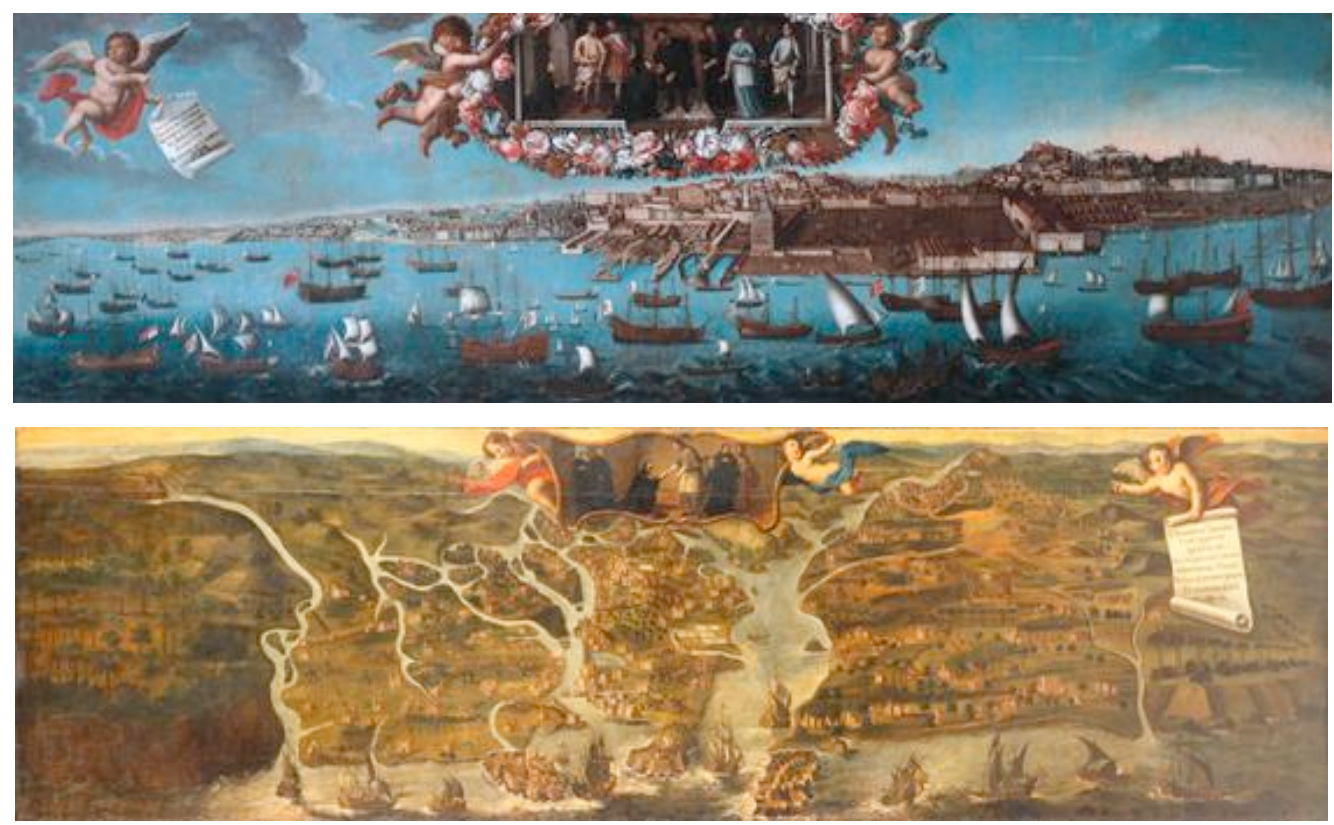

Fig. 50 - José Pinhão de Matos (atrib.), Panorama da cidade de Lisboa no século XVIII (partida de S. Francisco Xavier para a Índia), c. 1715-1765. MNAA, inv. 390 Pint

Fig. 51 - José Pinhão de Matos (atrib.), Visão perspéctica de Goa e terras próximas no século XVII, c. 1715-1765. MNAA, inv. 389 Pint

Muito pontualmente, houve entidades a contactar a Academia para cederem pinturas à sua guarda, podendo mencionar-se o caso da Escola Politécnica, ocorrido em Julho de 1866. O vice-inspetor participou então que o diretor da escola "o havia informado existirem naquele estabelecimento vários quadros pertencentes à antiga casa do Noviciado da Companhia de Jesus que podem ser entregues à Academia, sobressaindo dois de grandes dimensões que representam a partida de S. Francisco Xavier para a

\footnotetext{
171 Conferência extraordinária de 16 de Março de 1863. Arquivo da ANBA, disponível em http://digitarq.dgarq.gov.pt/ PT-ANBA-ANBA-F-002-00001_m0029.TIF e_m0030.TIF

172 Jornal do Commercio, 30 de Setembro de 1862. A este respeito cf. VASCONCELOS, Joaquim de - op. cit., pp. 35-37.
} 
Índia e a chegada do apóstolo a Goa" ${ }^{173}$. Expressando de imediato o desejo de aceitar as obras (figs. 50 e 51), aguardou todavia pelo parecer da comissão de pintura que entendeu deslocar-se à escola para as examinar, não sem a oposição de um dos seus membros, Cristino da Silva, por entender ser necessária uma autorização do governo para sair em trabalho da Academia. Após ter procedido ao exame das mesmas, foi a comissão favorável à sua transferência, apesar de não lhes reconhecer mérito artístico suficiente para as incluir na galeria de pintura ${ }^{174}$.

Centrado em valorizar e fazer crescer o acervo académico, inclusivamente após a abertura da pinacoteca (1868), Sousa Holstein mostrou-se atento às espécies de pintura com interesse artístico em poder de algumas dioceses, merecendo destaque o episódio ocorrido com arcebispado de Évora, cidade que com a extinção das ordens religiosas vira já partir para Lisboa a maioria das pinturas quinhentistas dos seus conventos. Em Fevereiro de 1876, num ofício dirigido ao ministro da Justiça, referia o marquês que estando a procurar "por todas as formas enriquecer a galeria nacional de Lisboa", solicitava a sua intervenção no sentido de autorizar "o reverendo arcebispo de Évora a ceder, querendo, para o museu nacional de pinturas uns quadros que existem no seu paço arquiepiscopal” ${ }^{\prime 175}$. Entre as obras em vista pelo vice-inspetor encontravase seguramente o retábulo da vida da Virgem, proveniente da catedral daquela cidade e recolhido ao Paço Episcopal na sequência da edificação da nova capela-mor projetada por Ludovice no século XVIII. Esse conjunto que prendera já a atenção de Raczynski, suscitava interesse no muito nebuloso panorama da pintura primitiva portuguesa, tendo sido depois comprovada a sua origem flamenga de filiação gantobrugense. A influência que exerceu sobre a pintura nacional da primeira metade de Quinhentos terá sido marcante, o que explica em parte as incertezas então mantidas. A provável recusa do arcebispo deitou por terra as pretensões do marquês e, só após a implantação da República, com a criação do Museu de Évora (1915), o retábulo

\footnotetext{
173 Conferência ordinária de 5 de Julho de 1866. Arquivo da ANBA, disponível em http://digitarq.dgarq.gov.pt/ PT-ANBA-ANBA-F-002-00001_m0359.

${ }^{174}$ Deram entrada na Academia a 8 de Abril de 1867. Cf. Arquivo do MNAA, Doações, depósitos e aquisições (1838-1912), livro n.o 86.

${ }^{175}$ Cópia do oficio original datada do de 1 de Fevereiro de 1876. Arquivo da ANBA, disponível em http://digitarq.dgarq.gov.pt/ PT-ANBA-ANBA-B-007-00002_m0325.TIF
} 
integrará o património do Estado, tornando-se num dos ícones artísticos daquela cidade $^{176}$.

O ofício dirigido ao ministro da Justiça reveste-se de especial interesse pela visão que o vice-inspetor transmite da pinacoteca académica decorridos oito anos da sua abertura, nomeadamente, em relação a incorporações futuras: "Na galeria de pinturas que o nosso país possui já e que pode e deve aumentar-se consideravelmente sem dispêndio nem sacrifício para o Estado, há uma série na qual facilmente tornará notabilíssimo o nosso museu. Falo dos quadros góticos da antiga escola portuguesa de pintura". Pragmático, acrescentava que "se não podemos aspirar a reunir em nossas salas obrasprimas dos grandes mestres das diferentes escolas italianas, é certo que poderemos por outro lado tornar muito valioso o nosso museu ajuntando nele grande número daqueles admiráveis painéis que são preciosíssimas jóias da arte dos séculos XV e XVI”. Explicava ao ministro estar subjacente a essa ideia não uma "questão de vaidade nacional ou desejo de brilhar aos olhos dos estrangeiros" mas sim uma motivação científica: "Há um fim mais elevado a formar semelhante coleção, pois que só por esta forma é que se poderá estudar a história da arte portuguesa e recompor os capítulos dispersos dum período importante da atividade artística na Europa" ${ }^{177}$.

As transferências ou pedidos de transferência estenderam-se igualmente aos conventos femininos entretanto extintos, e que de uma forma geral se revelaram mais copiosos no domínio das artes decorativas, destinadas por Sousa Holstein a um Museu de Arte Ornamental como veremos na IV parte. Ainda assim alguma pintura seria integrada na sequência de prospecções efectuadas um pouco por todo o país, não chegando o vice-inspetor a concretizar a mais relevante das transferências a que aspirava, relativa a uma emblemática casa religiosa da região de Lisboa: o convento da Madre de Deus. Fundado no início do século XVI pela rainha D. Leonor (1458-1525), mulher de D. João II (1455-1495), seria na segunda metade do século XIX adaptado a asilo com o patrocínio da rainha D. Maria Pia (1847-1911) que lhe emprestou o nome, encetando-se então uma extensa campanha de obras dirigidas pelo arquiteto José

\footnotetext{
${ }^{176}$ Para o historial do retábulo durante o século XIX e inícios do XX cf. CAETANO, Joaquim Oliveira - "O retábulo flamengo da Sé de Évora: algumas reflexões sobre um processo de investigação em curso". Museologia.pt, n.o 1, 2007, pp. 27-29.

${ }^{177}$ Cópia do oficio original datada do de 1 de Fevereiro de 1876. Arquivo da ANBA, disponível em http://digitarq.dgarq.gov.pt/ PT-ANBA-ANBA-B-007-00002_m0325.TIF
} 
Maria Nepomuceno (1836-1895). Consciente do notável património móvel que encerrava, o marquês conseguiu obter em 1874 uma autorização do provedor do asilo para o percorrer na companhia do referido arquiteto, com objectivo de efetuar uma relação das pinturas e demais objetos que interessavam à Academia, a ser submetida ao ministro e secretário de Estado dos Negócios do Reino. Esse documento e o ofício anexo revelam-se da maior importância para a análise daquele espólio que se encontrava já diminuído na sequência de outras prospecções ${ }^{178}$, assim como para o estudo da política de incorporações gizada pelo vice-inspetor, num período em que ponderava já a criação de um "museu nacional".

No intuito de convencer o ministro, Sousa Holstein começa por referir que os quadros selecionados "têm todos um grande valor ou como obras de arte ou como exemplares das antigas escolas, e muito convém depositá-los na galeria de pinturas não só para Ihes assegurar para sempre os cuidados que merecem, se não para os aproximar dos outros quadros ali existentes e ir pouco a pouco e por esta forma completando a reunião das obras cujo estudo há de um dia solver a questão das origens e da história da pintura em Portugal”179. Como há pouco tivemos oportunidade de constatar a respeito das pinturas de Évora, o estudo das primícias da nossa pintura motivava o marquês mas a conservação das obras também o preocupava, advertindo que "a administração de um asilo não é uma administração de Belas Artes e que num hospício e numa igreja os quadros não podem ser conservados como numa galeria exclusivamente destinada a este fim especial". Acrescentava que a generalidade das nações, "incluindo a Roma dos Papas, nos deram o exemplo de arrecadar os quadros originais nos museus, colocando cópias nas igrejas para que haviam sido destinados aqueles".

Numa elogiosa referência à intervenção de Nepomuceno, considerada hoje bastante discutível, é indicado que nenhum dos quadros solicitados "se acha por tal modo incorporado no edifício que a sua falta se torne importante no muito acertado plano

\footnotetext{
${ }^{178} \mathrm{O}$ caso mais significativo parece ter sido o de D. Fernando II que fez transportar para o Palácio das Necessidades outras obras, como o quase miniatural tríptico da sagrada família e anjos que esteve atribuído a Mabuse (MNAA, inv. 1479 Pint.), ou os quatro medalhões da oficina della Robbia com representações dos Quatro Evangelistas (MNAA, inv. 680 a 684 Esc. Em depósito no MNAz).

${ }^{179}$ Cópia manuscrita do ofício datado de 10 de Abril de 1874. Arquivo da ANBA, disponível em http://digitarq.dgarq.gov.pt/ PT-ANBA-ANBA-B-007-00001_m0129.TIF a_m0134.TIF. As seguintes citações reportam-se a esta referência.
} 
de restauração que o esclarecido e digno provedor empreende, auxiliado pelo arquiteto que dirige os trabalhos com tanto zelo e talento". No caso de algum o ser, e como acima havia sugerido, "poderia facilmente ser substituído por cópias que seriam executadas na Academia, sem despesa alguma para o asilo", indicando, a título de exemplo, "os quadros sobre os arcazes da sacristia" pertencentes ao denominado Retábulo de Santa Auta. Documentando o envio das relíquias daquela santa à fundadora do cenóbio pelo imperador Maximiliano (1459-1519), seu primo, essas pinturas prenderam desde logo a atenção do marquês que estendeu a sua seleção a outras 30, com destaque para o designado Retábulo da Madre de Deus ${ }^{180}$, então disseminado pelo coro alto, para as tábuas que revelaram formar o tríptico da Virgem com o Menino que será mais tarde associado ao mestre do tríptico de Morrison ${ }^{181}$, localizado numa capela junto ao mesmo coro, e ainda para o painel central e volantes do tríptico da Apresentação do Menino no templo, desmembrados na sacristia, obra que virá a ser atribuída a Goswin van der Weyden ${ }^{182}$.

Não passaram igualmente despercebidas ao vice-inspetor algumas esculturas, com especial evidência para os espécimes da oficina dos della Robbia e para um baixo relevo circular em mármore localizado numa gavetão da sacrista do andar superior, sem esquecer as cerâmicas, os têxteis e as peças de ourivesaria, destacando-se nesse último domínio o notável relicário em ouro que pertencera à rainha D. Leonor ${ }^{183}$. Terminava o ofício fazendo ver que se esta transferência e outras previstas merecessem a aprovação do governo, "poderão em breve os nossos museus tornar-se importantes sem agravamento algum para a Fazenda". Comprometia-se por isso a submeter ao ministro "as propostas que me parecerem conducentes a alcançar este fim, ao qual tenho há doze anos consagrado todos os meus esforços e todo o meu empenho".

Os esforços e o empenho de Sousa Holstein não chegaram a ter concretização, certamente por resistência do provedor do asilo que começou entretanto a considerar a formação de um núcleo museológico próprio. Em carta a Sousa Holstein datada de 1875, um ano após o envio do relatório ao ministro, Augusto Filipe Simões, lente da

\footnotetext{
${ }^{180}$ MNAA, inv. 1279, 2096, 1289, 1632, 1288, 2174, 1279 Pint.

${ }^{181}$ MNAA, inv. 1277 Pint.

182 MNAA inv. 1287 Pint.

${ }^{183}$ Idem, inv. 106 Our.
} 
Universidade de Coimbra que se encontrava ao serviço da Academia, integrado na comissão encarregada de estudar a reforma do ensino artístico e a organização dos museus, refere-se precisamente a essa situação: "estive com o Torres Pereira [provedor] que me disse querer fazer um presépio no ante coro da Madre de Deus e, ao mesmo tempo, um museuzinho que rendesse ao asilo as espórtulas dos visitantes. Disse-lhe que seria muito bem feito, mas que, tratando-se de fundar um museu nacional, os esforços dele Torres Pereira e de todas as pessoas que estivessem nas circunstâncias de coadjuvar tão importante empresa, deveriam convergir para esse fim $^{184}$.

O sucessor de Sousa Holstein, Delfim Guedes (1842-1895), conseguirá integrar nas coleções do Museu Nacional de Belas Artes e Arqueologia (1884) algumas peças da Madre de Deus cedidas à exposição de Arte Ornamental (1882), mas a transferência das pinturas e restantes objetos só virá a efetivar-se com José de Figueiredo (18721937) que, a partir de 1912, consegue obter do governo republicano a sua entrega ao recém-denominado Museu Nacional de Arte Antiga. Figueiredo reivindicará a "descoberta" de certas pinturas, como as tábuas agrupadas no tríptico por si atribuído ao Mestre do Tríptico de Morrison, o mesmo sucedendo com o pintor-restaurador Luciano Freire (1864-1935) que se deparou num gavetão da sacristia com os painéis do tríptico associado a Goswin van der Weyden, considerado então um valioso achado com honras de notícia na imprensa ${ }^{185}$. Quatro décadas antes, Sousa Holstein assinalava já estas e outras obras no seu ofício, acalentando o que Figueiredo e Freire acabaram por conseguir.

\subsection{Doações}

Ao contrário do que sucedia com a pintura dita contemporânea cuja entrada na coleção estava de certa forma assegurada pelos regulamentos académicos como

\footnotetext{
${ }^{184}$ FREITAS, Eugénio da Cunha e (org.) - "Cartas de Augusto Filipe Simões para o 1. marquês de Sousa Holstein". Sep. da Arqueologia e História, 8a série, vol. X, 1962, pp. 53-54. Estas e outras cartas integravam o espólio particular do marquês que foi leiloado em 2010. AZEVEDO, Pedro de (org.) - op. cit., p. 78 (lote 509).

${ }^{185}$ A este respeito cf. CARVALHO, José Alberto Seabra - "2. Tríptico da Virgem com o Menino e dois anjos músicos" e "4. Tríptico da Apresentação do Menino no Templo". CURVELO, Alexandra (coord.) Casa Perfeitíssima: 500 anos da fundação do Mosteiro da Madre de Deus 1509-2009, 2009, pp. 186-188 e 192-194.
} 
adiante veremos, as ofertas de obras de épocas mais recuadas eram praticamente inexistentes até à nomeação do marquês para vice-inspetor, em 1862. Logo no ano seguinte dará o exemplo com a doação de dois esboços do seu artista de eleição, Domingos Sequeira, mais tarde escolhidos para abrirem o Catalogo provisorio editado $^{186}$. O facto da coleção não estar ainda patente ao público, sem a visibilidade desejada, dificultou a repetição dessa prática que recebeu todavia outros impulsos, destacando-se o do rei $\mathrm{D}$. Luís a quem o colecionismo de pintura interessou ao ponto de organizar uma pinacoteca no Palácio da Ajuda como já foi referido. Em 1865, ano em que o pai dispensou os primeiros 20 contos de reis da sua dotação para aquisições, doou à Academia um quase miniatural Casamento místico de Santa Catarina de Josefa de Óbidos (fig. 52), escolha saudada pelo seu cariz nacionalista. Convém assinalar não ter sido este o primeiro gesto de apreço do jovem monarca para com a instituição, a quem havia oferecido pouco antes uma verba que permitiu a aquisição para a biblioteca de mais de 200 volumes "de obras excelentes, modernamente publicadas sobre assuntos de arquitetura, pintura, escultura, artes subordinadas e ofícios mecânicos"187.

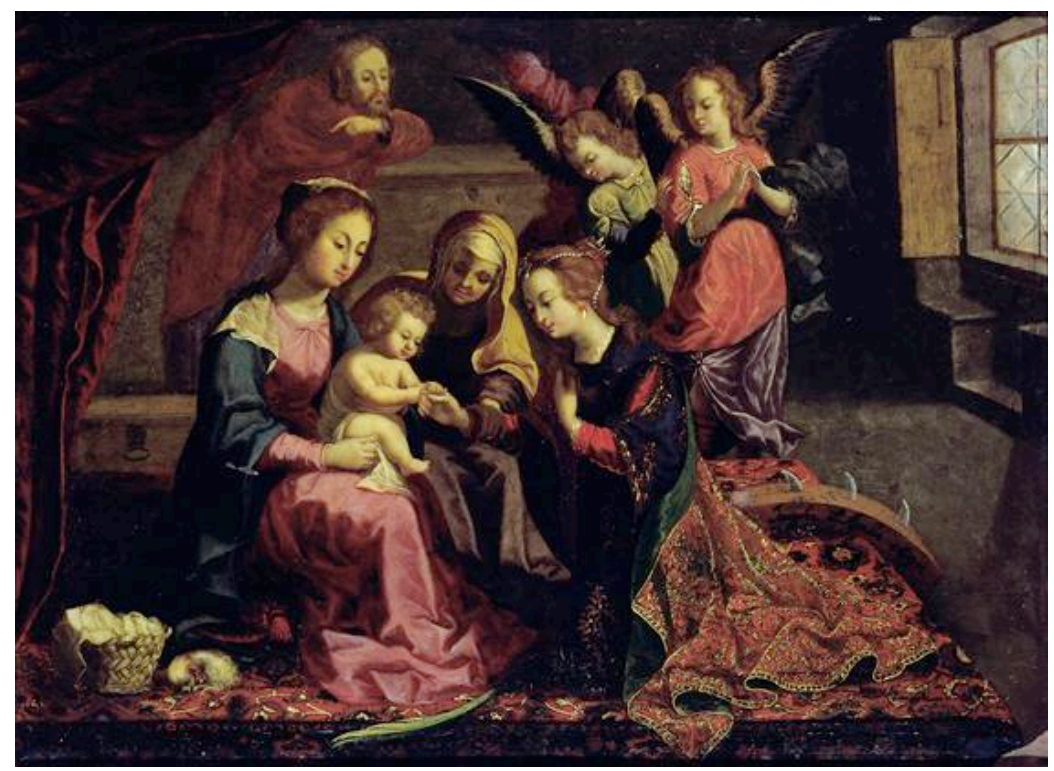

Fig. 52 - Josefa de Óbidos, Casamento místico de Santa Catarina, 1647. MNAA, inv. 197 Min

\footnotetext{
${ }^{186}$ Um anacoreta (cat. 1) e uma Flagelação de Cristo (cat. 2) respectivamente. HOLSTEIN, marquês de Sousa (co-auto) - op. cit, p. 23. MNAA, inv. 600 e 601 Pint.

${ }^{187}$ RIBEIRO, José Silvestre - op. cit., T. X, pp. 24-25.
} 
O ano de 65 será igualmente marcado pelas primeiras doações do conde de Carvalhido (1817-1900), negociante portuense enriquecido no Brasil e residente em Paris onde desenvolveu hábitos colecionistas. A partir de então, as remessas de pinturas para Lisboa sucedem-se com alguma regularidade, atingindo o volume de obras doadas tal dimensão que justifica por si só o tratamento individualizado que Ihes é consagrado no ponto seguinte. Sousa Holstein depositava grandes esperanças nesta modalidade de enriquecimento do acervo, desejando que viesse a ser seguida por outros colecionadores: "É de supor e de esperar que seja continuada esta prática, a qual em Inglaterra tem dado óptimo resultado. Uma parte importante da coleção existente em Trafalgar Square [Londres, National Gallery] foi formada deste modo. Todos devem ter interesse em engrandecer o museu nacional de pinturas e em contribuir para que esta instituição possa um dia alcançar o esplendor a que deve chegar" ${ }^{188}$. Como o tempo se encarregaria de confirmar, muito poucos potenciais doadores comungariam de tal prodigalidade, permanecendo Carvalhido um caso praticamente isolado. Na realidade, a primeira edição do Catalogo provisorio (1868), menciona apenas dois outros portugueses cujas dádivas foram consideradas dignas de ser integradas na galeria, 0 diplomata e colecionador João de Sousa Lobo que já vimos ter vendido algumas obras à Academia, com uma composição religiosa de autor desconhecido ${ }^{189}$, e o académico honorário Francisco Lourenço da Fonseca, com um cena de género holandesa atribuída a Adriaen Brouwer ${ }^{190}$.

Curiosamente, verifica-se uma maior adesão por parte de estrangeiros, alguns dos quais do meio diplomático-consular, no que deverá em parte ser atribuído à rede de contactos tecida pelo vice-inspetor. Assim aconteceu logo em 1864, ao ser apresentado à conferência "um pequeno quadro muito antigo atribuído a Agnolo Gaddi e oferecido à Academia por intervenção de S. Ex. [Sousa Holstein] pelos Srs. Francisco de Sousa, cônsul de Portugal em Madrasta e Giuseppe Nasini". Sendo

\footnotetext{
${ }^{188}$ HOLSTEIN, marquês de Sousa (co-auto) - op. cit., p. 10.

${ }^{189}$ Figura na 1a ed. do Catalogo provisorio com o n.o 93 como “Um milagre”. MNAA, inv. 604 Pint.

${ }^{190}$ Citamos a carta que acompanhou a dádiva: "Possuindo um quadro atribuído ao célebre Adriaen Brouwer e constando-me que a galeria nacional da Academia Real das Belas Artes não possui na sua coleção nenhum espécime deste autor, lacuna que muitas galerias de 1. a ordem na Europa não puderam ainda preencher, em razão de serem raras as pinturas desta artista; tomo a liberdade de o oferecer para fazer parte da coleção da Academia". Carta datada de 3 de Julho de 1866, Arquivo da ANBA, disponível em http://digitarq.dgarq.gov.pt/ PT-ANBA-ANBA-B-001-00003_m1224.TIF e _1225.TIF. A obra figura na 1. a ed. do Catalogo provisorio com o n. 979 mantendo a mesma atribuição.
} 
examinado o quadro, "e julgando-se assaz curioso, resolveu-se que se fizesse menção honrosa do oferecimento, escrevendo o secretário aos dois mencionados cavalheiros para lhes agradecer a doação em nome da Academia, dando o Exmo. vice-inspetor parte dela ao governo" ${ }^{191}$. Apesar de tal apreciação, o primitivo italiano parece não ter chegado a integrar a galeria, não constando do respectivo catálogo.

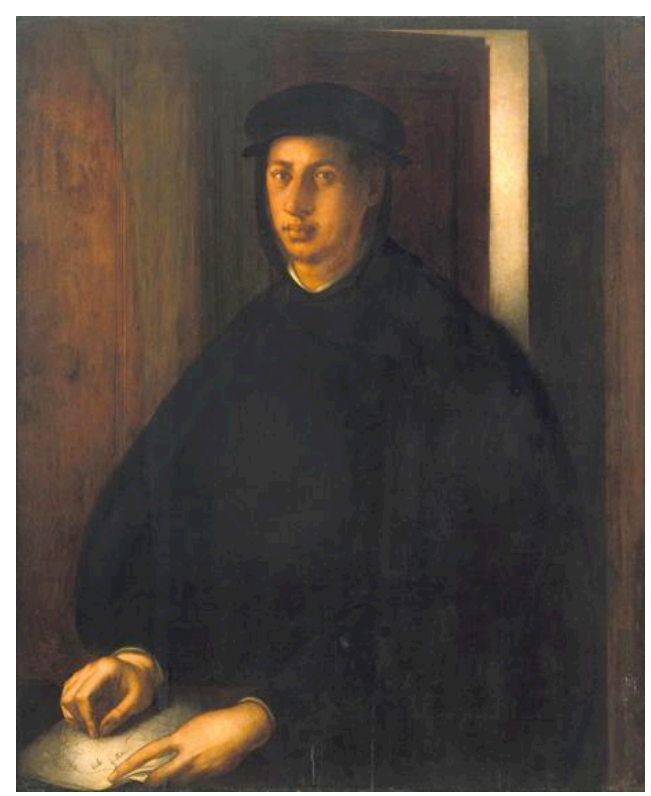

Fig. 53 - Jacopo da Pontormo (?), Retrato de Alexandre de Médicis, c. 1534-1540. MNAA, inv. 607 Pint

No ano seguinte registam-se outras ofertas, uma das quais do cônsul da República do Chile em Livorno, Pandley (Emanuel) Rodocanachi (1818-1882), membro de uma poderosa família de armadores de origem grega cuja atividade empresarial se entendia à banca. Na protocolar carta que acompanhava a dádiva, ${ }^{192}$ Rodocanachi refere-se elogiosamente ao marquês que poderá ter conhecido durante a permanência deste último em Itália, e a quem a pintura enviada agradou, um qualificado retrato masculino que sabemos hoje representar Alexandre de Médicis, atribuído então a Bronzino e atualmente dado a Pontormo (fig. 53). Presente pelo vice-inspetor aos professores de pintura, "concordaram estes que era obra de bastante merecimento,

\footnotetext{
191 Conferência ordinária de 13 de Outubro de 1864. Arquivo da ANBA, disponível em http://digitarq.dgarq.gov.pt/ PT-ANBA-ANBA-F-002-00001_m0200.TIF

${ }^{192}$ Carta datada de 21 de Abril de 1865. Idem, disponível em http://digitarq.dgarq.gov.pt/ PT-ANBAANBA-B-001-00003_m1178.TIF
} 
que Ihes parecia ser pintada no estilo de Bronzino, avaliando-a em um conto de reis aproximadamente" ${ }^{193}$.

Considerando o serviço prestado à Academia em prol do enriquecimento do seu acervo, Sousa Holstein intercederá junto do Ministério do Reino para que o doador fosse agraciado com o grau de comendador da ordem de Cristo. Cuidadoso na concessão daquele tipo de distinções, o ministro oficiou ao nosso embaixador em Itália, José Ferreira Borges de Castro, procurando obter mais informações sobre Pandley, no intuito de avaliar melhor a justeza da atribuição. O ofício de resposta traça o seguinte retrato do doador: "Pertence aquele individuo a uma família grega, cujos antecedentes são pouco conhecidos mas que há 30 anos veio estabelecer-se em Livorno e ali fez fortuna no comércio de câmbios (?) que continua a exercer mediante uma vasta associação de parentes, tendo casas em Londres, Marselha, Odessa, São Petersburgo e Nova Iorque" ${ }^{194}$.

Acrescenta Borges de Castro que na filial de Livorno, Pandley desempenhava apenas as funções de caixa, tendo porém "uma fortuna independente, consistindo em valores comerciais e um teatro de que muito se ocupa". Mau grado aquela ocupação, constava ser um homem reservado e pouco dado às belas artes: "É considerado completamente estranho a quaisquer estudos e às belas artes; é bem educado mas tem pouco uso da sociedade. A importância e consideração de que goza dependem unicamente da sua fortuna". Esse poder económico estava precisamente na origem das duas comendas que então detinha: a de cavaleiro da ordem do Salvador da Grécia, "por ter mandado para Atenas uma forte soma de dinheiro ao tempo da revolução de $1843^{\prime \prime}$, e a cruz de cavaleiro de S. Lázaro "por uma festa oferecida no seu teatro ao rei de Itália". Atendendo a esses factos, concluía o nosso embaixador não ver "motivo plausível para se dar a Pandley Rodocanachi o grau de comendador quando o de cavaleiro seria mais que suficiente para o recompensar de algum serviço que por acaso ele haja prestado à Academia Real de Belas Artes de Lisboa".

Na mesma sessão em que o vice-inspetor apresentou o retrato doado pelo cônsul do Chile em Livorno, convidou os académicos a examinarem uma pequena composição

\footnotetext{
${ }^{193}$ Conferência ordinária de 3 de Julho de 1865. Idem, disponível em http://digitarq.dgarq.gov.pt/ PTANBA-ANBA-F-002-00001_m0257.TIF

${ }^{194}$ Oficio datado de 19 de Outubro de 1865. Arquivo Histórico-Diplomático do MNE, Legação de Portugal em Florença, cx. 54, doc. 52. As restantes citações reportam-se à mesma referência.
} 
religiosa enviada por outro aspirante a doador e atribuída a Dürer. "Feito o exame, concordavam nisso os sobreditos professores, julgando que o dito quadro tinha merecimento e podia valer quinhentos mil reis, pouco mais ou menos". Em consequência dessa apreciação, e como era da praxe, "resolveu-se que se agradecesse a oferta e se desse parte dela ao governo"195, no intuito do doador vir a ser agraciado com alguma distinção honorífica. A oferta em questão fora efectuada pelo tenor franco-italiano Emilio Naudin (1823-1900) que meses antes havia desempenhado o papel de Vasco da Gama na estreia da ópera L'Africane (Paris, 28 de Abril de 1865), derradeira obra do compositor Giacomo Meyerbeer (1791-1864). A concessão de uma distinção honorífica por parte do país natal do navegador a quem dava vida na ópera seria eventualmente desejada pelo tenor que ficou para sempre associado àquele papel.

O desejo de distinções honoríficas estará na base de outras dádivas, como foi o caso de Antoine Schindler, "cavaleiro da ordem de Carlos III em Espanha e residente em Paris" que no mesmo ano enviava à Academia "um quadro pintado em pano representando quase em tamanho natural Vénus nua dando um beijo a cupido, obra esta que o oferente julga distinta, e executada por um dos mestres da escola bolonhesa, esperando que como tal seja aceite e recomendada ao governo". Analisado o quadro, Anunciação, Cristino, Lupi e Marciano "declararam formalmente que o não julgavam distinto, mas como uma cópia medíocre, sendo de parecer que como tal não podia ser aceite para servir na escola e fazer parte da galeria nacional” ${ }^{196}$. Tendo o vice-inspetor participado a Schindler a recusa da oferta pelas razões expostas, seria a obra entregue a João Baptista Testa, cônsul do reino das Duas Sicílias em Lisboa que terá exercido as funções de intermediário. No recibo então assinado ${ }^{197}$, Testa informa ter também recolhido o suposto Dürer enviado pelo tenor Nasini, inicialmente aceite pelos professores como vimos. Uma segunda análise terá estado provavelmente na

195 Conferência ordinária de 3 de Julho de 1865. Arquivo da ANBA, disponível em http://digitarq.dgarq.gov.pt/ PT-ANBA-ANBA-F-002-00001_m0258.TIF. Localizámos igualmente a carta enviada por Naudin ao vice-inspetor, a 4 de Março de 1865. Idem, disponível em http://digitarq.dgarq.gov.pt/ PT-ANBA-ANBA-B-001-00003_m1180.TIF

${ }^{196}$ Conferência extraordinária de 10 de Julho de 1865. Idem, disponível em http://digitarq.dgarq.gov.pt/ PT-ANBA-ANBA-F-002-00001_m0261.TIF. Localizámos igualmente a carta enviada por Schindler ao viceinspetor, a 22 de Julho de 1865. Idem, disponível em http://digitarq.dgarq.gov.pt/ PT-ANBA-ANBA-B001-00003_m1172.TIF

${ }^{197}$ Arquivo do MNAA, fundo José de Figueiredo, cx. 1, pasta 2, doc. 6. 
base de tal decisão, contrária como outras às expectativas dos aspirantes a doadores que viam na nossa Academia um mero veículo de obtenção das tão desejadas distinções honoríficas. Refira-se que esta prática se estendeu também então à galeria de pintura formada pelo rei D. Luís no Palácio da Ajuda, gerando algum desconforto junto da vedoria da Casa Real e do governo que se queriam parcimoniosos na atribuição de comendas ${ }^{198}$.

No que diz respeito à pintura contemporânea, e como já foi referido, a sua entrada estava de certa forma assegurada devido aos concursos para os lugares de professores de pintura, aos envios dos pensionistas do Estado no estrangeiro, e às ofertas implícitas às nomeações para académico de mérito. Estas últimas contribuíram pontualmente para o crescimento do acervo, podendo-se citar entre os nacionais os casos de Alfredo de Andrade (1863), Tomazini (1866), José Ferreira Chaves (1868) e Manuel Maria Bordalo Pinheiro (1868). Tais nomeações tanto podiam partir do artista ao enviar uma obra demonstrativa do seu mérito para ser examinada pelos académicos, como de uma decisão voluntária destes, reconhecendo determinado percurso artístico. Assim sucedeu com Manuel Maria Bordalo Pinheiro que ao ser notificado da sua nomeação, apressou-se a enviar um pequeno esboço inspirado num episódio do Monge de Cister de Alexandre Herculano, clarificando: "Não tendo eu solicitado a minha admissão na Academia e sendo aquela nomeação para mim a mais honrosa, pois que nasceu de um ato espontâneo do corpo académico, não estava prevenido e por enquanto não me tem sido possível dedicar-me a um trabalho expressamente destinado à Academia". Comprometia-se por isso a oferecer mais tarde "um outro trabalho que melhor represente o género a que me tenho dedicado ultimamente" ${ }^{199}$.

Aquele tipo de nomeações permitiu também a entrada de alguma pintura contemporânea estrangeira, a exemplo do austríaco Ferdinand Krumholz (1847), de passagem por Lisboa para retratar a família real, o brasileiro Manuel de Araújo Porto

\footnotetext{
${ }^{198}$ Em 1867, seria mesmo emitido um despacho da Secretaria de Estado dos Negócios Estrangeiros que instava a "não dar seguimento algum a pedidos por parte de autores que desejam oferecer a El-Rei exemplares de obras de sua composição, sendo quase sempre seguidos tais oferecimentos de solicitações afim de obterem distinções honoríficas". XAVIER, Hugo - Galeria de Pintura no Real Paço da Ajuda, 2013, p. 121.

${ }^{199}$ Carta datada de 15 de Julho de 1868. Arquivo da ANBA, disponível em http://digitarq.dgarq.gov.pt/ PT-ANBA-ANBA-B-001-00003_m1436.TIF e _m1437.TIF
} 
Alegre (1860) ou os espanhóis García Toledo (1868) e Ramon Rodriguez Barcaza (1870). Artistas de craveira mediana, a eles se deve acrescentar o francês Henri Coroënne (1869) (fig. 54), cuja oferta de um quadro representando o duque de Guise se ficou a dever à intervenção do seu amigo Luís Caetano Pedro de Ávila (1832-1904) que havia estudado arquitetura em Paris onde se terão conhecido. Logo após recebida a obra, Ávila escrevia a Sousa Holstein encarecendo as qualidades do pintor e insistindo "para que V. Ex. a se digne obter do governo de Sua Majestade a remuneração condigna ao seu oferecimento e talento" ${ }^{200}$. Estas ofertas vindas do estrangeiro tinham portanto à partida um custo equivalente a uma distinção honorífica, raras vezes se contentando o artista doador com o título académico que Ihes estava inerente.

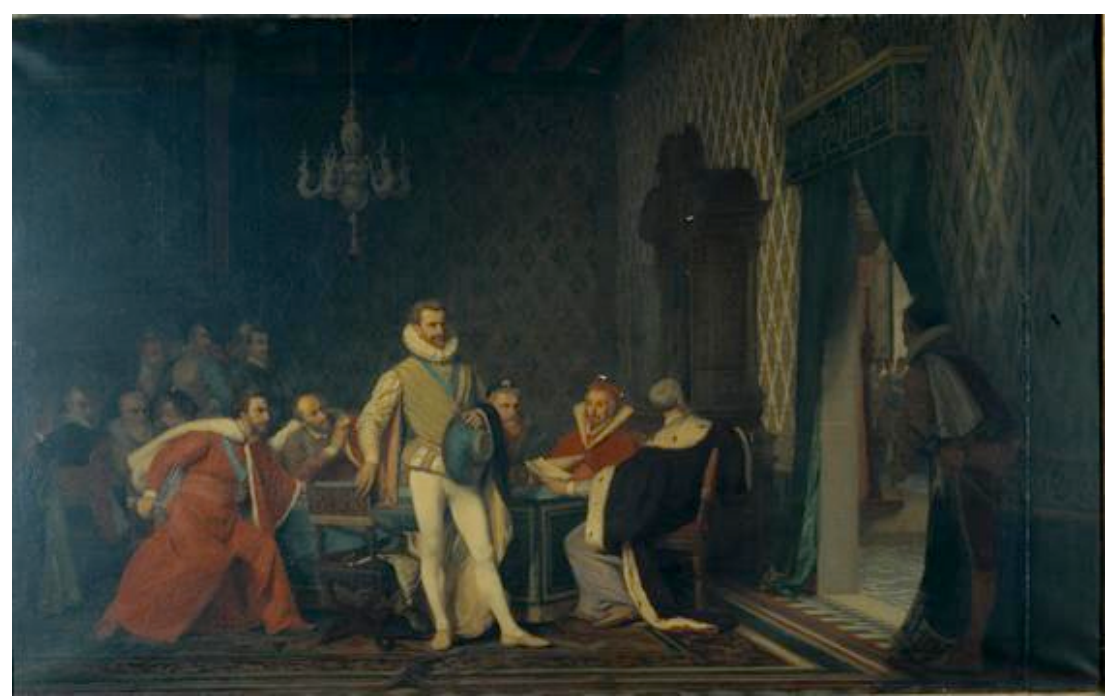

Fig. 54 - Henri Coroënne, O duque de Guise prestes a ser assassinado, 1863. MNAC-MC, inv. 68

\subsubsection{Doações Carvalhido}

Nos últimos anos de vida, Luís Augusto Ferreira de Almeida, conde de Carvalhido, viu concretizado um desejo há muito acalentado: a inauguração no Museu Nacional de Belas Artes e Arqueologia de uma sala com o seu nome (1896), destinada a expor a totalidade dos quadros por si doados à Academia, assim como a edição de um catálogo

\footnotetext{
${ }^{200}$ Carta datada de 1 de Novembro de 1869. Idem, disponível em http://digitarq.dgarq.gov.pt/ PT-ANBAANBA-B-001-00003_m1458.TIF
} 
(1898), pago do seu bolso, cujo produto de venda se destinava às instituições de beneficência apoiadas pela rainha $D$. Amélia. Como atesta a correspondência trocada com os responsáveis do museu, o doador acompanhou com empenho a elaboração daquela obra, não tanto pela classificação e descrição das pinturas nela contidas mas pela nota biográfica que pretendia deixar para a posteridade. Serviu-se para tal de um laudatório artigo consagrado à sua pessoa, publicado em 1888 no n. 992 dos Portuguezes Illustres, enviado para Lisboa com anotações manuscritas do seu próprio punho, clarificando ou corrigindo determinados pormenores mencionados ${ }^{201}$. Será essencialmente a partir desse texto que o conservador do museu, Manuel de Macedo (1839-1915), delineará o relato oficial dos feitos de que se orgulhava o conde.

Carvalhido é-nos apresentado como um benemérito titular descendente de uma família de origens beirãs estabelecida na cidade invicta. Nascido a 3 de Março de 1817, partiu novo para o Brasil para se dedicar ao comércio, tendo-se estabelecido no Rio de Janeiro onde $\operatorname{casou}^{202}$, acumulou fortuna e adquiriu influência "que ele com a sua inata fidalguia, soube pôr sempre ao serviço do seu país e da causa da civilização em geral” $^{203}$. Entre outros são mencionados os casos das contribuições para o resgate da nau Vasco da Gama que por incapacidade financeira do governo português corria o risco de ficar sinistrada no porto do Rio de Janeiro, para as vítimas do incêndio do teatro Baquet do Porto e para as obras do Mosteiro dos Jerónimos. Ao longo dos anos fez também importantes donativos a diversas instituições de caridade como a Misericórdia do Porto, o Albergue Noturno de Lisboa, de que foi sócio fundador, e a Sociedade Portuguesa de Órfãos, "atos estes de singular munificência que lhe dão jus a denominar-se o primeiro filantropo da nossa terra".

Demonstrará sempre especial apreço pela dinastia reinante, sendo ainda assinaladas as contribuições para as solenes exéquias celebradas no Rio de Janeiro por ocasião da morte de D. Maria II, assim como para os festejos que assinalaram a subida ao trono do filho, D. Pedro V. Os monarcas reconhecerão desde cedo as provas de dedicação à pátria e à família real, conferindo-Ihe sucessivamente as honras de comendador da

\footnotetext{
${ }^{201}$ Arquivo do MNAA, fundo José de Figueiredo, cx. 4, pasta 1, doc. s. $n$.

${ }^{202} \mathrm{Em} 1844$ com Luísa Joaquina de Oliveira, de quem teve um filho, José Alves Ferreira de Almeida. Fora do matrimónio teve outro filho, Luís de Oliveira, nascido em 1852 e legitimado em 1857.

203 [MACEDO, Manuel de] - Catalogo da collecção de quadros offerecida ao Estado pelo Sr. conde de Carvalhido, 1898, pp. 5-8. As restantes citações reportam-se à mesma referência.
} 
Ordem de Nossa Senhora da Conceição de Vila Viçosa, de cavaleiro da Ordem da Torre e Espada e de fidalgo cavaleiro da casa real. Em 1855, D. Fernando II, regente na menoridade de D. Pedro V, concedeu ao negociante o título de visconde de Carvalhido em sua vida, atendendo "aos bons serviços por ele feitos a bem dos seus compatriotas desvalidos, e em proveito dos melhoramentos materiais em Portugal" conforme descrito no respectivo decreto. Dezanove anos mais tarde, D. Luís elevou-o a conde, numa altura em que os "melhoramentos materiais" dispensados à nação se estendiam já à oferta de pinturas para a Academia de Belas Artes.

\section{Haro, o marchand}

As doações deverão ter sido motivadas pelo exemplo de D. Fernando II ao anunciar em finais de 1864 a cedência de parte da sua dotação à Academia para a aquisição de pinturas, datando de Janeiro de 1865 aquela que parece ser a primeira dádiva de Carvalhido, feita por intermédio de um seu parente, Miguel Osório Cabral, juiz do Tribunal da Relação de Lisboa. Na missiva dirigida ao vice-inspetor, marquês de Sousa Holstein, comunicava o juiz constar de "dois quadros de merecimento e raridade, sendo um de Murillo e outro de Carlo Dolci, os quais me encarrega de os oferecer ao museu nacional o Exmo. visconde de Carvalhido, residente em Paris, esperando que esta oferta se considere como testemunho do seu ardente desejo de engrandecimento dos nossos estabelecimentos artísticos e do muito amor e dedicação à sua pátria" ${ }^{204}$. Fixado na capital francesa após a morte da mulher, Carvalhido aí viria a desenvolver hábitos colecionistas, socorrendo-se dos serviços de um destacado agente do mercado de arte, Étienne-François Haro (1827-1897), pintor, restaurador, marchand e proprietário de um estabelecimento que fornecia telas, tintas, pincéis e demais materiais a alguns dos artistas mais proeminentes daquele tempo. À missiva redigida por Osório Cabral, foi anexada uma carta de Haro com lisonjeiras apreciações acerca dos dois quadros que haviam sido por si restaurados (e provavelmente comercializados), com destaque para o suposto Carlo Dolci, "un des plus parfaits de ce

\footnotetext{
${ }^{204}$ Carta datada de 27 de Janeiro de 1865. Arquivo da ANBA, disponível em http://digitarq.dgarq.gov.pt/ PT-ANBA-ANBA-B-001-00003_m1036.TIF e_m1037.TIF. MNAA, inv. 605 e 606 Pint.
} 
maître" escrevia convicto, assegurando que "cela a été jugé ansi chez moi par Mr. Ingres" 205 .

Jean Auguste Dominique Ingres havia dado lições de pintura a Haro, tornando-se seu amigo e cliente, tal como Eugène Delacroix, a quem o marchand convidou para padrinho de casamento e influenciou na escolha da casa da rue Furstemberg, atual Museu Delacroix, para residência e atelier. Como foi dado a conhecer em recente exposição, viria a desempenhar um papel fundamental na vida e no trabalho daqueles dois artistas, de quem reuniu um acervo considerável de obras, chegando a representá-los junto de potenciais compradores ${ }^{206}$. Situado em Saint-Germain-desPrés, com a divisa "Au génie des arts", o seu estabelecimento comercial era ainda frequentado por Corot, Courbet, Manet, Degas, Millet, Sisley e Carolus Duran. Bem próximo, na rue Visconti, ficava o atelier de restauro que atingiu notoriedade pelo desenvolvimento de inovadores produtos e procedimentos técnicos, levando a que lhe fossem confiadas as pinturas do Palácio das Tulherias e do Ministério das Obras Públicas francês.

Diversos indícios sugerem ter tido Haro um papel importante na formação da coleção Carvalhido, dando pareceres sobre aquisições, vendendo diretamente obras e assegurando os respectivos restauros. No mesmo ano em que se estreava como doador à Academia, o ainda visconde confiou ao marchand a organização do catálogo da sua pinacoteca, composta já então por 104 obras, divididas por escolas: espanhola (13), francesa (38), flamenga e holandesa (43) e italiana (10). Compreendia os principais vectores do colecionismo francês daquela época, na preferência pela pintura flamenga e holandesa do século XVII (Brueghel, Teniers, Cuyp, Wouwerman ou mesmo Rubens, entre outros autores citados) cujo interesse vinha já do ancien regime, tendo sido incrementado em meados de Oitocentos com o contributo de alguns estudos, ${ }^{207} \mathrm{e}$

\footnotetext{
205 Carta datada de 21 de Dezembro de 1864. Arquivo da ANBA, disponível em http://digitarq.dgarq.gov.pt/ PT-ANBA-ANBA-B-001-00003_m1038.TIF e_m1039.TIF

${ }^{206}$ A relação dos dois artistas com Haro foi objecto de uma exposição no Museu Delacroix comissariada por Arlette Sérullaz "Entre Ingres et Delacroix: Étienne-François Haro" (24 de Fevereiro a 15 de Maio 2006). Não foi editado catálogo. Cf. SÉRULLAZ, Arlette - "Étienne-François Haro, entre Ingres et Delacroix". Bulletin de la Societé des Amis du Musée National Eugène Delacroix, n. 4, 2006.

${ }^{207}$ Destaca-se o caso de Arsène Houssaye, autor de uma Histoire de la pinture flamande et hollandaise (1846) que se baseia em larga medida na Vie de peintres flamands, allemands e hollandais de JeanBaptiste Descamps (1753-1763). A partir de 1850, serão sobretudo os trabalhos de Théophile Thoré, publicados sob o pseudónimo de William Bürger que difundirão o conhecimento daquele tipo de produção.
} 
no nascente gosto pelos autores franceses de Setecentos (Boucher, Fragonard, Lancret, van Loo, Vernet...), definitivamente reabilitados na sequência de uma exposição a eles consagrada na Galerie Martinet, em $1860^{208}$. Mais tradicional era o pequeno agrupamento italiano (Guercino, Dolci, Correggio ou Tiepolo), merecendo maior atenção a apetência pelos mestres do Siglo de Oro espanhol (Murillo, Ribera, Alonso Cano e até Velázquez), fruto de uma corrente romântica pós-napoleónica que teve o seu momento maior na galeria espanhola do Louvre formada pelo barão Taylor (1838-1850). Como facilmente se depreende, a preferência do colecionador foi na sua esmagadora maioria para a pintura antiga, identificando-se todavia no núcleo francês alguns românticos (com destaque para Decamps, Delacroix e Géricault).

Nas escassas 10 linhas redigidas ao jeito de apresentação e assinadas com a inicial do seu nome, Haro informa serem várias pinturas provenientes de galerias de nomeada, como a do duque de Morny (1811-1875), conhecido estadista do Segundo Império, e do conde de Turenne (1776-1852), general de Napoleão Bonaparte. Refere ainda ter sido a coleção formada "à la suite de nombreux voyages", afigurando-se como o resultado "de longes stations faites dans les musées publics et les galeries particulières, qui ont développé chez cet amateur distingué le goût délicat de la peinture et le sentiment des beaux-arts" 209 .

\section{Viagens e exposições}

As visitas a museus e galerias terão sido uma constante na sequência das viagens empreendias após o titular ter conhecido em Paris Helena Leichtinger (1841-1934), natural de Budapest ${ }^{210}$, de quem virá a ter um único filho, Emílio, nascido em 1866 e que chegará a ser agraciado em 1881 com o título de conde ${ }^{211}$. Educado em prestigiados estabelecimentos de ensino franceses (colégio Vaugirard, Liceu Condorcet), seguirá a carreira diplomática, vindo a exercer as funções de secretário da

\footnotetext{
${ }^{208}$ Tableaux et dessins de l'école française, principalement du XVIIle siècle tirés de collections d'amateurs, 1860.

${ }^{209}$ [HARO, Étienne-François] - Catalogue de la collection de tableaux de M. le vicomte de Carvalhido, 1865.

${ }^{210} \mathrm{O}$ casamento do casal ocorrerá apenas em 1880.

${ }^{211}$ Em 1881, num oficio dirigido ao monarca, o titular solicitava que fosse concedido “o seu próprio título a seu único Filho, Emílio Leichtinger Ferreira de Almeida, que pela sua boa índole, pelos exemplos paternos, e pela educação cuidadosa que está recebendo em Paris, espero que sempre o honrará". Cf. cópia manuscrita do ofício original. Arquivo do MNAA, fundo José de Figueiredo, cx. 4, pasta 1, doc. 24.
} 
Legação de Portugal em São Petersburgo. Prematuramente falecido aos 29 anos de idade, a ele virá a ser dedicado um ensaio biográfico da autoria de José Frederico Laranjo, lente da Universidade de Coimbra, que dá conta da vivência cosmopolita da família Ferreira de Almeida ${ }^{212}$. Sabe-se que em 1870, por ocasião da guerra francoprussiana, se instalaram em Monte Carlo, passando depois a Nápoles onde iniciaram um périplo por Itália que incluiu as cidades de Roma, Florença, Veneza e Milão. Visitaram também a Hungria, seguindo pelo Danúbio até Viena e daí a Dresden, Munique e Colónia. Nos períodos estivais, frequentavam estâncias elegantes do circuito europeu, podendo mencionar-se o caso do Verão de 1874, passado em Uriage, onde travaram amizade com o pintor Eugène Lami (1800-1890) que viria então a dar lições de desenho ao pequeno Emílio.

As deslocações a Portugal foram frequentes, informando em 1866 o Diario de Noticias encontrar-se hospedado no Hotel Bragança o ainda visconde, "com justiça considerado com distinção entre os amadores das belas artes", e detentor de "uma coleção preciosa de boas pinturas, das quais há tempos ofereceu dois valiosos quadros à Academia das Belas Artes de Lisboa" ${ }^{213}$. Noticiava noutra edição o mesmo jornal ter sido o colecionador "visitado por alguns artistas", talvez professores de pintura e outros académicos responsáveis por aquele estabelecimento de ensino, no provável intuito de agradecer pessoalmente a dádiva efectuada um ano antes ${ }^{214}$. Ao regressar a Paris, repetirá o gesto com o envio de duas outras obras, uma cena de caça associada a Boons e uma composição mitológica dada a François Gérard, igualmente objecto de notícia na imprensa ${ }^{215}$. Cuidadoso, encarregava ainda o juiz seu parente de fazer comunicar ao vice-inspetor a necessidade de mandar retocar a moldura de uma das primeiras pinturas doadas, ligeiramente danificada durante a viagem ${ }^{216}$.

Naquele ano de 66 teve lugar em Paris uma exposition retrospective de tableaux anciens organizada em paralelo e no mesmo local (Palais de l'Industrie) da exposição anual de belas artes ou Salon, que ficaria então marcado pelas duras críticas do jovem Émile Zola à "arte oficial" em defesa de Manet e de outros pintores seus amigos, numa

\footnotetext{
212 LARANJO, José Frederico - O conde Emílio de Carvalhido: recordações de um amigo, 1895.

${ }^{213}$ Diario de Noticias, 14 de Novembro de 1866

${ }^{214}$ Idem, 18 de Novembro de 1866

${ }^{215}$ Idem, 27 de Dezembro de 1866

${ }^{216}$ Carta datada de 11 de Janeiro de 1867. Arquivo da ANBA, disponível em http://digitarq.dgarq.gov.pt/ PT-ANBA-ANBA-B-001-00003_m1264.TIF e_m1265.TIF
} 
série de artigos com o título de Mon Salon ${ }^{217}$. A mostra de pintura antiga contou com a participação de Étienne-François Haro, "délégué du comité pour l'organization de l'exposition", conforme surge indicado no catálogo cujo texto de apresentação fazia destacar "la comparaison immediate des oeuvres contemporaines avec les oeuvres des maîtres consacrés", susceptível de ter "une heureuse influence sur les peintres, en même temps qu'elle doit éclairer et fortifier le goût du public" ${ }^{218}$.

Dada a quantidade e importância das obras enviadas, ocupavam duas salas distintas as coleções do conde Duchâtel e dos irmãos Jacob e Isaac Pereire, de uma família judaica oriunda de Portugal (Peniche), fixada em França desde 1741. Não menos relevantes eram as participações dos barões de Rothschild e de Eugéne Dutuit cuja coleção estará mais tarde na origem do Museu do Petit Palais, figurando ainda entre os emprestadores o nosso visconde com obras de três autores (o italiano Ludovico Cardi, "Il Cigoli", e os holandeses Jan Asselyn e van der Wilt) ${ }^{219}$. Um ano após ver editado o catálogo da sua pinacoteca, congratulava-se seguramente por participar num evento de peso entre a elite do colecionismo francês, no que se poderá atribuir a uma intervenção de Haro que, para além de delegado do comité, colaborou também como emprestador.

Em 1867, Paris assistiu à abertura de uma ambiciosa iniciativa ideada por Napoleão III, a Exposição Universal de Arte e Indústria, a segunda a ter lugar na capital francesa após a sua congénere de $1855^{220}$. Nas vésperas da inauguração, Carvalhido recebeu na sua residência a visita do professor da Academia responsável por acompanhar o transporte e a montagem das obras de arte nacionais a figurar no certame, Joaquim Pedro de Sousa, acompanhado do seu colega Marciano Henriques da Silva, a quem D. Luís havia confiado a tarefa de viajar em busca de pinturas para a galeria em organização no Palácio da Ajuda ${ }^{221}$. De acordo com o correspondente do Diario de Noticias, o colecionador ficou muito reconhecido pelas manifestações de apreço

\footnotetext{
${ }^{217}$ Reunidos no seguinte opúsculo: ZOLA, Émile - Mon Salon: augmenté d'une dédicace et d'un appendice, 1866.

${ }^{218}$ Exposition rétrospective: tableaux anciens empruntés aux galeries particulières: Palais des ChampsÉlysées, 1866, p. 5.

${ }^{219}$ As obras em questão correspondem aos números 6, 25 e 180 do catálogo supra citado.

${ }^{220}$ A este respeito cf. SOUTO, Maria Helena - Portugal nas exposições universais 1851-1900, 2011, pp. 101-133.

${ }^{221}$ cf. XAVIER, Hugo - op. cit., pp. 117-118.
} 
dirigidas na ocasião à sua galeria, "e estando os dois artistas a observar um quadro de Lebrun, declarou-lhes que em honra da sua visita ia enviá-lo à Academia”222.

Dias após a inauguração, no intuito de celebrar a participação nacional, ofereceu um jantar de 18 talheres em honra dos membros da nossa comissão, representada por João Palha, vice-comissário, Teixeira de Aragão e Joaquim Pedro de Sousa, acompanhados de "outros distintos cavalheiros portugueses e brasileiros", conforme noticiado. Terminou a confraternização com uma visita às "salas onde se admiravam os mais preciosos quadros da sua seleta coleção, especialidade em que o Sr. visconde é um dos mais notáveis amadores"223.

Procurando tirar partido dos numerosos visitantes estrangeiros que acorreram à Exposição Universal, foi então publicado um detalhado guia de Paris que contou com as participações de conceituados escritores e historiadores como William Bürger, pseudónimo de Théophile Thoré, responsável pela reabilitação de artistas como Vermeer e Frans Hals, e a quem foi confiado um capítulo sobre as coleções particulares da capital ${ }^{224}$. Estimando em cerca de 300 as galerias privadas, entre pintura antiga e contemporânea, Bürger centra-se naturalmente nas mais conceituadas (Lord Hertford à cabeça, passando pelos barões de Rothschild, os irmãos Pereire, o conde de Duchâtel ou o Dr. La Caze de que adiante falaremos), parte das quais franqueadas ao público. Ao concluir, aproveita para elencar os nomes de uma trintena de colecionadores dignos de menção, entre os quais "le vicomte de Carvalhido" o que vindo daquele historiador não deixa de constituir um sinal de alguma distinção ${ }^{225}$.

\section{Novas remessas}

Em Maio de 67, o titular escreveu ao vice-inspetor comunicando o envio de mais cinco quadros: "tomo a liberdade de solicitar a benevolente intervenção de V. Ex.a a quem essa remessa vai dirigida, rogando-Ihe de guardar para a Academia os três dos mestres seguintes - D. Teniers; J. C. Haccou e H. Willems - e de apresentar pessoalmente em

\footnotetext{
222 Diario de Noticias, 30 de Março de 1867.

${ }^{223}$ Idem, 4 de Abril de 1867

224 BÜRGER, W. - “Les collections particulières". Paris guide par les principaux écrivains et artistes de la France, première partie, la science - l'art, 1867, pp. 536-551.

${ }^{225}$ Idem, ibidem, p. 550.
} 
meu nome a S. M. El-Rei os dois de - Brueghel (Peter) e Philippe de Champaigne"226. Decorrente da visita de Marciano da Silva, a oferta a D. Luís que em Outubro daquele ano viu inaugurada a sua pinacoteca, pretendia reforçar a imagem do visconde como colecionador e mecenas das artes. Refira-se que para além do Brueghel e do Philippe de Champaigne, pelo menos outras três obras enviará ao monarca: uns Salteadores de autor não identificado do século XVII, um Catão associado a Ribera, e uma Cabeça de negro dada a Géricault ${ }^{227}$. Em relação às dádivas efectuadas anteriormente à Academia, lamentava na mesma carta ao vice-inspetor o facto de D. Luís se ter "dignado apreciar com demasiada indulgência o pouco que me foi possível fazer para o nosso museu", mostrando estar à espera de uma comenda ou de outro testemunho régio de reconhecimento público. A nova oferta à galeria nacional em organização era assim "prova de que continuo e continuarei a aproveitar todas as ocasiões de contribuir para o aumento das riquezas artísticas do nosso país".

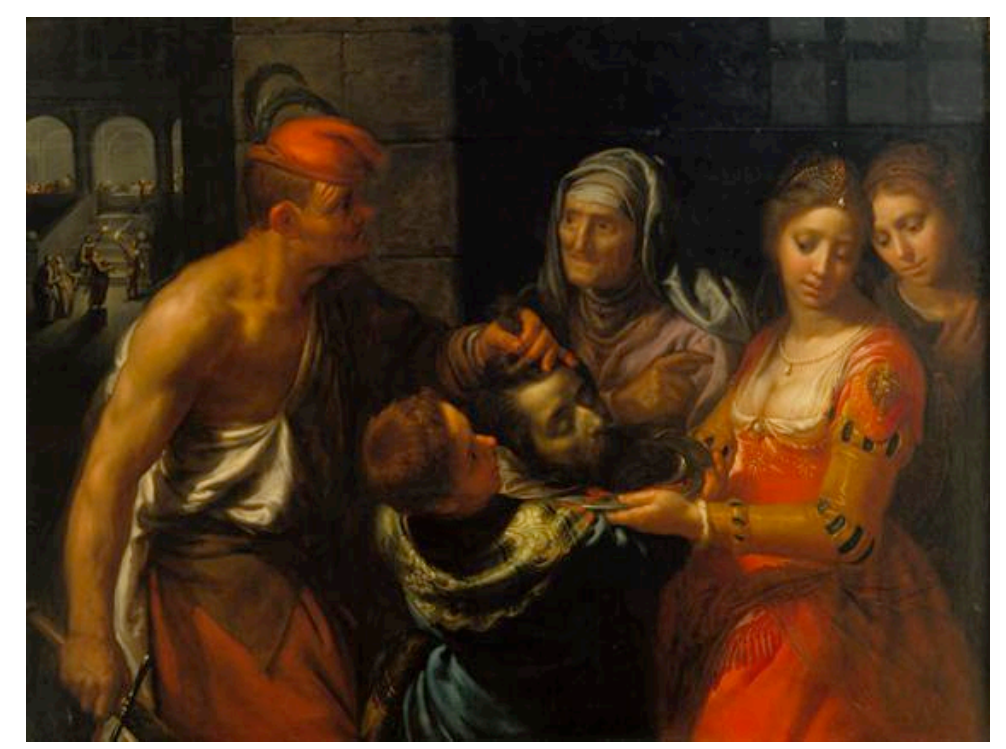

Fig. 55 - Paulus Moreelse, Salomé com a cabeça de S. João Baptista, 1618. MNAA, inv. 675.

A promessa não demorou a ser cumprida e meses depois anunciava Sousa Holstein a remessa de "mais dois quadros originais de Manglars", tendo a conferência determinado como habitualmente que "se fizesse menção honrosa na ata deste novo

\footnotetext{
${ }^{226}$ Carta datada de 28 de Maio de 1867. Arquivo do MNAA; fundo José de Figueiredo, cx. 4, pasta 1, doc. 1. As seguintes citações correspondem à mesma referência.

${ }^{227}$ Cf. XAVIER, Hugo - op. cit., pp. 117-118.
} 
oferecimento do Exmo. visconde, agradecendo-Ihe por escrito" 228 . De modo a tornar mais expressivo o reconhecimento da Academia pelas repetidas dádivas que totalizavam já 10 obras, seria proposta em Fevereiro de 1868 a eleição do colecionador para Académico de Honorário, colhendo a unanimidade dos votos ${ }^{229}$. Será muito provavelmente na sequência de tal distinção que fará o envio de outras obras, sobressaindo uma Salomé com a cabeça de São João Baptista de Paulus Moreelse (fig. $55)$.

Em Setembro daquele ano, Étienne-François Haro escrevia a Sousa Holstein "sous les auspices de mon noble ami, Mossieur le vicomte de Carvalhido", participando a oferta de uma "collection de gravures, lithographies et photographies d'après les ouvrages de mes illustres maîtres, Messieurs Ingres, Flandrin et Horace Vernet". ${ }^{230} \mathrm{Na}$ listagem anexada à carta, dominam as reproduções fotográficas de pinturas de Ingres, falecido no ano anterior, 17 das quais pertencentes ao próprio Haro, reunidas graças às privilegiadas relações mantidas com o artista. O envio das fotos não teve intuitos comerciais mas pedagógicos como refere ao declarar que sendo a arte universal, "il pourrait être bon et utile que les jeunes gens qui se destinent à la peinture puissent à défaut des originaux, consulter les reproductions et s'en inspirer" ${ }^{231}$. Assina como "peintre-expert", acrescentando ser "chevalier de la Légion d'Honneur et de l'Ordre de Notre Dame de la Conception de Vila Viçosa", esta última conferida pelo rei D. Luís e provavelmente relacionada com a formação da galeria da Ajuda. Marciano da Silva efetuou a pedido do monarca várias aquisições em Paris, sendo possível que se tenha dirigido a Haro, recomendado talvez por Carvalhido na sequência da visita atrás mencionada. A eventual oferta de algum quadro por ocasião das referidas compras poderá estar na origem da comenda, no seguimento de uma prática de gratificação régia comum na época.

\footnotetext{
228 Conferência ordinária de 21 de Outubro de 1867. Arquivo da ANBA, disponível em http://digitarq.dgarq.gov.pt/ PT-ANBA-ANBA-F-002-00001_m0440.TIF

${ }^{229}$ Conferência geral de 20 de Fevereiro de 1868. Idem, disponível em http://digitarq.dgarq.gov.pt/ PTANBA-ANBA-F-002-00001_m0469.TIF. Refira-se que, por ocasião da primeira oferta (1865), Cristino da Silva chegou a propor tal distinção, então recusada pela maioria dos académicos, porventura por a julgarem prematura. A este respeito cf. conferência geral de 28 de Janeiro de 1865. Idem, disponível em http://digitarq.dgarq.gov.pt/ PT-ANBA-ANBA-F-002-00001_m0223.TIF

${ }^{230}$ Carta datada de 23 de Setembro de 1868. Idem, disponível em http://digitarq.dgarq.gov.pt/ PTANBA-ANBA-B-001-00003_m1304.TIF

${ }^{231}$ Idem, disponível em http://digitarq.dgarq.gov.pt/ PT-ANBA-ANBA-B-001-00003_m1305.TIF
} 
Algo inesperadamente, em Março de 1870, Carvalhido decide vender parte importante da sua galeria num leilão organizado no Hôtel Drouot que contou com a consultoria de Haro, muitas vezes citado como "expert" nos catálogos das vendas daquela casa ${ }^{232}$. Motivado não por razões de necessidade financeira mas talvez pela vontade de reestruturar o acervo, o leilão compreendeu a quase totalidade das pinturas catalogadas cinco anos antes, acrescidas de outras entretanto adquiridas, num total de 148 lotes. Objecto de algumas rectificações relativamente ao catálogo de 1865, as autorias revelam uma vez mais o predomínio da pintura flamenga e holandesa de Seiscentos, verificando-se um ligeiro reforço das escolas francesa e italiana.

Algumas obras significativas foram então alienadas (mencione-se apenas o caso do Delacroix), mas cerca de um terço não chegaram a encontrar comprador e regressaram à coleção que recomeçou pouco depois a crescer com novas aquisições. Após um intervalo de quase dois anos correspondentes à guerra franco-prussiana e às atribulações relacionadas com a Comuna de Paris que levaram o visconde a deixar o país, as ofertas à Academia terão sido retomadas no final de 1871 com o envio de sete quadros retirados do leilão atrás mencionado, entre os quais um suposto Guercino ${ }^{233}$. No ofício de agradecimento dirigido ao titular, Sousa Holstein comunicava terem sido todos submetidos à apreciação dos professores de pintura daquela instituição, "deixando-se-Ihes provisoriamente as designações de autores que traziam", o que revela existirem dúvidas entre os nossos académicos quanto às atribuições, aspecto recorrente como veremos. Procurando incrementar as ofertas, acrescentava "que se V. Ex. a continuar seus valiosos donativos, esta Academia não deixará de promover que quando eles forem suficientes para guarnecer uma sala, que se reúnam nela todos os quadros oferecidos por V. Ex. a dando-se por esta ocasião o seu respeitável nome" ${ }^{234}$.

\section{Uma sala para albergar a coleção}

Aquela promessa parece ter cativado sobremaneira o colecionador que para além de ver publicamente reconhecidas as suas ofertas, poderia orgulhar-se de ombrear com

\footnotetext{
${ }^{232}$ Catalogue des tableaux anciens et modernes et des curiosités formant la collection du vicomte de Carvalhido dont la vente aura lieu Hotel Drouot, salle n. 1 , les Lundi 14 et Mardi 15 Mars 1870.

${ }^{233}$ Carta datada de 17 de Novembro de 1871. Arquivo do MNAA, fundo José de Figueiredo, cx. 4, pasta 1 , doc. 2

234 Cópia do oficio datado de 29 de Janeiro de 1872. Arquivo da ANBA, disponível em http://digitarq.dgarq.gov.pt/ PT-ANBA-ANBA-B-007-00002_m0133.TIF e_m0134.TIF
} 
D. Fernando II, a quem a Academia dedicara já uma sala na galeria, na sequência das aquisições empreendias com a verba dispensada para o efeito. Meses depois fazia a remessa de dois caixotes marcados "G. N." [Galeria Nacional], um com um grande quadro figurando Danäe, cópia de Ticiano, e outro com "dez ditos de diferentes escolas todos originais" destinados a "serem unidos aos vinte companheiros que a Academia já possui". ${ }^{235}$ Nesse conjunto encontravam-se obras com atribuições sonantes recentemente entradas na coleção (Tintoretto, Carracci, Pietro de Cortona ou Antonello da Messina) e outras que não haviam sido vendidas no leilão de 1870 , com destaque para a Salomé de Lucas Cranach (fig. 56) ${ }^{236}$, a pintura mais relevante de todas as doações efectuadas por Carvalhido.

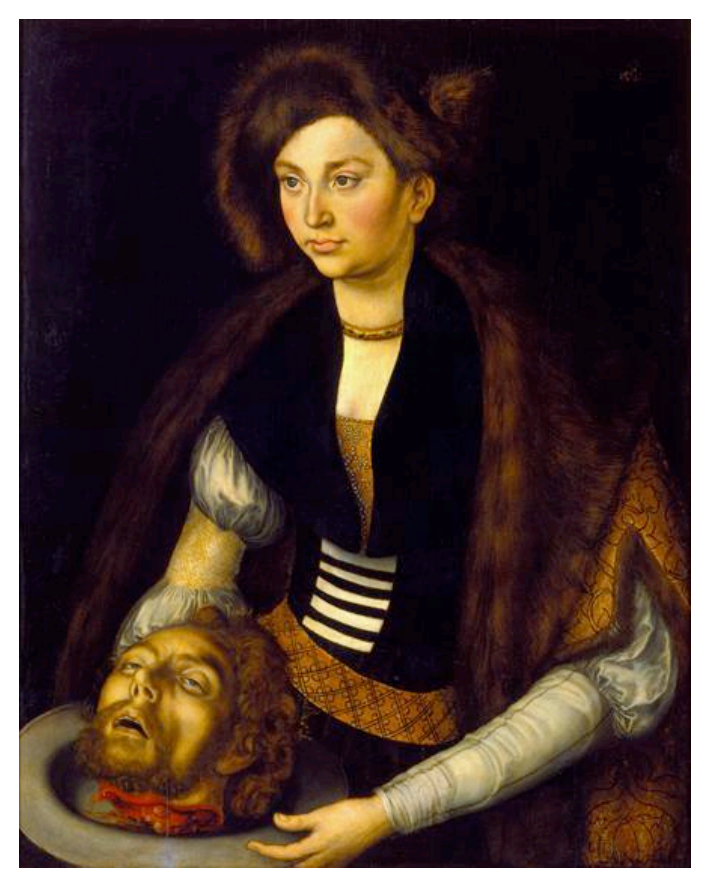

Fig. 56 - Lucas Cranach, o Velho, Salomé, séc. XVI (10 terço), MNAA, inv. 738 Pint

Ao comunicar a recepção dos quadros, entretanto acrescidos de dois outros associados a Goya e Brueghel ${ }^{237}$, Sousa Holstein não escondia o seu contentamento, prometendo informar o governo pela "nova prova do seu patriotismo e acrisolado amor às artes". De acordo com o desejo expresso pelo visconde, comprometia-se a

\footnotetext{
${ }^{235}$ Carta datada de 21 de Junho de 1872. Arquivo do MNAA, fundo José de Figueiredo, cx. 4, pasta 1, doc. 3.

${ }^{236}$ Lote 38 do catálogo do leilão de 1870 , identificada não como Salomé mas como Herodíade.

${ }^{237}$ Carta datada de 30 de Junho de 1872. Arquivo do MNAA, fundo José de Figueiredo, cx. 4, pasta 2, doc. 4.
} 
expô-los na galeria reunidos aos restantes, "e ainda que não sejam todos de 1 . a ordem, podem contudo ali ser colocados para exemplo de todos e satisfação de $\mathrm{V}$. Ex. ${ }^{\mathrm{a}}$ ", mostrando ser evidente a desigualdade das obras doadas. Consciente do peso persuasivo do argumento, voltava a lembrar ser opinião unânime do corpo académico que mal os "valiosos oferecimentos de V. Ex. a cheguem para encher uma sala, a esta se dê o nome do benemérito cidadão que tanto contribuiu para o engrandecimento da Galeria Nacional de Pintura"238.

No ofício então dirigido ao ministro e secretário de Estado dos Negócios do Reino, o vice-inspetor informava importarem a 35 as pinturas oferecidas pelo visconde, sugerindo ser conveniente "que por meio de algum agradecimento oficial ou mesmo alguma remuneração honorífica se testemunhasse oficialmente ao doador que foram tomadas na devida conta os seus patrióticos oferecimentos, não só para o animar a continuar se não também para excitar outros a imitar aquele exemplo"239. Contra as suas expectativas, muito poucos foram os colecionadores a evidenciar tal generosidade, podendo-se destacar alguns anos mais tarde e de uma forma bem menos pródiga o caso do luso-francês visconde de Daupias (1818-1900), detentor da mais importante pinacoteca reunida em Portugal na segunda metade de Oitocentos ${ }^{240}$. Empenhado em enriquecer a Academia e em se evidenciar junto do governo e da opinião pública, pois cada oferta era normalmente seguida de uma informação do vice-inspetor ao ministro e de uma notícia laudatória na imprensa, Carvalhido enviará ainda em finais de 1872 duas obras dadas a Lebrun e Marquerie, acrescidas em Janeiro do ano seguinte de uma paisagem e de uma figura alegórica representando a Justiça "d'aprés Rafael", associadas a Lucatelli e a Guido Reni respectivamente. Na carta dirigida a Sousa Holstein sublinhava em particular o suposto Reni, "aqui admirado e

\footnotetext{
238 Cópia do ofício datado de 28 de Agosto de 1872. Arquivo da ANBA, disponível em http://digitarq.dgarq.gov.pt/ PT-ANBA-ANBA-B-007-00002_m0156.TIF

${ }^{239}$ Cópia do ofício datado de 28 de Agosto de 1872. Idem, disponível em http://digitarq.dgarq.gov.pt/ PT-ANBA-ANBA-B-007-00001_m0083.TIF

${ }^{240}$ Bisneto de Jacques de Ratton, Pedro Eugénio Daupias viveu num palacete da rua de Santo António ao Calvário, junto à fábrica têxtil que herdara de família, onde construiu a partir da década de 1870 uma galeria de pintura particularmente rica em artistas contemporâneos, do gosto Salon à criação de Barbizon. Em Novembro de 1884, meses após a abertura do Museu Nacional de Belas Artes e Arqueologia, fez a doação de uma dezena de obras da sua colecção (Robert-Fleury, Dumaresq, Lameyer, Chavet, Diaque, Vaillant, Desportes, Serres e Hispaletto).
} 
estimado em oito mil francos; os grandes amadores e conhecedores me disseram que era uma obra capital do mestre e impagável para um museu"241.

Aos quadros enviados em Janeiro de 1873, seguir-se-ão em Março do mesmo ano outros três, um retrato de Ferdinand Bol, uma cena de género de Eugène Devéria e uma batalha naval de Vroom (fig. 57), "os quais ofereço para reunir aos outros e não mandando mais até que receba a participação de se achar pronta a sala que os há-de receber todos" ${ }^{242}$. Inserida num projeto de reforma e expansão da galeria, a sala mencionada não se encontrava sequer iniciada, conforme esclarece o marquês no ofício de resposta ao colecionador: "Devo dizer-lhe que ainda se não deu principio à construção da sala para a completa colocação de todos os quadros, no entanto, a Academia continua a ter as melhores esperanças que este melhoramento se realizará, e os últimos quadros que V. Ex. - tem doado a este estabelecimento acham-se expostos na galeria sobre cavaletes que para esse fim se mandaram fazer" ${ }^{243}$.

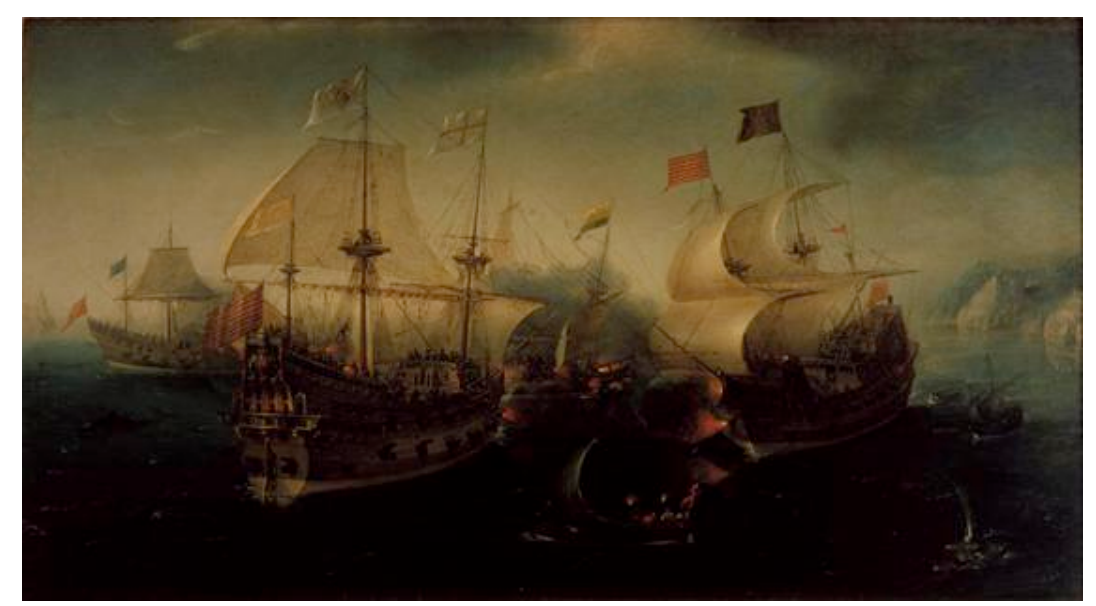

Fig. 57 - Hendrick Cornelisz. Vroom, Batalha naval, séc. XVII (início). MNAA, inv. 749 Pint

Apesar da nota de ameaça à oferta de mais obras, Carvalhido parece ter-se contentado com a justificação do vice-inspetor, procedendo em Junho ao envio de sete pinturas, entre as quais um tríptico tido como executado por Memling, o único primitivo flamengo citado na coleção. Curiosamente, informava desejar "caso sobrem alguns

\footnotetext{
${ }^{241}$ Carta datada de 25 de Janeiro de 1873. Arquivo do MNAA, fundo José de Figueiredo, cx. 4, pasta 1, doc. 5 .

${ }^{242}$ Carta datada de 17 de Março de 1873. Arquivo do MNAA, fundo José de Figueiredo, cx. 4, pasta 1, doc. s. n.

243 Cópia do ofício datado de 29 de Abril de 1873. Arquivo da ANBA, disponível em http://digitarq.dgarq.gov.pt/ PT-ANBA-ANBA-B-007-00002_m0197.TIF
} 
quadros depois de preenchida a sala, serem remetidos da minha parte para o Museu de S. Lázaro no Porto" ${ }^{244}$, mostrando não esquecer a cidade de onde era natural. 0 impasse gerado na construção do espaço levou entretanto a conferência académica a decidir a distribuição das pinturas doadas por três gabinetes anexos à galeria, solução recebida com desagrado pelo visconde. Ao ser informado, apressou-se a comunicar "não aceitar esta nova ideia, visto que todos os meus donativos foram feitos e aceites para serem reunidos em uma só sala", questionando o facto de não se adaptar para o efeito a maior das cinco salas já existentes. Ansioso por dar seguimento aos trabalhos, comprometia-se a enviar de Paris "os papéis para forrar a dita sala, pois desejo organizá-la como o Louvre fez com a coleção legada por Mr. La Caze”245.

\section{O exemplo do Dr. La Caze}

Médico afortunado, pintor amador e colecionador experiente, Louis La Caze (17981869) doou em testamento ao Musée de Paris, como era então também conhecido, a sua notável pinacoteca que à semelhança de outras coleções coevas abrangia a produção flamenga, holandesa, espanhola, italiana e francesa, esta última consagrada em larga medida aos mestres do século das Luzes. Na realidade, o colecionador foi um dos percursores da recuperação do gosto por aquele tipo de pintura, escassamente representada à data nas salas do museu, permitindo assim o seu enriquecimento e atualização com dezenas de trabalhos de Fragonard, Chardin, Greuze, Boucher ou Watteau com o icónico Gilles. Não menos relevantes eram as escolas estrangeiras, sobretudo as do norte da Europa (Flandres e Holanda do século XVII) que no seu conjunto rivalizavam em número com a francesa, e onde sobressaia a Bethsabée de Rembrandt, devendo igualmente mencionar-se entre a produção espanhola o Rapaz do pé boto de Ribera ${ }^{246}$.

La Caze, que se encontrava familiarizado com a realidade museológica, tendo pertencido a algumas comissões do Louvre relacionadas com a apreciação dos restauros efectuados e com as propostas de aquisição a submeter ao governo, gizou a

\footnotetext{
${ }^{244}$ Carta datada de 11 de Junho de 1873. Arquivo do MNAA, fundo José de Figueiredo, cx. 4, pasta 1, doc. 7.

${ }^{245}$ Carta datada de 1 de Julho de 1873. Idem, cx. 4, pasta 1, doc. 8.

${ }^{246}$ FAROULT, Guillaume - "Toutes les écoles, en exemplaires extrêmement artistes: Louis La Caze et la connaissance de la peinture ancienne en France (1830-1870)". La Collection La Caze: chefs-d'oeuvre des peintures des XVIle et XVIIle siècles, 2007, pp. 45-64.
} 
sua doação em termos bastante favoráveis, ao autorizar por exemplo a cedência das obras susceptíveis de serem consideradas secundárias aos museus provinciais (das 583 pinturas da coleção, o Louvre selecionou 275, procedendo à distribuição das restantes por diversos museus). Expressou também o desejo (não vinculativo) de the ser concedida uma sala, inaugurada em 1870 por Napoleão III, seis meses antes de perder o trono na sequência da guerra franco-prussiana. Muito espaçosa e com generoso pé direito (fig. 58), a sala que anteriormente albergara um dos núcleos de escultura do museu, apresentava-se agora repleta de pinturas sobre o encarnado das paredes, numa densa mistura de épocas e nacionalidades oposta a organização cronológica e por escolas que se encontrava já patente nas restantes salas do museu. Cenograficamente isolado numa das paredes de topo, entre colunas coríntias, um auto-retrato de La Caze celebrava o homem responsável pela doação mais importante do Segundo Império, inspiradora de outras ocorridas nas décadas subsequentes ${ }^{247}$.

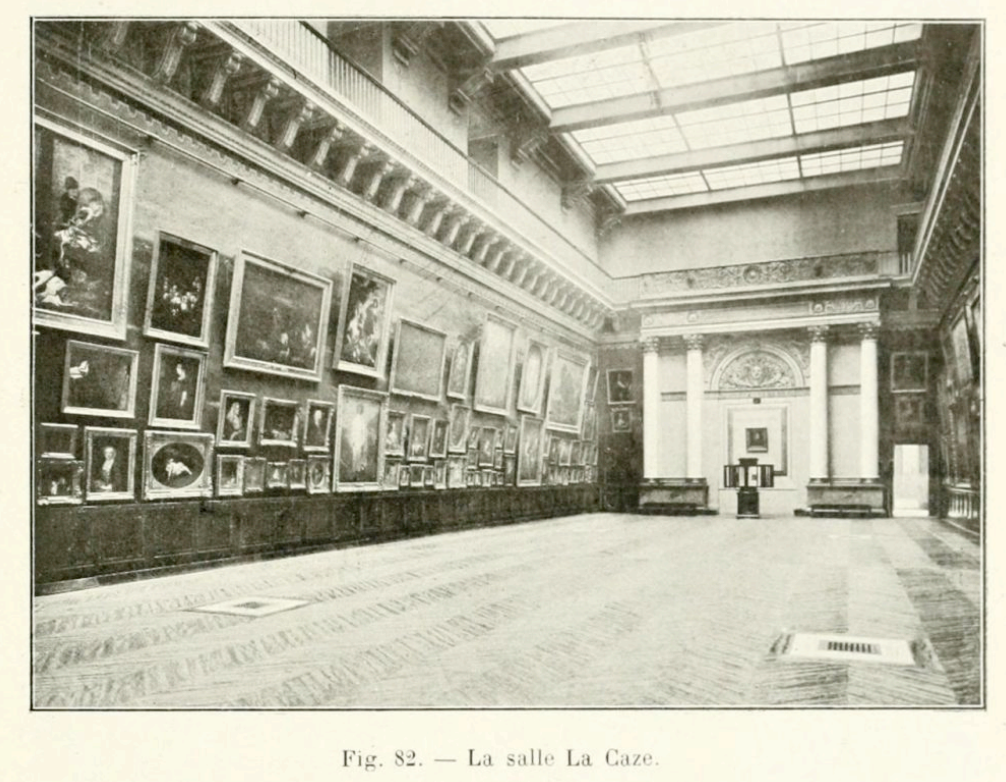

Fig. 58 - Sala La Caze, Museu do Louvre, fotografia, c. 1900

Decorridos três anos da abertura daquele espaço, afigura-se natural ser mencionado por Carvalhido ao vice-inspetor como o referente museológico a seguir, informando na mesma carta ter inclusivamente "mandado fazer meu retrato para ser colocado na

\footnotetext{
${ }^{247}$ ELOY, Sophie - "Je laisse au musée de Paris toute ma collection de tableaux: genèse du legs de Louis La Caze au musée du Louvre", idem, pp. 151-160; “La salle La Caze au Louvre”, idem, ibidem, pp. 177183.
} 
sala" que se comprometia a enviar "junto com uma flora que falta na minha coleção". Pretendia assim afirmar-se como o La Caze português, mas em vida para assistir ao reconhecimento devido, o que explica a vontade de dar seguimento à sala: "Seria muito agradável encontrar na minha próxima viagem esses trabalhos adiantados, desejaria mesmo assistir à colocação dos painéis para no caso que falte algum o fazer mandar daqui seguir" ${ }^{248}$. A preocupação pela quantidade, por preencher sem lacunas um espaço, dominava o espírito do colecionador, mostrando-se de certa forma alheio aos apurados critérios de seleção do exemplo museológico francês onde se inspirava.

Informado da impossibilidade de se proceder à desmontagem de qualquer das salas da galeria para instalar os seus quadros, Carvalhido ficará obrigado a se contentar com a solução provisória de os ver distribuídos por três gabinetes anexos, o que não obstou ao envio de mais obras. Em Novembro de 1873, comunicava a remessa de dois quadros, "um original de Carracci, Vénus e amor rodeados de uma grinalda de flores e o meu retrato para ser colocado na sala que destinarão à minha coleção"249. De autor não identificado, o retrato em questão espelha a personalidade do titular que se fez representar de forma algo ostentatória em traje de corte, junto de alguns livros e de um globo sugerindo a sua erudição, num cenário aparatoso com reposteiro e colunas e onde não falta o brasão de armas. A coroa de visconde depressa ficará desatualizada com a elevação de Carvalhido a conde pelo rei D. Luís, ocorrida em Março de 1874. Reconhecido por tal distinção, efetuará pouco depois o envio de sete quadros associados a de Heem, Ribera, ou Domenichino, "os quais ofereço à Academia para reunir aos outros, para serem definitivamente colocados na nova sala" ${ }^{250}$, insistia, procedendo em Agosto do mesmo ano à remessa de mais quatro pinturas não identificadas.

Falham-nos notícias quanto à atividade do colecionador durante os anos seguintes, pelo menos até 1878 , ano marcado pela morte do vice-inspetor da Academia, marquês de Sousa Holstein, aos 40 anos de idade. Decorreu então em Paris um novo certame universal projetado pelo jovem regime republicano que levou à construção do Palais du Trocadéro, onde teve lugar uma exposição de retratos históricos nacionais. Para tal

\footnotetext{
${ }^{248}$ Carta datada de 1 de Julho de 1873. Arquivo do MNAA, fundo José de Figueiredo, cx. 4, pasta 1, doc. 8.

${ }^{249}$ Carta datada de 4 de Novembro de 1873. Idem, cx. 4, pasta 2, doc. 9.

${ }^{250}$ Carta datada de 11 de Junho de 1874. Idem, cx. 4, pasta 1, doc. 10.
} 
foi nomeada uma comissão que selecionou 960 espécimes (entre pinturas, desenhos, esculturas, tapeçarias, miniaturas, etc.) pertencentes a diversos museus, congregações religiosas e particulares, entre os quais, o conde de Carvalhido que participou uma vez mais como emprestador numa mostra de relevo entre alguns dos mais destacados colecionadores franceses. Segundo o catálogo editado, da sua coleção foram cedidos dois retratos a óleo: um do conde da Provença, depois Luís XVIII, pintado por FrançoisHubert Drouais e outro de Josefina de Beauharnais, primeira mulher de Napoleão Bonaparte, da autoria de François Gérard ${ }^{251}$.

Com a chegada de 1879 , será organizado um novo leilão no Hotel Drouot, concentrado essencialmente na coleção de objets d'art et de curiosité (marfins, cerâmicas, armas, ourivesaria, bronzes, etc.) reunidos por Carvalhido que estendeu os seus interesses colecionistas à tendência do bric-à-brac então vigente ${ }^{252}$. Mais de cinco dezenas de pinturas foram também incluídas na venda, a maioria as quais secundárias, classificadas como d'après ou genre de, e de que entendeu então desfazer-se. 0 acervo ficou assim circunscrito às obras consideradas mais qualificadas, entre as quais o Drouais e o Gérard acima mencionados.

\section{A transferência para o Museu Nacional de Belas Artes e Arqueologia}

As doações à Academia serão retomadas em 1881, já sob a vigência de Delfim Guedes, sucessor de Sousa Holstein. Em Fevereiro daquele ano, no provável intuito testar a receptividade de Guedes às suas ofertas, fará a remessa de seis volumes com gravuras de vários mestres, expressando o desejo de que "tanto este meu pequeno oferecimento, como outros de diferente género que já fiz e algum mais que ainda possa vir a fazer, sejam de utilidade aos meus concidadãos na Academia das Belas Artes a cargo de V. Ex. ${ }^{2}{ }^{\prime 253}$. O protocolar agradecimento de Delfim Guedes estará na base da oferta, dois meses mais tarde, de um conjunto de 15 pinturas, em parte anónimas e parte associadas a diferentes autores (Filippo Lauri, Alonso Cano, van der

\footnotetext{
251 JOIN, Henry M. - Exposition Universelle de 1878 à Paris: notice historique et analytique des peintures, sculptures, tapisseries, miniatures, émaux, dessin, etc. exposés dans les galeries des portraits nationaux au Palais du Trocadéro, 1879. As obras em questão surgem catalogadas com os números 761 e 765 . Não serão incluídas nas futuras doações à Academia.

${ }^{252}$ Objets d'art et de curiosité; tableaux anciens appartenant à M. le Cte de $C^{* * *}$ [Carvalhido], 1879.

${ }^{253}$ Carta datável de Fevereiro de 1881. Arquivo do MNAA, fundo José de Figueiredo, cx. 4, pasta 1, doc.
} 22. 
Neer, van Ostade e Ingres com uma Angélica presa ao rochedo tirada de uma conhecida composição daquele mestre $\left.{ }^{254}\right)$. A diferença de qualidade das obras foi uma vez mais assinalada, registando a ata da conferência "que na coleção dos quadros ofertados, apenas havia dois de algum merecimento artístico e que foram oferecidos pelo mesmo conde a S. Majestade El-Rei o Senhor D. Fernando"255. Ao comunicar a sua oferta, Carvalhido referia aspirar pelo "adorno de uma sala de maiores dimensões no palácio destinado para esta tão útil instituição" ${ }^{256}$, mostrando estar ao corrente da projetada mudança de instalações e do respectivo aluguer do Palácio Alvor-Pombal, onde no ano seguinte virá a ter lugar a Exposição Retrospectiva de Arte Ornamental Portuguesa e Espanhola (1882).

Finda a exposição, e meses antes da abertura do Museu Nacional de Belas Artes e Arqueologia, o colecionador procederá à oferta de mais seis quadros (Zurbarán, Marratti e Mengs entre outros autores mencionados) "para serem reunidos à minha coleção, e mais tarde na sala que me deve ser destinada no novo museu" ${ }^{257}$. A inauguração teve lugar a 12 de Junho de 1884 e logo se constatou ter Delfim Guedes, entretanto agraciado com o título de conde de Almedina, ignorado o desejo expresso pelo colecionador, com as obras dispersadas pelas salas $A$ a $G$ do andar nobre, de acordo com o catálogo provisório editado ${ }^{258}$. Tal opção foi aliás extensível ao conjunto de pinturas doadas por D. Fernando II, igualmente disseminadas pelas salas, numa organização cronológica que começava na atualidade e terminava no século XVI.

Sentindo-se desconsiderado, Carvalhido parece ter cessado a correspondência com a Academia, suspendendo as ofertas num provável sinal de protesto. Entre 1888 e 1890, estabelece-se com frequência com a mulher em Portugal para acompanharem a candidatura do filho a secretário de legação, carreira interrompida em 1895 com a precoce morte de Emílio. ${ }^{259}$ Marcado também pelo desaparecimento de Delfim

\footnotetext{
${ }^{254}$ Roger délivrant Angélique (Louvre, inv. 5419) de que existem outras versões e estudos. Registe-se que a listagem das fotos com pinturas de Ingres pertencentes a Haro e oferecidas à Academia em 1868, assiná-la uma Angélique attaché au rocher. Cf. Carta datada de 23 de Setembro de 1868. Arquivo da ANBA, disponível em http://digitarq.dgarq.gov.pt/ PT-ANBA-ANBA-B-001-00003_m1304.TIF

${ }^{255}$ Conferência ordinária de 6 de Junho 1881. Idem, disponível em http://digitarq.dgarq.gov.pt/ PTANBA-ANBA-F-002-00002_m0633.TIF

${ }^{256}$ Carta datada de 19 de Abril de 1881. Arquivo do MNAA, fundo José de Figueiredo, cx. 4, pasta 1, doc. 12.

${ }^{257}$ Carta datada de 26 de Março de 1884. Idem, cx. 4, pasta 1, doc. 13.

${ }^{258}$ ALMEDINA, conde de (co-auto) - op. cit.

259 LARANJO, José Frederico - op. cit., pp. 10-21.
} 
Guedes, aquele ano parece ter determinado a reaproximação do colecionador com a Academia e com o seu museu, a quem enviará uma pintura representando um interior com fumadores atribuída a Joos van Craesbeeck (fig. 59).

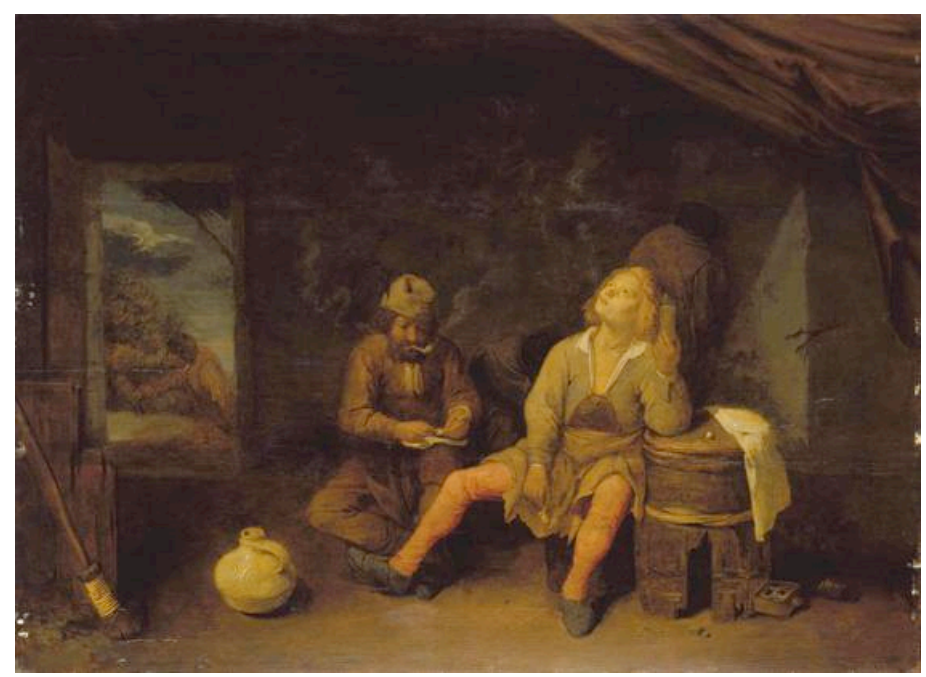

Fig. 59 - Joos van Craesbeeck (atrib.), Fumadores, c. 1650. MNAA, inv. 1141 Pint

Numa carta que deverá datar daquele período, manifestava a sua mágoa pela pouca importância dada aos seus donativos, pois "tendo sempre sido recebidos com grande apreço, logo que se tratava de remunerar esses valiosos serviços, o governo os amesquinhava, e dava pouca valia". Como tal, lamentava que assim se procedesse com "o português que habita no foco das artes, único que se dedicou a proteger as de seu país, tirando partido desta posição para auxiliá-las, como o tem feito tanto quanto Ihe permitem as suas forças". Apesar do que considerava uma "injustiça indevida", refere não ter resistido à aquisição de um novo quadro dado a Zurbarán, "obra capital deste grande mestre; para realizá-la fiz grande sacrifício, mas sendo um painel digno de 1.은 museu, assenti que não devia deixar escapar para enriquecer minha sala com esta grande composição". O projeto da sala voltava a estar portanto em cima da mesa, e Carvalhido que se mudara para um elegante apartamento na avenida Kléber, junto ao Trocadéro, ${ }^{260}$ acenava com mais ofertas no intuito de levar a bom porto o seu intento: "como me sobraram alguns [quadros] que não pude colocar no meu novo alojamento,

${ }^{260}$ Avenue Kléber, n. 95. Anteriormente habitava no n. 17 do Boulevard Haussmann. 
talvez me decida a juntar algum para o que peço a V. Ex. a o favor de me informar quando terá lugar a inauguração"261.

A abertura virá finalmente a ocorrer em Abril 1896, tendo sido precedida por um decreto publicado no Diario do Governo, louvando o "benemérito cidadão por tão valiosos oferecimentos", considerados de interesse nacional, e determinando a sua recolha "em sala especial para esse fim destinada, com a designação de Sala conde de Carvalhido" 262 . O colecionador deixava de ter motivos para se queixar do governo que se Ihe referia publicamente nos mais elogiosos termos, tornando possível a realização de um projeto com quase 30 anos. Situada no r/c do edifício (fig. 60), a sala, ou melhor, as duas salas (o elevado número de pinturas não pôde ser exposto numa só), contaram no dia da inauguração com a presença de D. Maria Pia, sendo dias depois visitadas por D. Carlos e D. Amélia para grande satisfação do doador.

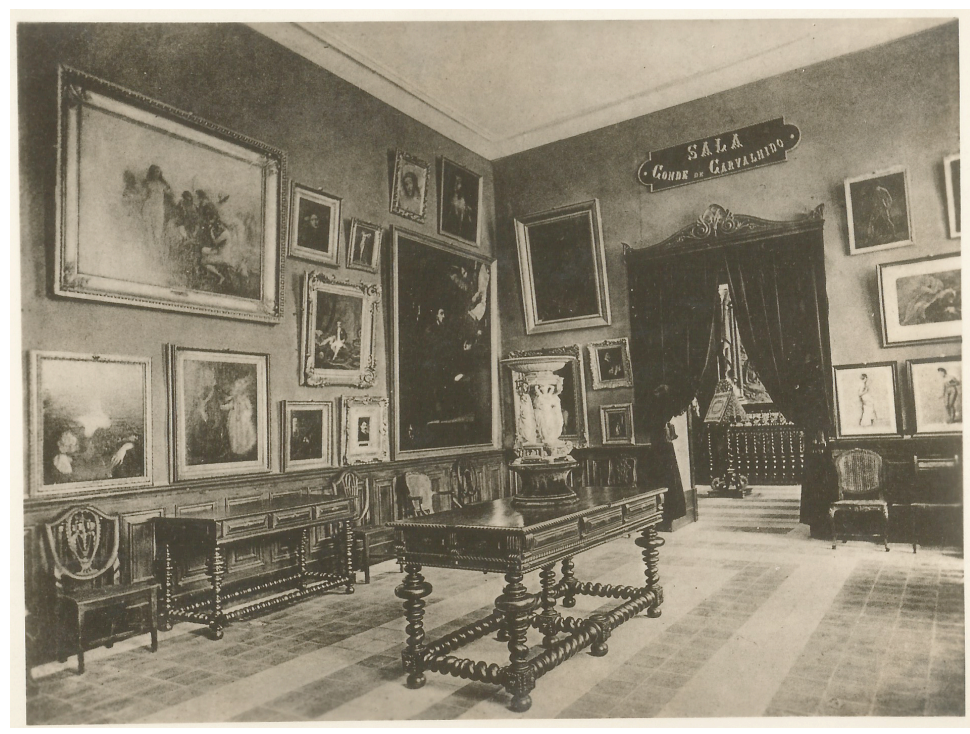

Fig. 60 - Sala conde de Carvalhido, Museu Nacional de Belas Artes e Arqueologia, c. 1896. Arquivo do MNAA

A partir de então o interesse de Carvalhido voltou-se para o catálogo, tarefa acompanhada com especial atenção como revela a correspondência trocada com os responsáveis do museu. Dois meses após a inauguração, numa carta dirigida com toda a probabilidade ao conservador Manuel de Macedo, referia desejar "ver concluído o mais depressa possível o catálogo", oferecendo-se para pagar pela contratação de um

\footnotetext{
${ }^{261}$ Carta s.d. Arquivo do MNAA, fundo José de Figueiredo, cx. 4, pasta 1, doc. 23.

262 Decreto assinado por João Franco e datado de 14 de Março de 1896.
} 
copista que adiantasse os trabalhos ${ }^{263}$. Estes irão todavia arrastar-se por mais de um ano para grande inquietação do colecionador que noutra carta pedia para ser acrescentada ao texto a referência a uma comenda olvidada, indagando pela reprodução do seu retrato que deveria figurar gravado no início da obra ${ }^{264}$. Provavelmente nesse sentido havia procedido ao envio de um novo retrato, pintado pelo seu amigo Andrzej Mniszech, aristocrata polaco estabelecido em Paris que o representou num medalhão oval, no esquema de quadro dentro do quadro, vislumbrando-se em primeiro plano diversos objets d'art, aludindo à sua atividade de colecionador (fig. 61). Mniszech seria também o autor de uma pequena pintura representando Emílio que os pais conservavam sempre junto a si e de que se desprenderam em 1897 "com grande sacrifício" para o integrar nas salas, naquela que foi provavelmente a última obra doada ${ }^{265}$.

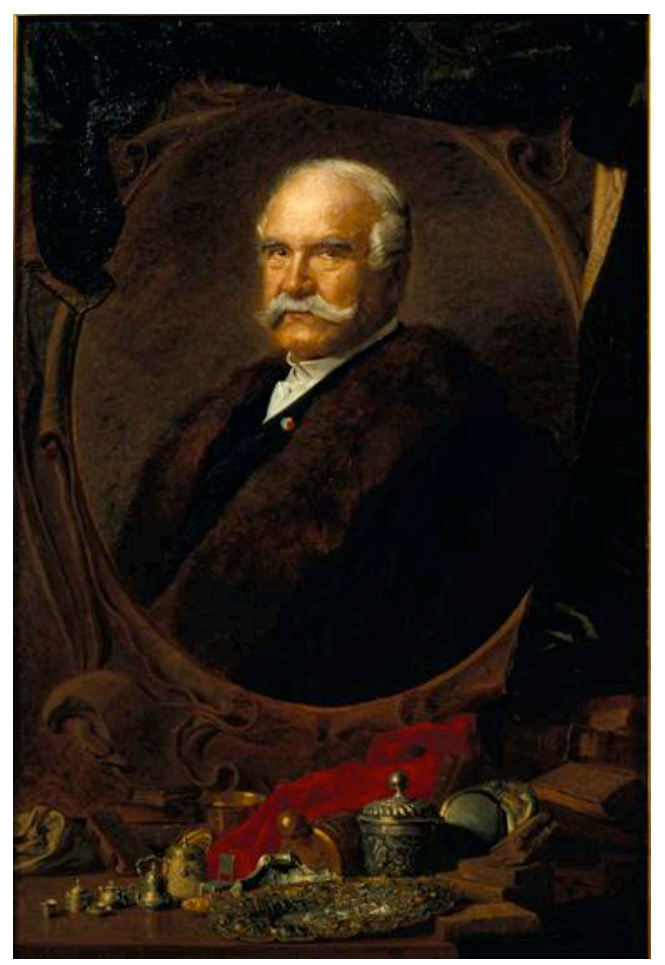

Fig. 61 - Andrzej Mniszech, Retrato do 1o conde de Carvalhido, 1891. MNAA, inv. 1125 Pint

\footnotetext{
${ }^{263}$ Carta datada de 21 de Junho de 1896. Arquivo do MNAA, fundo José de Figueiredo, cx. 4, pasta 1, doc. 16.

${ }^{264}$ Carta datada de 19 de Junho de 1897. Idem, cx. 4, pasta 1, doc. 18.

${ }^{265}$ Carta datada de 26 de Setembro de 1897. Idem, cx. 4, pasta 1, doc. 19. Em Novembro do mesmo ano, no intuito de decorar as duas mesas que se encontravam colocadas nas salas, doará ainda um busto em gesso do filho, duas estatuetas em bronze, um centro de mesa em porcelana e um par de jarras em laca oriental. Cf. carta datada de 27 de Novembro de 1897. Idem, cx. 4, pasta 1, doc. 20.
} 
O catálogo acabou por ser editado em 1898, com a tradicional divisão por escolas e descrição sumária das pinturas da autoria de Macedo, sendo antecedido por uma nota biográfica acompanhada não pela reprodução do retrato de Mniszech mas por uma fotografia ${ }^{266}$. Uma entrada baseada naquela biografia oficial seria publicada um ano depois no Dictionnaire national des contemporains, ${ }^{267}$ reservado às personalidades ilustres a residir em território francês, derradeira homenagem ao colecionador que viria a falecer a 18 de Julho de 1900 no seu apartamento em Paris, aos 83 anos de idade.

O espaço autónomo que Carvalhido conseguiu conquistar ao museu sobreviveu pouco mais de duas décadas à sua morte, tendo sido anulado na sequência das alterações introduzidas no discurso expositivo da coleção de pintura por José de Figueiredo, diretor a partir 1911 do então rebatizado Museu Nacional de Arte Antiga. Deve-se a Figueiredo uma primeira triagem das obras consideradas mais relevantes que integrará na exposição permanente, relegando para as reservas o que entendeu ser de interesse menor. Como vimos, a noção de uma coleção desigual, constituída parcialmente por obras de qualidade duvidosa, remontava já a Sousa Holstein que algumas vezes se referiu a essa circunstância, tal como Delfim Guedes a quem as doações efectuadas por Carvalhido pouco interesse terão suscitado. Esse facto marcará de forma negativa a opinião de alguns dos nossos críticos, podendo citar-se a apreciação mordaz de Fialho de Almeida ao referir-se às salas como "uma pobre tenda de burguês amador de obras baratas ${ }^{\prime 268}$.

Das 91 pinturas doadas por Carvalhido, apenas quatro se encontram hoje em dia em exposição no Museu Nacional de Arte Antiga (Cranach, Moreelse, Craesbeeck e Vroom, podendo ainda acrescentar-se o Brueghel doado a D. Luís), o que não deixa de causar alguma perplexidade, mesmo tendo em consideração a diferença de qualidade do conjunto. O papel aqui divulgado de Étienne-François Haro na formação desta coleção deveria desejavelmente levar a uma reavaliação cuidada das obras que permanecem em reserva há quase 90 anos, parte das quais depositadas em palácios nacionais, ministérios e embaixadas. Homem considerado no meio artístico parisiense, amigo

\footnotetext{
${ }^{266}$ [MACEDO, Manuel de] - op. cit.

${ }^{267}$ CURINIER, C. E. (dir.) - Dictionnaire National des Contemporains, T. II, 1899, p. 94.

${ }^{268}$ ALMEIDA, Fialho de - Os gatos: publicação mensal de inquérito à vida portuguesa, 2.o vol, 1945, p. 151.
} 
próximo de destacados pintores e expert de diversos leilões, Haro afigura-se como um factor positivo a ter em conta mas isso não determina por si só a eventual qualidade das obras que Ihe possam ser associadas. Em último caso, Haro e outros negociantes poderão ter enganado deliberadamente Carvalhido, um dos muitos brésiliens fixados em Paris e caricaturados de forma implacável no Vaudeville da época ${ }^{269}$.

O preconceito social para com os homens enriquecidos nas Américas, particularmente evidente em Portugal através da figura camiliana do "brasileiro de torna-viagem"270, torna-se fundamental para o entendimento da coleção e das respectivas doações à Academia. Ao conquistar uma posição económica vantajosa, Carvalhido utilizou a filantropia e sobretudo o colecionismo como forma de se nobilitar, alcançar status e se integrar na alta sociedade. Genuinamente interessado pelas belas artes mas detentor de pouca cultura artística, foi um comprador sintonizado com as tendências do seu tempo, graças a avisados contactos estabelecidos, preocupando-se todavia mais com a quantidade do que com a qualidade, no que estará relacionado com certa uma urgência em ser reconhecido como colecionador. A edição do catálogo da sua galeria, a cedência de obras para exposições, as notícias lisonjeiras dos jornais, as vendas no Hôtel Drouot e as repetidas dádivas à Academia foram instrumentos essenciais na construção dessa imagem que desejou perpetuar com uma sala no museu da capital do seu país, no intuito de ser recordado pelas gerações futuras.

\section{A organização da galeria}

Projeto há muito acalentado, a organização de uma galeria foi desde o início assumida como uma prioridade pelo vice-inspetor que se mostrou incansável na persecução dos trabalhos, sendo coadjuvado pelos professores de pintura agrupados em comissão

\footnotetext{
${ }^{269}$ Ao descrever a colónia hispano-americana de Paris, S. de Hebedia acrescenta que esta "a déjà eu I'honneur de fournir un type bien amusant - celui du Brésilien - à nos vaudevillistes du Palais-Royal. Le malheur est que ce Brésilien de fantaisie, sorte de fantoche grotesque, brutal, sensuel, vêtu de breloques et de pantalons clairs, réalise aux yeux de nos badauds le type le plus complet de l'Américain du Sud". HEBEDIA, S. de - "Les Hispano-Américains". Paris guide par les principaux écrivains et artistes de la France, deuxième partie - la vie, 1867, p. 1081.

${ }^{270}$ Camilo Castelo-Branco elegeu o "brasileiro de torna-viagem" num dos seus alvos privilegiados. A primeira obra em que troça desta personagem foi numa peça de teatro, Poesia ou Dinheiro (1855), sucedendo-se a partir de então diversos romances: $O$ que fazem as mulheres (1858), Anos de prosa (1863), Os brilhantes do brasileiro (1869), A brasileira de Prazins (1882), Serões de S. Miguel de Seide (1885), entre outros.
} 
nomeada para o efeito ${ }^{271}$. Como tivemos oportunidade de aludir na I parte deste trabalho, o caminho a seguir encontrava-se já apontado e passava naturalmente pela improvisação, adaptando-se para o efeito as salas de aula de pintura histórica e de paisagem que haviam sido remodeladas e que se encontravam dotadas de iluminação zenital. Tal obrigava à realização de mais algumas obras nas referidas salas, entre outras tarefas como o restauro de pinturas, a aquisição de molduras, e a edição de um catálogo, para as quais afigurava-se necessário encontrar financiamento.

Nesse sentido o vice-inspetor oficiou a 22 de Dezembro de 1862 ao Ministério do Reino solicitando uma autorização para proceder à "venda de alguns quadros velhos, móveis e outros objetos inúteis existentes nesta Academia", ao que o ministro anuiu mediante o envio de uma listagem com a apreciação das peças em questão ${ }^{272}$. Na sessão realizada a 3 de Março de 63 era dada por concluída "a venda dos quadros absolutamente reprovados pela Academia e dos objetos julgados inúteis", tendo sido votada a organização de mais dois leilões, decidindo-se que "tudo quanto restasse fosse vendido a retalho pelo fiel da Academia" ${ }^{273}$. Entretanto o ministro interpelava a conferência quanto ao destino a dar ao produto da venda de umas prensas litográficas que anteriormente se destinavam à compra "de uma boa prensa de ferro montada ao uso moderno". Esclareciam os professores terem optado por investir a verba em "objetos muito urgentes e necessários, tais como uma grade de defesa para isolar os quadros", e num "fardamento simples e decente para os guardas da galeria que vai ser exposta ao público", considerados "de maior utilidade do que a compra da referida prensa de ferro, visto ser impraticável por enquanto a reorganização e reforma da oficina litográfica da Academia"274.

Apesar dos esforços da instituição, o resultado das vendas em leilão não terá estado à altura das expectativas, com vários lotes retirados por não encontrarem comprador como deu conta na mesma ocasião o fiel da Academia. Fazia todavia notar a existência

\footnotetext{
${ }^{271}$ Ficou desde logo lavrado em ata "que a comissão encarregada da direção das galerias desta Academia ficasse composta dos Srs. Professores da aula de pintura". Conferência ordinária de 28 de Novembro de 1862. Arquivo da ANBA, disponível em http://digitarq.dgarq.gov.pt/ PT-ANBA-ANBA-A001-00008_m0387.TIF

${ }^{272}$ Conferência ordinária de 31 de Janeiro de 1863. Idem, disponível em http://digitarq.dgarq.gov.pt/ PT-ANBA-ANBA-F-002-00001_m0011.TIF

${ }^{273}$ Conferência ordinária de 3 de Março de 1863. Idem, disponível em http://digitarq.dgarq.gov.pt/ PTANBA-ANBA-F-002-00001_m0024.TIF

${ }^{274}$ Conferência ordinária de 16 de Março de 1863. Idem, disponível em http://digitarq.dgarq.gov.pt/ PTANBA-ANBA-F-002-00001_m0028.TIF e_m0029.TIF
} 
de um individuo, decerto um negociante, que estava disposto "a comprar por junto todos aqueles quadros e objetos que restavam dos últimos leilões pela quantia de $54 \$ 000$ reis", oferta que o agente leiloeiro conseguiu fazer ascender a $63 \$ 000$ reis. $\mathrm{Na}$ falta de outras propostas, resolveram os académicos "que se vendessem por esse preço os indicados objetos visto a sua absoluta inutilidade"275.

Os leilões constituíam portanto a única forma de encaixar algum dinheiro, pelo que o vice-inspetor encarregará a comissão formada pelos professores de pintura de proceder a uma seleção mais apurada dos quadros conservados na Academia com o objectivo de organizar uma nova venda. Em Março de 64, informava encontrarem-se expostos na sala das sessões públicas para ali ter lugar o leilão, mas que "antes de se publicarem os competentes avisos desejava que os mesmos quadros fossem examinados por todos os membros da conferência para que estes ficassem cientes do modo pelo qual a comissão procedera à referida escolha" ${ }^{276}$. O diretor da Academia, Francisco de Assis Rodrigues, notou então entre os espécimes selecionados alguns classificados 20 anos antes como "distintos" por uma comissão a que diz ter pertencido, solicitando "para fazer uma nota por escrito afim de se exarar na ata, declarando nela que se opunha à venda de todos os quadros que estivessem no caso ponderado" ${ }^{277}$. Referia-se Assis Rodrigues à comissão responsável pelo designado “catálogo analítico" de 1840 já aludido na I parte deste trabalho, trabalho para o qual foram nomeados o conde de Melo, António Manuel da Fonseca e o abade de Castro, mas não o agora diretor que, quando muito, acompanhou os trabalhos.

Sousa Holstein fez ver que apesar da classificação de "distintos", os referidos quadros "eram contudo tão ordinários que não podiam deixar de ser reprovados absolutamente por quem tivesse a mais leve noção de pintura". Apontou logo vários exemplos para corroborar a sua afirmação, referindo desejar apenas "que a Academia reservasse os quadros que tinham real valor artístico, desfazendo-se dos maus e inúteis que estavam obstruindo e empachando o edifício", e que para isto se efetuar "tencionava empregar todos os meios legais, mandando proceder às mais

\footnotetext{
${ }^{275}$ Idem, disponível em http://digitarq.dgarq.gov.pt/PT-ANBA-ANBA-F-002-00001_m0031.TIF

${ }^{276}$ Conferência ordinária de 3 de Março de 1864. Idem, disponível em http://digitarq.dgarq.gov.pt/ PTANBA-ANBA-F-002-00001_m0153.TIF a _m0156.TIF. As seguintes citações reportam-se a esta referência.

277 Para a declaração de Francisco de Assis Rodrigues cf. idem, disponível em http://digitarq.dgarq.gov.pt/ PT-ANBA-ANBA-F-002-00001_m015.TIF
} 
escrupulosas averiguações para o bom acerto da escolha e classificação de todos os quadros". Como tal, e apesar do apoio da generalidade dos membros da conferência (Anunciação, Cristino, Bastos e Oeirense), concordou o vice-inspetor nomear uma nova comissão composta pelo próprio diretor-geral, alguns professores (Silva Oeirense, José Maria Franco e o jubilado António Manuel da Fonseca), e dois académicos honorários: o abade de Castro e Jorge Husson da Câmara que, apesar de convocado, não chegou a comparecer por motivo de doença.

À declarada oposição de Assis Rodrigues, juntou-se desta vez a de António Manuel da Fonseca, o qual "negando-se ao exame, entregou uma declaração de voto que trazia escrita e que mandou juntar à ata"278. Recorde-se que apesar de Fonseca ter sido nomeado para a elaboração do "catálogo analítico", acabou por se distanciar do trabalho, viajando até Roma, motivo pelo qual o mesmo se ficou a dever ao conde de Melo e, sobretudo, ao abade de Castro. De acordo com uma relação então efetuada, das 167 obras consideradas (35 das quais não inventariadas), reservaram-se apenas 12, num total de 155 quadros indicados para venda ${ }^{279}$. À assinatura do abade de Castro acrescem no documento, junto às de Sousa Holstein, Oeirense e dos professores de pintura, as do visconde de Meneses e de Joaquim António Marques, o que estará provavelmente relacionado com a recusa de Fonseca em proceder ao exame, e com a ausência de Husson da Câmara.

De acordo com a ata, o vice-inspetor afirmou que "em resultado deste atento exame e das reiteradas instâncias para que se reservassem todos os quadros com valor artístico, arqueológico, histórico ou se tornassem recomendáveis por qualquer circunstância atendível", se venderiam apenas os considerados "inúteis", termo vago enquanto critério de seleção. Não querendo deixar margem para dúvidas, e numa preocupação digna de ser assinalada, ordenou ainda o marquês ao presidente da comissão de pintura, Tomás da Anunciação, "que mandasse examinar por dois artistas agregados se debaixo dos quadros considerados como inúteis, apareciam vestígios de

\footnotetext{
278 Para a declaração de António Manuel da Fonseca cf. idem, disponível em http://digitarq.dgarq.gov.pt/ PT-ANBA-ANBA-F-002-00001_m0163.TIF

${ }^{279}$ Cf. "Relação dos quadros existentes na Academia Real de Belas Artes de Lisboa, e que a mesma Academia propõe para se venderem em leilão, por não servirem para estudo nem para galeria, por serem muito inferiores e não terem valor algum artístico ou histórico". São apenas indicados os números correspondentes ao inventário, acrescidos de "32 quadros sem número e três retratos". Idem, disponível em http://digitarq.dgarq.gov.pt/ PT-ANBA-ANBA-F-002-00001_m0167.TIF
} 
pinturas melhores e mais antigas que devessem ser descobertas e restauradas dando conta por escrito do resultado desse exame ${ }^{280}$. Concluídas as indagações, o Ministério do Reino, por portaria de 9 de Abril de 64, autorizou finalmente a Academia a proceder a realização do leilão ${ }^{281}$.

O produto desta e das vendas anteriores irá permitir avançar então com alguns trabalhos mas era manifestamente insuficiente para todos os objectivos traçados. 0 anúncio da cedência de parte da dotação de D. Fernando II à Academia veio alterar em definitivo esse estado de coisas, facilitando a prossecução do projeto. Logo em Agosto de 65, ao ser discutida a aplicação da primeira tranche de cinco contos de reis, Tomás da Anunciação fazia notar "a absoluta necessidade de se empregar já alguma quantia em molduras e arranjos dos quadros que a Academia possui sem o que não será conveniente colocá-los definitivamente nas salas que para esse fim estão em arranjos". Concordando com a ideia de Anunciação, o vice-inspetor lembrou todavia que tendo sido a oferta do monarca "feita expressamente para compra de obras de arte, não poderíamos tomar uma tal deliberação sem para isso sermos autorizados por S. Majestade, o que supunha fácil obter-se e, por isso, lembrava se pusesse já de parte um conto de reis para o fim proposto pelo Sr. Anunciação" ${ }^{282}$. A suspeita de Sousa Holstein seria confirmada pelo conde da Foz, secretário de D. Fernando II, que oficiou cerca de um mês depois autorizando a aplicação da referida verba para o efeito ${ }^{283}$. Inesperadamente, no início de 1866, Tomás da Anunciação apresentou um requerimento "em o qual alega que tendo sido eleito presidente da comissão encarregada do arranjo da galeria da Academia, e não Ihe sendo possível continuar a servir como tal, por motivos que lhe são particulares, pede se the conceda a sua exoneração de presidente, continuando a exercer o cargo de simples vogal". Tanto o vice-inspetor como os restantes académicos procuraram demover o professor do seu intento, "mostrando todos a inconveniência de tal concessão e rogando ao Sr. Anunciação quisesse continuar a servir o cargo para que fora nomeado por bem do

\footnotetext{
280 Conferência extraordinária de 11 de Março de 1864. Idem, disponível em http://digitarq.dgarq.gov.pt/ PT-ANBA-ANBA-F-002-00001_m0160.TIF e_00161.TIF

${ }^{281}$ Conferência ordinária de 30 de Abril de 1864. Idem, disponível em http://digitarq.dgarq.gov.pt/ PTANBA-ANBA-F-002-00001_m0169.TIF

282 Conferência extraordinária de 18 de Agosto de 1865 . Idem, disponível em http://digitarq.dgarq.gov.pt/ PT-ANBA-ANBA-F-002-00001_m0279.TIF

${ }^{283}$ Carta datada de 13 de Setembro de 1865. Idem, disponível em http://digitarq.dgarq.gov.pt/ PTANBA-ANBA-B-001-00003_m1142.TIF
} 
estabelecimento". Instado a declarar as razões que a isso o obrigavam, deu vários esclarecimentos, "sendo os principais o precário estado da sua saúde e as ocupações que tem a desempenhar na Academia" ${ }^{284}$.

Nada se resolveu porém e só na sessão de 3 de Março se voltaria ao impasse gerado. Nessa ocasião, Cristino da Silva, "expressando o sentimento que tinha por ter sido exonerado da presidência da comissão de pintura o Sr. Anunciação, pediu que se provesse quanto antes aquele lugar para que, legalmente constituída a dita comissão, ele pudesse perante ela dar conta da incumbência que lhe fora encarregada, relativa à construção das novas molduras douradas para os quadros da galeria, das quais já se acham prontas 74, cuja importância consta de uma conta que apresentou" ${ }^{285}$. Conservada no arquivo do Museu Nacional de Arte Antiga, a factura em questão (fig. 62) importava a $297 \$ 369$ reis, reportando-se à oficina do dourador Celestino Barella, com estabelecimento na Rua Nova do Almada em Lisboa ${ }^{286}$. Com o excesso de zelo que Ihe era característico, Cristino referia "que não só se responsabilizava pela sua exatidão como pedia para se nomear uma comissão de inquérito para a examinar" ao que a conferência não anuiu por julgar inapropriado duvidar-se da integridade do professor. Quando ao cargo de presidente da comissão de pintura, foi então nomeado o diretor-geral, Francisco de Assis Rodrigues que, "apesar de fazer ver os múltiplos trabalhos de que se acha incumbido, aceitara o encargo".

Cristino da Silva aproveitou ainda a ocasião para fazer notar "os inconvenientes que resultam do atual estado da galeria e aulas de pintura, cujas obras estando já concluídas e prontas para a colocação dos quadros, existem estes amontoados, danificando-se e obstruindo os lugares em que se acham". O vice-inspetor e os restantes membros da comissão deram a conhecer os "motivos porque se não tem podido levar a efeito os definitivos arranjos da galeria, assegurando que se mandavam ativar com urgência" ${ }^{287}$. Assim vira a suceder como revelam algumas facturas relacionadas com os "definitivos arranjos", podendo mencionar-se o caso de Manuel

\footnotetext{
${ }^{284}$ Conferência ordinária de 10 de Janeiro de 1866. Idem, disponível em http://digitarq.dgarq.gov.pt/ PT-ANBA-ANBA-F-002-00001_m0319.TIF

${ }^{285}$ Conferência ordinária de 3 de Março de 1866. Idem, disponível em http://digitarq.dgarq.gov.pt/ PTANBA-ANBA-F-002-00001_m0329.TIF

${ }^{286}$ Factura datada de 1 de Fevereiro de 1866. Arquivo do MNAA, fundo José de Figueiredo, cx. 1, pasta 2, doc. 4.

287 Conferência ordinária de 3 de Março de 1866. Arquivo da ANBA, disponível em http://digitarq.dgarq.gov.pt/ PT-ANBA-ANBA-F-002-00001_m0330.TIF
} 
Gomes Alvares que a 11 de Outubro apresentava a "conta das ferragens que fiz para as salas que servem de galeria na Academia Real das Belas Artes para se puderem assentar os quadros" ${ }^{288}$. Destinadas a serem colocadas junto às sancas das salas, eram ao gosto grego como surge mencionado na factura, totalizando com outras peças em metal necessárias a importância de $196 \$ 520$ reis, incluindo o trabalho de assentamento. De assinalar são ainda os $115 \$ 000$ reis pagos a Silva \& Irmão, armazém de "armador e estofador" localizado na Praça Luís da Camões, que forneceu, entre outros materiais, uma quantidade assinável de "pano branco para estores" destinado a cobrir os tectos envidraçados nas horas de maior incidência solar ${ }^{289}$ (fig. 63).
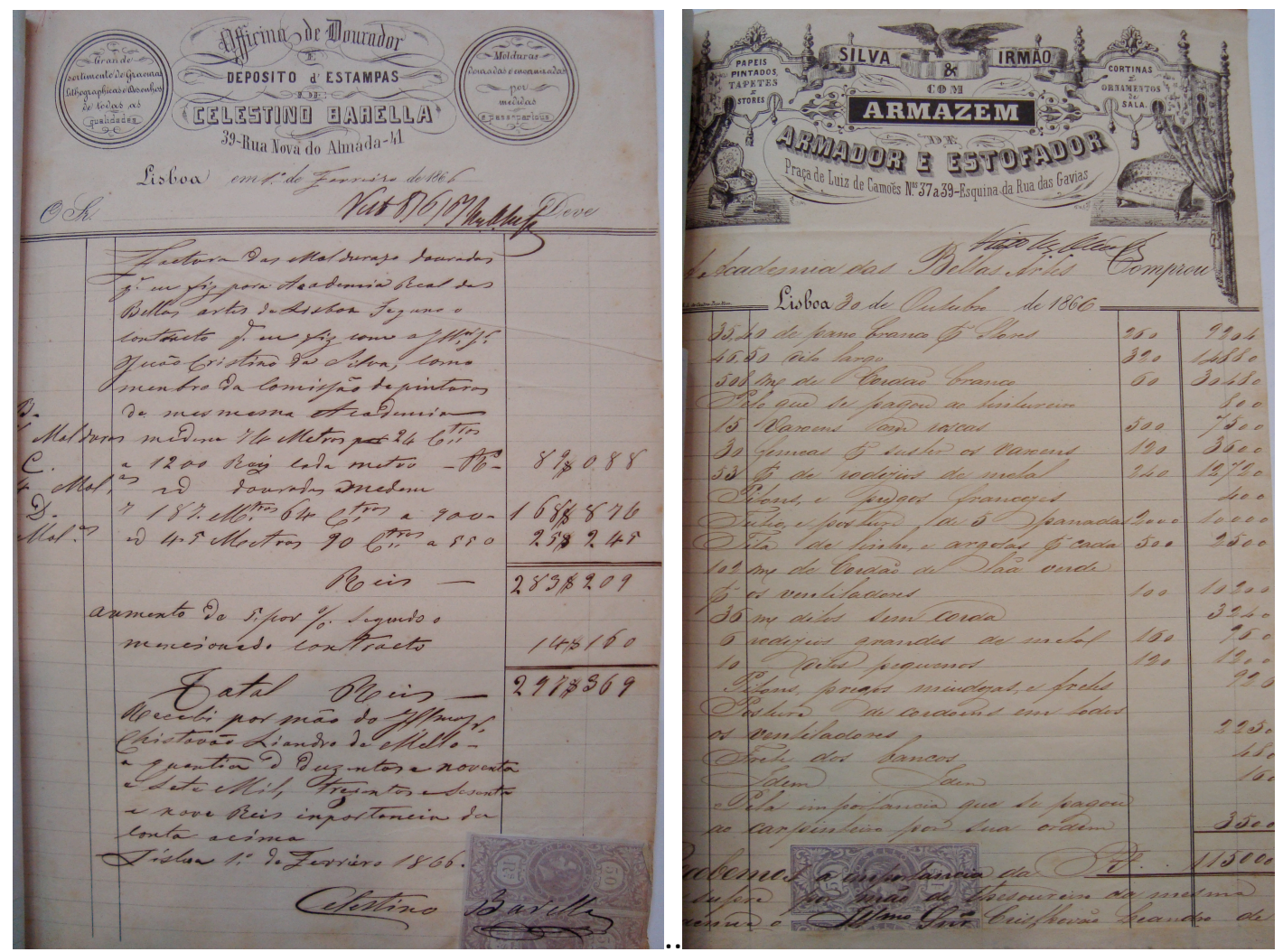

Fig. 62 - Factura do dourador Celestino Barella relativa à aquisição de molduras, 1866. Arquivo do MNAA

Fig. 63 - Factura do armazém de armador e estofador Silva \& Irmão com diversos materiais destinados à galeria, 1866. Arquivo do MNAA

Voltando às sessões académicas, declarava meses antes o vice-inspetor que "achandose próxima a organização da galeria nacional, a qual se deve expor ao público em

\footnotetext{
${ }^{288}$ Documento datado de 11 de Outubro de 1866. Arquivo do MNAA, fundo José de Figueiredo, cx. 1, pasta 2, doc. 4/40.

${ }^{289}$ Factura datada de 30 de Outubro de 1866. Idem, cx. 1, pasta 2, doc. 7.
} 
certos dias da semana" era necessário nomear quanto antes um guarda, tendo resolvido oficiar ao governo nesse sentido ${ }^{290}$. A resposta do Ministério do Reino não tardou, e por portaria de 27 de Julho de 66, seria autorizada "a nomeação de Marcelo Ferreira Lima para ser encarregado interinamente da polícia da galeria de pinturas com a gratificação anual de $120 \$ 000$ reis pagos pela verba do expediente da Academia na conformidade da proposta do Exmo. vice-inspetor e da conferência" ${ }^{291}$.

O Diario de Noticias acompanhou com interesse a evolução dos trabalhos, e em Outubro informava estar a decorrer, sob a direção do professor Miguel Ângelo Lupi, a "colocação dos quadros nas salas da Academia Real das Belas Artes", com o objectivo de ficarem "expostos ao público todos os domingos, destinando-se os outros dias para o estudo não só dos alunos da Academia, como também para os amadores ou estudantes de fora do estabelecimento" ${ }^{292}$. Num recado ao governo, o mesmo jornal fazia notar pouco depois que os esforços dos académicos na realização daquele intento, assim como as aquisições que em simultâneo se processavam com a verba de D. Fernando, "devem chamar necessariamente a atenção do Sr. ministro do Reino, afim de dotar a Academia com os meios necessários para que haja o indispensável pessoal que trate seriamente da conservação de tão preciosos objetos de arte e cuide da sua guarda e vigilância, para se poderem patentear ao público com aquela decência e decoro que se observa nos outros países" ${ }^{293}$.

Na sessão de 5 de Dezembro, Lupi dava a conhecer "ter concluído a comissão de que foi encarregado pela Academia relativa à colocação dos quadros e precisos arranjos da galeria", tarefa considerada "de muita importância e dificuldade" e de que dizia ter-se ocupado com empenho, sendo auxiliado pelo contínuo José Maria Martins "que se houve com habilidade e préstimo executando o que Sạ. Ex.a [Sousa Holstein] determinou, julgando-o por isso digno de ser recomendado à Academia" ${ }^{294}$. Apresentará depois um requerimento relativo aos "moços da Academia que coadjuvaram o contínuo José Maria Martins nos trabalhos do arranjo da galeria,

\footnotetext{
290 Conferência ordinária de 5 de Julho de 1866. Arquivo da ANBA, disponível em http://digitarq.dgarq.gov.pt/ PT-ANBA-ANBA-F-002-00001_m0360-1.TIF

${ }^{291}$ Conferência ordinária de 1 de Agosto de 1866. Idem, disponível em http://digitarq.dgarq.gov.pt/ PTANBA-ANBA-F-002-00001_m0365.TIF

${ }^{292}$ Diario de Noticias, 21 de Outubro de 1866

${ }^{293}$ Idem, 21 de Novembro de 1866

${ }^{294}$ Conferência ordinária de 5 de Dezembro de 1866. Arquivo da ANBA, disponível em http://digitarq.dgarq.gov.pt/ PT-ANBA-ANBA-F-002-00001_m0383.TIF
} 
pedindo que em atenção ao àquele serviço extraordinário que fizeram, e a exemplo do que se concedeu ao referido contínuo, se lhes desse uma pequena gratificação"295. Após alguma discussão, concordaram os académicos que aqueles haviam tido "excessivo trabalho e feito bom serviço", concedendo uma libra a cada um ${ }^{296}$.

Receando eventuais sinistros, Lupi fez igualmente notar a "necessidade que há de se proceder a certas obras de prevenção e segurança para pôr as salas em que estão colocados os quadros da galeria a coberto de incêndio, uma vez que as construções das ditas salas, sendo de madeira e muito antigas, estavam muito expostas a esse perigo" 297 . O vice-inspetor referiu ter essa problemática "em muita consideração", tendo ordenado a execução de um exame e orçamento dos trabalhos necessários a ser submetido ao Ministério do Reino. Enquanto tal, recomendava alguma prevenção, "pedindo aos Srs. professores que dessem as mais terminantes ordens aos porteiros, contínuos e moços para evitarem o uso do fumo dentro do recinto da Academia" ${ }^{298}$.

Apesar de Lupi ter dado por concluída a instalação das pinturas, o ano de 1867 continuará a ser marcado pela realização de diversos trabalhos, uns motivados pelos demorados acabamentos, outros talvez pelas questões de segurança contra incêndios atrás referidas, e ainda outros relacionados com a ampliação da galeria que se alargou por outros espaços, em virtude das salas disponíveis não serem suficientes para albergar as obras. Foram todos supervisionados pelo professor de arquitetura João Pires da Fonte que colocou o seu visto em diferentes documentos, entre facturas e recibos, como o de António Lopes, "pelos diferentes trabalhos de pedreiro que tomei de empreitada na galeria de pinturas da Academia" ${ }^{299}$ (fig. 64). Devem ainda mencionar-se as folhas referentes ao vencimento dos "operários que se empregaram em tapar de pedra e cal as portas que deitam para a galeria da Academia Real das

\footnotetext{
${ }^{295}$ Conferência ordinária de 11 de Janeiro de 1867. Idem, disponível em http://digitarq.dgarq.gov.pt/ PT-ANBA-ANBA-F-002-00001_m0388.TIF

${ }^{296}$ Foi ainda concedida meia libra à viúva de um dos ajudantes entretanto falecido. Conferência ordinária de 11 de Janeiro de 1867. Idem, disponível em http://digitarq.dgarq.gov.pt/ PT-ANBA-ANBA-F002-00001_m0388.TIF

${ }^{297}$ Conferência ordinária de 5 de Dezembro de 1866. Idem, disponível em http://digitarq.dgarq.gov.pt/ PT-ANBA-ANBA-F-002-00001_m0383.TIF

${ }^{298}$ Conferência ordinária de 11 de Janeiro de 1867. Idem, disponível em http://digitarq.dgarq.gov.pt/ PT-ANBA-ANBA-F-002-00001_m0389.TIF

${ }^{299}$ Recibo datado de 28 de Fevereiro de 1867. Arquivo do MNAA, fundo José de Figueiredo, cx. 1, pasta 2, doc. 48.
} 
Belas Artes", trabalho realizado em duas semanas do mês de $A_{b r i{ }^{300}}$. Nesse sentido seria encomendado um barril de cimento hidráulico "para os rebocos das salas que servem de galeria da dita Academia" ${ }^{301}$.

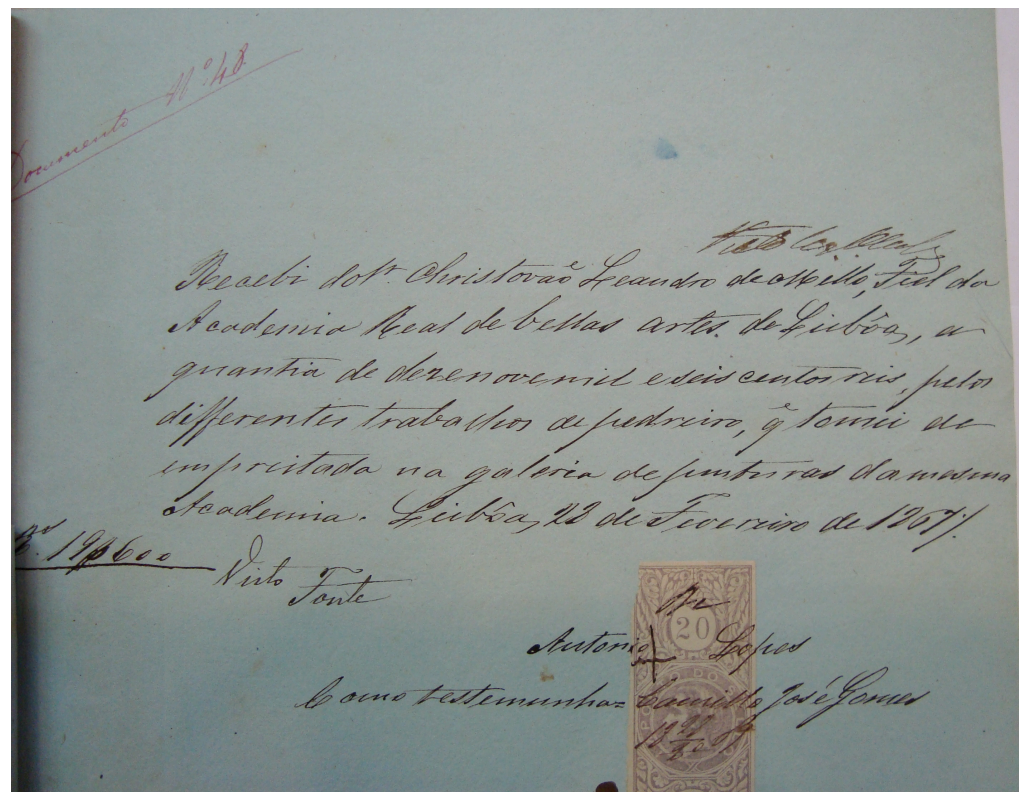

Fig. 64 - Recibo de António Lopes relativo aos trabalhos de pedreiro executado na galeria, 1867. Arquivo do MNAA

Em relação aos acabamentos, é de mencionar a factura de Tiago António da Silva, proprietário de um estabelecimento especializado em ferragens sito rua do Amparo, "pelos trabalho de serralheiro que mandei fazer e assentar nas salas de pintura que estão servindo de galeria na Academia Real das Belas Artes” ${ }^{302}$. Hábil no domínio da marcenaria, o contínuo José Martins seria encarregado de uma multiplicidade de tarefas, entre as quais a execução dos "corrimãos" em madeira destinados a rematar as guardas metálicas que tinham sido colocadas em redor das salas para evitar uma aproximação excessiva dos visitantes aos quadros ${ }^{303}$. De assinalar é a conta de João Maria dos Reis relativa à "pintura de fingidos" que incluiu não só a "imitação de madeira em oito bancos corridos" mas também nos "corrimãos das cinco salas" ${ }^{304}$ (fig. 65). Ao dourador Celestino Barella a quem Cristino da Silva havia encomendado as

\footnotetext{
${ }^{300}$ Arquivo do MNAA, fundo José de Figueiredo, cx. 1, pasta 2, doc. 57 e 61

${ }^{301}$ Recibo datado de 28 de Março de 1867. Idem, cx. 1, pasta 2, doc. 55.

302 Fatura datada de 26 de Março de 1867. Idem, cx. 1, pasta 2, doc. (número ilegível)

303 "Conta do trabalho nas salas de pintura que servem de galeria na Academia de Belas Artes de Lisboa", documento datado de 23 de Março de 1867. Idem, cx. 1, pasta 2, doc. 53

${ }^{304}$ Recibo datado de 24 de Abril de 1867. Idem, cx. 1, pasta 2, doc. 60
} 
molduras, seria ainda confiada a execução de "373 números para os quadros com a numeração de 1 a 373", para além de algumas "tabuletas" destinadas a identificarem as salas, discriminando-se as relativas à "Sala de D. Fernando"305.

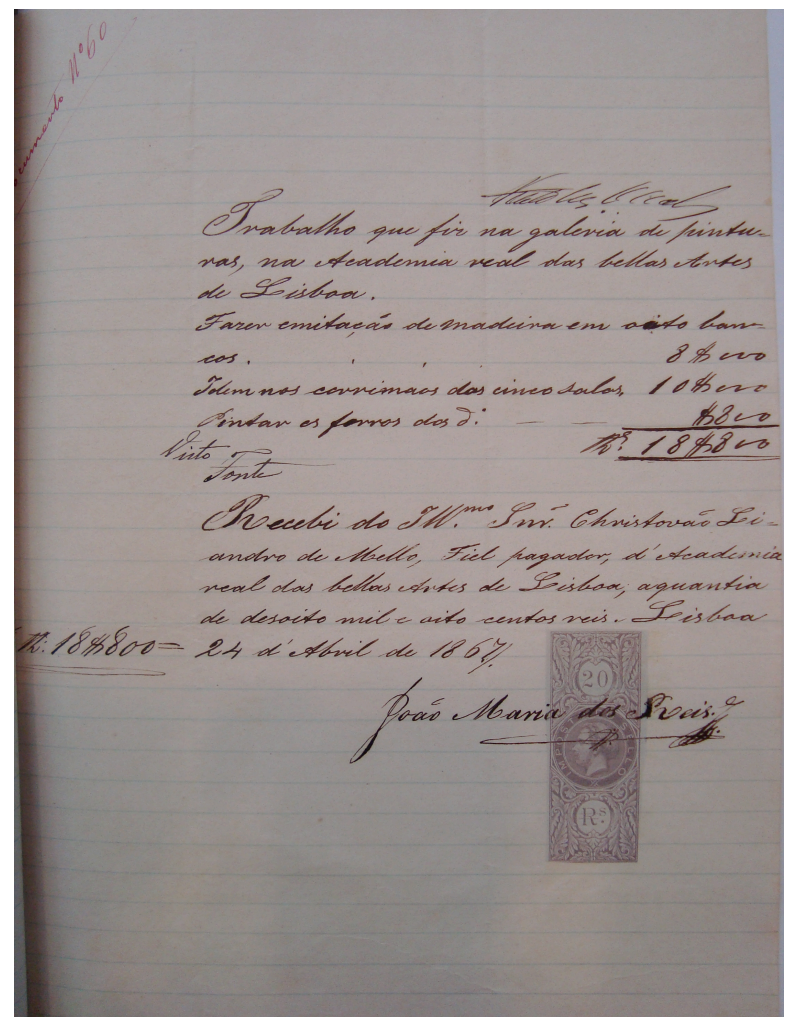

Fig. 65 - Recibo de João Maria dos Reis relativa à "pintura de fingidos" executada galeria, 1867.

Arquivo do MNAA

Para além de darem conta do avanço dos trabalhos e do papel dos diferentes professores na supervisão dos mesmos, este conjunto de recibos e facturas fornece valiosas informações quanto ao ambiente das salas, marcado por soluções austeras, como era o caso da "pintura de fingidos" efectuada para enobrecer as madeiras. A contenção na gestão das verbas a isso obrigava, não apresentando a galeria a opulência decorativa das grandes congéneres europeias que recorreram quase sempre a reputados fornecedores ${ }^{306}$, ou mesmo da galeria da Ajuda para citar um caso nacional coevo, onde a presença de elaborados reposteiros em veludo carmesim nas portas conferia um certo ar de magnificência régia ${ }^{307}$.

\footnotetext{
${ }^{305}$ Recibo datado de 27 de Junho de 1867. Idem, cx. 1, pasta 2, doc. 62

${ }^{306}$ A este respeito cf. GEORGEL, Chantal - "Meubles et peluche: les fournisseurs des mussés". La jeunesse des musées: les musées en France au XIXe siècle, 1994, pp. 215-220.

${ }^{307}$ XAVIER, Hugo - op. cit., pp. 125-130.
} 

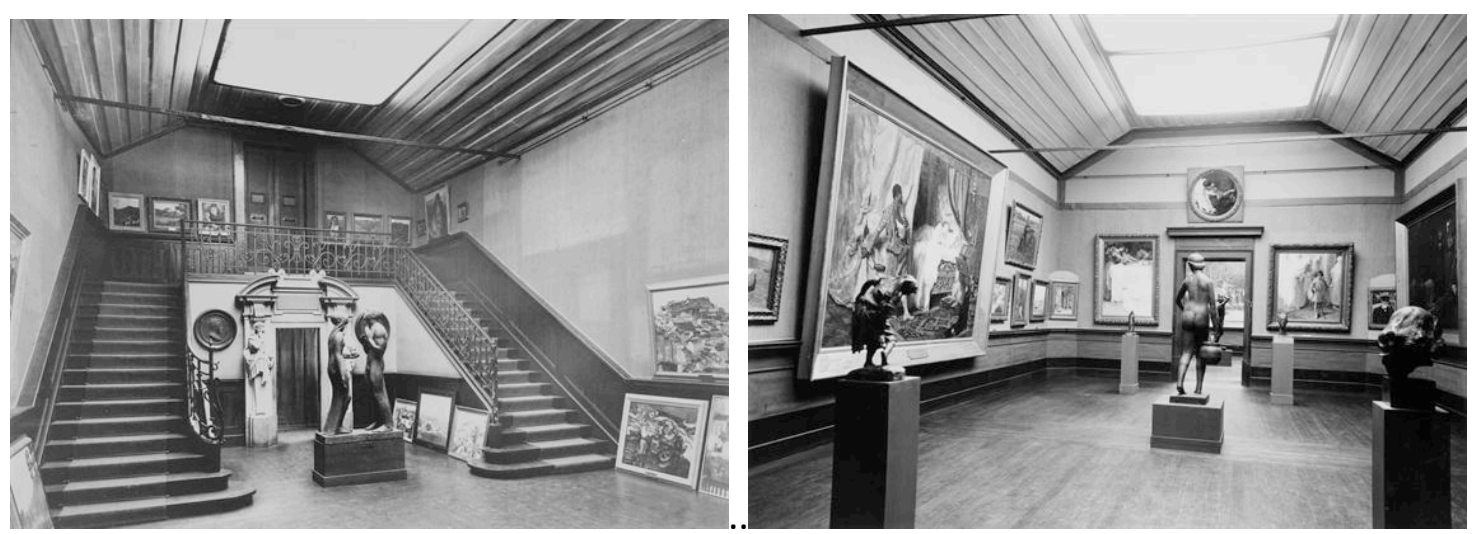

Figs. 66 e 67 - Museu Nacional de Arte Contemporânea, c. 1940. MNAC-MC, 09612 NPB e 48393 DIG

Na ausência de imagens coevas das salas, socorremo-nos de duas fotografias antigas do Museu Nacional de Arte Contemporânea (fig. 66 e 67) que, ao ser criado em 1911, se instalou após algumas obras no espaço ocupado pela Galeria Nacional de Pintura, deixado vago com a transferência do acervo para o Museu Nacional de Belas Artes e Arqueologia, inaugurado em 1884. Uma planta daquele museu publicada em $1913^{308}$, ajuda a contextualizar as fotografias e a entender melhor o espaço, dividido em cinco salas, em ângulo recto (fig. 68), correspondendo eventualmente a de "escultura e arte aplicada" à ampliação que se pensou inaugurar com uma mostra dedicada a Domingos Sequeira, aspecto a que adiante voltaremos. Existindo à partida cinco salas, aquela seria uma sexta mas a adaptação da última para servir de atelier de pintura (usado logo a partir de 1914 por Columbano Bordalo Pinheiro) explicará a manutenção de tal cifra $^{309}$.

Relacionada indiretamente com a galeria, há ainda a referir a encomenda efectuada a Henrique José Bruno \& Jorge, com estabelecimento na rua do Arco (a Jesus), que forneceu a mobília e demais complementos para a decoração de um gabinete destinado a receber de visitas importantes. Tecto e paredes foram forrados a papel, as janelas ocultadas com cortinados e o soalho com um tapete, sobre o qual se dispuseram cinco cadeiras de palhinha, um sofá estofado a pele, uma secretária com

\footnotetext{
${ }^{308}$ COSTA, L. de Mendonça e - Manual do viajante em Portugal, 1913, p. 53.

309 MACEDO, Diogo de - “Notas de arte: informações e história”. Ocidente, vol. LIII, n.o 234, 1957, pp. 172-173.
} 
respectiva cadeira, uma estante e uma mesa, num total de $308 \$ 000$ reis liquidados em Fevereiro de 1870, quase dois anos após a inauguração da galeria ${ }^{310}$.

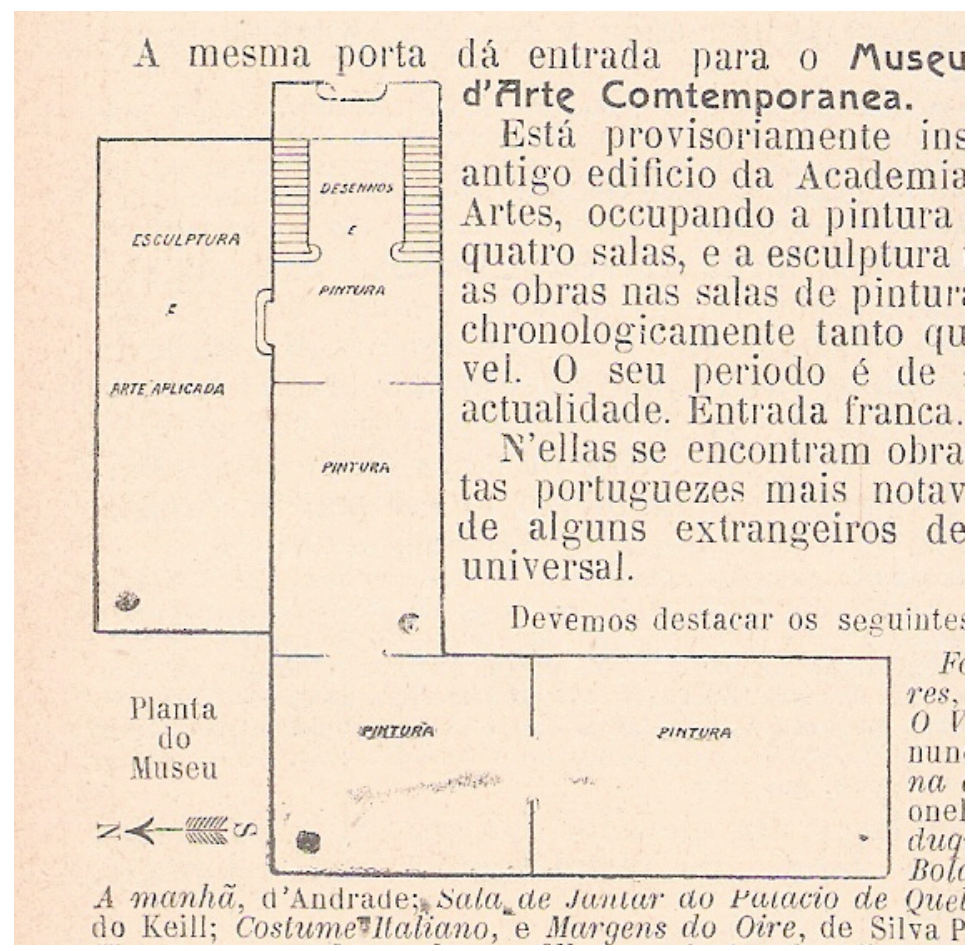

Fig. 68 - Planta do Museu Nacional de Arte Contemporânea in Manual do Viajante em Portugal, 1913

Data igualmente de Fevereiro de 1870 o relatório apresentado pelo vice-inspetor a D. Fernando II, onde são especificadas as quantias despendidas na aquisição de molduras (872\$269 reis) e nos "arranjos" efectuados na galeria ( $809 \$ 550$ reis). "A maior parte dos quadros que nela existiam não tinham molduras; hoje poucos são os que as não têm" escrevia Sousa Holstein que se congratulava igualmente com os pequenos melhoramentos: "As salas tinham más condições de luz e de ventilação, eram húmidas e os quadros deterioravam-se rapidamente; com a soma despendida fizeram-se algumas obras que remediaram quanto possível aqueles defeitos e adquiriu-se uma mobília singela mas decente para colocar nas mesmas salas". Referia-se essencialmente aos bancos corridos, não se esquecendo do "gabinete de espera que hoje lá existe graças à munificência de Vossa Majestade"311.

\footnotetext{
${ }^{310}$ Fatura datada de 1 de Fevereiro de 1870. Arquivo do MNAA, fundo José de Figueiredo, cx. 1, pasta 5, doc. $126 \mathrm{~A}$

${ }^{311}$ Relatório datado de 14 de Fevereiro de 1870. Idem, cx. 1, pasta 4, doc. 16.
} 
Parte ínfima se a compararmos ao total aplicado na aquisição de pinturas $(63.524 \$ 072$ reis), a verba que o vice-inspetor conseguiu direcionar para as obras e molduras seria portanto determinante para a concretização do projeto. Como veremos em seguida, serão ainda financiados pelo bolso régio a edição do catálogo da pinacoteca e a conservação de algumas pinturas, o que é bem revelador do estado generalizado de penúria da instituição. Atendendo às necessidades da Academia, Sousa Holstein procurou tirar o máximo partido do gesto mecenático do monarca, revelando-se hábil na gestão das verbas.

\subsection{A catalogação do acervo}

Como tivemos oportunidade de constatar na I parte deste trabalho, a necessidade de um catálogo da coleção de pintura foi desde cedo reivindicada pelos responsáveis da Academia, com algumas tentativas frustradas nesse sentido. Sousa Holstein procurará materializar esse projeto, numa nova sucessão de avanços e recuos reveladores das fragilidades da instituição que desperdiçou muito tempo no processo, por fim concretizado, e de uma forma menos ambiciosa do que inicialmente previsto, em 1868, com a inauguração da Galeria Nacional de Pintura.

Na sessão de 24 de Julho de 1862, menos de um mês após ter sido nomeado para o cargo de vice-inspetor, o marquês manifestava "a necessidade que há de classificar e catalogar os quadros existentes nesta Academia", tendo designado para esse fim uma comissão composta pelos professores de pintura António Manuel da Fonseca e Tomás da Anunciação ${ }^{312}$. Cerca de um mês mais tarde, a comissão dava conta "de ter escolhido os quadros grandes que devem figurar na nossa galeria", propondo o marquês a nomeação de uma "pessoa competente que se encarregasse de escrever o catálogo". Ciente da indisponibilidade dos professores de pintura, expressou então a ideia "que o artista agregado à aula de gravura, João José dos Santos, desempenharia cabalmente esta comissão mediante uma gratificação de seis libras pelo trabalho e 312 Conferência ordinária de 24 de Julho de 1862. Arquivo da ANBA, disponível em
http://digitarq.dgarq.gov.pt/ PT-ANBA-ANBA-A-001-00008_m0364.TIF 
tempo que deveria empregar na confecção do dito catálogo"313, ao que a conferência anuiu.

Discípulo de Gregório Francisco Queiroz, João José dos Santos acumulava desde 1854 a função de artista agregado à Aula de Gravura Histórica com o de bibliotecário da Academia, tendo sido naquele ano de 62 o anónimo autor do catálogo da biblioteca académica $^{314}$, o que terá estado na origem da sua escolha para se entregar a semelhante tarefa relativa ao acervo pictórico. Para tal não terá passado despercebido o facto de ter acompanhado Raczynski nas suas excursões artísticas pelo país, auxiliando-o nas pesquisas históricas e efetuando algumas gravuras publicadas em Les arts en Portugal ${ }^{315}$.

Em Outubro de 1863, após uma ausência prolongada da Academia "por urgentes motivos do serviço do Paço" ${ }^{316}$, o vice-inspetor referia "que tendo examinado atentamente o catálogo dos quadros que devem formar a nossa galeria, e achando nele muitas lacunas e omissões que infelizmente escaparam ao encarregado deste trabalho, apesar do zelo e boa vontade com que ele se tinha dedicado, e julgando que se não devia publicar e distribuir deste modo, porque daria causa a graves rasuras, propunha que se emendasse e se reformasse, embora se fizesse nova despesa com a sua impressão" ${ }^{317}$. No mês seguinte, voltava a falar do revés em que resultara o catálogo, recordando para não se "proceder à sua distribuição para não prejudicar o crédito da Academia". Lamentava a despesa feita "com a impressão de 2000 exemplares que de nada serviam, julgando que não podia deixar de se proceder à impressão de outro catálogo que espera seja feito com a devida inspeção e acerto". Solicitou de igual modo que se mandassem arquivar "dois exemplares do que fica inutilizado, para constar a todo o tempo os motivos desta deliberação e do transtorno notado, o qual deve ser atribuído à precipitação com que o encarregado deste serviço

\footnotetext{
${ }^{313}$ Conferência ordinária de 30 de Agosto de 1862. Idem, disponível em http://digitarq.dgarq.gov.pt/ PTANBA-ANBA-A-001-00008_m0375.TIF

${ }^{314}$ [SANTOS, João José dos] - Catalogo dos livros da bibliotheca da Academia das Bellas-Artes de Lisboa, 1862.

${ }^{315}$ LIMA, Henrique de Campos Ferreira - “O gravador João José dos Santos”. Revista de Guimarães, vol. 58, fasc. 3-4, 1949, pp. 314-315.

${ }^{316}$ Recordamos que Sousa Holstein desempenhava as funções de gentil-homem da câmara de D. Luís e de oficial-mor da Casa Real.

317 Conferência ordinária de 15 de Outubro de 1863. Arquivo da ANBA, disponível em http://digitarq.dgarq.gov.pt/ PT-ANBA-ANBA-F-002-00001_m0090.TIF e_m0091.TIF
} 
mandara proceder à impressão, antes das minuciosas revisões que estes trabalhos requerem" ${ }^{318}$.

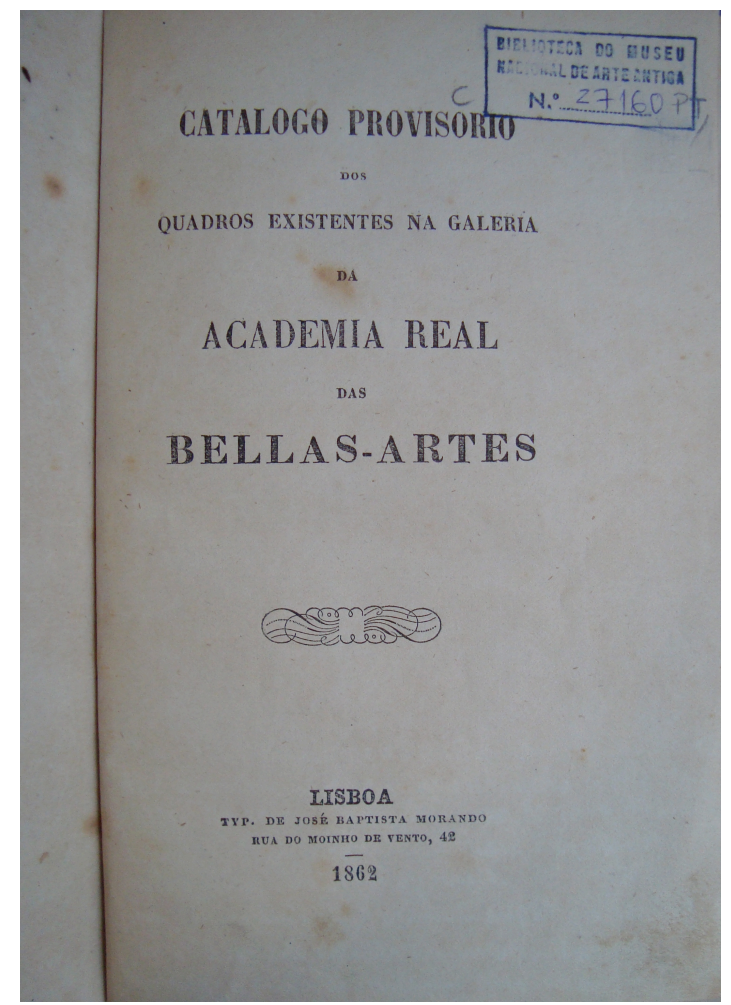

Fig. 69 - João José dos Santos, Catalogo provisorio, 1862 Biblioteca do MNAA, 27160 PT

A biblioteca do Museu Nacional de Arte Antiga conserva um desses exemplares (fig. 69), antecedido por uma pequena advertência assinada por Jorge Husson da Câmara, na qualidade de académico honorário, Fonseca e Anunciação que se desculpam com a urgência da tarefa pelo facto de não lhes ter sido possível "descer às amiudadas indagações que demanda tão delicado assunto" ${ }^{319}$. Não chegaram portanto a acompanhar de perto o trabalho de Santos que para além das discutíveis classificações apresentadas, revela algumas falhas nas biografias dos artistas e nas descrições das obras com que entendeu enriquecer o catálogo. No que diz respeito à pintura portuguesa, apoiou-se essencialmente em Raczynski, chegando no caso de algumas

\footnotetext{
318 Conferência extraordinária de 9 de Novembro de 1863. Idem, disponível em http://digitarq.dgarq.gov.pt/ PT-ANBA-ANBA-F-002-00001_m0106.TIF

${ }^{319}$ [SANTOS, João José dos] - Catalogo provisorio dos quadros existentes na galeria da Academia Real das Bellas-Artes, 1862, p. 5.
} 
obras a remeter para os escritos que aquele historiador elaborou durante a sua permanência no nosso país.

Tornando-se evidente a necessidade de um novo catálogo, Sousa Holstein comunicava em Outubro de 63 que devido "aos quotidianos trabalhos dos Srs. professores e dos artistas que poderiam ser encarregados da importante confecção do sobredito catálogo, tinha solicitado a coadjuvação do oficial da contadoria da Ex.a Câmara Municipal de Lisboa, José Ferreira Chaves, por ser pessoa dedicada ao estudo das belas artes e em a qual concorrem os precisos conhecimentos para o bom desempenho deste trabalho". Foi igualmente dado a conhecer "que tendo procedido a algumas confrontações e exames o aludido empregado, e verificando por elas as lacunas do catálogo impresso, fizera um relatório que S. Ex. [vice-inspetor] disse ter na sua mão, no qual as ponderava e provara". Como tal, "pedia autorização à conferência para que o sobredito empregado procedesse à formação de um novo catálogo, fundando-o nas bases que S. Ex. I Ihe havia dado, devendo em todo o caso ser tudo isto feito de acordo com os Srs. professores de pintura a quem desde já recomendava esse serviço" ${ }^{320}$. Antigo aluno da Academia onde se instruíra com o mestre Fonseca, sucedendo mais tarde a Lupi na regência da cadeira de pintura de história, Ferreira Chaves (1838-1899) afigurava-se porventura mais apto para a tarefa do que o seu antecessor. Fiel expositor da Promotora, foi um retratista apreciado e gozou de algum sucesso como pintor de flores, sem nunca deixar a segurança do seu lugar na repartição de contabilidade da Câmara de Lisboa. Em Agosto de 63, respondendo a um oficio do vice-inspetor no sentido de solicitar a dispensa de Chaves para os trabalhos de catalogação a efetuar, o barão de Santa Engrácia, chefe do Município, respondia que a Câmara, "não obstante o limitado número dos empregados que formam o quadro da repartição a que pertence o dito empregado, desejando satisfazer a V. Ex. a no seu pedido, resolveu na sessão de ontem que ele fosse dispensado do serviço municipal por espaço de um mês para ocupar do objecto de que se trata" ${ }^{321}$. Em finais de Setembro, na sequência de um novo ofício enviado por Sousa Holstein, seria concedido a Chaves "mais outro mês

\footnotetext{
${ }^{320}$ Conferência ordinária de 15 de Outubro de 1863. Idem, disponível em http://digitarq.dgarq.gov.pt/ PT-ANBA-ANBA-F-002-00001_m0091.TIF

${ }^{321}$ Ofício datado de 11 de Agosto de 1863. Idem, disponível em http://digitarq.dgarq.gov.pt/ PT-ANBAANBA-B-001-00003_m1634.TIF e_1635.TIF
} 
de licença para continuar nos trabalhos que Ihe foram confiados" ${ }^{322}$, seguindo-se em Novembro um novo pedido "para completar os catálogos cuja redação lhe foi confiada". O presidente acedeu mas fez saber que não voltaria a autorizar mais dispensas, pois "sendo limitado o número de empregados e grande o expediente desta repartição, não é possível distraí-los para outros serviços que lhes são estranhos" ${ }^{323}$. Uma das primeiras tarefas de que se ocupou Ferreira Chaves foi a elaboração do relatório mencionado pelo vice-inspetor na sessão acima citada, documento onde se alonga em reflexões sobre o estado das artes no nosso país, os problemas de conservação das pinturas e a inadequação das salas destinadas à galeria, "consequência do enxerto que se fez de uma Academia de Belas Artes num convento de frades". Quanto aos trabalhos de catalogação, menciona como prioritária "a medição de todos os quadros de que se compõe a galeria da Academia do que darei conta no catálogo que me cumpri confeccionar se V. Ex.ㄹ não entender o contrário". Informa ter examinado as descrições do exemplar impresso, assinalado os quadros que se encontravam assinados, e analisado o critério de organização dos mesmos. Em relação a esse último aspecto, e apesar "da boa vontade que presidiu à confecção do catálogo, do qual apenas se acha uma parte impressa, pouco ou nada se conseguiu que preencha o fim desejado". Como tal, submete à consideração do vice-inspetor dois caminhos possíveis a seguir no novo trabalho: "O primeiro é classificar todos os quadros por ordem cronológica. O segundo, que me parecer o preferível, é classificar os quadros de autor conhecido por ordem alfabética, e os demais por ordem cronológica", sistema que Ihe parecia "seguido nos catálogos do Louvre"324.

O relatório foi apresentado no início do Outubro a Sousa Holstein, pelo que o seu autor teve cerca de dois meses para efetuar o que propôs, inviabilizada que estava a concessão de uma nova licença por parte da Câmara Municipal para a prossecução dos trabalhos. Em Fevereiro de 64 estes encontravam-se ainda por concluir, como dá a conhecer o vice-inspetor num relatório dirigido ao ministro do Reino, onde faz o balanço das atividades desenvolvidas no ano anterior: "Tratou-se de confeccionar um

\footnotetext{
${ }^{322}$ Ofício datado de 26 de Setembro de 1863. Idem, disponível em http://digitarq.dgarq.gov.pt/ PTANBA-ANBA-B-001-00003_m1636.TIF

${ }^{323}$ Oficio datado de 10 de Novembro de 1863. Idem, disponível em http://digitarq.dgarq.gov.pt/ PTANBA-ANBA-B-001-00003_m1630.TIF

${ }^{324}$ Relatório datado de 3 de Outubro de 1863. Arquivo do MNAA, fundo José de Figueiredo, cx. 1, pasta 11, doc. 1.
} 
catálogo de todos os quadros. A falta de empregados não permitiu que este trabalho se ultimasse ainda. Tem sido forçoso recorrer à benevolência de pessoas estranhas à Academia para a sua execução. Continua a tratar-se deste importante assunto e é de esperar que o catálogo esteja terminado este ano"325.

A esperança de Sousa Holstein recairia então sobre um jovem que se vinha ocupando da coleção de desenhos, Henrique Feijó da Costa (1842-1864), prematuramente falecido naquele mesmo ano de 64 ao regressar de uma viagem a Paris e a várias cidades italianas, no intuito de aprofundar os seus conhecimentos artísticos e de se restabelecer de um problema de saúde. Pinheiro Chagas a ele dedicou um elogioso esboço biográfico onde enaltece as suas qualidades no domínio dos estudos históricos e filosóficos a que também se dedicava ${ }^{326}$, lamentando a perda de um talento considerado brilhante ${ }^{327}$. Sousa Holstein a quem foi solicitado um depoimento para incluir naquele opúsculo, fez notar que o jovem estudioso "prometia ser uma das pessoas que mais haviam de contribuir para a restauração das Belas Artes em Portugal, e um dos mais distintos cultores da literatura e da crítica artística" ${ }^{328}$.

Na realidade, foi o próprio marquês que, logo em 1862, pouco tempo após ter sido nomeado vice-inspetor, convidou Feijó da Costa a classificar e inventariar os desenhos da Academia, tarefa concluída em alguns meses, encetando depois um conjunto de biografias dos artistas representados nessa coleção. Durante a viagem ao estrangeiro, elaborou um estudo sobre os principais pintores italianos com a descrição de algumas obras célebres conservadas nas galerias de Florença, dando a conhecer o seu interesse pela pintura ${ }^{329}$. Em 1866, ao comunicar a publicação póstuma daquele trabalho, Sousa Holstein recordava à conferência que Feijó da Costa havia sido por ele incumbido de "fazer o catálogo dos quadros e desenhos da galeria" ${ }^{330}$, mostrando que as suas

\footnotetext{
325 "Relatório acerva do estado da Academia Real das Belas Artes". Documento datado de 26 de Fevereiro de 1864. Idem , cx. 1, pasta 11, doc. 1

${ }^{326}$ COSTA, Henrique Luís Feijó da - Descripção das armas reais de Portugal: dos brazões das cidades $e$ das principaes villas do reino (...), s.d. Publicou ainda, entre várias obras que permaneceram inéditas, Mysterios do mundo ou a história d'uma família, 1858.

${ }^{327}$ CHAGAS, M. Pinheiro - Esboço biographico de Henrique Luiz Feijó da Costa, 1864.

${ }^{328}$ HOLSTEIN, marquês de Sousa - "Uma página da vida de Henrique Feijó". Idem, ibidem, p. 71

${ }^{329}$ COSTA, Henrique Feijó da - Esbôços biographicos dos principaes pintores italianos e rapida descripção artistica e historica dos quadros existentes na galerias de Florença, 1866.

330 Conferência ordinária de 11 de Janeiro de 1867. Arquivo da ANBA, disponível em http://digitarq.dgarq.gov.pt/ PT-ANBA-ANBA-F-002-00001_m0387.TIF
} 
investigações na Academia se alargavam também às obras da futura pinacoteca, trabalho deixado inacabado com a morte precoce do autor.

Envolto desde o início em contrariedades, o projeto será então engavetado por algum tempo, não sendo a este respeito estranho o gesto mecenático de $D$. Fernando II que permitiu a partir do mesmo ano de 64 o crescimento exponencial do acervo com a incorporação de mais de uma centena de pinturas. Dois anos mais tarde, o viceinspetor reconhecia "não ser possível apresentar-se um catálogo dos quadros da galeria circunstanciadamente redigido quando esta se abrir ao público", lembrando a conveniência "de se fazer uma relação sumária para servir de guia aos visitantes enquanto se não fizer o dito catálogo" ${ }^{331}$. Nada se fez porém e um ano mais tarde, ao participar "a urgente necessidade de se abrir e franquear quanto antes ao público a galeria de pinturas que se achava organizada", Sousa Holstein fazia notar a existência de "um obstáculo que era a falta de um catálogo dos quadros que ainda não estava pronto". Anunciação, Cristino, Lupi e Bastos votaram a "confecção de um catálogo provisório que em breve tempo podia fazer-se", seguindo a anterior ideia da "relação sumária" proposta pelo vice-inspetor. Resolveu-se marcar a inauguração para "o 1.응 Domingo depois das próximas férias, aprontando-se para então o catálogo e tratandose do vestuário que devem ter os guardas para aparecerem com a necessária decência", tarefa de que se ocupou Vítor Bastos com o fiel da Academia ${ }^{332}$.

Com a designação de "provisório" o catálogo será então editado em 1868 (fig. 70), coincidindo com a inauguração da galeria, também ela por assim dizer provisória ${ }^{333}$. Destinado a servir de guião aos visitantes que o poderiam adquirir à entrada por 100 reis, foi organizado por Sousa Holstein em colaboração com os professores de pintura tomando provavelmente como ponto de partida os trabalhos efectuados por Ferreira Chaves e talvez mesmo os de Feijó da Costa. A organização não seguiu nenhuma das sugestões propostas por Chaves (cronológica ou alfabética), abrindo com obras de Domingos Sequeira. Não se regista qualquer divisão por salas, seguindo o catálogo uma numeração contínua de 324 obras que ascendem a 366 na segunda edição (1872),

\footnotetext{
${ }^{331}$ Conferência ordinária de 30 de Outubro de 1866. Idem, disponível em http://digitarq.dgarq.gov.pt/ PT-ANBA-ANBA-F-002-00001_m0379.TIF

${ }^{332}$ Conferência ordinária de 23 de Dezembro de 1867. Idem, disponível em http://digitarq.dgarq.gov.pt/ PT-ANBA-ANBA-F-002-00001_m0450.TIF e_m0451.TIF

${ }^{333}$ HOLSTEIN, marquês de Sousa (co-auto) - op. cit.
} 
crescimento relacionado essencialmente com as doações Carvalhido. Correspondendo a pequenas placas apostas às molduras, a numeração surge acompanhada pela identificação da obra, escola ou autoria (com os anos de nascimento e morte dos artistas), dimensões e, não sendo tela, especificações sobre o suporte. Não foram esquecidas as proveniências, adotando-se para o efeito as seguintes abreviaturas: D. (obras do antigo depósito de S. Francisco), C. J. (compradas no leilão da rainha Carlota Joaquina), D. F. (adquiridas com a verba cedida pelo rei D. Fernando), e A. S. (compradas no leilão da Academia das Ciências de Lisboa).

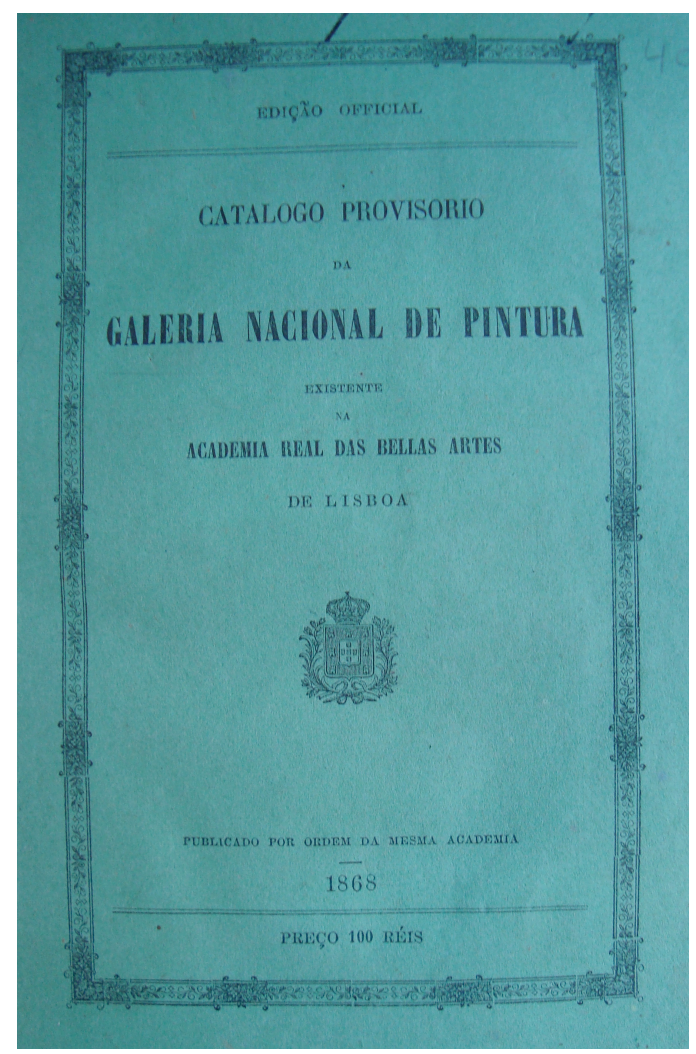

Fig. 70 - Marquês de Sousa Holstein (co-auto.), Catalogo provisorio, 1.a ed., 1868 Biblioteca do MNAA, 4086 PT

Estes níveis de informação, muito superiores ao catálogo da galeria da Ajuda compilado um ano depois por Marciano da Silva ${ }^{334}$, eram complementados pela presença de um índice alfabético dos artistas representados na galeria, e de um outro com a designação de "especial", relativo às obras atribuídas à antiga escola portuguesa. Numa curiosa preocupação em sistematizar aquele núcleo, ainda sem

\footnotetext{
${ }^{334}$ [SILVA, Marciano Henriques da] - Galeria de pintura do real paço da Ajuda fundada por Sua Magestade o Senhor D. Luiz I, 1869. Contará com uma segunda edição em 1872.
} 
atribuições definidas, agruparam-se alguns números do catálogo por letras (de $A$ a $M$ ), na tentativa de estabelecer afinidades estilísticas. A título de exemplo, os painéis que sabemos hoje terem integrado o chamado retábulo do Paraíso, atribuídos à oficina de Gregório Lopes, encontram-se assim reunidos sob a mesma letra (F) aos do retábulo de S. Bento, trabalho de parceria do mesmo autor com Jorge Leal. A opção deliberada em expor os primitivos - cerca de 85 tábuas - numa única sala, de acordo com um pensamento interpretativo acerca da sua identidade histórico-artística, facilitava aliás essas análises comparativas e o desejável aprofundamento de conhecimentos acerca dos mesmos.

Deve ser ainda registada a inclusão no catálogo de uma seleção bibliográfica "das obras que podem utilmente ser consultadas para conhecimento das biografias e trabalhos dos pintores que se acham representados na galeria". Assinalam-se os escassos autores que se debruçaram sobre a produção nacional tais como Cirilo, Cunha Taborda, Raczynski ou Robinson com a Memoria sobre a antiga escola portuguesa de pintura, editada naquele mesmo ano de 68 com o patrocínio da Sociedade Promotora de Belas Artes como já foi referido. Relativamente à pintura estrangeira, e com a exceção do exemplo clássico de Vasari, sobressai um agrupamento de autores contemporâneos como Charles Blanc, Alfred Michiels, Gustave-Frédéric Waagen e Ralph Nicholson Wornum. Indicava-se em nota que "todas estas obras existem na biblioteca da Academia Real de Belas Artes, a qual está aberta todos os dias das 10 às 2 da tarde, e contém uma óptima coleção de livros de belas artes e ciências acessórias $^{\prime 335}$.

O ponto forte do catálogo é a introdução assinada por Sousa Holstein que começa por traçar de forma sucinta o historial do acervo, recordando os nomes dos homens responsáveis pelos primeiros trabalhos de arrecadação e classificação das obras provenientes dos conventos extintos. Debruça-se em seguida nas aquisições efectuadas nos últimos anos e na necessidade de enriquecer a galeria nacional, para depois se concentrar na escola portuguesa de pintura, o grande atrativo da coleção, sintetizando os principais contributos publicados por Robinson. Detém-se, por último, no estado de conservação das obras, terminando com um apelo ao governo que pouco interesse dispensara ao projeto da galeria, e a quem reclama maior atenção.

\footnotetext{
${ }^{335}$ HOLSTEIN, marquês de Sousa (co-auto) - op. cit., p. 21
} 
Essa introdução que já fomos citando ao longo deste trabalho e a que voltaremos em breve, é antecedida por uma pequena advertência explicativa da obra editada. Refere destinar-se a "substituir provisoriamente um catálogo mais completo, que se vai elaborando, mas que algumas dificuldades não permitem publicar por agora". Gizado com base nos mais reputados exemplos estrangeiros, aquele catálogo "deverá reunir as descrições circunstanciadas dos quadros, a história dos mesmos, isto é, a sua proveniência e as vicissitudes por que passaram até entrar na coleção nacional". Trabalho de grande fôlego, teria ainda de "conter as biografias dos artistas a que se puderam atribuir os quadros, a discussão dos fundamentos das atribuições, e todos os mais esclarecimentos que possam tornar o catálogo um trabalho definitivo e completo, e um guia seguro para os visitantes da galeria".

Apesar de todos os esforços, Sousa Holstein nunca chegou a ver editado o catálogo sonhado, conformando-se com a versão provisória que critica de uma forma algo severa na mesma advertência: “O presente trabalho é sem dúvida muito incompleto, e será por certo fácil notar-Ihe inexatidões, omissões ou talvez mesmo erros mais graves. Pedimos para eles a indulgência de todos quantos sabem por experiência própria como é difícil tratar destes assuntos, sobretudo pela primeira vez". A inexistência de um conservador e a relativa indisponibilidade dos professores de pintura, quase sempre ocupados com funções lectivas, são apontadas como entraves à concretização de um trabalho com a exigência pretendia. "Ainda assim o zelo de alguns artistas que desempenham na Academia as funções do magistério, supriu quanto pôde a falta que temos de pessoal destinado para aquele serviço", o que conjugado com o desígnio de proceder à abertura da galeria, "deixou que se vencesse o natural receio de apresentar um trabalho que não satisfaz cabalmente". Refere todavia que antes de ser dada à estampa, foi a obra "examinada e revista, sobretudo no que respeita às atribuições, por algumas pessoas das mais entendidas nestes assuntos", numa provável alusão aos académicos como Charles Robinson ou Husson da Câmara a quem a Academia solicitou por vezes pareceres ${ }^{336}$.

${ }^{336}$ Idem, pp. 1-3. As citações anteriores reportam-se a esta referência. 
Entregue à Tipografia Universal de Tomás Quintino Antunes que cobrou $85 \$ 160$ reis pela sua edição ${ }^{337}$, custeados por D. Fernando $\|^{338}$, o catálogo cumprirá as necessidades da Academia, vindo a ser como atrás mencionado reimpresso em 1872, atualizando-se com a inclusão de cerca de 40 obras entretanto incorporadas (fig. $71)^{339}$.

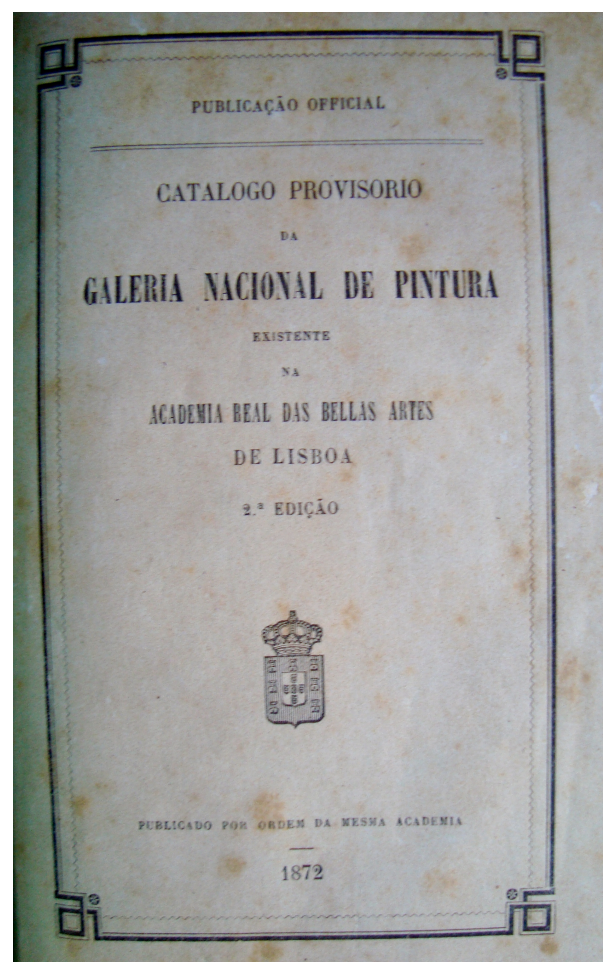

Fig. 71 - Marquês de Sousa Holstein (co-auto.), Catalogo provisorio, 2ª ed., 1872 Biblioteca do MNAA, 44087 PT

Sempre implacável para com Sousa Holstein e a instituição que dirigia, Joaquim de Vasconcelos não deixou de criticar o facto de aquele trabalho se apresentar "ainda como provisório na segunda edição", assinalando "erros de datas, datas omissas, erros de nomes e outros enganos, que não se podem admitir, mesmo num catálogo provisório" $^{340}$. Para os ensaístas espanhóis Francisco Giner de los Ríos (1839-1915) e seu irmão Hermenegildo (1847-1923), o catálogo recordava o que "por tanto tiempo

\footnotetext{
${ }^{337}$ Fatura datada de 6 de Novembro de 1868. Arquivo do MNAA, fundo José de Figueiredo, cx. 1, pasta 2, doc. 119

${ }^{338}$ Cf. "Desenvolvimento da receita e despesa da verba generosamente doada por Sua Majestade El-Rei o Senhor d. Fernando à Academia Real das belas Artes de Lisboa". Idem, cx. 1, pasta 4, doc. 17.

${ }^{339}$ HOLSTEIN, marquês de Sousa (co-auto) - Catalogo provisorio da Galeria Nacional de Pintura existente na Academia Real das Bellas Artes de Lisboa, 2. ed., 1872.

340 VASCONCELOS, Joaquim de - A reforma de bellas-artes: analyse do relatorio e projectos da commissão official nomeada em 10 de Novembro de 1875, 1877, p. 45, nota 3.
} 
ha existido en nuestro Museo del Prado, hasta que ha visto la luz el del Sr. D. Pedro Madrazo", valorizando o papel de Sousa Holstein na sua edição "al frente del cual ha puesto un interesante prólogo". Acrescentam que apesar de oferecer "en medio de su brevedad, materia no pocas veces para duda, todavía es innegable el servicio con el malogrado (murió en Septiembre de 1878, á los cuarenta años de edad) protector de la cultura artística de nuestros vecinos se hizo acreedor á la gratitud de su patria; servicio que habría aumentado corrigiendo más adelante las faltas que él mismo sinceramente reconoce en su Advertencia" ${ }^{341}$. O sucessor de Sousa Holstein, Delfim Guedes, pouco fez investir nesse sentido, e o catálogo da coleção de pintura publicado em 1883 com vista à abertura do Museu Nacional de Belas Artes e Arqueologia, ostentará ainda a designação de "provisório", revelando-se uma publicação menos trabalhada ao nível dos textos introdutórios ${ }^{342}$.

\subsubsection{O regulamento}

Publicado nas páginas iniciais do catálogo, o regulamento da galeria é constituído por 24 artigos que estipulam regras e orientações aos visitantes ou utilizadores do equipamento que se disponibilizava. A necessidade de regulamentar as visitas foi desde cedo sentida pelo corpo académico, tendo sido nomeada em 1861 uma comissão encarregada de gizar as suas premissas ${ }^{343}$, apresentadas à conferência de Julho do ano seguinte pelo professor Joaquim Pedro de Sousa, na qualidade de relator da comissão ${ }^{344}$. Em Agosto, após uma segunda leitura, seria esse regulamento aprovado por maioria, resolvendo-se que "em ocasião oportuna fosse remetido ao

\footnotetext{
${ }^{341}$ GINNER DE LOS RÍOS, Francisco e Hermenegildo - Portugal: impressiones para servir de guía al viajero, 1888, p. 96.

${ }^{342}$ ALMEDINA, conde de (co-auto) - Museu Nacional de Belas Artes e Archeologia: catalogo provisorio: secção de pintura, 1883.

343 "O Senhor Professor Joaquim Pedro de Sousa mandou para a mesa duas propostas que foram lidas e admitidas. A primeira proposta é para se facilitar aos artistas e amadores para visitarem e estudar aos Domingos [rasurado] a galeria de que trata a mesma proposta; o llmo. diretor-geral nomeou uma comissão composta dos Srs. Fonseca, Bastos e Sousa para fazer um regulamento para este fim e ser depois submetido à deliberação da conferência". Conferência ordinária de 21 de Dezembro de 1861. Arquivo da ANBA, disponível em http://digitarq.dgarq.gov.pt/PT-ANBA-ANBA-A-001-00008_m0303.TIF ${ }^{344}$ Conferência ordinária de 24 de Julho de 1862. Idem, disponível em http://digitarq.dgarq.gov.pt/ PTANBA-ANBA-A-001-00008_m0364.TIF
} 
governo, afim de ordenar a sua devida execução" ${ }^{345}$. Três meses mais tarde, continuavam todavia a discutir-se algumas ideias a esse respeito, tendo sido decidido que "quando as portas das galerias se abrirem ao público, cada pessoa pagaria dez reis pela guarda de bengalas e chapéus de chuva, cujo saldo eventual será aplicado para gratificar os guardas ou porteiros das mesmas galerias", e que fosse encarregada de dirigir as galerias uma comissão de que fariam parte os professores das aulas de pintura ${ }^{346}$.

As mudanças registadas pouco depois, sobretudo no que diz respeito ao enriquecimento do acervo e à reformulação do espaço destinado à galeria, alargaram o âmbito do projeto e impuseram novas exigências, levando ao abandono do documento inicial. Só em 1868, meses antes da abertura oficial, voltariam os académicos a discutir um projeto de regulamento, em duas sessões extraordinárias convocadas para o efeito. De acordo com o diretor-geral, o novo documento foi coordenado pelo vice-inspetor que recomendava "com urgência a revisão e aprovação dos seus artigos, afim de vigorarem depois de aprovados pelo governo" ${ }^{\prime 347}$. Começava por determinar a abertura ao público, "todos os domingos, desde as 11 horas da manhã até às 3 da tarde, para todas as pessoas que a quiserem visitar", tendo o corpo académico entendido suprimir a observação "sem distinção de classe ou vestuário contando que se apresente limpo" existente no documento original (art. 1.을 ${ }^{348}$.

De acordo com a tradicional prática académica que impunha a realização de cópias, estaria a galeria "aberta todos os dias às horas do estudo escolar para os alunos deste estabelecimento, e para todas as pessoas de ambos os sexos, estudantes, artistas ou amadores que ali desejarem estudar ou executar qualquer cópia” (art. 2.ํ). Para tal, seria concedido "um bilhete pessoal assinado pelo vice-inspetor da Academia" (art. 3. ), devendo os interessados inscrever-se "num livro que para esse fim está na mão do guarda, declarando o quadro ou objecto que se propõem estudar" (art. 7.ㅇ). No intuito de evitar eventuais falsificações, proibia-se "a cópia de quadros nas mesmas

\footnotetext{
${ }^{345}$ Conferência ordinária de 1 de Agosto de 1862. Idem, disponível em http://digitarq.dgarq.gov.pt/ PTANBA-ANBA-A-001-00008_m0366.TIF

${ }^{346}$ Conferência ordinária de 28 de Novembro de 1862. Idem, disponível em http://digitarq.dgarq.gov.pt/ PT-ANBA-ANBA-A-001-00008_m0387.TIF

${ }_{347}$ Conferência extraordinária de 31 de Janeiro de 1868. Idem, disponível em http://digitarq.dgarq.gov.pt/ PT-ANBA-ANBA-F-002-00001_m0454.TIF

${ }^{348}$ Rascunhos e documento original disponíveis em http://digitarq.dgarq.gov.pt/ PT-ANBA-ANBA-A-00600001_m0327.TIF a_0341.TIF
} 
dimensões dos originais" (art. 13.ํ), não tendo sido acatada a sugestão de alguns professores que expressaram a opinião de se manterem as dimensões, "uma vez que a tela ou qualquer outra matéria em que forem executadas as cópias sejam maiores que os originais" ${ }^{349}$. Interditava-se de igual modo a cópia de uma mesma obra por mais de duas pessoas, salvaguardando o caso de pontuais esboços, "com a expressa condição de não causar o menor incómodo às pessoas que estiverem trabalhando" (art. 16.). A ausência do trabalho por mais de três dias consecutivos, levava automaticamente à perda do lugar ocupado, devendo o interessado "inscrever-se novamente se esse lugar já estiver preenchido" (art. 18.ํ).

Por questões de segurança, era "expressamente proibido tocar nos objetos expostos" (art. 11.) ), ficando os visitantes e estudantes responsáveis "por toda a deterioração de que for causa" (art. 9.ํ). No sentido de evitar danos de maior, interditava-se a colocação de "cavaletes ou qualquer outro objecto no espaço reservado entre os quadros e a grade" (art. 15.), assim como a presença de bengalas ou chapéus de chuva dos visitantes que ficavam obrigados a "depositá-los à entrada do edifício" (art. 20.). Concluídas as cópias, deviam os seus autores "munir-se de um passe que será dado pelo secretário da Academia, sem o qual o guarda não consentirá que saia objeto algum" (art. 19.). Este zelava para que "a boa ordem, o silêncio, e o maior decoro fossem constantemente observados" (art. 22.ํ), proibindo "conversar alto, perturbar o silêncio sob qualquer pretexto, distrair ou incomodar os que estiverem trabalhando" (art. 12.ํ). Os indivíduos que desrespeitassem estas disposições "serão imediatamente excluídos da galeria" determinava o último artigo do regulamento (art. 24.ํ).

\subsection{Abertura ao público e planos de expansão}

O processo de formação da pinacoteca nacional foi acompanhado de perto pela imprensa, em especial pelo Diario de Noticias que foi dando conta aos seus leitores dos avanços e retrocessos registados. A 28 de Março de 1868, nas vésperas da inauguração, publicava um longo e enfático artigo saudando "com verdadeiro júbilo" o que dizia ser aos olhos de todos "um notável acontecimento para a arte em Portugal".

349 Conferência extraordinária de 1 de Fevereiro de 1868. Idem, disponível em http://digitarq.dgarq.gov.pt/ PT-ANBA-ANBA-F-002-00001_m0457.TIF 
Numa altura em que os restantes países europeus tinham "mais ou menos notáveis, mais ou menos grandiosas, as suas galerias nacionais de pintura", fazia notar a falta de um equipamento desse género entre nós, valorizando o papel exercido nesse sentido pelo vice-inspetor: "Há muito que a Academia tratava de inaugurar tal estabelecimento e só a vontade e talento do nobre marquês de Sousa Holstein se deve tê-lo conseguido". Colocava igualmente em evidência o gesto mecenático de D. Fernando II "que tanto tem animado e protegido a arte neste país que ele adoptou como seu", assim como o catálogo editado, não poupando encómios à introdução do vice-inspetor ${ }^{350}$. Parte da encarecida introdução, será transcrita na edição seguinte de maneira a coincidir com o dia de abertura (29 de Março), obrigando à interrupção do romântico folhetim que vinha sendo publicado, História de uma existência desvairada de Adriano Coelho ${ }^{351}$.

O mesmo jornal passou a acompanhar a afluência do público, informando terem dado entrada no dia inaugural 630 visitantes, 87 dos quais compraram catálogos. Quanto a reações, referia terem ficado todos "muito satisfeitos com a boa ordem e colocação dos quadros", dispensando ao vice-inspetor "os maiores elogios pela sua dedicação e empenho na realização de tão importante melhoramento" ${ }^{\prime 352}$. No segundo domingo, a afluência desceu para menos de metade com 256 pessoas contabilizadas, média que se manteve sem oscilações muito significativas a partir de então ${ }^{353}$.

Publicamente elogiada, a ação do vice-inspetor contaria ainda com o reconhecimento da conferência académica. O diretor-geral lembrou então "que tendo-se verificado a abertura da galeria de pinturas e a publicação do referido catálogo com feliz êxito, e sendo inegável que aos constantes esforços e diligências do Exmo. marquês viceinspetor se deve este importante melhoramento académico, propunha que se consignasse um voto de agradecimento a S. Ex. ํㅜ por tão distintos serviços prestados ao estabelecimento". Apreciada pelos professores, a proposta contou unicamente com a resistência de Cristino da Silva, ao declarar "que não tendo lido ainda o catálogo, só depois de bem o examinar poderia fazer um perfeito juízo dele e votar ao Exmo. vice-

\footnotetext{
${ }^{350}$ Diario de Noticias, 28 de Março de 1868

${ }^{351}$ Idem, 29 de Março de 1868

352 Idem, 31 de Março de 1868

${ }^{353}$ Idem, 7 de Abril de 1868
} 
inspetor os devidos elogios pelos seus bons serviços" ${ }^{\prime 354}$. Acabaria todavia por ser aprovada por unanimidade.

Organizadas em salas cedidas pela Academia, as exposições anuais da Sociedade Promotora das Belas Artes, constituirão um importante factor de dinamização e valorização da galeria nacional ao oferecerem um cruzamento produtivo com a pintura contemporânea, pouco representada no acervo. Em 1868, a exposição teve lugar em Novembro, e contou como habitualmente com as presenças de D. Luís e D. Fernando II que presidiram à cerimónia de abertura na companhia do marquês de Sousa Holstein e de alguns elementos do governo. "Acabada esta cerimónia, passaram novamente suas majestades a examinar todas as obras de arte, depois do que subiram ao pavimento superior do edifício para verem os trabalhos enviados pelos três pensionistas do Estado, estudantes em Paris" relatava o omnipresente Diario de Noticias. Dava igualmente conta que a galeria de pintura, "apesar de já ser bem conhecida pelos reais visitantes, não podia deixar-lhes de chamar à atenção, e para aí se dirigiram depois, demorando-se algum tempo, sobretudo na última sala, onde estão colocados os admiráveis quadros chamados góticos"355.

No relatório anual publicado por aquela sociedade, Sousa Holstein não deixará de fazer notar o seu contentamento pela inauguração da galeria, expressando o desejo de que a Academia patenteasse "logo que possa ao público a sua valiosa coleção de desenhos antigos e algumas outras coleções que naquele estabelecimento se vão sucessivamente organizando" ${ }^{356}$. A ideia era antiga pois logo em 1863, por sua solicitação, o professor João Pires da Fonte apresentava à conferência "os orçamentos da despesa em que devem importar as obras que se precisam nos três gabinetes onde se hão de expor os desenhos originais em bosquejo de artistas célebres"357. Como já referimos, essa coleção vinha sendo desde finais de 1862 estudada e inventariada por Feijó da Costa que acalentava vir a ser nomeado seu conservador. "Preparava-se com aturado trabalho para poder dignamente desempenhar as obrigações daquele

\footnotetext{
354 Conferência extraordinária de 24 de Março de 1868. Arquivo da ANBA, disponível em http://digitarq.dgarq.gov.pt/ PT-ANBA-ANBA-F-002-00001_m0481.TIF

${ }^{355}$ Diario de Noticias, 3 de Novembro 1868

${ }^{356}$ HOLSTEIN, marquês de Sousa; SOUSA, Joaquim Pedro de (co-auto.) - Relatório e contas da Sociedade Promotora das Bellas Artes em Portugal no ano de 1867-1868, 1869, p. 29.

357 Conferência extraordinária de 29 de Maio de 1863. Arquivo da ANBA, disponível em http://digitarq.dgarq.gov.pt/ PT-ANBA-ANBA-F-002-00001_m0056.TIF
} 
emprego" confidenciou o vice-inspetor por ocasião da desaparecimento do estudioso, precocemente falecido aos 22 anos de idade ${ }^{358}$.

Este e outros contratempos terão dificultado a pública exposição daquele acervo, entretanto enriquecido com importantes doações, e para o qual chegará também a ser mobilizado Alfredo Augusto da Costa Camarate, funcionário público em comissão na Academia, no sentido de se ocupar da sua organização ${ }^{359}$. "As circunstâncias não são porém favoráveis para a realização destes desejos, e forçoso será esperar melhores tempos", reconhecia Sousa Holstein em 1869 no relatório acima citado ${ }^{360}$. Decorridos oito anos, Vítor Bastos lamentava o facto daquela coleção não se encontrar patente ao público, dando a entender existir já um gabinete preparado para o efeito. Sousa Holstein justificou a demora com o impasse registado no respectivo catálogo que se procurava editar, esperando "em pouco tempo satisfazer os desejos da conferência, mandando abrir ao público todos os domingos, a galeria de pinturas e coleção de desenhos $^{\prime 361}$.

A preparação de um local adequado para expor os desenhos foi um projeto sempre enunciado, no entanto, a prioridade do vice-inspetor ia para o aumento do espaço ocupado pela galeria, desígnio que concentrou todos seus os esforços, pugnando energicamente junto dos poderes públicos pela sua concretização. Logo em Maio de 1868, menos de dois meses após a inauguração, anunciava com satisfação aos académicos "que bem depressa possuiria a Academia duas magníficas salas para as exposições das obras artísticas, porque além da completa restauração que se está construindo pelas Obras Públicas na antiga aula de desenho histórico, sabe que se resolveu favoravelmente o seu pedido para a construção de uma nova sala contígua" $^{362}$. Apesar do otimismo, o novo espaço contíguo à pinacoteca teve um desenvolvimento lento, não chegando nunca a acolher a exposição retrospectiva sobre Domingos Sequeira ideada por Sousa Holstein ${ }^{363}$.

\footnotetext{
${ }^{358}$ HOLSTEIN, marquês de Sousa - “Uma página da vida de Henrique Feijó”. CHAGAS, M. Pinheiro - op. cit., p. 70.

${ }^{359}$ Sobre Alfredo Augusto da Costa Camarate cf. o ponto 5.1 desta III parte.

${ }^{360}$ HOLSTEIN, marquês de Sousa; SOUSA, Joaquim Pedro de (co-auto.) - op. cit., p. 29.

361 Conferência ordinária de 5 de Outubro de 1877. Arquivo da ANBA, disponível em http://digitarq.dgarq.gov.pt/ PT-ANBA-ANBA-F-002-00002_m0527.TIF

${ }^{362}$ Conferência extraordinária de 16 de maio de 1868. Idem, disponível em http://digitarq.dgarq.gov.pt/ PT-ANBA-ANBA-F-002-00001_m0492.TIF e_m0493.TIF

${ }^{363}$ A este respeito cf. o ponto 3.1. da II parte.
} 
Vários foram os ofícios enviados ao Ministério das Obras Públicas, a quem em Novembro de 1870 era recordada a "urgente necessidade" de se avançar com o "prolongamento da galeria dos quadros desta Academia, para evitar a total ruína de alguns de conhecido mérito que se acham depositados em casas húmidas e inconvenientes" ${ }^{364}$. Um mês mais tarde, na ausência de resposta do ministro, recorreu o vice-inspetor ao Ministério do Reino, expondo o mesmo argumento: "existindo nesta Academia além dos quadros da galeria muitos outros de considerável valor, não há neste estabelecimento sala para os expor ao público nem sequer para os ter em arrecadação com todas as condições que requer a sua conservação". Referia encontrarem-se aqueles "em quatros húmidos privados de luz e ventilação por não haver local algum para os ter", colocando em sério risco "uma parte não pequena da riqueza pública". A ampliação era por isso premente, tendo a Academia encontrado uma solução que considerava eficaz: "Pela demolição de um telheiro provisório que se havia concedido ao professor Bastos ficou desimpedido junto à atual galeria, uma porção de terreno onde já existem alguns muros e alicerces para outros e na qual seria fácil e pouco dispendioso estabelecer duas novas salas para exposição permanente de quadros junto às cinco que já existem"365.

Os insistentes apelos e a força persuasiva do argumento não tiveram então qualquer efeito e só em 1873, decorridos três anos, teriam início os trabalhos. Em ofício ao ministro das Obras Públicas, o vice-inspetor congratulava-se com a iniciativa "que tão necessária se tornava para salvar da ruína a que estavam expostos nas arrecadações os quadros valiosos que o Estado possui e para os quais não havia espaço na galeria". Advertia que na nova sala em construção "apenas caberá uma pequena parte desses quadros, e que mais de trezentos ficarão ainda em péssimas condições, sendo portanto muito para desejar que desde já se dê começo a outra sala contígua à que se está construindo, e que sucessivamente se edifiquem outras pois para todas há espaço

\footnotetext{
364 Cópia do ofício datado de 8 de Novembro de 1870. Arquivo da ANBA, disponível em http://digitarq.dgarq.gov.pt/ PT-ANBA-ANBA-B-007-00002_m0042.TIF

365 Cópia do ofício datado de 10 de Dezembro de 1870 . Idem, disponível em http://digitarq.dgarq.gov.pt/ PT-ANBA-ANBA-B-007-00002_m0027.TIF
} 
no pátio junto à galeria" ${ }^{366}$. Os elementos coligidos dão a entender ter a ampliação ficado apenas por uma só sala, frustrando-se o desejo expresso por Sousa Holstein.

No guia para viajantes britânicos publicado em 1874 por Joaquim António de Macedo, vice-cônsul de Portugal em Leeds, a galeria de pintura é descrita como possuindo apenas cinco salas, não sendo feita qualquer menção ao alargamento que estaria ainda em curso. A descrição de Macedo revela-se importante por caracterizar sumariamente o discurso expositivo aplicado a cada sala, determinado de forma geral pelas proveniências, o que não se consegue depreender bem pelo catálogo:

"The first is devoted to paintings presented by the artists to the Academy to obtain the title of Academician, and are nearly all by Portuguese. The second room contains but few works by Portuguese artists. The third, called Sala de D. Fernando, contains the pictures bought with the subsidy of $£ 5,000$ a year generously conceded by his Majesty D. Fernando, who is himself an artist and who has contributed greatly to the elevation of the taste of the people by his example, and by his liberal patronage of the fine arts. In the fourth room are paintings by national and foreign artists; and the fifth is devoted entirely to paintings representing the Portuguese School of the end of the fifteenth and beginning of the sixteenth centuries, and is by far the most interesting part of the collection" ${ }^{367}$.

Como se verifica, valoriza o autor a última sala, remetendo os visitantes interessados para o artigo de Charles Robinson sobre a antiga escola portuguesa de pintura. Quanto aos mestres estrangeiros, faz notar a presença de alguns trabalhos considerados de somenos interesse: "it must be confessed that the works are inferior specimens, and not to be compared with the chefs d'oeuvre of these renowned masters" ${ }^{\prime 368}$. A pintura contemporânea afigurava-se escassa, e representação britânica contava apenas com duas obras de João Gresbante, obscuro artista estabelecido em Lisboa no século XVII.

\footnotetext{
${ }^{366}$ Cópia do ofício datado de 4 de Dezembro de 1873. Idem, disponível em http://digitarq.dgarq.gov.pt/ PT-ANBA-ANBA-B-007-00002_m0230-1.TIF e_m0230-2.TIF

367 MACEDO, Joaquim António de - A guide to Lisbon and its environs including Cintra and Mafra with a large plan of Lisbon, 1874, pp. 204-205.

${ }^{368}$ Idem, ibidem, p. 204
} 
No mesmo ano de 74, o escritor e jornalista espanhol Modesto Fernandez y Gonzalez (1838-1897) comparará no seu diário de viagem a nossa Academia com a de S. Fernando de Madrid, fundada em 1752 como estabelecimento de ensino e igualmente possuidora de uma pinacoteca. "No llega ni con mucho à la nuestra, ni en aulas, ni en modelos ni cuadros" advertia, fazendo notar de forma lapidar que no domínio das coleções de pintura, "nuestro Museo del Prado admite la competencia con todos los de Lisboa" ${ }^{369}$. Anos mais tarde, os também espanhóis Francisco e Hermenegildo Giner de los Rios deter-se-ão demoradamente sobre a galeria no seu guia de Portugal, pondo em evidência as aquisições efectuadas com a verba "nada insignificante en verdad (y menos en una nación tan modesta)" de D. Fernando II e as doações do conde de Carvalhido. "El interés capital de la galería de pintura está en los cuadros portugueses" consideram também estes autores, chamando a atenção para a "abundante colección de tablas" expostas na última sala. Ao olhar atento dos dois irmãos não passou despercebia a falta de condições da galeria, instalada "en un mal local que prejudica bastante á la conservación de los cuadros, por el excesivo calor que allí reina, según pudimos desgraciadamente observar por nosotros mismos, comprobando el dicho de los empleados" ${ }^{370}$.

As questões relacionadas com a conservação das pinturas constituíram desde há muito motivo de preocupação entre os professores, sendo discutidas amiúde nas sessões académicas. Como veremos oportunamente, o vice-inspetor procurou tomar medidas enérgicas nesse sentido mas a escassez de recursos contrariou os resultados desejados.

\subsection{A fotografia ao serviço da galeria: o caso de Jean Laurent}

Admirador do progresso técnico como tantos homens cultos da segunda metade do século XIX, Sousa Holstein procurou tirar partido das potencialidades da fotografia como forma de documentar e divulgar as obras de arte. Em certa medida, poderá ter sido influenciado nesse sentido por Charles Robinson, superintendente das coleções

\footnotetext{
369 FERNANDEZ Y GONZALES, Modesto - Portugal contemporáneo: de Madrid à Oporto pasando por Lisboa: diario de un caminante, 1874, p. 257.

${ }^{370}$ GINNER DE LOS RÍOS, Francisco e Hermenegildo - op. cit., pp. 94-99. A visita dos dois ensaístas terá sido efectuada entre 1879 e 1880.
} 
do South Kensignton Museum, que defendeu sempre a importância deste processo para fortalecer as instituições museológicas enquanto centros científicos e de estudo $^{371}$. Ao visitar Lisboa em 1865, o especialista inglês mostrou interesse em registar fotograficamente obras de arte representativas de coleções públicas e privadas nacionais, vendo no vice-inspetor o interolocutor indicado para the "abrir as portas". Tal viria a suceder e, logo em Novembro de 65, o marquês comunicava a Robinson que "any and every work of art in Portugal is entirely at your diposition for reproduction in any manner ${ }^{\prime 372}$. Para a tarefa foi mesmo mobilizado o fotógrafo oficial do South Kensington, Charles Thurston Thompson (1816-1868) que, em Agosto de 1866, após ter passado por Santiago de Compostela, se encontrava em Lisboa. Conhecemos vários espécimes da extensa série por ele realizada no Palácio das Necessidades, relativa às coleções de D. Fernando II, sobretudo no domínio da ourivesaria $^{373}$, mas não nos foi possível confirmar a ocorrência de qualquer campanha na Academia.

Se o contacto com o especialista inglês poderá ter consciencializado Sousa Holstein para a importância da fotografia no contexto do ensino e dos museus, convém salientar que meses antes de o ter conhecido, dava já provas desse interesse. Com efeito, na sessão de 5 de Agosto de 1865, informava ter mandado fotografar os quatro cartões de Domingos Sequeira da sua coleção pessoal, "e que desejando perpetuar na Academia a memória de um artista tão célebre, lhe oferece os clichés das ditas fotografias que se podem reproduzir e vender com vantajoso proveito da mesma Academia” $^{374}$. Como vinha sucedendo com alguns museus europeus, os benefícios comerciais inerentes à venda de fotos de obras de arte afiguravam-se atrativos, o que poderia constituir uma mais-valia para uma instituição com as carências da Academia. Decorridos dois anos, ao ser apreciada uma proposta efectuada pelo fotógrafo João Vítor Pereira Guimarães, essa questão será novamente recordada pelo vice-inspetor:

\footnotetext{
${ }^{371}$ Como veremos na IV parte deste trabalho, Robinson estará na base da oferta em 1866 à Academia de um amplo conjunto de fotografias de peças daquele museu londrino que eventualmente ainda se conservam na biblioteca daquele estabelecimento.

${ }^{372}$ Apud FONTANELLA, Lee - op. cit., s. p.

${ }^{373}$ Conjunto pertencente à Associação dos Arqueólogos Portugueses, em depósito no Arquivo de Documentação Fotográfica da DGPC. Este fundo será por nós estudado no âmbito de uma exposição sobre as coleções de ourivesaria da Casa Real projetada para o Palácio da Ajuda.

${ }^{374}$ Conferência ordinária de 5 de Agosto de 1865. Idem, disponível em http://digitarq.dgarq.gov.pt/ PTANBA-ANBA-F-002-00001_m0276.TIF
} 
“O Exmo. marquês fez algumas ponderações a respeito do modo porque se podiam e deviam fotografar as melhores obras existentes na galeria de pinturas e nos arquivos da academia e sobre o método que se devia adoptar para se efetuar a sua venda, da qual grande proveito podia tirar o estabelecimento" ${ }^{375}$.

Mau grado o declarado apoio de Sousa Holstein, aquele projeto não terá então vingado e só após a abertura ao público da pinacoteca, na sequência de todo o mediatismo gerado, veremos surgir novas solicitações. Com efeito, em Abril de 1869 era apresentada à conferência "uma proposta de Mr. Laurent e um requerimento de Augusto César Pardal e filho, pedindo autorização para extraírem cópias fotográficas dos melhores quadros e desenhos originais, mediante certas e determinadas condições". Foi-lhes então concedida permissão, "devendo entender-se com a comissão de pintura pelo que diz respeito aos processos de execução e colocação dos quadros, etc." ${ }^{376}$. O português Augusto César Pardal, em colaboração com o filho, Carlos Augusto Pardal ${ }^{377}$, centrar-se-á não nas pinturas mas nas alfaias litúrgicas do futuro Museu de Arte Ornamental, reproduzidas a partir de 1869 numa obra editada por subscrição, a Publicação Photographica, em que adiante nos iremos deter ${ }^{378}$. Mr. Laurent, ou melhor, Jean Laurent (1816-1886), fotógrafo francês estabelecido em Madrid, captará igualmente algumas alfaias daquela coleção, dedicando todavia maior atenção às pinturas da galeria.

O trabalho de Laurent, nomeadamente a extensa série relativa às pinturas do Museu do Prado por si comercializada, ${ }^{379}$ havia já chamado a atenção de Sousa Holstein que muito apostava na fotografia como meio privilegiado de difusão da arte, consciente talvez da complexidade da gravura e do fracasso dos projetos anteriores da Academia nesse sentido ${ }^{380}$. Logo em Junho de 1863 , apresentava à conferência um "catálogo

\footnotetext{
${ }^{375}$ Conferência ordinária de 13 de Março de 1867. Idem, disponível em http://digitarq.dgarq.gov.pt/ PTANBA-ANBA-F-002-00001_m0397.TIF

${ }^{376}$ Conferência ordinária de 13 de Abril de 1869. Idem, disponível em http://digitarq.dgarq.gov.pt/ PTANBA-ANBA-F-002-00002_m0024.TIF

${ }^{377}$ Foi colocada a hipótese de se tratar de um colega de Rafael Bordalo Pinheiro nas aulas de modelo vivo da Academia, por volta de 1875-1876, admitido na instituição desde 1869. Cf. SENA, António Sena História da imagem fotográfica em Portugal (1839-1997), 1998, p. 57.

${ }^{378}$ A este respeito cf. o ponto 2 da IV parte.

${ }^{379}$ GALLARDO, Helena Pérez - "La democracia del arte: el Museo del Prado, objetivo de la fotografia". MATILLA, José Manuel; PORTÚS, Javier (ed.) - El grafoscopio: un siglo de miradas al Museo del Prado (1819-1920) (cat. expo), 2004, pp. 259-273.

${ }^{380}$ A este respeito cf. o ponto 2.1 da I parte.
} 
impresso das fotografias que se vendem em casa do fotógrafo da rainha de Espanha, J. Laurent", fazendo notar que "entre grande número de obras ali indicadas lhe parem muito dignas de apreço as que dizem respeito aos quadros originais do museu de Madrid, cuja aquisição utilíssima se pode fazer pela módica quantia de $60 \$ 000$ reis, incluindo as despesas com o encarregado da compra, etc." ${ }^{381}$. Pioneiro da reprodução fotográfica em larga escala de obras de arte, a par da casa Braun de Paris, dos florentinos Alinari ou de Hafstaengl de Munique ${ }^{382}$, Laurent seria bem acolhido pelo vice-inspetor que the dispensou todas as facilidades para a persecução da tarefa na Academia, facultando igualmente o acesso à sua residência para fotografar uma vez mais os célebres cartões de Domingos Sequeira ${ }^{383}$.

A viagem do reputado fotógrafo ao nosso país surge enquadrada pela instabilidade política vivida em Espanha com o golpe de Estado que depôs a rainha Isabel II (18301904) de quem era retratista oficial. A crise sucessória espanhola levantou uma onda de iberismo que resultou na oferta do trono do país vizinho a D. Luís e, na recusa deste, a seu pai, D. Fernando II. Para Laurent, a hipotética subida ao trono de um português ou mesmo a união dos dois reinos acalentada por vários sectores "era mais um argumento a favor da ampliação do seu vasto catálogo de imagens de Espanha e de obras de artes espanholas às terras portuguesas" ${ }^{384}$. Tirou então partido das potencialidades dos caminhos-de-ferro recentemente implantados na Península Ibérica, chegando a Lisboa com o seu pesado equipamento no final do Inverno 1869.

O processo fotográfico utlizado por Laurent era o dominante entre os profissionais daquela época, o chamado "colódio-húmido" que se obtinha emulsionando uma chapa de vidro com colódio, sensibilizando-a com sais de prata numa câmara escura. Era depois colocado na máquina, ainda húmido, dado que a emulsão perdia propriedades com a secagem, e tirava-se a fotografia que, em condições normais de luz, podia conseguir-se em apenas alguns segundos de exposição, revelando-se de seguida. Tal exigia que, ao trabalhar fora do ateliê, o fotógrafo se fizesse acompanhar de um

\footnotetext{
381 Conferência extraordinária de 15 de Junho de 1863. Arquivo da ANBA, disponível em http://digitarq.dgarq.gov.pt/ PT-ANBA-ANBA-F-002-00001_m0067.TIF. Refere-se provavelmente o marquês ao seguinte catálogo: El Real Museo del Prado en la mano: álbum artístico; colección de algunos cuadros del Museo de Pinturas, 1861.

382 GALLARDO, Helena Pérez - op. cit., pp. 268.

${ }^{383}$ A este respeito cf. o ponto 3.1. da II parte.

${ }^{384}$ ARAÚJO, Nuno - “A singular viagem do fotógrafo Jean Laurent a Portugal, em 1869". CEM: Cultura, Espaço \& Memória, n.ำ 1, 2011, p. 91.
} 
laboratório portátil, utilizando Laurent na sua viagem a Portugal um curioso carrolaboratório a que recorrera amiúde nas suas deslocações pelo território espanhol ${ }^{385}$.
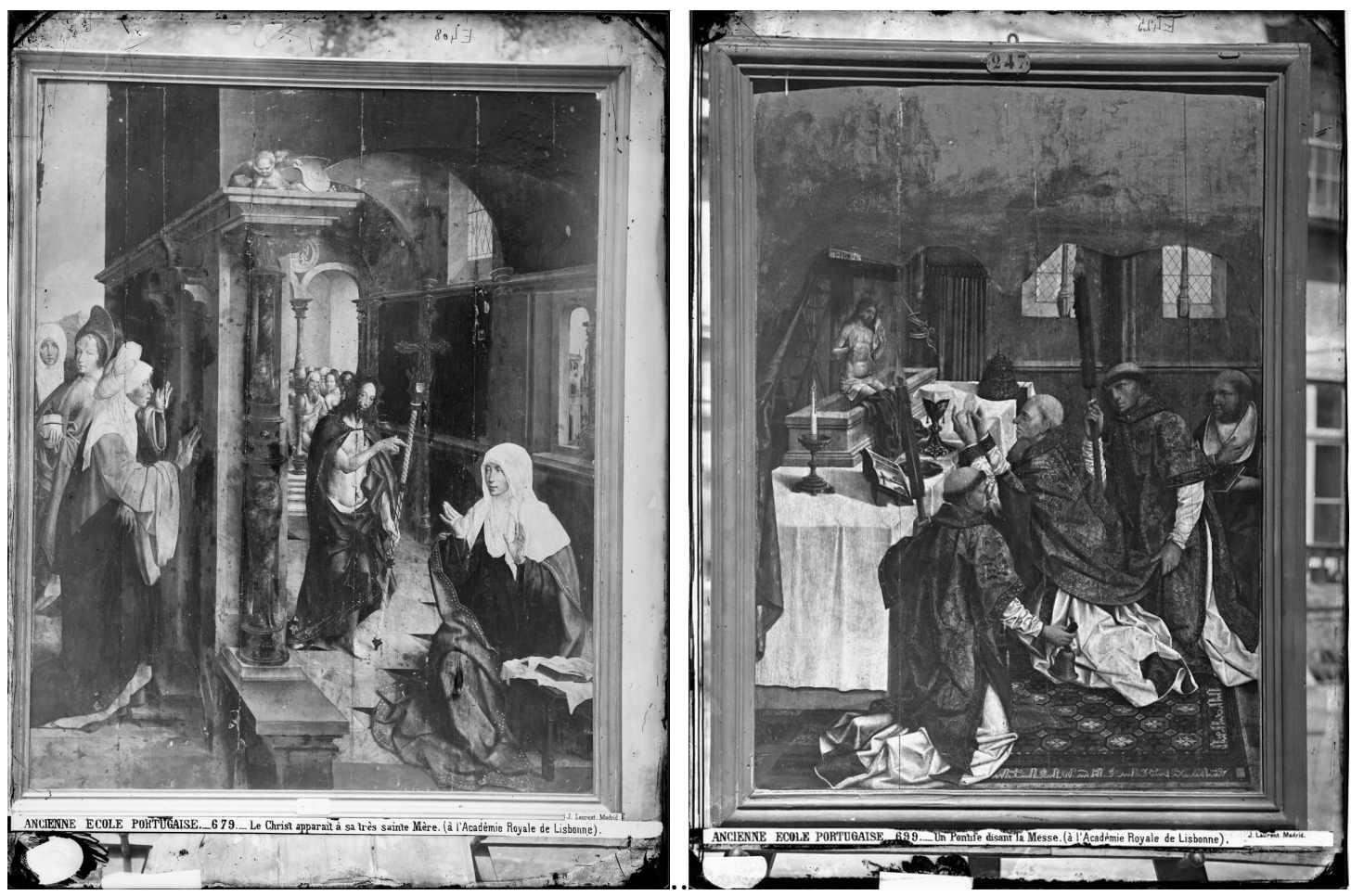

Figs. 72 e 73 - Frei Carlos, Aparição de Cristo à Virgem, 1529; Francisco Henriques, Missa de São Gregório, c. 1508-1511. MNAA, inv. 2 e 91 Pint. Digitalizações a partir de negativos de Jean Laurent, 1869. IPCE, VN-06611_P e VN-06940_P

Para além de vistas de espaços urbanos nacionais, edifícios e monumentos significativos como os mosteiros da Batalha e de Alcobaça, Laurent fotografou a família real, diversos objetos das coleções de D. Luís no Palácio da Ajuda, e alguns coches do picadeiro real de Belém. Segundo o seu catálogo de $1872^{386}$ ou sobretudo o de $1879^{387}$, mais completo, convenientemente redigidos em francês para maior divulgação, a Academia foi objecto de uma campanha extensa, com destaque para os designados "tableaux d'auteurs inconnus de l'ancienne école portugaise" de que apresenta um total de 28 provas (série A, n. 678 a 705), entre as quais uma Aparição de Cristo à Virgem de Frei Carlos proveniente do convento eborense do Espinheiro (fig.

\footnotetext{
${ }^{385}$ Idem, ibidem, p. 93

${ }^{386}$ Oeuvres d'art en photographie: l'Espagne et le Portugal au point de vue artistique, monumental et pittoresque: catalogue: catalogue des chefs d'oeuvre de peinture ancienne et moderne, de sculpture, ciselure, d'ornamentation, etc., photographié sur les originaux meme des musées d'Espagne et du Portugal (...) 1872.

${ }^{387}$ Catálogo incluído na obra de ROSWAG, A. - Nouveau guide du touriste en Espagne et Portugal: itinéraire artistique, 1879, pp. 180-184.
} 
72), e uma Missa de S. Gregório pintada por Francisco Henriques para o retábulo altarmor da igreja de S. Francisco da mesma cidade (fig. 73).
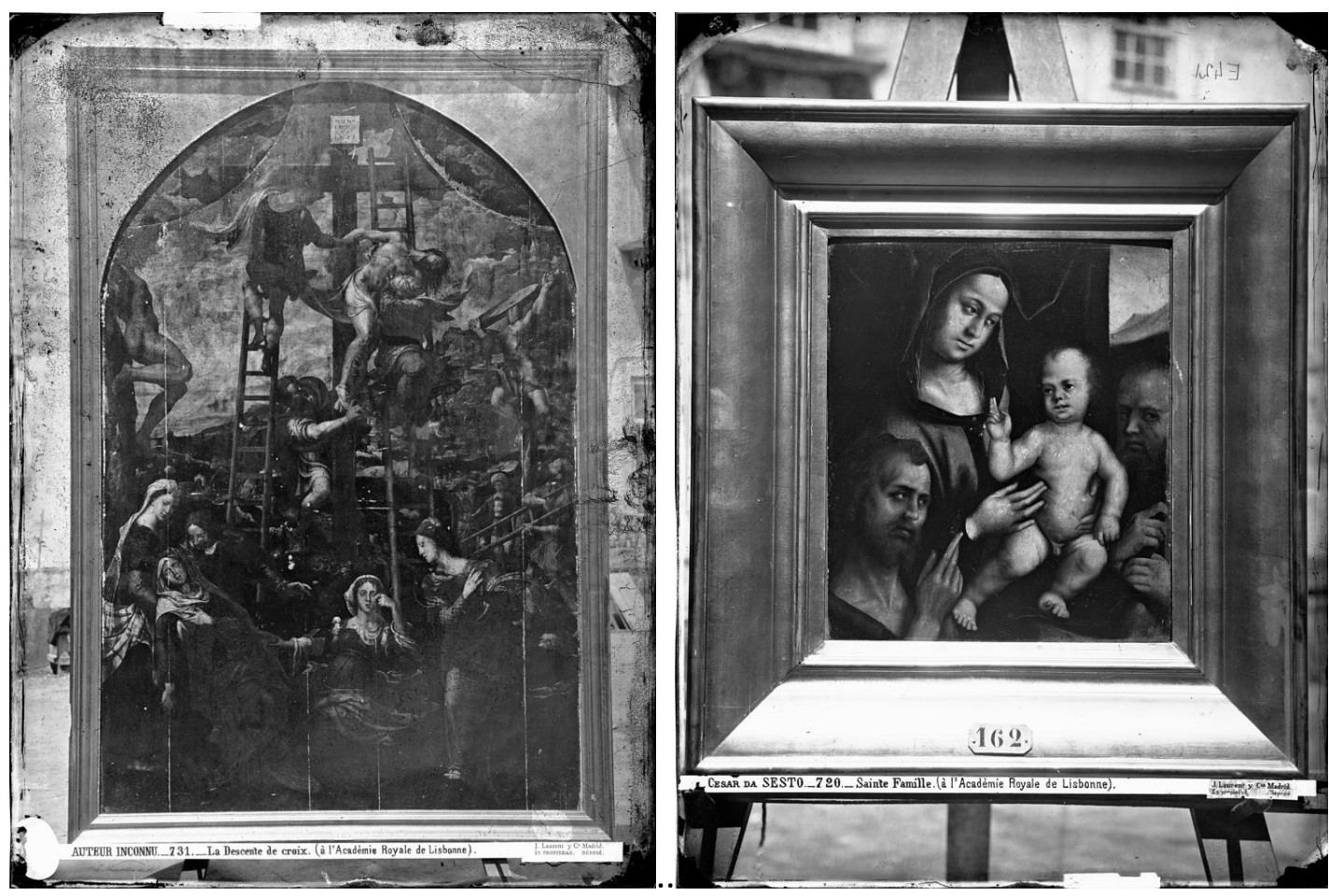

Figs. 74 e 75 - Pieter Coecke van Aelst, Descida da Cruz (painel central de um tríptico), c. 1540-1550; Anónimo italiano, Virgem com o Menino, São José e Santo, séc. XV-XVI. MNAA, inv. 112 e 510 Pint. Digitalizações a partir de negativos de Jean Laurent, 1869. IPCE, VN-06943_P e VN-06944_P

Acordada no início de Março ${ }^{388}$, a seleção destas obras foi seguramente efectuada pelo vice-inspetor em colaboração com os membros da comissão de pintura que escolheram ainda uma vintena de trabalhos de artistas nacionais representativos de épocas posteriores, como Josefa de Óbidos com o Casamento místico de Santa Catarina oferecido por D. Luís (A 709), Vieira Lusitano com o seu Santo Agostinho (A 710) ou Domingos Sequeira, com o estudo para a Alegoria à Constituição (A 711). Nesse agrupamento incluíram-se ainda duas folhas de um álbum com 10 desenhos de Amaro do Vale provenientes da Imprensa Nacional (A 736 a 737). No domínio da pintura estrangeira, exceptuando alguns quadros da coleção da rainha Carlota Joaquina e do painel central do tríptico da Descida da Cruz de Pieter Coecke van Aelst (fig. 74), classificado como d'auteur inconnu após de ter sido dado pelos académicos a Júlio Romano, selecionaram-se essencialmente obras adquiridas com a verba de D.

${ }^{388}$ Jornal do Commercio, 9 de Março de 1869. 
Fernando II, a exemplo do Rafael (A 717) proveniente da coleção Husson da Câmara, do presumível retrato de Vasco da Gama (A 733) vendido pelo conde de Farrobo, ou de um pretenso Cesar da Sesto comprado a João de Sousa Lobo (fig. 75).

Recentemente digitalizadas e disponibilizadas on-line pelo Instituto del Patrimonio Cultural de España onde se encontra o arquivo fotográfico da casa Laurent ${ }^{389}$, as imagens aqui apresentadas não foram ainda publicadas em estudos da especialidade nem sequer incluídas na exposição dedicada àquele fotógrafo que teve lugar entre nós em $2010^{390}$. Encontrando-se entre as mais antigas das pinturas em questão, afiguramse curiosas por vários aspectos, nomeadamente por revelarem o estado de conservação original das mesmas e, em alguns casos, as imaculadas molduras com placas para numeração de que se havia encarregue Cristino da Silva. Registe-se ainda o facto de em certas imagens ser dada conhecer a forma como foram fotografados os quadros, por vezes sobre cavaletes, e com luz apropriada vinda do exterior, no que corresponderá a um dos pátios do edifício de S. Francisco.

Quando o catálogo de 1879 foi editado, a firma J. Laurent \& C.ie encontrava-se no seu auge. Compreendendo mais de 5000 imagens (locais, edifícios e obras de arte), surgia integrado numa publicação mais vasta, com um "itinéraire artistique" escrito por Alfonso Roswag, marido da enteada de Laurent e seu colaborador, e com um mapa com a rede dos caminhos-de-ferro na Península Ibérica ${ }^{391}$. Como já foi notado por Nuno Araújo, trava-se "de uma perspicaz forma de aliar o desenvolvimento do turismo, fomentado pela comodidade que significava viajar na recente rede de caminhos de ferro, à componente comercial da sua firma", revelando a competência do fotógrafo enquanto homem de negócios ${ }^{392}$. Para além da comercialização através de catálogo, Laurent vendia as suas imagens no ateliê de Madrid (carrera de San Jerónimo, 39) no Museu do Prado, e no seu estabelecimento em Paris (rue Richelieu, 27 e mais tarde 90). Celebrou ainda acordos de venda com mais de 20 estabelecimentos comerciais espalhados por Espanha, e também por algumas cidades

\footnotetext{
${ }^{389}$ A este respeito cf. http://ipce.mcu.es/documentacion/fototeca/fondos/vernacci.html

${ }^{390}$ Intitulada J. Laurent e Portugal - Fotografia do século XIX, a exposição foi organizada pela APPh. Associação Portuguesa de Photographia em parceria com a DGARQ - Direção Geral de Arquivos, compreendendo sobretudo provas em papel albuminado pertencentes a colecionadores particulares e instituições oficiais. Não foi editado catálogo.

391 ROSWAG, A. - op. cit.

392 ARAÚJO, Nuno - op. cit., p. 105
} 
europeias (Londres, Bruxelas, Viena, Roma e Estugarda). Em Portugal, o catálogo de 1879 refere como seu depositário em Lisboa o Depósito Geral de Estampas de A. de Matos Antunes (rua do Chiado, 88), e no Porto, o estabelecimento de Manuel Costa (rua de Santo António, 198-202) ${ }^{393}$.

O interesse comercial subjacente à reprodução fotográfica de obras de arte não passou naturalmente desapercebido à Academia, e a contracapa da segunda edição do Catalogo provisorio anunciará a venda de "fotografias dos principais monumentos arquitectónicos do país, dos quadros, desenhos e objetos de arte mais notáveis existentes nas coleções nacionais". Apesar de não ser feita referência ao trabalho de Laurent ou de qualquer outro fotógrafo, acreditamos que ele aí estivesse incluído (à semelhança do Museu do Prado), acrescentando-se que "quem desejar ver espécimes de todas as fotografias, pode dirigir-se ao guarda da galeria que tomará nota de todas as encomendas" ${ }^{394}$. Refira-se que o guarda detinha ainda uma listagem de modelos em gesso "dos principais ornamentos das igrejas de Belém, Batalha, Coimbra, Alcobaça, etc." para venda ao público, nomeadamente a estudantes ou amadores de arte, assim como uma meia dúzia de compêndios e opúsculos sobre pintura, desenho ou arquitetura.

\subsection{Conservação e restauro}

Apesar dos esforços anteriores desenvolvidos nesse sentido ${ }^{395}$, o restauro das pinturas existentes na Academia constituía à chegada de Sousa Holstein uma necessidade premente que obstava de certa forma a desejada organização da galeria nacional. No relatório dirigido ao vice-inspetor em 1863, Ferreira Chaves é particularmente crítico em relação a este tema:

"Tratando-se da conservação dos quadros, direi que segundo as observações que fiz, tem havido o maior descuido para com esses poucos mas preciosos que a nossa Academia possui. Pelo estado de alguns quadros que estavam escondidos (e tinham

\footnotetext{
${ }^{393}$ Idem, ibidem, p. 106

${ }^{394}$ HOLSTEIN, marquês de Sousa (co-auto) - op. cit.

${ }^{395}$ A este respeito cf. o ponto 2.1 da I parte.
} 
razão para os esconder) se pode bem avaliar a competência de quem tem dirigido os destinos da Academia. A falta de limpeza, a pouca segurança da tinta em alguns, a má restauração, a falta de molduras e grades, e outras mais coisas que se não influem na boa conservação dos quadros, os torna decentes para serem vistos, estão infelizmente servindo de vergonha para o corpo académico" ${ }^{396}$.

Na sessão extraordinária convocada em Março daquele ano para discutir o assunto, o vice-inspetor comunicava "que atendendo ao mau estado em que se acham muitos quadros de grande merecimento, e à imediata necessidade de se tratar do seu reparo para não se estragarem de todo, encarregara o Exmo. Sr. Silva Oeirense de dirigir estes reparos e concertos, limitando-se aos que fossem indispensáveis". A escolha de Oeirense prendeu-se provavelmente com a necessidade de manter ocupado aquele que desempenhava o vazio cargo de diretor honorário da Academia, na sequência de Domingos Sequeira, de quem como vimos possuía algumas obras que chegará a vender para a galeria. Acrescentava a ata ter o marquês oficiado ao artista para que, "de acordo com a comissão encarregada de classificar os referidos quadros, e tendo debaixo da sua direção os artistas agregados à aula de pintura e alguns discípulos da Academia que desejarem adquirir conhecimentos destes processos, começasse a fazer os sobreditos reparos, acudindo aos quadros mais estragados, etc."

Após alguma discussão entre os académicos, Cristino da Silva perguntou "qual era a receita que se aplicava às despesas de drogas e outros objetos precisos para estas obras", retorquindo o vice-inspetor "que por enquanto destinara o produto da venda dos objetos inúteis" a que já tivemos oportunidade de nos deter anteriormente. Tendo Silva Oeirense esclarecido algumas questões colocadas pelos membros da conferência, comunicaram estes "que se continuassem a fazer os reparos dos quadros mais danificados, sem que se retocassem ou alterassem as pinturas, estucando-se-lhe as faltas que tiverem e cobrindo-se com as cores mais análogas aos tons gerais dos quadros $^{\prime 397}$. A esse respeito, não queremos deixar de citar o curioso reparo posterior

\footnotetext{
${ }^{396}$ Relatório datado de 3 de Outubro de 1863. Arquivo do MNAA, fundo José de Figueiredo, cx. 1, pasta 11 doc. 1.

397 Conferência extraordinária de 3 de Março de 1863. Arquivo da ANBA, disponível em http://digitarq.dgarq.gov.pt/ PT-ANBA-ANBA-F-002-00001_m0019.TIF e_m0020.TIF
} 
de um leitor das atas, talvez Luciano Freire, que à margem acrescentou a lápis "mas o que era isto se não retoque?".

Destinado a financiar também as obras a empreender nas salas adaptadas a galeria, o produto da venda dos objetos e das pinturas com interesse secundário ficou aquém do esperado, revelando-se insuficiente para os objectivos traçados. Nesse sentido, em Dezembro de 63, ao participar à conferência "a notória falta de meios da Academia para ocorrer às despesas do material e mão-de-obra indispensáveis nos reparos de que tanto carecem os melhores quadros que hão de compor a galeria", Sousa Holstein propôs "que se compensassem estas despesas por meio de dádivas de alguns quadros de insignificante valor artístico existentes em depósito na Academia, e considerados como inúteis para os estudos". Tomás da Anunciação interveio e referiu que a medida só poderia ter lugar depois a um minucioso exame das obras em questão, isto porque como recordaram então alguns académicos, "entre os quadros depositados, alguns há que não tendo valor artístico o têm contudo histórico e por isso devem ser conservados". Aprovada a ideia de Anunciação, "resolveu-se que os professores de pintura procedessem à indicada escolha, podendo ter lugar depois a proposta de S. Ex. [ [vice-inspetor]" ${ }^{398}$. As atas posteriores são totalmente omissas à alienação de qualquer pintura para aquele fim, pelo que a ideia não terá chegado a ser posta em prática.

No relatório dirigido meses mais tarde ao ministro do Reino, Sousa Holstein lamentava a inexistência na Academia de uma "oficina para a restauração de quadros", fazendo notar serem muitas as obras que "pediam arranjo e ameaçavam total ruína se lhes não acudisse". Referia ter tratado ultimamente de proceder "aos reparos mais urgentes, destinando para isto o produto da venda dos quadros" e remetia o ministro para um documento anexo: "pelo mapa junto verá V. Ex. a que foram restaurados 21 quadros à custa de muito trabalho e lutando com a escassez dos meios" ${ }^{399}$.

No documento em questão (fig. 76), especificam-se as intervenções levadas a cabo nas obras mencionadas, na sua maioria pintadas sobre madeira e de temática religiosa. Para cada uma são fornecidas as seguintes informações: autor (predomina a lacónica

\footnotetext{
398 Conferência extraordinária de 4 de Dezembro de 1863 . Idem, disponível em http://digitarq.dgarq.gov.pt/ PT-ANBA-ANBA-F-002-00001_m0114.TIF

399 "Relatório acerca do estado da Academia Real das Belas Artes". Documento datado de 26 de Fevereiro de 1864. Arquivo do MNAA, fundo José de Figueiredo, cx. 1, pasta 11, doc. 1
} 
designação "antigo"), assunto, dimensões, dias de entrada e de saída, número do catálogo geral, artista(s) encarregue(s) da intervenção, e descrição do trabalho efectuado. Este foi como acima referido dirigido por Silva Oeirense que contou com uma pequena equipa de artistas agregados (José Maria Franco, António da Costa Oliveira, Augusto César Silva), acrescidos do contínuo José Martins a quem coube a tarefa de desempenar e "grudar" a maioria das tábuas. As intervenções são-nos descritas em termos muito gerais, "limpou, betumou, estucou e envernizou", "segurou a tinta" ou "restaurou a pincel", revelando práticas artesanais ainda distantes da definição oficial de restauro.

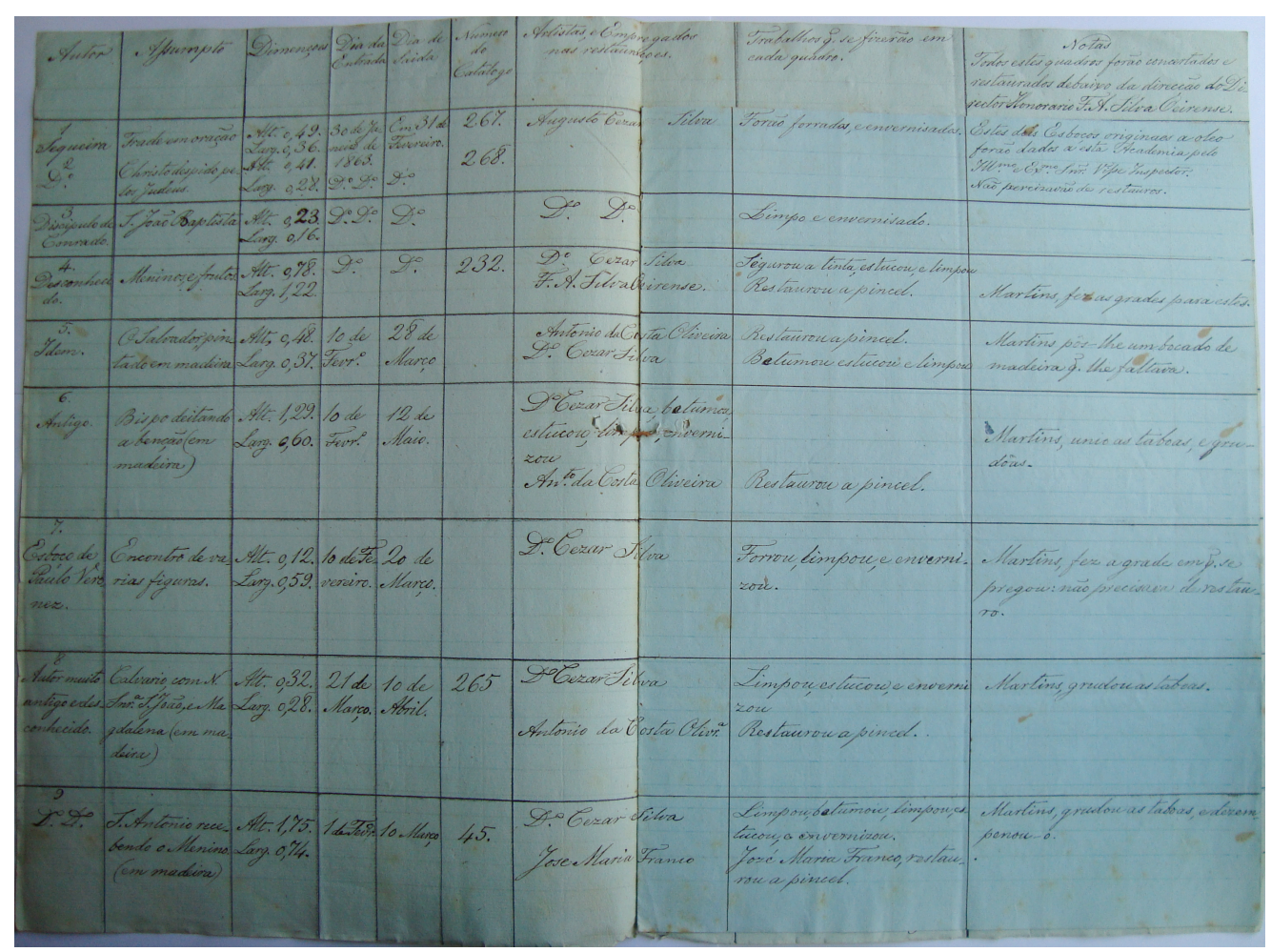

Fig. 76 - Mapa dos restauros promovidos na Academia, 1864. Arquivo do MNAA

Apesar de não ser discutido em ata, o trabalho efectuado sob a direção de Oeirense parece ter desagradado aos professores de pintura que provavelmente fizeram notar ao vice-inspetor eventuais erros nas intervenções. Certo é que menos de um mês após ter enviado o relatório ao ministro, Sousa Holstein afasta o diretor honorário da coordenação dos restauros, nomeando uma comissão específica presidida por Tomás da Anunciação: 
“Devendo empregar-se o maior cuidado para que os processos de restauração, conservação e reparos dos quadros que devem compor a galeria da Academia se executem com todo o acerto e perfeição, mediante uma inteligente e legal direção que fiscalize rigorosamente os referidos processos, encarrego a V. Ex. a e aos IImos. Srs. professores Marciano Henriques da Silva, João Cristino da Silva, e Miguel Ângelo Lupi, constituídos em comissão permanente à qual V. Ex. presidirá, de entender e administrar este importantíssimo serviço académico, em o qual a comissão deverá ser coadjuvada por todos os Srs. artistas agregados da respectiva classe, cessando desde já a autorização e ingerência direta de outra qualquer pessoa neste ramo de serviço académico cuja direção e execução unicamente pertence aos Srs. professores de pintura"$^{\prime 400}$.

A comissão irá beneficiar pontualmente com a verba concedida a partir de 1865 por D. Fernando II à Academia, permitindo-Ihe a contratação de "restauradores" externos ${ }^{401}$, como foi o caso de Zeferino Augusto Teixeira, obscuro personagem com formação artística, tendo participado com duas pinturas na Exposição Philantropica promovida em 1851 com o patrocínio de D. Amélia, duquesa de Bragança ${ }^{402}$. Em Março de 66, Anunciação, Lupi e Cristino faziam notar "o bom serviço prestado à Academia pelo restaurador de quadros Zeferino Augusto Teixeira que se acha incumbido da preparação do importante quadro que representa [espaço em branco, sem indicação], cujo trabalho tem sido muito além do que fora convencionado com ele e executado com muita perfeição" ${ }^{403}$. No recibo passado (fig. 77), Zeferino declara ter recebido a importância de $52 \$ 000$ reis pelo restauro de uma pintura atribuída a Guercino,

\footnotetext{
${ }^{400}$ Oficio datado de 14 de Março de 1864. Arquivo da ANBA, disponível em http://digitarq.dgarq.gov.pt/ PT-ANBA-ANBA-B-001-00003_m1052.TIF

${ }^{401}$ Registe-se que a primeira notícia à contratação de um restaurador externo surge em 1852, ao ser aceite a pretensão de José Inácio de Basto para exercer essa função. Dez anos mais tarde será apresentada uma proposta para a sua substituição por João António Gomes, respondendo a Academia não ter verbas para essa contratação, devendo os seus trabalhos ser pagos pelo governo, por ajustes diretos. A este respeito cf. ALVES, Alice - "Os restauradores da coleção de pintura da Academia de Belas Artes de Lisboa proveniente dos conventos extintos". SOARES, Clara Moura (coord.) - O Património Artístico das Ordens Religiosas: entre o Liberalismo e a atualidade, 2014/2015, [no prelo].

402 "51. Cópia, pintada a óleo, de um baixo relevo de Miguel Angelo Buonarotti" e "53. Quadro pintado a óleo, representando vários produtos marinhos". Catalogo dos objetos particulares colocados na exposição philantropica, 1851, pp. 4-5.

${ }^{403}$ Conferência ordinária de 3 de Março de 1866. Arquivo da ANBA, disponível em http://digitarq.dgarq.gov.pt/ PT-ANBA-ANBA-F-002-00001_m0328.TIF
} 
incluindo-se nessa soma uma gratificação, "pelo excesso de trabalho que tive com o mesmo quadro" ${ }^{404}$. O mapa das contas apresentadas anos mais tarde pelo viceinspetor a D. Fernando II, atesta ter sido essa despesa suportada pelo monarca, assim como a aquisição de algum material susceptível de ter sido utilizado naquela tarefa ${ }^{405}$.

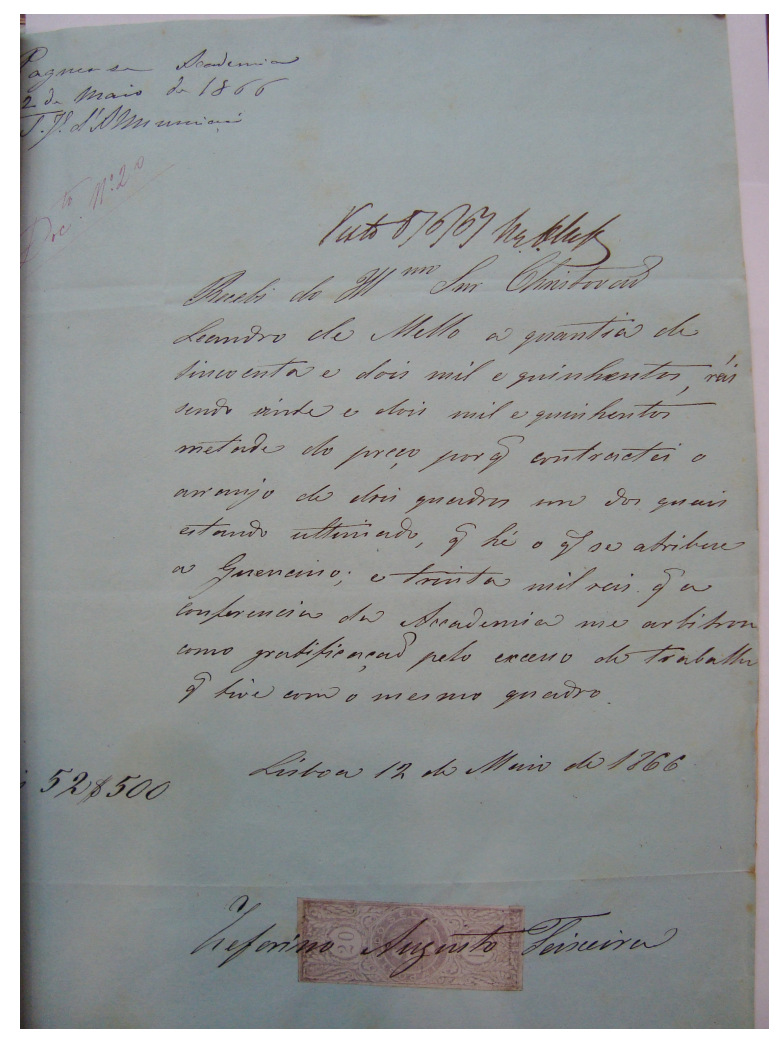

Fig. 77 - Recibo de Zeferino Augusto Teixiera, 1866. Arquivo do MNAA

A possibilidade de contratar artistas externos para as intervenções de restauro não quebrou a tradicional colaboração nesse domínio dos artistas agregados e académicos de mérito, como é revelado em Outubro de 66, ao ser discutida a necessidade de se tratar de uma outra pintura atribuída a Guercino para poder ser integrada na galeria. Comprometendo-se o vice-inspetor a assegurar o financiamento, propôs o presidente da comissão "que se convidasse o Sr. académico de mérito José Maria Franco por o considerar muito competente a desempenhar aquele trabalho" ${ }^{406}$. Franco que chegou

\footnotetext{
${ }^{404}$ Recibo datado de 12 de Maio de 1866. Arquivo do MNAA, fundo José de Figueiredo, cx. 1, pasta 2, doc. 20.

405 "Desenvolvimento da receita e da despesa da verba generosamente doada por Sua Majestade El-Rei o Senhor D. Fernando à Academia Real das Belas Artes de Lisboa". Idem, cx. 1, pasta 4, doc. 17.

406 Conferência ordinária de 30 de Outubro de 1866. Arquivo da ANBA, disponível em http://digitarq.dgarq.gov.pt/ PT-ANBA-ANBA-F-002-00001_m0379.TIF
} 
a integrar a equipa dirigida por Oeirense, e que virá pouco depois a ocupar o cargo de professor interino de pintura de história, em substituição de Marciano da Silva, ficou reconhecido pela distinção e prontificou-se a executar a tarefa. Cinco meses mais tarde, Anunciação participava ter sido "concluída a restauração do belo quadro original de Guercino", considerando-a "primorosamente executada", opinião partilhada por outro membro da comissão: “O Sr. Lupi concordou que a dita restauração era perfeita, e propôs que a conferência votasse os ditos agradecimentos ao Sr. Franco, consignando-se na ata que o seu importante trabalho tinha merecido geral aprovação" ${ }^{407}$.

Este tipo de colaborações tornar-se-ão ocasionais, prevalecendo as solicitações de artistas externos que, conscientes das necessidades da Academia, se dirigiam ao Ministério do Reino propondo efetuar restauros nas pinturas destinadas à galeria. Foi o caso de José Vicente de Sales "que alegando ter feito estudos de belas artes no estrangeiro auxiliado por uma pensão que Ihe fora concedida por el-rei D. João VI, e julgando-se habilitado na arte de restaurador de quadros, pretende como tal ser empregado e adido à Academia". O requerimento seria remetido ao vice-inspetor e apresentado à conferência, sendo desde logo notado nada constar a respeito do artista no arquivo da instituição. Resolveu todavia Sousa Holstein comunicar ao governo "que na falta de restauradores de quadros da galeria, julgava conveniente empregar-se o suplicante, depois de bem comprovada a sua aptidão" ${ }^{408}$. Será então convidado a comparecer na Academia para restaurar um quadro "sem valor artístico nem histórico", destinado a ser avaliado por um júri constituído pelos professores de pintura $^{409}$.

Figura multifacetada (desenhador, gravador, pintor, litografo, fotógrafo e restaurador), José Vicente Sales (1801-1888) teve uma existência agitada, em parte consequência das vicissitudes políticas que o levaram a utilizar frequentemente o pseudónimo de Augusto Belvedere, numa defesa contra eventuais perseguições políticas como

\footnotetext{
${ }^{407}$ Conferência ordinária de 18 de Março de 1867. Idem, disponível em http://digitarq.dgarq.gov.pt/ PTANBA-ANBA-F-002-00001_m0379.TIF

${ }^{408}$ Conferência ordinária de 21 de Outubro de 1867. Idem, disponível em http://digitarq.dgarq.gov.pt/ PT-ANBA-ANBA-F-002-00001_m0437.TIF

${ }^{409}$ Conferência ordinária de 23 de Dezembro de 1867. Idem, disponível em http://digitarq.dgarq.gov.pt/ PT-ANBA-ANBA-F-002-00001_m0448.TIF
} 
sugerem os seus biógrafos ${ }^{410}$. Pensionista de D. João VI em Paris onde conheceu Domingos Sequeira, ascenderia a gravador dileto de D. Miguel que tornou vitalícia a pensão que usufruía, permitindo-lhe fazer estudos em Roma. Aí aprendeu técnicas de restauro de pinturas antigas, prática que lhe garantiu a subsistência quando, ao ver cortada a pensão com a guerra civil, se fixou em Barcelona, restaurando quadros comprados a baixo preço e vendendo-os para Inglaterra por intermédio do vice-cônsul inglês em Tarragona. Sales que também se havia destacado como miniaturista, dedicou-se depois à litografia e também à fotografia, vindo a montar um estabelecimento em Madrid. No final de 1867 regressa a Lisboa ${ }^{411}$ com o projeto de estabelecer um atelier de fotografia, sem sucesso, constando ter sido pouco depois apresentando pelo major Chaby ao ministro do Reino que o recomendou a Sousa Holstein como restaurador. As condições impostas pela Academia não terão cativado todavia o alvoraçado artista que pouco tempo permaneceu entre nós, partindo para Espanha onde nunca Ihe havido faltado ocupação.

Falhada a tentativa de José Vicente Sales, outro artista externo seria anos mais tarde contratado para dar continuidade às intervenções de restauro que vinham sendo levadas a cabo, Manuel de la Mata, pintor espanhol de origem sevilhana, segundo as poucas informações identificadas a seu respeito ${ }^{412}$. Com efeito, em Novembro de 1871, três anos após a abertura da galeria de pintura, o diretor-geral, Francisco de Assis Rodrigues, na ausência de Sousa Holstein, comunicava a necessidade de se examinarem "os quadros ultimamente restaurados pelo artista D. Manuel de la Mata afim de se saber se o mesmo artista poderá continuar com aquele trabalho que tem sido desempenhado sob a direção do Sr. Anunciação" ${ }^{\prime 413}$. Na qualidade de presidente da comissão responsável pelos restauros, aquele professor solicitou então à

\footnotetext{
${ }^{410}$ A este respeito cf. VALENTE, Vasco - "Augusto Belvedere: pintor, miniaturista, gravador e litógrafo, sua identificação". Sep. Mvseu, vol. II, 1943; FEIO, Alberto - Um artista minhoto, 1946; SOARES, Ernesto - José Vicente Sales: pintor, desenhador e gravador, 1954.

${ }^{411}$ Alberto Feio, a quem se deve a investigação mais aprofundada sobre o artista, indica que a sua partida para Lisboa ocorreu na sequência da revolução de Setembro de 1868. Esse facto é contrariado pela documentação da Academia já que em Outubro de 68 encontrava-se efetivamente entre nós. Cf. FEIO, Alberto - op. cit, p. 12.

412 PAMPLONA, Fernando de - Dicionário de pintores e escultores portugueses ou que trabalharam em Portugal, vol. IV, 1954-59, p. 91.

413 Conferência ordinária de 29 de Novembro 1871. Arquivo da ANBA, disponível em http://digitarq.dgarq.gov.pt/ PT-ANBA-ANBA-F-002-00002_m0250.TIF e_m0251.TIF. As seguintes citações reporta-se à mesma referência.
} 
conferência para declarar "bem positivamente se acha o trabalho que vai examinar desempenhado de maneira que ao mesmo artista possam ser dados outros quadros que se acham na galeria carecendo muito de iguais reparos".

Convidados a deslocarem-se até à galeria de pintura para avaliarem os quadros recuperados, os membros da conferência confidenciaram longamente a esse respeito, tendo Lupi e Joaquim Nunes Prieto, concluído "que sendo o processo de restauro um trabalho de difícil desempenho para que se não altere o original, e raros os artistas que bem o executem, o trabalho que estavam examinando, conquanto deixasse ainda um pouco a desejar, era satisfatório". Anos mais tarde, Luciano Freire, referindo-se ao trabalho exercido no mesmo período por um restaurador espanhol que corresponde seguramente a Mata, dirá ter resultado em "perigo para a integridade da obra de arte $^{\prime 414}$, contrariando a opinião daqueles professores. Voltando à ata, e em relação a determinado quadro intervencionado por outro artista cujo nome não surge especificado, referiam não "dever ser dado mais nenhum e que muito conviria se mandasse limpar o retoque que fez na figura principal". Anunciação apressou-se a declarar ter sido aquela intervenção utilizada como "experiência para se conhecer a perícia de um artista recomendado ao conselho e que não era apresentado à conferência como um bom trabalho" no que poderá hipoteticamente tratar-se de uma referência à anterior prestação de José Vicente Sales.

Mau grado os esforços dispensados nos restauros, Sousa Holstein reconhecerá na introdução ao catálogo provisório ser desagradável aos olhos do visitante a impressão causada pelo estado de conservação de alguns dos melhores quadros da galeria. A falta de meios (financeiros e técnicos) era apontada como o principal entrave, tendo sido nesses casos julgado preferível "não tocar nos quadros do que sujeitá-los a uma restauração imperfeita que ainda mais os danificaria" ${ }^{415}$. Presumível conhecedor dos tratados editados a partir de meados do século XIX, período fundamental para a reflexão e definição das práticas de conservação e restauro ${ }^{416}$, o marquês mostra-se particularmente cuidadoso a esse respeito:

\footnotetext{
${ }^{414}$ Apud GONÇALVES, António Manuel - Do restauro do painéis de São Vicente de Fora, 1960, p. 78.

${ }^{415}$ HOLSTEIN, marquês de Sousa (co-auto) - Catalogo provisorio da Galeria Nacional de Pintura existente na Academia Real das Bellas Artes de Lisboa, 1868, p. 17.

${ }^{416}$ A este respeito cf. CRUZ, António João - "Em busca da imagem original: Luciano Freire e a teoria e a prática do restauro em Portugal cerca de 1900". Conservar património, 5, 2007, pp. 67-83.
} 
"Quando o estrago produzido no quadro destrói completamente a tinta primitiva, um restauro consciencioso torna-se impossível: restaurar um quadro nestes casos seria fazê-lo de novo. Quando porém o estrago é somente superficial, fácil é, sem alterar a originalidade da pintura, restituir-lhe a aparência que devera ter. Numa coleção pública é indispensável sempre seguir esta norma. É faltar à verdade querer suprir com pintura nova ou composição de lavra do restaurador as partes do quadro que sofreram estragos irreparáveis. Na coleção nacional há exemplos de um e outro caso, e se todos os esforços devem ser empregados para se conseguir que os quadros susceptíveis de reparação sejam convenientemente restaurados, é mister desde já estabelecer o principio que serão respeitadas as ruínas das pinturas que fora profanação querer executar de novo. Até hoje, e nos poucos quadros em que se tem tocado, é esta a regra seguida" ${ }^{417}$.

Os bons desígnios de Sousa Holstein não viriam todavia a ter junto do Estado o necessário apoio que conduzisse à especialização da atividade, à separação entre o artista e o restaurador, e ao abandono das práticas oficinais por métodos mais científicos. Não possibilitaram também a criação de um serviço próprio na Academia, e muito menos a formalização, dentro do ensino artístico, de uma área dedicada ao restauro de obras de arte, inexistente até à reforma republicana de $1911^{418}$.

\subsubsection{Alfredo Augusto da Costa Camarate, conservador}

No início Março de 1868, ao participar ao corpo académico a tão desejada abertura da galeria que teria lugar no dia 29 desse mês, concluídos que estavam os derradeiros trabalhos com o catálogo e o regulamento, o vice-inspetor fazia notar a necessidade de se nomear alguém para exercer as funções de conservador do acervo. Uma vez que as atividades lectivas dos professores de pintura tornavam impossível a acumulação desse cargo, lembrava o bom trabalho ultimamente desenvolvido por um funcionário

\footnotetext{
${ }^{417}$ HOLSTEIN, marquês de Sousa (co-auto) - op. cit., pp. 17-18.

${ }^{418}$ Cf. RODRIGUES, Paulo Simões - "Da história do restauro em Portugal: das origens ao Portugal oitocentista". 40 anos do Instituto José de Figueiredo, 2007, p. 29.
} 
público em comissão na Academia, Alfredo Augusto da Costa Camarate, que se ocupara à experiência da coleção de desenhos, em substituição do falecido Feijó da Costa, propondo "que a Academia the confirmasse a nomeação interinamente enquanto bem o servisse, retirando-se-lhe a nomeação em caso contrário". A sugestão foi recebida com alguma desconfiança pelos professores que se pronunciaram a esse respeito, "ponderando os inconvenientes de tal nomeação e duvidado se o Sr. Camarate cumpriria as obrigações daquele cargo". Tornando o funcionário a ser afiançado pelo marquês "que lembrou the fosse conferido [o cargo] interinamente, e com expressa condição de bem o desempenhar, anuiu a conferência à proposta do Exmo. vice-inspetor, determinando que se passasse ao Sr. Camarate a nomeação de conservador interino da galeria" ${ }^{419}$ (fig. 78).

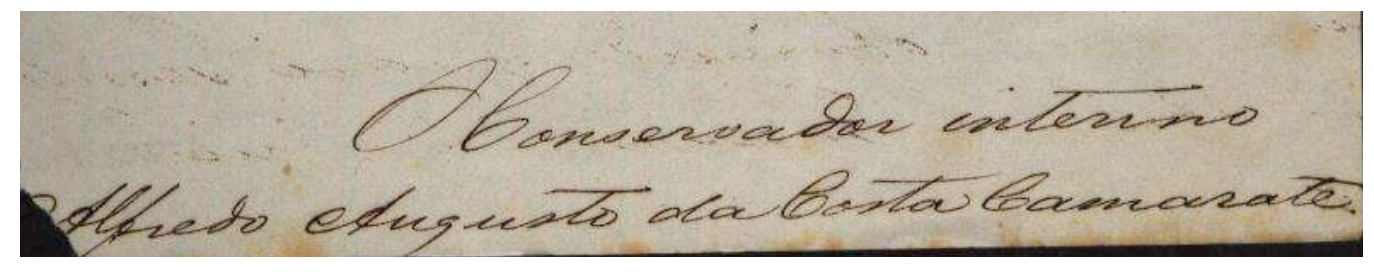

Fig. 78 - Assinatura do conservador interino, 1868. Arquivo da ANBA

Alfredo Camarate desempenhava em 1867 as funções de responsável pela coleção de desenhos e gravuras, datando de Outubro do mesmo ano um oficio dirigido ao viceinspetor e escrito em conjunto com o seu colega Domingos Maria Gonçalves, apontado pela mesma altura para conservador do futuro Museu de Arte Ornamental de que adiante falaremos. Nele apelavam à necessidade de se habilitarem "com os necessários estudos afim de cumprirem as obrigações a seu cargo", o que não poderia ser feito "sem visitarem alguns museus estrangeiros e tratarem com indivíduos que pelos seus conhecimentos e práticas lhes possam servir de mestres" ${ }^{420}$ Para tal, propunham-se residir durante três meses em Madrid e Paris, enviar mensalmente à Academia relatórios circunstanciados dos seus trabalhos, e estudar conjuntamente sobre belas artes e organização de bibliotecas, devendo o Estado assegurar uma verba adicional aos vencimentos que usufruíam. Destinada a preparar convenientemente os

\footnotetext{
419 Conferência ordinária de 7 de março 1868. Arquivo da ANBA, disponível em http://digitarq.dgarq.gov.pt/ PT-ANBA-ANBA-F-002-00001_m0476.TIF

${ }^{420}$ Ofício datado de 12 de Outubro de 1867. Idem, disponível em http://digitarq.dgarq.gov.pt/ PT-ANBAANBA-B-001-00003_m1296.TIF e_m1297.TIF
} 
dois funcionários para cargos sem tradição entre nós, aquela diligência deverá ter ficado sem efeito atendendo às recusas do Estado em dar seguimento às constantes solicitações da Academia.

Dois anos mais tarde, na qualidade já de conservador interino da galeria, Camarate teria oportunidade de viajar mas até ao arquipélago dos Açores, encarregado por Sousa Holstein de efetuar um levantamento artístico da cidade de Ponta Delgada, no intuito de identificar pinturas e outros testemunhos de interesse maior. Reveladora da preocupação do marquês em se documentar sobre os bens artísticos conservados em território nacional, sobretudo no caso de uma cidade longínqua como Ponta Delgada, aquela deslocação não chegou a ser muito profícua como relata o funcionário numa missiva enviada para Lisboa. "Não é esta cidade a que me parece mais fértil para os estudos e indagações que V. Ex. me prescreveu" começa por escrever Camarate após nove dias de pesquisas, desagradado talvez por se ver "desterrado" para tais paragens. Refere ter localizado apenas um único testemunho digno de interesse, o portal lateral da igreja matriz de São Sebastião, "o mais belo espécime de arquitetura góticomanuelina que tenho visto", acerca do qual procurou investigar, sem grande sucesso: "o que tenho encontrado é obscuro e contraditório, e se não fora alguma coisa que conheço de arquitetura manuelina, teria por informações de cá de qualificar aquela arquitetura por gótico-sarracena e outras quejandas que saem dos filhos desta boa terra". No que diz respeito ao domínio que mais interessaria ao vice-inspetor, escreve convicto: “Enquanto a pinturas - miséria - e mais nada. Espero pelas coleções particulares do António Borges, José do Canto e visconde da Praia” ${ }^{421}$. Termina acusando a inexistência de fotografias do portal e solicitando o envio de uma verba para as mandar executar.

O desempenho de Camarate enquanto conservador da galeria foi vigiado de perto pelos professores que vimos terem hesitado em votar a sua aceitação para o cargo, não o poupando a reparos e críticas por eventuais faltas cometidas no seu trabalho. Assim sucedeu, por exemplo, em Fevereiro de 1870, ao ausentar-se aparentemente durante a colocação de um quadro numa das salas. Na qualidade de secretário da Academia, Joaquim Pedro de Sousa apressou-se a denunciar o facto achando "pouco

\footnotetext{
${ }^{421}$ Oficio datado de 27 de Abril de 1869. Idem, disponível em http://digitarq.dgarq.gov.pt/ PT-ANBAANBA-B-001-00003_m1468.TIF a_m1470.TIF
} 
regular que havendo um empregado encarregado como conservador interino da galeria, empregado subordinado a uma comissão especial [...] tal trabalho se fizesse sem ser fiscalizado de perto por alguém que pudesse responder por qualquer prejuízo, e não ficando a galeria unicamente entregue a um carpinteiro que nem sequer é empregado da Academia, e a um dos moços que de certo não sabe avaliar o prejuízo que causaria a danificação de algum quadro" ${ }^{\prime 22}$. 0 assunto não foi dado por encerrado e, na sessão seguinte, era a vez de Lupi frisar que "havendo um empregado encarregado interinamente como conservador da galeria a esse pertencia vigiar tais trabalhos", recordando ter sido anos antes responsável pela montagem de todos os quadros, trabalho que fizera sempre questão de acompanhar presencialmente ${ }^{423}$. Mau grado as faltas que Ihe possam ser apontadas, Camarate revelou-se um conservador atento e diligente ao participar e tentar solucionar os problemas registados desde cedo nas salas. Logo em 1868, ao reabrir a galeria após ter estado ausente no campo por prescrição médica, oficiava ao vice-inspetor participando "a urgentíssima necessidade de mandar reparar o tecto da quarta sala" cuja argamassa corria o risco de desabar e danificar alguns dos quadros próximos. Aproveitava ainda para alertar "que se não tenha podido evitar que a água da chuva passe pelos interstícios das clarabóias da galeria, quando a mais insignificante galeria fotográfica o consegue sem a menor dificuldade". Assinaladas já desde o tempo em que as salas possuíam funções lectivas, as infiltrações de águas pluviais pelas estruturas envidraçadas dos tectos constituíam um problema crónico que tardava em ser solucionado, danificando estores e soalhos e imprimindo elevados índices de humidade ao espaço. "Um modesto operário vidraceiro, pondo os vidros como indica a regra, evita por uma só vez que a conservação das persianas esteja dependente das observações astronómicas do guarda da galeria" sugeria Camarate, chamando ao mesmo tempo a atenção para o "gravíssimo erro económico" que consistia em

\footnotetext{
${ }^{422}$ Conferência ordinária de 26 de Fevereiro 1870. Idem, disponível em http://digitarq.dgarq.gov.pt/ PTANBA-ANBA-F-002-00002_m0124.TIF

${ }^{423}$ Conferência ordinária de 30 de Março 1870. Idem, disponível em http://digitarq.dgarq.gov.pt/ PTANBA-ANBA-F-002-00002_m0126.TIF
} 
"sobrecarregar o pessoal e a despesa da conservação de qualquer edifício por erros e defeitos da sua construção" ${ }^{424}$.

As soluções não se afiguravam porventura tão simples como referia o conservador, uma vez que as problemáticas estendiam-se a outros domínios e começavam aparentemente a afectar as pinturas, o que obrigará à convocação da conferência académica. Para tal terá contribuído a visita à galeria e os eventuais reparos efectuados por D. Luís e D. Fernando II, por ocasião da abertura da exposição da Sociedade Promotora das Belas Artes de 68. De acordo com a ata, o vice-inspetor começou por chamar a atenção para as "providências que se devem tomar quanto antes para se conservar e preservar da ruína a magnífica coleção de quadros denominados góticos da galeria nacional, os quais tanta consideração mereceram a Suas Majestades na sua última visita à Academia". Solicitou à comissão de pintura para se reunir com brevidade de maneira a examinar pormenorizadamente o estado de conservação das pinturas, as condições da sala e demais circunstâncias, devendo ser coadjuvada nessa tarefa pelo professor de arquitetura Pires da Fonte, "bem como pelo Sr. conservador Camarate que podia prestar serviços na parte relativa à escrituração". Cristino da Silva perguntou então "se o Sr. Camarate, na qualidade de conservador interino, possui alguns conhecimentos técnicos de química que possam esclarecer a comissão num trabalho que depende desta ciência". Pertinente e atualizada com as mais recentes noções de conservação e restauro que impunham o conhecimento daquela ciência ${ }^{425}$, a questão do professor de pintura de paisagem não dissimula uma certa crítica às qualificações do funcionário escolhido por Sousa Holstein. Este voltou a recordar que "só como secretário da comissão se devia aproveitar o préstimo do Sr. Camarate, e lembrou então que se podia convidar o digno lente de química da Escola Politécnica A. A. de Aguiar para coadjuvar a comissão no que diz respeito a estes conhecimentos" $^{\prime 426}$.

A comissão reuniu dias depois no espaço da galeria e elaborou um longo relatório com várias observações acerca das quais nos debruçaremos no ponto seguinte. Quanto ao

\footnotetext{
${ }^{424}$ Ofício datado de 23 de Setembro de 1868. Idem, disponível em http://digitarq.dgarq.gov.pt/ PTANBA-ANBA-B-001-00003_m1428.TIF a _1430.TIF

${ }^{425}$ A este respeito cf. CRUZ, António João - op. cit., pp. 53-83.

426 Conferência ordinária 5 de Novembro de 1868. Arquivo da ANBA, disponível em http://digitarq.dgarq.gov.pt/ PT-ANBA-ANBA-F-002-00001_m0531.TIF
} 
responsável pela redação do documento, Alfredo Camarate, efémero foi o exercício do seu cargo enquanto conservador. Sabe-se que em Julho 1870, após ter regressado dos Açores, se ocupou do inventário da coleção, tendo o Ministério da Instrução Pública de que dependia requisitado a sua colaboração noutras funções. O vice-inspetor solicitou então ao ministro para "dar as providências que julgar necessárias afim de que o mencionado empregado se conserve em comissão neste estabelecimento", pedido que não deverá ter sido atendido ou quando muito prorrogado por mais uns meses, deixando aquele nome de ser mencionado nas atas e restantes documentos da Academia.

\section{Em busca de soluções}

Convocada para o dia 21 de Novembro de 68, a reunião da comissão encarregada de proceder ao exame do estado de conservação das pinturas foi presidida pelo diretorgeral, Francisco de Assis Rodrigues, tendo contado como previsto com a presença de Anunciação, Cristino, Lupi, Pires da Fonte, Camarate e do lente de química da Escola Politécnica, António Augusto de Aguiar (1838-1887). Começam por referir no relatório terem ficado profundamente impressionados com o "deplorável estado a que chegaram os quadros", fazendo notar os danos causados em alguns espécimes das escolas estrangeiras, "em grande parte em completa ruína" ${ }^{427}$, apreciações alarmantes com o objectivo de chamar a atenção dos governantes para o problema. Os que escapavam apresentavam-se ainda assim "cobertos com um véu branco azulado a que tecnicamente se chama a constipação do verniz", consequência da elevada concentração de humidade, apontada como o grande mal. A esse respeito referiam: "É preciso notar que a humidade, principal causa dos estragos nas pinturas, não se infiltra unicamente pelas paredes em contacto com o ar exterior, existe espalhada por todo o recinto da galeria fornecida pelos ventiladores que ela possui, e que neste caso dão efeito contraproducente em consequência de vir já o ar exterior impregnado da mesma humidade".

\footnotetext{
${ }^{427}$ Documento datado de 21 de Dezembro de 1868. Arquivo do MNAA, fundo José de Figueiredo, cx. 1, pasta 11, doc. 3. As citações seguintes reportam-se à mesma referência.
} 
As tentativas que haviam sido utilizadas para atalhar aquela problemática revelaramse totalmente desadequadas: "Isolaram-se os quadros das paredes exteriores por meio de panos de linhagem pintada a tinta de óleo, ficando desta forma um espaço cheio de ar, renovado por orifícios praticados no rodapé. Este processo que em qualquer outra circunstância dava óptimos resultados, agravou ainda mais o defeito em consequência de conservar encerrado em tão pequeno espaço o ar que já do exterior vinha saturado de humidade". A situação era por tal forma peculiar que a comissão se via confrontada com um dilema: "ou não estabelecer a ventilação o que é absurdo, ou estabelecendoa, alimentá-la com o ar que já do exterior vem viciado".

Perante o exposto, uma única solução se impunha, "a construção de uma nova sala, em sítio apropriado, que reúna todas as condições que demanda a higiene dos quadros". Dada a pouca receptividade do Estado em dar seguimento a tal projeto, em larga medida devido ao crónico mau estado financeiro, recordava-se que a economia nacional passava também pela conservação das riquezas públicas, não se podendo negar uma necessidade tão premente como aquela. Apelava-se por isso ao governo a quem o relatório iria ser apresentado, escusando-se a comissão a assumir qualquer responsabilidade por eventuais problemas de maior registados a partir de então.

Os trabalhos da comissão viriam a ter uma consequência imediata no domínio do que designamos hoje de "conservação preventiva": a monitorização das temperaturas e dos níveis de humidade, prática provavelmente inédita até então no meio museológico nacional. Procedeu-se para tal ao registo detalhado dos dados, daí resultando um "Mapa das diferentes temperaturas marcadas pelo termómetro centígrado e pelo higrómetro de Saussure nas salas da Galeria Nacional de Pintura nos anos de 18691870-1871"428 (figs. 79 e 80). Organizado em diversas páginas de um caderno, esse mapa ou tabela revela terem sido instalados termómetros nas cinco salas da galeria, registando-se diariamente em cada uma as temperaturas (às nove horas da manhã, meio dia e três da tarde), e testando-se a influência dos ventiladores que se mantiveram alternadamente abertos ou fechados como também foi anotado. Na sala D. Fernando colocou-se um higrómetro de absorção, dito de árvore ou de Saussure, cujo funcionamento se baseava na dilatação de um fio de cabelo sob tensão, quando

\footnotetext{
428 Arquivo da ANBA, disponível em http://digitarq.dgarq.gov.pt/ PT-ANBA-ANBA-B-00100005_m0006.TIF a_m0048.TIF
} 
se dava o aumento da humidade do ar. De maneira a permitir estudos comparativos, os valores atingidos pelo higrómetro foram registados às mesmas horas adoptadas para os termómetros, facilmente se constatando serem elevados os índices de humidade, o que conjugado com as temperaturas (chegavam a variar seis ou sete graus centigrados em 24 horas), conferia um ambiente adverso às pinturas.
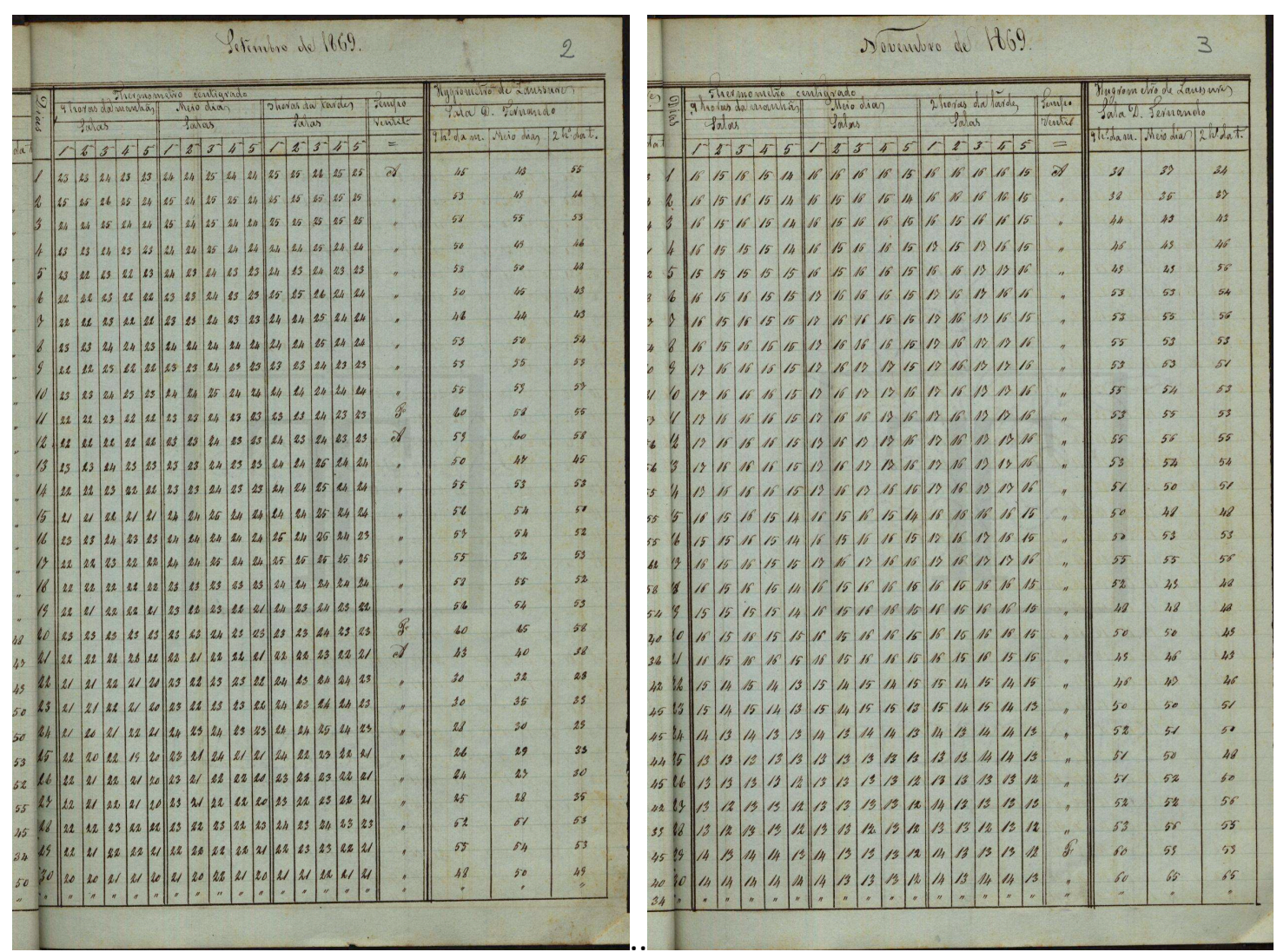

Figs. 79 e 80 - "Mapa das temperaturas da Galeria Nacional de Pintura" (meses de Setembro e Novembro de 1869). Arquivo da ANBA

Publicado no Diario do Governo de 28 de Março de 1869, o relatório supracitado terá pesado na elaboração da portaria que um ano mais tarde (22 de Março de 1870) designou outra comissão encarregada de estudar a reforma do ensino na Academia e a instalação adequada das suas coleções. Para além do vice-inspetor, era composta pelo conselheiro João Palha de Faria Lacerda, pelo lente da Escola Médica Tomás de Carvalho (1819-1897), e por quatro artistas académicos (Francisco de Assis Rodrigues, Visconde de Meneses, Vítor Bastos e António Tomás da Fonseca). Criada pelo duque de Loulé (1804-1875), morreu praticamente à nascença por alegadamente se terem 
escusado e ausentado alguns dos seus membros ${ }^{429}$, pelo que será necessário aguardar cinco anos para ser dada à luz nova comissão sob os auspícios de António Rodrigues Sampaio (1806-1882), ministro do Reino.

Com efeito, por decreto de 10 de Novembro de 1875, um vasto conjunto de personalidades seria encarregue de propor aos poderes públicos uma reforma mais abrangente do ensino artístico assim como um plano de organização de um museu nacional, recomendando-se para tal "a maior economia da despesa" ${ }^{430}$. Da antiga comissão transitaram Sousa Holstein, Assis Rodrigues, António Tomas da Fonseca, Vítor Bastos e Tomás de Carvalho, entretanto promovido a diretor da Escola Médica, acrescentando-se os condes de Valbom (1822-1901) e Samodães (1828-1918), este último inspetor da Academia de Belas Artes do Porto, assim como Tadeu de Almeida Furtado (1813-1901), professor da mesma Academia. Pertenciam ainda ao agrupamento o provedor da Casa Pia, Eugénio de Almeida (1845-1914), Teixeira de Vasconcelos (1816-1878), sócio e futuro vice-presidente da Academia de Ciências, os arquitetos Possidónio da Silva e José Maria Nepomuceno (1836-1895), o diretor do gabinete de numismática da Ajuda, Teixeira de Aragão (1823-1903), o lente da Universidade de Coimbra, Augusto Filipe Simões, e o escritor Luciano Cordeiro (18441900).

Eleito secretário e relator da comissão, Luciano Cordeiro havia-se destacado até à data como crítico de arte e de literatura, tento publicado num curto período uma meia dúzia de volumes reunindo conferências, críticas, notas de viagem e polémicas ${ }^{431}$. Cedo se aproximou da Academia e de Sousa Holstein como revela uma carta datada de 1867 onde lamenta o estado da pintura portuguesa coeva e expressa a vontade de “labutar pelo melhoramento e regeneração entre nós daquele ramo da arte que é a manifestação mais elevada desta", destacando o papel do vice-inspetor, "exemplo edificante e zeloso chefe nesta honrada empresa". Como tal, disponibiliza-se para

\footnotetext{
429 “Muito provavelmente, não terá sido alheio a este desfecho o facto de, dois meses após a nomeação desta comissão, se ter verificado o golpe de Estado perpetrado pelo Duque de Saldanha". LISBOA, Maria Helena - op. cit., p. 365.

${ }^{430} \mathrm{Cf}$. decreto in [HOLSTEIN, marquês de Sousa] - Observações sobre o actual estado do ensino das artes em Portugal: a organização dos museus e o serviço dos monumentos historicos e da archeologia: offerecidas á commissão nomeada por decreto de 10 de Novembro de 1875 por um vogal da mesma commissão, 1875, p. 2

${ }^{431}$ Livro de crítica, 1869; Segundo livro de crítica, 1871; Viagens, I, 1874; Viagens, II, 1875; Da arte nacional, 1876; Ideias e concursos, 1876.
} 
colaborar com a instituição: "tomo a liberdade de lhe oferecer as horas vagas dos meus afazeres literários para que V. Ex. as empregue no que entender que posso de alguma forma servir à Academia” ${ }^{432}$. Conhecedor das suas capacidades enquanto crítico, Sousa Holstein não desperdiçou os serviços do jovem Cordeiro a quem passou a recorrer, devendo-se-lhe seguramente a indicação do seu nome para integrar aquele agrupamento.

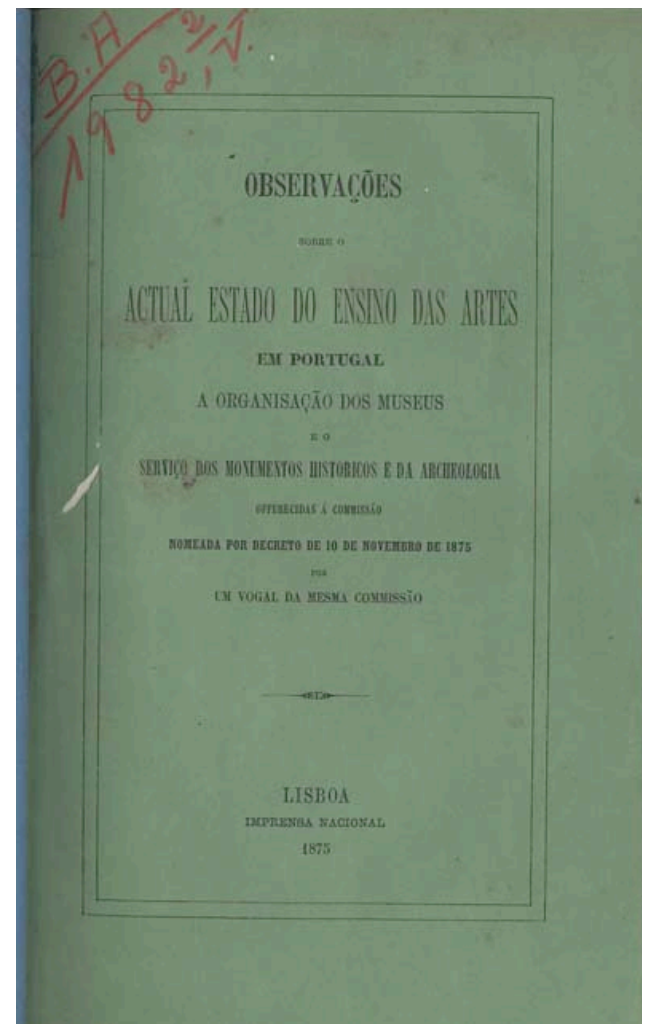

Fig. 81 - Marquês de Sousa Holstein, Observações sobre o actual estado do ensino das artes em Portugal, a organização dos museus e o serviço dos monumentos historicos e da arqueologia, 1875. BNP, BA-1982-2-V

O estado do ensino e das coleções públicas de arte foi analisado pelo marquês num relatório apresentado voluntariamente aos membros da comissão, documento ao qual foi dispensado o maior aplauso, tendo sido votada na sessão de 6 de Dezembro de 1875 a sua publicação (fig. 81). Intitulado "Observações sobre o actual estado do ensino das artes em Portugal, a organização dos museus e o serviço dos monumentos historicos e da archeologia", contou com uma tiragem excecional de 4000 exemplares no intuito de ser profusamente distribuído, tendo-Ihe sido acrescentada uma pequena

\footnotetext{
${ }^{432}$ Carta datada de 2 de Maio de 1867. Arquivo da ANBA, disponível em http://digitarq.dgarq.gov.pt/ PT-ANBA-ANBA-B-001-00003_m1248.TIF a_m1251.TIF
} 
advertência assinada por Luciano Cordeiro que, na qualidade de secretário, solicitava aos "Srs. diretores e redatores dos jornais de qualquer índole ou carácter político o obséquio de apreciarem nas suas folhas este trabalho" ${ }^{\prime 43}$. Procurava-se assim envolver a sociedade civil no debate e consciencializar os mais cépticos para a necessidade de uma profunda reforma das artes em Portugal. Os ecos serão quase sempre derrotistas, podendo assinalar-se o caso de Ramalho Ortigão que n'As Farpas não se escusou de censurar a iniciativa: "A restauração da arte em Portugal acaba de ser confiada pelo governo aos cuidados de uma comissão. Aquilo que durante um século não puderam conseguir todas as forças da civilização reunidas, vai agora fazê-lo, num mês ou dois, a referida comissão" ${ }^{434}$. Sarcasticamente, acrescentará: “Para organizar o museu, a comissão principiará por procurar todas as obras-primas de arte disseminadas em Lisboa e não coligidas nas galerias. Para esse fim andará de noite pelas ruas, com uma lanterna e um gancho, alumiando, espreitando, escarafunchando" ${ }^{435}$.

Nas suas "Observações", o marquês demonstra a necessidade da constituição de museus nacionais e provinciais, onde se organizassem as coleções que existiam no país de forma dispersa e instaladas em deficientes condições. Para a capital, idealizava uma pinacoteca inserida num projeto mais abrangente de "museu central", composto por diferentes secções analisadas no ponto seguinte. Considerava que o conjunto pictórico conservado na Academia poderia ser enriquecido não só com os quadros oriundos dos conventos femininos e com os que se encontravam disseminados por edifícios públicos, mas com a concessão por parte do governo de uma verba anual para aquisições de pintura contemporânea. "É triste dizer-se que não há na galeria de pintura quadros alguns dos nossos artistas contemporâneos, a não ser os que eles fizeram para os concursos de pensões ou dos lugares do professorado" ${ }^{436}$ comentava a esse respeito, procurando chamar a atenção para uma lacuna que só com o Legado Valmor começará a ser preenchida de forma mais sistemática ${ }^{437}$. Sugeria ainda 0

\footnotetext{
433 [HOLSTEIN, marquês de Sousa] -op. cit., p. 1

434 ORTIGÃO, Ramalho; QUEIRÓS, Eça de - As farpas: chronica mensal da política das letras e dos costumes, nova série, Tomo I, Dezembro de 1875, p. 17.

${ }^{435}$ Idem, ibidem, p. 18

${ }^{436}$ HOLSTEIN, marquês de Sousa (co-auto) - op. cit., p. 25.

${ }^{437}$ Legado constituído em 1898 por vontade testamentária de José Isidoro Guedes, 1. visconde de Valmor. A este respeito cf. FIGUEIREDO, José - O Legado Valmor e a reforma dos serviços de belas artes, Lisboa, 1901 e MACEDO, Diogo de - "Registo do Legado Valmor". Belas Artes: revista e boletim da Academia nacional de Belas Artes, 2. série, n.o 7, 1954, pp. 53-54.
} 
desenvolvimento de uma secção dedicada à história pátria, inspirada seguramente no exemplo francês de Louis-Philippe d'Orléans para Versailles, transformado num museu destinado a celebrar "toutes les gloires de la France" através de grandes composições encomendadas a artistas contemporâneos. Subjacente ao pensamento do marquês estava portanto uma preocupação didática, pelo que a nova galeria seria "como um grande livro em cujas páginas os mais ignorantes poderiam ler as admiráveis lições que tanto abundavam na história do nosso Portugal” ${ }^{438}$.

Consciente da impossibilidade do museu sonhado poder vir a incluir "telas de todas as grandes escolas e mármores das melhores épocas da Grécia e Roma", insistia no aproveitamento e valorização dos testemunhos artísticos disseminados pelo país e no recurso a cópias, de maneira a formar coleções "interessantes e úteis". A galeria patenteada ao público na Academia estava longe de cumprir esses objectivos, afigurando-se no seu entender como um espaço indigno que envergonhava o país aos olhos dos que nos visitavam:

"Os estrangeiros que vêm a Lisboa procuram os museus, e informados de que apenas existem aqueles barracões decorados com o nome de salas, onde estão dependuradas as telas que possuímos pasmam que numa capital já hoje tão populosa haja uma falta que não sentem muitas pequenas cidades da Alemanha e da França; pasmam sobretudo ao verem a ultima sala da galeria, onde estão aqueles quadros góticos, admiráveis testemunhas da nossa grande fecundidade artística em passadas eras, que um país possuidor de tão notáveis trabalhos, não tome a peito conservar com mais amor as frágeis relíquias da sua antiga escola" ${ }^{439}$.

Sousa Holstein dedica especial atenção às questões da conservação, aludindo aos infrutuosos protestos junto do governo contra a falta de condições da galeria nacional. Recorda que em 1868 havia nomeado uma comissão encarregada de examinar as salas e o acervo, a quem se ficou a dever um relatório de que cita as passagens mais relevantes. Segundo refere, aquele documento "provocou algumas correspondências oficiais; falaram nele dois dias os periódicos, mas infelizmente não trouxe o remédio

\footnotetext{
${ }^{438}$ HOLSTEIN, marquês de Sousa (co-auto) - op. cit., pp. 29-30.

${ }^{439}$ Idem, ibidem, pp. 27-28.
} 
que tão urgente era. Apesar das repetidas instâncias, que até hoje não descontinuaram, tudo permaneceu como estava" 440 . Como já fora notado no relatório de 68, impunha-se a mudança de instalações, sendo uma vez mais observada a obrigatoriedade de esta ser parcimoniosa na despesa, dadas as dificuldades do tesouro público. "Assim talvez fosse possível encontrar na capital um edifício que pudesse ser apropriado para os museus centrais sem necessidade de levantar expressamente uma construção para tal destino" ${ }^{441}$ declarava na conclusão o vice-inspetor, deitando por terra qualquer aspiração mais ambiciosa nesse sentido.

\subsection{Um palácio para o museu nacional}

As ideias desenvolvidas nas "Observações" serão sintetizadas com especial arrobo lírico por Luciano Cordeiro no relatório da comissão nomeada pelo governo em 1875, mostrando que as reuniões tidas entre os seus elementos pouco acrescentaram ao exposto anteriormente pelo vice-inspetor ${ }^{442}$. Distingue-se esse relatório por incluir uma detalhada proposta definindo a criação de um "Museu Nacional de Arte e Indústria" dotado de cinco conservadores correspondentes às diferentes secções (incluindo-se uma biblioteca de belas artes) que assegurariam rotativamente a direção do mesmo ${ }^{443}$. Foram igualmente anexadas ao relatório as comunicações escritas submetidas à comissão por alguns dos seus membros, assim como as atas das reuniões decorridas entre finais de 75 e inícios de 76 onde o tema da mudança de instalações que aqui nos interessa foi profusamente debatido.

\footnotetext{
${ }^{440}$ Idem, ibidem., p. 53

${ }^{441}$ Idem, ibidem, p. 55

442 "O que aconselhamos nós? Que os grandes valores, propriedade da nação, por assim dizer amontoados na chamada Academia de Lisboa onde enfim são uma afirmação desairosa até para a nossa economia administrativa, visto que são riquezas que nós deixamos apodrecer e extinguir: que essas interessantes coleções de pinturas, de gravuras, de desenhos, de ourivesaria, etc., sejam devidamente alojadas, conservadas, estudadas, patenteadas ao público, franqueadas ao estudo e à admiração de nacionais e estrangeiros, metodicamente acrescentadas por outras, pelas muitas que por esse país se estão perdendo, ignoradas, e pelas que facilmente se podem adquirir ainda, havendo quem disto tenha o especial encargo e a necessária competência. A verdade, em suma, é que temos à mão, sem dispêndio de aquisições, um núcleo importantíssimo de museu nacional”. Relatorio dirigido ao illustrissimo e excellentissimo senhor ministro e secretário de Estado dos Negocios do Reino pela comissão nomeada por decreto de 10 de Novembro de 1875 para propor a reforma do ensino artistico, a organização do serviço de museus, monumentos historicos e arqueologia, I parte, 1876, p. XXXV.

${ }^{443}$ Idem, ibidem, pp. 9-12.
} 
A 11 de Janeiro de 1876, consistente das dificuldades em adoptar soluções definitivas, Augusto Filipe Simões insistia na "urgente necessidade de pedir ao governo que desde já se removessem provisoriamente para local apropriado os valiosos quadros que se estavam deteriorando na Academia pelas péssimas condições do edifício", lembrando ao mesmo tempo a possibilidade entretanto levantada por Teixeira de Aragão de se poder enriquecer o acervo com as pinturas conservadas no Convento de Jesus de Setúbal. Respondeu o vice-inspetor ter "escrúpulo em receber na Academia quadros valiosos que nela venham expor-se a uma fatal e rápida deterioração [...] vendo-se além disso obrigado, por falta de espaço, a conservar nos armazéns muitos e muitos outros quadros" ${ }^{444}$. Dada a situação de emergência, propuseram alguns elementos entrar pessoalmente em contacto com o governo, tendo sido encarregados para o efeito Sousa Holstein, conde de Valbom e Teixeira de Vasconcelos.

Na sessão de 13 de Janeiro, seriam os membros da comissão chamados a pronunciarse sobre os edifícios mais adequados para instalar as pinturas e restantes coleções da Academia, tendo Teixeira de Aragão e Vítor Bastos lembrado a existência de uma grande sala que acabara de ser reconstruída no mosteiro do Jerónimos, em Belém. Possidónio da Silva considerou ser preferível o convento da Estrela cuja comunidade se encontrava quase extinta, dando a entender que a proximidade do rio no caso dos Jerónimos traria graves prejuízos para a conservação das pinturas. Aquele argumento seria contrariado por Augusto Filipe Simões, ao referir não ter visto na Holanda ou noutros países onde se regista grande proximidade com a água qualquer impeditivo, "e que razão havia em inclinar-se a comissão, e muitas outras pessoas, para que os museus fossem alojados em Belém, pelo carácter monumental e histórico do edifício". Teixeira de Aragão rejeitou igualmente a ideia de que o ar do rio danificasse por si só as pinturas, achando a Estrela mais adequada para receber a Casa Pia no caso do governo ceder as dependências que esta ocupava nos Jerónimos para a instalação do museu.

Procurando fazer um ponto de situação, Luciano Cordeiro concluiu ser natural a dificuldade da escolha e, tendo talvez presente a situação traumática vivida em $\mathrm{S}$. Francisco, não duvidada em expressar "que melhor do que os antigos conventos eram

${ }^{444}$ Ata n. 8, 11 de Janeiro de 1876. Idem, ibidem, II parte, 1876, pp. 38-39. 
os palácios de época mais moderna". Encontrava-se o secretário seguramente ao corrente dos últimos desenvolvimentos e dos planos de Sousa Holstein que, ausente da reunião por se encontrar "em serviço" na companhia do arquiteto António Tomás da Fonseca, entraria pouco depois na sala com uma comunicação a fazer. De acordo com a ata, "Expôs o Sr. marquês de Sousa que, tendo-o encarregado o Sr. presidente do conselho de ministros, no dia anterior, de procurar casa apropriada, cuja renda não excedesse 3:000\$000 reis, para receber os quadros da Academia, em virtude do que a comissão resolvera e representara, fora com o Sr. Fonseca ver os palácios do infante D. Sebastião e do marquês da Ribeira, à Junqueira, podendo qualquer dos dois servir, se a comissão não entendesse dever preferir-se algum outro edifício” ${ }^{445}$.
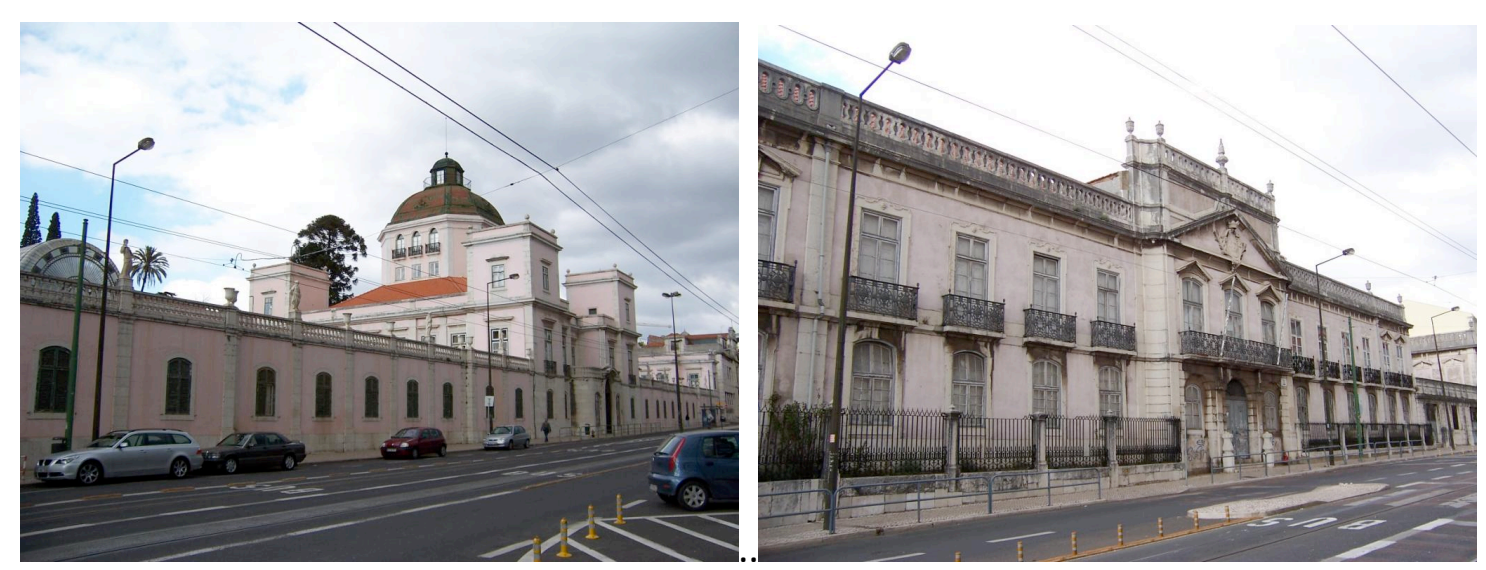

Figs. 82 e 83 - Palácio Burnay e Palácio Ribeira Grande na atualidade

A resolução tomada em alugar um edifício particular em detrimento de qualquer espaço cedido pelo governo não deixa de ser significativa, assim como a alusão ao palácio do infante de D. Sebastião que o arquiteto António Tomás da Fonseca bem conhecia. Neto de D. João VI, o infante espanhol D. Sebastião de Bourbon (1811-1875) havia adquirido por volta de 1865 o antigo palácio dos patriarcas à Junqueira, então conhecido por palácio do Monte Cristo e mais tarde por palácio Burnay, para utilizar nas suas frequentes deslocações ao nosso país (fig. 82). Desde cedo interessado pelas belas artes, comprou por intermédio do pintor José Madrazo diversas obras provenientes da desamortización de Mendizabal, reunindo uma notável coleção enriquecida durante a sua permanência em Itália ${ }^{446}$. Significativamente, em Outubro

\footnotetext{
445 Ata n.o 9, 13 de Janeiro de 1876. Idem, ibidem, 1876, pp. 41-43.

${ }^{446}$ Sobre o infante D. Sebastião e a sua coleção de pintura cf. XAVIER, Hugo - op. cit., pp. 113-116.
} 
de 1866, o Diario de Noticias informava ter o infante encarregado "o seu arquiteto, o Sr. António Tomás da Fonseca, de construir uma galeria no seu palácio à Junqueira para nela mandar colocar todos ou parte dos quadros que possui em Espanha"447, projeto que não teve seguimento mas que terá chegado a ser trabalhado pelo agora membro da comissão.

As duas hipóteses avançadas pelo marquês de Sousa Holstein - palácio do infante D. Sebastião e palácio Ribeira Grande (fig. 83), seu vizinho - foram então debatidas, lembrando o conde de Valbom poder-se considerar ainda o palácio dos duques de Palmela ao Calhariz, igualmente disponível. Conhecedor das intenções da duquesa sua sobrinha que optara por se fixar com a família no palácio do Rato, o vice-inspetor referiu que tal só seria possível "na certeza de que num prazo fixo se faria dali a remoção dos quadros", propondo como alternativa o palácio do marquês de Abrantes em Santos. Após várias considerações, deliberam os membros da comissão "que se desse preferência ao palácio do marquês de Abrantes, se pudesse obter-se"448 (fig. 84). $\mathrm{Na}$ ata da sessão de 15 de Janeiro, ficou registado "que o administrador do palácio do marquês de Abrantes concordara em arrendá-lo ao governo para o fim indicado na ata anterior, pela quantia de 2:700\$000 reis, tendo porém de entender-se primeiro com o atual inquilino" que era já então o ministro de França em Lisboa. Igualmente consultado, o conde da Ribeira "pedira pelo seu palácio a renda de $3.500 \$ 000$ reis, com exclusão de algumas casas", importância superior ao limite estabelecido (3.000\$000 reis). Perante isso, acordou-se que se "comunicasse tudo ao governo, dando-se a preferência ao palácio do marquês de Abrantes, e lembrando-se a conveniência de incluir no contrato uma cláusula relativa a hipótese de compra por parte do governo" ${ }^{\prime 49}$. O carácter vetusto do edifico, antiga residência real durante o século XVI, e o facto dos seus interiores possuírem relevante património integrado, com destaque para o célebre tecto decorado com pratos em porcelana da China, poderão ter tido algum peso na escolha, mas determinante foi seguramente a renda solicitada pelo procurador do proprietário. A circunstância do palácio possuir terrenos

\footnotetext{
${ }^{447}$ Diario de Noticias, 25 de Outubro de 1866.

${ }^{448}$ Ata n.o 9, 13 de Janeiro de 1876. Relatorio dirigido ao illustrissimo e excellentissimo senhor ministro e secretário de Estado dos Negocios do Reino pela comissão nomeada por decreto de 10 de Novembro de 1875 para propor a reforma do ensino artistico, a organização do serviço de museus, monumentos historicos e arqueologia,, II parte, 1876, p. 42.

${ }^{449}$ Ata n.o 10, 15 de Janeiro de 1876. Idem, ibidem, p. 43.
} 
anexos e de apresentar uma ala incompleta, permitindo futuras ampliações, não terá passado igualmente desapercebido à comissão. Dada a urgência em retirar os quadros da galeria nacional, e tendo em conta a demora que se perspectivava para a necessária negociação, Sousa Holstein resolveu ainda que fossem ouvidos os professores de pintura da Academia "sobre se obtido aquele edifício, desde o começo do ano próximo, conviria fazer antes disso a remoção dos quadros para outro edifício que se obtivesse provisoriamente".
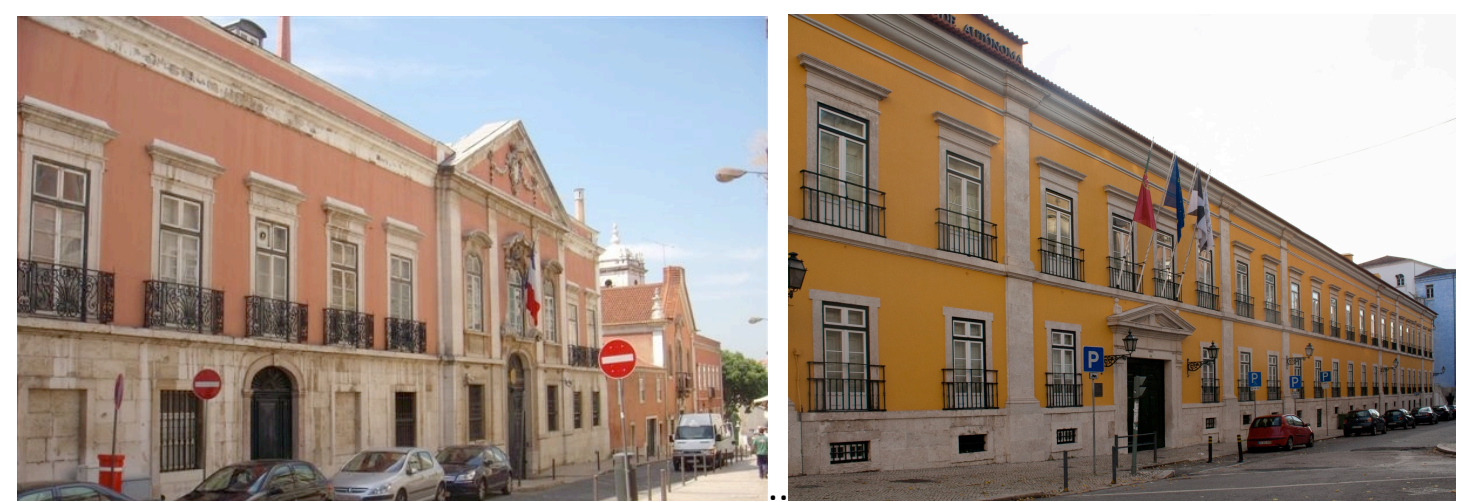

Figs. 84 e 85 - Palácio Abrantes e Palácio dos condes de Redondo na atualidade

Meses após terminados os trabalhos da comissão, editado o relatório que condensa os projetos, atas e comunicações dos membros, regista-se de forma algo inesperada uma inflexão quanto ao edifício escolhido para servir de museu. A legação de França que ocupava desde 1870 o palácio Abrantes não terá manifestado vontade em rescindir o contrato e nele continuou a permanecer, vindo o edifício a ser definitivamente adquirido pelo Estado francês em 1909. Houve que encontrar uma nova solução, e a preferência registada até à data pelos bairros ocidentais da cidade (Belém, Junqueira e Santos), inverteu-se mais para nordeste, para a rua de Santa Marta onde se ergue o palácio dos condes de Redondo (fig. 85). Remontando à segunda metade do século XVII, este edifício com amplo pátio interior e extensa fachada de 22 vãos encontravase na posse de D. Fernando de Sousa (1835-1928) que, tal como outros aristocratas depauperados daquela época, se viu obrigado alugá-lo, após o ter hipotecado ao Banco de Portugal.

Estas informações são-nos dadas por alguns documentos conservados no arquivo da Academia, nomeadamente pelo "projeto de escritura de arrendamento do palácio e 
quinta de Santa Marta" elaborado por Sousa Holstein e datado de Agosto de $1876^{450}$. De acordo com as cláusulas gizadas, sabemos ter sido a renda fixada em $4.500 \$ 000$ reis anuais, importância que ultrapassa os $3.000 \$ 000$ reis inicialmente previstos e que está seguramente relacionada com a amplidão do edifício e do próprio terreno subjacente. $\mathrm{O}$ contrato seria feito por 10 anos, período em que seria possível ao Estado proceder à aquisição do imóvel pelo valor de $80.000 \$ 000$ de reis, pagos tal como a renda ao Banco de Portugal na qualidade de credor hipotecário. Ao governo era dado o direito de fazer todas as obras convenientes para a adaptação do palácio a museu, podendo inclusivamente ser utilizada a quinta para levantar outras construções julgadas necessárias.

Convém assinalar que de todos os palácios considerados até à data, o dos condes de Redondo seria talvez aquele que melhor se adequava às funções museológicas ideadas pela Academia, dada a generosa área ocupada e as hipóteses de expansão. Beneficiava também por ficar paredes-meias com a "Lisboa moderna" que começava então a ser projetada, nomeadamente do chamado Bairro Camões (construído a partir de 1878) e sobretudo da Avenida da Liberdade (a partir de 1879), ficando futuramente dotado de largos acessos.

Tudo parecia encaminhado e Sousa Holstein enviará ao presidente do conselho de ministros, juntamente com o projeto de contrato de arrendamento, um memorando acerca das providência imediatas a tomar. Enumera então diversas medidas, a começar pela necessidade de negociar com os inquilinos que ocupavam o palácio a sua saída, a fim de se poder dar início sem demora às obras. A esse respeito escreve: "Como se trata do museu, lembro de se incumbir a obra a um arquiteto da Academia. Fonseca seria muito hábil para este fim. Se porém é contrária a sua nomeação às praxes adoptadas, peço que para o plano se nomeie uma comissão a que presidirei, se quiserem, sendo vogais Fonseca e Nepomuceno ou Ferraz" ${ }^{\prime 451}$. Acrescentava que o orçamento feito por alto por uma comissão que examinara o palácio ascendia a

\footnotetext{
450 "Projeto de escritura de arrendamento do palácio e quinta de Santa Marta" datado de 2 de Agosto de 1876. Arquivo da ANBA, disponível em http://digitarq.dgarq.gov.pt/ PT-ANBA-ANBA-B-00700002_m0358.TIF a_m0359.TIF

451 "Notas apresentadas ao Exmo. Presidente do Conselho de Ministros a seu pedido, acerca das providencias imediatas a tomar para os museus" datadas de 2 de Agosto de 1876. Idem, disponível em http://digitarq.dgarq.gov.pt/ PT-ANBA-ANBA-B-007-00002_m0356.TIF a _m0358.TIF As citações seguintes reportam-se à mesma referência.
} 
$30.000 \$ 000$ reis, sendo ainda necessário autorizar a despesa de $2.000 \$ 000$ "para reparos urgentíssimos nos quadros e compra de molduras" (sublinhado no texto). Era igualmente indispensável tratar de "vitrines e armários envidraçados para as variadas secções do Museu de Arte Ornamental, como ourivesaria, rendas, tecidos, loiças, pequena escultura, etc." sendo estimada para o efeito a quantia de $1.500 \$ 000$ reis.

Dada a falta de pessoal disponível na Academia, e tal como sucedera anteriormente com o conservador interino Alfredo Camarate, solicitava o vice-inspetor a autorização para "requisitar das secretarias de Estado dois ou três empregados que me mereçam confiança para proceder desde já ao longo e difícil trabalho dos inventários dos objetos existentes". Consciente das lacunas existentes no acervo, "pobríssimo em epigrafia e monumentos originais de escultura", lembrava a necessidade de se obter $1.000 \$ 000$ reis para custear a transferência de alguns objetos desse tipo existentes na província que se encontravam na posse do Estado. Igual atenção era dada à arqueologia, nomeadamente à urgência em mandar explorar dois antigos cemitérios ultimamente descobertos no Algarve, recomendando Estácio da Veiga (1828-1891) para dirigir esse trabalho que importaria a $300 \$ 000$ reis.

Nada parecia escapar a Sousa Holstein que via nessa abertura do governo a grande oportunidade para concretizar um projeto acalentado desde a sua entrada na Academia em 1862. O investimento feito à partida nos trabalhos de remodelação, transferências de objetos, restauros e demais melhoramentos, representava praticamente metade do valor total acordado para a aquisição do palácio, o que terá tido como consequência o recuo do ministro promotor da reforma, Rodrigues Sampaio, que em 1878 abandonou o governo em clima de crise financeira.

O projeto de reforma então elaborado não chegou assim a dar entrada nas Cortes para satisfação do maior dos seus críticos, Joaquim de Vasconcelos que, em 77, polemicou com exagero o texto da comissão, fulminando-a com uma série de acusações que recaíram sobre o presidente e o seu secretário. Analisou os pontos vagos do documento, considerando a cidade do Porto lesada pelo centralismo de Lisboa: “O relatório pretende centralizar e absorver todos os elementos artísticos das províncias para beneficiar o museu da capital e a biblioteca desse museu” ${ }^{452}$. A este respeito questionava com ironia: "Que se fará dos objetos de arte expropriados por utilidade

${ }^{452}$ VASCONCELOS, Joaquim - op. cit., p. 68. 
pública de que reza o artigo 71. do projeto? Irão para Lisboa, sem exceção, porque ali reside o único Museu oficialmente reconhecido; ali está a Direção Geral de Belas Artes que decide sobre eles por maioria de votos que a lei - justa lei na verdade! - há-de sancionar" ${ }^{\prime 453}$. Entendia ainda que se interpretava mal o modelo museológico inglês e que não se levavam em conta os exemplos franceses, austríacos e alemães nesse domínio, propondo-se criar um Museu de Artes Industriais com metade da quantia que D. Fernando II tinha dispensado à Academia entre 1865 e $1868^{454}$.

Manifestando sinais de doença em 1877, Sousa Holstein faleceria no ano seguinte sem ver concretizada a reforma do ensino artístico e a organização do museu nacional em que tanto se empenhara. "Era esta a sua grande aspiração que os governos lhe iludiram com enganosas esperanças, até que a morte lhe cerrou os olhos sem ver cumprido o seu desejo", escreverá Augusto Filipe Simões no obituário que lhe dedicou $^{455}$. O sucessor do marquês, Delfim Guedes, será pouco depois encarregado pelo ministro José Luciano de Castro (1834-1914) de apresentar novo projeto de reforma, para o que consultou apressadamente os professores da Academia, obtendo de Lupi umas Indicações inspiradas nas ideias da comissão de $75^{456}$. Após mais polémicas esta virá finalmente a ser realizada em 1881, com manifesto prejuízo da Academia do Porto, ficando a vigorar até 1911.

Quanto à instalação do museu, abortado o projeto de Sousa Holstein para Santa Marta, decidiu-se o novo vice-inspetor pelo palácio Alvor-Pombal às Janelas Verdes, bem próximo do palácio dos marqueses de Abrantes que vimos ter sido também considerado. Mandado construir no século XVII pelo primeiro conde de Alvor e adquirido mais tarde pela família Pombal, este edifício mantinha curiosamente alguns paralelismos com a derradeira escolha do marquês pela sua acentuada compleição seiscentista e por confinar com um convento (convento das Albertas nas Janelas Verdes e de Santa Marta junto ao palácio dos condes de Redondo). As diferenças mais evidentes iam para os terrenos anexos que no caso do palácio Alvor-Pombal se limitavam a um pequeno jardim com soberba vista de rio mas com limitadas hipóteses

\footnotetext{
453 Idem, ibidem, p. 24.

${ }^{454}$ Apesar de definitivamente arredada a hipótese de reforma, Joaquim de Vasconcelos não hesitou em fazer publicar, em 78 e 79 dois novos opúsculos críticos. A este respeito cf. LISBOA, Maria Helena - op. cit., pp. 374-377.

455 SIMÕES, Augusto Filipe - op. cit., p. 206.

${ }^{456}$ LUPI, Miguel Ângelo - Indicações para a reforma da Academia Real de Bellas Artes de Portugal, 1879.
} 
de expansão, o que levará mais tarde a tirar partido do convento para a construção de um anexo. Celebrado em Maio de 1879, o contrato de arrendamento incluiu a opção de compra por parte do Estado que havia sido sugerida pela comissão de 75, e que anos depois virá a ser concretizada. Após custosas obras de adaptação, ali se realizou em 82 uma grande exposição de arte ornamental, cujo êxito serviu de bom argumento junto do governo para a definitiva instalação do museu da Academia, finalmente ocorrida em $84^{457}$.

Por detrás dos vaivéns de comissões oficiais e de uma reforma sucessivamente protelada, está a rocambolesca história da instalação do museu nacional onde emerge a figura do marquês de Sousa Holstein, homem que lutou teimosamente pela concretização daquele projeto. Não fosse a assinatura de Delfim Guedes, diríamos serem suas as palavras na introdução ao catálogo provisório editado em 1884: “O museu que vai ser inaugurado está longe de poder ser colocado a par dos que existem lá fora, em Londres, Berlim, Paris, Viena, Madrid, Roma, Nápoles, etc., em muitas cidades secundárias; mas a verdade é que, tal como se apresenta, merece a atenção dos estudiosos e amadores, sobretudo no que se refere à arte em Portugal, e de nenhum modo pode envergonhar-nos aos olhos dos estranhos" ${ }^{458}$. Marcado pela densidade da montagem, num sistema museológico característico da época, mais do que uma segunda versão da Galeria Nacional de Pintura era, como observou JoséAugusto França, um "importante passo para a existência do verdadeiro museu que todos reclamavam" ${ }^{459}$.

\footnotetext{
${ }^{457}$ A este respeito cf. FERREIRA, Emília - Lisboa em festa: a exposição retrospectiva de arte ornamental portuguesa e espanhola, 1882: antecedentes e materialização. Dissertação de Doutoramento em História da Arte Contemporânea apresentada à FCSH-UNL, 2010.

${ }^{458}$ ALMEDINA, conde de (co-auto) - op. cit., p. V.

${ }^{459}$ FRANÇA, José-Augusto - op. cit., II vol., 3.a ed., 1990, p. 69.
} 


\section{PARTE - AS RESTANTES COLEÇÕES DA ACADEMIA}

“Em Lisboa há alguns núcleos para organizar um princípio de museu central. Temos a galeria de quadros, uma boa coleção de desenhos originais, bastantes gravuras, e alguns objetos de arte ornamental tais como pratas, louças e tecidos. A galeria de quadros é a única que está exposta ao público; as outras coleções não o têm sido, não só por falta de salas para a sua colocação, mas pela falta de pessoal, que absolutamente não existe. Sem edifício, sem dotação, sem pessoal não pode haver museus".

marquês de Sousa Holstein, 1875

\section{Diferentes secções para um museu nacional: o núcleo de arte ornamental}

Em 1875, nas suas Observações, Sousa Holstein dava a conhecer um projeto museológico para a capital há muito reclamado e que vinha acalentando, o de um "museu central" cientificamente dividido em secções especializadas: pintura, desenho, gravura, escultura, arquitetura, arqueologia e arte ornamental ${ }^{1}$. A coleção de pintura encontrava-se já organizada mas o vice-inspetor propunha o seu crescimento, não só com as obras conservadas nos conventos femininos que se iam extinguindo mas com a concessão de uma verba anual para a aquisição de pinturas contemporâneas, pouco representadas na galeria. O mesmo sucedia com o núcleo de desenhos antigos que reputava de excelente qualidade e com as gravuras que convinha também acrescer por meio de subsídio estatal.

No que diz respeito à escultura, e num período em que à dimensão aurática da obra de arte se sobrepunha a visão pedagógica, sugeria o seu incremento por meio de cópias, mais fáceis de obter através de compras ou permutas com outros museus como acontecia com alguns dos gessos conservados na Academia. Para estimular essa política de trocas e enriquecer simultaneamente o acervo, considerava

\footnotetext{
${ }^{1}$ [HOLSTEIN, marquês de Sousa] - Observações sobre o actual estado do ensino das artes em Portugal: a organização dos museus e o serviço dos monumentos historicos e da archeologia: offerecidas á commissão nomeada por decreto de 10 de Novembro de 1875 por um vogal da mesma commissão, 1875, pp. 27-40.
} 
necessário continuarem-se a reproduzir os mais notáveis elementos escultóricos existentes nos portais e claustros dos edifícios religiosos nacionais. A secção de arquitetura compreenderia projetos encomendados pelo Estado, trabalhos dos nossos pensionistas no estrangeiro e ainda modelos em vulto, plantas ou fotografias dos mais representativos edifícios construídos até então em Portugal e no estrangeiro, oferecendo assim um panorama histórico desta disciplina. O núcleo arqueológico teria já um cariz exclusivamente nacional, sendo constituído por objetos doados ou adquiridos pela Academia e encontrados um pouco por todo o país, da numismática, à epigrafia, passando pela estatuária, pelos objetos do quotidiano, entre outros domínios.

Cientificamente dividida nos seus diferentes agrupamentos e épocas, a coleção de arte ornamental incluiria espécimes portugueses e estrangeiros, estes últimos representados essencialmente através de reproduções (galvanoplastias, fotografias ou gessos) de objetos emblemáticos conservados noutros museus. Devido às alfaias litúrgicas provenientes dos conventos extintos e conservadas na Academia, a representação portuguesa apresentar-se-ia opulenta e poderia ser aumentada com outras recolhas, doações e aquisições, sendo uma vez mais necessária uma verba estatal para o efeito.

Sousa Holstein depositava grandes esperanças naquele núcleo museológico, "indispensável complemento das aulas de desenho aplicadas à indústria", devendo ser "o mais público possível e de fácil acesso, aberto até de noite para cómodo das classes operárias" ${ }^{2}$. Preconizava assim a organização do ensino e dos museus por modelos estrangeiros, nomeadamente o do South Kensington Museum de Londres (atual Victoria \& Albert Museum) que, assumindo-se como um instrumento pedagógico por excelência, tinha um horário bastante amplo, oferendo admissões gratuitas durante alguns dias da semana.

O South Kensington Museum abrira em 1857 ao abrigo de um sonho partilhado, entre outros pensadores britânicos, por Henry Cole (1808-1882) que apostara na educação artística como forma de elevação nacional. Como faz notar Emília Ferreira, tal ambição cultural alicerçava-se na crença de que os conhecimentos de arte e de

\footnotetext{
${ }^{2}$ [HOLSTEIN, marquês de Sousa] - op. cit., pp. 32-33.
} 
design haviam de melhorar as condições de saber e de vida dos cidadãos, em especial das classes laboriosas, minimizando as questões hierárquicas entre as artes, no seguimento dos ideais de John Ruskin (1819-1900) e William Morris (1834-1896) ${ }^{3}$. O vice-inspetor mostrou-se particularmente sensível às doutrinas desses pensadores, escrevendo nas Observações que o domínio da arte "abrange todos os objetos do uso quotidiano, os móveis, os fatos, as louças, as pratas, tudo em uma palavra quanto serve para a vida. Em tudo pode e deve haver belo, não só no sentido limitado de ornamentação e decoração, mas só no sentido menos restrito de harmonia e proporção, mas sobretudo no sentido mais lato da perfeita correspondência entre a forma do objecto e o seu uso" ${ }^{4}$.

O interesse de Sousa Holstein pela arte ornamental ou industrial como era também designada (entenda-se: indústria de cerâmica, têxteis, mobiliário...), levou-o desde cedo a trabalhar na organização de uma coleção que abrangesse os seus diferentes vectores, procurando formar na Academia um núcleo museológico com alguma consistência. Como veremos no ponto seguinte, a primeira iniciativa nesse domínio remonta a 1863, um ano após a chegada do marquês à instituição, decorrendo a recolha do acervo em paralelo com a organização da Galeria Nacional de Pintura. Um ano depois, num relatório dirigido ao ministro do Reino, o vice-inspetor ponderava a "vantagem que haveria em formar um museu, recolhendo em um só local os inúmeros objetos de valor histórico que no nosso país se acham dispersos e muitas vezes ignorados" ${ }^{\prime \prime}$. A esse respeito dava como exemplo o museu criado pouco antes na escola naval ${ }^{6}$ com diversos testemunhos relacionados com a atividade marítima portuguesa, e questionava: "Não conviria criar um museu igual para receber todas as relíquias históricas que naquele não têm cabimento ?"7 .

Em Novembro de 1868, ao relatar uma visita de D. Luís à Academia por ocasião da sétima exposição da Sociedade Promotora das Belas Artes, o Diario de Noticias mencionava já a existência de uma "sala destinada a museu de arte antiga, onde se

\footnotetext{
${ }^{3}$ FERREIRA, Emília - op. cit., p. 74.

${ }^{4}$ Idem, ibidem, p. 12.

${ }^{5}$ Relatório acerca do estado da Academia Real das Belas Artes. 26 de Fevereiro de 1864. Arquivo do MNAA, fundo José de Figueiredo, cx. 1, pasta 1, doc. 1.

${ }^{6}$ Embrião do atual Museu de Marinha, foi criado em 1863 por decreto de D. Luís.

${ }^{7}$ Relatório acerca do estado da Academia Real das Belas Artes. 26 de Fevereiro de 1864. Arquivo do MNAA, fundo José de Figueiredo, cx. 1, pasta 1, doc. 1.
} 
conservam hoje os interessantes objetos que tanto tempo estiveram ocultos à luz do dia na Casa da Moeda, coleção já aumentada pelo Sr. marquês de Sousa” ${ }^{8}$. Ficará conhecido por Museu de Arte Ornamental, designação inspirada talvez nas origens do South Kensington Museum, conhecido anteriormente a 1857 por Museum of Ornamental Art, quando se encontrava provisoriamente instalado na Marlborough House. O acervo não se encontrava todavia patente ao público como sucedida já então com a Galeria Nacional de Pintura, assemelhando-se mais propriamente ao que chamaríamos hoje uma "coleção visitável", com visitas condicionadas a autorização superior. Disso nos dá conta o guia para viajantes britânicos publicado em 1874 por Joaquim António de Macedo, vice-cônsul de Portugal em Leeds, que advertia: "Permission to visit the museum may be obtained by applying to the director of the Academy" ${ }^{\prime \prime}$. A exiguidade do espaço disponível para acolher o acervo, a falta de pessoal e de condições de segurança impunham seguramente tal restrição. Sousa Holstein pugnou no entanto pela abertura do seu museu, escrevendo em 1875 nas Observações terem começado "no edifício de S. Francisco umas obras com o fim muito modesto de dar luz e serventia a algumas celas onde possam ser expostos ao público os objetos, aliás interessantes, que formam os nascentes museus portugueses e que sem dotação, nem pessoal, nem meios alguns, a não ser muita força de vontade e muita perseverança, tem sido possível ir coligindo" ${ }^{10}$. Não chegou a viver o marquês para possibilitar tal intento que só teria lugar com o seu sucessor, Delfim Guedes, em $1879^{11}$.

De todos os relatos identificados acerca daquele núcleo museológico, o que oferece maior soma de pormenores será talvez o dos irmãos Francisco e Hermenegildo Giner de los Ríos, ensaístas espanhóis que viajaram pelo nosso país entre 1879 e 1880, deixando-nos curiosas impressões sobre os vários estabelecimentos visitados ${ }^{12}$. Começaram por escrever que "el nasciente museo de la Academia contiene no sólo

\footnotetext{
${ }^{8}$ Diario de Noticias, 3 de Novembro de 1868

${ }^{9}$ MACEDO, Joaquim António de - op. cit., p. 121.

${ }^{10}$ [HOLSTEIN, marquês de Sousa] - op. cit., p. 49.

11 "O Museu de Arte Ornamental, nome com que ele [Sousa Holstein] batizou alguns grupos das artes decorativas em que a ourivesaria religiosa tinha o maior quinhão, só veio a ser facultado ao público com a entrada do novo inspetor Delfim Guedes (meados de 1879)". VASCONCELOS. Joaquim de - Arte religiosa em Portugal, vol. I, 1914-1915, fasc. 14.

${ }^{12}$ GINER DE LOS RíOS, Francisco e Hermenegildo - op. cit., pp. 201-203. As citações feitas em seguida reportam-se todas a esta obra.
} 
objetos de platería y joyería, bronces y obras en otros metales, sino telas, encajes y bordados; si bien todo my en pequeño". Não surpreende a alusão à pequenez do espaço e das colecções que se encontravam divididas essencialmente em duas secções, ourivesaria e têxteis, merecendo especial destaque a primeira - "La primera sección, que es la más importante, comprende principalmente alhajas de los extinguidos conventos, gran parte de las cuales, si mal no recordamos, se custodiaban antes en la Casa de Moneda". Com efeito, antes de darem entrada na Academia, tais alfaias podiam ser visitadas na Casa da Moeda onde se encontravam desde a extinção das ordens religiosas, facto que é corroborado por outros relatos mais antigos. Estas prenderam particularmente a atenção dos dois visitantes que fazem destacar algumas peças significativas, lamentando o facto de apenas terem tido oportunidade de dar "una ojeada más que rápida, única que se nos permitió á pesar de nuestros contrarios deseos". Numa curiosa preocupação didática, era notada a existência naquele núcleo de um conjunto de fotografias relativas à notável coleção de ourivesaria que o rei D. Fernando II conservava no Palácio das Necessidades, riquíssima em espécimes de uso civil em que o acervo da Academia era pobre ${ }^{13}$.

A segunda secção era, como se referiu, reservada aos têxteis, "en su mayor parte, producto de las antiguas artes industriales del país, que todavía en la actualidad ofrecen muestras como los encajes de Peniche. No creemos haya tapices, que, por lo demás, ya ha habido ocasión de indicar son en Portugal muy poco abundantes". Efetivamente, e ao contrário do que se registara no passado, as tapeçarias encontravam-se poucos presentes nas coleções nacionais, enquanto em Espanha eram ainda predominantes.

Atendendo a outras coleções visitadas em Lisboa, os irmãos Giner de los Ríos concluíam a sua análise referindo que "si el pequeño Museo de Arte Ornamental que se há comenzado á formar en una sala de la Academia de Bellas Artes" se reunisse aos objetos de arte conservados na Biblioteca Nacional ${ }^{14}$, igualmente instalada em

\footnotetext{
${ }^{13}$ Resultado da campanha efetuada em 1866 por Charles Thurston Thompson para o South Kensington Museum a que nos referimos no ponto 2.3 da III parte.

${ }^{14}$ Considerada modesta, aquela coleção reduzia-se a um pequeno núcleo numismático e a um conjunto variado de objetos (esmaltes, camafeus, estatuetas em bronze, etc). A peça mais significativa seria uma patena que pertencera ao Mosteiro de Alcobaça e que desapareceria em 1892
} 
São Francisco, e ao acervo do Museu Arqueológico do Carmo, "poniendolo todo, adémas, en relación con la ensenãnza teórica y pratica, se podría crear una escuelamuseo de artes decorativas, por menos, á imitación de las que, siguiendo el ejemplo de Kensington, vienen continuamente fundándose en las principales ciudades de Europa". O bom exemplo do South Kensington que enformara o pensamento do marquês de Sousa Holstein era aqui recordado, mas a dificuldade de o implementar era desde logo notada, a começar pela falta de um local adequado. Uma vez que o antigo convento de São Francisco e a cabeceira da igreja do Carmo tinham constrangimentos fortíssimos, era sugerida a utilização do quartel contíguo a esta última, edifício que "oferecería los medios necessários para una empresa de que tantos bienes podía reportar la cultura y aun la prosperidad material del generoso pueblo lusitano".

\section{Tesouros conventuais}

A ata da conferência académica de 19 de Janeiro de 1864 dava a conhecer que, por portaria do Ministério do Reino de 23 de Outubro do ano transacto, se havia ordenado "ao provedor da Casa da Moeda que dos objetos de ouro e prata pertencentes aos extintos conventos e depositados naquela repartição, se conservassem ali os que tivessem merecimento artístico para serem entregues a esta Academia" ${ }^{15}$. Resultante da vontade do marquês de Sousa Holstein em diversificar as coleções do estabelecimento que dirigia, aquela portaria estará na base do núcleo fundador do futuro Museu de Arte Ornamental.

A adaptação de uma sala para colocar em segurança as preciosas alfaias foi naquela ocasião discutida, tendo o vice-inspetor solicitado previamente a colaboração dos professores de arquitetura que elaboraram uma exposição sobre as obras a realizar para o efeito, acompanhada de um projeto de orçamento do custo aproximado das

na Exposição Colombina de Madrid. Os visitantes não lhe pouparam encómicos: "El interés culminante de la colección, á nuestro ver, se halla en la célebre patena de Alcobaça, preciosa peça de oro con esmaltes translúcidos y una inscripción, al parecer, en alemán antiguo. [...] A nuestro entender, es una de las más interesantes obras de platería que la Península posee, aunque manifiestamiente es alemana ó flamenca; y nunca nos consolaremos de no haber tomado de ella siquiera un ligero apunte que ahora permitiese bosquejar su descripción". Idem, ibidem, pp. 201-203. As citações feitas em seguida reportam-se todas a esta obra.

${ }^{15}$ Conferência extraordinária de 19 de Janeiro de 1864. Arquivo da ANBA, disponível em http://digitarq.dgarq.gov.pt/ PT-ANBA-ANBA-F-002-00001_m0125. 
mesmas. Na ata seguinte, e no intuito de se proceder à seleção dos referidos objetos, "nomeava os Srs. professores Tomás José da Anunciação, Victor Bastos e João Cristino da Silva para o coadjuvarem nesse trabalho em um dos próximos dias $^{\prime 16}$.

Menos de um mês depois, no Relatório acerca do estado da Academia Real de Belas Artes dirigido ao ministro do Reino, Sousa Holstein advogava que aquela coleção "sendo convenientemente colocada, classificada e catalogada, será de grande proveito para os industriais e para os artistas. É um núcleo precioso que muito convém ir aumentando, já com aquisições, já com idênticos objetos pertencentes ao governo ou que de futuro the venham a pertencer e que se acham espalhados em diferentes localidades" ${ }^{17}$. Reclama a necessidade da Academia dispor de uma verba para aquisições, e também para "pagar a um conservador inteligente e ilustrado a quem fosse cometido o cuidado de classificar estes objetos, estudá-los, publicar sobre eles trabalhos, e que tratasse de promover o aumento deste museu procurando objetos para o enriquecer e indicando o modo de os adquirir" ${ }^{18}$. Como adiante veremos, um conservador, ainda que interino, aparecerá oportunamente, mas mais complexa será a obtenção de uma verba estatal para aquisições.

Gizado a partir de 1863 , o processo transferência das alfaias para a Academia foi lento, não se sabe se pela demora das obras de adaptação do local que Ihes foi destinado, se por eventuais resistências do provedor da Casa da Moeda que nos ofícios trocados com Sousa Holstein deixa transparecer alguma crispação a esse respeito $^{19}$. Em Outubro de 1866, o Diario de Noticias anunciava estar para breve a transferência, afirmando ser "possível que a aparição de tais objetos, colocados em boa ordem e onde possam ser devidamente analisados, desperte o louvável desejo de se cuidar seriamente em se organizar um museu de antiguidades, coisa que ainda não possuímos" ${ }^{20}$. Não se enganava o jornal quanto ao real objectivo do marquês que viria finalmente a receber as peças a 14 de Fevereiro de 1867, na sequência de

\footnotetext{
${ }^{16}$ Conferência ordinária de 30 de Janeiro de 1864. Idem, disponível em http://digitarq.dgarq.gov.pt/ PT-ANBA-ANBA-F-002-00001_m0134.

${ }^{17}$ Relatório acerca do estado da Academia Real das Belas Artes. 26 de Fevereiro de 1864. Arquivo do MNAA, fundo José de Figueiredo, cx. 1, pasta 1, doc. 1.

18 Idem, ibidem.

${ }^{19}$ Veja-se, por exemplo, o ofício datado de 29 de Janeiro de 1864. Arquivo da ANBA, disponível em http://digitarq.dgarq.gov.pt/ PT-ANBA-ANBA-B-001-00003_m1770.

${ }^{20}$ Diario de Noticias, 21 de Outubro de 1866.
} 
um ofício emitido pela Secretaria de Estado dos Negócios da Fazenda. A relação então efectuada elenca um total de 65 lotes, sobretudo alfaias litúrgicas e jóias, sem indicação de proveniência, identificando-se facilmente algumas peças de importância maior como os dois cálices românicos ou a cruz processional gótica do Mosteiro de Alcobaça ${ }^{21}$.

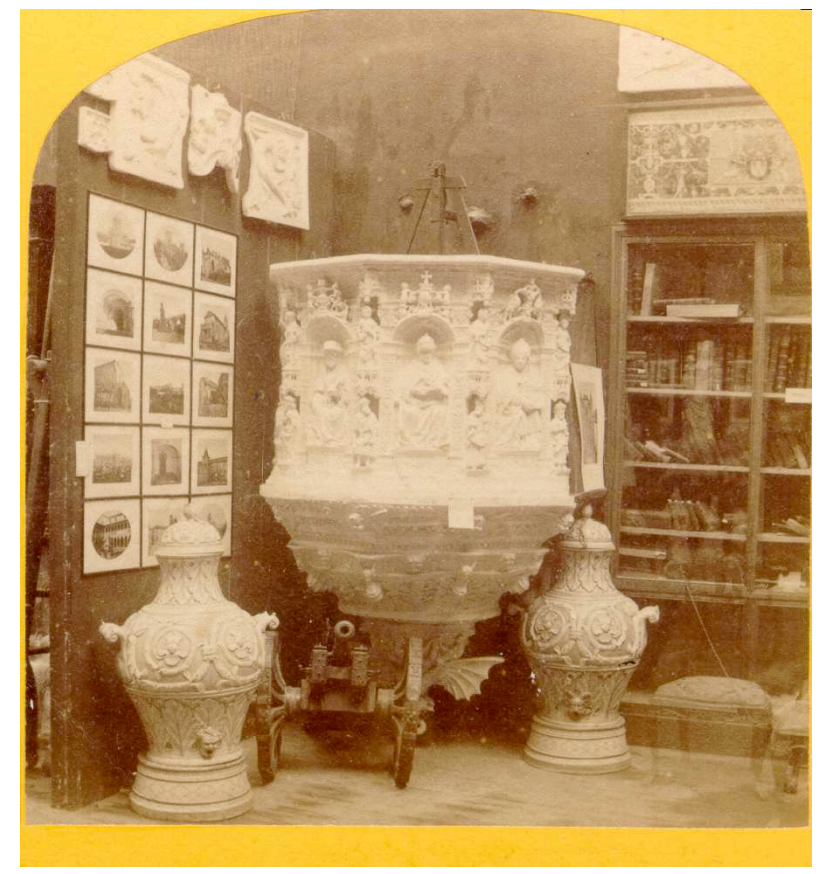

Fig. 86 - Fotografia da representação portuguesa da secção de História do Trabalho da Exposição Universal de Paris de 1867. Coleção particular.

O que parece ter impulsionado realmente a transferência daqueles objetos foi a aproximação da Exposição Universal de Paris de 1867, para a qual o nosso país tinha sido convidado a participar, tendo o governo nomeado Sousa Holstein para presidir à organização das secções de Belas Artes e de História do Trabalho ${ }^{22}$. Enquanto a primeira seria constituída por pinturas, esculturas, gravuras e desenhos de

\footnotetext{
${ }^{21}$ Relação dos objetos preciosos entregues em 14 de Fevereiro de 1867 ao vice-inspetor da Academia

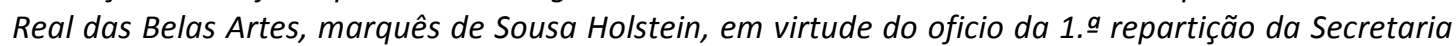
de Estado dos Negócios da Fazenda de 13 de Fevereiro de 1867. Arquivo do MNAA, fundo José de Figueiredo, cx. 1, pasta 2, doc. 8. Os objetos referenciados conservam-se atualmente no MNAA (inv. 87, 89 e 91 Our.).

${ }^{22}$ A nomeação ocorreu oficialmente a 14 de Fevereiro de 1867: "Atendendo ao merecimento e mais circunstâncias que concorrem na pessoa do marquês de Sousa Holstein, par do reino e vice-inspetor da Academia Real das Belas Artes de Lisboa: hei por bem nomeá-lo para organizar, na futura Exposição Universal de Paris as secções de Belas Artes e de História do Trabalho nas diferentes épocas anteriores ao séculos atual, devendo a instalação destas secções ser feita debaixo da sua imediata fiscalização". Apud SOUTO, Maria Helena - op. cit., p. 119.
} 
arquitetura executadas essencialmente por professores e académicos de mérito daquele estabelecimento, enformavam a segunda diversos objets d'art et d'industrie provenientes de coleções públicas e privadas (fig. 86). Marcaram presença algumas moldagens em gesso, cerâmicas, livros, manuscritos, fotos de monumentos e sobretudo uma alargada seleção das alfaias litúrgicas que haviam sido entregues meses antes à Academia pela Casa da Moeda, naquela que foi a primeira cedência de peças das suas coleções para uma exposição no estrangeiro ${ }^{23}$.

Presença destacada teve o rei D. Luís que fez enviar valiosos objetos em ouro e prata do tesouro real e da sua coleção pessoal, para além de uma alargada seleção da coleção de moedas que adquiria a Teixeira de Aragão. Distinto cirurgião militar e colecionador, com interesses centrados na numismática, Teixeira de Aragão seria encarregue de proceder à organização de parte do catálogo ${ }^{24}$ e à supervisão do transporte das moedas e dos restantes objetos enviados para a secção de História do Trabalho, onde figuraram com assinalável sucesso como nos dão conta os rapports $d u$ jury internacional ${ }^{25}$, entidade que conferiu à Academia uma medalha de prata $^{26} \mathrm{e}$ à participação de D. Luís uma médaille d’or. Encorajado por esse reconhecimento, e seguindo talvez o exemplo de Sousa Holstein com o Museu de Arte Ornamental que então se projetava, o monarca irá promover a pública exposição das moedas e dos objetos de ourivesaria no Palácio da Ajuda, paralelamente à pinacoteca que inaugurara naquele mesmo ano de 1867, no que ficará conhecido por Museu de Antiguidades da Ajuda ${ }^{27}$.

\footnotetext{
${ }^{23}$ No total a Academia cedeu 14 daqueles objetos. Cf. Catalogue spécial de la section portugaise à l'Exposition Universelle de Paris en 1867, pp. 345-352.

${ }^{24}$ Tratou-se especificamente da Description des monnaies, médailles et autres objets d'art incluída no catálogo citado na nota anterior. Foi também publicada em separado.

25 “De toutes les nations qui ont pris part à l'exposition internationale de l'Histoire du Travail, il en est peu dont le succès ait dépassé celui qu'a obtenu la section portugaise; ce succès dû à la magnificence de quelques-unes des oeuvres exposées et à leur bon classement, peut être aussi, à juste titre, attribué pour une bonne part aux efforts poursuivis par la commission royale [...]". CHEVALIER, Michel M. (dir) - Exposition universelle de 1867 à Paris: rapports du jury international, T. I, 1868, p. 236.

${ }^{26} \mathrm{Cf}$. a este respeito o ofício do Mistério das Obras Públicas datado de 6 de Outubro de 1868. Arquivo da ANBA, disponível em http://digitarq.dgarq.gov.pt/ PT-ANBA-ANBA-B-001-00003_m1794.

${ }^{27}$ XAVIER, Hugo - "O 'Museu de Antiguidades' da Ajuda: numismática e ourivesaria das coleções reais ao tempo de D. Luís". SILVA, Raquel Henriques da (coord.) - Revista de História da Arte, n. 8, 2011, pp. 71-87.
} 

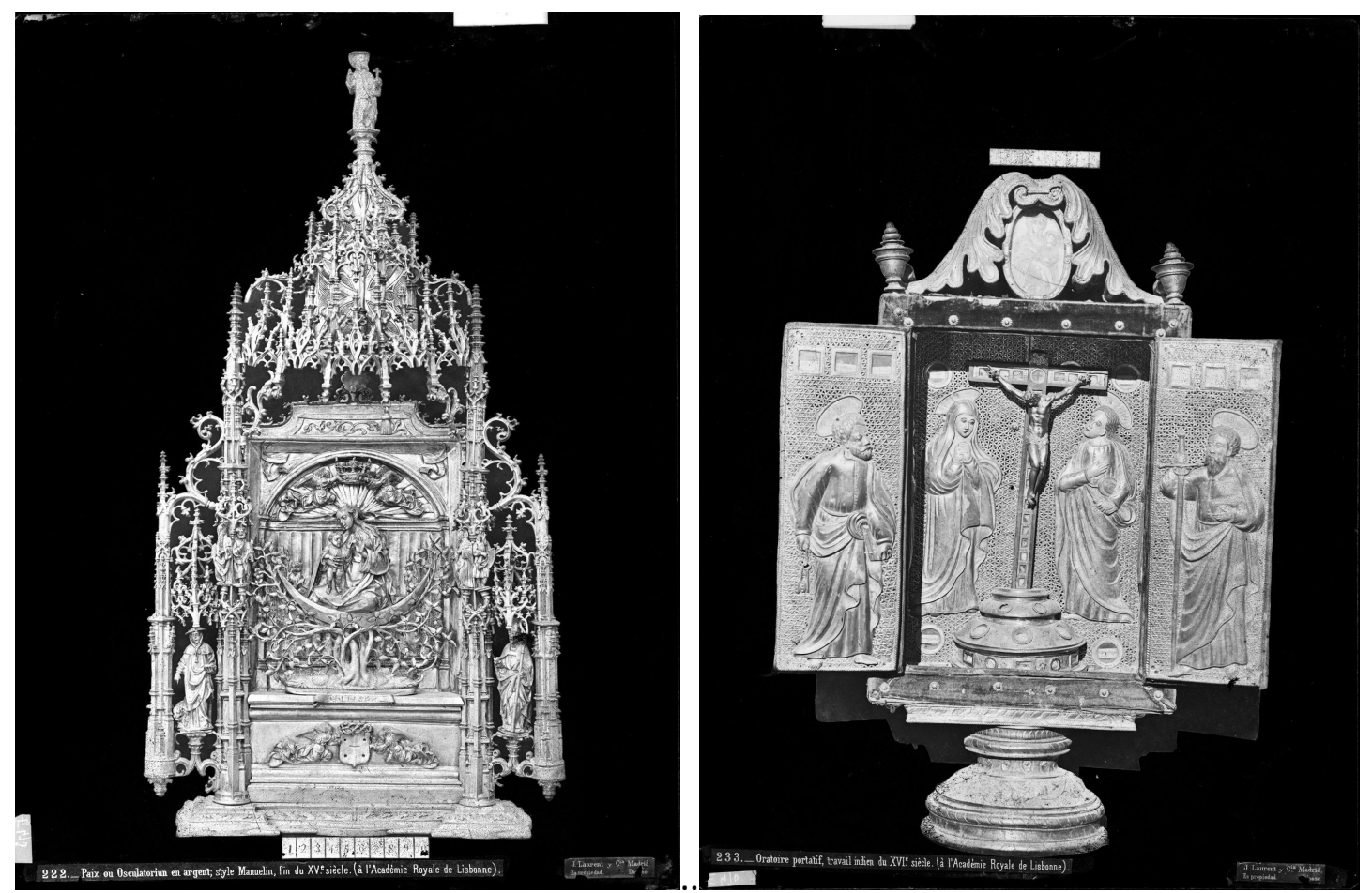

Figs. 87 e 88 - Porta-paz, prata, 1520-30; Oratório-relicário, séc. XVI. MNAA, inv. 93 e 99 Our. Digitalizações a partir de negativos de Jean Laurent, 1869. IPCE, VN-06591_P e VN-06595_P

Colocadas em evidência na exposição parisiense, com ecos na nossa imprensa que acompanhou de perto a representação nacional naquele certame ${ }^{28}$, as valiosas alfaias dos conventos extintos despertaram pouco depois a atenção de alguns fotógrafos no intuito de as reproduzirem e comercializarem as respectivas provas. Foi o caso de Jean Laurent que, em 1869, na campanha fotográfica analisada no ponto 3 da III parte, centrada essencialmente no acervo da Galeria Nacional de Pintura, não deixará de incluir alguns daqueles objetos, contribuindo assim para a divulgação internacional do acervo da Academia (figs. 87 e 88). Com efeito, os seus catálogos elencam um total de 14 fotos de diferentes alfaias (série B n.o 221 a 234) ${ }^{29}$, algumas das quais captadas em ângulos distintos para fixar diferentes pormenores, podendo ser adquiridas um pouco por toda a Europa através de uma excelente rede de agentes comerciais ${ }^{30}$. Algumas dessas fotografias serviram a partir de então de base a gravuras publicadas com alguma frequência em revistas

\footnotetext{
${ }^{28}$ Cf. Diario de Noticias, 9 Março 1867 e 30 Março 1867.

${ }^{29}$ Veja-se o catálogo de 1879 incluído na obra de ROSWAG, A. - op. cit., pp. 184-185.

${ }^{30}$ ARAÚJO, Nuno-op. cit., p. 105.
} 
nacionais, vindo a desempenhar um papel fundamental entre os ilustradores daquele período ${ }^{31}$.

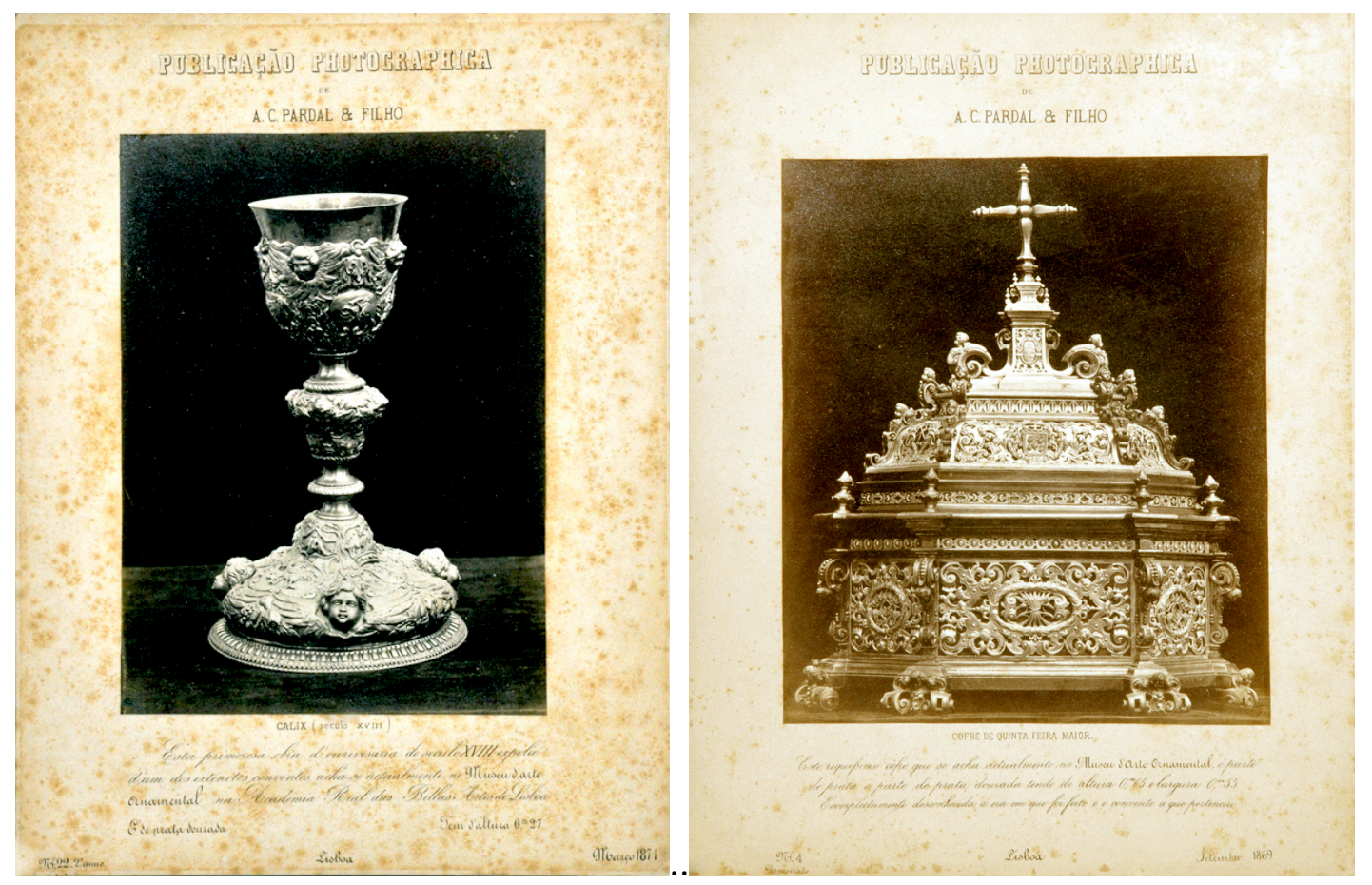

Figs. 89 e 90 - Cálice e cofre eucarístico. Publicação Photographica, n.o 22, Março 1871 e n. 4, Setembro de 1879

Entre nós avulta a iniciativa de Augusto César Pardal e do filho, Carlos Augusto Pardal, que, no mesmo ano de 1869, deram início à Publicação Photographica, obra editada por subscrição, com distribuição mensal e numeração sucessiva até 1877. Noticiava O Diario Popular que aquela publicação se destinava a "copiar alguns objetos de arte que existem na Academia de Belas Artes, saindo uma estampa por mês em formato igual ao do nosso jornal, custando cada uma 300 réis para os Srs. assinantes, pagos no ato da entrega de cada estampa" ${ }^{32}$. Não se circunscreveu todavia às alfaias da coleção académica, entremeadas com reproduções de matrizes negativas estrangeiras com gravuras de pintores célebres (Rafael, Poussin, Boucher, Ingres, entre outros) que passarão mais tarde a dominar a publicação. Na realidade, foram apenas reproduzidas 11 peças de ourivesaria, acompanhadas por curtas

\footnotetext{
${ }^{31}$ Entre outros exemplos, pode mencionar-se a revista O Occidente de 11 de Fevereiro de 1882, com uma gravura do oratório-relicário do Convento de Vidigueira "segundo uma fotografia de Laurent" como atesta a legenda.

${ }^{32}$ O Diario Popular, 21 Abril 1869.
} 
legendas explicativas como a de um cálice (fig. 89), ou sobretudo a de um cofre eucarístico (fig. 90) publicado em Setembro de 1869: "Este riquíssimo cofre que se acha atualmente no Museu de Arte Ornamental é parte de prata e parte de prata dourada tendo de altura 0,65 e largura 0,55. É completamente desconhecida a era em que foi feito e o convento a que pertenceu" ${ }^{\prime 33}$.

O desconhecimento sobre alguns dos objetos que integravam o acervo era efetivamente uma realidade mas as provas de albumina então realizadas irão constituir uma ferramenta essencial para o seu estudo. Joaquim de Vasconcelos que cedo reconheceu a importância das reproduções fotográficas para as suas investigações, recordará em 1908 o exemplo pioneiro a nível nacional da Publicação Photographica - “A coleção de fotografias da casa Pardal (1865-1872), que começou a arquivar os tesouros do chamado Museu de Arte Ornamental existente outrora em duas salas escuras da Academia de Belas Artes (Convento de S. Francisco de Lisboa) foi uma muito louvável tentativa, hoje esquecida"34.

\section{Enriquecimento do acervo}

Sousa Holstein mostrou-se atento ao processo de extinção das casas religiosas femininas que marcou a segunda metade de Oitocentos, procurando enriquecer o acervo da Academia com peças pertencentes ao domínio das artes decorativas. Ao contrário do que sucedera em 1834 relativamente aos conventos masculinos onde a pintura dominara o interesse das autoridades, procurava-se agora recolher também espécimes de mobiliário de uso civil ou eclesial, cerâmica, ourivesaria, joalharia, paramentaria, imaginária... Assim se reforçava a componente de origem conventual da coleção académica e se abriam novas possibilidades à afirmação do património móvel nacional, tudo sem dispêndio de aquisições. Como fez notar José Alberto Seabra Carvalho, essa oportunidade histórica veio assim "dar consistência a um

\footnotetext{
${ }^{33}$ Publicação Photographica, n.o 4, 1869

${ }^{34}$ VASCONCELOS, Joaquim de - "Arte decorativa portuguesa: ourivesaria portuguesa". ARROIO, António (dir.) - Notas sobre Portugal: exposição nacional do Rio de Janeiro: secção portuguesa, vol. II, 1908, pp. 260-261.
} 
modelo de museu central, eclético na natureza e conteúdos das suas coleções, representativo de uma secular produção artística nacional”35.

Em Dezembro de 1866, na sequência de um requerimento apresentado um mês antes ao Ministério dos Negócios Eclesiásticos e de Justiça, o vice-inspetor recebia um ofício concedendo "a autorização necessária para que V. Ex. a mande examinar se entre os objetos do suprimido convento de Nossa Senhora da Esperança de Vila Viçosa, existem alguns que por sua antiguidade ou mérito artístico devam ser conservados no museu ou nas galerias da Academia Real das Belas Artes de Lisboa, devendo a pessoa para esse fim comissionada por V. Ex. $\underline{\text { a }}$ dirigir-se ao arcebispo de Évora, a quem V. Ex.a se servirá de prevenir oportunamente" ${ }^{36}$. O encarregado de tal missão elaboraria meses mais tarde um longo relatório dirigido a Sousa Holstein com curiosas observações que importa aqui analisar ${ }^{37}$.

Começa por referir que tendo sido enviado a Vila Viçosa "para escolher no extinto convento de N. Sr.a da Esperança os objetos que fossem dignos de figurar no projetado Museu de Arte Ornamental, entendi que devia visitar não só o ponto que especialmente me fora designado mas todos os edifícios públicos ou particulares daquela Vila e arredores onde me constasse existirem objetos de arte notáveis por qualquer razão". Acrescenta pouco depois que, com as restantes visitas, teve por intenção fazer "uma resenha que pudesse servir de base às pesquisas da Academia, dando a essa repartição elementos para de certo modo poder vigiar pela conservação de tantas coisas de valor que ali se perdem por ignorância ou por incúria".

Depois de várias divagações sobre o vandalismo e sobre a necessidade do Estado proceder "sistemática e minuciosamente a pesquisas como esta", concentra-se no objectivo principal da missão, o convento de Nossa Senhora da Esperança que havia

\footnotetext{
${ }^{35}$ CARVALHO, José Alberto Seabra - “'A recolta devia fazer-se estugadamente e por completo'. Patrimónios em trânsito: extinguir conventos e criar museus". 100 anos de património: memória e identidade, 2010, p. 37.

36 Ofício datado de 4 de Dezembro de 1866. Arquivo da ANBA, disponível em http://digitarq.dgarq.gov.pt/ PT-ANBA-ANBA-B-001-00003_m1830 e_m1831.

37 "Relatório dirigido ao vice-inspetor da Academia Real de Belas Artes de Lisboa o Ilmo. e Exmo. Sr. marquês de Sousa Holstein por Domingos Maria Gonçalves em 6 de Maio de 1867". Arquivo do MNAA, fundo José de Figueiredo, cx. 1, pasta 11, doc. 2. As citações feitas em seguida reportam-se todas a este documento.
} 
sido extinto por decreto de 27 de Outubro de $1864^{38}$. De acordo com o relato, a igreja daquela casa religiosa fora "entregue a uma ordem terceira que a conserva com certa decência; o resto do edifício não encontrou aplicação à exceção do dormitório que atualmente serve de sala de representações dramáticas a uma companhia espanhola. Os quadros, alfaias e outros objetos de culto, tendo sido depositados em casa do prior de N. Sr.a da Conceição, José Vaz Touro, foram depois dados a diversas confrarias e pessoas particulares".

$\mathrm{Na}$ realidade, o encarregado seria confrontado com poucas peças de interesse maior, selecionando para o acervo da Academia uma imagem de pedra representado Nossa Senhora da Conceição e uma cadeira em madeira e couro, muito provavelmente uma cadeira de sola, "por me parecerem objetos, não direi de valor artístico, mas de certo merecimento pela época em que deviam ter sido feitos". Mostrando interesse pelas nossas antigas artesanias ou indústrias artísticas, informa ter igualmente reservado uma arca em couro decorada com ferragens "que me atraiu a atenção pela originalidade das formas e que no meu entender pode bem marcar um período em que o trabalho em ferro estava em grande atraso".

Quase sempre resultado de alienações promovidas pelas últimas freiras ou por funcionários governamentais pouco escrupulosos, as referências à pobreza das coleções dos conventos femininos extintos foram então uma constante. Tais situações serão até ao início do século XX muitas vezes denunciadas, conhecendo em Fialho de Almeida um dos críticos mais insistentes: "Morre a última freira dum recolhimento... quando o delegado do museu lá chega, ou já não encontra nada que arrolar, ou recolhe apenas bugigangas e tarecos velhos, sem valor - não sendo raro que mesmo destes, a quantidade baixe, não se sabe entre mãos de quem, no trajeto de uma casa para outra" ${ }^{39}$. Como já foi notado, o aparente exagero dos críticos é "certamente verosímil" dada a exiguidade das incorporações registadas, muito longe da torrente de bens móveis acalentada ${ }^{40}$.

\footnotetext{
${ }^{38}$ Após a extinção do Convento, as religiosas professas Angélica Perpétua Peregrina do Céu, Ana Peregrina (Rijo), e Mariana Peregrina da Conceição, foram obrigadas a sair por não constituírem canónica e civilmente o número legal para satisfazer os fins da instituição. A este respeito cf. Inventário de extinção do Convento de Nossa Senhora da Esperança de Vila Viçosa, disponível em http://digitarq.dgarq.gov.pt/ PT/TT/MF-DGFP/E/002/00036.

${ }^{39}$ ALMEIDA, Fialho de - op. cit., p. 84.

${ }^{40}$ CARVALHO, José Alberto Seabra - op. cit., p. 38.
} 
Relativamente a Nossa Senhora da Esperança de Vila Viçosa, o encarregado de Sousa Holstein informa que sobre a antiga abadessa "pesam graves suspeitas de roubo, isto no dizer de diversos funcionários e de diferentes pessoas que conheciam perfeitamente o mosteiro". Ao notar a falta de um crucifixo em marfim a que diz aludir Frei Jerónimo de Belém na sua Chronica Seraphica ${ }^{41}$, entraria em contacto com uma das três últimas freiras a ocupar o edifício, transferida para outro recolhimento daquela vila. "O que essa senhora me contou sobre o viver dos últimos tempos naquela casa monacal é coisa curiosíssima, e que agravou bastante mais o meu conceito em que já era tida por mim a ex-abadessa".

Terminada a indagação sobre o recheio daquele convento, deu então início à prospecção por outras casas religiosas da zona, como o convento de S. Paulo onde assinalou algumas telas de "muito valor", passando depois a Estremoz, com visitas a diferentes igrejas e conventos, como o das freiras de Malta onde se deparou com "uma bela custódia de rico lavor cuidadosamente conservada que muito me prendeu à atenção".

Foi ainda conhecer a igreja matriz de Borba e o convento da Luz de Rio de Moinhos, este último na posse de um particular, lamentando não ter conseguido visitar o convento de São Paulo da Serra d'Ossa “onde me dizem existirem objetos de muito merecimento, mas o estado precário da minha bolsa, vazia quase do meu dinheiro e do pouco que recebera da Academia [...] obrigou-me a retirar para Lisboa". Ao terminar, não deixa de deplorar a forma "porque está sendo executada a lei de 4 de Abril de 1861 sobre as corporações religiosas". Acrescenta que os inventários de 1858 pecavam por ser vagos e genéricos, sem menção explicita aos objetos de valor, "sendo porta aberta a quantos abusos se quiserem praticar".

O relatório encontra-se assinado por Domingos Maria Gonçalves, homem de espírito voluntarista e de consciência patrimonial que se predispôs fazer mais do que the havia sido solicitado, deixando à Academia um levantamento artístico possível das localidades visitadas. Dominando bem a escrita, conhecedor de fontes históricas (recorde-se a referência à Chronica Seraphica de Frei Jerónimo de Belém), e dotado

\footnotetext{
${ }^{41}$ BELÉM, Frei Jerónimo de - Chronica Seraphica da Sancta Província dos Algarves, da regular observancia do seraphico P. S. Francisco; em que se trata da sua origem, progressos e fundação dos seus conventos, 1750.
} 
de genuíno interesse por todos os domínios da história da arte, este funcionário público que exercia até então funções de "condutor de engenharia civil", será convidado a assumir o cargo de conservador do futuro Museu de Arte Ornamental. Meses após o regresso da viagem ao Alentejo, e como já tivemos anteriormente oportunidade de aludir, escreve com o seu colega Alfredo Camarate, responsável pela coleção de desenhos e gravuras, um pertinente ofício dirigido ao vice-inspetor, onde apelam à necessidade de se habilitarem "com os necessários estudos afim de cumprirem as obrigações a seu cargo", o que não poderia ser feito "sem visitarem alguns museus estrangeiros e tratarem com indivíduos que pelos seus conhecimentos e práticas lhes possam servir de mestres" ${ }^{\prime 2}$. Para tal, propõem-se residir durante três meses em Madrid e Paris, e enviar mensalmente à Academia relatórios circunstanciados dos seus trabalhos, devendo o Estado assegurar uma verba adicional ao valor dos vencimentos que usufruíam. Destinada a preparar convenientemente os dois funcionários para cargos sem tradição entre nós, aquela diligência terá ficado sem efeito atendendo às recusas do governo em dar seguimento às constantes solicitações da Academia.

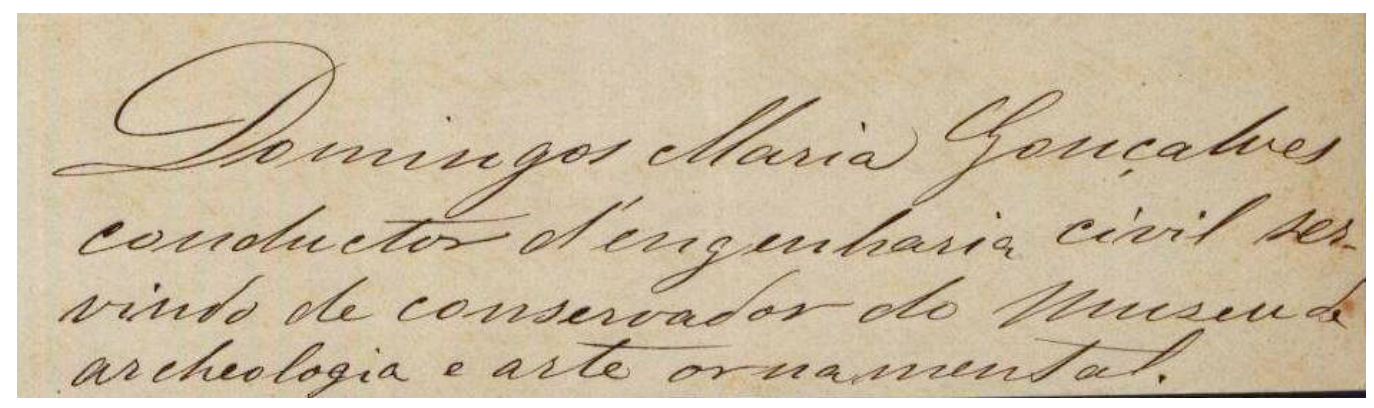

Fig. 91 - Assinatura de Domingos Maria Gonçalves, 1869. Arquivo da ANBA.

Domingos Gonçalves continuará a ser encarregue por Sousa Holstein de outras "comissões artísticas", como a que efetuou em Maio de 1869 ao distrito da Guarda. Essa informação é-nos revelada num ofício onde participa ao vice-inspetor a existência de problemas burocráticos relativos ao pagamento de honorários que the eram devidos e à sua entrada efetiva nos quadros da Academia, assinando como

42 Ofício datado de 12 de Outubro de 1867. Arquivo da ANBA, disponível em http://digitarq.dgarq.gov.pt/ PT-ANBA-ANBA-B-001-00003_m1296 e_m1297. 
"condutor de engenharia civil servindo de conservador do museu de arqueologia e arte ornamental" (fig. 91) ${ }^{43}$.

Não dispomos de mais dados sobre a campanha empreendia na Guarda mas sabemos que a viagem ao Alentejo teve bom eco junto do então ministro da Fazenda, José Luciano de Castro, que em Agosto de 1868 ordenou a transferência para a Academia de todos os objetos selecionados no Convento de Nossa Senhora da Esperança de Vila Viçosa ${ }^{44}$.

Encarregado por Sousa Holstein de algumas campanhas de recolha de objetos foi também Augusto Filipe Simões, lente da Universidade de Coimbra que entre 1875 e 1876 esteve ao serviço da Academia, integrado na comissão encarregada de estudar a reforma do ensino artístico e a organização dos museus. Concluídos os trabalhos da comissão, Filipe Simões cujas investigações nos domínios da arqueologia e da história da arte eram já reconhecidas, ${ }^{45}$ viria a exercer algumas tarefas relacionadas com a classificação e a incorporação de peças, entre as quais uma deslocação a Montemor-o-Novo para examinar o espólio de um convento feminino extinto. A 13 de Março de 1876, enviava a seguinte carta ao vice-inspetor: "Não tenho querido escrever a V. Ex. a antes de concluir a minha missão em Montemor, afim de poder dar-Ihe melhor informação. O resultado não foi muito bom, porém também não foi tão mau como se esperava. Deixei apartados 14 objetos de prata e o mais que V. Ex. verá nas relações que irão com o ofício que somente de Setúbal poderei dirigir-lhe. De sedas, damascos e brocados há grande variedade. Creio que se fará boa aquisição para a secção de tecidos. É lamentável que alguns estejam muito estragados” ${ }^{46}$. Modesto como não era de estranhar, o acervo selecionado pertencia ao convento da Saudação de Montemor-o-Novo que Filipe Simões entendia dever ser adaptado a asilo como sucedeu a tantos outros. Durante a sua estadia naquela localidade, procurou identificar alguns objetos de importância maior e, ao visitar a Misericórdia, encontrou uma arqueta gótica em prata dourada que quis fazer reverter para a

\footnotetext{
${ }^{43}$ Ofício datado de 1 de Julho de 1869. Arquivo da ANBA, disponível em http://digitarq.dgarq.gov.pt/ PT-ANBA-ANBA-B-001-00003_m1490 a_m1492.

${ }_{44}$ Ofício datado de 6 de Agosto de 1868. Arquivo da ANBA, disponível em http://digitarq.dgarq.gov.pt/ PT-ANBA-ANBA-B-001-00003_m1804.

${ }^{45}$ Autor de vasta bibliografia, destacando-se Relíquias da arquitectura romano-bizantina em Portugal, e particularmente na cidade de Coimbra (1870) ou Da arquitectura religiosa em Coimbra, durante a Idade Média (1875), para além das colaborações em periódios.

${ }^{46}$ FREITAS, Eugénio da Cunha e (org.) - op. cit., p. 57.
} 
Academia, trocando-a com alguma das pinturas existentes em reserva. Confidenciou a Sousa Holstein que "se a troca se realizar será uma aquisição valiosíssima. Duvido, porém, disto, apesar de não ligarem até hoje à arqueta importância alguma, hão-de imaginar de hoje em diante que têm ali um grande tesouro" ${ }^{\prime 47}$.

A troca de alfaias litúrgicas na posse de irmandades, paróquias ou Misericórdias por pinturas consideradas de interesse menor ou por outras alfaias de valor artístico inferior na posse da Academia, foi outra das modalidades utilizadas para o enriquecimento do acervo. De acordo com a ata da conferência académica de 19 de Agosto de 1868, o Ministério do Reino, atendendo a uma proposta do vice-inspetor, deliberara nesse sentido, autorizando-o "a obter por troca dos párocos e juntas de paróquia as alfaias e paramentos a que estejam ligadas recordações históricas ou que tenham reconhecido merecimento artístico, afim de serem colocados os referidos objetos no museu nacional ${ }^{\prime 48}$. Exemplo disso foi a permuta efectuada a 13 de Janeiro de 1875 com a Ordem Terceira de Nossa Senhora do Carmo de Lisboa, detentora de uma importante custódia "de prata dourada e lavrada", cedida em substituição de uma outra custódia e de um pequeno conjunto de objetos em prata, tais como patenas e colheres litúrgicas, no valor total de $259 \$ 958$ reis $^{49}$. Permitia-se assim a Academia acrescer o seu acervo com peças de relevo sem dispêndio de verbas, utilizando como moeda de troca as alfaias e restantes objetos de somenos importância recolhidos nos conventos femininos que se iam extinguindo.

As corporações religiosas não foram as únicas a ser alvo da atenção do vice-inspetor que procurou de igual modo indagar por objetos com interesse histórico e artístico existentes em ministérios, secretarias de Estado e em outras repartições públicas. Em 1868, ao tomar conhecimento de uma cadeira alegadamente utilizada pelo marquês de Pombal enquanto ministro, peça localizada no Ministério da Guerra que a recolhera na antiga Secretaria de Estado do Pátio das Vacas, em Belém, solicita de imediato a sua transferência para as coleções da Academia. O ministro da Guerra

\footnotetext{
${ }^{47}$ Idem, ibidem, p. 57.

48 Conferência ordinária de 19 de Agosto de 1868. Arquivo da ANBA, disponível em http://digitarq.dgarq.gov.pt/ PT-ANBA-ANBA-F-002-00001_m0511.

49 "Relação e valor intrínseco dos objetos de prata e ouro que a Academia Real das Belas Artes de Lisboa foi autorizada a trocar por uma custódia de prata dourada e lavrada pertencente à venerável ordem de Nossa Senhora do Monte do Carmo da mesma cidade". Arquivo do MNAA, fundo José de Figueiredo, cx. 1, pasta 2, doc. 9.
} 
que se servia da referida cadeira no seu gabinete, responderá ao vice-inspetor num longo ofício onde questiona o valor artístico da mesma e a sua associação ao célebre ministro de D. José: “Quanto ao valor artístico é completamente nulo e mal figura ela entre os primores de arte coligidos pela Academia. Estas razões juntas à incerteza da origem fazem com que eu não possa satisfazer o pedido de V. Ex. ${ }^{\prime \prime}{ }^{50}$. Dezasseis anos mais tarde, ultrapassadas as resistências dos sucessivos ministros, a cadeira era finalmente entregue ao sucessor de Sousa Holstein, Delfim Guedes ${ }^{51}$.

Especial relevância terá a transferência para a Academia de grande parte do espólio da Sociedade Arqueológica Lusitana, responsável pelas escavações das ruínas romanas de Cetóbriga, em Tróia ${ }^{52}$. Fundada por vários associados em 1849 e presidida pelo pai do marquês de Sousa Holstein, a quem a Antiguidade Clássica muito interessou, aquela sociedade encontrava-se então moribunda, encontrandose o produto das escavações dividido entre os diferentes associados. Uma portaria do Ministério do Reino obtida a instâncias do vice-inspetor obrigará, em 1868, à entrega do material constituído essencialmente por jóias em ouro, objetos em barro e fragmentos arquitectónicos em mármore como se pode depreender de algumas relações efectuadas ${ }^{53}$. Como adiante veremos, o marquês procurará incrementar aquele espólio com vista à criação de uma secção arqueológica que só terá lugar a partir de 1884 com o nascimento do Museu Nacional de Belas Artes e Arqueologia. Refira-se ainda que o interesse de Sousa Holstein por esse domínio levou-o a manter contactos com o arqueólogo Martins Sarmento (1833-1899), a quem recomendou para louvor a D. Luís pelos trabalhos de exploração da citânia de Briteiros, nos arredores de Guimarães ${ }^{54}$.

50 Oficio datado de 26 de Junho de 1868. Arquivo da ANBA, disponível em http://digitarq.dgarq.gov.pt/ PT-ANBA-ANBA-B-001-00003_m1796 a_m1798.

${ }^{51}$ Oficio datado de 21 de Novembro de 1884. Idem, disponível em http://digitarq.dgarq.gov.pt/ PTANBA-ANBA-B-001-00002_m0311.

${ }^{52}$ Cf. RIBEIRO, José Silvestre - op. cit., T. VII, pp. 303-324.

53 "Relação de vários objetos ou antigualhas pertencentes à Sociedade Arqueológica Lusitana que o sócio o Sr. Domingos Garcia Peres tinha em seu poder e entregou à Academia das Belas Artes de Lisboa" e "Relação de vários objetos ou antigualhas pertencentes à Sociedade Arqueológica Lusitana que estavam em poder do sócio João Carlos de Almeida Carvalho e que este entregou à Academia das Belas Artes de Lisboa". Documentos datado de 26 e 21 de Fevereiro de 1868 respectivamente. Arquivo do MNAA, fundo José de Figueiredo, cx. 1, pasta 3, doc. 5.

${ }^{54}$ RIBEIRO, José Silvestre - op. cit., T. VII, p. 324. 
Mas não só de transferências de objetos se enriqueceu o acervo da Academia que foi sendo também objecto de algumas doações. Logo em 1866, o vice-inspetor anunciava em sessão académica "o valioso oferecimento recebido do célebre Museu de South Kensington da cidade de Londres, feito por imediata intervenção do ilustre e benemérito consultor de belas artes do dito museu, J. C. Robinson" ${ }^{55}$. Entre outros artigos, tais como catálogos ou álbuns fotográficos destinados à biblioteca, compreendia a oferta um conjunto de 33 reproduções em gesso de placas de marfim e metal, possivelmente de espécimes medievais e renascentistas de que a coleção daquele museu era rica, uma cópia também em gesso de um pequeno cupido em bronze cuja autoria era dada a Miguel Ângelo, e uma reprodução galvanoplástica do "Martelli Mirror" que então se atribuía a Donatello ${ }^{56}$. Impossibilitada de competir no mercado internacional por originais daqueles autores, regozijava-se a Academia com aquela doação que ocorreu na sequência da visita Robinson ao estabelecimento, em 1865, e da sua nomeação para académico honorário, no início do ano seguinte.

Como bem refere Emília Ferreira, se em termos artísticos o valor da reprodução nos parece hoje questionável, convém recordar que sob o ponto de vista pedagógico, "em especial quando estava em causa a formação de estudantes, ela era então tida como absolutamente incontornável, sendo prática regular em inúmeros museus (e academias) oitocentistas, sobretudo nos que tinham claras ambições e responsabilidades educativas" 57 . A responsabilidade pedagógica do South Kensington Museum estendia-se portanto à oferta de cópias às instituições com quem mantinha contactos. Não será caso isolado pois em 1871, numa demonstração de boa vizinhança, o governo espanhol oferecia à Academia algumas cópias em gesso de originais da Antiguidade conservados na Academia de S. Fernando e no Museu do Prado de Madrid ${ }^{58}$.

\footnotetext{
55 Conferência ordinária de 5 de Julho de 1866. Arquivo da ANBA, disponível em http://digitarq.dgarq.gov.pt/ PT-ANBA-ANBA-F-002-00001_m0361.

56 "Relação dos objetos recebidos do Museu de South Kensington, no dia 12 de Junho de 1866". Arquivo do MNAA, fundo José de Figueiredo, cx. 1, pasta 2, doc. 5.

${ }^{57}$ FERREIRA, Emília - op. cit., p. 131. Sobre a questão das reproduções nos museus oitocentistas cf. também Chantal Georgel - "Le musée, lieu d'enseignment, d'instrution et d'edification". La jeunesse des musées: les musées en France au XIXe siècle, 1994, pp. 58-70.

${ }^{58}$ Cf. Catalogo dos objectos offerecidos pelo governo hespanhol à Academia Real das Bellas Artes de Lisboa e a outros estabelecimentos de Portugal em 1871.
} 
Fora do âmbito institucional, deve ser aqui mencionada a iniciativa de alguns particulares que procuraram contribuir também com algumas ofertas. Foi o caso do marquês de Penafiel que, tendo emprestado à Academia três pratos em faiança da fábrica portuense do Cavaquinho para figurarem secção de História do Trabalho da Exposição Universal de Paris, entendeu oferecer um deles para o museu ${ }^{59}$. De assinalar foi igualmente a doação de um frontal de altar em azulejos localizado e mandado arrancar por um conhecido do vice-inspetor, José de Sousa Freire, numa igreja arruinada de Coruche ${ }^{60}$. Ainda no domínio da azulejaria, merece destaque uma incorporação ocorrida em 1868: um conjunto não especificado de painéis provenientes do convento de São Paulo da Serra de Ossa. O arranque e o transporte ficaram por conta da Academia como atesta uma pormenorizada factura que discrimina, por exemplo, a aquisição na vila do Redondo dos caixotes em madeira para a colocação dos azulejos, a condução dos mesmos até o convento da Serra de Ossa, os pagamentos efectuado aos dois operários encarregados de proceder ao arranque dos painéis, e o transporte dos ditos para Évora onde seguiram pelos caminhos de ferro ${ }^{61}$.

Aquela despesa totalizou $38 \$ 300$ reis e foi suportada pelo remanescente da verba que o rei D. Fernando II cedera da sua dotação à Academia para a aquisição de quadros com destino à Galeria Nacional de Pintura ${ }^{62}$. O que restou dessa verba foi ainda utilizado para pagar uma "bandeja de cobre dourado" (eventual prato de oferendas de Nuremberga), uma espada e uma cruz processional em metal, estas duas últimas compradas a um intermediário do marquês de Sousa Holstein, José Joaquim de Almeida, que naquele ano de 68 enviava à Academia um conjunto muito

\footnotetext{
${ }^{59}$ Carta datada de 5 de Abril de 1869. Arquivo da ANBA, disponível em http://digitarq.dgarq.gov.pt/ PT-ANBA-ANBA-B-001-00003 m1542 e m1543.

${ }^{60}$ Carta datada de 15 de Março de 1876. Arquivo do MNAA, fundo José de Figueiredo, cx. 1, pasta 6, doc. 5

61 "Relação do que despendi por conta, ordens e autorização do Exmo. Sr. marquês de Sousa, com o arranque dos azulejos e colocação de outros e no mais que abaixo menciono, praticado em Setembro de 1868". Idem, cx. 1, pasta 3, doc. 6/122.

62 "Objetos de arte ornamental comprados com a verba cedida à Academia Real de Belas Artes de Lisboa por Sua Majestade El-Rei o Senhor D. Fernando". Documento datado de 1 de Fevereiro de 1870. Arquivo do MNAA, fundo José de Figueiredo, cx. 1, pasta 3, doc. 6.
} 
diversificado de objetos (armas, móveis, têxteis, cerâmicas, pratas...) oriundos do norte do país ${ }^{63}$.

Sempre que as magras possibilidades do cofre da Academia permitiam, Sousa Holstein efetuará aquisições, procurando colmatar lacunas em algumas áreas do acervo. Logo em 1867 adquiria no estabelecimento de Martin Blumberg, "antiquário de S. M. El-Rei D. Fernando" como era orgulhosamente indicado no cabeçalho da factura, uma "talha de louça antiga portuguesa com cores" pela importância de $36 \$ 000$ reis $^{64}$. Anos mais tarde, e ainda no domínio da cerâmica cujos preços se revelavam mais apelativos, temos registo da aquisição de dois pratos em faiança e dois outros "da Índia", isto é, em porcelana chinesa da Companhia das Índias, na agência de leilões de Casimiro Cunha (fig. 92) ${ }^{65}$, destacado negociante que já vimos ter vendido à Academia uma natureza-morta proveniente da coleção dos duques de Lafões.

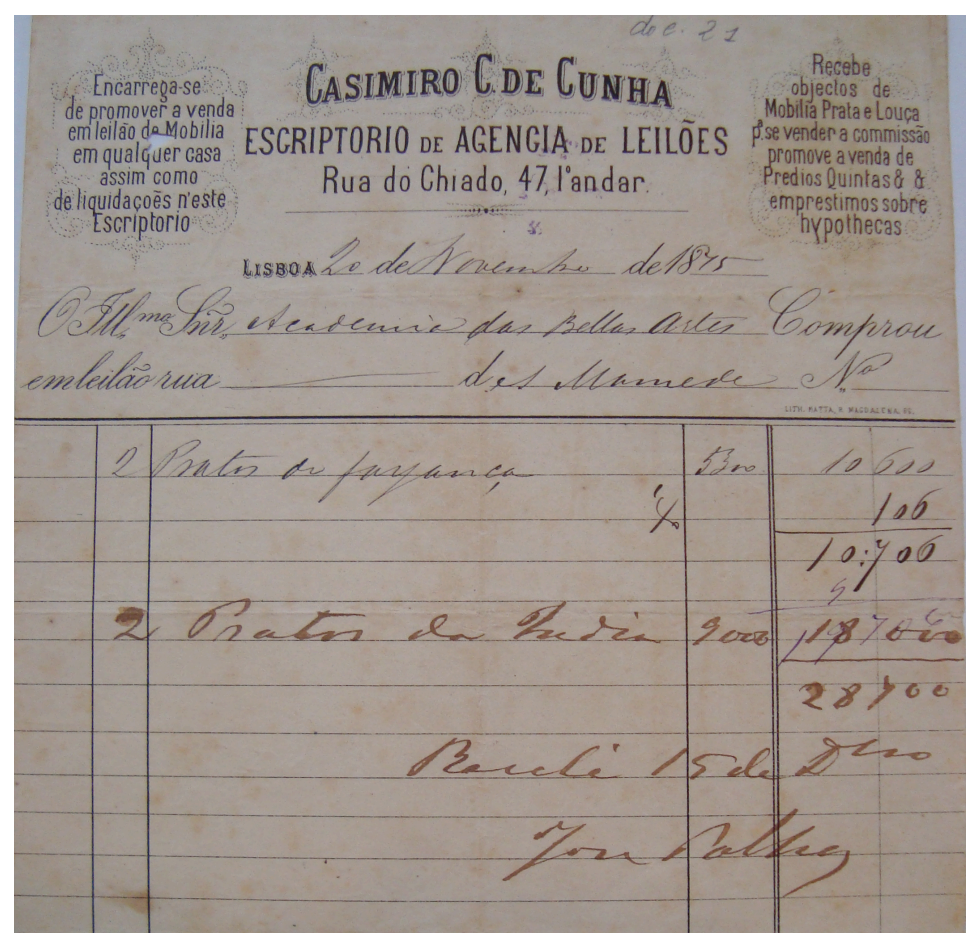

Fig. 92 - Factura da leiloeira de Casimiro Cunha relativa à aquisição de quatro pratos em cerâmica pela Academia de Belas Artes, 1875. Arquivo do MNAA

\footnotetext{
63 "Objetos comprados por José Joaquim de Almeida da cidade de Braga e remetidos à Real Academia das Belas Artes por ordem do Exmo. Sr. marquês de Sousa Holstein". Idem, cx. 1, pasta 3, doc. 2.

${ }^{64}$ Factura datada de 20 de Maio de 1867. Idem, cx. 1, pasta 2, doc. 9.

${ }^{65}$ Factura datada de Novembro/Dezembro de 1875. Idem, cx. 1, pasta 5, doc. 21.
} 
Esse tipo registos, de que citamos apenas dois exemplos, revelam a existência de um mercado de arte especialmente direcionado para as artes decorativas, o bric-à-brac na jocosa expressão coeva, que havia sido em larga medida impulsionado e alimentado pelo rei-artista, possuidor de uma notabilíssima coleção nesse domínio. Nas palavras de Ramalho Ortigão, "Foi ele quem pôs em moda na sociedade de Lisboa o gosto do bric-à-brac, salvando por esse modo de se dispersarem ao desbarato, ridiculamente e vergonhosamente vendidos, para a Inglaterra e Holanda, os últimos documentos que ainda existiam no país para a história de tantas industrias famosas e perdidas, iniciando assim por uma corrente de dandismo e de imitação aristocrática o gosto dos estudos históricos, da arqueologia, da história da arte ornamental” ${ }^{66}$.

O apetite dos estrangeiros pelas peças conservadas em Portugal era desde há muito notado por vários autores. "Há sessenta anos que o South-Kensington Museum de Londres mantém entre nós agentes seus, com ordem de vindimarem o país de todos os objetos de arte que apareçam" acusava em 1893 Fialho de Almeida ${ }^{67}$. Agentes do South-Kensignton ou não, certo é que havia ingleses a deslocarem-se expressamente a Lisboa e a publicarem anúncios nos jornais para esse efeito. Durante o mês de Novembro de 1867, foram vários os anúncios publicados no Diario de Noticias por um "cavalheiro inglês, colecionador de obras de arte e curiosidades antigas" que desejava comprar diversos tipos de peças, de porcelanas a bronzes passando por esmaltes e objetos em cristal de rocha ou outros materiais com montagens em metais preciosos. Os interessados apenas teriam de "dirigir-se em pessoa ou por escrito ao Hotel Bragança, sala n. 5 , das 10 às 12 da manhã, e das 3 às 5 da tarde" ${ }^{68}$. Sousa Holstein estava consciente do perigo que represava o êxodo de objetos de arte das coleções nacionais para o exterior, como bem expressou logo em 1864, no relatório dirigido ao ministro do Reino, "porque o estabelecimento dos caminhos de ferro deve trazer a Portugal grande número de estrangeiros; as províncias serão mais facilmente visitadas e os objetos de arte ali existentes, ou serão exportados ou subirão de valor". Chamava particularmente a atenção do ministro para as partilhas

\footnotetext{
${ }^{66}$ ORTIGÃO, Ramalho - As Farpas, t. III, 3. ed., 1945, p. 153.

${ }^{67}$ ALMEIDA, Fialho de - Vida irónica: jornal d'um vagabundo, 5.a ed, 1924, p. 31.

${ }^{68}$ Diario de Noticias, 5 de Novembro de 1867.
} 
efectuadas por algumas grandes casas, consequência da extinção dos vínculos, que lançariam para o mercado peças de valor que importava acautelar. Como tal, lembrava não existirem "no nosso país leis que proíbam a exportação de objetos de arte. Conviria muito determinar que nenhum destes pudesse ser levado para fora sem ser oferecido ao Governo que deveria ter a preferência para comprá-lo". Refere por isso ser "de suma utilidade que a Academia pudesse dispor de uma soma anual para estas aquisições" ${ }^{69}$. Passados alguns anos e diferentes ministérios, a tão sonhada verba seria prometida ao vice-inspetor que se envolveu precipitadamente num grande fulgor aquisitivo, com pesadas consequências. Veremos o seu resultado no ponto seguinte.

\section{Derradeiras aquisições de Sousa Holstein}

A 3 de Outubro de 1878, o então diretor Tomás da Anunciação, reunido com os restantes professores da Academia, propunha que "se lançasse na ata um voto de profundo sentimento pelo falecimento do vice-inspetor o Exmo. marquês de Sousa Holstein" ocorrido três dias antes. Simultaneamente, seria levantada uma questão relativa às aquisições efectuadas nos últimos anos pelo marquês, ficando na mesma ata registado que "não tendo a conferência conhecimento de vários contratos feitos pelo Exmo. Sr. marquês de Sousa Holstein com referência à compra de objetos para enriquecimento das coleções existentes nesta Academia, resolveu depois de larga discussão que se oficiasse ao governo participando que não tomaria ingerência neste assunto, enquanto não for superiormente autorizada" ${ }^{\prime 70}$.

Obrigando à convocação expressa da conferência, a resposta do Ministério do Reino não se fez tardar e ordenará que a Academia esclareça melhor a sua posição, tendo Miguel Ângelo Lupi elaborado um esboço de um ofício que será naquela ocasião aprovado. Entre outras considerações, declarava que tendo o vice-inspetor chamado a si a administração exclusiva das aquisições, "e parecendo à conferência que para isso ele estava superiormente autorizado, além da autorização que Ihe dava o

\footnotetext{
69 "Relatório acerca do estado da Academia Real das Belas Artes". 26 de Fevereiro de 1864. Arquivo do MNAA, fundo José de Figueiredo, cx. 1, pasta 1, doc. 1.

70 Conferência ordinária de 3 de Outubro de 1878. Arquivo da ANBA, disponível em http://digitarq.dgarq.gov.pt/ PT-ANBA-ANBA-F-002-00002_m543 e_m544.
} 


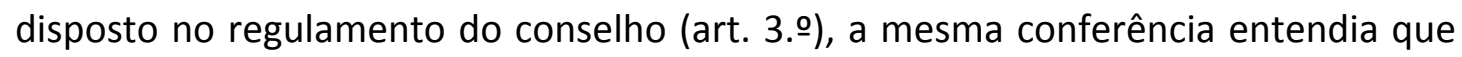
nenhuma responsabilidade daí lhe provinha" ${ }^{71}$.

A questão era delicada e dizia respeito a várias dívidas contraídas pelo marquês que ultimamente se havia comprometido a adquirir a crédito um número considerável de peças pertencentes a diferentes negociantes, colecionadores ou simples proprietários. Esses objetos encontravam-se à guarda da Academia mas o pagamento das prestações não chegara a ser cumprido, gerando grande inquietação nos credores e também no corpo académico a quem o governo pedia agora satisfações.

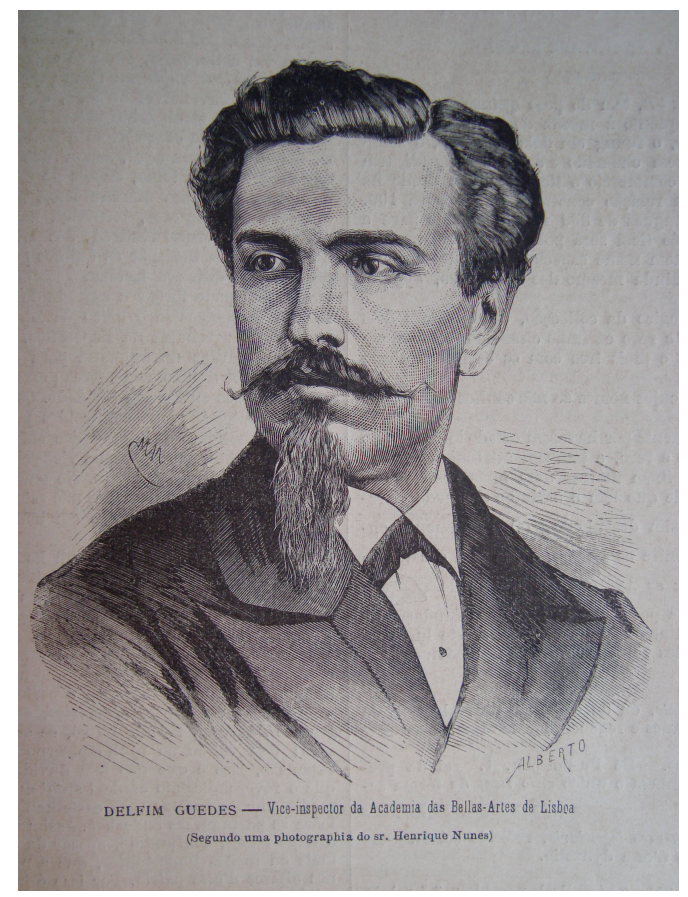

Fig. 93 - Delfim Guedes (1842-1895). Gravura publicada n' O Occidente, 1878

Amador afortunado, mecenas e pintor diletante, Delfim Guedes (fig. 93) seria apontado por decreto de 30 de Setembro de 1878 para suceder a Sousa Holstein, escolha que satisfez a generalidade dos professores e restantes membros da Academia que o nomearam académico honorário por aclamação ${ }^{72}$. Na primeira conferência a que presidiu, seria interpelado por Miguel Ângelo Lupi sobre "se o

71 Conferência extraordinária de 8 de Outubro de 1878. Idem, disponível em http://digitarq.dgarq.gov.pt/ PT-ANBA-ANBA-F-002-00002_m546 a_m549.

${ }^{72}$ Conferência geral de 30 de Outubro de 1878. Idem, disponível em http://digitarq.dgarq.gov.pt/ PTANBA-ANBA-F-002-00002_m0550 a_m0553. 
governo havia resolvido alguma coisa relativamente aos contratos que o Sr. marquês de Sousa fez para as coleções desta Academia". De acordo com o que ficou lavrado em ata, Delfim Guedes respondeu que "conquanto particularmente tenha falado no ministério sobre este assunto, nada havia ainda sido resolvido oficialmente" ${ }^{73}$.

Na realidade, o ministro do Reino não demoraria a tomar uma resolução e, por portaria de 5 de Dezembro, nomeava uma comissão encarregada de examinar os contratos de aquisição efectuados pelo falecido vice-inspetor. Era composta por Delfim Guedes, Tomás da Anunciação, substituído pouco depois pelo arquiteto António Tomás da Fonseca, indigitado para a direção da Academia, e por Joaquim Antunes da Silva Castro que exerceu as funções de secretário. No decorrer do mesmo mês, o secretário escreveu a cada credor, dando a conhecer o objectivo da comissão e mostrando ser necessário "para o bom andamento dos seus trabalhos, consultar os documentos relativos aos objetos que estão em poder desta Academia". Solicitava assim o envio "com a maior brevidade possível" de todos documentos relacionados com os referidos objetos, assim como de quaisquer esclarecimentos que julgassem oportunos ${ }^{74}$.

Um dos primeiros credores a responder foi Luís Maria da Costa, proprietário de um estabelecimento de antiguidades localizado no n.ㅇ 119 da Rua da Madalena, em Lisboa. Começou por relatar que o falecido vice-inspetor o havia visitado no início de Dezembro de 1875, "dizendo-me que estando autorizado pelos Exmos. Srs. António Maria Fontes Pereira de Melo e António Rodrigues Sampaio, então ministros, para organizar um Museu Nacional, precisava de adquirir alguns objetos das minhas coleções e escolheu e ajustou os móveis, faianças e porcelanas mencionados na minha primeira conta com data de 12 de Fevereiro de 1876 e no valor de 2:160\$000 reis". De acordo com o mesmo relato, as quatro prestações mensais acordadas para o pagamento daquela importância ficaram por cumprir, alegando o marquês que "tendo havido desastre nos bancos, e tendo o governo de acudir a esses desastres, que os Srs. Fontes e Sampaio não Ihe haviam fornecido os meios que lhe haviam

73 Conferência ordinária de 20 de Novembro de 1878. Idem, disponível em http://digitarq.dgarq.gov.pt/ PT-ANBA-ANBA-F-002-00002_m0555 e m_0556.

${ }^{74}$ Citamos, a título de exemplo, o ofício dirigido ao negociante A. de Varennes e datado de 23 de Dezembro de 1878. Arquivo do MNAA, fundo José de Figueiredo, cx. 1, pasta 9, doc. 14. 
prometido"75. 0 "desastre nos bancos" corresponde à primeira crise financeira que afectou o sector bancário português nos primeiros meses de 1876, atribuída à especulação produzida em Espanha com os títulos da dívida pública, obrigando o governo fontista a obter junto de Londres um empréstimo para compensar a falta de numerário que afectara o Tesouro $^{76}$.

Essenciais para se compreender todo o processo, as declarações do negociante Luís Maria da Costa necessitam de ser devidamente enquadradas. Para tal, convém recordar que por decreto de 10 de Novembro de 1875, António Rodrigues Sampaio, ao tempo ministro e secretário de Estado dos Negócios do Reino, havia decretado a constituição de uma comissão encarregada de estudar a reforma do ensino artístico e a organização de um museu nacional, composto por diferentes secções. Decerto entusiasmado pelo bom rumo que a Academia parecia por fim tomar, Sousa Holstein que presidia à comissão terá conseguido sensibilizar o chefe do governo e o seu ministro para a necessidade de encetar uma política de aquisições no domínio das artes decorativas, sendo considerada a concessão uma verba específica para o efeito, paralela à que nos últimos anos lograra ver aprovada para as restantes coleções da Academia. Precipitado, envolveu-se logo a partir de Dezembro do mesmo ano numa série de compras a crédito que ficaram comprometidas pelo facto da promessa governamental não se ter efectivado, mau grado os continuados apelos desenvolvidos nesse sentido. Em certos casos, chegou a liquidar prestações com a verba de que dispunha para as outras coleções, o que não deixou de the ser altamente censurado pela comissão como iremos ver. Em desespero de causa, procurou renegociar os contratos de aquisição, sem grande sucesso ${ }^{77}$, permanecendo assim numa situação embaraçosa, interrompida com a sua morte.

Dado o grande volume de correspondência, facturas e demais documentos a analisar, os trabalhos da comissão estenderam-se por todo o ano de 1879,

\footnotetext{
${ }^{75}$ Cópia manuscrita da carta de Luís Maria da Costa datada de 24 de Dezembro de 1879. Idem, cx. 1, pasta 7 , doc. 7.

${ }^{76}$ A este respeito cf. ANTUNES, João Carlos da Silva Jorge - A bolsa de valores de Lisboa e a crise bancaria de 1876. Dissertação de mestrado apresentada ao Instituto Superior de Economia e Gestão, Universidade de Lisboa, 2013.

${ }^{77}$ Luís Maria da Costa, no documento acima citado, refere-se a esse respeito: “(...) avistou-se comigo o falecido vice-inspetor dizendo-me que se reformaria aquele documento, juntando-lhe os juros da lei a que tinha direito, a que eu não acedi pois exigia o cumprimento das prestações mencionadas no mesmo". Arquivo do MNAA, fundo José de Figueiredo, cx. 1, pasta 7, doc. 7.
} 
realizando-se em Novembro uma avaliação independente de parte importante dos objetos, da qual ficou encarregue João António Passos, proprietário de um "bazar de móveis, louças, cristais, metais, roupas, painéis, livros, etc." no n. 164 da rua Direita do Passeio Público ${ }^{78}$. O chefe da oficina galvanoplástica da Imprensa Nacional seria pouco depois encarregue de apurar o valor de uma numerosa coleção de mais de 60 reproduções de objetos e estatuetas em diversos metais pertencentes, na grande maioria, às coleções imperais austríacas ${ }^{79}$. A sua aquisição havia sido feita em 1875 por intermédio da firma Henry Burnay \& Cie. que, não tendo sido ressarcida de qualquer das prestações anuais contratadas, se vira obrigada a participar ao rei D. Luís o sucedido ${ }^{80}$.

A 24 de Abril de 1880 a comissão dá por concluído um longo relatório dirigido ao ministro e secretário de Estado dos Negócios do Reino ${ }^{81}$. Começa por elencar os credores, oito no total, alguns dos quais detentores de dívidas mais antigas, e em outros domínios que não apenas o das artes decorativas. Era o caso das herdeiras do falecido professor José da Costa Sequeira, a quem era ainda devido parte do pagamento pelos 387 desenhos de Domingos Sequeira vendidos no ano de 1874, entre os quais se incluíam os célebres retratos dos deputados às Cortes Constituintes.

Recordava a comissão que os $5.700 \$ 000$ reis cedidos anualmente pelo Ministério do Reino à Academia tinham perante a lei aplicações muito específicas: $2.500 \$ 000$ reis para despesas com o expediente das aulas e da biblioteca, incluindo a compra de modelos em gesso e o pagamento de modelos vivos; $3.000 \$ 000$ reis para a "aquisição e conservação das coleções da Academia" que, apesar não surgirem discriminadas, afiguram-se como circunscritas à pintura, à escultura, ao desenho e à gravura, e $200 \$ 000$ reis para despesas de iluminação.

Perante estas disposições, considerava que o vice-inspetor "não podia dar àquelas verbas aplicação diversa da que a lei lhe prescreve e muito menos obrigar ao

\footnotetext{
78 “Objetos que existiam na Academia em 16 de Novembro de 1879, e que foram avaliados por João António Passos, com bazar de móveis, louças, cristais, metais, roupas, painéis, livros, etc., na Rua Direita do Passeio Público, n.o 164 e avaliador ajuramentado, etc.". Idem, cx. 4, pasta 2, doc. 14.

${ }^{79}$ Relação datada de 9 de Dezembro de 1879. Idem, cx. 1, pasta 7, doc. 1.

${ }^{80}$ Cópia manuscrita da exposição ao rei datada de 21 de Agosto de 1878. Idem, cx. 1, pasta 7, doc. 4.

81 "Documentos relativos aos contratos e liquidação das dívidas da Academia na gerência do marquês de Sousa Holstein" (cópia manuscrita) Idem, cx. 1, pasta 9, doc. 19/1. As citações feitas em seguida reportam-se todas a este documento.
} 
pagamento dos objetos que comprava a crédito as dotações futuras da Academia". Acrescenta que "não existindo o intitulado Museu [de Arte Ornamental], nem sendo o referido vice-inspetor autorizado a constituí-lo ou a adquirir a dinheiro ou a crédito os objetos que atualmente se acham em dívida, parece à comissão que o falecido funcionário andou menos regularmente contratando e despendendo quantias contra as indicações da lei".

A referência à inexistência oficial do museu e ao facto do vice-inspetor não estar autorizado a organizá-lo merece desde já um comentário. Com efeito, a criação do Museu de Arte Ornamental não se encontrava sustentada por qualquer decreto-lei mas, como vimos, o Estado fora dando luz verde à sua organização, ao autorizar a transferência das alfaias litúrgicas da Casa da Moeda e a adaptação de um espaço na Academia para as acolher, ao autorizar também as recolhas promovidas nos conventos femininos extintos e ao consentir a troca de objetos com paróquias e irmandades. Nos ofícios relativos a essas questões, o Ministério do Reino mostra-se ao corrente da organização do acervo e não consta ter alguma vez questionado o marquês que chegou inclusivamente a dar conhecimento público do seu projeto nas Observações publicadas em 1875.

Voltando ao relatório, referia a comissão que "querendo dar o seu parecer com toda a imparcialidade, mandou avaliar e examinar por peritos os diferentes objetos de que provêm as mencionadas dívidas", como já tivemos oportunidade de referir. Constava serem "exorbitantes os preços porque foram comprados e de que nada servem para coleções de estudo, tendo apenas algum valor para núcleos de um museu de antiguidades". Lastimava ainda que o marquês não tivesse aplicado como deveria a verba destinada pelo governo à aquisição e conservação das coleções da Academia (3.000\$000 reis), "porque se o houvesse feito não estariam decerto em tão lamentável estado como efetivamente estão, quadros de grande valor que a Academia possui, alguns dos quais não têm molduras, outros têm mas de madeira tosca" e não se encontrariam "milhares de objetos das coleções de estudo" consideradas agora como tal - "encerrados em caixas, arruinando-se e perdendo-se por não estarem convenientemente colocados".

Depois de todos esses juízos críticos, passou a comissão a dar os seus pareceres sobre os contratos de aquisição efectuados. Relativamente aos desenhos de 
Domingos Sequeira que haviam importado em $750 \$ 000$ reis, recomendava o pagamento da última prestação de $170 \$ 000$, por aquela compra estar enquadrada na verba destinada às coleções da Academia, o mesmo sucedendo com a conta do livreiro Augusto Ferrin, fornecedor da biblioteca, na importância $649 \$ 000$ reis. Já a Francisco de Sande Salema que em 1876 havia autorizado o marquês a proceder à desmontagem no seu palácio do Largo de S. Tiago, então a ser adaptado a prédio de rendimento, de um singular revestimento azulejar representando uma vista panorâmica de Lisboa antes do terramoto de 1755, era indicado que deviam "entregar-se os azulejos que constituem o seu crédito por haverem sido adquiridos contra a lei e não ter o vice-inspetor autorização para fazer tal compra e também por não valerem a sexta parte do preço porque foram comprados". Aos $600 \$ 000$ reis acordados com o proprietário, contrapunha-se a avaliação realizada em 1879 por João António Passos que, indiferente à importância histórica e artística daquele painel, hoje peça central do acervo do Museu Nacional do Azulejo ${ }^{82}$, o avaliara tãosomente em $100 \$ 000$, facto sancionado pela comissão ${ }^{83}$.

Semelhante parecer de devolução era dado em relação a uma cama dita "de gosto oriental", a um escudo e a um baixo-relevo, entre outras peças antigas em madeira entalhada pertencentes a José Agostinho da Costa, no total de $270 \$ 000$ reis. Tornase curioso notar que a factura relativa a esse negócio, datada de Setembro de 1876, refere destinarem-se os objetos não ao Museu de Arte Ornamental mas ao Museu de Belas Artes e Arqueologia, oficialmente criado oito anos mais tarde ${ }^{84}$. Seria esta a designação que Sousa Holstein acalentava dar ao "Museu Central” projetado?

No que diz respeito ao já mencionado negociante Luís Maria da Costa, a quem havia sido entregue parte do valor de um "contador indiano com embutidos em marfim" 85 , seguramente indo-português, era proposto que se efetuasse o resto do pagamento, "entregando-se-lhe todos os demais objetos que constituem o seu crédito", compreendendo outros móveis, faianças e porcelanas no valor de $2.860 \$ 000$ reis.

\footnotetext{
${ }^{82}$ MNAz, inv. 1

${ }^{83}$ A respeito deste processo cf. XAVIER, Hugo - "Incorporações de azulejos pela Academia de Belas Artes na segunda metade do século XIX: a aquisição da Vista de Lisboa". FLOR, Pedro (coord.) Revista de História da Arte, n. 11, 2014 [no prelo].

${ }^{84}$ Cópia manuscrita da factura. Arquivo do MNAA, fundo José de Figueiredo, cx. 1, pasta 9, doc. 12/5.

${ }^{85}$ Cópia manuscrita da factura. Idem, cx. 1, pasta 6 , doc. 3.
} 
Advertia-se que "se assim Ihe não convier, se lhe deverá restituir tudo, recebendo-se dele os $80 \$ 000 "$ avançados pelo contador.

Outro negociante, A. Varennes, proprietário do "Bazar de Antiguidades" situado no n. 112 da Rua do Alecrim, recebia idêntica sentença relativamente às peças de mobiliário e cerâmica cedidas em 1876, acrescidas de duas pinturas sobre tela, num total de $2.100 \$ 000$ reis: "Que a A. Varennes se deverão entregar todos os objetos que the pertencem porque foram adquiridos contra as disposições da lei, sem autorização do governo, e também por não ter sido aprovada pelas Cortes a criação do Museu como se acha exposto no seu contrato". Com efeito, o marquês acrescentara na factura relativa a essa aquisição que o pagamento seria efectuado em duas prestações "se as Cortes aprovarem a dotação do Museu" ${ }^{86}$ mas, como vimos, o projeto-lei não chegou sequer a ser apresentado.

No valor de $2.500 \$ 000$ reis, a coleção de galvanoplastias fornecida pela firma Henry Burnay \& Cie. deveria de igual modo ser devolvida, o mesmo sucedendo com um conjunto de mais de uma centena de objetos arqueológicos adquiridos a António Faria Gentil, proprietário de um olival em Alcácer do Sal onde foram casualmente encontrados. Reveste-se de particular significado este negócio, representativo do interesse do marquês de Sousa Holstein em acrescer a coleção de arqueologia da Academia que vimos ter a sua origem com a transferência de parte do espólio da Sociedade Arqueológica Lusitana, em 1868. Ficou enquadrado pela celebração de uma escritura entre as partes, assinada 9 de Fevereiro de 1876, onde é referido que entre os objetos se encontravam "vasos etruscos, uma máscara em barro, espadas, lâmpadas mortuárias, lacrimatórios e outros que demonstram a existência de uma necrópole romana”. O proprietário comprometia-se não só a vender todo o espólio à Academia mas também o direito de esta "fazer escavações e explorações arqueológicas no terreno do dito olival" pela quantia de $3.000 \$ 000$ reis, paga em dezasseis prestações trimestrais de $187 \$ 500^{87}$.

Considerava a comissão ter sido feita a escritura "em condições onerosíssimas para a Academia e que seria altamente prejudicial o cumprimento de tais condições por lhe trazerem despesas enormes sem grande vantagem para o estudo das belas artes".

\footnotetext{
${ }^{86}$ Cópia manuscrita da factura datada 20 de Novembro de 1876. Idem, cx. 1, pasta 9, doc. 12/7.

${ }^{87}$ Cópia manuscrita da escritura. Idem, cx. 1, pasta 6, doc. 1.
} 
Declarando-a nula "por falta de competência da pessoa que a assinou" [Sousa Holstein], indicava dever o credor restituir o valor das prestações com que fora embolsado, "recebendo os objetos que the pertencem ou sujeitar-se a serem os mesmos vendidos em hasta pública para indemnização da fazenda".

Concluíam os académicos o relatório com a ideia de terem emitido todas as opiniões "com a maior justiça e equidade" e rogando ao ministro que os desculpasse por qualquer falta cometida "no desempenho da sua espinhosa missão". Várias faltas podem ser na realidade apontadas, da omissão de dados a certas contradições, sempre em desfavor do marquês de Sousa Holstein cuja atuação fui indiscutivelmente imprudente. Não podemos deixar de notar a dureza da análise que procura salvaguardar sempre os interesses do Estado e imputar todas as responsabilidades a alguém que já não se podia pronunciar a esse respeito. Parece estar aqui subjacente uma questão política devido à mudança de governo com a chegada ao poder, em 1879, de Anselmo José Braamcamp (1817-1885) e, talvez mesmo, um acerto de contas com a anterior administração da Academia.

Atendendo ao real interesse da maioria dos objetos, não podemos deixar de estranhar que Delfim Guedes, futuro conde de Almedina, a quem se ficou a dever pouco depois a grande Exposição Retrospectiva de Arte Ornamental Portuguesa e Espanhola, ocorrida em 1882, tenha subscrito certas afirmações. Reconhecendo a importância dos mesmos, procurará desde logo entrar em acordo com alguns dos proprietários, contrariando de certa forma o argumento explanado de que as aquisições não poderiam vir a ter lugar por não estarem legalmente enquadradas. Assim aconteceu com os móveis e cerâmicas de Luís Maria da Costa que permanecerão na Academia após aquele ter feito um abatimento de $360 \$ 000$ reis no valor total (2.500\$000). O mesmo sucedeu também com as galvanoplastias fornecidas pela firma Henry Burnay \& Cie., e com os objetos de A. Varennes que ao tomar conhecimento do conteúdo do relatório, apressou-se a escrever ao viceinspetor, lamentando que este tivesse tomado uma "resolução tão injusta como funesta" para os seus interesses. Fora do interesse de Delfim Guedes ficaram, por exemplo, a cama e as restantes objetos em madeira entalhada de José Agostinho da Costa, entregues aos seus herdeiros, e o espólio arqueológico de Alcácer do Sal que 
acabaria por ser doado pelo seu proprietário ao município daquela região, enformando hoje as coleções do Museu Municipal de Arqueologia Pedro Nunes ${ }^{88}$.

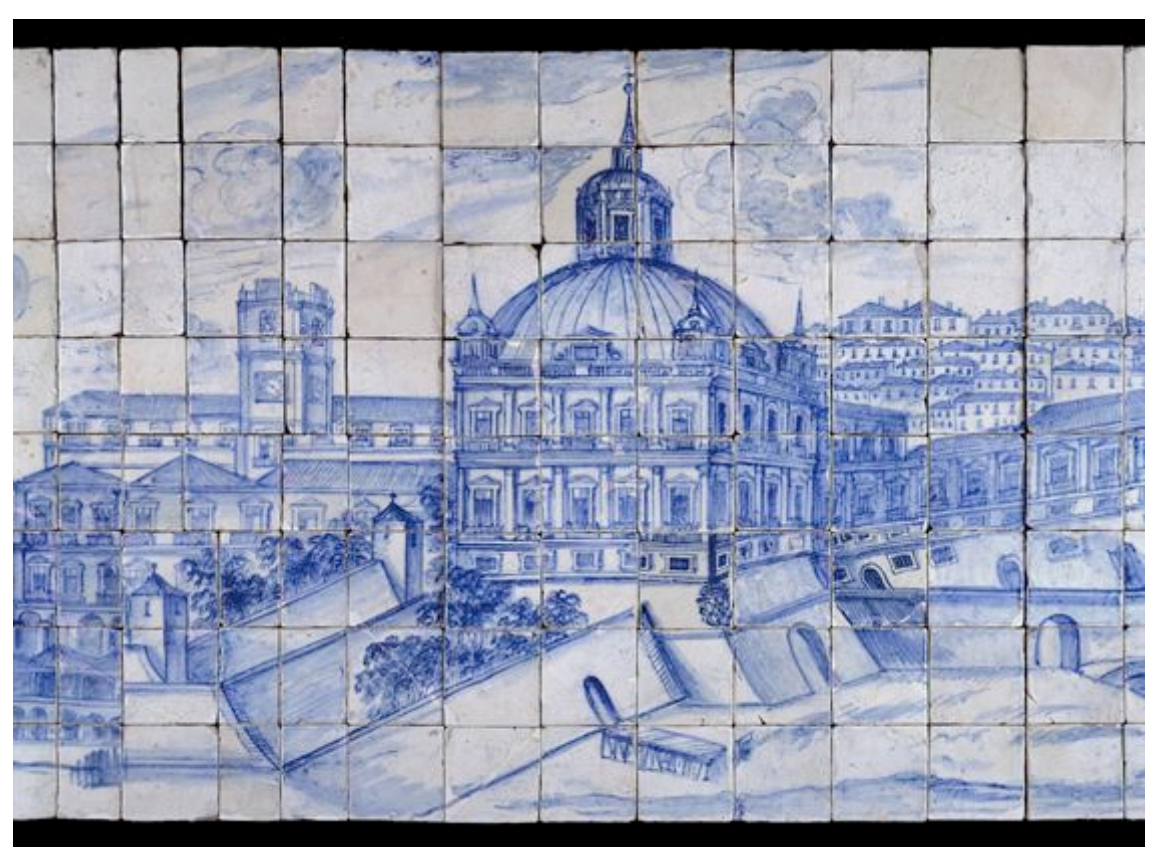

Fig. 94 - Gabriel del Barco (atrib.), Vista de Lisboa (pormenor), c. 1700. MNAz, inv. 1

Quanto ao grande painel da vista de Lisboa (fig. 94), seguramente a peça mais reconhecível, valerá a pena determo-nos na definitiva declaração de venda assinada pelo proprietário, Francisco de Sande Salema, em 1881: “[...] fui ultimamente convidado pelo atual vice-inspetor o Exmo. Sr. Delfim Guedes a entrar em um acordo, diminuindo tanto quanto possível o preço ajustado para assim facilitar o mais pronto e integral pagamento do meu crédito. Declaro que faço o abatimento de cem mil reis no preço dos azulejos, ficando este reduzido a 500 mil reis; mais declaro que esta redução é devida às diligências que para esse fim empregou o Exmo. Sr. vice-inspetor e de modo algum porque se tenha duvidado acerca da validade do contrato $^{\prime 89}$. Na realidade, não só a comissão havia considerado nulo o contrato de aquisição como fixara o valor dos azulejos em apenas $100 \$ 000$ reis, recomendado a entrega dos mesmos ao proprietário. Delfim Guedes ignora o que subscrevera e

\footnotetext{
${ }^{88}$ António Faria Gentil efetuou a doação em 1896, tendo o museu sido fundado em 1894. Proveniente da necrópole do Olival do Senhor dos Mártires, o espólio é da Idade do Ferro e não do período romano como surge identificado na documentação.

${ }^{89}$ Cópia manuscrita da declaração datada de 18 de Março de 1881. Arquivo do MNAA, fundo José de Figueiredo, cx. 1, pasta 9, doc. 19/3.
} 
paga pela vista de Lisboa $500 \$ 000$ reis, menos $100 \$ 000$ do que havia sido acordado por Sousa Holstein. Esta inflexão põe de certa forma em causa a atuação do novo vice-inspetor no processo, assim como a imparcialidade do relatório produzido pela comissão que procurou atacar deliberadamente o falecido marquês e a sua política de aquisições.

O fracasso que caracterizou os esforços do marquês vice-inspetor na organização do tão sonhado "Museu Central" acabou por deixar vivo o embrião do que viria a ser o Museu Nacional de Belas Artes e Arqueologia, inaugurado pelo seu sucessor, em 1884. Para além do enriquecimento e inauguração da Galeria Nacional de Pintura, não esquecendo também o incremento e valorização do núcleo de desenhos, devem-se portanto a Sousa Holstein as primeiras incorporações da Academia nos domínios da ourivesaria, do mobiliário, da cerâmica, dos têxteis ou da arqueologia que constituirão o cerne do acervo daquele museu. Alguns daqueles núcleos irão mais tarde autonomizar-se, mas o atual Museu Nacional de Arte Antiga permanece ainda como um digno herdeiro das aspirações do marquês. 


\section{CONSIDERAÇÕES FINAIS}

Perante um tema tão amplo, afigura-se imprescindível definir e alinhar algumas ideias fundamentais desenvolvidas ao longo das quatro partes que enformam este trabalho. Assim, e sem pretendermos ser terminantemente conclusivos, procuraremos traçar em síntese o quadro que se nos deparou.

Na sequência do estabelecimento do Liberalismo em Portugal, o decreto de 28 de Maio de 1834 veio abolir as ordens religiosas, extinguindo de imediato os conventos masculinos, e fechando os femininos logo após a morte das últimas freiras. Ficou então o novo poder político com um enorme volume de bens culturais móveis para conservar, levando no mesmo ano à criação no vetusto convento de $\mathrm{S}$. Francisco de Lisboa de um depósito onde foram arrecadas inúmeras pinturas, livros e outros objetos oriundos das casas religiosas da capital e da região da Estremadura. Para dirigir esses trabalhos foi na mesma ocasião nomeado um fiel adepto do novo regime, António Nunes de Carvalho, doutor em Jurisprudência pela Universidade de Coimbra, que contou com a colaboração de um pequeno corpo de funcionários, constituído essencialmente por excedentes oriundos de organismos públicos extintos.

À falta de meios para dar conta das massivas incorporações de livros e pinturas, acresceram algumas contrariedades relacionadas com o próprio convento de $\mathrm{S}$. Francisco que começou a ser cobiçado para nele se instalarem alguns organismos da administração pública nascidos com o Liberalismo. Em 1836, decorridos dois anos da criação do depósito, Nunes de Carvalho será afastado da sua direção, em virtude dos conflitos mantidos com as instituições com quem passou a partilhar o convento, bem com pela falta de uma gestão controlada do numeroso espólio. No seguimento desta alteração, nomeou-se uma comissão administrativa presidida pelo conde da Taipa, dividida em duas secções: a artística, de que ficaram incumbidos o cónego Vilela da Silva e o pintor André Monteiro da Cruz, e a bibliográfica, por sua vez desdobrada em várias subsecções confiadas a outros vogais.

À secção artística caberá, em particular, a articulação com a Academia de Belas Artes no processo de transferência das pinturas conservadas no depósito. Criada naquele

mesmo ano de 36 por decreto de Passos Manuel, e igualmente instalada em S. 
Francisco, aquela instituição de ensino artístico cedo reclamará a posse das pinturas, devido às instâncias desenvolvidas nesse sentido por um artista próximo de Passos, e por isso, em breve nomeado diretor-honorário, Silva Oeirense. Com a colaboração dos vogais da secção artística da referida comissão administrativa, e o auxílio do professor António Manuel da Fonseca, conseguiu-se proceder à seleção das obras consideradas mais relevantes, 540 no total, assim como à sua entrada nas dependências da Academia.

Se o processo de seleção e transferência das pinturas decorreu de forma célere, o mesmo não sucedeu com a sua classificação e sobretudo com o catálogo que se pretendia editar, envolto num impasse revelador das fragilidades da nova instituição. A queda de Passos Manuel e a consequente partida de Silva Oeirense para o Porto, os cortes no financiamento, e a falta de empenho de alguns professores e artistas agregados contribuíram para a ausência de resultados expressivos neste e noutros domínios, sobretudo em relação aos trabalhos de conservação e restauro das pinturas. De maneira a dar a conhecer as obras mais notáveis do acervo, com destaque para os primitivos atribuídos genericamente a Vasco Fernandes, pensou-se lançar uma coleção de gravuras, projeto frustrado por falta de meios mas que viria a ser adaptado pelo Jornal das Bellas-Artes subdirigido pelo mestre Fonseca, com cinco gravuras apenas publicadas entre 1843-46.

Disseminada pelas salas de aula e por outros espaços do estabelecimento, a coleção padecia com as deficientes condições do convento de S. Francisco, sobretudo no que dizia respeito à falta de luz, ventilação e à humidade, recorrentemente apontada como a principal causa de degradação das pinturas. As dificuldades do Tesouro Público obstavam a qualquer construção de raiz e, como tal, os académicos acalentaram durante muito tempo ser possível (e até preferível) proceder à reformulação do edifício existente que, apesar dos problemas enunciados, possuía inegáveis vantagens pela sua amplitude e situação central. Porventura mais económica, esta solução ocupou longamente o professor João Pires da Fonte que elaborou alguns projetos onde previa a construção de uma galeria de pintura, sem qualquer consequência prática. Dada a manutenção deste impasse, a instituição verse-á obrigada a contentar-se com os reparos efectuados pelas Obras Públicas nas salas de aulas de pintura histórica e de paisagem, cujas estruturas envidraçadas 
rasgadas nos tectos deixavam entrar águas pluviais, tornando-se numa das principais causas da humidade aludida. Reformadas, aquelas salas voltaram no essencial ao que haviam sido desde o início - um arremedo de galeria cujo acesso público era muito limitado devido às funções lectivas a elas adstritas, adivinhando-se a falta de critério expositivo agravado pela ausência de um catálogo.

Era este o estado de coisas até à chegada de um filho do primeiro duque de Palmela, o marquês de Sousa Holstein, em 1862, nomeado vice-inspetor da instituição, da qual já era académico honorário. A sua eleição para presidente da Sociedade Promotora das Belas Artes, ocorrida alguns meses antes, não passou naturalmente desapercebida ao governo, tendo estado na base da escolha do jovem marquês que cursara Direito em Coimbra, e cuja fugaz permanência em Itália enquanto diplomata desenvolvera a propensão pelas artes, quer como estudioso quer como colecionador, com especial evidência para a obra de Domingos Sequeira. Sousa Holstein procurará dar resposta às diversas carências do estabelecimento, lutando não só pela sua atualização de acordo com outros modelos europeus, mas também pela pública exposição do acervo e seu enriquecimento.

Após a transferência dos espécimes conventuais conservados no depósito de $S$. Francisco, pouco mais se havia passado em termos de incorporações na Academia, exceptuando a iniciativa do governo ao comprar, em 1848, parte selecionada da coleção de pintura da rainha Carlota Joaquina, caso isolado que tardou a ser repetido. O marquês procurou desde logo gizar uma política de aquisições, concretizada graças a um gesto mecenático de D. Fernando II que, da sua dotação, cedeu parte assinalável à Academia com a determinação de favorecer o enriquecimento do acervo. Pretendia assim o régio mecenas engrandecer a galeria nacional que há muito se reclamava para Lisboa e, simultaneamente, fornecer qualificadas ferramentas para o ensino, de acordo com a tradicional prática académica que impunha a cópia continuada de modelos.

Ocorrida em 1865, a doação financeira de D. Fernando II repetir-se-á nos anos seguintes até 1869 , num total de 65 contos de reis aplicados, na sua esmagadora maioria, na aquisição de 114 pinturas, essencialmente junto de particulares, alguns dos quais do meio diplomático, facto decerto relacionado com os contactos efectuados em Itália pelo vice-inspetor (Husson da Câmara, Sousa Lobo, Cambiaço, 
Pereira Crespo, conde de Farrobo, Silva Oeirense, Bustelli entre outros). Estas coleções revelaram-se todavia férteis em obras de autenticidade duvidosa que o olhar pouco experimentado dos professores de pintura da Academia, reunidos em comissão especial para o efeito, tomou quase sempre por genuínas, sobretudo em relação aos grandes mestres estrangeiros, lacuna do acervo que importava preencher. Cabe ainda assim assinalar a compra de alguns valores seguros, como um pequeno painel de predela do jovem Rafael Sanzio, sem esquecer o apreciável conjunto de pintura de flamenga e holandesa do século XVII (David Teniers, Jan Steen, Gerrit Dou ou Pieter Neefs só para dar alguns exemplos). Entre os autores nacionais domina o nome de Domingos Sequeira com mais de uma dúzia de telas adquiridas, consequência do interesse que Sousa Holstein nutria pelo artista de quem publicou um ensaio biográfico, repartido por vários números da revista Artes $e$ Letras.

Se o enriquecimento do acervo da Academia se deveu em larga medida ao gesto mecenático de D. Fernando II, convém assinalar a ocorrência de outras incorporações fora desse âmbito, começando desde logo por uma trintena de quadros provenientes da coleção do padre Mayne, existente na Academia das Ciências, conjunto maioritariamente secundário e desigual. Caso raro e de especial relevo será em 1876 a aquisição do tríptico da Virgem da Misericórdia, obra do flamengo Jan Provoost que pertenceu à desaparecida capela de S. João de Latrão da ilha da Madeira, tratando-se da pintura mais dispendiosa adquirida pelo Estado durante o mandato de Sousa Holstein.

Centrado em valorizar o acervo académico, o vice-inspetor mostrou-se atento às espécies de pintura com interesse artístico que se encontravam na posse de instituições públicas e religiosas, com especial evidência para as dioceses e conventos femininos. Procurava assim, sem dispêndio de verbas, incrementar a coleção do estabelecimento, sobretudo em relação à antiga escola portuguesa, processo nem sempre exequível dadas as frequentes resistências das entidades detentoras das pinturas. Ainda assim algumas obras foram sendo integradas na sequência de prospecções efectuadas um pouco por todo o país, não chegando o vice-inspetor a concretizar a mais relevante das transferências a que aspirava, relativa ao espólio do convento da Madre de Deus em Lisboa. 
Ao contrário do que sucedia com a pintura dita contemporânea cuja entrada na coleção estava de certa forma assegurada pelos regulamentos académicos (concurso de professores, envios de pensionistas do Estado no estrangeiro, ofertas implícitas às nomeações para académico de mérito), as dádivas de obras de épocas mais recuadas eram praticamente inexistentes até à chegada do marquês. Este depositava grandes esperanças nesta modalidade de enriquecimento da coleção, acreditando no envolvimento da sociedade civil, à semelhança do que sucedia então com a National Gallery de Londres, em franca expansão do seu acervo. Neste contexto merece especial destaque o conde de Carvalhido, negociante portuense enriquecido no Brasil e residente em Paris onde desenvolveu hábitos continuados de compra, efetuando a partir de 1865 generosas doações à Academia, com o objectivo de aí ver criada uma sala com o seu nome. Curiosamente, verifica-se alguma adesão a essa tendência por parte de estrangeiros, alguns dos quais do meio diplomático, no que pode em parte ser atribuído à rede de contactos tecida pelo vice-inspetor. Estas ofertas vindas do estrangeiro tinham, no entanto, um custo equivalente a uma distinção honorífica por parte do Estado português, raras vezes se contentando o doador com o título académico que lhes estava inerente.

Paralelamente ao enriquecimento do acervo, a organização da galeria ia sendo acalentada pelo vice-inspetor que se mostrou incansável no andamento dos trabalhos, coadjuvado pelos professores de pintura do estabelecimento. O caminho a seguir encontrava-se já apontado e passava pela improvisação, adaptando-se para o efeito as salas de aula de pintura histórica e de paisagem que haviam sido remodeladas há alguns anos. Tal obrigava à realização de mais algumas obras nas referidas salas e ao seu alargamento por outros espaços, entre outras tarefas como o restauro de pinturas, a aquisição de molduras e a edição de um catálogo, para as quais afigurava-se necessário encontrar financiamento. Começou-se pela venda em leilão dos quadros considerados de interesse menor, sem grande sucesso, até ao anúncio do gesto mecenático de D. Fernando II que veio alterar em definitivo esse estado de coisas. Com efeito, e apesar das verbas terem sido concedidas para a compra de pinturas, o monarca autorizou desde logo a aplicação de uma pequena parte para outros fins, facilitando a prossecução do projeto. 
João Cristino da Silva foi então encarregue da compra de molduras pois poucas eram as pinturas provenientes do depósito que as possuíam, enquanto Miguel Ângelo Lupi dirigiu a sua montagem nas salas, cinco no total, remodeladas sob a supervisão do arquiteto João Pires da Fonte, com materiais custeados também pelo régio mecenas. Os espaços ficariam marcados por soluções austeras, como era o caso da "pintura de fingidos", efectuada para enobrecer as madeiras dos bancos corridos para os visitantes. A contenção na gestão das verbas a isso obrigava, não apresentando a galeria a opulência decorativa das grandes congéneres europeias que recorreram quase sempre a reputados fornecedores.

Componente indispensável da pinacoteca académica era o catálogo cuja existência havia sido desde cedo reivindicada pelos responsáveis da Academia, com diversas tentativas frustradas nesse sentido. Sousa Holstein procurará materializar esse projeto, numa nova sucessão de avanços e recuos reveladores das limitações da instituição que desperdiçou muito tempo no processo, por fim concretizado, e de uma forma menos ambiciosa do que inicialmente previsto, em 1868, com a designação de "provisório". Destinado a servir de guião aos visitantes, foi gizado pelo vice-inspetor e pelos professores de pintura, tomando provavelmente como ponto de partida os trabalhos efectuados nesse sentido por alguns antigos colaboradores no projeto como Ferreira Chaves e Feijó da Costa. Nele não se regista qualquer divisão por salas, seguindo uma numeração continua de 324 obras que ascendem a 366 na segunda edição (1872), crescimento relacionado essencialmente com as doações Carvalhido. O ponto forte do catálogo é a introdução de Sousa Holstein que começa por traçar de forma sucinta o historial do acervo. Debruça-se em seguida nas aquisições efectuadas, para depois se concentrar na escola portuguesa de pintura, o grande atrativo da coleção, sintetizando os principais contributos publicados por Charles Robinson.

Outro ponto focado por Sousa Holstein prende-se com o estado de conservação das obras que era, na maioria dos casos, delicado, mau grado os esforços desenvolvidos nesse sentido. Meses após a sua chegada à Academia, o marquês começou por encarregar Silva Oeirense de dirigir os restauros com uma pequena equipa de artistas agregados, para mais tarde entregar a fiscalização dos mesmos a uma comissão presidida por Tomás da Anunciação. Esta irá beneficiar pontualmente com 
a verba concedida a partir de 1865 por D. Fernando II, permitindo-lhe a contratação de um ou outro "restaurador" como foi o caso de Zeferino Augusto Teixeira. A possibilidade de contratar pessoal externo para estas intervenções, não quebrou todavia a tradicional colaboração nesse domínio dos artistas agregados e académicos de mérito, podendo referir-se José Maria Franco que veio pouco depois a ocupar o cargo de professor interino de pintura histórica.

A abertura ao público da galeria ocorrerá a 29 de Março de 1868, tendo sido meses antes aprovado um regulamento com 24 artigos que estipulavam regras e orientações aos visitantes ou utilizadores do novo equipamento. As reações serão em regras elogiosas, colocando em evidência os esforços do vice-inspetor e do corpo académico, assim como o gesto mecenático de D. Fernando II, sem o qual nada teria sido possível. Sousa Holstein procurará a partir de então patentear a coleção de desenhos que procurava incrementar, dando todavia prioridade ao aumento do espaço ocupado pela galeria de pintura, desde logo julgado insuficiente, pugnando energicamente junto dos poderes públicos pela sua concretização.

Na sequência da abertura do novo equipamento, surgirão solicitações por parte de fotógrafos no intuito de captar e comercializar as pinturas do acervo, para agrado do vice-inspetor que muito apostava nas potencialidades daquela técnica como forma de documentar e divulgar as obras de arte. Logo em 1869, destacam-se os pedidos de Augusto César Pardal \& filho e, sobretudo, de Jean Laurent, fotógrafo francês estabelecido em Madrid, retratista de Isabel II de Espanha e autor da mais numerosa campanha fotográfica até então realizada no Museu do Prado. Pioneiro da reprodução fotográfica em larga escala de obras de arte, a par da casa Braun de Paris, dos florentinos Alinari ou de Hafstaengl de Munique, Laurent seria bem acolhido pelo vice-inspetor que lhe dispensou todas as facilidades para a persecução da tarefa na Academia.

Meses antes da abertura da galeria, Sousa Holstein conseguiu, não sem alguma resistência do corpo académico, nomear um funcionário público em comissão na Academia para exercer o cargo de conservador interino. A escolha recaiu em Alfredo Augusto da Costa Camarate que se vinha ocupando à experiência da coleção de desenhos, tendo também viajado pelo país, nomeadamente, até ao arquipélago dos Açores, em busca de pinturas e demais obras de arte susceptíveis de interessar ao 
acervo. Camarate revelou-se um conservador atento e diligente ao participar e tentar solucionar os problemas registados desde cedo nas salas, com especial evidência para as infiltrações oriundas das estruturas envidraçadas dos tectos, problema crónico que tardava em ser solucionado, danificando estores e soalhos e imprimindo elevados índices de humidade ao espaço.

Em virtude dessa problemática será nomeada uma comissão encarregada de proceder ao exame do espaço e do estado de conservação dos quadros, contando com a presença dos professores de pintura, do arquiteto Pires da Fonte, de um lente de química da Escola Politécnica e de Camarate. Os trabalhos da comissão e o consequente relatório publicado viriam a ter uma consequência imediata no domínio do que designamos hoje de conservação preventiva: a monitorização das temperaturas e dos níveis de humidade, prática provavelmente inédita até então no meio museológico nacional, procedendo-se ao registo detalhado dos dados com recurso a vários termómetros e de um higrómetro. Publicado no Diario do Governo, o relatório mencionado terá pesado na elaboração da portaria que um ano mais tarde (22 de Março de 1870) designou outra comissão encarregada de estudar a reforma do ensino na Academia e a instalação adequada das suas coleções. Criada pelo duque de Loulé, morreu à nascença por alegadamente se terem escusado e ausentado alguns dos seus membros, pelo que será necessário aguardar cinco anos para ser dada à luz nova comissão sob os auspícios de António Rodrigues Sampaio, ministro do Reino.

Com efeito, por decreto de 10 de Novembro de 1875, um vasto conjunto de personalidades seria encarregue de propor aos poderes públicos uma reforma mais abrangente do ensino artístico assim como um plano de organização de um museu nacional. Da defunta comissão transitaram Sousa Holstein, Assis Rodrigues, António Tomas da Fonseca, Vítor Bastos e Tomás de Carvalho, entretanto promovido a diretor da Escola Médica, acrescentando-se os condes de Valbom e Samodães, este último inspetor da Academia de Belas Artes do Porto, assim como Tadeu de Almeida Furtado, professor da mesma Academia. Pertenciam ainda ao agrupamento o provedor da Casa Pia, Eugénio de Almeida, Teixeira de Vasconcelos, sócio e futuro vice-presidente da Academia de Ciências, os arquitetos Possidónio da Silva e José Maria Nepomuceno, o diretor do gabinete de numismática da Ajuda, Teixeira de 
Aragão, o lente da Universidade de Coimbra, Augusto Filipe Simões, e o escritor Luciano Cordeiro, este último na qualidade de secretário.

O estado do ensino e das coleções públicas de arte foi analisado pelo marquês num relatório apresentado voluntariamente aos membros da comissão, documento ao qual foi dispensado o maior aplauso, tendo sido decidida a sua publicação. Intitulado Observações sobre o actual estado do ensino das artes em Portugal, a organização dos museus e o serviço dos monumentos historicos e da archeologia, contou com uma tiragem excecional de 4000 exemplares no intuito de ser profusamente distribuído, procurando-se assim envolver a sociedade civil no debate e consciencializar os mais cépticos para a necessidade de uma profunda reforma das artes em Portugal. Como revela no documento, Sousa Holstein idealizava para a capital uma pinacoteca inserida num projeto mais abrangente de "museu central", composto por outras secções especializadas: desenho, escultura, arquitetura, arqueologia e arte ornamental. Preconizava assim a organização do ensino e dos museu por modelos estrangeiros, com destaque para o South Kensington Museum de Londres (atual Victoria \& Albert Museum), onde a arte ornamental tinha peso maior.

O interesse do vice-inspetor por aquele domínio levo-o logo em 1863 a requisitar à Casa da Moeda as alfaias litúrgicas dos conventos extintos ali conservadas, no que será o núcleo fundador de um "museu de arte ornamental", mais tarde improvisado em duas salas da Academia. Parte importante destes objetos serão aliás enviados e colocados em evidência na Exposição Internacional de Paris de 1867, com elogiosos ecos na nossa imprensa que acompanhou de perto a representação nacional naquele certame, vindo a despertar a atenção dos fotógrafos atrás citados. 0 conjunto de arte ornamental será ainda acrescido com algumas doações, permutas e com transferências dos conventos femininos entretanto extintos, levando o marquês a promover algumas prospecções pelo país, parte das quais efectuadas por Domingos Maria Gonçalves, nomeado conservador interino daquele núcleo museológico. Sousa Holstein efetuará ainda diversas aquisições (mobiliário, cerâmica, têxteis...) que se verão comprometidas pelo facto da promessa governamental para um subsídio não se ter efectivado, mau grado os continuados apelos desenvolvidos nesse sentido. 
As ideias desenvolvidas nas Observações serão sintetizadas por Luciano Cordeiro no relatório da comissão nomeada pelo governo em 1875, mostrando que as reuniões tidas entre os seus elementos pouco acrescentaram ao exposto anteriormente pelo vice-inspetor. Distingue-se esse relatório por incluir uma detalhada proposta definindo a criação de um "Museu Nacional de Arte e Indústria", assim como as atas das reuniões decorridas entre finais de 75 e inícios de 76 onde o tema da mudança de instalações foi profusamente debatido. Várias foram as hipóteses consideradas, a começar por uma ala do mosteiro dos Jerónimos, em Belém, e pelo convento da Estrela, passando-se depois ao palácio do marquês da Ribeira Grande e ao dos patriarcas ou Monte Cristo, ambos à Junqueira, para depois se optar pelo arrendamento do palácio do marquês de Abrantes em Santos.

Meses após terminados os trabalhos da comissão, editado o relatório, regista-se de forma algo inesperada uma inflexão quanto ao edifício escolhido para servir de museu. A legação de França que ocupava desde 1870 o palácio Abrantes não terá manifestado vontade em rescindir o contrato, obrigando a uma nova solução. A preferência registada até à data pelos bairros ocidentais da cidade (Belém, Junqueira e Santos), inverteu-se mais para nordeste, para a rua de Santa Marta onde se ergue o palácio dos condes de Redondo que Sousa Holstein pretendeu alugar. O investimento necessário para os trabalhos de remodelação, transferências de objetos, restauros e demais melhoramentos teve todavia como consequência o recuo do ministro promotor da reforma, Rodrigues Sampaio, que em 1878 abandonou o governo em clima de crise financeira.

Manifestando sinais de doença em 1877, Sousa Holstein faleceria no ano seguinte sem ver concretizada a reforma do ensino artístico e a organização do museu nacional em que tanto se empenhara. O seu sucessor, Delfim Guedes, será pouco depois encarregado pelo ministro José Luciano de Castro de apresentar novo projeto de reforma, assim como nova proposta para a instalação de um museu, decidindo-se pelo palácio Alvor-Pombal às Janelas Verdes. Após custosas obras de adaptação, ali se realizou em 82 uma grande exposição de arte ornamental, cujo êxito serviu de bom argumento junto do governo para a definitiva instalação do então designado Museu Nacional de Belas Artes e Arqueologia, finalmente ocorrida em 84. 


\section{FONTES MANUSCRITAS}

\section{Arquivo da Academia Nacional de Belas Artes}

Disponível online em http://digitarq.dgarq.gov.pt/

últimas consultas: Agosto de 2014

Livro de Actas (1836-1837) - PT/ANBA/ANBA/A/001/00001 (cota: 1-A- SEC.6) Livro de Actas (1838-1839) - PT/ANBA/ANBA/A/001/00002 (cota: 1-A- SEC.7) Livro de Actas (1843) - PT/ANBA/ANBA/A/001/00003 (cota: 1-A- SEC.8) Livro de Actas (1844-1850) - PT/ANBA/ANBA/A/001/00004 (cota: 1-A- SEC.9) Livro de Actas (1845-1858) - PT/ANBA/ANBA/A/001/00005 (cota: 1-A- SEC.12) Livro de Actas (1845-1857) - PT/ANBA/ANBA/A/001/00006 (cota: 1-A- SEC.14) Livro de Actas (1851-1856) - PT/ANBA/ANBA/A/001/00007 (cota: 1-A- SEC.13) Livro de Actas (1857-1862) - PT/ANBA/ANBA/A/001/00008 (cota: 1-A- SEC.13) Livro de Actas (1857-1867) - PT/ANBA/ANBA/A/001/00009 (cota: 1-A- SEC.15) Livro de Actas (1875-1876) - PT/ANBA/ANBA/A/001/00010 (cota: 1-A- SEC.22) Livro de Actas (1879-1881) - PT/ANBA/ANBA/A/001/00011 (cota: 3-B- SEC.217) Projectos de regulamentos (1868-1895) - PT/ANBA/ANBA/A/006/00001 (cota 2-ASEC.76)

Correspondência recebida vol. I (1826-1869) - PT/ANBA/ANBA/B/001/00003 (cota 1-BSEC.48)

Registo das propostas e ofícios dirigidos ao governo (1841-1844) PT/ANBA/ANBA/B/003/00002 (cota 1-A-SEC.2)

Livro de registo de correspondência recebida (1862-1925) PT/ANBA/ANBA/B/006/00001 (cota: 3-D- SEC. 291)

Livro de registo de correspondência recebida (1862-1925) PT/ANBA/ANBA/B/006/00002 (cota: 2-A- SEC. 96)

Livro de registo de correspondência expedida (1870-1884) PT/ANBA/ANBA/B/007/00001 (cota: 2-A- SEC. 93)

Livro de registo de correspondência expedida (1870-1877) PT/ANBA/ANBA/B/007/00002 (cota: 2-A- SEC. 91)

Registo de inventário (1866) - PT/ANBA/ANBA/E/001/00003 (cota 3-D-SEC.233) Registo de inventário (1867) - PT/ANBA/ANBA/E/001/00004 (cota 3-D-SEC.231) Registo de inventário (1876-1879) - PT/ANBA/ANBA/E/001/00006 (cota 3-D-SEC.232) Livro de entrada e saída de objectos (1850-1855) - PT/ANBA/ANBA/E/002/00001 (cota 2-B-SEC.132)

Índice das conferências gerais, ordinárias e extraordinárias (1863-1868) PT/ANBA/ANBA/F/002/00001 (cota: 1-A- SEC.16)

Índice das conferências gerais, ordinárias e extraordinárias (1869-1881) PT/ANBA/ANBA/F/002/00002 (cota: 1-A- SEC.17) 


\section{Arquivo do Ministério dos Negócios Estrangeiros}

Legação de Portugal em Florença, cx. 54 e 55

\section{Arquivo do Museu Nacional de Arte Antiga}

Arquivo José de Figueiredo

Documentação tratada arquivisticamente ao abrigo do projeto "Fontes para a História dos Museus de Arte em Portugal" e disponível online em http://digitarq.dgarq.gov.pt/

Relatórios - PT/MNAA/AJF/DC-OI-ARBA/001

Documentação geral (1838-1884) - PT/MNAA/AJF/DC-OI-ARBA/002

Obras de arte adquiridas pela doação de D. Fernando - PT/MNAA/AJF/DC-OIARBA/003

Arqueologia (1867-1882) - PT/MNAA/AJF/DC-OI-ARBA/004

Avaliação de obras de arte (1852-1880) - PT/MNAA/AJF/DC-OI-ARBA/005

Inventários - PT/MNAA/AJF/DC-OI-ARBA/006

Diversos - PT/MNAA/AJF/DC-OI-ARBA/007

Exposições (1840-1886) - PT/MNAA/AJF/DC-OI-ARBA/008

Referências antigas

cx. 1 (pasta 1 a 15); cx. 2 (pasta 1 a 3); cx. 4 (pasta 1 e 3)

\section{Arquivo da secretaria do MNAA}

Doações, depósitos e aquisições (1838-1912), livro n.o 86

Aquisições 1850-1900, livro n.o 87

\section{Arquivo Nacional da Torre do Tombo}

Arquivo da Casa Palmela, disponível online em http://digitarq.dgarq.gov.pt/

Funções privadas - PT/TT/CPLM/B

Funções públicas - PT/TT/CPLM/C

Gestão Patrimonial - PT/TT/CPLM/E

Arquivo da Casa Real, cx. 7100 e 7327

Casa das Rainhas, liv. 234 


\section{FONTES IMPRESSAS}

Academia Real de Bellas-Artes de Lisboa: organização primitiva e organização actual: academicos: Lisboa: Imprensa Nacional, 1904.

ALMEIDA, Fialho de - Os gatos: publicação mensal de inquérito à vida portuguesa, 2.으 vol. Lisboa: Livraria Clássica Editora, 1945.

ALMEIDA, Fialho de - Vida irónica: jornal d'um vagabundo, 5. a ed. Lisboa: Livraria Clássica Editora, 1924.

ALMEDINA, conde de (co-auto) - Museu Nacional de Bellas Artes e Arqueologia: catalogo provisorio: secção de pintura. Lisboa: Imp. Nacional, 1883.

Antiguidades e obras de arte, pintura, pratas e jóias, n. 128. Lisboa: Cabral Moncada Leilões, Maio 2011.

ARAGÃO, Teixeira de A. C. - Description des monnaies, médailles et autres objets d'art concernant l'histoire du travail. Paris: Imprimerie administrative de Paul Dupont, 1867.

AZEVEDO, Pedro de (org.) - Biblioteca Eugénio da Cunha e Freitas, parte II. Lisboa: PALL, 2010.

BELÉM, Frei Jerónimo de - Chronica Seraphica da Sancta Província dos Algarves, da regular observancia do seraphico $P$. S. Francisco; em que se trata da sua origem, progressos e fundação dos seus conventos. Lisboa: Na Officina de Ignacio Rodrigues, 1750.

BIESTER, Ernesto - "Crónica”. Revista Contemporanea de Portugal e Brazil, vol. II, (n.ㅇ 8). Lisboa: Typ. Franco-Portugueza ,1860, pp. 388- 390.

BIESTER, Ernesto - "Crónica". Revista Contemporanea de Portugal e Brazil, vol. II, (n. 10). Lisboa: Typ. Franco-Portugueza, 1860, pp. 484-486.

BIESTER, Ernesto - "Crónica Literária". Revista Contemporanea de Portugal e Brazil, vol. III, (n.o 6). Lisboa: Typ. do Futuro, 1861, pp. 329-330.

BLANCO, Francisco Cordeiro - "Uma carta inédita de Vieira Portuense". Boletim do Museu Nacional de Arte Antiga, vol. I, n. 3. Lisboa: Museu Nacional de Arte Antiga, 1848, pp. 149-151.

Boletim da Academia Nacional de Belas-Artes: documentos, III. Lisboa: Academia Nacional de Belas-Artes, 1938

Boletim da Academia Nacional de Belas-Artes: documentos, IV. Lisboa: Academia Nacional de Belas-Artes 1939. 
BONIFÁCIO, Maria de Fátima (trans., pref. e ed.) - Memórias do duque de Palmela. Alfragide: D. Quixote, 2011

BRIGOLA, João Carlos Pires - "Colecções, gabinetes, jardins botânicos e museus em Portugal: o testemunho dos viajantes estrangeiros (1750-1900)". Leituras. Revista da Biblioteca Nacional de Lisboa, Série 3, n. 3, 1998.

BRIGOLA, João Carlos Pires - Os viajantes e o "livro dos museus": as coleções portuguesas através do olhar dos viajantes estrangeiros (1700-1900). Porto: Dafne; Évora: CHAIA, 2010.

BÜRGER, W. - "Les collections particulières". Paris guide par les principaux écrivains et artistes de la France, première partie, la science - l'art. Paris: A. Lacroix Verboenckhoven, 1867, pp. 536-551.

CASTELO BRANCO, José Barbosa - Estudos biographicos ou noticia das pessoas retratadas nos quadros historicos pertencentes à Bibliotheca Nacional de Lisboa. Lisboa: F. A. da Silva, 1854.

CASTIILHO, António Feliciano - "S. Bruno". Jornal das Bellas-Artes, vol. I, n.ㅇ 2. Lisboa: [s. n.], 1844, pp. 18-27.

CASTILHO, Júlio - Lisboa antiga: o Bairro Alto, vol. III, 3ae ed. Lisboa: Oficinas Gráficas da CML, 1956.

Catalogo da galeria do P.e Mayne que se ha de arrematar em hasta publica perante o Conselho Administrativo da Academia Real das Sciencias de Lisboa no dia 27 e seguintes do mez de Novembro às 11 horas da manhã. Lisboa: [Academia das Ciências.], [1864].

Catalogo da livraria do finado marquez de Souza Holstein, sub-inspector da Real Academia das Bellas-Artes, etc. que se há-se vender judicialmente, em hasta pública na Calçada dos Caetanos, n. 9 48, no mez de Outubro de 1879, aproximadamente de seis mil volumes. Lisboa: Typ. de J. H. Verde, 1879.

Catalogue des tableaux anciens et modernes et des curiosités formant la collection du vicomte de Carvalhido dont la vente aura lieu Hotel Drouot, salle n.․ 1, les Lundi 14 et Mardi 15 Mars 1870. Paris: Typ. Pillet fils ainé, 1870.

Catálogo dos desenhos originais do pintor Domingos António de Sequeira que constituíam a importante e valiosa coleção Rebelo Valente. Lisboa: Leiria \& Nascimento, 1936.

Catalogo dos objectos particulares colocados na exposição philantropica. Lisboa: Imp. Nacional, 1851. 
Catálogo dos objectos offerecidos pelo governo hespanhol à Academia Real das Bellas Artes de Lisboa e a outros estabelecimentos de Portugal em 1871. Lisboa: Tipografia Universal, 1871.

Catalogo dos quadros existentes no real palacio das Necessidades pertencentes á herança de Sua Magestade el-rei o senhor D. Fernando e que hão de ser vendidos em leilão. Lisboa: Typ. e lith. a vapor da Papelaria Progresso, 1892.

Catalogo illustrado da Exposição Retrospectiva de Arte Ornamental Portugueza e Hespanhola, celebrada em Lisboa em 1882 sob a protecção de Sua Magestade El-Rei o Senhor D. Luiz e a presidencia de Sua Magestade El-Rei o Senhor D. Fernando. Lisboa: Imprensa Nacional, 1882.

Catalogue of the special loan Exhibition of the Spanish and Portuguese Ornamental Art, South Kensington Museum. London: Chapman and Hall, 1881.

Catalogue spécial de la section portugaise à l'Exposition Universelle de Paris en 1867. Paris: Librairie administrative de Paul Dupont, 1867.

CHAGAS, Pinheiro - Diccionario popular, historico, geographico, mytologico, biographico, artistico, bibliographico e litterario, vol. I a VIII, 1876-1890.

CHAGAS, M. Pinheiro - Esboço biographico de Henrique Luiz Feijó da Costa. Lisboa: Typ. Universal, 1864.

CHAGAS, Pinheiro - "Marquês de Sousa Holstein". O Occidente, 1ำ ano, vol. I, n.ㅇ 20. Lisboa: (s. n.), 15 de Outubro de 1878, pp. 156-157.

CHEVALIER, Michel M. (dir) - Exposition universelle de 1867 à Paris: rapports du jury international, T. I. Paris : Imprimerie administrative de Paul Dupont, 1868.

COLAÇO, Branca de Gonta - Memórias da marquesa de Rio Maior, 2. a ed. Lisboa: Parceria A. M. Pereira, 2005.

CORDEIRO, Luciano - Segundo livro de critica: arte e litteratura portugueza d'hoje (livros, quadros e palcos). Porto: Typ. Lusitana, 1871.

CORDEIRO, Luciano - Thesouros d'arte: relances d'um viajante. Lisboa: Imprensa de Joaquim Germano de Sousa Neves, 1875.

COSTA, Henrique Luís Feijó da - Descripção das armas reais de Portugal: dos brazões das cidades e das principaes villas do reino. Lisboa: Typ. Lisbonense de Aguiar Vianna, [s.d.]

COSTA, Henrique Feijó da - Esbôços biographicos dos principaes pintores italianos e rapida descripção artistica e historica dos quadros existentes na galerias de Florença. Lisboa: Typ. Universal, 1866. 
COSTA, L. de Mendonça e - Manual do viajante em Portugal, 4a ed. Lisboa: Typ. da Gazeta dos Caminhos de Ferro, 1913.

CURINIER, C. E. (dir.) - Dictionnaire National des Contemporains, T. II. Paris : Office Général d’Édition, 1899.

Diario de Noticias, 9 Março 1865; 2 Junho 1865; 9 Julho 1865; 9 Setembro 1865; 11 Janeiro 1866; 21 Outubro 1866; 14 Novembro 1866; 18 Novembro 1866; 21 Novembro 1866; 30 Novembro 1866; 27 Dezembro 1866; 25 Janeiro 1867; 9 Março 1867; 5 Novembro 1867; 11 Fevereiro 1868; 28 Março 1868; 29 Março 1868; 31 Março 1868; 7 Abril 1868; 26 Maio 1868; 3 Novembro 1868; 8 Janeiro 1869; 16 Janeiro 1869; 6 Fevereiro 1869; 18 Novembro 1869; 7 Abril 1870; 1 Outubro 1878; 5 Dezembro 1879; 27 Dezembro 1879; 28 Dezembro 1879; 30 Dezembro 1879.

Diario Popular, 21 Abril 1869; 18 Outubro 1869; 19 Outubro 1869

Exposition rétrospective: tableaux anciens empruntés aux galeries particulières: Palais des Champs-Élysées. Paris: J. Claye Imprimeur, 1866.

FERNANDEZ Y GONZALES, Modesto - Portugal contemporáneo: de Madrid à Oporto pasando por Lisboa: diario de un caminante. Madrid: Imprenta y Fundicion de M. Tello, 1874.

FERREIRA, José Maria Andrade - A reforma da Academia das Bellas Artes de Lisboa. Lisboa: Imp. Nacional, 1860.

FIGUEIREDO José de - "O Museu Nacional de Arte Antiga de Lisboa". Sep. Atlântida, vol. 1, n. 92,15 de Dezembro de 1915, pp. 142-153.

FREITAS, Eugénio da Cunha e (org.) - "Cartas de Augusto Filipe Simões para o 1.은 marquês de Sousa Holstein". Sep. Arqueologia e História, 8a série, vol. X. Lisboa: Arqueologia e História, 1962, pp. 49-59.

GINER DE LOS RÍOS, Francisco e Hermenegildo - Portugal: impressiones para servir de guía al viajeiro. Madrid: Imprenta Popular, 1888.

[GUIMARÃES, Daniel M. de Moura] - Guia do Amador de Bellas-Artes. Porto: Tipografia Comercial, 1871.

GUIZOT, François - História da civilização na Europa, 2. ed. Lisboa: Parceria António Maria Pereira, 1907.

[HARO, Étienne-François] - Catalogue de la collection de tableaux de M. le vicomte de Carvalhido. Paris: (s. n.), 1865.

HENRIQUES, Guilherme João Carlos - Novo guia luso-brasileiro do viajante na Europa. Lisboa: Editores - Ferreira Lisboa \& C.. , 1876. 
HOLSTEIN, marquês de Sousa - A Escola de Sagres e as tradições do Infante $D$. Henrique. Lisboa: Typ da Academia, 1877.

HOLSTEIN, marquês de Sousa (co-auto.) - Catalogo provisorio da Galeria Nacional de Pintura existente na Academia Real das Bellas Artes de Lisboa. Lisboa: Academia Real das Bellas Artes, 1868.

HOLSTEIN, marquês de Sousa (co-auto.) - Catalogo provisorio da Galeria Nacional de Pintura existente na Academia Real das Bellas Artes de Lisboa. 2.a ed. Lisboa: Academia Real das Bellas Artes, 1872.

HOLSTEIN, marquês de Sousa - "Domingos António de Sequeira". Artes e Letras, n. 5 a 12, 3. a série; n.o 1 a 4, 4. a série: Lisboa: Rolland \& Semiond, 1874-1875.

HOLSTEIN, marquês de Sousa - "Grão Vasco e a história da arte em Portugal". Artes e Letras, n.ㅇ 1 e 2, 1a série. Lisboa: Rolland \& Semiond, 1872.

HOLSTEIN, marquês de Sousa - "O conde Ugolino (gravura de D. A. Sequeira)" Revista contemporanea de Portugal e Brazil, vol. IV, (n.ㅇ 8). Lisboa: Typ. Franco-Portugueza, 1862-1863, pp. 404-407.

[HOLSTEIN, marquês de Sousa] - Observações sobre o actual estado do ensino das artes em Portugal: a organisação dos museus e o serviço dos monumentos historicos e da archeologia: offerecidas á commissão nomeada por decreto de 10 de Novembro de 1875 por um vogal da mesma commissão. Lisboa: Imp. Nacional, 1875.

HOLSTEIN, marquês de Sousa - "Sua alteza real a Senhora D. Maria Pia, princeza d'Italia". Revista contemporanea de Portugal e Brazil, vol. IV, (n. 2), 1862-1863, pp. 61-64.

HOLSTEIN, marquês de Sousa; SOUSA, Joaquim Pedro de (co-auto.) - Relatório e contas da Sociedade Promotora das Bellas Artes em Portugal no anno de 1863-1864. Lisboa: Typ. Universal, 1864.

HOLSTEIN, marquês de Sousa; SOUSA, Joaquim Pedro de (co-auto.) - Relatório e contas da Sociedade Promotora das Bellas Artes em Portugal no anno de 1865-1866. Lisboa: Typ. Universal, 1867.

HOLSTEIN, marquês de Sousa; SOUSA, Joaquim Pedro de (co-auto.) - Relatório e contas da Sociedade Promotora das Bellas Artes em Portugal no anno de 1866-1867. Lisboa: Typ. Universal, 1868.

HOLSTEIN, marquês de Sousa; SOUSA, Joaquim Pedro de (co-auto.) - Relatório e contas da Sociedade Promotora das Bellas Artes em Portugal no anno de 1867-1868. Lisboa: Typ. Universal, 1869. 
HOLSTEIN, marquês de Sousa; SOUSA, Joaquim Pedro de (co-auto.) - Relatório e contas da Sociedade Promotora das Bellas Artes em Portugal no anno de 1869-1870. Lisboa: Typ. Universal, 1871.

HOLSTEIN, marquês de Sousa; SOUSA, Joaquim Pedro de (co-auto.) - Relatório e contas da Sociedade Promotora das Bellas Artes em Portugal no anno de 1872-1873. Lisboa: Typ. Universal, 1873.

HOLSTEIN, marquês de Sousa; SOUSA, Joaquim Pedro de (co-auto.) - Relatório e contas da Sociedade Promotora das Bellas Artes em Portugal no anno de 1873-1874. Lisboa: Typ. Universal, 1875.

JARDIM, António dos Santos Pereira - Oração recitada na Universidade de Coimbra no doutoramento do marquez de Sousa Holstein. Coimbra: Imprensa da Universidade, 1858.

JOIN, Henry M. - Exposition Universelle de 1878 à Paris: notice historique et analytique des peintures, sculptures, tapisseries, miniatures, émaux, dessin, etc. exposés dans les galeries des portraits nationaux au Palais du Trocadéro. Paris: Imp. Nationale, 1879.

Jornal do Commercio, 30 Setembro 1862; 9 Março 1869.

LARANJO, José Frederico - $O$ conde Emílio de Carvalhido: recordações de um amigo. Lisboa: Typ. e lit. de Barata \& Sanches, 1895.

LEAL, J. M. da Silva - "A Descida ao Limbo por Júlio Romano". Jornal das Bellas-Artes, n. 6. Lisboa: [s. n.], 1846, pp. 88-90

LEAL, J. M. da Silva - "Ancilla Domini: quadro de Rafael”. Jornal das Bellas-Artes, vol. I, n.ㅇ 3, Lisboa: [s. n.], 1845, pp. 37-42.

LEAL, J. M. da Silva - "Biografia: Domingos António de Sequeira". Jornal das BellasArtes, vol. I, n.ㅇ 2, Lisboa: [s. n.] 1844, pp. 28-32.

LEAL, J. M. da Silva - "São João Baptista”. Jornal das Bellas-Artes, vol. I, n.o 1, Lisboa: [s. n.], 1843, pp. 12-16.

Leilão de quadros a oleo antigos pertencentes à galeria do illm.. e exm.. sr. duque de Lafões, existentes no seu palacio ao Grillo (proximo do Beato) em Lisbo: por intervenção do Agente Casimiro Cândido da Cunha no dia 23 de Abril de 1865, e dias seguintes ás 11 horas da manhã. Lisboa: [s. n.], 1865.

LICHNOWSKY, Felix - Portugal: recordações do ano de 1842, 3.a ed. Lisboa: Frenesi, 2005.

LUPI, Miguel Ângelo - Indicações para a reforma da Academia Real de Bellas Artes de Portugal. Lisboa: Imp. Nacional, 1879. 
MACEDO, Joaquim António de - A guide to Lisbon and its environs including Cintra and Mafra with a large plan of Lisbon. Londres: Simpkin, Marshall \& Co; Lisboa: Mattew Lewtas, 1874.

[MACEDO, Manuel de] - Catalogo da collecção de quadros offerecida ao Estado pelo Sr. conde de Carvalhido. Lisboa: Typ. Phenix, 1898.

[MACEDO, Manuel de] - "O Muzeu Nacional de Bellas Artes: apontamentos". Congresso Pedagógico Hispano-Portuguez-Americano. Coimbra: Imprensa da Universidade, 1892.

MACHADO, Alda de Guimarães Guedes Pinto (org.) - $O$ conde de Almedina e a arte em Portugal no século XIX. Lisboa: [s. n.], 1954.

MACHADO, Cyrillo Wolkmar - Collecção de Memórias. Lisboa: [s. n.], 1823

MACHADO, Júlio César - Novo Guia do Viajante em Lisboa. 3a ed. Lisboa, J. J. Bordalo Editor, 1872.

MARTINS, Francisco Vasques - Relatório lido em 2 de Dezembro de 1852 na sessão pública e distribuição de prémios da Academia das Bellas Artes de Lisboa: Lisboa: Typ. de José Baptista Morando, 1852.

MÓNICA, Maria Filomena (coord.) - As farpas: Eça de Queiroz, Ramalho Ortigão: As Farpas originais de Eça de Queiroz. S. João do Estoril: Principia, 2004.

MÓNICA, Maria Filomena (org.) - Isabel, condessa de Rio Maior: correspondência para seus filhos 1852-1865. Lisboa: Quetzal, 2004.

Negocios externos: documentos apresentados ás Cortes na sessão legislativa de 1875 pelo ministro e secretário d'Estado dos Negocios Estrangeiros: emigração Portuguesa. Lisboa: Imp. Nacional, 1875.

NORONHA, Eduardo de - Estroinas e estroinices: ruina e morte do conde de Farrobo. Lisboa: João Romano Torres, 1922.

Objets d'art et de curiosité, tableaux anciens appartenant à $M$. le Cte de $C^{* * *}$ [Carvalhido]. Paris: [s. n.], 1879.

Oeuvres d'art en photographie: l'Espagne et le Portugal au point de vue artistique, monumental et pittoresque: catalogue: catalogue des chefs d'oeuvre de peinture ancienne et moderne, de sculpture, ciselure, d'ornamentation, etc., photographié sur les originaux meme des musées d'Espagne et du Portugal (...) Madrid/Paris: J. Laurent, 1872.

ORTIGÃO, Ramalho - Arte Portuguesa, T. I, II e III. Lisboa: Livraria Clássica Editora, 
$1943-1947$.

ORTIGÃO, Ramalho; QUEIRÓS, Eça de - As farpas: chronica mensal da política das letras e dos costumes. Lisboa: Typ. Universal, 1871-1883.

PAMPLONA, Fernando de; SILVA, Ricardo do Espírito Santo (pref.) - Dicionário de pintores e escultores portugueses ou que trabalharam em Portugal, vol. I a IV. Lisboa: (s. n.), 1954-1959.

PEREIRA, Esteves; RODRIGUES, Guilherme - Portugal: diccionario historico, chorografico, heraldico, biographico, bibliographico, numismatico e artistico. vol. I a VII. Lisboa: João Romano Torres 1904-1915.

PEREIRA, Gabriel - A coleç̧ão de pinturas do Sr. duque de Palmela no pallacio do Rato. Lisboa: Typ. Lallement, 1903.

PEREIRA, Gabriel - Biblioteca Nacional de Lisboa: noticia dos retratos em tela. Lisboa: Biblioteca Nacional, 1900.

PEREIRA, Gabriel - O Museu Nacional de Bellas Artes. Lisboa: Officina Typographica, 1908.

PERNES, visconde de; PRIETO, Joaquim (co-auto.) - Relatório e contas da Sociedade Promotora das Bellas Artes em Portugal no anno de 1875-1876. Lisboa: Typ. Universal, 1879.

PRIETO, Joaquim - "Sociedade Promotora das Bellas Artes em Portugal: relatório do ano social de 1861-1862, apresentado pelo conselho administrativo". Revista Contemporanea de Portugal e Brazil, vol. IV, (n.o 6). Lisboa: Typ. Franco-Portugueza 1862-1863, pp. 318-323.

Publicação Photographica, n.o 4, 1869.

RACZYNSKI, A. - Dictionnaire historico-artistique du Portugal pour faire suite á l'ouvrage ayant pour titre Les arts en Portugal. Paris: Jules Renouard, 1847.

RACZYNSKI, A - Les arts en Portugal: lettres adressées a la Société Artistique de Berlin et accompagnées de documents. Paris: Jules Renouard, 1846.

RATAZZI, Maria - Portugal de Relance, 2. ed. Lisboa: Antígona, 2004.

Relação e indice alphabetico dos estudantes matriculados na Universidade de Coimbra e no Lyceu no anno lectivo de 1854 para 1855 com suas filiações, naturalidades e moradas e com a designação das diversas cadeiras e disciplinas, e dos lentes $e$ professores respectivos. Coimbra: Imprensa da Universidade, 1854.

Relatorio dirigido ao illustrissimo e excellentissimo senhor ministro e secretario de 
Estado dos Negocios do Reino pela comissão nomeada por decreto de 10 de Novembro de 1875 para propor a reforma do ensino artistico, a organização do serviço de museus, monumentos historicos e archeologia, I e II parte. Lisboa: Imp. Nacional, 1876.

RIBEIRO, João Baptista - Exposição historica da creação do Museo Portuense: com documentos officiaes para servir à historia das bellas artes em Portugal e à do cêrco do Porto. Porto: Imp. de Coutinho, 1836.

RIBEIRO, José Silvestre - Historia dos estabelecimentos scientificos, litterarios $e$ artisticos de Portugal nos successivos reinados da monarchia, T. VI e X. Lisboa: Typ. da Academia Real das Sciencias, 1876 e 1882.

ROBINSON, John Charles - "The early Portuguese school of painting: with notes on the pictures at Viseu and Coimbra traditionally ascribed to Gran Vasco". The Fine Arts Quarterly Review, n. 2. Londres: (s.n.) Oct. 1866, pp. 375-400.

ROBINSON, John Charles; HOLSTEIN, marquês de Sousa (pref.) - A antiga escola portugueza de pintura: com notas acerca dos quadros existentes em Vizeu e Coimbra e attribuidos por tradição a Grão Vasco. Lisboa: Typ Universal, 1868.

ROSWAG, A. - Nouveau guide du touriste en Espagne et Portugal: itinéraire artistique. Madrid: J. Laurent et Cie., 1879.

SÁ, S. J. Ribeiro de - "Academia de Bellas-Artes de Lisboa: exposição de 1843". O Panorama, vol. III, 3ㅇ da 2a série, n. 107, 13 de Janeiro de 1844. Lisboa: Imprensa da Sociedade Propagandora dos Conhecimentos Uteis, pp. 11-13.

SÁ, S. J. Ribeiro de - "Bellas-artes: almoeda no Palácio da Bemposta". Revista Universal Lisbonense, vol. VII, série I, n.o 2, 16 de Dezembro de 1847. Lisboa: Imprensa Nacional, pp. 19-20.

SÁ, S. J. Ribeiro de - "Os quadros da Bemposta e a possibilidade de organizar em Lisboa um Muzeu Nacional". Revista Universal Lisbonense, vol. VII, série II, n.o 21, 27 de Abril de 1848. Lisboa: Imprensa Nacional, pp. 241-246.

SÁ, S. J. Ribeiro de - "Um brado a favor da glória nacional e das bellas-artes". $O$ Panorama, vol. III, 3ㅇ da 2a série, n. 109, 27 de Janeiro de 1844. Lisboa: Imprensa da Sociedade Propagandora dos Conhecimentos Uteis, pp. 27-28.

[SANTOS, João José dos] - Catalogo dos livros da bibliotheca da Academia das BellasArtes de Lisboa. Lisboa: Typ. de José Baptista Morando, 1862.

[SANTOS, João José dos] - Catalogo provisorio dos quadros existentes na galeria da Academia Real das Bellas-Artes. Lisboa: Typ. de José Baptista Morando, 1862.

SANTOS, João José dos - Exame critico do opusculo reforma d'Academia de Bellas Artes de Lisboa pelo Sr. José Maria de Andrade Ferreira. Lisboa: Typ. de G. M. Martins, 1860. 
SEQUEIRA, José da Costa (co-auto) - Descripção das obras apresentadas na primeira exposição triennal da Academia das Bellas Artes de Lisboa. Lisboa: [s.n.], 1840.

SESIMBRA, Mariana - Madre Monfalim: memórias de sua irmã Marianna Cezimbra. Lisboa: Bertrand, 1946.

SILVA, L. A. Rebelo da - "A Epifania”. Jornal das Bellas-Artes, vol. I, n. 1. Lisboa: [s.n.], 1843, pp. 2-7.

[SILVA, Marciano Henriques da] - Galeria de pintura do real paço da Ajuda fundada por Sua Magestade o Senhor D. Luiz I. Lisboa: Typ. Universal de Tomaz Quintino Antunes, 1869.

[SILVA, Marciano Henriques da] - Galeria de pintura no real paço da Ajuda fundada por Sua Magestade o Senhor D. Luiz I, 2a ed. [Lisboa]: Typ. Belenense de José Maria da Costa Fortinho, 1872.

SIMÕES, Augusto Filipe - "Marquês de Sousa Holstein". Escriptos diversos de Augusto Filippe Simões. Coimbra: Imprensa da Universidade, 1888, pp. 205-208.

Sociedade Promotora das Bellas-Artes em Portugal: primeira exposição. Lisboa: Typ. do Futuro, 1862.

Sociedade Promotora das Bellas-Artes em Portugal: segunda exposição. Lisboa: Typ. Franco-portuguesa, 1863.

Sociedade Promotora das Bellas-Artes em Portugal: terceira exposição. Lisboa: Typ. Franco-portuguesa, 1864.

Sociedade Promotora das Bellas-Artes em Portugal: quarta exposição. Lisboa: Typ. Franco-portuguesa, 1865.

Sociedade Promotora das Bellas-Artes em Portugal: quinta exposição. Lisboa: Typ. Universal, 1866.

Sociedade Promotora das Bellas-Artes em Portugal: sexta exposição. Lisboa: Typ. Universal, 1867.

Sociedade Promotora das Bellas-Artes em Portugal: séptima exposição. Lisboa: Typ. Universal, 1868.

Sociedade Promotora das Bellas-Artes em Portugal: oitava exposição. Lisboa: Typ. Universal, 1870.

Sociedade Promotora das Bellas-Artes em Portugal: nona exposição. Lisboa: Typ. Universal, 1872. 
Sociedade Promotora das Bellas-Artes em Portugal: décima exposição. Lisboa: Typ. Universal, 1874.

Sociedade Promotora das Bellas-Artes em Portugal: undécima exposição. Lisboa: Typ. Universal, 1876.

Sociedade Promotora das Bellas-Artes em Portugal: duodécima exposição. Lisboa: Typ. Universal, 1880.

The stranger's guide in Lisbon or an historical and descriptive view of the city of Lisbon and its environs with a new and correct map of the city. Lisboa: A. J. P., 1847.

Theses ex universo jure selectae pro doctorali obtienda in Conimbricensi Academia: propugnandas marchio de Sousa Holstein. Conimbricae: Typis Academis, 1858.

VASCONCELOS, Joaquim de - A pintura portuguesa nos séculos XV e XVI, 2. a ed. Coimbra: Imp. da Universidade, 1929.

VASCONCELOS, Joaquim de - A reforma de bellas-artes: analyse do relatorio $e$ projectos da commissão official nomeada em 10 de Novembro de 1875. Porto: Imprensa Litterario-Commercial, 1877.

VASCONCELOS, Joaquim de - A reforma do ensino de Bellas-Artes II: analyse da $2^{a}$ parte do relatorio official. Porto: Imprensa Litterario-Commercial, 1878.

VASCONCELOS, Joaquim de - "Arte decorativa portuguesa: ourivesaria portuguesa". ARROIO, António (dir.) - Notas sobre Portugal: exposição nacional do Rio de Janeiro: secção portuguesa, vol. II. Lisboa: Imprensa Nacional, 1908.

VASCONCELOS, Joaquim de - Arte religiosa em Portugal, vol. I. Porto: Emílio Biel \& C.a Editores, 1914-1915.

VASCONCELOS, Joaquim de - História da Arte em Portugal: a pintura portuguesa nos séculos XV e XVI. Porto: Officina typografica de João Eduardo Alves, 1881.

WORDSWORTH, Dorothy - Journal of a few months' residence in Portugal and glimpses of the south of Spain, vols. I-II. London: Edward Moxon, 1847.

ZOLA, Émile - Mon Salon: augmenté d'une dédicace et d'un appendice. Paris, Librairie Centrale, 1866. 


\section{BIBLIOGRAFIA}

ALDEMIRA, Luís Varela - Um ano trágico: Lisboa 1836: a propósito do centenário da Academia de Belas Artes: impressões, comentários, documentos. Lisboa: La Bécarre (dep.), 1937.

ALMEIDA, António Manuel Passos - Museu Municipal do Porto: das origens à sua extinção (1836-1940). Dissertação de mestrado em Museologia apresentada à Faculdade de Letras da Universidade do Porto, 2008 [policopiada].

ALVES, Alice - "O restauro de pintura na Academia de Belas-Artes de Lisboa: a contribuição de António Manuel da Fonseca". Arte e Teoria, n. 16-17. Lisboa: FBAULCIEBA, 2014 [no prelo].

ALVES, Alice - "Os restauradores da coleção de pintura da Academia de Belas Artes de Lisboa proveniente dos conventos extintos". SOARES, Clara Moura (coord.) - 0 Património Artístico das Ordens Religiosas: entre o Liberalismo e a atualidade: Lisboa: BNP, 2014/2015 [no prelo].

ANTUNES, João Carlos da Silva Jorge - $A$ bolsa de valores de Lisboa e a crise bancaria de 1876. Dissertação de mestrado apresentada ao Instituto Superior de Economia e Gestão da Universidade de Lisboa, 2013.

ARAÚJO, Agostinho - "O restauro de painéis e a actividade de alguns pintores italianos em Portugal (c. 1710-1860)". Nel mezzo del cammin: atas da Jornada de Estudos Italianos em honra de Giuseppe Mea. Porto: Sombra pela Cintura, 2009, pp. 11-63.

ARAÚJO, Nuno - "A singular viagem do fotógrafo Jean Laurent a Portugal, em 1869". CEM: Cultura, Espaço \& Memória, n. 1. Porto/Braga: CITCEM, 2011, pp. 87-108.

BARATA, Paulo J. S. - Os livros e o Liberalismo: da livraria conventual à biblioteca pública: uma alteração de paradigma. Lisboa: Biblioteca Nacional, 2003.

BASTOS, Celina - Os interiores régios de D. Maria I a D. Maria II". SOUSA, Gonçalo de Vasconcelos e (dir.) - Matrizes da investigação em artes decorativas, V. Porto: UCE/CITAR, 2013, pp. 115-145.

BASTOS, Celina - "Percurso de uma pintura". CAETANO, Joaquim Oliveira (comiss.) Luca Giordano: Êxtase de São Francisco (cat. expo.). Lisboa: Museu Nacional de Arte Antiga, 2014, pp. 7-32.

BOLANÕS, María - Historia de los museos en España: memoria, cultura, sociedad. Gijon: Ediciones Trea, 1997.

BRIGOLA, João Carlos Pires - Colecções, gabinetes e museus em Portugal no século XVIII. Lisboa: FCG/FCT, 2003. 
BURTON, Anthony - Vision \& Accident: The story of the Victoria and Albert Museum. London: V\&A Publications, 1999.

CAETANO, Joaquim Oliveira - "O retábulo flamengo da Sé de Évora: algumas reflexões sobre um processo de investigação em curso". Museologia.pt, n. 1. Lisboa: Instituto dos Museus e da Conservação, 2007, pp. 25-33.

CAETANO, Joaquim Oliveira; CARVALHO, José Alberto Seabra (coord.) - Jan Provoost: 0 tríptico de Nossa Senhora da Misericórdia (cat. expo.): Lisboa: MNAA, 2012.

CALADO, Margarida - O convento de São Francisco da cidade. Coleção B'A - Biblioteca d'Artes, n.ㅇ 1. Lisboa: Faculdade de Belas Artes, 2000.

CARVALHO, A. Ayres de - A galeria de pintura da Ajuda e as galerias do século XIX. Lisboa: ANBA, 1982.

CARVALHO, José Alberto Seabra - "'A recolta devia fazer-se estugadamente e por completo'. Patrimónios em trânsito: extinguir conventos e criar museus". CUSTÓDIO, Jorge (coord.) - 100 anos de património: memória e identidade. Lisboa: Igespar, 2010, p. 35-39.

CARVALHO, José Alberto Seabra - "Dos conventos aos museus: histórias que o forno apagou". Inventário do Museu Nacional de Arte Antiga: coleção de ourivesaria: do Românico ao Manuelino, vol. I. Lisboa: Instituto Português de Museus, 1995, pp. 2021.

CARVALHO, José Alberto Seabra - Estudo sobre as proveniências do Museu Nacional de Arte Antiga, 1991 [inédito].

CARVALHO, José Alberto Seabra; BARREIRA, Marta - "Museus e exposições: ideias, formas e discursos de representação e celebração da arte portuguesa (do Liberalismo ao Estado Novo)". RODRIGUES, Dalila (coord.) - Arte portuguesa: da pré-história ao século XX, Vol. 20. Lisboa: Fubu Editores. 2009.

CARVALHO, José Alberto Seabra; CAETANO, Joaquim Oliveira (coord.) - Primitivos Portugueses 1450-1550: o século de Nuno Gonçalves (cat. expo.). Lisboa: MNAA/Athena, 2011.

CARVALHO, José Alberto Seabra; CURVELO, Alexandra - "1834-1981: breve história da formação de uma coleç̧ão". PORFíRIO, José Luís (comiss.) - Museu Nacional de Arte Antiga (cat. expo). Lisboa: Inapa, 1999, pp. 44-53.

CARVALHO, Rómulo de - O material didáctico dos séculos XVIII e XIX do Museu Maynense da Academia das Ciências de Lisboa. Lisboa: Academia das Ciências, 1993.

Chantal Georgel (dir.) - La jeunesse des musées: les musées en France au XIXe siècle 
(cat. expo.). Paris: Réunion des musées nationaux, 1994.

CORTE-REAL, Manuel - O Palácio das Necessidades. Lisboa: Chaves Ferreira, 2001.

CORTEZ, Fernando Russel - "A Academia Real de Belas-Artes e a proteç̧ão do património artístico: seu resultado na criação dos museus portugueses". Revista $e$ Boletim da Academia Nacional de Belas-Artes, 3. série, n. 4 a 6. Lisboa: ANBA, 1982 a 1984.

CORTEZ, Fernando Augusto de Barros Russel - Antecedentes do Museu Nacional de Arte Antiga. Dissertação para o estágio de conservador dos museus e dos palácios nacionais apresentada no MNAA, 1954 [dactilografada].

COSTA, Luís Xavier da - A morte de Camões: quadro do pintor Domingos António de Sequeira. Lisboa: Imp. Libânio da Silva, 1922.

COSTA, Luís Xavier da - Domingos António Sequeira: notícia biográfica, Lisboa: Amigos do MNAA, 1939.

COSTA, Lucília Verdelho - Alfredo de Andrade 1839-1915: da pintura à invenção do património. Lisboa: Vega, 1997.

CRUZ, António João - "Em busca da imagem original: Luciano Freire e a teoria e a prática do restauro em Portugal cerca de 1900". Conservar património, 5. Lisboa: ARP, 2007, pp. 67-83.

CUESTA, Miguel Hermoso - "A propósito de un lienzo de Lucas Jordán en el Museu Nacional de Arte Antiga de Lisboa". Anales de Historia da Arte, n. 20. Madrid: Publicaciones Universidad Complutense de Madrid, 2010, pp. 183-207.

CUESTA, Miguel Hermoso - "Un quadro del Museu Nacional de Arte Antiga en Lisboa procedente de la colección de Carlos IV". Reales Sitios, n.ㅇ 165. Madrid: Patrimonio Nacional, 2005, pp. 174-177.

CUSTÓDIO, Jorge - Renascença artística e práticas de conservação e restauro arquitectónico em Portugal durante a I República: fundamentos e antecedentes. Casal de Cambra: Caleidoscópio, 2011.

CURVELO, Alexandra (coord.) - Casa Perfeitíssima: 500 anos da fundação do Mosteiro da Madre de Deus 1509-2009 (cat. expo.). Lisboa: MNAZ, 2009.

DESWARTE-ROSA, Sylvie - "Athanase Raczynski au Portugal, 1842-1848". Artis, n.ㅇ 9/10. Lisboa: Instituto de História da Arte - FLUL, 2010-2011, pp. 19-91.

DUARTE, Eduardo Manuel Alves - Desenho romântico português: cinco artistas desenham em cintra. Dissertação de Doutoramento em História da Arte apresentada à FBAUL, 2006 [policopiada]. 
FAROULT, Guillaume (dir.); ELOY, Sophie (col.) - La Collection La Caze: chefs-d'oeuvre des peintures des XVIle et XVIIle siècles (cat. expo.). Paris: Musée du Louvre Éditions, 2007.

FEIO, Alberto - Um artista minhoto. Sep. Minia: revista do Instituto Minhoto de Estudos Regionais, vol. I. Braga: Oficinas Gráficas “Pax”, 1946.

FERREIRA, Emília - História dos museus públicos de arte no Portugal de Oitocentos. Dissertação de Mestrado em História da Arte Contemporânea apresentada à FCSHUNL, 2001 [policopiada].

FERREIRA, Emília - Lisboa em festa: a exposição retrospectiva de arte ornamental portuguesa e espanhola, 1882: antecedentes e materialização. Dissertação de doutoramento em História da Arte Contemporânea apresentada à FCSH-UNL, 2010 [policopiada].

FIGUEIREDO, José - O Legado Valmor e a reforma dos serviços de belas artes, Lisboa: M. Gomes, 1901.

FONTANELLA, Lee - Charles Thurston Thompson e o proxecto fotográfico ibérico. A Coruña: Centro Galego de Artes da Imaxe, 1996.

FRANÇA, José-Augusto - $A$ arte em Portugal no século $X I X$, vol. I e II, 3a. ed. Venda Nova: Bertrand, 1990.

FRANÇA, José-Augusto (org.) - Homenagem a Sequeira. Lisboa: Grémio Literário, 1968.

FRANÇA, José-Augusto - O Romantismo em Portugal: estudo de factos socioculturais. Lisboa: Livros Horizonte, 1993.

GARCÍA-FRIAS, Carmen - "Nuevas aportaciones al estudio de la collección pictórica de Carlos IV en el exilio". Actas de las Jornadas de Arte y Iconografía sobre Carlos IV y el arte de su reinado: Seminario de Arte e Iconografía "Marqués de Lozoya". Madrid: Fundación Universitaria Española, 2011, pp. 211-261.

GOMES, Alexandra Reis - "A coleção de desenho do Museu das Janelas Verdes". Desenho: a coleção do Museu Nacional de Arte Antiga (cat. expo.). Lisboa: Lisboa 94 / Electa, 1994, pp. 16-21.

GONÇALVES, António Manuel - As origens do Museu Nacional de Belas Artes. Dissertação para o estágio de conservador dos museus e dos palácios nacionais apresentada no Museu Nacional de Arte Antiga, 1957 [dactilografada].

GONÇALVES, António Manuel - Do restauro do painéis de São Vicente de Fora. Lisboa: Amigos do MNAA, 1960. 
GONÇALVES, António Nogueira - Joaquim de Vasconcelos e o opúsculo "São Pedro de Rates". Coimbra: Instituto de História da Arte, 1976.

GOUVEIA, Henrique Coutinho - Museologia e Etnologia em Portugal. Instituições de Personalidades. Dissertação de Doutoramento em Antropologia, área da Museologia, apresentada à FCSH-UNL, 1999 [policopiada].

GUIMARÃES, Carlos - Arquitectura e museus em Portugal: entre reinterpretação e obra nova, Porto: FAUP Publicações, 2004.

JOÃO, Maria Isabel - "História e ficção: o infante D. Henrique em Oliveira Martins". Sep. da Revista da Universidade de Coimbra, vol. XXXVIII. Coimbra: Imprensa de Coimbra, 1999.

JOÃO, Maria Isabel - "Sagres, lugar mítico da memória". Des(a)fiando discursos: homenagem a Maria Emília Ricardo Marques. Lisboa: Universidade Aberta, 2005, pp. 409-422

JORDÁN DE URRÍES, Javier; SANCHO, José Luis (comiss.) - Carlos IV: mecenas y coleccionista (cat. expo.). Madrid: Patrimonio Nacional / Ediciones El Viso, 2009.

LEANDRO, Sandra - Joaquim de Vasconcelos (1849-1946): historiador, crítico de arte e museólogo. Dissertação de doutoramento em História da Arte Contemporânea apresentada à FCSH-UNL, 2008 [policopiada].

LEITE, José R. Teixeira - "Um quadro de Metsijs no Brasil". Colóquio, n.ㅇ 8. Lisboa: Fundação Calouste Gulbenkian, 1960, p. 25.

LIMA, Henrique de Campos Ferreira - "O gravador João José dos Santos". Revista de Guimarães, vol. 58, fasc. 3-4. Guimarães: Tip. Minerva Vimaranense, 1949, pp. 314325.

LISBOA, Maria Helena - As academias e escolas de Belas Artes e o ensino artístico (1836-1910). Lisboa: Edições Colibri / IHA - Estudos de Arte Contemporânea FCSHUNL, 2007.

LOURENÇO, Marta; NETO, Maria João (coord.) - Património da Universidade de Lisboa: ciência e arte. Lisboa: Tinta de China, 2011.

MACEDO, Diogo de - Académicos e românticos: a fundação. Coleção Museum, 1a série, n. 7. Lisboa: Museu Nacional de Arte Contemporânea, 1950.

MACEDO, Diogo de - "Notas de arte: informações e história". Ocidente, vol. LIII, n.음 234: Lisboa: [s. n.], Outubro 1957, pp. 170-173.

MACEDO, Diogo de - "Registo do Legado Valmor". Belas Artes: revista e boletim da Academia Nacional de Belas-Artes, 2. série, n.o 7. Lisboa: ANBA, 1954, pp. 53-54. 
MACEDO, Diogo de - "Uma pequena galeria de retratos". Belas Artes: revista e boletim da Academia Nacional de Belas-Artes, 2.a série, n.ㅇ 9, Lisboa: ANBA, 1956.

MANAÇAS, Vítor - Museu Nacional de Arte Anriga: uma leitura da sua história 19111962. Dissertação de Mestrado em História da Arte Contemporânea apresentada à Faculdade de Ciências Sociais e Humanas da Universidade Nova de Lisboa, 1991 [policopiada].

MARQUES, Luiz - "A contribuição de D. João VI para a formação do acervo de pintura italiana nas coleções públicas do Brasil". NETO, Maria João; MALTA, Mariz (eds.) Coleções de arte em Portugal e Brasil nos séculos XIX e XX: perfis e trânsitos. Casal de Cambra: Caleidoscópio, 2014, pp. 249-264.

MARTINHO, Maria José - "HOLSTEIN, D. Francisco de [...]". MÓNICA, Maria Filomena (dir.) - Dicionário biográfico parlamentar 1834-1910, vol. 2. Lisboa: Assembleia da República: Imprensa de Ciências Sociais, 2005, pp. 430-431.

MARTINS, Ana Cristina - Possidónio da Silva (1806-1896) e o elogio da memória: um percurso na arqueologia de Oitocentos. Lisboa: Associação dos Arqueólogos Portugueses, 2003.

MATILLA, José Manuel; PORTÚS, Javier (ed.) - El grafoscopio: un siglo de miradas al Museo del Prado (1819-1920) (cat. expo.). Madrid: Museo Nacional del Prado, 2004.

MATOS, Maria Antónia Pinto de; CAMPILHO, Maria de Sousa Holstein (coord.) - Uma familia de coleccionadores: poder e cultura: antiga colecção Palmela (cat. expo). Lisboa: IPM/CMAG, 2001.

MONTEIRO, Joana Sousa - "Os Espaços do conventos de S. Francisco: da progressiva desagregação ao Museu do Chiado". SILVA, Raquel Henriques da (coord.) - Obraçom: Museu do Chiado: histórias vistas e contadas (cat. expo.). Lisboa: Instituto Português de Museus, 1995, pp. 19-34.

NETO, Maria João - "A propósito da descoberta dos Painéis de São Vicente de Fora: contributo para o estudo e salvaguarda da pintura gótica em Portugal". Artis, n. 2 . Lisboa: Instituto de História da Arte - FLUL, 2003, pp. 219-260.

NETO, Maria João - "Coleccionadores e Connaisseurs de obras de arte: Francis Cook (1817-1901) e John Charles Robinson (1824-1913) em Portugal". Artis, n.ㅇ 6. Lisboa: Instituto de História da Arte FLUL, 2007, pp. 403-442.

NETO, Maria João - "Construção e desconstrução de coleções: o mercado de arte em Roma no período napoleónico aos olhos dos diplomatas portugueses". NETO, Maria João; MALTA, Marize (eds.) - Coleções de arte em Portugal e Brasil nos séculos XIX e XX: perfis e trânsitos. Casal de Cambra: Caleidoscópio, 2014, pp. 51-69. 
PEREIRA, Maria Helena da Rocha - "Notícia sobre vasos gregos existentes em Portugal". Sep. Humanitas, v. 8, nova série. Coimbra: FLUC-IEC, 1959, pp. 11-26.

PIMENTEL, Cristina - O sistema museológico português, 1833-1991: em direcção de um novo modelo teórico para o seu estudo. Lisboa: FCG, 2005.

PORFÍRIO, José Luís - Pintura europeia: roteiro: Museu Nacional de Arte Antiga. Lisboa: Instituto Português de Museus, 2005.

PORFÍRIO, José Luís (comiss.) - Sequeira: um português na mudança dos tempos 17681837 (cat. expo.). Lisboa: IPM/MNAA, 1997.

POULOT, Dominque - Musée, Nation, Patrimoine: 1789-1815. Paris: Éditions Gallimard, 1997.

POULOT, Dominique - Patrimoine et musée: l'instituition de la culture. Paris: Hachete Livre, 2007.

QUEIRÓS, Amílcar de Barros - Da Sociedade Promotora de Belas Artes e do Grémio Artístico à Sociedade Nacional de Belas Artes: exposição documental 1860-1951. Lisboa: Sociedade Nacional de Belas Artes, 1951.

RAMALHO, Maria de Magalhães - "O sítio e o convento de S. Francisco da Cidade: da fundação ao Terramoto de 1875". SILVA, Raquel Henriques da (coord.) - Obraçom: Museu do Chiado: histórias vistas e contadas (cat. expo.). Lisboa: Instituto Português de Museus, 1995, pp. 19-34.

RAMOS, Afonso - "José Rodrigues e 'O cego rabequista'". SILVA, Raquel Henriques da (coord.) - Revista de História da Arte, n.ㅇ 8. Lisboa: Instituto de História da Arte FCSHUNL, 2011, pp. 276-285.

RODRIGUES, Dalila - "Vasco Fernandes ou a contemporaneidade do diverso". Vasco Fernandes e a pintura europeia do Renascimento (cat. expo.). Lisboa: Comissão Nacional para as Comemorações dos Descobrimentos Portugueses, 1992.

RODRIGUES, Paulo Simões - "Da história do restauro em Portugal: das origens ao Portugal oitocentista". 40 anos do Instituto José de Figueiredo, 2007. Lisboa: IPCR, pp. 17-38.

RODRIGUES, Paulo Simões - "O conde Athanasius Raczynski e a historiografia da arte em Portugal". SILVA, Raquel Henriques da (coord.) - Revista de História da Arte, n. 8. Lisboa: Instituto de História da Arte da FCSH-INL, 2011, pp. 264-277.

ROSMANINHO, Nuno - A historiografia artística portuguesa de Raczynski ao dealbar do Estado Novo: 1846-1935. Dissertação de Mestrado em História Contemporânea de Portugal apresentada à Universidade de Coimbra, 1993 [policopiada]. 
SAMPSON, Robert - John L. O'Sullivan and his times. Kent, Ohio: Kent State University Press, 2003.

SANCHO, José Luis - "Coleccionista hasta la muerte: casas y obras artísticas de Carlos IV en Francia y Roma 1808-1819". Reales Sitios, n. 175, Madrid: Patrimonio Nacional, 2008, pp. 4-25.

SANTOS, Paula - "A colecção de pintura de D. Carlota Joaquina de Bourbon, oriunda do em Sintra: o seu resultado na formação do Museu Nacional de Arte Antiga". Varia Escrita, n.o 2. Sintra: [s. n.], 1995, pp. 261-318.

SANTOS, Paula - Um coleccionador do Porto romântico: João Allen (1781-1848). Porto: Imprensa Portuguesa, 2005.

SANTOS, Paula; REIS, Ana - "Os museus de arte de Lisboa e Porto e a sua relação com as artes industriais e o ensino artístico no século XIX". Sep. Revista Mvseu, n. 9. Porto: Círculo Dr. José de Figueiredo, 2000.

SARAIVA, José da Cunha - "Os quadros do Ramalhão que foram para a Academia de Belas Artes". Sep. Feira da Ladra, Lisboa: [s. n.], 1937.

SENA, António - História da imagem fotográfica em Portugal (1839-1997). Porto: Porto Editora, 1998.

SERRÃO, Vítor - "Quatro ignorados painéis dos Mestres de Ferreirim no Museu D. João VI da Universidade Federal do Rio de Janeiro". Estudo da Pintura Portuguesa: oficina de Gregório Lopes: actas/seminário internacional. Lisboa: Instituto José de Figueiredo, 1999, pp. 123-127.

SÉRULLAZ, Arlette - "Étienne-François Haro, entre Ingres et Delacroix". Bulletin de la Societé des Amis du Musée National Eugène Delacroix, n.ำ 4. Paris: Société des Amis du Musée National Eugène Delacroix, 2006.

SILVA, António Martins da - Nacionalizações e privatizações em Portugal: a desamortização oitocentista. Coimbra: Minerva, 1997.

SILVA, António Martins da - "O fenómeno desamortizador e a sua inserção histórica". MATTOSO, José (dir.) - História de Portugal, vol. V, 1993. Lisboa: Círculo de Leitores, pp. 339-340.

SILVA, Luís Cristino da - A sede da Academia Nacional de Belas-Artes no vetusto edifício do antigo convento de $S$. Francisco da cidade: estudos e subsídios diversos. Lisboa: Direcção-Geral dos Assuntos Culturais, 1973.

SILVA, Raquel Henriques da - "Museus: História e Prospectiva". PERNES, Fernando (coord.) - Panorama da Cultura Portuguesa no século XX. Porto: Fundação de Serralves, 2002. 
SILVA, Raquel Henriques da; BAIÃO, Joana; OLIVEIRA, Leonor (coord.) - Sources for the History of Art in Portugal. Coleção Projetha: projects of the Institute of Art History, n.․․ 1, Lisboa: Instituto de História da Arte FCSH-UNL, 2013 (publicação online).

SILVEIRA, Luís Espinha da - "A venda dos bens nacionais (1834-43): uma primeira abordagem". Análise Social, vol. XVI (61-62). Lisboa: ISCEF, 1980, pp. 87-110.

SILVEIRA, Maria de Aires (comiss.) - João Cristino da Silva 1829-1877 (cat. expo.). Lisboa: IPM/Museu do Chiado, 2000.

SILVEIRA, Maria de Aires; TAVATRES, Cristina Azevedo (comiss.) - Miguel Ângelo Lupi 1826-1883 (cat. expo.). Lisboa: IPM/Museu do Chiado, 2002.

SOARES, Clara Moura - "D. Pedro I do Brasil, IV de Portugal: o 'gosto do bello' e o incremento das Belas-Artes: traços de um perfil quase desconhecido do rei-soldado". NETO, Maria João; MALTA, Marize (eds.) - Coleções de arte em Portugal e Brasil nos séculos XIX e XX: perfis e trânsitos. Casal de Cambra: Caleidoscópio, 2014, pp. 381-398.

SOARES, Clara Moura - "Na origem da Galeria Nacional de Pintura da Academia de Belas Artes de Lisboa: 540 quadros selecionados do Depósito das Livrarias dos Conventos Extintos". Artis, n. 2, 2a série. Casal de Cambra: Caleidoscópio, 2014, pp. 200-201.

SOARES, Clara Moura; RODRIGUES, Rute Massano - "A criação de um Museu Nacional de Belas Artes no Convento de S. Francisco: um desígnio de D. Pedro IV". Artis, n. 1, 2. a série. Casal de Cambra: Caleidoscópio, 2013, pp. 170-171.

SOARES, Clara Moura; RODRIGUES, Rute Massano - "A salvaguarda do património histórico-artístico na regência de D. Pedro IV: a consciência patrimonial no contexto das guerras liberais". Atas do Simpósio Património em Construção: contextos para a sua preservação. Lisboa: LNEC, 2011, pp. 351-358.

SOARES, Clara Moura; RODRIGUES, Rute Massano; CRUZ, António João; REGO, Carla "Conservação e destruição de pinturas dos conventos em Portugal durante o século XIX". ECR: estudos de conservação e restauro, n.․ 4. Porto: CITAR, 2012, pp. 231-248

SOARES, Ernesto - José Vicente Sales: pintor, desenhador e gravador. Braga: Bracara Augusta, 1954.

SOUTO, Maria Helena - Portugal nas exposições universais 1851-1900. Lisboa: Edições Colibri / IHA - Estudos de Arte Contemporânea FCSH-UNL, 2011.

TEIXEIRA, José - D. Fernando II: rei-artista: artista-rei (cat. expo.). Lisboa: Fundação da Casa de Bragança, 1986.

URBANO, Pedro - A Casa Palmela. Lisboa: Livros Horizonte, 2008. 
VALE, Teresa Leonor M. - "Coleccionadores ou adquirentes de obras de arte? Os embaixadores portugueses na Roma barroca e seus contactos com a produção artística: o caso de D. Luís de Sousa (1676-1682)". Artis, n. 2, 2a série. Casal de Cambra: Caleidoscópio, 2014, pp. 22-31.

VALENTE, Vasco - "Augusto Belvedere: pintor, miniaturista, gravador e litógrafo, sua identificação”. Sep. Mvseu, vol. II. Porto: Círculo Dr. José de Figueiredo, 1943.

XAVIER, António de Abreu - "A comunidade portuguesa na Venezuela: uma cronologia da sua presença contemporânea". PADILHA, Beatriz; XAVIER, Maria (org.) Revista Migrações, n.o 5. Lisboa: ACIDI, pp. 171-184.

XAVIER, Hugo - "As doações do conde de Carvalhido à Academia de Belas Artes de Lisboa". NETO, Maria João; MALTA, Marize (eds.) - Coleções de arte em Portugal e Brasil nos séculos XIX e XX: perfis e trânsitos. Casal de Cambra: Caleidoscópio, 2014, pp. 399-424.

XAVIER, Hugo - Galeria de pintura no Real Paço da Ajuda. Coleção Arte e Museus. Lisboa: INCM / IHA-FCSH-UNL 2013.

XAVIER, Hugo - "Incorporações de azulejos pela Academia de Belas Artes na segunda metade do século XIX: a aquisição da Vista de Lisboa”. FLOR, Pedro (coord.) - Revista

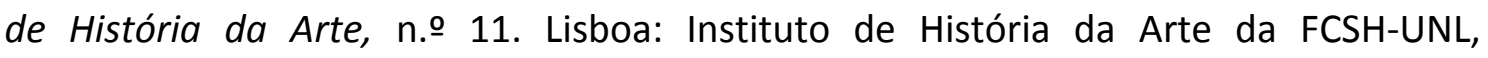
2014/2015 [no prelo].

XAVIER, Hugo - "O marquês de Sousa Holstein e a formação da Galeria Nacional de Pintura da Academia de Belas Artes de Lisboa". SOARES, Clara Moura (coord.) - O património artístico das ordens religiosas: entre o Liberalismo e a atualidade. Lisboa: BNP, 2014/2015 [no prelo].

XAVIER, Hugo - "O Museu de Antiguidades da Ajuda: ourivesaria e numismática das colecções reais ao tempo de D. Luís". SILVA, Raquel Henriques da (coord.) - Revista de História da Arte, n. ㅇ 8. Lisboa: Instituto de História da Arte da FCSH-UNL, 2011, pp. 7087.

XAVIER, Hugo - "O Museu de Arte Ornamental da Academia de Belas Artes de Lisboa". Mvseu, n.o 19, IV série. Porto: Amigos do Museu Nacional de Soares dos Reis/Círculo Dr. José de Figueiredo, 2011-2012, pp. 67-94.

XAVIER, Hugo - "Os tempos monárquicos: dos faustos joaninos ao ateliê de D. Carlos". Pintura e mobiliário do Palácio de Belém. Lisboa: Museu da Presidência da República, 2005, pp. 14-49. 